\title{
Forest Health Monitoring: 2009 National Technical Report
}

Editors Kevin M. Potter Barbara L. Conkling

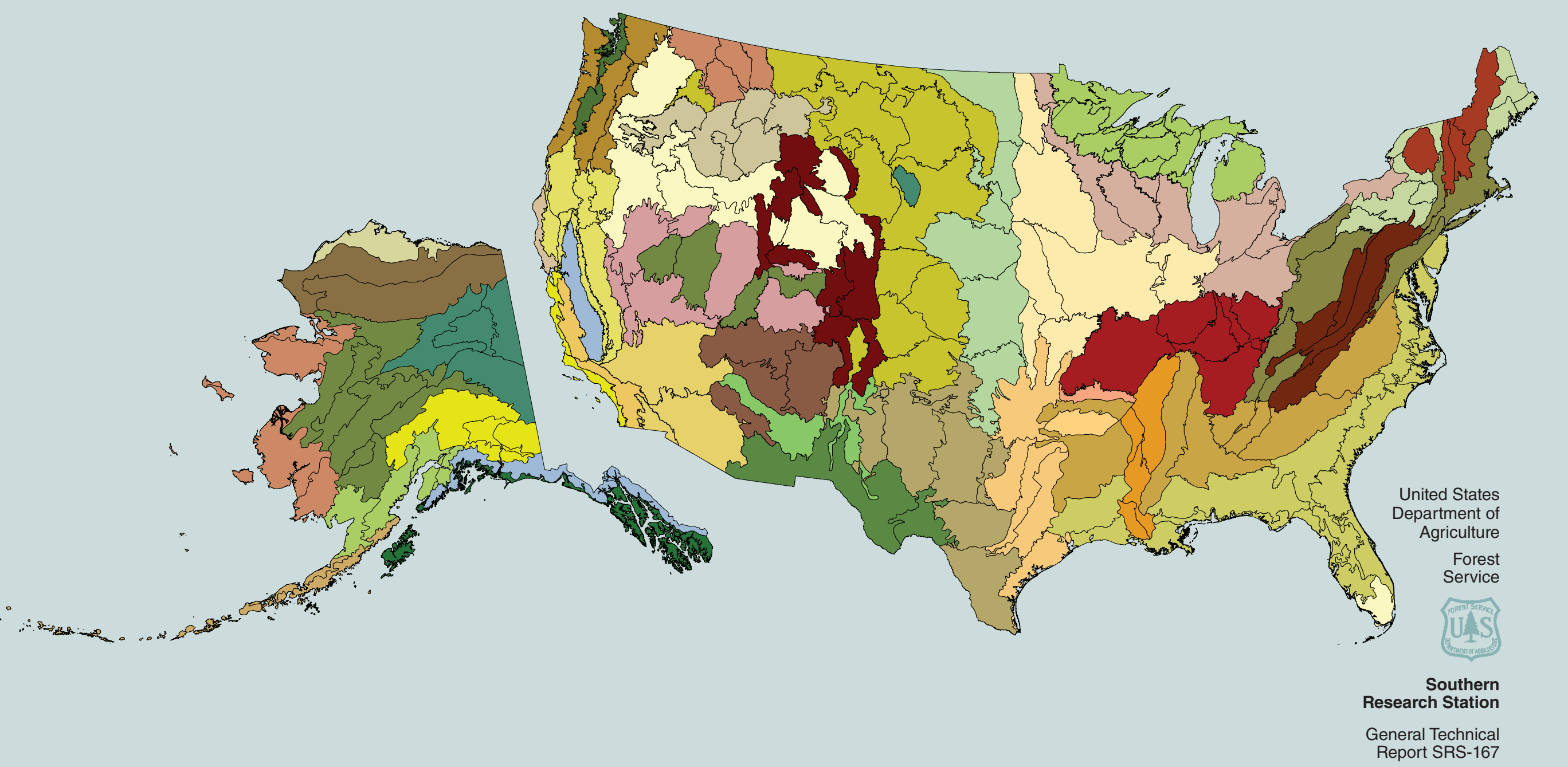


Front cover map: Bailey's ecoregion provinces and ecoregion sections for the conterminous United States (Cleland and others 2007) and for Alaska (Nowacki and Brock 1995).

Back cover map: Forest cover (green) backdrop derived from Moderate Resolution Imaging Spectroradiometer (MODIS) satellite imagery by the U.S. Forest Service Remote Sensing Applications Center.

\section{DISCLAIMER}

The use of trade or firm names in this publication is for reader information and does not imply endorsement by the

U.S. Department of Agriculture of any product or service.

November 2012

Southern Research Station 200 W.T. Weaver Blvd.

Asheville, NC 28804

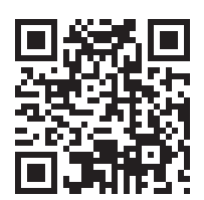

WWW.srs.fs.usda.gov 


\section{Forest Health Monitoring: 2009 National Technical Report}

Editors

Kevin M. Potter, Research Assistant Professor, North Carolina State University, Department of Forestry and Environmental Resources,

Raleigh, NC 27695

Barbara L. Conkling, Research Assistant Professor, North Carolina State University, Department of Forestry and Environmental Resources, Raleigh, NC 27695 
he annual national technical report of the Forest Health Monitoring Program of the Forest Service, U.S. Department of Agriculture, presents forest health status and trends from a national or multi-State regional perspective using a variety of sources, introduces new techniques for analyzing forest health data, and summarizes results of recently completed Evaluation Monitoring projects funded through the national Forest Health Monitoring program. Landscape pattern assessments are presented for Alaska, Hawaii, and Puerto Rico. Data from detection and monitoring surveys are used to identify trends relating to biotic agents posing forest sustainability concerns. Survey data are used to identify geographic patterns of insect and disease activity. Data from the Forest Inventory and Analysis Program of the Forest Service are used to identify geographic patterns of nonnative tree species occurrence.
Forest Inventory and Analysis data from 20 States also are employed to detect regional differences in tree mortality. A new risk map for Phytophthora ramorum is presented to assist in detection surveys. Quantitative temporal analyses are conducted for five categories of abiotic agents impacting forest health. Satellite data are employed to detect geographic patterns of forest fire occurrence. A new methodology for the comparison of moisture conditions among different geographical areas and time periods is described using multi-year windows. Nine recently completed evaluation monitoring projects are summarized, addressing forest health concerns at smaller scales.

Keywords: Drought, fire, forest health, forest insects and disease, fragmentation, nonnative species, tree mortality. 
List of Figures.

viii

List of Tables

xix

Executive Summary

Literature Cited

SECTION 1. Recent National and Regional

Forest Health Status and Trends....

Chapter 1. Introduction

Kevin M. PotTer

Organization of the Report

Data Sources

The Forest Health Monitoring Program .. 15

Literature Cited

CRITERION 1-

Chapter 2. Landscape Pattern and Context

of Forest and Grassland in Alaska, Hawaii

and Puerto Rico

KuRT H. RiITTERS

Introduction

Methods

Results

Discussion.

Literature Cited
CRITERION 3-

Chapter 3. Area and Percent of Forest Affected

by Biotic Agents Bevond Reference Conditions.. 37

JeFFrey A. MAI

Introduction/Background...................... 37

Objectives and Methods ......................... 38

Results and Products .............................. 39

Predictions and Effects .......................... 42

Literature Cited .................................... 62

7

CRITERION 3-

Chapter 4. Large-Scale Patterns of Insect

and Disease Activity in the Conterminous

United States and Alaska from the National

Insect and Disease Detection Survey Database,

2007 and 2008

Kevin M. Potter

Introduction ....................................... 63

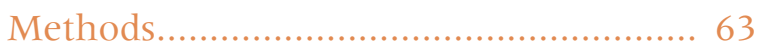

Results and Discussion .......................... 66

Literature Cited ...................................... 78

\section{Table of Contents}




\section{Contents, cont. CRITERION 3-}

Chapter 5. Larce-Scale Assessment of Invasiveness and Potential for Ecological Impact by Nonnative Tree Species

Kevin M. Potter and William D. Smith

Introduction

Methods.

Results and Discussion

Literature Cited

CRITERION 3-

Chapter 6. Tree Mortality

Mark J. Ambrose

Introduction 95

Data 95

Methods. .. 98

Results and Discussion ....

Literature Cited 106

CRITERION 3-

Chapter ?. A Revised Sudden Oak Death Risk

Map to Facilitate National Surveys.

Frank H. Koch and William D. Smith Introduction

Methods.

112

Results and Discussion

129

Literature Cited

134
CRITERION 3-

Chapter 8. Area and Percent of Forest

Affected by Abiotic Agents Beyond

Reference Conditions

Jim ElLenwood

Introduction

Objectives and Methods ......................... 137

Results and Products ............................ 139

Summary .................................................. 147

Literature Cited ...................................... 150

CRITERION 3-

Chapter 9. Large-Scale Patterns of Forest Fire

Occurrence in the Conterminouss United States and Alaska.2001-08

Kevin M. PotTer

Introduction

Methods................................................ 151

Results and Discussion .......................... 153

Literature Cited ....................................... 162

CRITERION 3-

Chapter 10. Mapping Drought Conditions

Using Multi-Year Windows

Frank H. Кoch, John W. Coulston,

and William D. Smith

Introduction

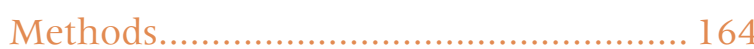

Results and Discussion .......................... 167

Issues and Implications.......................... 176

Literature Cited 
SECTION 2. Evaluation Monitoring

Project Summaries

Literature Cited 181

181

Chapter 11. Climate, Canker, and Alder

Mortality in the Southern Rockies

JAMES J. WORRALL

Introduction

Methods......

Results and Discussion

Conclusions

Literature Cited

Chapter 12.Tracking Population Loss in

Cornus florida Since Discovery of Discula

destructiva, Causal Agent of Dogwood

Anthracnose, in Eastern North America

William E. Jones, William D. Smith,

and Daniel B. Twardus

Introduction

Methods and Results of the Three

Project Components

Conclusions

Literature Cited
Chapter 13. Risk Factors for Oak Decline

and Recional Mortality Patterns in the

Ozark Highlands of Arkansas and Missouri .... 199

Martin A. Spetich, Zhaofei Fan, XiUli Fan,

Hong He, Stephen R. Shifley,

and W. Keith Moser

Introduction

Methods and Data ................................. 199

Results and Discussion .......................... 200

Conclusions ............................................ 202

Literature Cited ...................................... 202

Chapter 14. Understanding the Effects of

Fire Management Practices on Forest

Health: Implications for Weeds and

Vegetation Structure

Anne E. Black and Peter Landres

Introduction ............................................ 203

Objectives ................................................. 203

Methods.................................................. 204

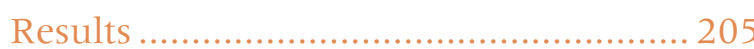

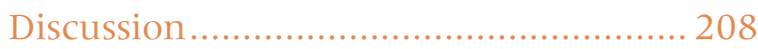

Literature Cited ..................................... 210 
Contents, cont. Chapter 15. Documenting the Regional and Local Distribution of Kalmia latifolia and Rosa multiflora in West Virginia, Ohio, and Pennsylvania Forests along a Soil Fertility Gradient

Cynthia D. Huebner, Todd Hutchinson

Todd Ristau, Alejandro Royo,

And James Steinman

Introduction .................................... 211

Methods........................................ 212

Results .......................................... 212

Discussion and Conclusions .................. 217

Literature Cited ................................. 217

Chapter 16. Evaluating Elevated Levels of

Crown Dieback among Northern Whitecedar (Thuija occidentalisL.) Trees in

Maine and Michican: A Summary of

Evaluation Monitoring

KaDonna Randolph, William A. Bechtold,

Randall S. Morin, and Stanley J. Zarnoch

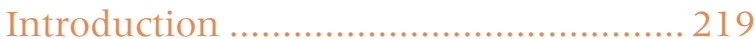

Methods........................................ 219

Results ......................................... 221

Conclusions ..................................... 222

Literature Cited ..................................... 222
Chapter 17. Probabilistic Commodity-FlowBased Focusing of Monitoring Activities to Facilitate Early Detection of Phytophthora

ramorum Outhreaks

Steven C. McKelvey, William D. Smith, AND FranK Koch

Introduction ...................................... 225

Methods............................................. 225

Results ............................................. 228

Discussion ........................................ 229

Chapter 18. Monitoring Limber Pine Health in the Rocky Mountains and North Dakota ...... 233

Kelly Burns, Jim Blodgett, Marcus Jackson, Brian Howell, William Jacobi, Anna Schoettle,

Anne Marie Casper, and Jennifer Klutsch

Introduction

233

Methods....

233

Results and Discussion ....................... 236

Conclusions ................................... 239

Literature Cited ..................................240 
Chapter 19. Influence of Bark Beetle-Caused

Mortality on Fuel Loadings and Crown

Fire Hazard in Southwestern Ponderosa

Pine Stands

Chad M. Hoffman, Joel D. McMillin,

Carolyn Hull Sieg, and Peter Z. Fulé

Methods............................................. 241

Results .......................................... 242

Discussion ........................................ 244

Acknowledgments ................................ 245

Literature Cited ................................. 245
Acknowledgments 


\section{List of Figures}

Figure 1.1-Ecoregion provinces and

ecoregion sections for the conterminous

United States (Cleland and others 2007) and

Alaska (Nowacki and Brock 1995). Ecoregion

sections within each ecoregion province are

shown in the same color

Figure 1.2-The mapped plot design used by the Forest Inventory and Analysis Program of the Forest Service, U.S. Department of Agriculture. Subplot 1 is the center of the cluster with subplots 2, 3, and 4 located 120 feet away at azimuths of $360^{\circ}, 120^{\circ}$ and $240^{\circ}$, respectively (Forest Inventory and Analysis 2009)

Figure 1.3-The design of the Forest Health Monitoring (FHM) Program of the Forest Service, U.S. Department of Agriculture (FHM 2003). A fifth component, analysis and reporting of results, draws from the four FHM components shown here and provides timely information to help support land management policies and decisions

Figure 2.1-Generalized landcover types for Alaska, Hawaii, and Puerto Rico. Source:

NLCD 2001 (Homer and others 2007)

Figure 2.2-Illustration of the area density metric for an arbitrary landcover type called foreground using landscape sizes of 15 ha and 590 ha. The original landcover map was converted to a binary map of "foreground" (forest or grassland) and "background" (top). Maps of the foreground area density in a surrounding landscape are shown for 15-ha (middle) and 590-ha (bottom neighborhoods. See table 2.2 for definitions of the area density classes

Figure 2.3-The landscape mosaic tri-polar classification model identifies 19 landscape mosaic categories according to the proportions of developed, agriculture, and natural (i.e., neither developed nor agriculture) landcover types in a surrounding landscape. See text for explanation of the landscape mosaic coding system

Figure 2.4-Illustration of the landscape mosaic metric for landscape sizes of 15 ha and 590 ha. The generalized landcover map (top) portrays developed, agriculture, and natural pixels. Maps of the landscape mosaic class in a surrounding landscape are shown for 15-ha (middle) and 590-ha (bottom) landscapes. See text for definitions of landscape mosaic classes. Note that by comparisons to figure 2.3, the inset figure at bottom right can be used to interpret the colors in the landscape mosaic class legend

Figure 2.5-Illustration of the morphological spatial pattern classification for effective edge widths of $30 \mathrm{~m}$ and $240 \mathrm{~m}$. The legend of the original landcover map has been converted to "foreground" (e.g., forest, or grassland) and "background" (top). Maps of the morphological spatial pattern classes are shown for effective edge widths of $30 \mathrm{~m}$ (middle) and $240 \mathrm{~m}$ (bottom). See text for definitions of the pattern classes 
Figure 3.1-Forest Health Monitoring regions and area flown during the 2008 insect and disease detection survey

Figure 3.2-Areas with mortality mapped during the 2008 detection survey; graphed acres exclude widely scattered mortality primarily from bronze birch borer, beech bark disease, and gypsy moth

Figure 3.3-Total forest insect and disease mortality in the conterminous United States for two periods; the area with mortality for select indicators (specific biotic indicators are listed elsewhere in this chapter) is summed for all years within the period. Cumulative impacts are occurring where mortality continues within previously mapped areas and expands into new areas .... 41

Figure 3.4-2008 National Insect and Disease Detection Survey forest injury by ownership; the total is approximately 16.7 million acres, of which approximately 10.5 million acres are classified as "mortality" damage type

Figure 3.5-An area of approximately 58 million acres is predicted to be at risk of disturbance by biotic factors; risk is defined as the predicted "loss of $25 \%$ standing volume over the next 15 years” (2006 National Insect and Disease Risk Map

Figure 3.6-The top five mortality agents mapped during 2008 are listed to provide current status; graphed are the acres with mortality from all damage agents and area flown during surveys conducted over the last 5 years

Figure 3.7-Annual National Insect and Disease Detection Survey results for area with mortality and area flown for Alaska (left) and the conterminous United States (right); the area includes select insects, diseases, and complexes as listed in table 3.1. The large increase in the conterminous United States during 2003 reflects a spike in pinyon mortality extending into 2004, mortality during more recent years has increased in other softwood, oak, and aspen types due to a variety of agents. Regional reporting of area flown began in 1999

Figure 3.8-The top six biotic defoliating (left) and mortality (right) agents in aspen mapped during the last 6 years of National Insect and Disease Detection Surveys; total acres with defoliation and mortality are approximately 5.5 million and 0.7 million acres respectively; dieback and beavers are

Figure 3.9-Annual acres with biotic injury in western five-needle pines; the biotic agents included are primarily mortalitycausing agents. "Five-needle pine (generic)" includes white pine blister rust injury where a host is not specified; National Insect and Disease Detection Survey forest or host type codes "mixed conifer" and "pine" are not included, possibly not reporting some fiveneedle pine injury 
Figures, cont. Figure 3.10-Proportion of 4.4 million acres affected by the top five-needle pine damage agents mapped during aerial surveys conducted from 1997 to 2008. Most but not all charted are mortality-causing agents; in reality, complexes play a more significant role than this chart indicates

Figure 3.11-Pine injury mapped during 12 years of National Insect and Disease Detection Survey on 30-m elevation pixels, within map zone 28 in Colorado; the histograms for each year are proportioned to display normalized injury occurrence to pine species, primarily caused by mountain pine beetle. Damage is at its maximum at an elevation of approximately $2600 \mathrm{~m}$ in 1997, gradually moving uphill to peak at approximately $2900 \mathrm{~m}$ in 2008

Figure 3.12-2003-08 total mortality and defoliation acres for Alaska (left) and the conterminous United States (right) as compared to average annual National Insect and Disease Detection Survey flown area and total forest; Alaska surveys are confined to major river drainages with flights based out of Fairbanks, Anchorage, Juneau, and Wrangell; sources of total forest cover estimated for Alaska and conterminous United States are varied, 1991-2003 data were used (see Krist and others 2007)

Figure 3.13-Hawaii forests are dominated by overstory native, mixed, and alien species (Cannarella 2008); approximately half of Hawaii's remaining forest has been transformed from reference conditions by alien plants
Figure 3.14-Gypsy moth counties impacted/ progression of quarantine, 1987-2008 ..... 58

Figure 3.15-Hemlock woolly adelgid spread by county

Figure 3.16-Sirex noctilio spread

by county

Figure 3.17-Emerald ash borer spread by county

Figure 4.1-The extent of surveys for insect and disease activity conducted in the conterminous United States and Alaska in (A) 2007 and (B) 2008. The lines delineate Forest Health Monitoring regions. (Data source: U.S. Department of Agriculture Forest Service, Forest Health Protection.) ...... 64

Figure 4.2-Hot spots of exposure to mortalitycausing insects and diseases in (A) 2007 and (B) 2008. Values are Getis-Ord $G_{i}^{*}$ scores, with values greater than 2 representing strong and significant clustering of high percentages of forest area exposed to mortality agents. (No areas of significant clustering of low percentages of exposure, less than -2, were detected). The gray lines delineate ecoregion sections (Cleland and others 2007), and blue lines delineate Forest Health Monitoring regions. Background forest cover is derived from MODIS imagery by the U.S. Forest Service Remote Sensing Applications Center. (Data source: U.S. Department of Agriculture Forest Service, Forest Health Protection.) 
Figure 4.3-Hot spots of exposure to defoliation-causing insects and diseases in (A) 2007 and (B) 2008. Values are GetisOrd $G_{i}{ }^{*}$ scores, with values greater than 2 representing strong and significant clustering of high percentages of forest area exposed to defoliation agents. (No areas of significant clustering of low percentages of exposure, less than -2 , were detected). The gray lines delineate ecoregion sections (Cleland and others 2007), and blue lines delineate Forest Health Monitoring regions. Background forest cover is derived from MODIS imagery by the U.S. Forest Service Remote Sensing

Applications Center. (Data source: U.S.

Department of Agriculture Forest Service,

Forest Health Protection.)

Figure 4.4-Percent of surveyed forest in Alaska ecoregion sections exposed to mortality-causing insects and diseases in (A) 2007 and (B) 2008. The gray lines delineate ecoregion sections (Nowacki and Brock 1995). Background forest cover is derived from MODIS imagery by the U.S. Forest Service Remote Sensing Applications Center. (Data source: U.S. Department of Agriculture Forest Service, Forest Health Protection.)

Figure 4.5-Percent of surveyed forest in Alaska ecoregion sections exposed to defoliation-causing insects and diseases in (A) 2007 and (B) 2008. The gray lines delineate ecoregion sections (Nowacki and Brock 1995). Background forest cover is derived from MODIS imagery by the U.S. Forest Service Remote Sensing
Applications Center. (Data source: U.S. Department of Agriculture Forest Service,

Forest Health Protection.)

Figures, cont.

Figure 5.1-Species richness of (A) all nonnative forest tree species, (B) exotic nonnative forest tree species, and (C) nonindigenous native forest tree species at the ecoregion section scale (Cleland and others 2007). Forest cover is derived from MODIS imagery by the U.S. Forest Service Remote Sensing Applications Center. (Data source:

U.S. Department of Agriculture Forest Service, Forest Inventory and Analysis Program.)

Figure 5.2-Percent of Forest Inventory and Analysis plots at the ecoregion section scale (Cleland and others 2007) containing at least one (A) nonnative tree, (B) exotic nonnative tree, and (C) non-indigenous native tree,

Forest cover is derived from MODIS imagery by the U.S. Forest Service Remote Sensing Applications Center. (Data source: U.S. Department of Agriculture Forest Service, Forest Inventory and Analysis Program.)

Figure 5.3-Mean percent of plot-level basal area that is (A) nonnative, (B) exotic nonnative, and (C) non-indigenous native, across Forest Inventory and Analysis plots at the ecoregion section scale (Cleland and others 2007). Forest cover is derived from MODIS imagery by the U.S. Forest Service Remote Sensing Applications Center. (Data source: U.S. Department of Agriculture Forest Service, Forest Inventory and Analysis Program. 
Figures, cont. Figure 5.4-Percent of Forest Inventory and Analysis plots at the ecoregion section scale (Cleland and others 2007) containing at least one (A) nonnative sapling, (B) exotic nonnative sapling, and (C) non-indigenous native sapling. Forest cover is derived from MODIS imagery by the U.S. Forest Service Remote Sensing Applications Center. (Data source: U.S. Department of Agriculture Forest Service, Forest Inventory and Analysis Program.

Figure 5.5-Mean percent of total saplings per acre that are (A) nonnative, (B) exotic nonnative, and (C) non-indigenous native, across Forest Inventory and Analysis plots at the ecoregion section scale (Cleland and others 2007). Forest cover is derived from MODIS imagery by the U.S. Forest Service Remote Sensing Applications Center. (Data source: U.S. Department of Agriculture Forest Service, Forest Inventory and Analysis Program.

Figure 6.1-Forest cover in the States where mortality was analyzed. Forest cover was derived from Advanced Very High Resolution Radiometer satellite imagery (Zhu and Evans 1994)

Figure 6.2-Tree mortality expressed as the ratio of annual mortality of woody biomass to gross annual growth in woody biomass (MRATIO) by ecoregion section (Cleland and others 2007). (Data source: U.S.

Department of Agriculture Forest Service,

Forest Inventory and Analysis Program) ...... 100
Figure 6.3-The ratio of average dead tree diameter to average surviving tree diameter (DDLD) on each plot at the time of its last measurement: (A) Eastern United States,

(B) Upper Midwest, (C) Northeast, (D)Southeast. DDLD is indicated by dot color; dot sizes are scaled relative to the biomass that died on each plot. Plot locations are approximate. (Data source: U.S. Department of Agriculture Forest Service, Forest Inventory and Analysis Program)

Figure 7.1-2002 national sudden oak death (Phytophthora ramorum) risk map, designed to facilitate surveys of forested environments. State boundaries are included for reference

Figure 7.2-Host sub-layers used in the construction of the combined host layer: (A) overstory hosts with high predicted mortality levels; (B) evergreen midstory foliar hosts; (C) deciduous midstory foliar hosts; (D) evergreen background hosts; and (E) deciduous background hosts. The rank scoring criteria for (A), (B), and (C) are described in tables 7.2, 7.3, and 7.4, respectively. For (D) and (E), a rank of 1 indicates the presence of at least one species listed in table 7.5 or table 7.6 , respectively, while a rank of 0 indicates absence of listed species. See text regarding data sources for each sub-layer. Ecoregion section boundaries (Cleland and others 2007) are included for reference 
Figure 7.3-Host layer created by combining the host sub-layers. Please see text regarding the determination of rank scores. Ecoregion section (Cleland and others 2007) and State boundaries are included for reference

Figure 7.4-Climatic suitability layer. Please see text regarding the determination of rank scores. Ecoregion section (Cleland and others 2007) and State boundaries are included for reference

Figure 7.5-Hazard layer generated by combining the host and climatic suitability layers. Please see text regarding the determination of rank scores. Ecoregion section (Cleland and others 2007) and State boundaries are included for reference....

Figure 7.6-Introduction pathways layer developed from wildland-urban interface data. Inset shows the distribution of all four risk categories across the San Francisco Bay area. Please see text regarding determination of rank scores. Ecoregion section (Cleland and others 2007) and State boundaries are included for reference

Figure 7.7-New national risk map for sudden oak death (Phytophthora ramorum). State boundaries are included for reference

Figure 8.1-Historical acreage burned (Data source: National Interagency Coordination Center, Heinz Center 2008)
Figure 8.2-Weather-related forest damage areas, 2003-07 (Data source: U.S.

Department of Agriculture Forest

Service 2008a)

Figure 8.3-Weather-related damagereference period comparison to current period (Data source: U.S. Department of Agriculture Forest Service 2008a)

Figure 8.4-Regional comparison of 5-year reference period for ozone plant injury by region (Data source: Smith and others 2008)

Figure 8.5-Comparison of projected housing density (Data source: Theobald 2005)

Figure 8.6-Mean moisture index deficit for the reference period, 1998-2002

(Data source: derived from Koch and others 2012)

Figure 8.7-Mean moisture index deficit for the most recent period, 2003-07 (Data source: derived from Koch and others 2012)

Figure 9.1-Forest fire occurrences detected by MODIS from 2001 to 2008, for the conterminous United States and Alaska (Data source: U.S. Department of Agriculture Forest Service, Remote Sensing Applications Center.) 
Figures, cont. Figure 9.2-The mean annual number of forest fire occurrences, per $100 \mathrm{~km}^{2}$ (10 000 ha) of forested area, by ecoregion section (Cleland and others 2007) within the conterminous United States, for (A) 200108, (B) 2003-05 and (C) 2006-08. The gray lines delineate ecoregion sections (Cleland and others 2007). Forest cover is derived from MODIS imagery by the U.S. Forest Service Remote Sensing Applications Center. (Source of fire data: U.S. Department of Agriculture Forest Service, Remote Sensing Applications Center.)

Figure 9.3-The mean annual number of forest fire occurrences, per $100 \mathrm{~km}^{2}$ (10 000 ha) of forested area, by ecoregion section (Nowacki and Brock 1995) within Alaska, for (A) 2001-08, (B) 2003-05, and (C) 2006-08. The gray lines delineate ecoregion sections. Forest cover is derived from MODIS imagery by the U.S. Forest Service Remote Sensing Applications Center. (Source of fire data: U.S. Department of Agriculture Forest Service, Remote Sensing Applications Center.)

Figure 9.4-Hot spots of high fire occurrence density across the conterminous United States for the years 2001-08. Values are
Getis-Ord $G_{i}^{*}$ scores, with values greater than 2 representing strong and significant clustering of high fire occurrence densities. (No areas of significant clustering of low fire occurrence densities, less than -2, were detected.) The gray lines delineate ecoregion sections (Cleland and others 2007).

Background forest cover is derived from MODIS imagery by the U.S. Forest Service Remote Sensing Applications Center. (Source of fire data: U.S. Department of Agriculture Forest Service, Remote Sensing Applications Center.)

Figure 9.5-Hot spots of high fire occurrence across the conterminous United States for (A) 2005, (B) 2006, (C) 2007, and (D) 2008. Values are Getis-Ord $G_{i}{ }^{*}$ scores, with values greater than 2 representing strong and significant clustering of high fire occurrence densities. (No areas of significant clustering of low fire occurrence densities, less than

-2 , were detected.) The gray lines delineate ecoregion sections (Nowacki and Brock 1995). Background forest cover is derived from MODIS imagery by the U.S. Forest Service Remote Sensing Applications Center. (Source of fire data: U.S. Department of Agriculture Forest Service, Remote Sensing Applications Center.) 
Figure 10.1-Maps for 5-year drought probability in the conterminous United States: probability (A) of at least mild drought; (B) at least moderate drought; (C) at least severe drought; (D) extreme drought. Probabilities were calculated as the number of 5-year windows out of 100 possible overlapping windows (from 1904-08 to 2003-07) in which the 5-year moisture index difference $\left(M I D_{5}\right)$ was less than or equal to corresponding drought category threshold values (see table 10.1). Ecoregion section (Cleland and others 2007) boundaries are included for reference. Forest cover data (overlaid green hatching) derived from MODIS imagery by the U.S. Department of Agriculture Forest Service, Remote Sensing Applications Center. (Data source: PRISM Group, Oregon State University) ...... 168

Figure 10.2-Maps for 1-year drought probability in the conterminous United States: (A) probability of at least mild drought; (B) at least moderate drought; (C) at least severe drought; (D) extreme drought. Maps adapted from figure 4.2 in Koch and others (2012). Ecoregion section (Cleland and others 2007) boundaries are included for reference. Forest cover data (overlaid green hatching) derived from MODIS imagery by the U.S. Department of Agriculture Forest Service, Remote Sensing Applications Center. (Data source: PRISM Group, Oregon State University)

Figure 10.3-Moisture index difference $\left(M I D_{5}\right)$ maps for California for overlapping 5-year time windows: (A) 1983-87;
(B) 1985-89; (C) 1987-91; (D) 1989-93; (E) 1991-95. Ecoregion section (Cleland and others 2007) and State boundaries are included for reference. Forest cover data (overlaid green hatching) derived from MODIS imagery by the U.S. Department of Agriculture Forest Service, Remote Sensing Applications Center. (Data source: PRISM Group, Oregon State University)

Figure 10.4-Moisture index difference $\left(M I D_{5}\right)$ maps for the Southwestern United States for overlapping 5-year time windows: (A) 1991-95; (B) 1993-97; (C) 1995-99; (D) 1997-2001; (E) 1999-2003; (F) 2001-05; (G) 2003-07. Ecoregion section (Cleland and others 2007) and State boundaries are included for reference. Forest cover data (overlaid green hatching) derived from MODIS imagery by the U.S. Department of Agriculture Forest Service, Remote Sensing Applications Center. (Data source: PRISM Group, Oregon State University)

Figure 10.5-Map of the 2003-07 moisture index difference $\left(M I D_{5}\right)$ for the conterminous United States. Ecoregion section (Cleland and others 2007) boundaries and labels are included for reference. Forest cover data (overlaid green hatching) derived from MODIS imagery by the U.S. Department of Agriculture Forest Service, Remote Sensing Applications Center. (Data source: PRISM Group, Oregon State University) ....................................... 177 
Figures, cont. Figure 11.1-Dieback and mortality of thinleaf alder in Colorado and associated Cytospora canker. (A) Mortality in 2005 on a tributary of Eight Mile Creek in the Cottonwood grazing allotment near Granby, $\mathrm{CO}$. The larger stems shown here were already dead in a 1996 photo (not shown). (B) Dead and dying alder in 2005 on both sides of Taylor River near Gunnison, CO, heavily used for recreation. (C) and (D) Cytospora canker associated with dieback and mortality. Note the dense fruiting completely filling the canker surface. The top (C) and side (D) of a canker are marked with white paint. [Photos by Doreen Sumerlin, U.S. Department of Agriculture Forest Service (A) and James Worrall, U.S. Department of Agriculture Forest Service (B), (C), and (D)]

Figure 11.2-Transect and watershed locations in the extensive survey, 2004. The proportion of the circle that is filled indicates the severity of dieback and mortality as calculated by the Genet Condition Index ..... 185

Figure 11.3-Development of 39 marked cankers (thin blue lines) that grew significantly during March-October 2006, expressed as percent girdling (growth of canker around the circumference). The bold red line is the average of all cankers. The graph below shows weather at Gunnison (weather station number 724677) for the corresponding period. Bold red and green lines are moving averages of the 10-day period centered at each point
Figure 11.4-Spectral analysis of Gunnison summer heat index using Blackman-Tukey, Maximum Entropy Method, Multi-Taper Method, and Singular Spectrum Analysis. The first pair of components in the eigenvalue plot (upper right) represent a significant oscillation ( $f=0.047)$, which is reconstructed at lower right against the raw index

Figure 12.1-Change in the unweighted mean number of dogwoods trees per acre from Cycle 1 (1980s), Cycle 2 (1990s) and Cycle 3 (2000s) in the Coastal Plain, Piedmont, and Northern Blue Ridge Mountain ecoregions. (Data source: U.S. Department of Agriculture Forest Service, Forest Inventory and Analysis Program)

Figure 12.2-Change in the number of dogwood trees per acre from the past three Forest Inventory and Analysis (FIA) measurements, Cycle 1 (A), Cycle 2 (B), and Cycle 3 (C). The regions are identified as: mountains—white background; piedmont—-tan background; coastal— yellow background. Plot locations are approximate

Figure 13.1-Temporal mortality trends for the white oak group, red oak group, and the non-oak group. (Data source: U.S. Department of Agriculture Forest Service, Forest Inventory and Analysis Program) ...... 200 
Figure 13.2-Spatial mortality (dead basal area/total basal area) trends of red oak group in the Ozark Highlands. (Data source: U.S. Department of Agriculture Forest Service, Forest Inventory and Analysis Program)

Figure 13.3-Annual mortality (percent) of red oak group species by risk factors for the Missouri Ozark Forest Ecosystem Project (MOFEP) sites. Crown classes are:

(I) dominant, (II) codominant,

(III) intermediate, and (IV) suppressed

Basal area in larger trees (bal) is computed uniquely for each tree on an inventory plot as the total basal area $\left(\mathrm{m}^{2} / \mathrm{ha}\right)$ of the trees on that plot that are as large or larger in diameter at breast height (d.b.h.). Tree d.b.h. classes are in cm (from Shifley and others 2006). Note: the numbers in the boxes are the mortality percent at each node

Figure 14.1-Comparison of fire and internal patch shape (defined by severity class and measured by Area Weighted Mean Shape Index) for wildland fire use $(w)$,

confinement $(c)$, and suppression $(s)$ fires in 2003 and 2005. Note: there were no

confinement fires in 2005

Figure 14.2-Class metrics, defined by severity class, for wildland fire use, confinement, and suppression strategies for subalpine fires $>3$ ha in and around the Selway-Bitterroot Wilderness in 2003 and 2005
Figure 15.1-Soil pH (A), soil calcium (mg/ $\mathrm{kg})$ (B), soil total N (percent) (C), and soil

Pennsylvania, and West Virginia

Figure 15.2-Soil pH (A), soil calcium (mg/ $\mathrm{kg})($ B), soil potassium $(\mathrm{mg} / \mathrm{kg})(\mathrm{C})$, and soil manganese $(\mathrm{mg} / \mathrm{kg})$ (D) on Kalmia latifolia and Rosa multiflora plots in Ohio,

Pennsylvania, and West Virginia

Figure 15.3-Plant total nitrogen (percent (A), plant potassium (percent) (B), plant calcium (percent) (C), and plant manganese (percent) (D) of Kalmia latifolia and Rosa multiflora plots in Ohio, Pennsylvania, and West Virginia

Figure 16.1-Northern white-cedar trees with poor crown conditions observed during the 2001 summer assessment. (Photos by KaDonna Randolph)

Figure 17.1-Sample results for the

SODBuster example described in the

Methods section

Figure 17.2-Sample output information from the SODBuster computer program. Note values of input parameters (a priori) are presented as well as the likelihoods of each source being a source of infection as determined by the model (a posteriori) 
Figures, cont. Figure 17.3-Example map output from the SODBuster computer program showing the underlying commodity transportation network (red lines) superimposed upon the various Freight Analysis Framework (FAF) regions. (Data source: U.S. Federal Highway Administration)

Figure 17.4-Example map output from the SODBuster computer program showing solid red discs to indicate the relative risks of destinations, superimposed upon the various Freight Analysis Framework (FAF) regions. (Data source: U.S. Federal Highway Administration)

Figure 18.1-Limber pine monitoring plots (yellow dots) in Colorado, Wyoming, Montana, and North Dakota .. 234

Figure 18.2-Diagram of plot layout
Figure 19.1-Simulated torching index (mean with standard error) for plots with tree mortality and with no mortality for three sets of assumptions in ponderosa pine stands of north-central Arizona. Simulation 1 shows changes in torching index based only on changes in the canopy fuels complex; simulation 2 shows changes in torching index based on combined effects of changes in canopy and surface fuels complex; and simulation 3 shows changes in torching index based on a combination of changes in canopy and surface fuels complex as well as a reduction in wind adjustment factor. Means within a group followed by a different letter are significantly different $(\alpha=0.05)$ 
Table 2.1-The percentages of Alaska,

Hawaii, and Puerto Rico that are covered by each of the eight generalized National Land Cover Database (NLCD) landcover classes. The original 19 NLCD landcover types are shown for comparisons

Table 2.2-Conversion of continuous areadensity measurements to categorical values for reporting

Table 2.3-Landscape-level summary of the landscape mosaic metric. The percent of total State area in each of 19 landscape mosaic classes is shown for two landscape sizes. The subtotals show the percentages in subgroups of landscape mosaic dominance classes (natural, agriculture, developed, mixed)

Table 2.4-Landscape-level summary

of (A) forest area density class and

(B) grassland area density class for two landscape sizes by State

Table 2.5-Forest sector-level summary of the landscape mosaic metric. The percent of total forest area in each State in each of 19 landscape mosaic classes is shown for two landscape sizes. The subtotals show the percentages in subgroups of landscape mosaic dominance classes (natural, agriculture, developed, mixed)
Table 2.6-Grassland sector-level summary of the landscape mosaic metric. The percent of total grassland area in each State in each of 19 landscape mosaic classes is shown for two landscape sizes. The subtotals show the percentages in subgroups of landscape mosaic dominance classes (natural, agriculture, developed, mixed)

2. - Sector-level summary of

(A) forest area density class and (B) grassland area density class for two landscape sizes

by State

Table 2.8-Summary of forest morphological spatial pattern analysis (MSPA) classes for

four effective edge widths by State

Table 2.9-Summary of grassland morphological spatial pattern analysis (MSPA) classes for four effective edge widths by State

Table 3.1-Area (acres) by damage class and ownership from the 2008 National Insect and Disease Detection Survey for Alaska and the conterminous United States

Table 3.2-Select mortality and defoliation agent impact totals from surveys during two analysis periods 
Tables, cont. Table 4.1-Biotic mortality agents and complexes affecting more than 5,000 ha of forested area in the conterminous United

States during 2007 and 2008 66

Table 4.2-Biotic defoliation agents and complexes affecting more than 5,000 ha of forested area in the conterminous United States during 2007 and 2008

Table 5.1-Four metrics of "invasiveness" for nonnative tree species: overall abundance in the Forest Inventory and Analysis data, overall abundance of saplings, number of ecoregion sections in which each species occurs, and the mean percent of trees per acre represented by each species on the plots on which it occurs

Table 6.1-States from which repeated Forest Inventory and Analysis phase 2 measurements were available, the time period spanned by the data, and the number of panels of data available. Each panel represents approximately one-fifth of the plots in a State

Table 6.2-Tree species responsible for at least 10 percent of the mortality (in terms of biomass) for ecoregions where the MRATIO was 0.60 or greater, including the mean age of the dead trees of these species and the species-level percent mortality within the ecoregion
Table 7.1-Oak species included in the overstory host layer for P. ramorum. All species listed are classified as red oaks or black oaks (Quercus sect. Lobatae) except for canyon live oak (Quercus chrysolepis), which is an intermediate oak (Quercus sect. Protobalanus)

Table 7.2-Decision rules used to reclassify overstory host basal area (BA) values into an ordinal ranking

Table 7.3-Decision rules used to develop ordinal rankings for important evergreen midstory hosts found in the Eastern and Western United States

Table 7.4-Decision rules used to reclassify deciduous midstory host trees per acre (TPA) values into an ordinal ranking

Table 7.5-List of species used in constructing the evergreen background host layer ........... 118

Table 7.6-List of species used in constructing the deciduous background host layer ........... 119

Table 7.7-Decision rules for combining the midstory and background host layers into a single ordinal ranking. See tables 7.3 and 7.4, respectively, regarding the evergreen and deciduous midstory host ranks 121

Table 7.8-Decision rules for the final combined host layer ranking 
Table 7.9-Ordinal ranking of climatic suitability derived by reclassifying adjusted climate scores

Table 7.10-Decision rules for the final hazard layer ranking

Table 7.11-Original wildland-urban interface categories, with brief descriptions, and their new ranking values for the introduction pathways layer

Table 7.12-Rules for selecting the high, moderate, and low risk hexagons that were retained in the final composite risk map ...... 128

Table 8.1-Severity of forested area burned for the Pacific and Rocky Mountain regions

Table 8.2-Grand summary of fire abiotic sub-indicators

Table 8.3-Grand summary of nonfire

abiotic sub-indicators

Table 10.1-Moisture index difference $\left(M_{5}\right)$ value ranges for nine wetness and drought categories, along with the equivalent ranges in standard deviation from the mean value (i.e., zero)
Table 12.1-Data structure of the number of Forest Inventory and Analysis plots per ecoregion and the number of plots in each of the six disease hazard classes

Table 12.2-Definition table for Forest Inventory and Analysis measurement Cycle 1, Cycle 2, and Cycle 3 of year of inventory and type ( $\mathrm{P}=$ Periodic survey and $\mathrm{A}=$ annualized survey

Table 18.1-Limber pine by health status and percent impacted by white pine blister rust (WPBR), twig beetles, and bark beetles in northern Colorado and southern Wyoming (COWY), northern Wyoming (NWY),

Montana (MT), and North Dakota (ND)

study areas

Table 18.2-Mean incidence and severity of white pine blister rust in northern Colorado and southern Wyoming (COWY), northern Wyoming (NWY), Montana (MT), and

North Dakota (ND) study areas

Table 18.3-Proportion of living limber pine trees infected with white pine blister rust (WPBR) by size class, mean number of WPBR cankers per infected limber pine, and proportion of infected trees with stem cankers by size clas 
Tables, cont.

Table 19.1-Comparison of stand structural characteristics in mortality and no-mortality plots in ponderosa pine stands of northcentral Arizona

Table 19.2— Surface fuel loadings by fuel classes and duff and fuel bed depth in mortality and no-mortality plots in ponderosa pine stands of north-central Arizona
Table 19.3-Canopy fuel loadings by size class, total and available canopy fuel, and canopy bulk density of mortality and nomortality plots in ponderosa pine stands of north-central Arizona 
ealthy ecosystems are those that are stable and sustainable, able to maintain their organization and autonomy over time while remaining resilient to stress (Costanza 1992). The Forest Health Monitoring (FHM) Program of the Forest Service, U.S. Department of Agriculture, with cooperating researchers from within and from outside the Forest Service, quantifies the health of the forests of the United States within the context of the sustainable forest management criteria and indicators outlined in the Criteria and Indicators for the Conservation and Sustainable Management of Temperate and Boreal Forests (Montréal Process Working Group 2007)

The analyses and results outlined in this FHM annual national technical report offer a snapshot of the current condition of forests from a national or multi-State regional perspective, incorporating baseline investigations of forest ecosystem health, examinations of change over time in forest health metrics, and assessments of developing threats to forest stability and sustainability. Several chapters describe new techniques for analyzing forest health data as well as new applications of established techniques. Most chapters address Criterion 3 of the Montréal Process, which focuses on maintenance of forest ecosystem health and vitality. Half of the research chapters address Indicator 15, “Area and Percent of Forest Affected by Biotic Agents beyond Reference Conditions," while half address Indicator 16 "Area and Percent of Forest Affected by Abiotic Agents beyond Reference Conditions."
Finally, this report presents summaries of results from recently completed evaluation monitoring (EM) projects that have been funded through the FHM national program to determine the extent, severity, and causes of specific forest health problems (FHM 2008).

The spatial arrangement of environmental features is expected to affect all ecological processes in that environment. A prerequisite for informed natural resource management actions at local, regional, and national scales, therefore, is reliable information about landscape patterns at those scales. Previous assessments of forest and grassland spatial patterns have been limited by the available data on the conterminous United States plus the District of Columbia, but the recently released 2001 National Land Cover Database (NLCD) includes Alaska, Hawaii, and Puerto Rico (chapter 2). Landscape pattern assessments now have been extended to these three jurisdictions. The spatial patterns of forest and grassland ("sectors") were evaluated with several measures of landcover composition and configuration. The analyses were conducted at several spatial scales, and the results summarized in two ways to highlight landscape-level and sector-level interpretations.

Where change to forests due to biotic agents and processes occurs beyond a critical threshold, forest ecosystem health and vitality may be significantly altered and a forest's ability to recover could be reduced or lost (Montréal Process Criterion 3, Indicator 15). Monitoring 
and measuring the effects of these processes provide information helpful in the formulation of management strategies to mitigate risk (chapter 3). Data from a variety of detection and monitoring surveys, primarily National Insect and Disease Detection Surveys, conducted annually by the Forest Health Protection (FHP) Program of the Forest Service and FHP partners, were used to present survey results as related to the 2008 forest condition; examine the trend of biotic indicator impacts for the current period compared to a reference period; and highlight areas, agents, and possible changes in host distribution and climate appearing to contribute toward sustainability concerns.

Monitoring the occurrence of forest pest and pathogen outbreaks is important at regional scales because of the significant impact insects and disease can have on forest health across landscapes (chapter 4). Hot spot analysis of FHP national insect and disease survey data from 2007 and 2008 detected significant clusters of forest mortality associated with mountain pine beetle in the West, including northern Colorado and southern Wyoming, western Montana, and northern Washington. Forest winter moth, gypsy moth, and Diplodia canker were responsible for a mortality hot spot in New England. The most extensive hot spot of defoliation in both 2007 and 2008 occurred in the Northeast, and was associated with forest tent caterpillar and gypsy moth. Spruce beetle and northern spruce engraver beetle were the most significant causes of mortality in Alaska, while aspen leafminer was the most important defoliation agent there.
Nonnative plant species pose a serious environmental concern because they can alter fire regimes, nutrient cycling, hydrology, energy budgets, and biodiversity (chapter 5). Data from the Forest Inventory and Analysis (FIA) Program of the Forest Service were used to quantify the invasiveness of nonnative tree species, while identifying locations in which nonnative tree species are concentrated and where they may have the most significant ecological impacts. Scots pine (Pinus sylvestris) was the most abundant nonnative species, relatively common throughout the Great Lakes States and the Northeast. Nonnative tree species were much more prevalent in the eastern half of the country than in the West, where they were largely absent. Nonnative tree species tended to be more common in ecoregion sections along the Gulf Coast, in the Mid-Atlantic States, and in the eastern portions of the Midwest, while native tree species that have expanded past their historical range were more prevalent in the central Midwest and in the Southern Plains States.

Mortality is a natural process in all forested ecosystems, but high levels of mortality at large scales may indicate that the health of forests is declining. FIA phase 2 data offer tree mortality information at a more spatially intense sample than the FHM and FIA phase 3 data used in past forest health annual technical reports (chapter 6). An analysis of FIA plots from 20 States found that the highest ratios of annual mortality to gross growth occurred in ecoregion sections of 
the Plains States. In the three ecoregions having highest mortality, the predominant vegetation is grassland, and there were few forested plots measured. Most of the forest in these ecoregions is riparian forest, and the species experiencing greatest mortality are commonly found in riparian areas.

The past actual movement and the future potential movement of infected plants via the commercial nursery trade has raised sudden oak death, a disease caused by the fungus-like Phytophthora ramorum, from a regional forest health issue in California and Oregon to one of global concern (chapter 7). Since the publication in 2002 of a P. ramorum risk map to serve as a national sampling frame, the list of hosts susceptible to the pathogen has expanded, the climatic factors favoring P. ramorum are better understood, and much more is known about its basic epidemiology. Therefore, a new national risk map was created utilizing the most current information and also incorporating data sources and analytical techniques not employed for the 2002 map.

Various abiotic agents, both natural and human-induced, can change forest structure and species composition (Montréal Process Criterion 3, Indicator 16). Where such change crosses a critical threshold, a forest ecosystem's health and vitality may be significantly altered and their ability to recover from disturbance is reduced or lost, often meaning a reduction or loss of benefits associated with that ecosystem (chapter 8). Monitoring of the area and percent of forests affected by abiotic agents beyond reference conditions may provide information needed in the formulation of management strategies to mitigate risk. Five abiotic subindicators were identified as having the greatest impact on forest health: (1) fire, (2) weatherrelated events, (3) climate, (4) pollution, and (5) land use. Quantitative temporal analyses of these abiotic sub-indicators were completed based on spatial and tabular data between a recent 5-year analysis period (2003-2007) and the previous 5-year time period (1998-2002).

Forest fire occurrence outside the historic range of frequency and intensity can result in extensive economic and ecological impacts. The detection of regional patterns of fire occurrence can allow for the identification of areas at greatest risk of significant impact and for the selection of locations for more intensive analysis (chapter 9). Over the 8-year period during which Moderate Resolution Imaging Spectroradiometer (MODIS) fire occurrence data have been recorded (2001-2008), the Central California Coast has experienced the most fires per year per $100 \mathrm{~km}^{2}$ of forested area. In Alaska, the most fire occurrences were recorded in the four ecoregion sections of the Upper Yukon Taiga Province. Annual hot spots of fire occurrence differed by year from 2005 to 2008. Of these years, 2008 was the only year not containing a fire occurrence hot spot in central Idaho. In 2006 and 2008, the data indicated the presence of a hot spot in northern California. 
Drought conditions can affect forest health both directly and indirectly, so an appropriate regional index of drought is necessary to gain important insights about the health of forests (chapter 10). A newly developed moisture index difference $(M I D)$ methodology allows for the reasonable comparison of moisture conditions between different geographical areas and time periods. This approach is computationally simple and repeatable, requiring only climate variables and omitting soil or other environmental factors that are unavailable nationally at fine scales. To provide a more realistic characterization of drought impact in forested areas, this methodology was expanded to examine moisture conditions over longer multi-year time windows. Several regions, including northern portions of the Interior West, the Pacific Coast, and much of the Eastern United States, exhibit lower probabilities of long-term drought than of short-term, 1-year moisture deficits.

Finally, nine recently completed evaluation monitoring projects address a wide variety of forest health concerns at a scale smaller than the national or multi-State regional analysis included in the first part of the report. The projects, funded by FHM:

- Quantify the extent and severity of thinleaf alder (Alnus incana ssp. tenuifolia) dieback and mortality from southern Wyoming to northern New Mexico, and assess a variety of potential direct and indirect causal factors (chapter 11).
- Determine the potential impacts to flowering dogwood (Cornus florida) following the introduction of dogwood anthracnose, and test a previously developed dogwood anthracnose hazard rating system (chapter 12).

- Analyze oak mortality by species groups and inventory year to illustrate the general spatial and temporal trends of oak decline and mortality, using the 1999-2006 FIA plots measured annually in the Ozark Highlands of Arkansas and Missouri (chapter 13).

- Examine the implications of fire management practices on nonnative weed establishment and vegetation patch structure in the northern Rocky Mountains of Idaho and Montana (chapter 14).

- Determine if a soil fertility gradient exists across regional and local scales, and if this fertility gradient helps explain the regional vegetation pattern or local presence of Kalmia latifolia or Rosa multiflora (chapter 15).

- Verify the apparent elevated levels of crown dieback among northern white-cedar (Thuja occidentalis) trees in Michigan and Maine, and assess whether a change occurred in the average level of crown dieback over an approximate 10-year period (chapter 16).

- Develop an analytical tool designed to help focus scarce inspection resources on the early detection of Phytophthora ramorum outbreaks 
in parts of North America where the organism that causes sudden oak death (SOD) is not yet present (chapter 17).

- Assess the current ecological impacts of white pine blister rust on limber pine (Pinus flexilis) in the Rocky Mountains; establish plots for future re-measurement to assess long-term and cumulative ecological impacts; and gather baseline information to sustain, protect, and restore impacted stands (chapter 18).

- Quantify effects of bark beetle outbreaks on canopy and surface fuels in ponderosa pine (Pinus ponderosa) forests of the Southwest, model potential fire behavior in stands with bark beetle-caused tree mortality, and examine the relationship between bark beetle mortality and fuel loadings and fire hazard (chapter 19).

The FHM program, in cooperation with researchers inside and outside the Forest Service, continues to investigate a broad range of issues relating to forest health using a wide variety of data and techniques. This report presents some of the latest results from ongoing national-scale Detection Monitoring and smaller-scale environmental monitoring efforts by FHM and its cooperators. For more information about efforts to determine the status, changes, and trends in indicators on the condition of U.S. forests, please visit the FHM Web site at www.fs.fed.us/foresthealth/fhm.

\section{Literature Cited}

Costanza, R. 1992. Toward an operational definition of ecosystem health. In: Costanza, R.; Norton, B.G.; Haskell, B.D., eds. Ecosystem health: New goals for environmental management. Washington, DC: Island Press: 239-256.

Forest Health Monitoring (FHM). 2008. Program description. Forest Health Monitoring Fact Sheet Series. http://www.fhm/fs.fed.us/fact/. [Date accessed: September 3, 2008]

Montréal Process Working Group. 2007. The Montréal Process, third edition. 12 p. http://www.rinya.maff.go.jp/ mpci/rep-pub/1995/santiago_e.html. [Date accessed: May 22, 2008] 



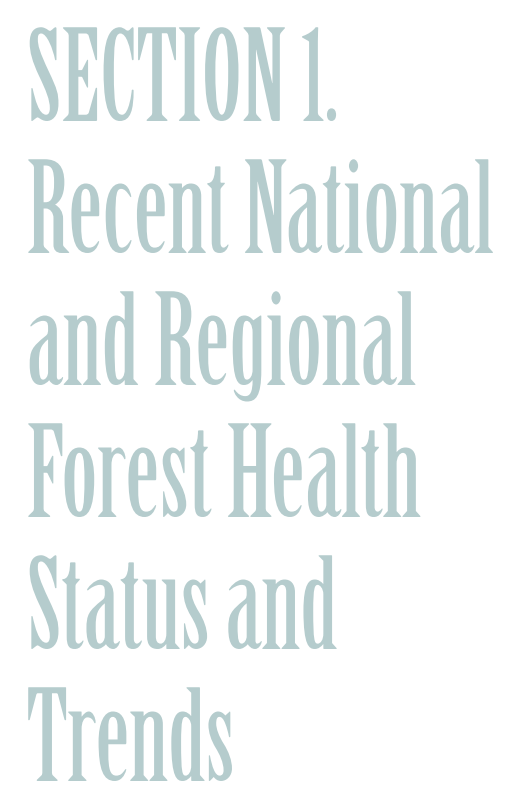




orests cover a vast area of the United States: 03.1 million ha or approximately onehird of the Nation's land (Smith and others 2004). These forests are of substantial ecological, economic, and social importance. Both their ecological integrity and their continued capacity to provide goods and services are of considerable concern in the face of a long list of threats, including insect and disease infestation, fragmentation, catastrophic fire, invasive species, and the effects of global climate change.

Assessing and monitoring the health of these forests is a critical and challenging task. While there is no universally accepted definition of forest health, the current understanding of ecosystem dynamics suggests that evaluations of forest health should emphasize factors that affect the inherent processes and resilience of forests (Raffa and others 2009). Consistent with this understanding, Kolb and others (1994) listed four characteristics that a healthy forest ecosystem is likely to possess:

- The physical environment, biotic resources, and energy consumption networks to support productive forests during at least some successional stages.

- Resistance to catastrophic change or the ability to recover from catastrophic change at the landscape level.
- A functional equilibrium between supply and demand of essential resources (water, nutrients, light, growing space) for major portions of the vegetation.

- A diversity of seral stages and stand structures that provide habitat for many native species and all essential ecosystem processes.

This annual national technical report on the health of the forests of the United States is produced by the Forest Health Monitoring Program (FHM) of the Forest Service, U.S. Department of Agriculture, with three specific objectives. The first is to present information about forest health from a national perspective, or from a multi-State regional perspective when appropriate, using data collected by the Forest Health Protection (FHP) and Forest Inventory and Analysis (FIA) programs of the Forest Service, as well as data from other sources. The first section of the report achieves this objective, with results stemming from the ongoing national-scale Detection Monitoring efforts from FHM and its cooperators using a wide variety of regional-scale data and analytical techniques. While in-depth interpretation and analysis of specific geographic or ecological regions are beyond the scope of this section of the report, the chapters in the first section of the report present information for the identification of areas that may require investigation at a finer scale.

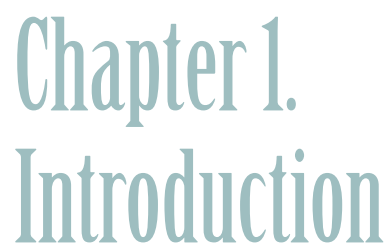

Kevin M. Potter 
The second objective of the report is to present new techniques for analyzing forest health data as well as new applications of established techniques. Examples in this report are chapter 5, which presents metrics quantifying the invasiveness of nonnative forest tree species and the large-scale potential for ecological impacts on forest communities by nonnative tree species; chapter 10, which describes a newly developed drought index methodology that allows for the comparison of moisture conditions between geographical areas and across periods of time; and chapters 4 and 9 , which use a geographical information system (GIS) hot spot analysis to detect significant clusters of forest mortality and defoliation as well as significant clusters of forest fire occurrences.

The third objective of the report, addressed in the second section, is to present results of recently completed evaluation monitoring (EM) projects funded through the FHM national program. These projects determine the extent, severity, and causes of forest health problems (FHM 2009), generally at a finer scale than that addressed by the analyses in the first section of the report. Each chapter in the second section of the report contains an overview of the EM project, key results, and contacts for more information.

\section{Organization of the Report}

The Forest Service has adopted the Santiago Declaration and accompanying Criteria and Indicators for the Conservation and Sustainable Management of Temperate and Boreal Forests (Montréal Process Working Group 2007) as a forest sustainability assessment framework (Smith and others 2001, USDA Forest Service 2004). The seven criteria are:

Criterion 1-Conservation of biological diversity

Criterion 2-Maintenance of productive capacity of forest ecosystems

Criterion 3-Maintenance of forest ecosystem health and vitality

Criterion 4-Conservation and maintenance of soil and water resources

Criterion 5-Maintenance of forest contribution to global carbon cycles

Criterion 6-Maintenance and enhancement of long-term multiple socio-economic benefits to meet the needs of societies

Criterion 7-Legal, institutional, and economic framework for forest conservation and sustainable management 
Chapter 2 addresses Criterion 1, conservation of biological diversity. The rest of the first section of this report is limited to assessments relating to Criterion 3, maintenance of forest ecosystem health and vitality, specifically Indicator 15, which quantifies the area and percent of forest affected by biotic agents beyond reference conditions (chapters $3,4,5,6$, and 7), and Indicator 16, which quantifies the area and percent of forest affected by abiotic agents beyond reference conditions (chapters 8, 9, and 10).

When appropriate throughout this report, authors use Bailey's revised ecoregion provinces and sections (Cleland and others 2007) as a common ecologically based spatial framework for their forest health assessments (fig. 1.1). Specifically, when the spatial scale of the data and the expectation of an identifiable pattern in the data are appropriate, authors use ecoregion sections as assessment units for their analyses. In Bailey's hierarchical system, the two broadest ecoregion scales, domains and divisions, are based on large ecological climate zones, while each division is broken into provinces based on vegetation macrofeatures (Bailey 1995). Provinces are further divided into sections, which may be thousands of $\mathrm{km}^{2}$ in extent and are expected to encompass regions similar in their geology, climate, soils, potential natural vegetation, and potential natural communities (Cleland and others 1997).

\section{Data Sources}

Forest Service data sources included in this report are FIA annualized phase 2 survey data, FHP insect and disease survey forest mortality and defoliation data (1997-2008), Moderate Resolution Imaging Spectroradiometer (MODIS) Active Fire Detections for the United States database (2001-08), and forest cover data developed from MODIS satellite imagery by the U.S. Forest Service Remote Sensing Applications Center.

Other sources of data are a list from the Animal and Plant Health Inspection Service (APHIS), U.S. Department of Agriculture, of proven and associated hosts for Phytophthora ramorum (USDA Animal and Plant Health Inspection Service 2008); daily weather station data from the National Climatic Data Center (NCDC); Biota of North America county-level plant species distribution data (Kartesz 2009); digital representations of the distributions of North American forest tree species (United States Geological Survey 1999); wildland-urban interface data (Radeloff and others 2005); Parameter-elevation Regression on Independent Slopes (PRISM) climate mapping system data (PRISM Group 2009); and the 2001 National Land Cover Database (NLCD) map (Homer and others 2007). 

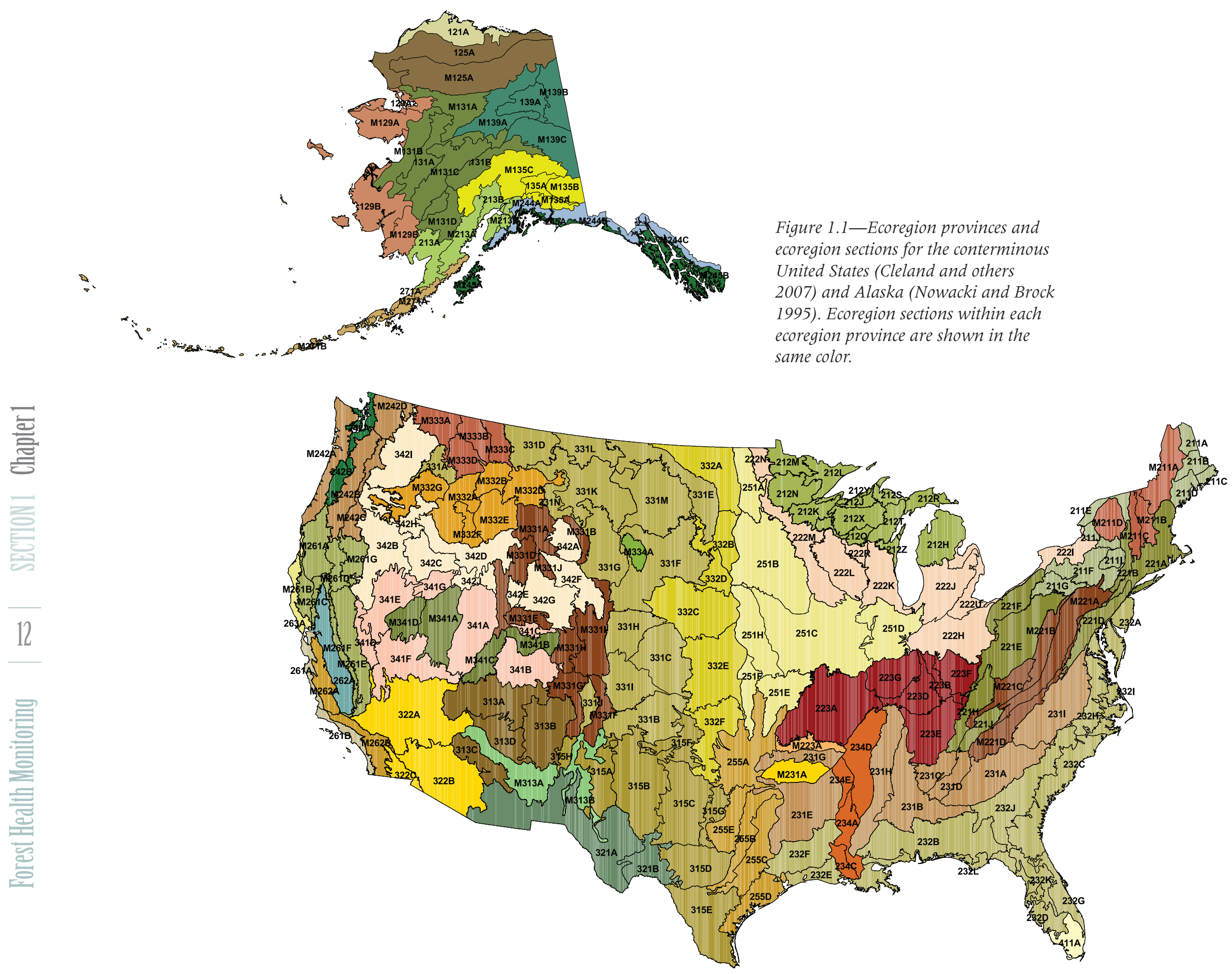
Alaska ecoregion provinces

Alaska Mixed Forest (213)

Alaska Range Taiga (135)

Aleutian Meadow (271)

Arctic Tundra (121)

Bering Sea Tundra (129)

Brooks Range Tundra (125)

Pacific Coastal Icefields (244)

Pacific Coastall Icefields (244)

Upper Yukon Taiga (139)

Yukon Intermontaine Taiga (131)

Eastern ecoregion provinces

Adirondack-New England Mixed Forest-Coniferous Forest-Alpine Meadow (M211)

Central Appalachian Broadleaf Forest-Coniferous Forest-Meadow (M221)

Central Interior Broadleaf Forest (223)

Eastern Broadleaf Forest (221)

Everglades (411)

Laurentian Mixed Forest (212)

Lower Mississippi Riverine Forest (234)

Midwest Broadleaf Forest (222)

Northeastern Mixed Forest (211)

Ouachita Mixed Forest-Meadow (M231)

Outer Coastal Plain Mixed Forest (232)

Ozark Broadleaf Forest (M223)

Prairie Parkland (Subtropical) (255)

Prairie Parkland (Temperate) (251)

Southeastern Mixed Forest (231)

Western ecoregion provinces

American Semi-Desert and Desert (322)

Arizona-New Mexico Mountains Semi-Desert-Open Woodland—Coniferous Forest—Alpine Meadow (M313)

Black Hills Coniferous Forest (M334)

California Coastal Chapparal Forest and Shrub (261)

California Coastal Range Open Woodland-Shrub-Coniferous Forest-Meadow (M262)

California Coastal Steppe-Mixed Forest—Redwood Forest (263)

California Dry Steppe (262)

Cascade Mixed Forest-Coniferous Forest-Alpine Meadow (M242)

Chihuahuan Semi-Desert (321)

Colorado Plateau Semi-Desert (313)

Great Plains-Palouse Dry Steppe (331)

Great Plains Steppe (332)

Intermountain Semi-Desert (342)

Intermountain Semi-Desert and Desert (341)

Middle Rocky Mountain Steppe-Coniferous Forest-Alpine Meadow (M332)

Nevada—Utah Mountains Semi-Desert-Coniferous Forest-Alpine Meadow (M341)

Northern Rocky Mountains Forest-Steppe-Coniferous Forest-Alpine Meadow (M333)

Pacific Lowland Mixed Forest (242)

Sierran Steppe-Mixed Forest-Coniferous Forest-Alpine Meadow (M261)

Southern Rocky Mountain Steppe-Open Woodland-Coniferous Forest-Alpine Meadow (M331)

Southwest Plateau and Plains Dry Steppe and Shrub (315) 
A major source of data for FHM analyses is the FIA program, which collects forest inventory information across all forest land ownerships in the United States. The FIA program maintains a network of more than 125,000 permanent ground plots across the conterminous United States, with a sampling intensity of approximately one plot per 2,428 ha. The FIA program's phase 2 encompasses the annualized inventory measured on plots at regular intervals, with each plot surveyed every 5 to 7 years in most eastern States, but with plots in the Rocky Mountain and Pacific Northwest regions surveyed once every 10 years (Reams and others 2005). The standard 0.067-ha plot (fig. 1.2) consists of four 7.315-meter radius subplots (approximately $168.6 \mathrm{~m}^{2}$ ), on which field crews measure trees at least 5 inches in diameter. Within each of these subplots is nested a 2.073-meter radius microplot (approximately $13.48 \mathrm{~m}^{2}$ ), on which crews measure trees smaller than 5 inches in diameter. A coreoptional variant of the standard design includes four "macroplots," each with radius of 17.953 meters or approximately 0.1012 hectare that originates at the center of each subplot (FIA 2009).

FIA phase 3 plots represent a subset of these phase 2 plots, with one phase 3 plot for every 16 standard phase 2 plots. In addition to traditional forest inventory measurements, data for a variety of important ecological indicators are collected from phase 3 plots, including tree crown condition, lichen communities, down woody material, soil condition, and vegetation

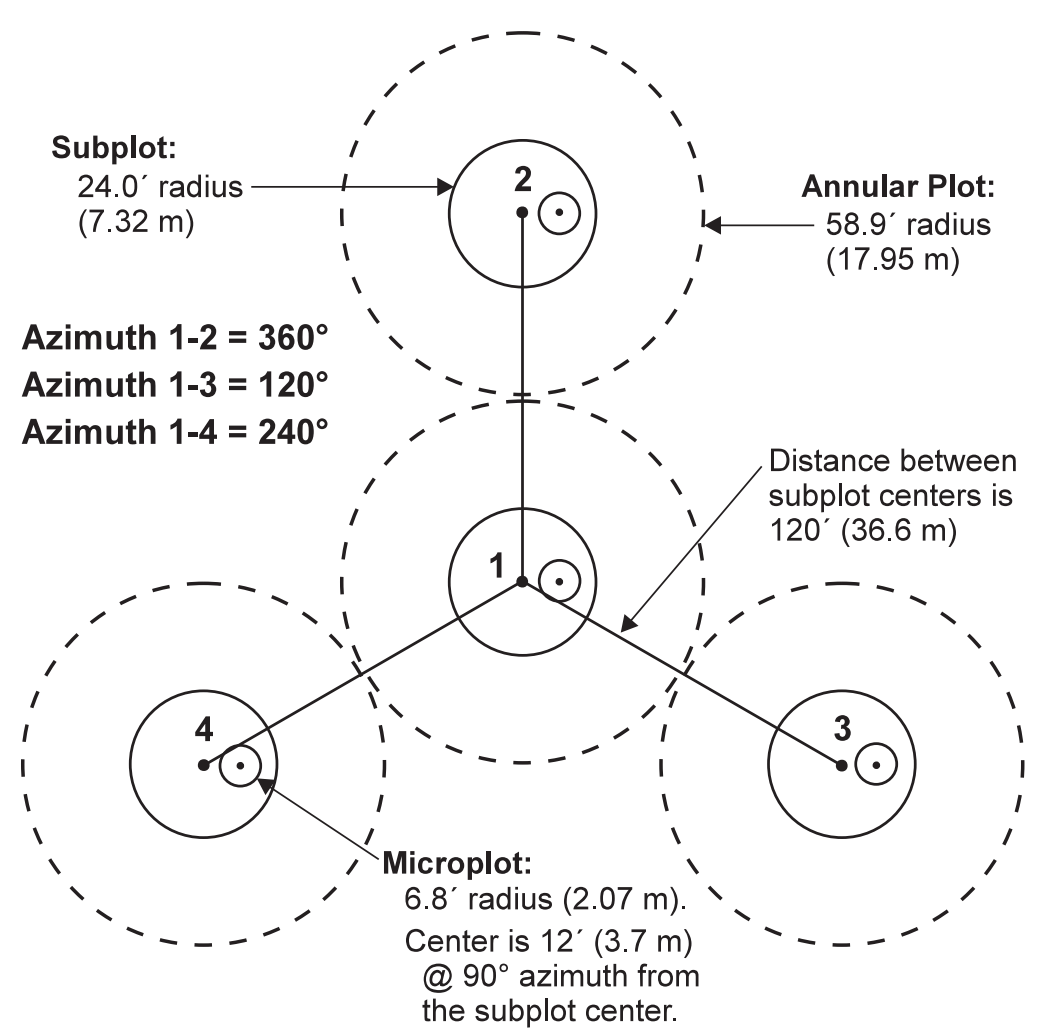

Figure 1.2-The mapped plot design used by the Forest Inventory and Analysis Program of the Forest Service, U.S. Department of Agriculture. Subplot 1 is the center of the cluster with subplots 2, 3, and 4 located 120 feet away at azimuths of $360^{\circ}, 120^{\circ}$, and $240^{\circ}$, respectively (Forest Inventory and Analysis 2009). 
structure and diversity. Additionally, data on ozone bioindicator plants are collected on a separate grid of plots. Most of these additional forest health indicators were measured as part of the FHM Detection Monitoring ground plot system prior to $2000^{1}$ (Palmer and others 1991).

\section{The Forest Health}

\section{Monitoring Program}

The national FHM Program is designed to determine the status, changes, and trends in indicators of forest condition on an annual basis, and covers all forested lands through a partnership encompassing the Forest Service, State foresters, and other State and Federal agencies and academic groups (FHM 2008). The FHM program utilizes data from a wide variety of data sources, both inside and outside the Forest Service, and develops analytical approaches for addressing forest health issues that affect the sustainability of forest ecosystems. It has five major activities (fig. 1.3):

- Detection Monitoring-nationally standardized aerial and ground surveys to evaluate status and change in condition of forest ecosystems

\footnotetext{
${ }^{1}$ U.S. Department of Agriculture, Forest Service. 1998 Forest Health Monitoring 1998 field methods guide. Research Triangle Park, NC: U.S. Department of Agriculture, Forest Service, National Forest Health Monitoring Program. 473 p. On file with: Forest Health Monitoring Program, 3041 Cornwallis Rd., Research Triangle Park, NC 27709.
}

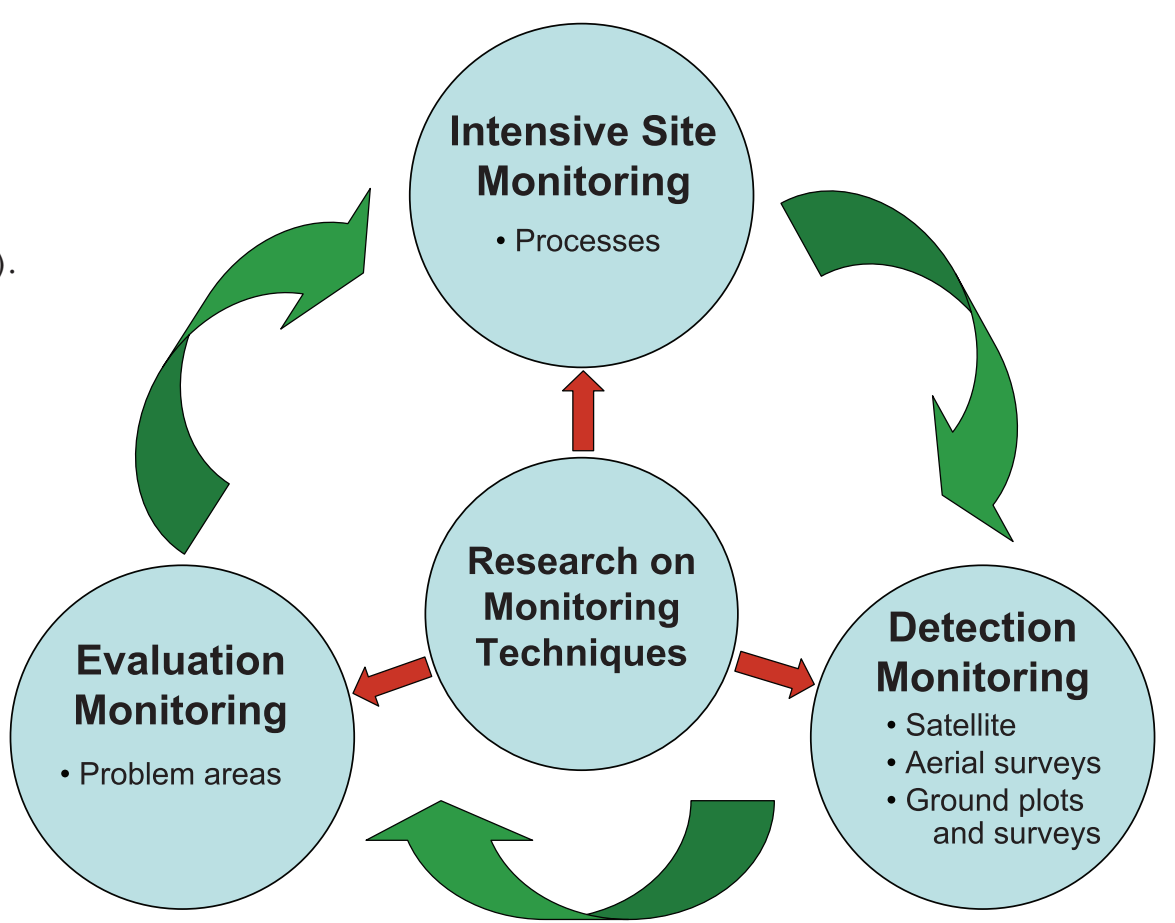

Figure 1.3-The design of the Forest Health Monitoring (FHM) Program of the Forest Service, U.S. Department of Agriculture (FHM 2003). A fifth component, analysis and reporting of results, draws from the four FHM components shown here and provides timely information to help support land management policies and decisions. 
- Evaluation Monitoring-projects to determine extent, severity, and causes of undesirable changes in forest health identified through detection monitoring

- Intensive Site Monitoring-projects to enhance understanding of cause-effect relationships by linking detection monitoring to ecosystem process studies and assess specific issues, such as calcium depletion and carbon sequestration, at multiple spatial scales

- Research on Monitoring Techniques-work to develop or improve indicators, monitoring systems, and analytical techniques, such as urban and riparian forest health monitoring, early detection of invasive species, multivariate analyses of forest health indicators, and spatial scan statistics

- Analysis and Reporting — synthesis of information from various data sources within and external to the Forest Service to produce issue-driven reports on status and change in forest health at national, regional, and State levels

In addition to its national reporting efforts, the FHM program generates regional and State reports. These reports may be produced with FHM partners, both within the Forest Service and in State forestry and agricultural departments. Recent examples are Cumming and others $(2006,2007)$, Keyes and others (2003), Lake and others (2006), Laustsen and others (2003), Morin and others (2006), Neitlich and others (2003), and Steinman (2004). The Forest Health Highlights series, available on the FHM Web site at www.fs.fed.us/foresthealth/ $\mathrm{fhm}$, is produced by the FHM regions in cooperation with their respective State partners. The FHM program and its partners also produce reports on monitoring techniques and analytical methods, including analyzing forest health data (Smith and Conkling 2004), soils as an indicator of forest health (O'Neill and others 2005), crown-condition classification (Schomaker and others 2007), and sampling and estimation procedures for vegetation diversity and structure (Schulz and others 2009).

For more information, visit the FHM Web site at www.fs.fed.us/foresthealth/fhm. This report is produced by the national FHM research team, part of the Eastern Forest Environmental Threat Assessment Center, which was established under the Healthy Forest Restoration Act to generate knowledge and tools needed to anticipate and respond to environmental threats. For more information about the research team, and about threats to forests, please visit www. forestthreats.org/about. 


\section{Literature Cited}

Bailey, R.G. 1995. Descriptions of the ecoregions of the United States. $2^{\mathrm{d}}$ ed. Misc. Publ. 1391. Washington, DC: U.S. Department of Agriculture Forest Service. 108 p. Map scale $1: 7,500,000$.

Cleland, D.T.; Avers, P.E.; McNab, W.H. [and others]. 1997. National hierarchical framework of ecological units. In Boyce, M.S.; Haney, A., eds. Ecosystem management applications for sustainable forest and wildlife resources. New Haven, CT: Yale University Press: 181-200.

Cleland, D.T.; Freeouf, J.A.; Keys, J.E. [and others]. 2007. Ecological subregions: Sections and subsections for the conterminous United States. Sloan, A.M., tech. ed. Gen. Tech. Rep. WO-76. Washington, DC: U.S. Department of Agriculture Forest Service. [Map, presentation scale 1:3,500,000; Albers equal area projection; colored]. Also on CD-ROM as a GIS coverage in ArcINFO format or at http://fsgeodata.fs.fed.us/other_resources/ecosubregions. html. [Date accessed: March 18, 2011].

Cumming, A.B.; Twardus, D.B.; Smith, W.D. 2006. Maryland and Massachusetts Street Tree Monitoring Pilot Projects. NA-FR-01-06. Newtown Square, PA: U.S. Department of Agriculture Forest Service, Northeastern Area, State and Private Forestry. 23 p. http://na.fs.fed.us/pubs/fhm/street trees/md_ma_street_tree_proj_lr.pdf. [Date accessed: March 18, 2011].

Cumming, A.B.; Nowak, D.J.; Twardus, D.B. [and others] 2007. Urban forests of Wisconsin: pilot monitoring project 2002. NA-FR-05-07. Newtown Square, PA: U.S. Department of Agriculture Forest Service, Northeastern Area State and Private Forestry. 33 p. Available online: Low resolution: http://www.na.fs.fed.us/pubs/fhm/ pilot/pilot_study_wisconsin_02_lr.pdf. High resolution: http://www.na.fs.fed.us/pubs/fhm/pilot/pilot study wisconsin2_02_hr.pdf. [Date accessed: October 19, 2007]

Forest Health Monitoring (FHM). 2003. Forest Health Monitoring: A National Strategic Plan. http://fhm.fs.fed. us/annc/strategic_plan03.pdf. [Date accessed: August 24, 2011]

Forest Health Monitoring (FHM). 2008. Program description. Forest Health Monitoring Fact Sheet Series. http://www. fhm.fs.fed.us/fact/. [Date accessed: September 3, 2008].
Forest Health Monitoring (FHM). 2009. Evaluation monitoring. Forest Health Monitoring Fact SheetSeries. http://fhm.fs.fed.us/fact/pdf_files/fhm_em_2009.pdf. [Date accessed: December 8, 2009].

Forest Inventory and Analysis (FIA). 2009. The Forest Inventory and Analysis Database: Database Description and Users Manual Version 4.0 for Phase 2 draft (April, 2009). http://www.fia.fs.fed.us/library/databasedocumentation. [Date accessed: May 1, 2009].

Homer, C.; Dewitz, J.; Fry, J. [and others]. 2007. Completion of the 2001 National Land Cover Database for the conterminous United States. Photogrammetric Engineering and Remote Sensing. 73: 337-341.

Kartesz, J.T. 2009. A synonymized checklist and atlas with biological attributes for the vascular flora of the United States, Canada, and Greenland. Version 2.0 [CD-ROM]. Chapel Hill, NC: Biota of North America Program, North Carolina Botanical Garden, University of North Carolina.

Keyes, C.: Rogers, P.; LaMadeleine, L. [and others]. 2003. Utah forest health report: a baseline assessment, 1999 2001. Salt Lake City, UT: Utah Dept. of Natural Resources, Division of Forestry, Fire and State Lands. 47 p.

Kolb, T.E.; Wagner, M.R.; Covington, W.W. 1994. Concepts of forest health: Utilitarian and ecosystem perspectives. Journal of Forestry. 92: 10-15.

Lake, M.; Marshall, P.; Mielke, M. [and others]. 2006. National Forest Health Monitoring program monitoring urban forests in Indiana: pilot study 2002, Part 1. Analysis of field methods and data collection. Gen. Tech Rep. NA FR-06-06. Newtown Square, PA: U.S. Department of Agriculture Forest Service, Northeastern Area. http:// www.fhm.fs.fed.us/pubs/ufhm/indianaforests02/ indianaforests02.html. [Date accessed: November 6, 2007]

Laustsen, K.M.; Griffith, D.M.; Steinman, J.R. 2003. Fourth annual inventory report on Maine's forests. Newtown Square, PA: U.S. Department of Agriculture Forest Service, Northeastern Research Station and Northeastern Area. 49 p. http://www.maine.gov/doc/mfs/pubs/pdf/ anninv/2002invrpt.pdf. [Date accessed: March 18, 2011]

Montréal Process Working Group. 2007. The Montréal Process, third edition. 12 p. http://www.rinya.maff.go.jp/ mpci/rep-pub/1995/santiago_e.html. [Date accessed: May 22, 2008] 
Morin, R.S.; Liebhold, A.M.; Gottschalk, K.W. [and others] 2006. Analysis of Forest Health Monitoring surveys on the Allegheny National Forest (1998-2001). Gen. Tech. Rep. NE-339. Newtown Square, PA: U.S. Department of Agriculture Forest Service, Northeastern Research Station. 102 p. http://www.fs.fed.us/ne/newtown_square/ publications. [Date accessed: November 6, 2007].

Neitlich, P.; Rogers, P.; Rosentretter, R. 2003. Lichen communities indicator results from Idaho: baseline sampling. Gen. Tech. Rep. RMRS-GTR-103. Fort Collins, CO: U.S. Department of Agriculture Forest Service, Rocky Mountain Research Station. $14 \mathrm{p}$.

Nowacki, G.; Brock, T. 1995. Ecoregions and Subregions of Alaska, EcoMap. Version 2.0. Juneau, AK: U.S. Department of Agriculture Forest Service, Alaska Region. Map 1:5,000,000; colored.

O'Neill, K.P.; Amacher, M.C.; Perry, C.H. 2005. Soils as an indicator of forest health: a guide to the collection, analysis, and interpretation of soil indicator data in the Forest Inventory and Analysis Program. Gen. Tech. Rep. NC-258. St. Paul, MN: U.S. Department of Agriculture Forest Service, North Central Research Station. 53 p.

Palmer, C.J.; Riitters, K.H; Strickland, T. [and others] 1991. Monitoring and research strategy for forestsEnvironmental Monitoring and Assessment Program (EMAP). EPA 600/4-91/012. Washington, DC: U.S. Environmental Protection Agency, Office of Research and Development. $189 \mathrm{p}$

PRISM Group. 2009. 2.5-arcmin (4 km) gridded monthly climate data. ftp://prism.oregonstate.edu//pub/prism/us/ grids. [Date accessed: April 6, 2009].

Radeloff, V.C.; Hammer, R.B.; Stewart, S.I. [and others]. 2005. The wildland-urban interface in the United States. Ecological Applications. 15(3): 799-805.

Raffa, K.F.; Aukema, B.; Bentz, B.J. [and others]. 2009. A literal use of "forest health" safeguards against misuse and misapplication. Journal of Forestry. 107: 276-277.

Reams, G.A.; Smith, W.D.; Hansen, M.H. [and others]. 2005. The Forest Inventory and Analysis sampling frame. In: Bechtold, W.A.; Patterson, P.L., ed. The Enhanced Fores Inventory and Analysis Program-National Sampling Design and Estimation Procedures. Asheville, NC: United States Department of Agriculture Forest Service, Southern Research Station: 11-26.
Schomaker, M.E.; Zarnoch, S.J.; Bechtold, W.A. [and others]. 2007. Crown-condition classification: a guide to data collection and analysis. Gen. Tech. Rep. SRS-102. Asheville, NC: U.S. Department of Agriculture Forest Service, Southern Research Station. 78 p.

Schulz, B.K.; Bechtold, W.A.; Zarnoch, S.J. 2009. Sampling and estimation procedures for the vegetation diversity and structure indicator. Gen. Tech. Rep. PNW-GTR-781. Portland, OR: U.S. Department of Agriculture Forest Service, Pacific Northwest Research Station. 53 p.

Smith, W.D.; Conkling, B.L. 2004. Analyzing forest health data. Gen. Tech. Rep. SRS-077. Asheville, NC: U.S. Department of Agriculture Forest Service, Southern Research Station, 33 p. http://www.srs.fs.usda.gov/pubs gtr/gtr_srs077.pdf. [Date accessed: November 6, 2007].

Smith, W.B.; Vissage, J.S.; Darr, D.R.; Sheffield, R.M 2001. Forest resources of the United States, 1997. Gen. Tech. Rep. NC-219. St. Paul, MN: U.S. Department of Agriculture Forest Service, North Central Research Station. $191 \mathrm{p}$.

Smith, W.B.; Miles, P.D.; Vissage, J.S.; Pugh, S.A. 2004 Forest resources of the United States, 2002. Gen. Tech. Rep. NC-241. St. Paul, MN: U.S. Department of Agriculture Forest Service, North Central Research Station. 137 p.

Steinman, J. 2004. Forest Health Monitoring in the Northeastern United States: Disturbances and Conditions during 1993-2002. NA-Technical Paper 01-04. Newtown Square, PA: U.S. Department of Agriculture Forest Service, State and Private Forestry, Northeastern Area. 46 p. http:// thm.fs.fed.us/pubs/tp/dist_cond/dc.shtml. [Date accessed: December 8, 2009].

U.S. Department of Agriculture, Animal and Plant Health Inspection Service (APHIS). 2008. APHIS list of regulated hosts and plants associated with Phytophthora ramorum. http://www.aphis.usda.gov/plant_health/plant_pest_info/ pram/downloads/pdf_files/usdaprlist.pdf. [Date accessed: February 11, 2009].

U.S. Department of Agriculture, Forest Service. 2004. National report on sustainable forests-2003. FS-766. Washington, DC: U.S. Department of Agriculture Forest Service. $139 \mathrm{p}$.

U.S. Geological Survey. 1999. Digital representation of "Atlas of United States Trees" by Elbert L. Little, Jr. http://esp. cr.usgs.gov/data/atlas/little/. [Date accessed: March 13, 2009]. 


\section{Introduction}

s development introduces competing land uses into forest and grassland landscapes, the 1 public concerns for landscape patterns are expressed through headline issues such as urban sprawl and forest fragmentation. The task for resource managers is to maintain an appropriate balance of biodiversity, water quality, recreation experience, and other amenities in forest and grassland ecosystems. A prerequisite for informed actions at local, regional, and national scales is reliable information about landscape patterns at those scales. National assessments document the status and trends of landscape patterns in a consistent fashion nationwide, making it possible to identify national strategies to achieve particular objectives. To the extent that nationally available input data are able to also capture important local details, the same information can be used for local planning as well.

Previous reports by the national Forest Health Monitoring (FHM) Program of the Forest Service, U.S. Department of Agriculture, (Ambrose and others 2008, Conkling 2011, Coulston and others 2005, Potter and Conkling 2012) have addressed different aspects of forest and grassland spatial patterns, but have been limited by data available for the conterminous United States plus the District of Columbia. Following the recent release (Homer and others 2007) of the 2001 National Land Cover Database (NLCD) for the States of Alaska and
Hawaii and the Commonwealth of Puerto Rico (hereafter, all referred to as "States"), the objective of this chapter is to extend landscape pattern assessments to these additional States. The spatial patterns of forest and grassland ("sectors") are evaluated with several measures of landcover composition and configuration. The analyses are conducted at several spatial scales, and the results are summarized in two ways to highlight landscape-level and sector-level interpretations.

\section{Methods}

Three fundamental metrics of landscape patterns are measured on landcover maps of Alaska, Hawaii, and Puerto Rico. The three metrics are "area density" (a measure of landcover dominance), "landscape mosaic" (landcover juxtaposition), and "morphological spatial pattern" (landcover spatial structure). Several analysis scales are defined by neighborhood size (for area density and landscape mosaic) or by effective edge width (morphological spatial pattern). The results are summarized separately at the landscape level, and separately for the forest and grassland sectors, by scale and by State. This section describes with examples the input landcover maps and the procedures for measuring the metrics and summarizing the results.

Landcover maps-The input database is a set of landcover maps for Alaska, Hawaii, and Puerto Rico that were extracted from the 2001
CRITERION ]-

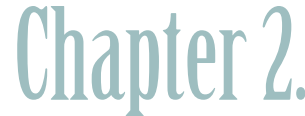

Landscape Patternand Context of Forest and Grassland in Alaska, Hawail, and Puerto Rico

KURT H. RIITTERS 
NLCD (Homer and others 2004, 2007). The NLCD maps have a spatial resolution of 0.09 ha pixel $^{-1}$ (i.e., each pixel is $30 \mathrm{~m} \times 30 \mathrm{~m}$, about the size of a baseball diamond infield) and a thematic resolution of 19 landcover types (table 2.1). The landcover maps of Alaska, Hawaii, and Puerto Rico contain approximately 1.7 billion, 19 million, and 10 million pixels, respectively.

For analyses, the thematic resolution was condensed from 19 to 8 generalized landcover types (table 2.1), including generalized "forest" and "grassland" types. Since landcover patterns are typically correlated with the amounts of different landcover types in a landscape, the proportions of each State that are covered by each of the eight generalized NLCD classes (table 2.1) provide information for interpreting the pattern measurements. The analyses considered adjacent ocean water area; for reporting, the map extents were limited to the boundaries of detailed State maps (fig. 2.1) (ESRI 2005).

Area density-As a measure of landcover dominance, area density describes a given pixel on a landcover map by the proportion of the neighboring pixels that are either forest ("forest area density") or grassland ("grassland area density"). The measurements were conducted with a "moving window" algorithm (e.g., Riitters and others 2002) that measured both forest and grassland area density in the unique neighborhoods (hereafter, "landscapes") surrounding each individual pixel on the landcover maps. The measurements were
Table 2.1 - The percentages of Alaska, Hawaii and Puerto Rico that are covered by each of the eight generalized NLCD landcover classes. The original 19 NLCD

\section{landcover types are shown for comparisons}

\begin{tabular}{|c|c|c|c|c|}
\hline \multirow{2}{*}{$\begin{array}{l}\text { Generalized } \\
\text { landcover type }\end{array}$} & Alaska & Hawaii & $\begin{array}{l}\text { Puerto } \\
\text { Rico }\end{array}$ & \multirow{2}{*}{$\begin{array}{l}\text { Included original NLCD } \\
\text { landcover types }\end{array}$} \\
\hline & \multicolumn{3}{|c|}{ Percent of total State area } & \\
\hline Water, Ice & $\begin{array}{r}8.9 \\
(2)^{a}\end{array}$ & $\begin{array}{r}0.3 \\
(50)\end{array}$ & $\begin{array}{r}0.9 \\
(45)\end{array}$ & $\begin{array}{l}\text { Open water; } \\
\text { Perennial ice/snow }\end{array}$ \\
\hline Developed & $\begin{array}{r}0.1 \\
(52)\end{array}$ & $\begin{array}{r}8.6 \\
(19)\end{array}$ & $\begin{array}{r}14.6 \\
(6)\end{array}$ & $\begin{array}{l}\text { Developed, open space; } \\
\text { Developed, low intensity; } \\
\text { Developed, medium intensity; } \\
\text { Developed, high intensity }\end{array}$ \\
\hline Barren & $\begin{array}{l}8.4 \\
(3)\end{array}$ & $\begin{array}{r}14.1 \\
(1)\end{array}$ & $\begin{array}{r}0.5 \\
(22)\end{array}$ & Barren land \\
\hline Forest & $\begin{array}{l}29.0 \\
(34)\end{array}$ & $\begin{array}{l}28.4 \\
(35)\end{array}$ & $\begin{array}{l}46.5 \\
(22)\end{array}$ & $\begin{array}{l}\text { Deciduous forest; } \\
\text { Evergreen forest; } \\
\text { Mixed forest; } \\
\text { Woody wetlands }\end{array}$ \\
\hline Shrubland & $\begin{array}{r}43.0 \\
(7)\end{array}$ & $\begin{array}{l}29.0 \\
(11)\end{array}$ & $\begin{array}{r}2.7 \\
(23)\end{array}$ & $\begin{array}{l}\text { Dwarf scrub; } \\
\text { Scrub/shrub }\end{array}$ \\
\hline Grassland & $\begin{array}{r}7.3 \\
(17)\end{array}$ & $\begin{array}{l}13.4 \\
(12)\end{array}$ & $\begin{array}{l}28.3 \\
(10)\end{array}$ & $\begin{array}{l}\text { Grassland/herbaceous; } \\
\text { Sedge herbaceous; } \\
\text { Moss }\end{array}$ \\
\hline Agriculture & $\begin{array}{l}<0.1 \\
(52)\end{array}$ & $\begin{array}{r}6.2 \\
(42)\end{array}$ & $\begin{array}{r}4.9 \\
(43)\end{array}$ & $\begin{array}{l}\text { Pasture/hay; } \\
\text { Cultivated crops }\end{array}$ \\
\hline Wetland & $\begin{array}{l}3.3 \\
(7)\end{array}$ & $\begin{array}{r}0.1 \\
(49)\end{array}$ & $\begin{array}{r}1.5 \\
(16)\end{array}$ & Emergent herbaceous wetland \\
\hline
\end{tabular}

Due to rounding, columns may not sum to 100 .

${ }^{a}$ The numbers in parentheses indicate the descending rank among the 50 States plus the District of

Columbia and Puerto Rico for that proportion. 


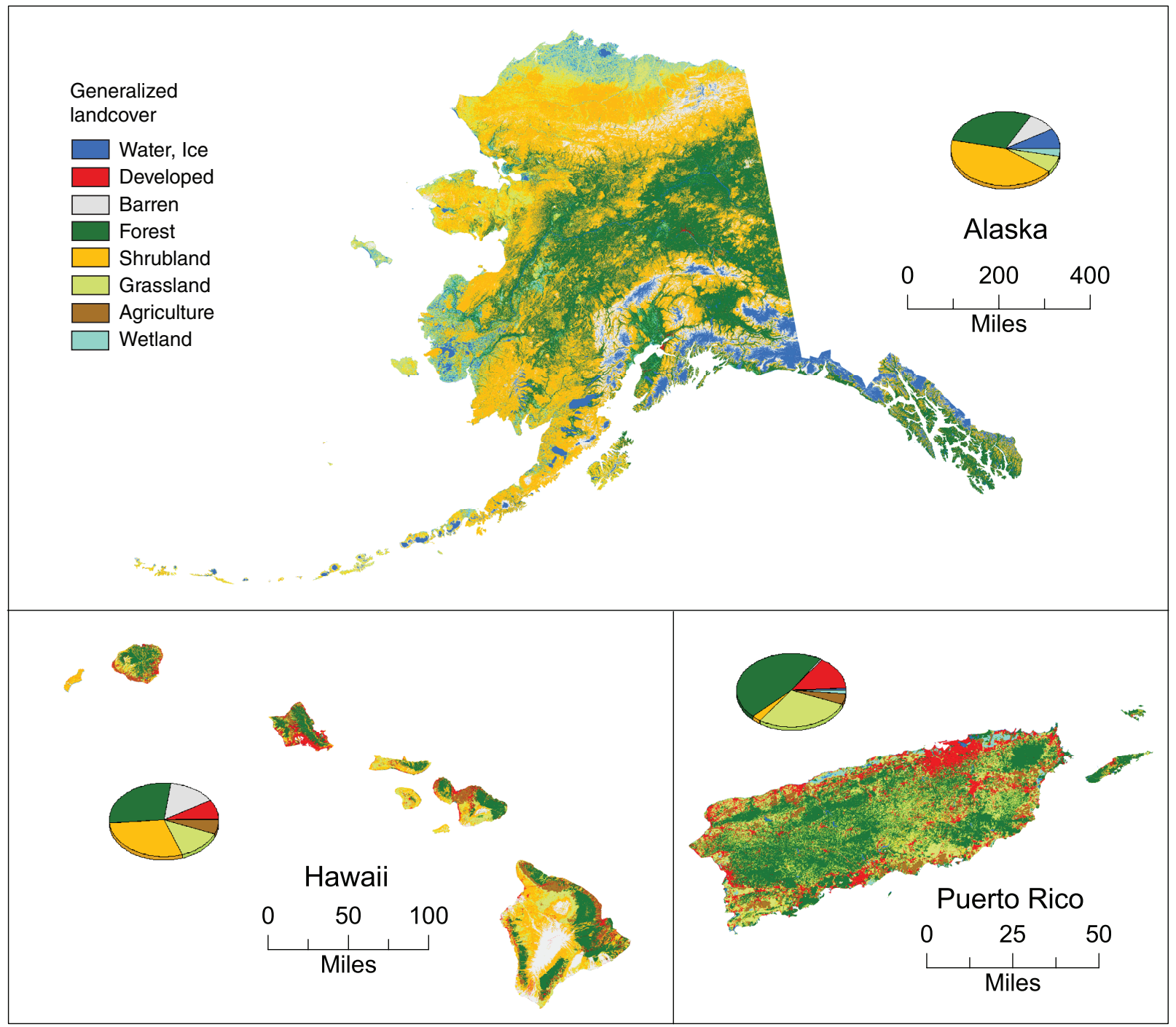

Figure 2.1-Generalized landcover types for Alaska, Hawaii, and Puerto Rico. Source: NLCD 2001 (Homer and others 2007). 
repeated using square landscapes of size 15.21 ha ( 13 pixels $x 13$ pixels) and 590.49 ha $(81 \times 81)$. The four measured area density values for a given landcover pixel were then stored as new pixel values on four new maps at the location of that landcover pixel. For example, a pixel value on a map of grassland area density, 15.21-ha scale, represents the proportion of the surrounding 15.21-ha landscape that was grassland on the input landcover map. Generally, a pixel value on a map of forest (or grassland) area density represents the proportion of the surrounding 15.21-ha (or 590.49-ha) landscape that was forest (or grassland) on the original landcover map. By using that procedure, area density is defined as a contextual (landscape) attribute. The procedure preserves options for post-stratification because the spatial resolution of the four area density maps is the same as that of the input landcover maps (0.09 ha pixel ${ }^{-1}$ ). The measured values were continuous in the range $[0,1]$ and were converted to seven area density classes for reporting (table 2.2). Figure 2.2 illustrates the input and output maps for an arbitrary landcover type called "foreground."

Landscape mosaic - As a measure of landcover juxtaposition and anthropogenic interface zones, the landscape mosaic metric describes a given pixel on a landcover map by the relative proportions of the neighboring pixels that are "agriculture," "developed," or "natural" (i.e., neither agriculture nor developed) on the landcover map. The measurements were conducted by using an algorithm (Riitters and others 2009b) that is similar to the algorithm used for the area density measurements, and employed the same two landscape sizes (15.21 ha and 590.49 ha). For a given pixel on the landcover map, the measured proportions of the three generalized landcover types (i.e., agriculture, developed, and natural) were converted to a landscape mosaic categorical value by using a tri-polar classification model (fig. 2.3). Thus, a pixel value on a map of landscape mosaics represents the landscape mosaic category of the 15.21-ha (or 590.49-ha) landscape surrounding that pixel location on the original landcover map. Like the area density maps, the landscape mosaic maps describe the landscape context surrounding a given landcover pixel, and options are preserved for post-

stratification because the spatial resolution of the landscape mosaic maps is the same as that of the input landcover maps (0.09 ha pixel $\left.{ }^{-1}\right)$.

\section{Table 2.2-Conversion of continuous area-density} measurements to categorical values for reporting

\begin{tabular}{lc}
\hline Area density class & $\begin{array}{c}\text { Continuous area density } \\
(\mathrm{p}) \text { range }\end{array}$ \\
\hline Intact & $\mathrm{p}=1.0$ \\
Interior & $0.9 \leq \mathrm{p}<1.0$ \\
Dominant & $0.6 \leq \mathrm{p}<0.9$ \\
Transitional & $0.4 \leq p<0.6$ \\
Patchy & $0.1 \leq p<0.4$ \\
Rare & $0.0 \leq p<0.1$ \\
None & $p=0.0$ \\
\hline
\end{tabular}

Note: area density (p) was measured separately for forest and grassland. 


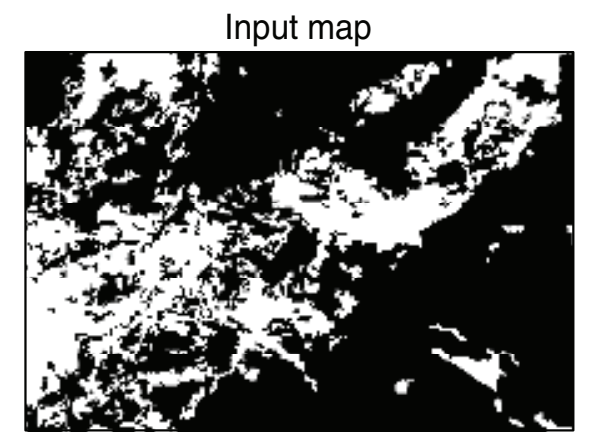

15-ha landscape

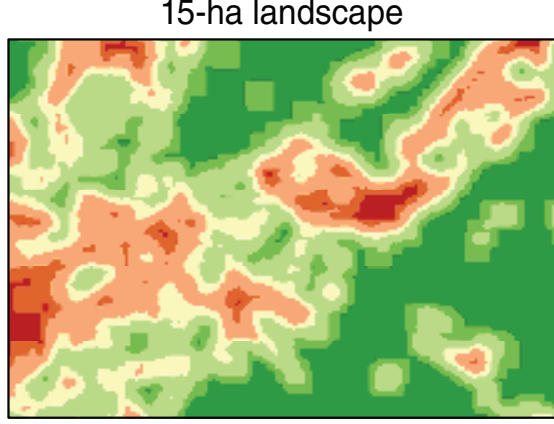

Foreground

density class

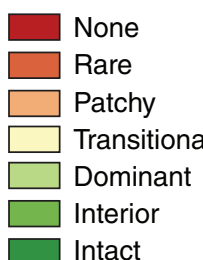

590-ha landscape

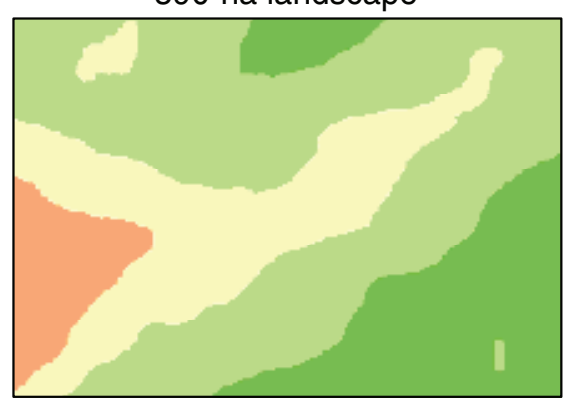

Figure 2.2-Illustration of the area density metric for an arbitrary landcover type called foreground using landscape sizes of 15 ha and 590 ha. The original landcover map was converted to a binary map of "foreground" (forest or grassland) and "background" (top). Maps of the foreground area density in a surrounding landscape are shown for 15-ha (middle) and 590-ha (bottom) neighborhoods. See table 2.2 for definitions of the area density classes.

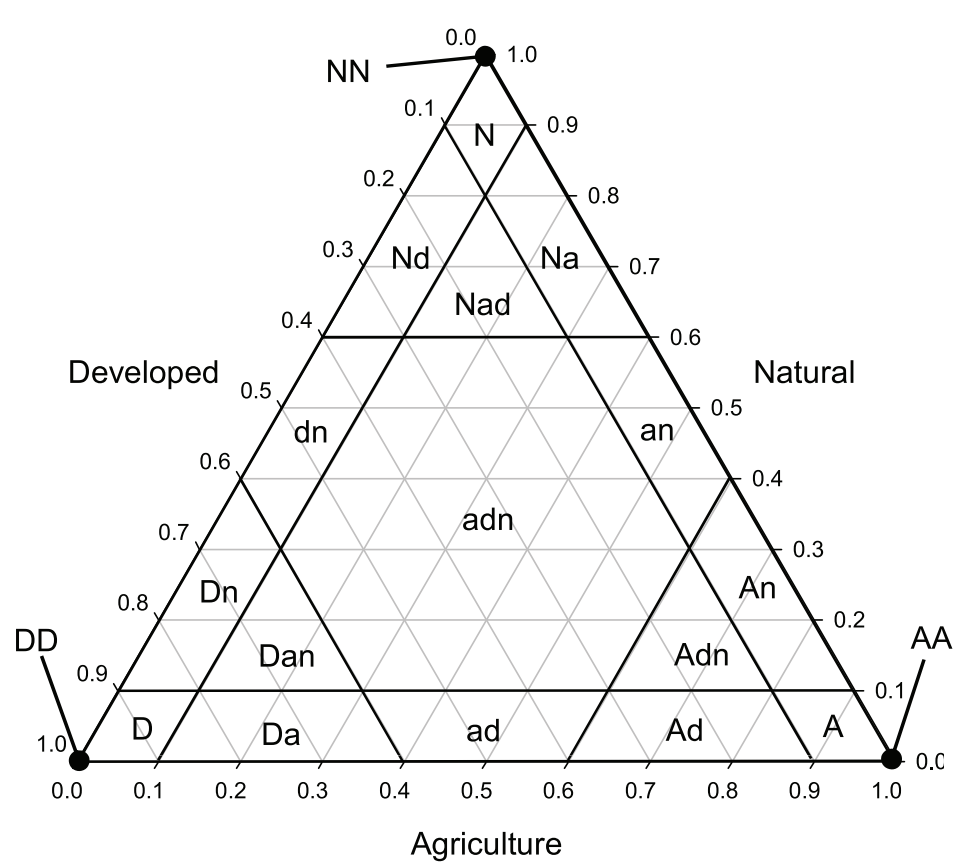

Figure 2.3-The landscape mosaic tri-polar classification model identifies 19 landscape mosaic categories according to the proportions of developed, agriculture, and natural (i.e., neither developed nor agriculture) landcover types in a surrounding landscape. See text for explanation of the landscape mosaic coding system. 
The partitioning of the tri-polar classification model (fig. 2.3) indicates the critical values of 10 percent, 60 percent, and 100 percent along each axis. The landscape mosaic category labels are coded as follows. A lower-case letter (n, $\mathrm{d}$, a) appears in a label if the corresponding landcover type (natural, developed, agriculture, respectively) comprises at least 10 percent but $<60$ percent of the landscape. An upper-case letter $(\mathrm{N}, \mathrm{D}, \mathrm{A})$ appears if that landcover type comprises at least 60 percent but $<100$ percent of the landscape. A letter does not appear if that landcover type comprises $<10$ percent of the landscape. The labels NN, DD, and AA indicate landscapes that contain exactly 100 percent of the corresponding landcover type. Figure 2.4 illustrates the generalized landcover input map and the corresponding landscape mosaic output maps for two landscape sizes.

Morphological spatial pattern-Landcover spatial structure is described by metrics from morphological spatial pattern analysis (MSPA). Each pixel on a landcover map is labeled according to the structural role that is played by that pixel, relative to other pixels of the same landcover type. For example, a pixel may be part of a "connector" cluster between two "core" clusters. The labels were determined by using an algorithm (Soille and Vogt 2009) that classifies individual forest or grassland pixels on a landcover map into one of 19 mutually exclusive MSPA categories. As illustrated in figure 2.5, those 19 categories were condensed to six categories which are the essential features of spatial structure from MSPA (Riitters and others

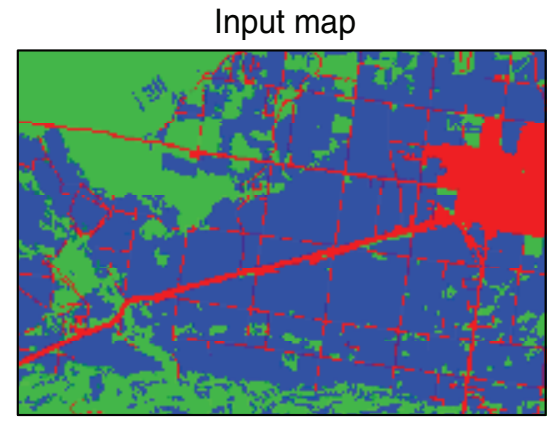

Generalized

landcover

$\square$ Natural

Developed

Agriculture

15-ha landscape

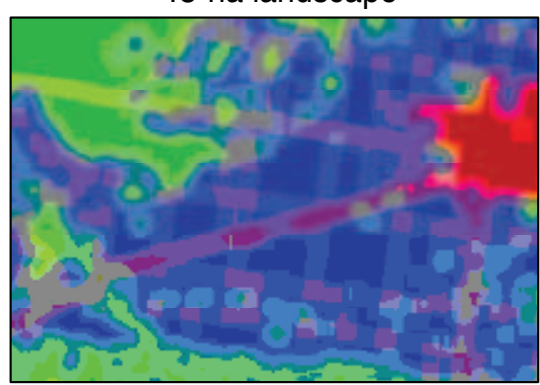

590-ha landscape

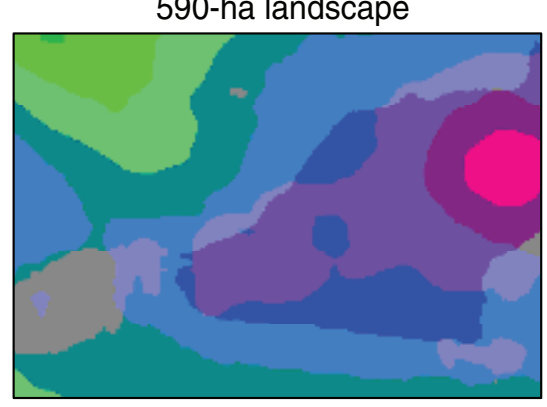

Landscape

mosaic class
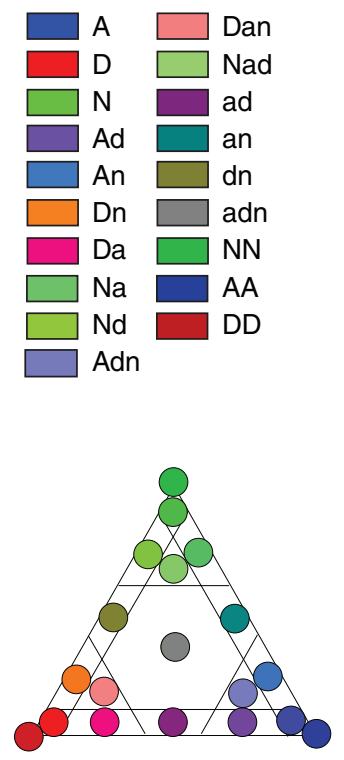

Figure 2.4-Illustration of the landscape mosaic metric for landscape sizes of 15 ha and 590 ha. The generalized landcover map (top) portrays developed, agriculture, and natural pixels. Maps of the landscape mosaic class in a surrounding landscape are shown for 15-ha (middle) and 590-ha (bottom) landscapes. See text for definitions of landscape mosaic classes. Note that by comparisons to figure 2.3, the inset figure at bottom right can be used to interpret the colors in the landscape mosaic class legend. 


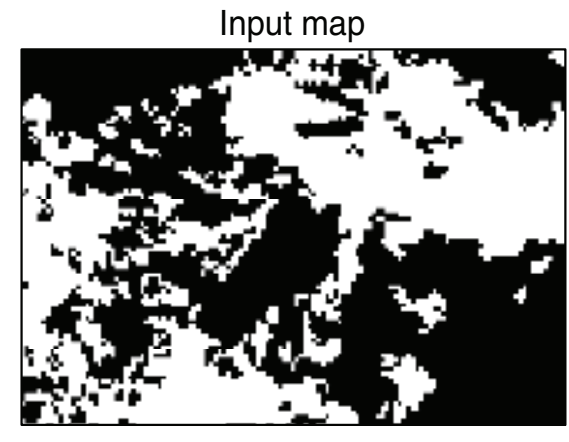

Input map

Backgroun

Foreground

30-m edge width

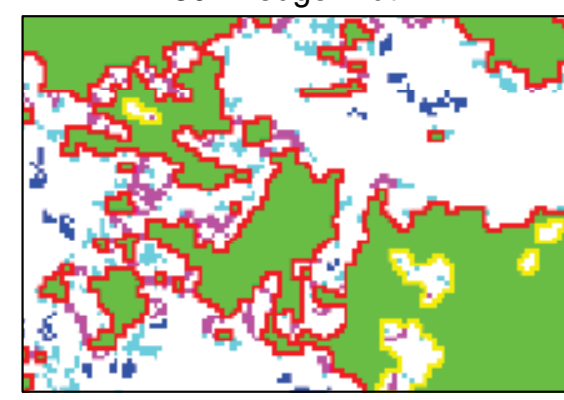

MSPA class

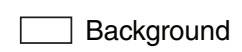

$\square$ Branch

Edge

Islet

Core

Connector

Perforated

240-m edge width

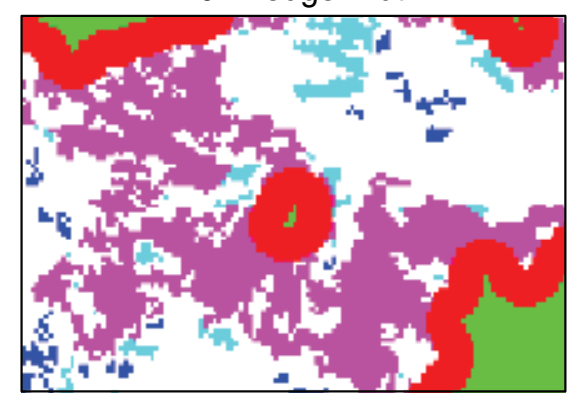

Figure 2.5-Illustration of the morphological spatial pattern classification for effective edge widths of $30 \mathrm{~m}$ and $240 \mathrm{~m}$. The legend of the original landcover map has been converted to "foreground" (e.g., forest, or grassland) and "background" (top). Maps of the morphological spatial pattern classes are shown for effective edge widths of $30 \mathrm{~m}$ (middle) and $240 \mathrm{~m}$ (bottom). See text for definitions of the pattern classes.
2007, 2009a). The forest results are referred to as "forest MSPA" and the grassland results are called "grassland MSPA." The measurements were repeated using four "effective edge widths" (Soille and Vogt 2009) of 30 m, 60 m, 120 $\mathrm{m}$, and $240 \mathrm{~m}$, which define the scales of the MSPA (Ostapowicz and others 2008). Figure 2.5 illustrates the differences between results obtained for effective edge widths of $30 \mathrm{~m}$ and $240 \mathrm{~m}$.

Using the forest landcover type as an example, the MSPA algorithm starts by defining "core" forest pixels as those which were more than the effective edge width away from any nonforest pixel. The remaining forest pixels are then subdivided into five categories representing their structural roles in relation to clusters of core forest pixels as follows. "Edge" forest pixels form the exterior perimeters of clusters of core forest, and "perforated" forest pixels form the interior perimeters (i.e., forest pixels adjacent to holes in core forest clusters). "Connector" forest pixels are clusters that are connected to edge forest pixels at both ends, or to perforated forest pixels at both ends. "Branch" forest pixels are clusters that are connected to edge, perforated, or connector forest pixels at one end only. "Islet" forest pixels are isolated clusters that were too small to contain core pixels.

Google Earth examples of forest area density, landscape mosaic, and morphological spatial pattern (http://www.forestthreats.org/tools/ landcover-maps/landcover-maps) may be valuable for visualizing how the spatial pattern 
metrics relate to the underlying landcover at local to national scales. A complete description of the Google Earth examples is contained in the FHM 2008 national technical report (Potter and Conkling 2012).

Data summaries-The area density maps and the landscape mosaic maps were first summarized at the "landscape level," which means that every pixel location on the original landcover maps was included in a summary, regardless of its particular landcover type. The same maps were then summarized at the "sector level" by summarizing only the values for the pixels that were either forest or grassland on the original landcover maps. The sector-level pixels to be included in a given summary were identified by simple geographic overlays of the maps of pattern metrics and the original landcover maps. As the names imply, landscapelevel summaries describe landscape patterns without regard to actual landscape composition, whereas sector-level summaries describe the specific patterns in locations that have forest or grassland. The MSPA metrics are by definition sector-level only. For each scale of analysis, summary tables were prepared at the State level by examining the proportions of total area that were in the landscape pattern classes. For landscape-level summaries, the proportions were based on the total area of a State. For sectorlevel summaries, the proportions were based on the total area of forest or grassland in a State.

\section{Results}

The landscape-level summaries of the landscape mosaic metric, by landscape size and by State, are shown in table 2.3. The percentages are based on the total area in each State. The four subtotals in the table refer to landscape mosaic "dominance" classes (Conkling 2011), which refer to landscapes that are dominated by (i.e., contain at least 60 percent of) the three generalized landcover types (natural, agriculture, developed) and landscapes that are not dominated by any one of those three types (mixed).

The landscape-level summaries of the forest area density and grassland area density metrics, by landscape size and by State, are shown in table 2.4. Table 2.4a refers to forest area density and table $2.4 \mathrm{~b}$ refers to grassland area density, and the percentages are based on the total area of each State in both cases.

The forest sector-level summaries of the landscape mosaic metric, by landscape size and by State, are shown in table 2.5. The values shown in these summaries are calculated using a subset of the pixels used in the landscapelevel summaries (table 2.3); the subset consists of all the pixel values corresponding to forest landcover on the original landcover map. The percentages are based on the total forest area in each State. The landscape mosaic dominance classes are as defined above for table 2.3. 
Table 2.3-Landscape-level summary of the landscape mosaic metric. The percent of total State area in each of 19 landscape mosaic classes is shown for two landscape sizes. The subtotals show the percentages in subgroups of landscape mosaic dominance classes (natural, agriculture, developed, mixed)

\begin{tabular}{|c|c|c|c|c|c|c|}
\hline \multirow[t]{2}{*}{ Landscape size } & \multicolumn{3}{|c|}{15.21 ha } & \multicolumn{3}{|c|}{590.49 ha } \\
\hline & Alaska & Hawaii & $\begin{array}{l}\text { Puerto } \\
\text { Rico }\end{array}$ & Alaska & Hawaii & $\begin{array}{c}\text { Puerto } \\
\text { Rico }\end{array}$ \\
\hline Landscape mosaic class & \multicolumn{6}{|c|}{ Percent of total area in State } \\
\hline NN & 99.3 & 61.6 & 45.9 & 97.4 & 28.6 & 4.7 \\
\hline $\mathrm{N}$ & 0.3 & 9.1 & 16.7 & 2.4 & 42.4 & 47.0 \\
\hline $\mathrm{Na}$ & 0.0 & 0.9 & 1.6 & 0.0 & 2.8 & 4.4 \\
\hline $\mathrm{Nd}$ & 0.2 & 13.5 & 15.8 & 0.1 & 10.8 & 24.9 \\
\hline Nad & 0.0 & 0.5 & 0.2 & 0.0 & 1.9 & 3.0 \\
\hline Natural subtotal & 99.9 & 85.7 & 80.2 & 100.0 & 86.5 & 83.9 \\
\hline AA & 0.0 & 0.8 & 1.0 & 0.0 & 0.0 & 0.0 \\
\hline$A$ & 0.0 & 1.1 & 1.1 & 0.0 & 0.7 & 0.1 \\
\hline Ad & 0.0 & 1.8 & 0.3 & 0.0 & 0.6 & 0.0 \\
\hline An & 0.0 & 0.9 & 1.5 & 0.0 & 1.0 & 0.6 \\
\hline Adn & 0.0 & 0.6 & 0.2 & 0.0 & 0.6 & 0.2 \\
\hline Agriculture subtotal & 0.0 & 5.2 & 4.0 & 0.0 & 2.9 & 0.9 \\
\hline $\mathrm{DD}$ & 0.0 & 0.9 & 1.9 & 0.0 & 0.0 & 0.0 \\
\hline D & 0.0 & 0.8 & 2.0 & 0.0 & 0.3 & 0.9 \\
\hline $\mathrm{Da}$ & 0.0 & 0.1 & 0.1 & 0.0 & 0.0 & 0.0 \\
\hline Dn & 0.0 & 1.8 & 5.0 & 0.0 & 1.3 & 3.2 \\
\hline Dan & 0.0 & 0.1 & 0.1 & 0.0 & 0.1 & 0.0 \\
\hline Developed subtotal & 0.0 & 3.7 & 9.0 & 0.0 & 1.7 & 4.1 \\
\hline ad & 0.0 & 0.3 & 0.1 & 0.0 & 0.1 & 0.0 \\
\hline an & 0.0 & 0.6 & 1.0 & 0.0 & 1.3 & 1.5 \\
\hline $\mathrm{dn}$ & 0.0 & 1.9 & 4.7 & 0.0 & 2.1 & 4.9 \\
\hline $\operatorname{adn}$ & 0.0 & 2.6 & 1.1 & 0.0 & 5.5 & 4.8 \\
\hline Mixed subtotal & 0.0 & 5.4 & 6.8 & 0.0 & 8.9 & 11.1 \\
\hline Total & 100 & 100 & 100 & 100 & 100 & 100 \\
\hline
\end{tabular}


Table 2.4-Landscape-level summary of (A) forest area density class and (B) grassland area density class for two landscape sizes, by State

(A) Forest area density

\begin{tabular}{l|rrrrrr}
\hline Landscape size & \multicolumn{3}{c}{15.21 ha } & \multicolumn{3}{c}{590.49 ha } \\
\hline State & Alaska & Hawaii & $\begin{array}{c}\text { Puerto } \\
\text { Rico }\end{array}$ & Alaska & Hawaii & $\begin{array}{c}\text { Puerto } \\
\text { Rico }\end{array}$ \\
\hline $\begin{array}{l}\text { Forest area } \\
\text { density class }\end{array}$ & & & & & \\
No forest & 48.7 & 51.4 & 14.2 & 33.4 & 35.5 & 0.8 \\
Rare forest & 8.6 & 7.3 & 10.1 & 18.5 & 16.6 & 11.7 \\
Patchy forest & 11.0 & 10.4 & 22.3 & 15.0 & 16.1 & 32.1 \\
Transitional forest & 5.7 & 5.2 & 14.2 & 8.6 & 8.4 & 21.0 \\
Dominant forest & 10.3 & 9.6 & 21.4 & 15.6 & 14.1 & 28.3 \\
Interior forest & 6.8 & 5.9 & 9.2 & 8.7 & 8.6 & 5.7 \\
Intact forest & 8.9 & 10.1 & 8.6 & 0.3 & 0.8 & 0.4 \\
\hline \multicolumn{1}{c}{ Total } & 100.0 & 100.0 & 100.0 & 100.0 & 100.0 & 100.0
\end{tabular}

(B) Grassland area density

\begin{tabular}{l|rrrrrrr}
\hline Landscape size & \multicolumn{3}{c}{15.21 ha } & \multicolumn{3}{c}{590.49 ha } \\
State & Alaska & Hawaii & $\begin{array}{c}\text { Puerto } \\
\text { Rico }\end{array}$ & Alaska & Hawaii & $\begin{array}{c}\text { Puerto } \\
\text { Rico }\end{array}$ \\
\hline $\begin{array}{l}\text { Grassland area } \\
\text { density class }\end{array}$ & \multicolumn{7}{c}{ Percent of total area in State } \\
No grassland & 76.7 & 59.6 & 17.6 & 62.2 & 29.0 & 1.2 \\
Rare grassland & 8.2 & 13.7 & 16.6 & 20.5 & 36.4 & 14.7 \\
Patchy grassland & 7.8 & 13.4 & 35.8 & 10.6 & 24.6 & 59.2 \\
Transitional grassland & 2.6 & 4.2 & 15.1 & 3.2 & 4.7 & 20.5 \\
Dominant grassland & 2.9 & 5.2 & 11.9 & 3.0 & 4.0 & 4.3 \\
Interior grassland & 1.0 & 2.1 & 2.1 & 0.5 & 1.4 & 0.2 \\
Intact grassland & 0.7 & 1.8 & 0.9 & 0.0 & 0.0 & 0.0 \\
\hline \multicolumn{1}{l}{ Total } & 100.0 & 100.0 & 100.0 & 100.0 & 100.0 & 100.0
\end{tabular}


Table 2.5-Forest sector-level summary of the landscape mosaic metric. The percent of total forest area in each State in each of $\mathbf{1 9}$ landscape mosaic classes is shown for two landscape sizes. The subtotals show the percentages in subgroups of landscape mosaic dominance classes (natural, agriculture, developed, mixed)

\begin{tabular}{|c|c|c|c|c|c|c|}
\hline \multirow[t]{2}{*}{ Landscape size } & \multicolumn{3}{|c|}{$15.21 \mathrm{ha}$} & \multicolumn{3}{|c|}{590.49 ha } \\
\hline & Alaska & Hawaii & $\begin{array}{c}\text { Puerto } \\
\text { Rico }\end{array}$ & Alaska & Hawaii & $\begin{array}{c}\text { Puerto } \\
\text { Rico }\end{array}$ \\
\hline Landscape mosaic class & \multicolumn{6}{|c|}{ Percent of total forest area in State } \\
\hline NN & 98.8 & 71.2 & 67.8 & 94.9 & 32.6 & 8.9 \\
\hline $\mathrm{N}$ & 0.7 & 10.7 & 17.2 & 4.7 & 45.2 & 64.3 \\
\hline $\mathrm{Na}$ & 0.0 & 1.4 & 1.2 & 0.1 & 3.9 & 3.3 \\
\hline $\mathrm{Nd}$ & 0.4 & 12.5 & 10.9 & 0.3 & 11.3 & 18.7 \\
\hline $\mathrm{Nad}$ & 0.0 & 0.6 & 0.1 & 0.0 & 2.0 & 1.4 \\
\hline Natural subtotal & 100.0 & 96.5 & 97.2 & 100.0 & 95.0 & 96.5 \\
\hline $\mathrm{AA}^{a}$ & - & - & - & - & - & - \\
\hline A & 0.0 & 0.0 & 0.0 & 0.0 & 0.0 & 0.0 \\
\hline $\mathrm{Ad}$ & 0.0 & 0.0 & 0.0 & 0.0 & 0.0 & 0.0 \\
\hline An & 0.0 & 0.2 & 0.1 & 0.0 & 0.1 & 0.1 \\
\hline Adn & 0.0 & 0.1 & 0.0 & 0.0 & 0.1 & 0.0 \\
\hline Agriculture subtotal & 0.0 & 0.2 & 0.2 & 0.0 & 0.3 & 0.1 \\
\hline $\mathrm{DD}^{a}$ & - & - & - & - & - & - \\
\hline D & 0.0 & 0.0 & 0.0 & 0.0 & 0.0 & 0.0 \\
\hline $\mathrm{Da}$ & 0.0 & 0.0 & 0.0 & 0.0 & 0.0 & 0.0 \\
\hline Dn & 0.0 & 0.4 & 0.5 & 0.0 & 0.3 & 0.6 \\
\hline Dan & 0.0 & 0.0 & 0.0 & 0.0 & 0.0 & 0.0 \\
\hline Developed subtotal & 0.0 & 0.5 & 0.5 & 0.0 & 0.3 & 0.6 \\
\hline ad & 0.0 & 0.0 & 0.0 & 0.0 & 0.0 & 0.0 \\
\hline an & 0.0 & 0.4 & 0.4 & 0.0 & 0.7 & 0.3 \\
\hline$d n$ & 0.0 & 1.2 & 1.5 & 0.0 & 1.2 & 1.5 \\
\hline adn & 0.0 & 1.2 & 0.2 & 0.0 & 2.6 & 1.0 \\
\hline Mixed subtotal & 0.0 & 2.8 & 2.1 & 0.0 & 4.4 & 2.9 \\
\hline Total forest area & 100 & 100 & 100 & 100 & 100 & 100 \\
\hline
\end{tabular}

${ }^{a}$ This class is not possible in a forest-level summary. 
The grassland sector-level summaries of the landscape mosaic metric, by landscape size and by State, are shown in table 2.6. The values shown in these summaries are calculated using a subset of the pixels used in the landscape-level summaries (table 2.3); the subset consists of all the pixel values corresponding to grassland landcover on the original landcover map. The percentages are based on the total grassland area in each State. The landscape mosaic dominance classes are as defined above for table 2.3.

The forest and grassland sector-level summaries of the forest area density and grassland area density metrics, by landscape size and by State, are shown in table 2.7. Table 2.7a refers to forest area density and table $2.7 \mathrm{~b}$ refers to grassland area density. The values included in these summaries are subsets of the values included in the landscape-level summaries (table $2.4 \mathrm{a}$ and table $2.4 \mathrm{~b}$, respectively); the subsets consist of all the pixel values corresponding to forest (table 2.7a) or grassland (table 2.7b) on the original landcover map. The percentages are based on the total forest area (table 2.7a) or total grassland area (table $2.7 \mathrm{~b}$ ) in each State.

The summaries of the forest MSPA classes, by effective edge width and by State, are shown in table 2.8. The percentages are based on the total forest area in each State. Similarly, table 2.9 shows the summaries of the grassland MSPA classes, with the percentages based on the total grassland area in each State.
Table 2.6-Grassland sector-level summary of the landscape mosaic metric. The percent of total grassland area in each State in each of 19 landscape mosaic classes is shown for two landscape sizes. The subtotals show the percentages in subgroups of landscape mosaic dominance classes (natural, agriculture, developed, mixed)

\begin{tabular}{|c|c|c|c|c|c|c|}
\hline Landscape size & & 15.21 ha & & & 590.49 ha & \\
\hline State & Alaska & Hawaii & $\begin{array}{l}\text { Puerto } \\
\text { Rico }\end{array}$ & Alaska & Hawaii & $\begin{array}{c}\text { Puerto } \\
\text { Rico }\end{array}$ \\
\hline
\end{tabular}

\section{Landscape}

mosaic class Percent of total grassland area in State

$\begin{array}{lrrrrrr}\mathrm{NN} & 99.7 & 60.1 & 40.5 & 98.3 & 17.0 & 1.5 \\ \mathrm{~N} & 0.2 & 14.7 & 25.1 & 1.6 & 55.6 & 46.4 \\ \mathrm{Na} & 0.0 & 1.4 & 2.6 & 0.0 & 5.0 & 5.2 \\ \mathrm{Nd} & 0.1 & 19.3 & 23.7 & 0.1 & 13.0 & 32.1 \\ \mathrm{Nad} & 0.0 & 0.8 & 0.5 & 0.0 & 2.7 & 4.5 \\ \text { Natural subtotal } & 100.0 & 96.2 & 92.4 & 100.0 & 93.3 & 89.6\end{array}$

\begin{tabular}{lcccccc}
$\mathrm{AA}^{a}$ & - & - & - & - & - & - \\
$\mathrm{A}$ & 0.0 & 0.0 & 0.0 & 0.0 & 0.0 & 0.0 \\
$\mathrm{Ad}$ & 0.0 & 0.0 & 0.0 & 0.0 & 0.0 & 0.0 \\
$\mathrm{An}$ & 0.0 & 0.2 & 0.1 & 0.0 & 0.2 & 0.2 \\
Adn & 0.0 & 0.1 & 0.0 & 0.0 & 0.1 & 0.0 \\
\hline Agriculture subtotal & 0.0 & 0.3 & 0.1 & 0.0 & 0.4 & 0.3
\end{tabular}

\begin{tabular}{lcccccc}
$\mathrm{DD}^{a}$ & - & - & - & - & - & - \\
$\mathrm{D}$ & 0.0 & 0.0 & 0.1 & 0.0 & 0.0 & 0.1 \\
$\mathrm{Da}$ & 0.0 & 0.0 & 0.0 & 0.0 & 0.0 & 0.0 \\
$\mathrm{Dn}$ & 0.0 & 0.3 & 1.5 & 0.0 & 0.2 & 0.9 \\
Dan & 0.0 & 0.0 & 0.0 & 0.0 & 0.0 & 0.0 \\
\hline Developed subtotal & 0.0 & 0.3 & 1.6 & 0.0 & 0.2 & 1.0
\end{tabular}

\begin{tabular}{|c|c|c|c|c|c|c|}
\hline Developed subtotal & 0.0 & 0.3 & 1.6 & 0.0 & 0.2 & 1.0 \\
\hline ad & 0.0 & 0.0 & 0.0 & 0.0 & 0.0 & 0.0 \\
\hline an & 0.0 & 0.5 & 0.7 & 0.0 & 1.2 & 1.1 \\
\hline $\mathrm{dn}$ & 0.0 & 1.3 & 4.2 & 0.0 & 1.3 & 3.9 \\
\hline $\operatorname{adn}$ & 0.0 & 1.4 & 0.9 & 0.0 & 3.6 & 4.2 \\
\hline Mixed subtotal & 0.0 & 3.2 & 5.9 & 0.0 & 6.1 & 9.2 \\
\hline Total grassland area & 100 & 100 & 100 & 100 & 100 & 100 \\
\hline
\end{tabular}

${ }^{a}$ This class is not possible in a grassland-level summary. 
Table 2.7-Sector-level summary of (A) forest area density class and (B) grassland area density class for two landscape sizes, by State

(A) Forest area density

\begin{tabular}{l|cc|ccc}
\hline Landscape size & \multicolumn{3}{|c|}{15.21 ha } & \multicolumn{3}{c}{590.49 ha } \\
\hline State & Alaska & Hawaii & $\begin{array}{c}\text { Puerto } \\
\text { Rico }\end{array}$ Alaska & Hawaii & $\begin{array}{c}\text { Puerto } \\
\text { Rico }\end{array}$
\end{tabular}

Forest area

density class

Percent of total forest area in State

\begin{tabular}{lcccccc}
\hline Rare forest & 0.7 & 0.6 & 0.5 & 1.7 & 1.6 & 0.9 \\
Patchy forest & 7.3 & 6.9 & 9.5 & 10.7 & 11.4 & 16.2 \\
Transitional forest & 9.8 & 9.4 & 15.3 & 15.1 & 15.3 & 23.3 \\
Dominant forest & 28.7 & 27.4 & 36.9 & 42.5 & 39.6 & 46.7 \\
Interior forest & 22.9 & 20.3 & 19.3 & 29.0 & 29.3 & 11.9 \\
Intact forest & 30.7 & 35.4 & 18.6 & 1.0 & 2.8 & 0.9 \\
\hline \multicolumn{1}{c}{ Total forest } & 100 & 100 & 100 & 100 & 100 & 100
\end{tabular}

(B) Grassland area density

\begin{tabular}{l|cccccc}
\hline Landscape size & \multicolumn{7}{c}{15.21 ha } & \multicolumn{3}{c}{590.49 ha } \\
State & Alaska & Hawaii & $\begin{array}{c}\text { Puerto } \\
\text { Rico }\end{array}$ & Alaska & Hawaii & $\begin{array}{c}\text { Puerto } \\
\text { Rico }\end{array}$ \\
\hline $\begin{array}{l}\text { Grassland area } \\
\text { density class }\end{array}$ & \multicolumn{7}{c}{ Percent of total grassland area in State } \\
\hline Rare grassland & 3.0 & 2.5 & 1.3 & 8.1 & 7.9 & 2.1 \\
Patchy grassland & 21.9 & 19.5 & 26.3 & 31.1 & 37.9 & 49.2 \\
Transitional grassland & 18.9 & 17.2 & 28.2 & 22.9 & 19.9 & 37.0 \\
Dominant grassland & 32.4 & 31.9 & 33.6 & 30.9 & 24.7 & 11.1 \\
Interior grassland & 13.7 & 15.3 & 7.3 & 6.8 & 9.8 & 0.6 \\
Intact grassland & 10.1 & 13.5 & 3.2 & 0.2 & 0.0 & 0.0 \\
\hline \multicolumn{1}{c}{ Total grassland } & 100 & 100 & 100 & 100 & 100 & 100 \\
\hline
\end{tabular}

Note: the "no forest" and "no grassland" classes are not possible in sector-level summaries. 
Table 2.8-Summary of forest morphological spatial pattern analysis (MSPA) classes for four effective edge widths, by State

\begin{tabular}{|c|c|c|c|c|c|c|}
\hline \multirow[t]{2}{*}{ Edge width } & \multicolumn{3}{|c|}{$30 \mathrm{~m}$} & \multicolumn{3}{|c|}{$60 \mathrm{~m}$} \\
\hline & \multicolumn{5}{|c|}{ Puerto } & Puerto \\
\hline State & Alaska & Hawaii & Rico & Alaska & Hawaii & Rico \\
\hline MSPA class & \multicolumn{6}{|c|}{ Percent of total forest area in State } \\
\hline Core & 70.9 & 74.5 & 64.2 & 57.6 & 61.1 & 46.2 \\
\hline Edge & 10.9 & 13.9 & 18.6 & 15.4 & 18.6 & 25.0 \\
\hline Perforated & 4.9 & 2.4 & 4.0 & 5.8 & 2.9 & 2.7 \\
\hline Connector & 6.1 & 3.1 & 4.9 & 11.6 & 6.9 & 12.1 \\
\hline Branch & 3.8 & 3.8 & 6.0 & 4.1 & 5.3 & 8.6 \\
\hline Islet & 3.2 & 2.3 & 2.3 & 5.5 & 5.3 & 5.5 \\
\hline Total forest area & 100 & 100 & 100 & 100 & 100 & 100 \\
\hline Edge width & \multicolumn{3}{|c|}{$120 \mathrm{~m}$} & \multicolumn{3}{|c|}{$240 \mathrm{~m}$} \\
\hline State & \multicolumn{3}{|r|}{$\begin{array}{l}\text { Puerto } \\
\text { Rico }\end{array}$} & \multicolumn{3}{|r|}{$\begin{array}{l}\text { Puerto } \\
\text { Rico }\end{array}$} \\
\hline MSPA class & \multicolumn{6}{|c|}{ Percent of total forest area in State } \\
\hline Core & 45.4 & 49.4 & 32.1 & 27.3 & 32.3 & 16.0 \\
\hline Edge & 19.9 & 21.9 & 27.3 & 23.8 & 24.0 & 21.5 \\
\hline Perforated & 5.4 & 3.0 & 1.3 & 3.4 & 2.2 & 0.6 \\
\hline Connector & 18.6 & 11.8 & 22.7 & 33.8 & 23.6 & 43.6 \\
\hline Branch & 3.4 & 5.3 & 8.2 & 1.7 & 3.6 & 4.0 \\
\hline Islet & 7.2 & 8.7 & 8.5 & 10.0 & 14.3 & 14.3 \\
\hline Total forest area & 100 & 100 & 100 & 100 & 100 & 100 \\
\hline
\end{tabular}


Table 2.9-Summary of grassland morphological spatial pattern analysis (MSPA) classes for four effective edge widths, by State

\begin{tabular}{|c|c|c|c|c|c|c|}
\hline Edge width & & $30 \mathrm{~m}$ & & & $60 \mathrm{~m}$ & \\
\hline State & Alaska & Hawaii & $\begin{array}{c}\text { Puerto } \\
\text { Rico }\end{array}$ & Alaska & Hawaii & $\begin{array}{c}\text { Puerto } \\
\text { Rico }\end{array}$ \\
\hline MSPA class & \multicolumn{6}{|c|}{ Percent of total grassland area in State } \\
\hline Core & 46.3 & 53.7 & 39.7 & 30.7 & 36.7 & 19.8 \\
\hline Edge & 18.0 & 22.3 & 30.0 & 20.0 & 24.2 & 26.2 \\
\hline Perforated & 3.5 & 1.4 & 0.9 & 2.7 & 1.3 & 0.5 \\
\hline Connector & 12.0 & 6.0 & 9.0 & 19.2 & 11.0 & 18.5 \\
\hline Branch & 8.0 & 8.0 & 12.5 & 7.0 & 9.0 & 14.7 \\
\hline Islet & 12.2 & 8.6 & 8.1 & 20.5 & 17.9 & 20.4 \\
\hline Total grassland area & 100 & 100 & 100 & 100 & 100 & 100 \\
\hline Edge width & \multicolumn{3}{|c|}{$120 \mathrm{~m}$} & \multicolumn{3}{|c|}{$240 \mathrm{~m}$} \\
\hline State & Alaska & Hawaii & $\begin{array}{l}\text { Puerto } \\
\text { Rico }\end{array}$ & Alaska & Hawaii & $\begin{array}{c}\text { Puerto } \\
\text { Rico }\end{array}$ \\
\hline MSPA class & \multicolumn{6}{|c|}{ Percent of total grassland area in State } \\
\hline Core & 19.8 & 24.8 & 9.4 & 8.4 & 11.5 & 2.4 \\
\hline Edge & 20.1 & 23.7 & 18.8 & 14.5 & 18.1 & 7.8 \\
\hline Perforated & 1.6 & 1.1 & 0.3 & 0.7 & 0.7 & 0.1 \\
\hline Connector & 26.3 & 15.9 & 28.0 & 36.9 & 21.3 & 32.2 \\
\hline Branch & 4.9 & 7.3 & 11.5 & 1.9 & 3.3 & 4.1 \\
\hline Islet & 27.3 & 27.2 & 32.0 & 37.6 & 45.1 & 53.5 \\
\hline Total grassland area & 100 & 100 & 100 & 100 & 100 & 100 \\
\hline
\end{tabular}




\section{Discussion}

The objective of this chapter is to take advantage of the newly released landcover maps for Alaska, Hawaii, and Puerto Rico to extend previous landscape pattern assessments to those areas. Three landscape pattern metrics-area density, landscape mosaic, and morphological spatial pattern-were measured at multiple spatial scales for the three States, and the results were mapped at the same spatial resolution as the original landcover maps. A set of summary tables demonstrates data aggregation strategies to estimate the proportions of area that are characterized by different types of landscape patterns, considering both total State area (landscape-level) and total forest or grassland area within States (sector-level).

The three types of pattern metrics that appear in this chapter are the same as reported in several other Forest Service assessment reports. The forest area density metric is the basis for reporting "fragmentation of forests" in national reports on sustainable forests (2003 and 2010), and all three types of metrics appear as descriptors of landscape, forest, and grassland patterns in the 2010 Resources Planning Act Assessment. Those reports also include the conterminous United States, providing comparisons with the three States considered in this chapter.
Full data interpretations usually must proceed with finer-scale aggregations such as counties or watersheds, and ideally are conducted by specialists with reference to individual pixel values instead of aggregations of any kind. Such detailed interpretations necessarily are outside the practical scope of the present chapter. In the future, specialists might access the detailed maps of landscape patterns for a variety of interpretations, probably using geographic overlays with other local and/or issue-specific maps for that purpose. At the levels of aggregation reported here, the results can be interpreted in roughly the same ways as previous reports that considered the same metrics in the conterminous United States.

In broad terms, the results of this chapter indicate that the landscape pattern metrics, when aggregated to State level, paint the same sort of pictures that are painted for other States with comparable intensities of human land uses. Alaska will be important in national assessments because of the relatively minor human footprint compared to all other States. The sheer size of Alaska relative to all other States means that national-level summaries will be weighted heavily by the results for Alaska alone. Thus, an important question for future assessments is whether to consider Alaska as a separate population for aggregating and reporting results. 
In contrast, both Hawaii and Puerto Rico are unusual because both comprise sets of islands, and as a result, some of the landscape patterns reflect the influence of adjacent water, especially when the metrics are calculated within large landscapes that include substantial amounts of water. It may be useful to restrict the range of scales reported for Hawaii and Puerto Rico to minimize any "island effect" in the data. In summary, the analyses and databases presented in this chapter open the door to future work aimed at addressing the causes and consequences of landscape patterns in a consistent fashion nationwide.

\section{Literature Cited}

Ambrose, M.J.; Conkling, B.L.; Riitters, K.H.; Coulston, J.W. 2008. The forest health monitoring national technical reports: examples of analyses and results from 2001-2004. Science Update SRS-018. Asheville, NC: U.S. Department of Agriculture Forest Service, Southern Research Station. $6 \mathrm{p}$.

Conkling, B.L., ed. 2011. Forest health monitoring 2007 national technical report. Gen. Tech. Rep. SRS-147, Asheville, NC: U.S. Department of Agriculture Forest Service, Southern Research Station. 159 p.

Coulston, J.W.; Ambrose, M.J.; Riitters, K.H.; Conkling B.L. 2005. Forest health monitoring 2004 national technical report. Gen. Tech. Rep. SRS-90. Asheville, NC: U.S. Department of Agriculture Forest Service, Southern Research Station. $81 \mathrm{p}$
ESRI. 2005. ESRI Data and Maps 2005 [DVD]. Redlands, CA: Environmental Systems Research Institute.

Homer, C.; Huang, C.; Yang, L. [and others]. 2004 Development of a 2001 national land cover database for the United States. Photogrammetric Engineering and Remote Sensing. 70: 829-840.

Homer, C.; Dewitz, J.; Fry, J. [and others]. 2007.

Completion of the 2001 national land cover database for the conterminous United States. Photogrammetric Engineering and Remote Sensing. 73: 337-341.

Ostapowicz, K.; Vogt, P.; Riitters, K.H. [and others]. 2008. Impact of scale on morphological spatial pattern of forest. Landscape Ecology. 23: 1107-1117.

Potter, K.M.; Conkling, B.L., eds. 2012. Forest health monitoring 2008 national technical report. Gen. Tech. Rep. SRS-158, Asheville, NC: U.S. Department of Agriculture Forest Service, Southern Research Station $179 \mathrm{p}$

Riitters, K.H.; Wickham, J.D.; O'Neill, R.V. [and others]. 2002. Fragmentation of continental United States forests. Ecosystems. 5: 815-822.

Riitters, K.H.; Vogt, P.; Soille, P. [and others]. 2007. Neutral model analysis of landscape patterns from mathematical morphology. Landscape Ecology. 22: 1033-1043.

Riitters, K.H.; Vogt, P.; Soille, P.; Estreguil, C. 2009a. Landscape patterns from mathematical morphology on maps with contagion. Landscape Ecology. 24: 699-709.

Riitters, K.H.; Wickham, J.D.; Wade, T.G. 2009b. An indicato of forest dynamics using a shifting landscape mosaic. Ecological Indicators. 9: 107-117.

Soille, P.; Vogt, P. 2009. Morphological segmentation of binary patterns. Pattern Recognition Letters. 30: 456-459. 



\section{Introduction}

Yriterion 3, Indicator 15, of the Montréal Process identifies the impact that biotic processes and agents have on forests (Montréal Process Working Group 2007). Where change due to these agents and processes occurs beyond a critical threshold, forest ecosystem health and vitality may be significantly altered and a forest's ability to recover could be reduced or lost. Monitoring and measuring the effects of these processes provides information helpful in the formulation of management strategies to mitigate risk. A variety of detection and monitoring surveys are conducted annually by Forest Health Protection (FHP) Program of the Forest Service, U.S. Department of Agriculture, and FHP partners. Aerial detection survey (ADS) data are the primary focus of this chapter, though additional ground survey data are considered and reported.

Aerial surveys have been conducted in the United States since the early 1900s. During the early years, surveys were conducted intermittently by various Federal, State, and local governments and private individuals. Survey expertise grew as frequency of flights at regular intervals within a few geographic areas improved over time. The Forest Service began coordinating aerial surveys nationwide during the mid-1990s. Since 1997, FHP and its partners have consistently been using aerial surveys to collect forest injury data caused by a variety of biotic and abiotic agents. Standard methods and regular survey intervals have been established through the Forest Health Monitoring (FHM) Program of the Forest Service, and national efforts continue to improve the reliability and accuracy of data, as described at www.fs.fed. us/foresthealth/aviation/qualityassurance. shtml. These data have not only been important at the local level for decades but, in terms of trends and forecasting, the analysis of annually surveyed areas is becoming increasingly useful. The ADS program is also credited with new pest detections utilizing fixed or rotor wing aircraft and digital aerial sketchmapping techniques (DASM - a computerized data capture system). The ADS program is also credited with new pest detections. Some examples of new pest detections in either country, State, or county are: Agrilis coxalis in southern California 2008 (new introduction, native to Mexico), ${ }^{1}$ Phytophthora ramorum confirmed in Lake County California 2004 (expanding list of regulated CA counties), ${ }^{2}$ Agrilis planipennis in Michigan 2002 (discovered during field trip, followed with aerial and ground surveys to locate additional infestations and aid defining regulated area). ${ }^{3}$

To provide scientists, managers, and the public with information necessary to aid resource decisions, this chapter focuses on survey results

\footnotetext{
${ }^{1}$ Personal communication. 2009. Zachary Heath, U.S. Department of Agriculture Forest Service, Pacific Southwest Region, 1731 Research Park Drive, Davis, CA 95618.

${ }^{2}$ Personal survey experience and sample collection. 2004. Jeff Mai, U.S. Department of Agriculture Forest Service FHTET, 2150 Centre Ave., Bldg. A, Suite 331, Fort Collins, CO 80526 .

${ }^{3}$ Personal communication. 2009. Roger Mech, Michigan Department of Natural Resources, P.O. Box 30452, Lansing, MI 48909.
}

CRITERION 3-
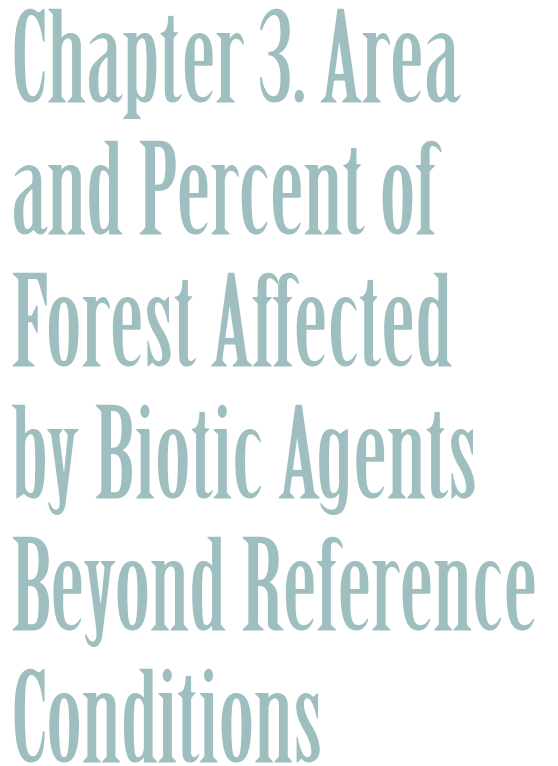

JeFFrey A. MAI 
as related to current forest condition, trends of biotic indicator impacts for the current period compared to a reference period, and highlighting areas, agents, and possible changes in host distribution and climate that appear to contribute to sustainability concerns.

\section{Objectives and Methods}

To gain an understanding of what the future of our forests may be, it is necessary to examine historic processes impacting forest health. Biotic indicator impacts have been estimated using several methods at varying scales. Few, however, are as consistently gathered at a national scale as ADS. Aerial estimates of affected forested area, damage intensity, and associated biotic agents are the primary data for this chapter providing current information and trend data over broad areas. The objective of this information is to help guide resource decisions that improve forest health and provide for the future of the Nation's forests. These data may be combined with other forest-health related data and products to further refine and highlight resources at risk.

Insect and disease damage estimates were created using ADS data (primarily from aerial detection surveys). Areas of insect and disease impact either were sketched directly on maps using standard coding and reporting criteria, or were captured using DASM as an aide in the airplane. Some data were also captured through DASM on the ground; all have consistent reporting formats. Temporally, the data represent damage from 1997 to 2008. The selected agents and forest injury data were subsequently analyzed and mapped using ArcGIS.
Additionally, for the purpose of highlighting county-level presence of select invasive species reported, county-level maps were created in ArcGIS 9.2 and ArcView 3.3.

Aerial survey protocol requires the annual mapping of new defoliation, mortality, and other damage that has occurred since the last observation (current damage). As a consequence, forested areas with chronic health issues may be repeatedly mapped as long as trees continue to die or otherwise show signs of decline. For example, a stand with 100 trees per acre and a mortality rate of 10 dead trees per acre per year could be mapped every year for 10 years (even longer with ingrowth followed by additional mortality). Damage must exhibit visible signatures in order to be mapped, and some of the most damaging biotic agents (such as root diseases and dwarf mistletoes) are rarely isolated during aerial survey. Aerial survey areas are largely predetermined as part of an annual program of work; however, some flexibility is desired to further prioritize based on pest reports (nonnative and endemic), specific areas of concern (for example, high value plantations, recreational areas, and forest host types of interest) and flight logistics. Surveys are conducted by resource experts with local forest health knowledge and highly trained to safely manage flights. Resource professionals conducting ADS include foresters, entomologists, and pathologists. For more information

pertaining to objectives and methods, please see McConnell and others (2000) and Forest Health Monitoring $(1999,2005)$. 


\section{Results and Products}

Damage caused by select forest insect and disease indicators are presented to highlight changes and trends due to biotic impacts comparing two 6-year periods, the reference period from 1997 through 2002 to the current period from 2003 through 2008. Though surveys have been conducted for more than 60 years in some areas, complete national data are only available since 1997. Important nonnative invasive plant, insect, and disease establishment and spread are also detailed.

The 2008 aerial survey area by FHM region is shown in figure 3.1. Acres with mortality reported due to insects and diseases during 2008 are shown in figure 3.2 (note that the

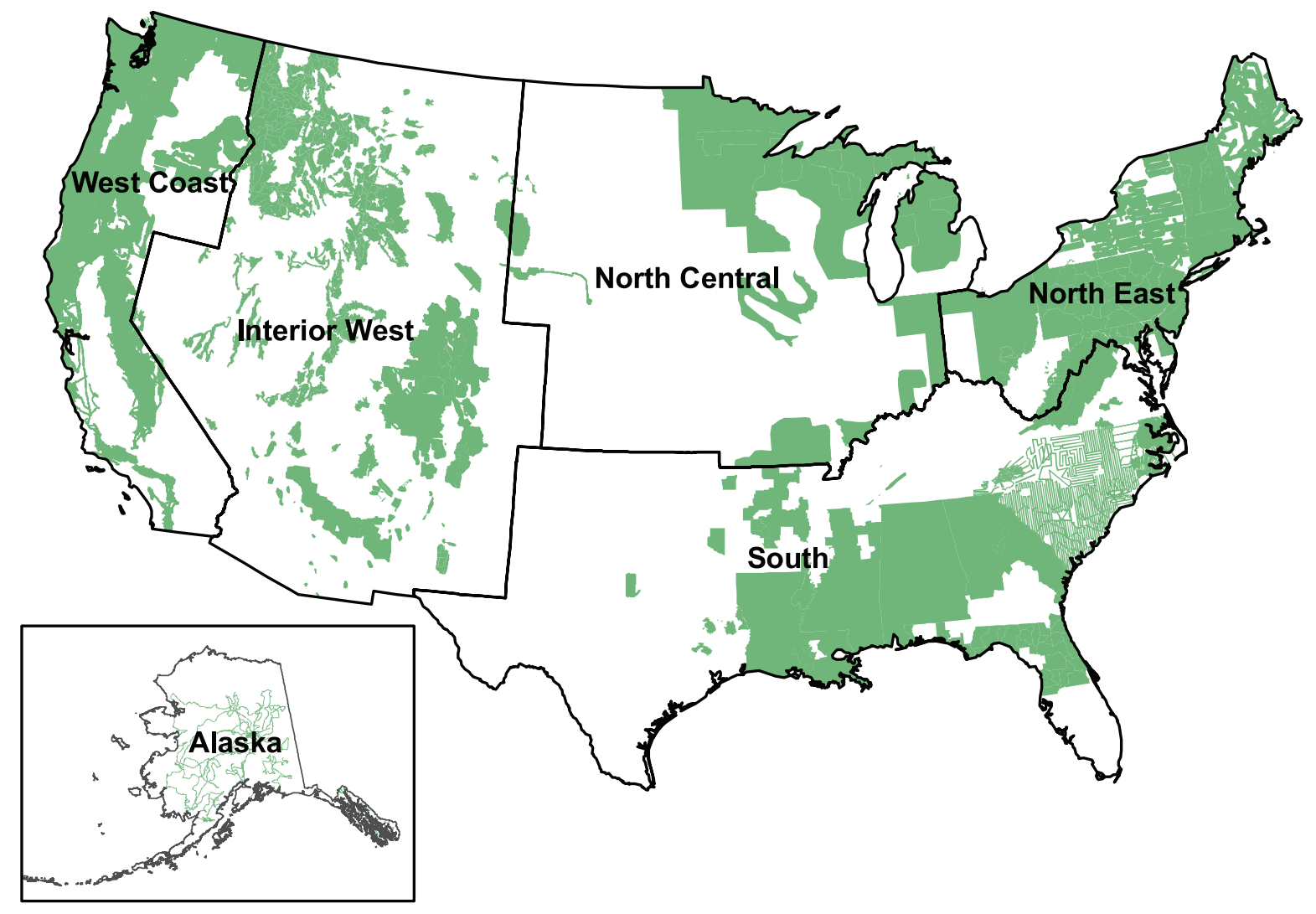

Figure 3.1-Forest Health Monitoring regions and area flown during the 2008 insect and disease detection survey. 


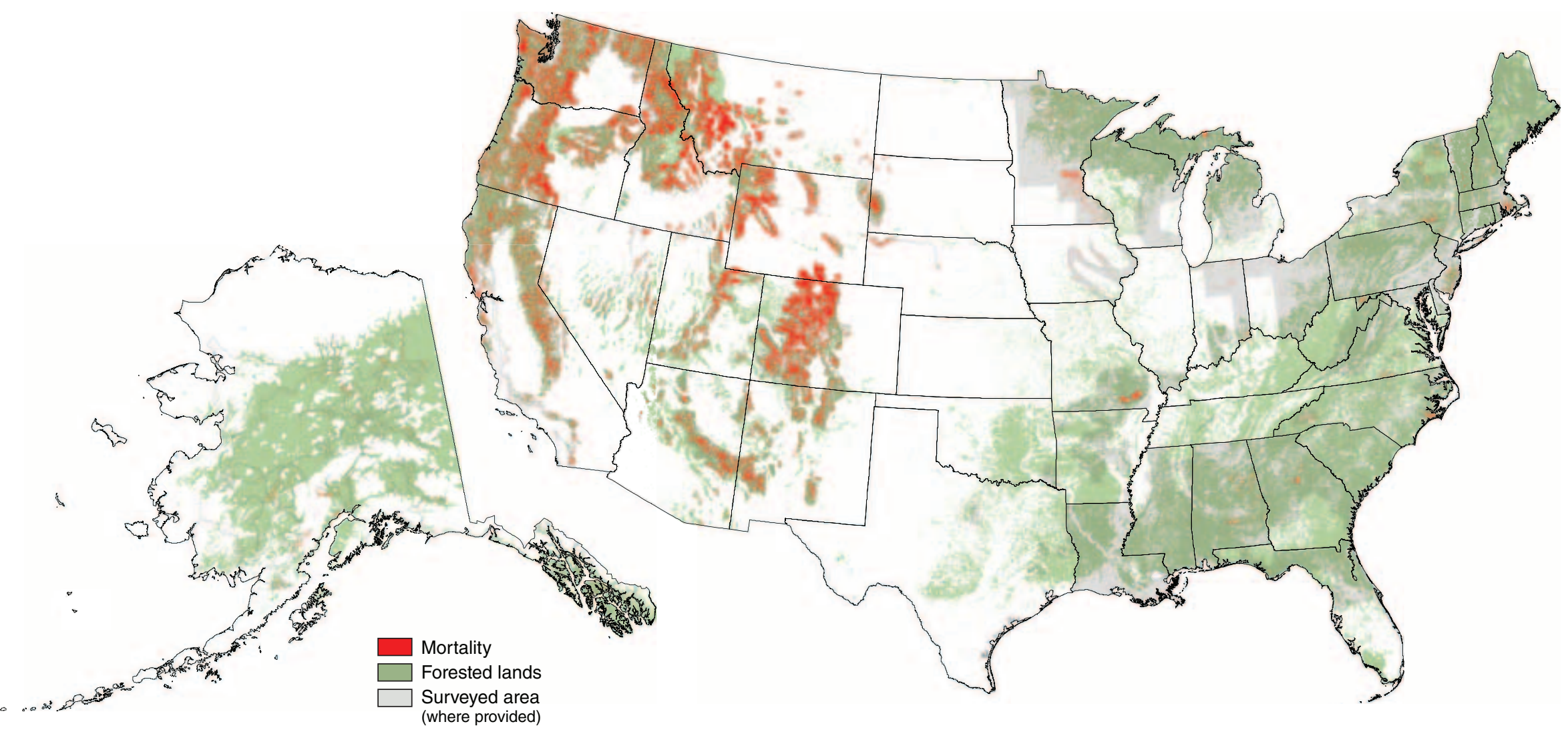

Figure 3.2-Areas with mortality mapped during the 2008 detection survey; graphed acres exclude widely scattered mortality primarily from bronze birch borer, beech bark disease, and gypsy moth.

figure includes only areas with some level of visible tree mortality; other damage types such as defoliation are described elsewhere in this chapter). Consistently surveyed and reported areas with mortality and defoliation make trend analysis possible and facilitate describing cumulative environmental effects.
(Cumulative effects analyses are conducted to evaluate a variety of factors combining to cause negative environmental consequences and described for specific resource areas analyzed in Environmental Analyses or Environmental Impact Assessments, such as for fish and wildlife habitat, forest health, fire and fuels, 
cultural resources, recreation watersheds, etc.). The forested area with mortality mapped has quadrupled over that mapped during the reference period (fig. 3.3). These impacts should be considered cumulative where they occur repeatedly on the same acreage and expand into new areas. The impacts described are likely underestimated because understory pest impacts may be only partially observable during aerial survey and because not all of the forested area in the United States is surveyed.

Forest health issues occur regardless of ownership; consequently, aerial surveys are conducted regardless of ownership. The proportion of all damage types observed and mapped during the 2008 ADS on Forest Service, other Federal, and non-Federal lands is shown in figure 3.4. The most prevalent damage types mapped include forest injury classified as mortality, defoliation, dieback, and discoloration (table 3.1). Though not broken down further in this report, finer resolution for specific land classes or ownership is possible representing all resource interests, stakeholders, and the public. The genetic resources which may be threatened also transcend boundaries. Important genomes are possibly located among the smallest of land ownership classifications. However, the degree of collaborative intervention necessary to maintain genetic variability is beyond the scope of this chapter but appears to be a developing concern for forward-thinking resource managers.

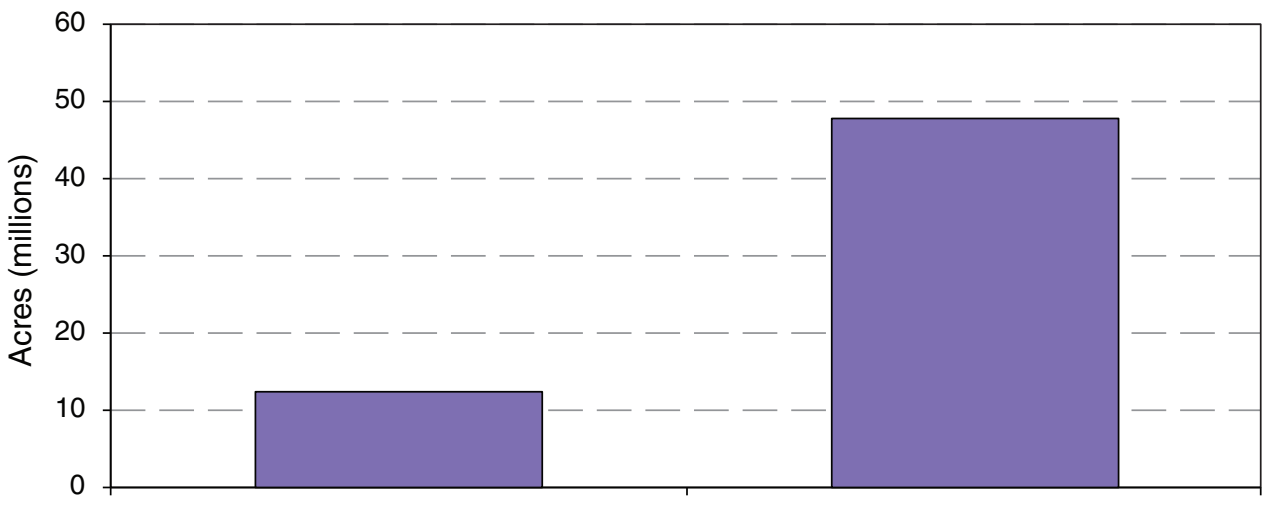

$1997-2002$

2003-2008

Year

Figure 3.3-Total forest insect and disease mortality in the conterminous United States for two periods; the area with mortality for select indicators (specific biotic indicators are listed elsewhere in this chapter) is summed for all years within the period. Cumulative impacts are occurring where mortality continues within previously mapped areas and expands into new areas.

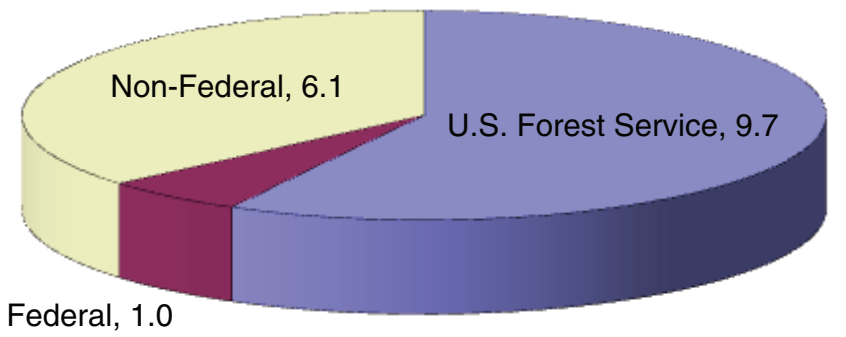

Figure 3.4-2008 National Insect and Disease Detection Survey forest injury by ownership; the total is approximately 16.7 million acres, of which approximately 10.5 million acres are classified as "mortality" damage type. 
Table 3.1—Area by damage type and ownership from the 2008 National Insect and Disease Detection Survey for Alaska and the conterminous $\mathbf{4 8}$ states

\begin{tabular}{lrrrr}
\hline Damage type & U.S. Forest Service & Other Federal & Non-Federal & \multicolumn{1}{c}{ Total } \\
\hline Branch breakage & \multicolumn{4}{c}{ acres } \\
Branch flagging & 101 & 6 & 27,298 & 27,405 \\
Defoliation & 177,899 & 20,807 & 10,239 & 208,945 \\
Dieback & $2,085,390$ & 290,605 & $2,802,881$ & $5,178,876$ \\
Discoloration & 187,698 & 46,993 & 249,751 & 484,442 \\
Main stem broken/uproot & 183,051 & 20,881 & 101,856 & 305,788 \\
Mortality & 8,897 & 2,908 & 120,510 & 132,316 \\
Other damage & $7,155,549$ & 580,896 & $2,760,447$ & $10,496,892$ \\
Topkill & 6,274 & 1,973 & 9,979 & 18,227 \\
Footprint total & 1,074 & 4,487 & 244 & 5,805 \\
ADS area flown & $9,661,441$ & 956,590 & $6,053,196$ & $16,671,228$ \\
\hline
\end{tabular}

Note: the "footprint total" omits overlapping damage types and thus does not double count acreage.

\section{Predictions and Effects}

The 2006 National Insect and Disease Risk Map (NIDRM) ${ }^{4}$ predicted the following mortality-causing or defoliating agents would have the greatest impacts on U.S. forests: mountain pine beetle, red oak decline, southern pine beetle, root diseases, gypsy moth, pine engravers, fir engraver, Douglas-fir beetle, spruce beetle, hardwood decline, and western pine beetle (fig. 3.5). The purpose of NIDRM

${ }^{4}$ U.S. Department of Agriculture Forest Service. 2007. Mapping risk from forest insects and diseases 2006. On file with: The Forest Health Technology Enterprise Team, 2150 Centre Avenue, Building A, Suite 331, Fort Collins, CO 80526. is to provide a strategic assessment estimating risk of tree mortality due to major insects and diseases, specifically, highlighting areas where 25 percent of live tree volume loss is expected during the next 15 years.

All of those agents were observed as causal factors of forest injury during the 2008 surveys. The survey results reported are not all-inclusive in terms of agent or damage extents. Though specific agents are reported from these data, interpretation must consider the role of pest groups and a long list of individual agents (biotic and abiotic) that function as a complex on any given acre. The top five damage agents identified 


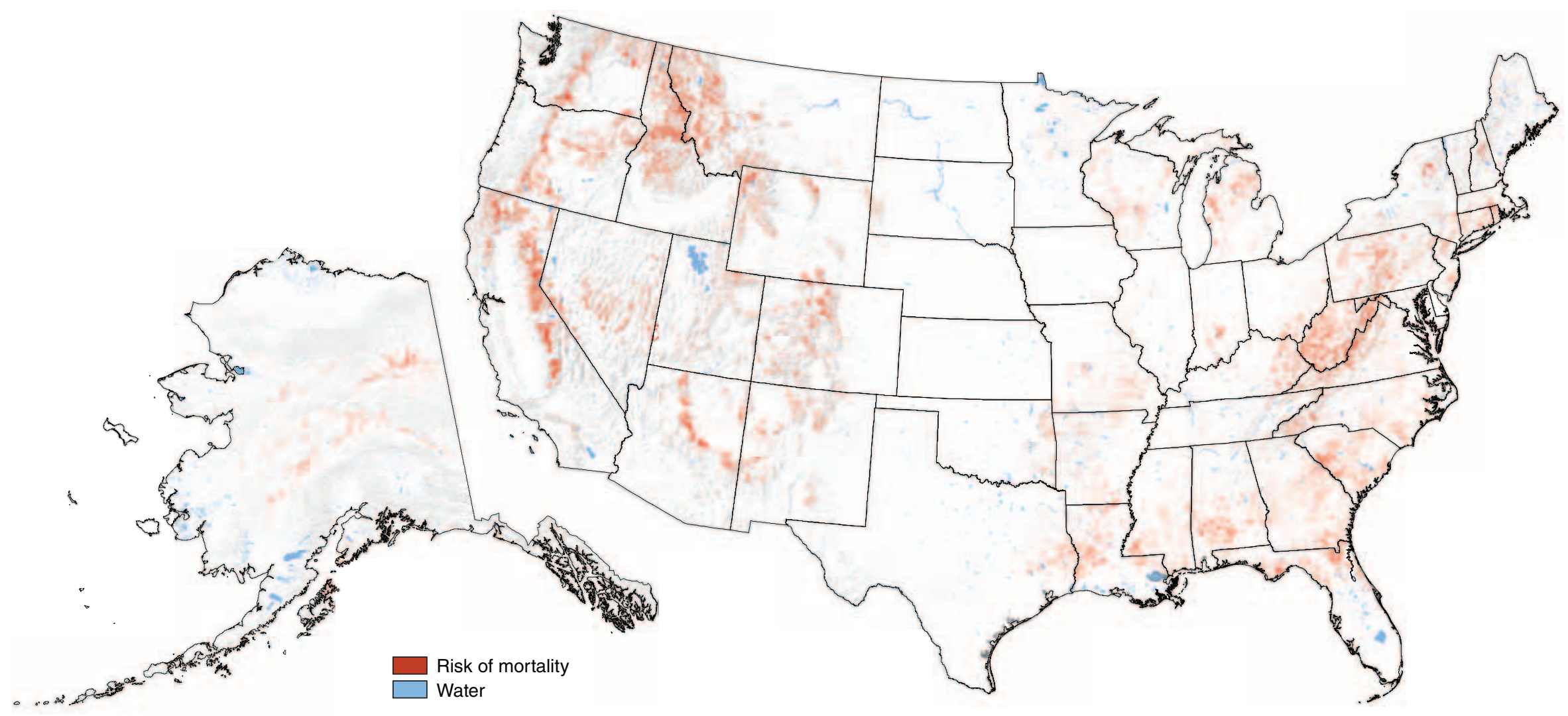

Figure 3.5-An area of approximately 58 million acres is predicted to be at risk of disturbance by biotic factors; risk is defined as the predicted "loss of $25 \%$ standing volume over the next 15 years" (2006 National Insect and Disease Risk Map).

during 2008 surveys are shown in figure 3.6 and are detailed further in this report, as are a few key nonnative pests. Based on the numbers of tabulated acres from surveys, nonnative pests appear to have lesser impacts than native pests. However, as displayed at the end of this chapter nonnative pests increasingly present a serious threat to forest sustainability.
Of the top five mortality agents in 2008 ADS, mountain pine beetle tops the list with the affected area increasing over what was mapped during 2007 (table 3.2). Lodgepole pine stands are severely affected, as are whitebark and other five-needle pine species. In general, the sustainability of certain five-needle pine species 
The top five mortality agents are:

Mountain pine beetle $66 \%$ Subalpine fir mortality $7 \%$ (Including western balsam bark beetle)

Aspen defoliation $6 \% \quad$ Fir engraver $5 \%$ Bear damage $4 \%$

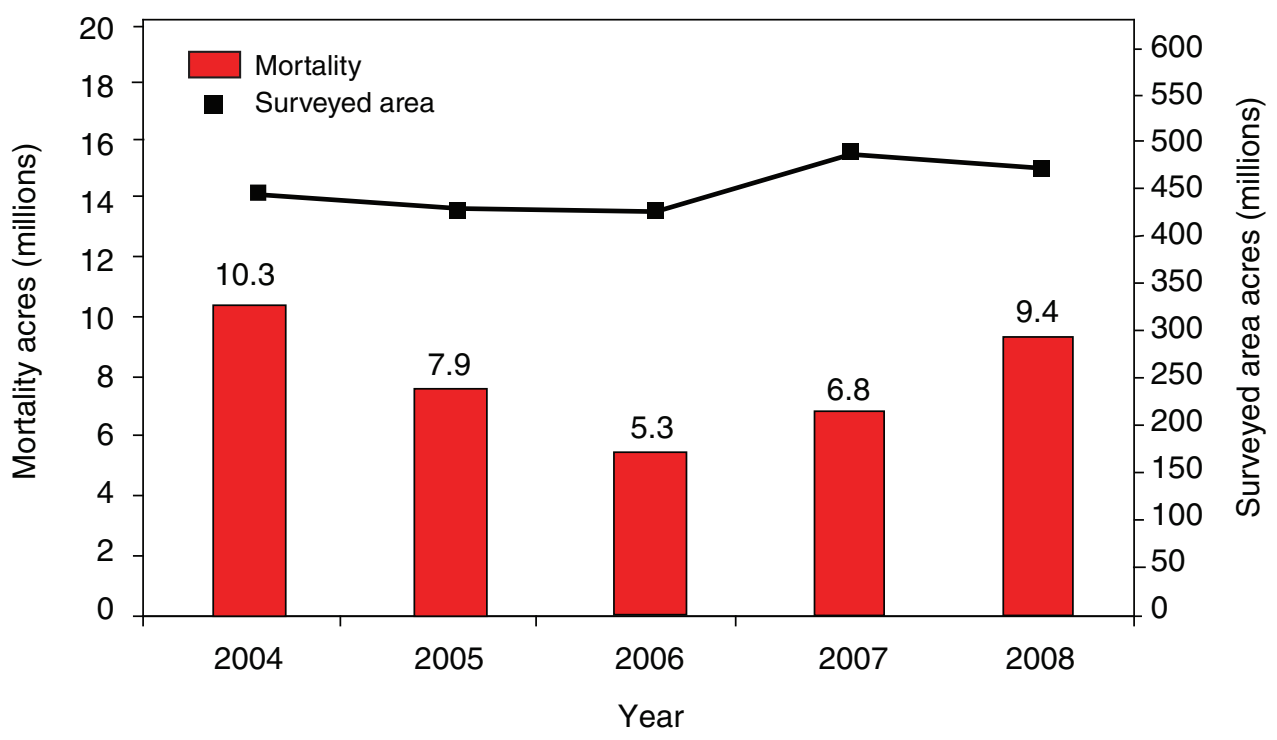

Total acres with mortality from insect and disease detection surveys

Figure 3.6-The top five mortality agents mapped during 2008 are listed to provide current status; graphed are the acres with mortality from all damage agents and area flown during surveys conducted over the last 5 years.

has long been a concern and, combined with the effects of white pine blister rust, mountain pine beetle activity may have permanent effects upon the range of five-needle pine. Additional information and important questions regarding impacts of various agents upon these pines are detailed in the FHP publication Mountain Pine Beetle Impacts in High Elevation
Five-Needle Pines: Current Trends and Challenges (Gibson and others 2008). Subalpine fir mortality is once again second, followed closely by aspen defoliation. Aspen defoliation seems to be resulting in mortality and, though the phenomenon did not make the top five list in 2007, has been gaining importance as observers and scientists work to describe what 


\section{Table 3.2 - Select mortality and defoliating agent impact totals from surveys during two analysis periods}

\begin{tabular}{|c|c|c|c|c|c|c|c|c|c|c|c|c|c|c|c|}
\hline \multirow{2}{*}{$\begin{array}{l}\text { Indicator } \\
\text { Conterminous States }\end{array}$} & \multicolumn{6}{|c|}{$\begin{array}{l}\text { Acres }(1000 \text { s) with mortality } \\
\text { reference period }\end{array}$} & \multirow[t]{2}{*}{$\begin{array}{l}\text { Total acres } \\
\text { reference }\end{array}$} & \multicolumn{6}{|c|}{$\begin{array}{c}\text { Acres (1000s) with mortality } \\
\text { current period }\end{array}$} & \multirow[t]{2}{*}{$\begin{array}{l}\text { Total acres } \\
\text { current }\end{array}$} & \multirow[t]{2}{*}{$\begin{array}{c}\text { Ratio of } \\
\text { increase or } \\
\text { decrease }\end{array}$} \\
\hline & 1997 & 1998 & 1999 & 2000 & 2001 & 2002 & & 2003 & 2004 & 2005 & 2006 & 2007 & 2008 & & \\
\hline Mountain Pine Beetle & 317 & 352 & 421 & 432 & 805 & 1,336 & 3,663 & 1,581 & 2,418 & 2,930 & 2,722 & 3,921 & 6,015 & 19,587 & 5.35 \\
\hline Fir Engraver & 177 & 44 & 59 & 18 & 46 & 308 & 651 & 912 & 1,774 & 960 & 381 & 442 & 492 & 4,962 & 7.62 \\
\hline Douglas-fir Beetle & 49 & 134 & 352 & 353 & 415 & 319 & 1,622 & 385 & 551 & 676 & 200 & 287 & 196 & 2,294 & 1.41 \\
\hline Western Pine Beetle & 38 & 43 & 24 & 22 & 57 & 121 & 305 & 189 & 254 & 101 & 146 & 30 & 104 & 823 & 2.70 \\
\hline Other Insects & 490 & 476 & 376 & 543 & 1,047 & 2,382 & 5,313 & 3,820 & 2,470 & 1,856 & 1,206 & 1,308 & 963 & 11,623 & 2.19 \\
\hline $\begin{array}{l}\text { Oak Mortality (SOD and } \\
\text { decline) }\end{array}$ & 0 & 0 & 0 & 2 & 0 & 0 & 2 & 0 & 1 & 4 & 24 & 65 & 34 & 129 & 59.37 \\
\hline $\begin{array}{l}\text { Port-Orford-cedar } \\
\text { Root Disease }\end{array}$ & 4 & 2 & 3 & 5 & 6 & 6 & 27 & 9 & 10 & 9 & 11 & 12 & 6 & 58 & 2.18 \\
\hline Annosus Root Disease & 0 & 0 & 0 & 0 & 0 & 0 & 0 & 7 & 0 & 0 & 0 & 5 & 0 & 13 & 2516.14 \\
\hline Armillaria Root Disease & 0 & 0 & 0 & 0 & 0 & 0 & 1 & 3 & 0 & 31 & 0 & 18 & 0 & 52 & 85.16 \\
\hline $\begin{array}{l}\text { Other Root Diseases } \\
\text { (mostly Black Stain) }\end{array}$ & 18 & 75 & 1 & 6 & 4 & 4 & 108 & 1 & 1 & 2 & 1 & 8 & 1 & 14 & 0.13 \\
\hline Pinyon (multi) & 17 & 0 & 0 & 5 & 17 & 266 & 306 & 3,779 & 1,738 & 74 & 34 & 20 & 6 & 5,652 & 18.47 \\
\hline Subtotal & 1,110 & 1,125 & 1,236 & 1,386 & 2,397 & 4,744 & 11,998 & 10,686 & 9,218 & 6,644 & 4,723 & 6,116 & 7,818 & 45,206 & 3.77 \\
\hline Alaska & 1997 & 1998 & 1999 & 2000 & 2001 & 2002 & & 2003 & 2004 & 2005 & 2006 & 2007 & 2008 & & \\
\hline Insects & 573 & 335 & 288 & 121 & 104 & 59 & 1480 & 115 & 157 & 114 & 134 & 184 & 129 & 833 & 0.56 \\
\hline $\begin{array}{l}\text { Yellow Cedar Decline } \\
\text { (multi) }\end{array}$ & 0 & 0 & 0 & 0 & 1 & 3 & 4 & 9 & 14 & 33 & 32 & 26 & 9 & 123 & 28.17 \\
\hline Subtotal & 573 & 335 & 288 & 121 & 106 & 62 & 1,485 & 124 & 171 & 147 & 166 & 210 & 138 & 956 & 0.64 \\
\hline Total mortality & 1,683 & 1,460 & 1,524 & 1,507 & 2,503 & 4,806 & 13,483 & 10,811 & 9,389 & 6,791 & 4,889 & 6,326 & 7,956 & 46,162 & $\begin{array}{c}3.42 \\
\text { continued }\end{array}$ \\
\hline
\end{tabular}


Table 3.2—Select mortality and defoliating agent impact totals from surveys during two analysis periods (continued)

\begin{tabular}{|c|c|c|c|c|c|c|c|c|c|c|c|c|c|c|c|}
\hline \multirow{2}{*}{$\begin{array}{l}\text { Indicator } \\
\text { Conterminous States }\end{array}$} & \multirow[b]{2}{*}{1997} & \multicolumn{4}{|c|}{$\begin{array}{c}\text { Acres (1000s) with defoliation } \\
\text { reference period }\end{array}$} & \multirow[b]{2}{*}{2002} & \multirow[t]{2}{*}{$\begin{array}{l}\text { Total acres } \\
\text { reference }\end{array}$} & \multicolumn{6}{|c|}{$\begin{array}{l}\text { Acres (1000s) with defoliation } \\
\text { current period }\end{array}$} & \multirow[t]{2}{*}{$\begin{array}{l}\text { Total acres } \\
\text { current }\end{array}$} & \multirow[t]{2}{*}{$\begin{array}{c}\text { Ratio of } \\
\text { increase or } \\
\text { decrease }\end{array}$} \\
\hline & & 1998 & 1999 & 2000 & 2001 & & & 2003 & 2004 & 2005 & 2006 & 2007 & 2008 & & \\
\hline Tent Caterpillars & 11 & 98 & 569 & 3,325 & 21,007 & 12,475 & 37,485 & 3,622 & 1,122 & 1,776 & 2,899 & 614 & 402 & 10,435 & 0.28 \\
\hline Leafminers & 4 & 603 & 41 & 22 & 0 & 8 & 678 & 15 & 17 & 26 & 16 & 0 & 1 & 76 & 0.11 \\
\hline Budworms & 796 & 1,154 & 637 & 696 & 930 & 711 & 4,922 & 1,112 & 1,295 & 1,891 & 2,978 & 2,596 & 2,092 & 11,965 & 2.43 \\
\hline Leafrollers & 0 & 537 & 308 & 179 & 63 & 199 & 1,286 & 0 & 310 & 66 & 102 & 7 & 19 & 505 & 0.39 \\
\hline Gypsy Moth & 51 & 350 & 569 & 1,559 & 1,473 & 441 & 4,442 & 250 & 128 & 652 & 1,280 & 1,399 & 1,551 & 5,260 & 1.18 \\
\hline Subtotal & 862 & 2,741 & 2,123 & 5,781 & 23,473 & 13,834 & 48,814 & 4,999 & 2,873 & 4,411 & 7,275 & 4,616 & 4,065 & 28,239 & 0.58 \\
\hline Alaska & 1997 & 1998 & 1999 & 2000 & 2001 & 2002 & & 2003 & 2004 & 2005 & 2006 & 2007 & 2008 & & \\
\hline Leafminers & 4 & 123 & 181 & 44 & 11 & 330 & 692 & 467 & 834 & 734 & 512 & 848 & 287 & 3,684 & 5.32 \\
\hline Sawflies & 274 & 466 & 160 & 70 & 19 & 2 & 991 & 1 & 15 & 17 & 3 & 0 & 0 & 35 & 0.04 \\
\hline Budworms & 69 & 88 & 1 & 41 & 76 & 9 & 284 & 46 & 85 & 17 & 55 & 48 & 9 & 260 & 0.92 \\
\hline Other & 39 & 76 & 29 & 60 & 44 & 83 & 329 & 237 & 58 & 161 & 129 & 67 & 16 & 667 & 2.03 \\
\hline Subtotal & 386 & 752 & 370 & 215 & 150 & 423 & 2,296 & 751 & 993 & 930 & 698 & 963 & 312 & 4,646 & 2.02 \\
\hline Total defoliation & 1,248 & 3,493 & 2,493 & 5,997 & 23,623 & 14,257 & 51,110 & 5,750 & 3,866 & 5,341 & 7,973 & 5,578 & 4,377 & 32,885 & 0.64 \\
\hline
\end{tabular}

Note: The ratio is expressed as increase or decrease for each pest or pest grouping; all estimates are a subset of national totals, which consider other damage agents (not included). "Multi" indicates pest complex. Oak Mortality includes general decline and sudden oak death (SOD) aerially mapped as "likely to be infected" plus areas subsequently confirmed through official sampling, but does not include all SOD special surveys (many of which were reported separately during early 2000s). 
some feel is a significant aspen-related event. ${ }^{5}$ Fir engraver-caused mortality also makes the top five list again in 2008 but has slipped to fourth, edged out by aspen defoliation. Among the top five agents in 2007, spruce and Douglasfir beetles do not make the list in 2008; bearcaused damage does. The increase in bearcaused damage is documented primarily in the Northwestern United States. The priority for ADS is to capture data relating to insect and disease activity; however, these surveys are useful to report on a variety of biotic and abiotic damage types. For a complete list of possible damage agents, see appendix E in Forest Health Monitoring (2005).

There are many factors which determine tree species distribution, overall stand composition, and the number and extent of live trees. Tree species composition, abundance, and other environmental conditions contribute to elevated levels of mortality and epidemics that, in some cases, result in forest type conversion. Mortality and other types of damage are important to characterize but the number and extent of live trees is an alternative and perhaps an improved expression of forest health. Additional conclusions regarding sustainability in a spatial and temporal context may be derived by considering areas with damage as inversely

\footnotetext{
${ }^{5}$ Various professional communication regarding Sudden Aspen Decline, including workshop discussion at the Cooperative U.S. Department of Agriculture, Forest Service and Colorado State Forest Service Aerial Survey Calibration and Conformity Fly-In. 2008. Fort Collins Loveland Airport Loveland, CO 80538.
}

related to the approximate number and extent of live trees remaining. Areas with mapped mortality have yet to be fully developed as a proxy for the extent of live trees and in fact, the approach may not be entirely appropriate. Though methods to accurately describe the number and extent of live trees are not referenced within this chapter, areas mapped with mortality and other damage remain credible indicators of forest sustainability. Described elsewhere in this chapter are some examples of regional effects threatening sustainability such as invasive pests and plants in Hawaii, Douglas-fir/spruce beetles in the Northwest, and mountain pine beetle in the Rocky Mountains.

\section{Trends in Alaska and the conterminous}

United States-The total area flown remains fairly consistent from year to year, particularly in the conterminous United States, which adds significance to the annual increase in area mapped with forest injury. Within the last decade, annual mortality estimates peaked in 2003 for the conterminous United States (fig. 3.7), and then declined somewhat during subsequent years. However, the area with mortality during the current period (the last 6 years) has never dropped below any year in the reference period. Alaska mortality levels appear to be slightly more stable statewide during the current period. However, less confidence should be associated with the notion that Alaska may be more stable since the flown area has been relatively more sporadic and there is a much smaller proportion of forested area surveyed. 

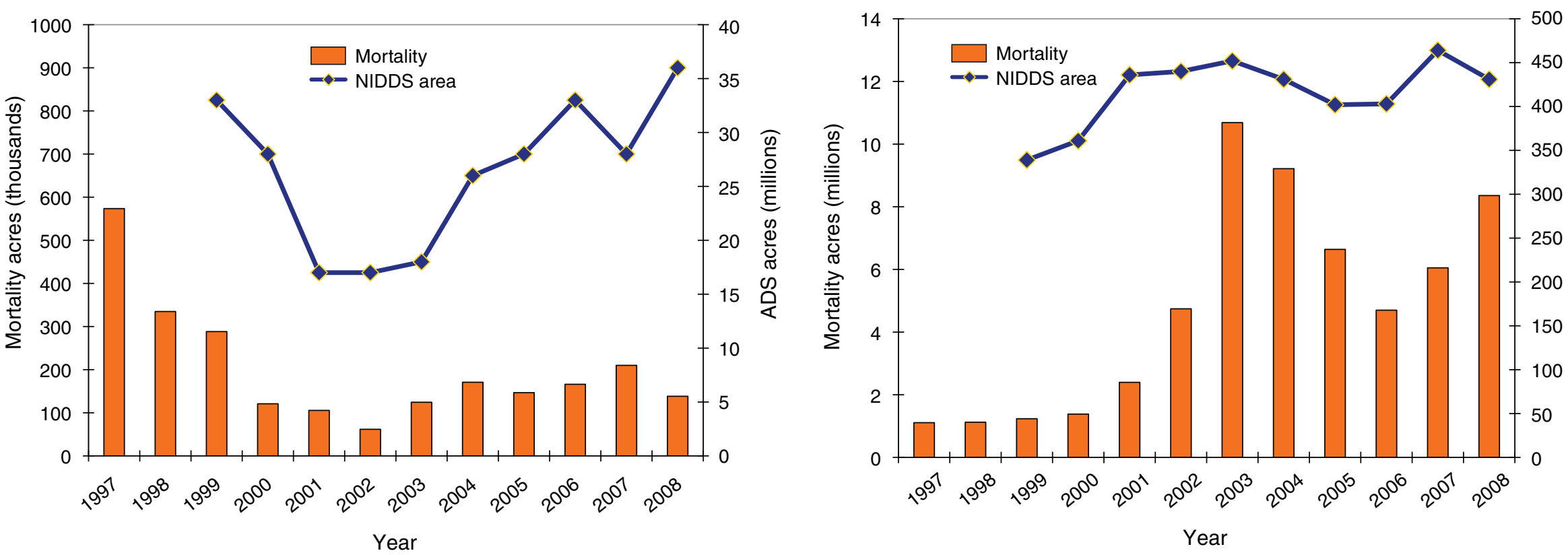

500

Year

Year

Figure 3.7-Annual National Insect and Disease Detection Survey results for area with mortality and area flown for Alaska (left) and the conterminous United States (right); the area includes select insects, diseases, and complexes as listed in table 3.1. The large increase in the conterminous United States during 2003 reflects a spike in pinyon mortality extending into 2004; mortality during more recent years has increased in other softwood, oak, and aspen types due to a variety of agents. Regional reporting of area flown began in 1999.

The following highlights trends for two tree species groupings, connectivity to climate and concludes with a more detailed description of effects within Alaska, the conterminous United States, and Hawaii.

\section{Recent trends highlighted for aspen and}

five-needle pines-Using ADS data to examine trends in aspen damage indicates gradual decreases in defoliation accompanied by gradual increases in mortality. Large areas of defoliation caused by forest tent caterpillar were recorded in the late 1990s through the early 2000s, and the defoliation since has subsided. A varied range of aspen-defoliating agents has been mapped more recently. Large areas with prior defoliation are recently experiencing mortality. The top six defoliating and mortality-causing agents or complexes are shown in figure 3.8.

Historical records indicate aspen was affected primarily by the following (in decreasing order of area impacted): defoliation agents-forest tent caterpillar, large aspen tortrix, Marssonina blight, 


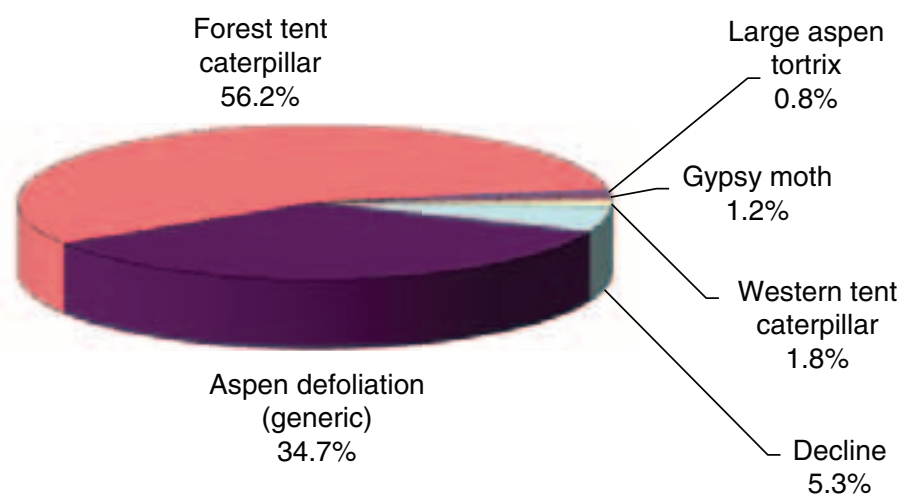

Top Six Defoliating Agents in Aspen 2003-2008 (5.5 M acres)

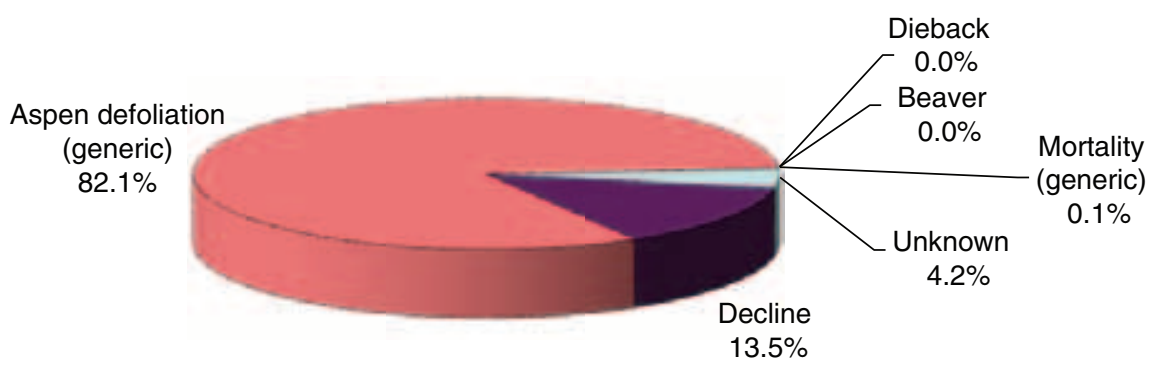

Top Six Mortality Agents in Aspen 2003-2008 (0.7 M acres)

Figure 3.8-The top six biotic defoliating (left) and mortality (right) agents in aspen mapped during the last 6 years of National Insect and Disease Detection Surveys; total acres with defoliation and mortality are approximately 5.5 million and 0.7 million acres respectively; dieback and beavers are among the top six mortality agents, but amount to only trace acreages.

Melampsora rusts; and mortality agents - the leading causes of mortality in aspen are due to defoliation from the specific agents listed above and from a general "decline" damage agent. Decline is one option among damage agents available to attribute mapped polygons, and is often used when symptoms do not indicate anything more specific. Early in the 2000s, some large areas of forest tent caterpillar outbreaks were mapped in Minnesota and Wisconsin and, to a lesser extent, in the southern and northeastern areas of the conterminous United States. More recently, mortality is occurring from defoliation and from decline, mostly mapped in the FHM Interior West Region. Many aspen stands are relatively old (80-100 years) and in declining health, but the stands continue to regenerate from healthy, long-lived root systems. Where these stands of mature trees are dying rapidly without successful regeneration, and where the causal agents are not readily identifiable, there is cause for concern. Drought and high temperatures are implicated as inciting factors. The term "sudden aspen decline" has been used to describe this phenomenon (Worrall and others 2008).

Trends in five-needle pine injury mapped within western FHM regions are shown in figure 3.9. The total for the 12-year period is 4.4 million acres, with injury compared to 24,000 acres for eastern white pine (sum of annual totals including mortality, defoliation, and other damage). Surveys indicate a steady increase in acres affected throughout the analysis period. The most damaging biotic agents mapped in the West (in descending order of area impacted) are mountain pine beetle, 


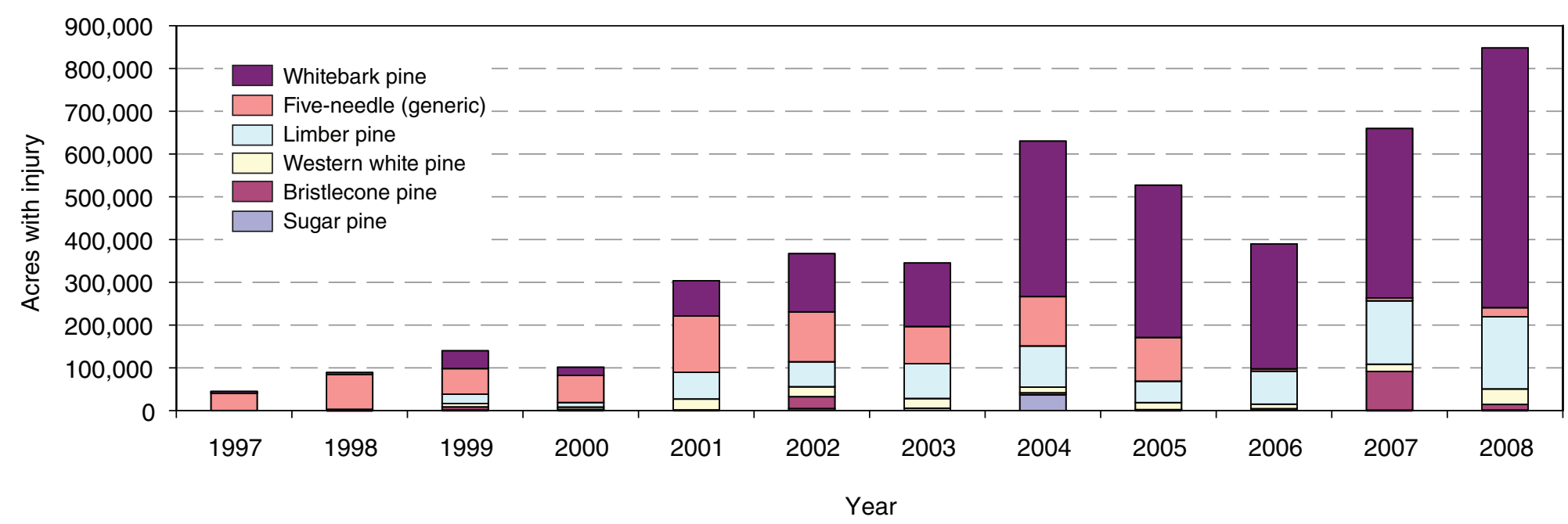

Biotic Injury in Western Five-Needle Pine 1997-2008 National Insect and Disease Detection Survey

Figure 3.9-Annual acres with biotic injury in western five-needle pines; the biotic agents included are primarily mortalitycausing agents. "Five-needle pine (generic)" includes white pine blister rust injury where a host is not specified; National Insect and Disease Detection Survey forest or host type codes "mixed conifer" and "pine" are not included, possibly not reporting some five-needle pine injury.

five-needle pine decline, white pine blister rust, bark beetles (general), and multi-damage (fig. 3.10). Trend data and research indicate a proactive approach to reducing impacts to fiveneedle pine is prudent. These stands are likely to continue to decline without some form of intervention to enhance and regenerate them.

Influence of climate upon succession and host/pest relationships-Much research is being done to evaluate the effects of climate upon terrestrial resources and systems, including forest types. Tree growth, species composition, and distribution are certain to be impacted by climate change. Current examination of biotic indicator data suggests tree hosts and pests are responding to climactic effects now. Temperature time trend and geographic extent were queried (using NASA's online query builder at http:// data.giss.nasa.gov/) to illustrate that global changes may currently be contributing to the observed increases in forest area with damage and reduced productivity. Are we beginning to see a shift in where certain species are able to grow well? Survey data indicate biotic impacts are increasing at worrisome rates, and desired natural regeneration may be compromised 


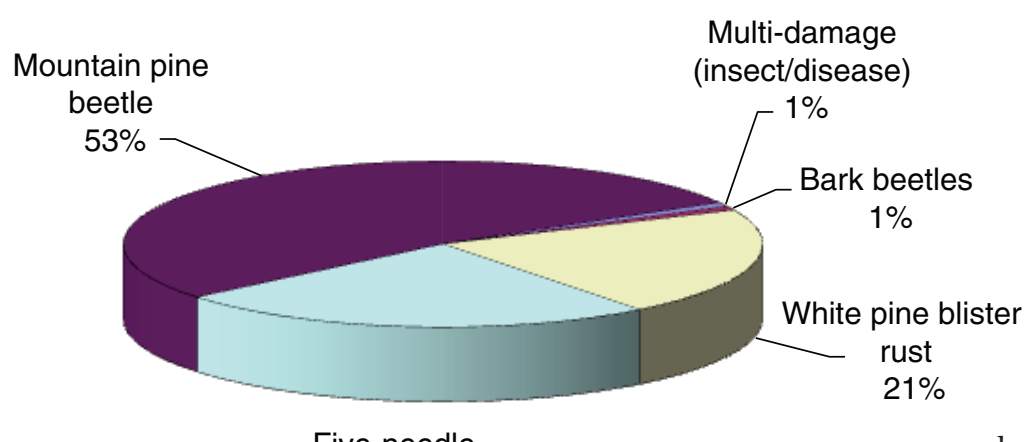

Five-needle pine decline

$24 \%$

are beyond the scope of this chapter, but figure 3.11 hints at the effects climate may be having upon mountain pine beetle movement in Colorado. Based on aerial survey data, there is an apparent shift upward in elevation for mapped pine mortality due to mountain pine beetle. The proportion of beetle occurrence charted can be interpreted to have climbed 300-400 m during recent years, moving from lodgepole pine into upper elevation pine species within the confined, localized area of analysis

during a changing climate. The trend for warmer global temperatures and reduced precipitation in certain areas is expected to continue.

Generally, climate models suggest that a warmer earth will be wetter on average, but the rain might not be where it is needed to maintain existing ecosystems.

Some questions relating climate to host and pest distribution remain, such as: are climate changes affecting host species distribution and/or historical pest range? Is warming also associated with lower precipitation and changes in generational times or numbers of annual generations for pests? If climate is connected to changes we are seeing in North American forests and their long-term resource implications, what will be the social and biological effects and possible mitigations? Answers to these questions numbers of insects and/or availability of host.

Regardless of real or perceived climatic influences, the total forest area with defoliation and mortality mapped from 1997 to 2002 compared to 2003 to 2008 has changed (see select biotic indicators and damage types, table 3.2). Note that "footprint" of forest damage is reconciled within individual years, i.e., the subtotal for any given year represents footprint area with damage and does not count overlapping impacts within that year; a simple summation of annual impacts across years shows total increase or decrease in area mapped for the two time periods indicated. In general, increasing amounts of area with mortality have been mapped annually in the conterminous 


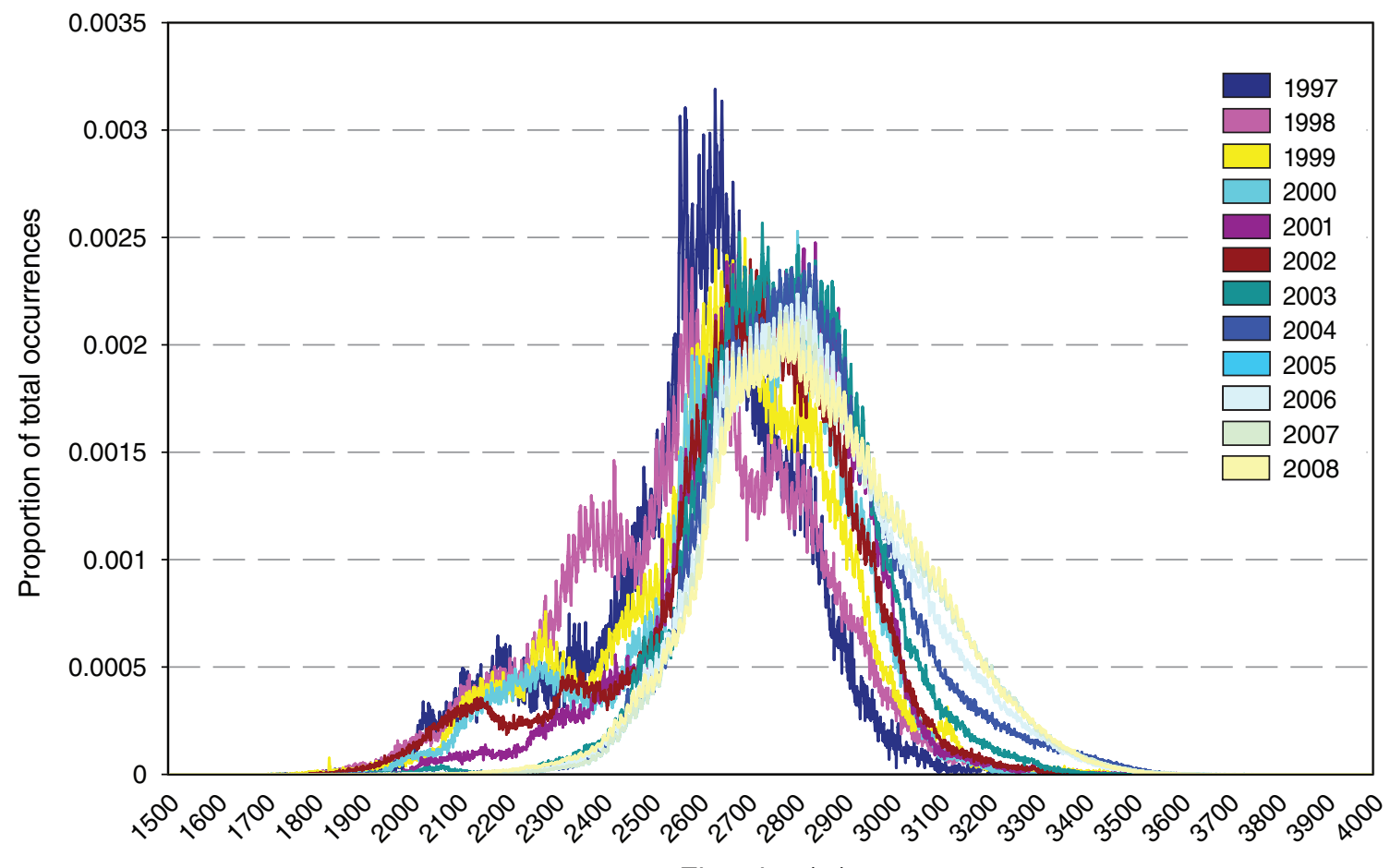

Elevation (m)

Proportional Elevation Distribution of MPB By Year

Figure 3.11-Pine injury mapped during 12 years of National Insect and Disease Detection Survey on 30-m elevation pixels, within map zone 28 in Colorado; the histograms for each year are proportioned to display normalized injury occurrence to pine species, primarily caused by mountain pine beetle. Damage is at its maximum at an elevation of approximately $2600 \mathrm{~m}$ in 1997, gradually moving uphill to peak at approximately $2900 \mathrm{~m}$ in 2008. 
United States, and increasing amounts of area with defoliation have been mapped annually in Alaska. The sum total of this change within the two periods is as follows:

- Mortality in the conterminous United States has increased by approximately 33.2 million acres

- Mortality in Alaska has decreased by approximately 0.5 million acres

- Defoliation in the conterminous United States has decreased by approximately 20.6 million acres

- Defoliation in Alaska has increased by approximately 2.3 million acres
Aerial and ground survey results presented in this chapter include a large proportion, but not all, of the total forested area in the United States. Annual aerial surveys cover up to 70 percent and 23 percent of forested area in the conterminous United States and Alaska, respectively. Though surveys are prioritized within areas where impacts are most likely to occur, the area surveyed remains considerably less than the total forested for both Alaska and the conterminous United States (fig.

3.12). Therefore, interpreters of these data should consider insect and disease impacts underestimated. Underestimates are further compounded by impacts within the understory
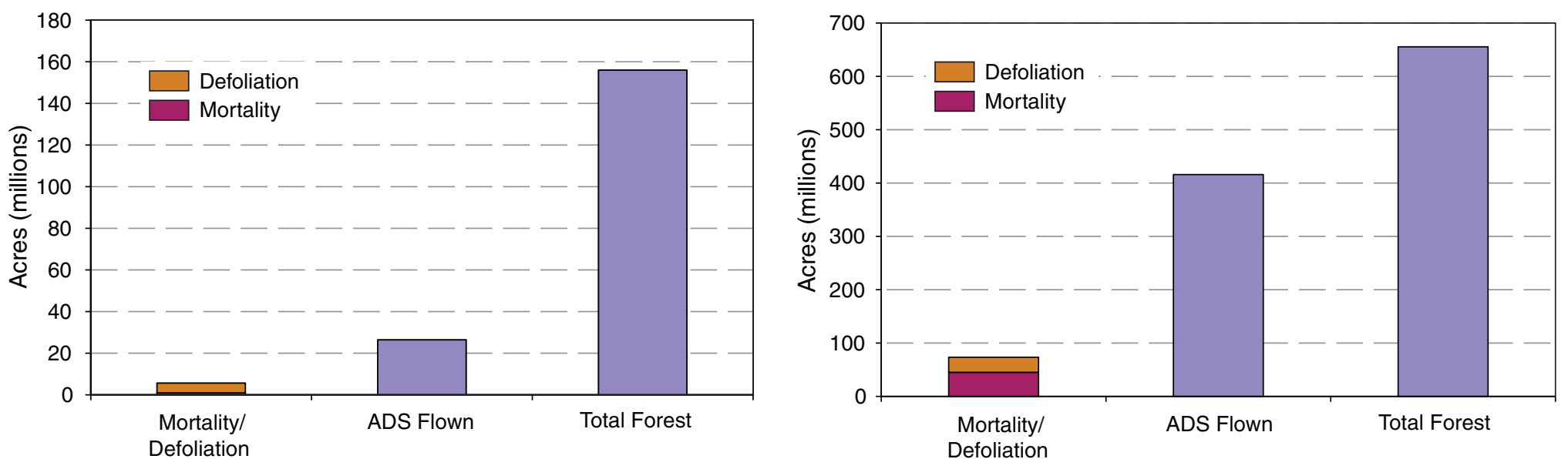

Figure 3.12-2003-08 total mortality and defoliation acres for Alaska (left) and the conterminous United States (right) as compared to average annual National Insect and Disease Detection Survey flown area and total forest; Alaska surveys are confined to major river drainages with flights based out of Fairbanks, Anchorage, Juneau, and Wrangell; sources of total forest cover estimated for Alaska and conterminous United States are varied, 1991-2003 data were used (see Krist and others 2007). 
that are not readily visible during aerial survey. Due to accessibility, only a fraction of the forested area in Alaska is surveyed and priority is given to surveying major river drainages. Aerial surveys are not reported for Hawaii; however, there are serious forest sustainability issues on the islands (see below).

Aerial detection surveys in Alaska show that yellow-cedar decline, spruce beetle, larch beetle, and engraver beetles are the leading contributors to current mortality. Unique to Alaska is the issue of yellow-cedar decline, believed to be directly related to climate (Hennon and others 2006). As shown in table 3.2, there is a 31 -fold increase in yellow-cedar decline over reference condition. Though many biotic indicators are present in these yellow-cedar stands, current evidence points to poorly drained soils as perhaps one of the inciting factors and freeze injury to roots due to low snow pack as being the most likely cause. ${ }^{6}$ Overall, a comparison of current condition to reference conditions indicates defoliation is increasing and mortality is decreasing. Current mortality and defoliation for Alaska should be considered grossly underestimated since, owing to remoteness and logistical constraints, surveys currently cover only a fraction of the total forested lands in the State. The total area with mortality and defoliation since 2003 is approximately 6 million acres.

${ }^{6}$ U.S. Department of Agriculture, Forest Service. Uncovering
the cause of yellow-cedar decline. www.fs.fed.us/r10/spf/ fhp/cedar/causes.html.
Aerial detection surveys in the conterminous United States show total area with mortality has increased from 12 million acres (1997-2002) to 45 million acres (2003-2008) (table 3.2). Bark beetle, engraver beetle, gypsy moth-caused mortality, and mortality in the pinyon-juniper type are leading contributors to this increase. Areas impacted by root disease are documented as decreasing; however, it should be noted that root diseases are rarely mapped using ADS.

Currently reported insect-caused mortality often includes complexes of both insects and diseases, so disease acreage is much higher than recorded. The total area with defoliation has decreased by approximately 40 percent compared to reference conditions. This decrease is likely attributable to effective gypsy moth suppression and eradication efforts and, in some cases, to repeated defoliation events that move some areas into the mortality category. The total area with both mortality and defoliation since 2003 is approximately 73 million acres.

While the percentage of affected forest land in the United States may appear relatively low, the rate at which acreage is being impacted is alarming. As predicted by risk modeling, and confirmed by site-specific observations, actual impacts at local or regional levels are often extreme. ${ }^{7}$ Overall, the indicator shows a continuing trend in forest decline. Arguably, and considering the potential for certain

\footnotetext{
${ }^{7}$ U.S. Department of Agriculture, Forest Service. National Insect and Disease Detection Survey interactive map. http:// svinetfc8.fs.fed.us/aerialsurvey.
} 
outbreak events to be cyclical in nature (e.g., mountain pine beetle in pure, unmanaged lodgepole pine stands), many affected areas will likely regenerate; however, the resulting single-species/single-age-class regeneration will not provide a sustainable forest. Spikes in mortality during the reporting period are largely due to a combination of high stand density in unmanaged forests and drought. Cumulative impacts are occurring within previously surveyed areas and expanding into new areas. The total area with mortality and defoliation has quadrupled over recent years for select indicators (table 3.2). Regardless of whether the cause of impacts is overstocking, climate, invasive pests, or a combination of all three, intervention may be necessary to restore ecosystems to health, vigor, and productivity.

Other important local or regional impactsFinally, this chapter highlights a few of the important invasive pests managers have been wrestling during recent years. Cumulative impacts from both native and nonnative pests are particularly evident at regional and local scales where insect, pathogen, and invasive plant impacts are often considered to be of epidemic proportions or chronic in nature. Combined with other environmental factors, invasives are often responsible for affecting the number and extent of live trees, causing large fuel accumulations, and altering successional processes.

Whether flora or fauna, native or nonnative, invasive pests have a history of causing serious resource problems not only in terms of public nuisance and safety, but also problems for industry, wildlife habitat, air, and water quality. Examples include gypsy moth frass in recreational use areas, reduced mast production in tanoak forests affected by $P$. ramorum, reduced stocking leading to increased runoff, fuel accumulations from mortality, and nonnative grass invasion leading to increased burn intensity. The focus of this chapter is on insect and diseases but it must also acknowledge invasive plants. Aerial surveys have been done for invasive plant species, for example scotch broom and buffelgrass. Though not reported in great detail, aerial detection surveys for plants, combined with other detection methods, are critical to increased understanding of current forest dynamics. Other important invasive 
plant species such as cheat grass, salt-cedar, tree-of-heaven, spotted knapweed, miconia, and many more are contributing to localized sustainability issues.

Invasive species often become established and readily spread within forested regions currently out of the range of natural variability. For example in the West, stands that become dominated by shade tolerant tanoak due to a variety of factors (e.g., fire exclusion, absence of harvest practices that increase age and species diversity) provide optimum conditions for the presumed nonnative pathogen $P$. ramorum causing sudden oak death to become established and spread (e.g., Moritz and Odion 2005).

Hawaii is also negatively affected by invasive pathogen, plant, and insect pests. Impacts of invasive species, including animals, have been profound in Hawaii and are at the root of Hawaii's biodiversity crisis (fig. 3.13). Guava rust is currently defoliating nonnative forests at low elevation; there is a potential threat to native ohia, which dominates 80 percent of Hawaii's native forests. The erythrina gall wasp threatens widespread mortality of native wili trees, a component of much of Hawaii's remaining dry forests, and has almost eliminated the introduced coral tree. Nonnative invasive plant species impacting ecosystems in Hawaii include strawberry guava, velvet tree, peacock plume, and hundreds of other plants; there are nearly as many naturalized alien plant species as native species. Hawaii is particularly vulnerable to invasive species because its native species evolved in the absence of ungulates, rodents and predators, which have since been introduced. Nonnative mosquitoes carry avian malaria, decimating native birds. Invasive grasses provide fuel for fire. ${ }^{8}$

Additional nonnative invasive insects and diseases which threaten the mainland include sudden oak death and Port-Orford-cedar root disease in the West; gypsy moth (fig. 3.14), hemlock woolly adelgid (fig. 3.15), sirex woodwasp (fig. 3.16), and emerald ash borer (fig. 3.17) in the Northeast; chestnut blight and butternut canker in the East; white pine blister rust, Dutch elm disease, and more.

Monitoring regional indicator impacts is critical to early detection in order to apply management strategies for prevention and control in infested areas, areas currently in a condition predisposed to pest attack, and areas that are approaching a condition in which sustainability is at risk without management.

${ }^{8}$ Personal communication. 2009. Katie Friday and Anne Marie LaRosa. U.S. Department of Agriculture, Forest Service Pacific Southwest Region, Institute of Pacific Islands Forestry, 60 Nowelo Street, Hilo, HI 96720 


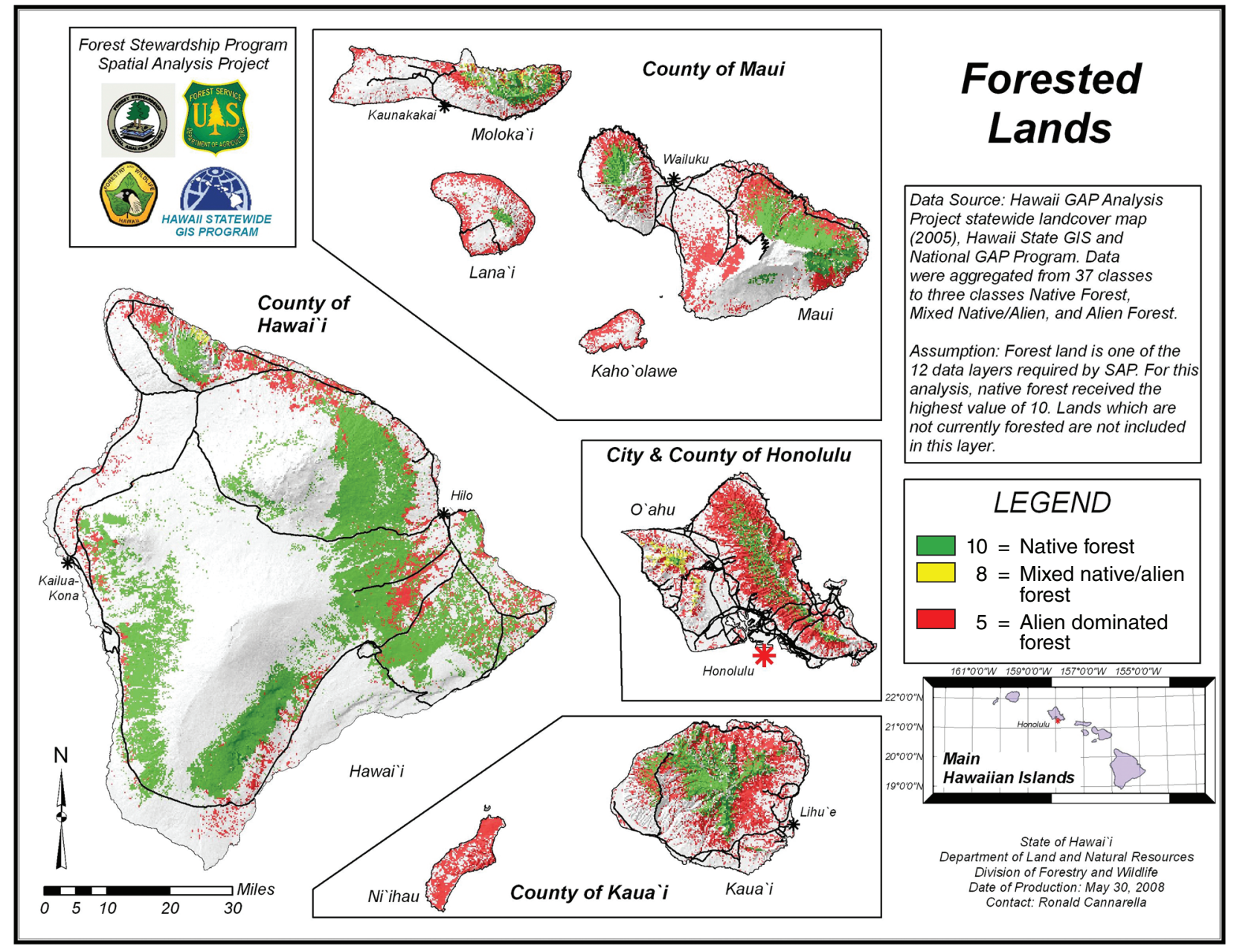

Figure 3.13-Hawaii forests are dominated by overstory native, mixed, and alien species; approximately half of Hawaii's remaining forest has been transformed from reference conditions by alien plants. 


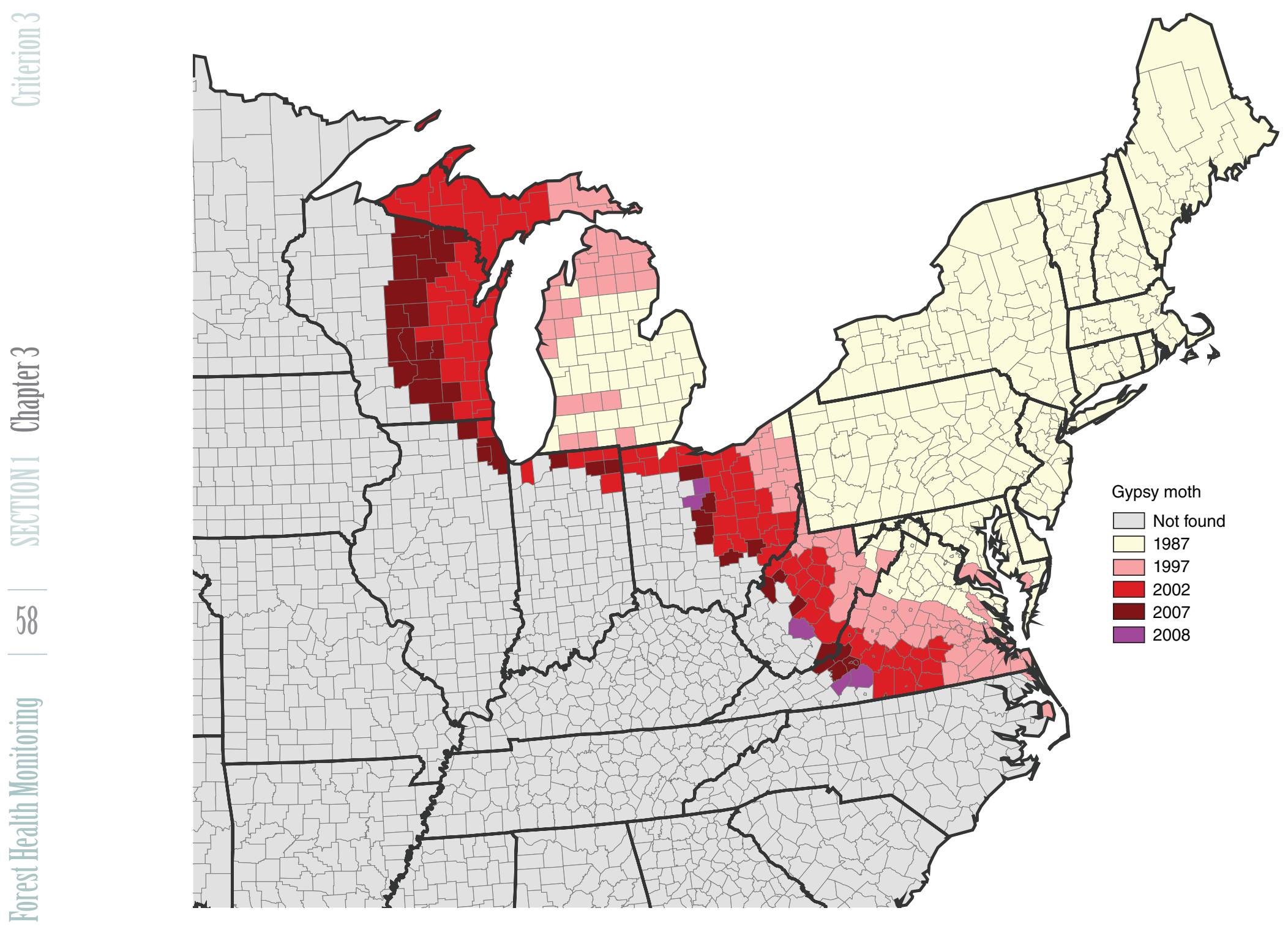

Figure 3.14-Gypsy moth counties impacted/progression of quarantine, 1987-2008. 


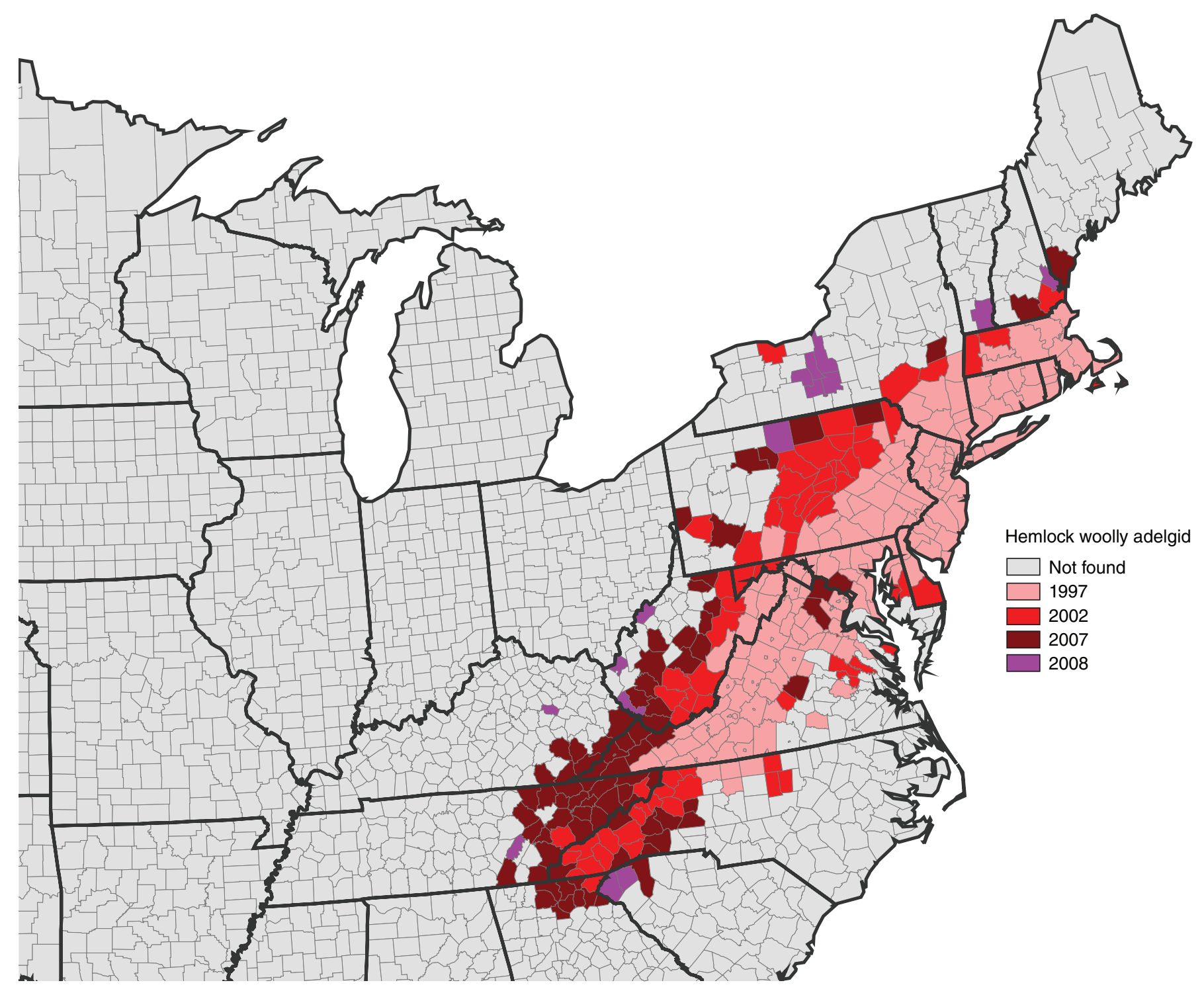

Figure 3.15-Hemlock woolly adelgid spread by county. 


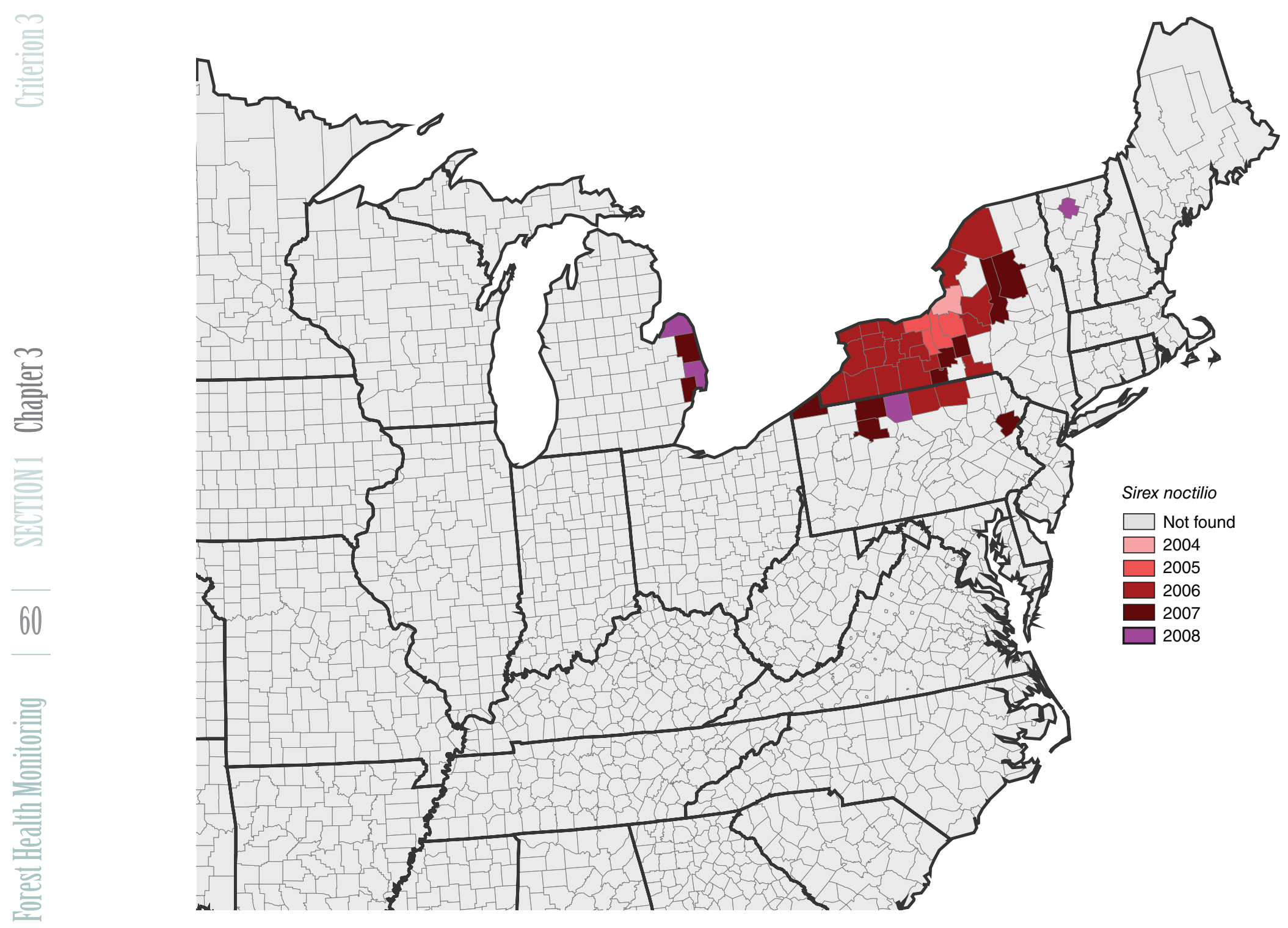

Figure 3.16-Sirex noctilio spread by county. 


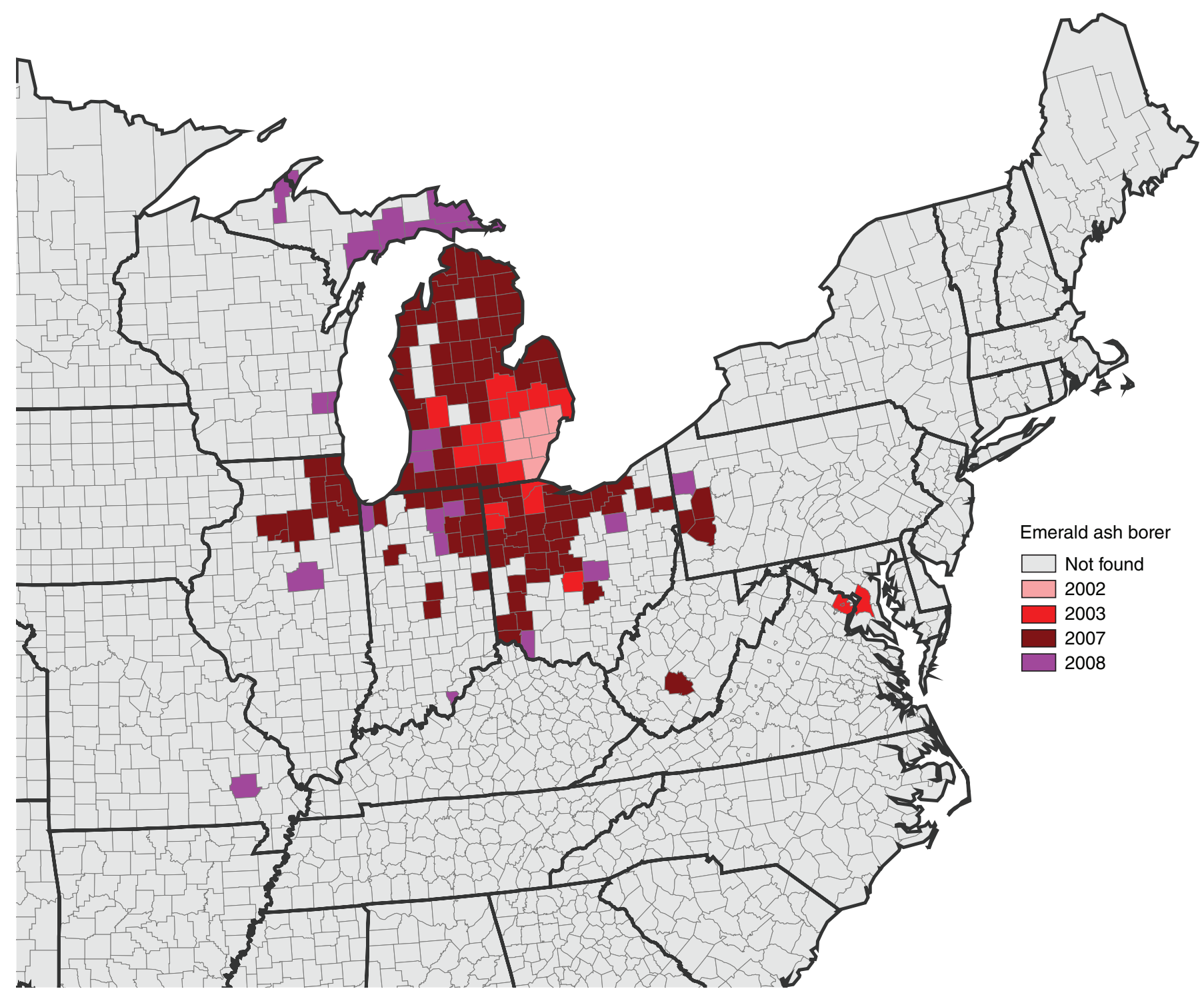

Figure 3.17-Emerald ash borer spread by county. 


\section{Literature Cited}

Forest Health Monitoring (FHM). 1999. Aerial survey standards. 7 p. http://www.fs.fed.us/foresthealth/

technology/pdfs/standards_1099.pdf. [Date accessed: Sept. 1, 2009].

Forest Health Monitoring (FHM). 2005. Aerial survey Geographic Information System handbook. 27 p. http:// www.fs.fed.us/foresthealth/aviation/resources/docs/ GISHandbook body apndxA-C.pdf. [Date accessed: September 1, 2009].

Gibson, K.; Skov, K.; Kegley, S. [and others]. 2008. Mountain pine beetle impacts in high-elevation fiveneedle pines: current trends and challenges. R1-08-020. Missoula, MT: United States Department of Agriculture Forest Service, Forest Health Protection. 32 p. http://www. fs.fed.us/rl-r4/spf/fhp/publications/bystate/R1-08-020 MPBHighElevation5Needle_gibson_10232008.pdf. [Date accessed: September 1, 2009].

Hennon, P.; D'Amore, D.; Wittwer, D. [and others]. 2006. Climate warming, reduced snow, and freezing injury could explain the demise of yellow-cedar in southeast Alaska, USA. World Resource Review. 18: 427-450.
Krist, F.J.; Sapio, F.J.; Tkacz, B.M. 2007. Mapping risk from forest insects and diseases 2006. FHTET 2007-06. Fort Collins, CO: U.S. Department of Agriculture Forest Service, Forest Health Technology Enterprise Team. 114 p.

McConnell, T.J.; Johnson, E.W.; Burns, B. 2000. Guide to conducting aerial sketchmapping surveys. FHTET 00-01 Fort Collins, CO: U.S. Department of Agriculture Forest Service, Forest Health Technology Enterprise Team. 96 p. http://www.fs.fed.us/foresthealth/aviation/resources/docs/ Sketchmapping.pdf. [Date accessed: Sept. 1, 2009].

Montréal Process Working Group. 2007. The Montréa Process, third edition. 12 p. http://www.rinya.maff.go.jp/ mpci/rep-pub/1995/santiago_e.html. [Date accessed: May 22, 2008].

Moritz, M.A.; Odion, D.C. 2005. Examining the strength and possible causes of the relationship between fire history and Sudden Oak Death. Oecologia. 144: 106-114.

Worrall, J.J.; Egeland, L.; Eager, T. [and others]. 2008. Rapid mortality of Populus tremuloides in southwestern Colorado, USA. Forest Ecology and Management. 255(3-4): 686-696. 


\section{Introduction}

nalyzing patterns of forest pest infestation is necessary for monitoring the health of

1 forested ecosystems because of the impacts that insects and diseases can have on forest structure, composition, biodiversity, and species distributions (Castello and others 1995). In particular, introduced nonnative insects and diseases can extensively damage the diversity, ecology, and economy of affected areas (Brockerhoff and others 2006, Mack and others 2000). Examining pest occurrences from a landscape-scale perspective is useful, given the regional extent of many infestations and the interaction between landscape characteristics and the development of pest outbreaks (Holdenrieder and others 2004). The detection of geographic clusters of disturbance is one such landscape-scale approach, which allows for identification of areas at greatest risk and for selection of locations for more intensive analysis.

\section{Methods}

Low-altitude aerial survey and ground survey data from 2007 and 2008, compiled nationally by the Forest Health Protection (FHP) Program of the Forest Service, U.S. Department of Agriculture, were used to identify landscape-scale patterns of forest insect and disease activity in the conterminous United States, and to summarize insect and disease activity by ecoregion section in Alaska. Surveys covered 73.3 percent of the forested area in the conterminous United States in 2007 and 68.8 percent in 2008, and 19.2 percent of Alaska's forested area in 2007 and 18.0 percent in 2008 (fig. 4.1).

These surveys identify areas of mortality and defoliation caused by insect and pathogen activity in a given year, although some important forest insects (e.g., emerald ash borer and hemlock woolly adelgid), diseases (e.g., laurel wilt, Dutch elm disease, white pine blister rust, and thousand cankers disease), and mortality complexes (e.g., oak decline) are not easily detected or thoroughly quantified through aerial detection surveys. Such pests may attack hosts that are widely dispersed throughout diverse forests or may cause mortality or defoliation that is otherwise difficult to detect. A pathogen or insect might be considered a mortalitycausing agent in one location and a defoliationcausing agent in another, depending on the level of damage to the forest in a given area and the convergence of stress factors such as drought. In some cases, the identified agents of mortality or defoliation are actually complexes
CRITERION 3Chapter 4. Large-Scale Patterns of Insect and Disease Activity in the Conterminous United States and Alaska from the National Insect and Disease Detection Survey and 2008

Kevin M. Potter 

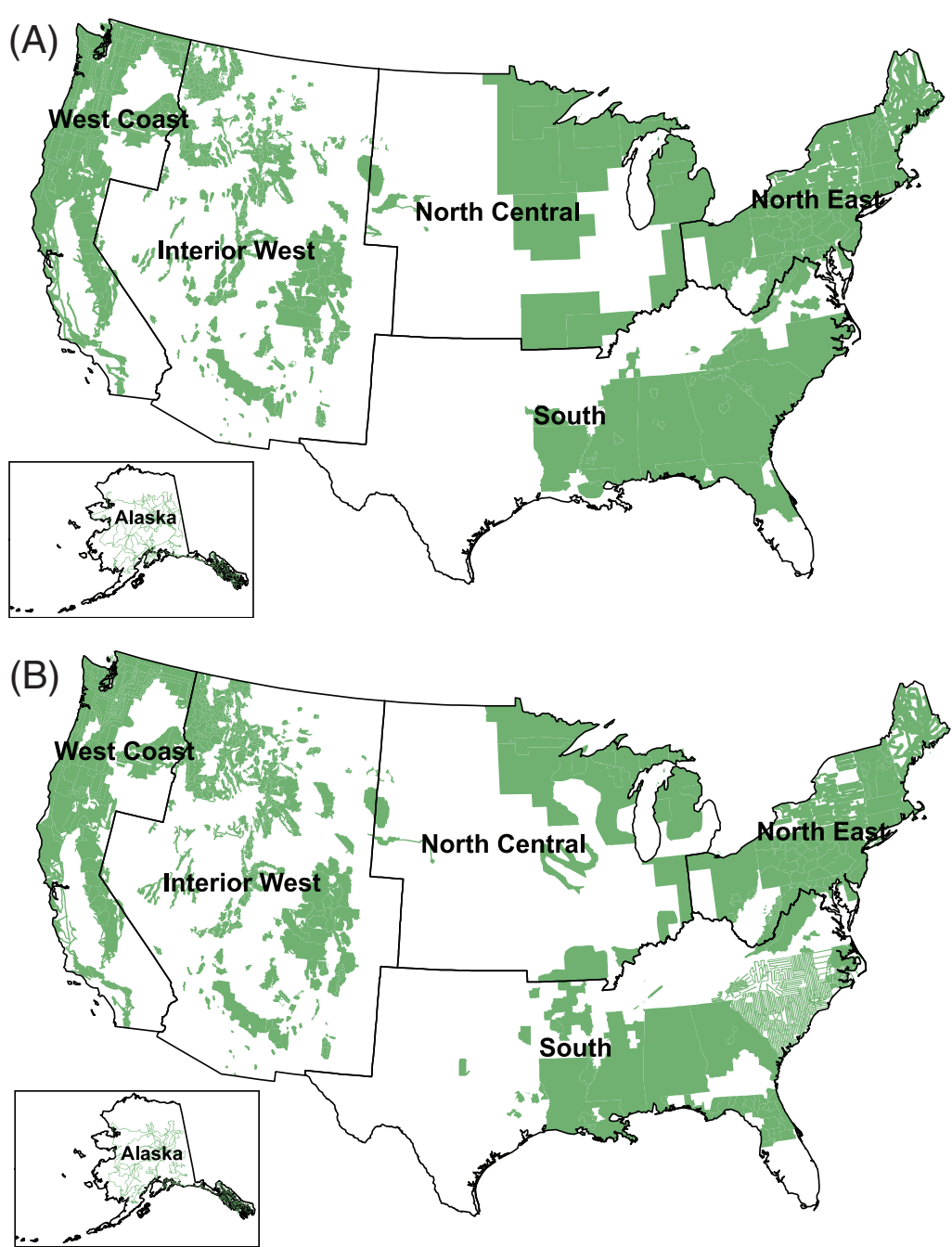

Figure 4.1-The extent of surveys for insect and disease activity conducted in the conterminous United States and Alaska in (A) 2007 and (B) 2008. The lines delineate Forest Health Monitoring regions. (Data source: U.S. Department of Agriculture Forest Service, Forest Health Protection.) of multiple agents summarized under an impact label related to a specific host tree species (e.g., "subalpine fir mortality" or "aspen defoliation"). Additionally, differences in data collection, attribute recognition, and coding procedures among States and regions can complicate the analysis of the data and the interpretation of the results. The data from 2007 and 2008 were analyzed separately because both the location and extent of the areas surveyed and the classification of forest tree mortality and defoliation agents varied across years.

The 2007 and 2008 mortality and defoliation polygons were used to identify the mortality and defoliation agents and complexes found on more than 5000 ha in the conterminous United States in that year, and to identify and list the most widely detected defoliation and mortality agents for Alaska. All quantities are "footprint" areas for the agent or complex. The sum of agents and complexes is not equal to the total affected area as a result of reporting multiple agents per polygon in some situations.

A forest cover map (1-km² resolution), derived from Moderate Resolution Imaging Spectroradiometer (MODIS) imagery by the U.S. Forest Service Remote Sensing Applications Center (USDA Forest Service 2008), was used to determine the amount and location of forest within survey defoliation and mortality polygons for the identification of geographic hot spots of surveyed forest exposed to defoliation-causing and mortality-causing agents. 
This Getis-Ord hot spot analysis (Getis and Ord 1992) was employed in ArcMap 9.2 (ESRI 2006). The Environmental Monitoring and Assessment Program (EMAP) North American hexagon coordinates (White and others 1992) were intensified to develop a lattice of hexagonal cells, of approximately $2500 \mathrm{~km}^{2}$ extent, for the conterminous United States. This cell size allows for analysis at a medium-scale resolution of approximately the same area as a typical county. The percent of forest area in each hexagon exposed to either mortality- or defoliationcausing agents was then calculated. The percent of forest exposed to the identified mortality or defoliation agents was calculated by dividing the forest-masked damage area by the forest-masked surveyed area.

The Getis-Ord $G_{i}{ }^{*}$ statistic summed the differences between the mean values in a local sample, determined by a moving window consisting of each hexagon and its six adjacent hexagons, and the global mean of all the forested hexagonal cells in the conterminous United States. It was then standardized as a $z$ score with a mean of 0 and a standard deviation of 1, with values greater than 1.96 representing significant $(p<0.025)$ local clustering of high values and values less than -1.96 representing significant clustering of low values $(p<0.025)$, since 95 percent of the observations under a normal distribution should be within approximately 2 standard deviations of the mean (Laffan 2006). In other words, a $G_{i}{ }^{*}$ value of 1.96 indicates that the local mean of percent forest exposed to mortality-causing or defoliation-causing agents for a hexagon and its six neighbors is approximately 2 standard deviations greater than the mean expected in the absence of spatial clustering, while a $G_{i}{ }^{*}$ value of -1.96 indicates that the local mortality or defoliation mean for a hexagon and its six neighbors is approximately 2 standard deviations less than the mean expected in the absence of spatial clustering. Values between -1.96 and 1.96 have no statistically significant concentration of high or low values. In other words, when a hexagon has a $G_{i}{ }^{*}$ value between -1.96 and 1.96, it and its six neighbors have neither consistently high nor consistently low percentages of forest exposed to mortality- or defoliation-causing agents.

The threshold values are not exact because the correlation of spatial data violates the assumption of independence required for statistical significance (Laffan 2006). The GetisOrd approach does not require that the input data be normally distributed because the local $G_{i}^{*}$ values are computed under a randomization assumption, with $G_{i}{ }^{*}$ equating to a standardized $z$ score that asymptotically tends to a normal distribution (Anselin 1992). The $z$ scores are reliable, even with skewed data, as long as the distance band is large enough to include several neighbors for each feature (ESRI 2006).

The low density of survey data from Alaska (fig. 4.1) precluded the use of hot spot analyses for the State. Instead, mortality and defoliation data were summarized by ecoregion section (Nowacki and Brock 1995), calculated as the 
percent of the forest within the surveyed areas affected by agents of mortality or defoliation. For reference purposes, ecoregion sections (Cleland and others 2007) were also displayed on the geographic hot spot maps of the conterminous United States.

\section{Results and Discussion}

FHP survey data identified 60 different mortality-causing agents and complexes on 2466924 ha of forest across the conterminous United States in 2007 (an area slightly larger than New Hampshire), and 61 agents and complexes on 3888868 ha in 2008 (an area similar in size to that of Maryland and Delaware combined). Mountain pine beetle (Dendroctonus ponderosae) was the most widespread mortality agent in both years (1 564092 ha in 2007 and 2387062 ha in 2008) (table 4.1). Other agents affecting more than 100000 ha were subalpine fir (Abies lasiocarpa) mortality, fir engraver (Scolytus ventralis), and Douglas-fir beetle (Dendroctonus pseudotsugae) in 2007 and bronze birch borer (Agrilus anxius), aspen defoliation, fir engraver, and subalpine fir mortality in 2008.

Additionally, the survey identified 62 defoliation agents and complexes affecting 2516812 ha of forest across the conterminous United States in 2007, an area slightly larger than Vermont, and 61 defoliation agents and complexes affecting 1908566 ha in 2008, an area slightly larger than Connecticut and Rhode Island combined. The most widespread defoliators in both years were western spruce budworm (Choristoneura occidentalis) and gypsy
Table 4.1-Mortality agents and complexes affecting more than 5000 ha of forested area in the conterminous 48 States during 2007 and 2008

\begin{tabular}{lclr}
\hline 2007 Mortality agents & Area & \multicolumn{1}{c}{2008 Mortality agents } & \multicolumn{1}{c}{ Area } \\
\hline Mountain pine beetle & ha & & \multicolumn{1}{c}{ ha } \\
Subalpine fir mortality & 1564092 & Mountain pine beetle & 2387062 \\
Fir engraver & 211470 & Bronze birch borer & 381332 \\
Douglas-fir beetle & 151979 & Aspen defoliation & 228783 \\
Western balsam bark beetle & 105498 & Fir engraver & 179237 \\
Spruce beetle & 75673 & Subalpine fir mortality & 176395 \\
Five-needle pine decline & 74621 & Douglas-fir beetle & 74513 \\
Bark beetles & 57127 & Beech bark disease & 69927 \\
Oak decline & 43623 & Five-needle pine decline & 68367 \\
Beech bark disease & 26367 & Spruce beetle & 51558 \\
Balsam woolly adelgid & 24822 & Western balsam bark beetle & 50226 \\
Ips engraver beetles & 17436 & Western pine beetle & 36074 \\
Western pine beetle & 13815 & Gypsy moth & 34372 \\
Hemlock woolly adelgid & 10484 & Bark beetles & 24386 \\
Decline & 8872 & Forest tent caterpillar & 20648 \\
Jack pine budworm & 8008 & Ips engraver beetles & 17112 \\
Pinon ips & 7903 & Sudden oak death & 13686 \\
Armillaria root disease & 7800 & Decline & 11989 \\
Forest tent caterpillar & 6536 & Pine engraver & 9734 \\
Eastern larch beetle & 5501 & White pine blister rust & 8488 \\
Port-Orford-Cedar root disease & 5234 & Winter moth & 8056 \\
& 5016 & Eastern larch beetle & 7625 \\
\hline & & Balsam woolly adelgid & 6066 \\
\hline
\end{tabular}


moth (Lymantria dispar), followed by aspen defoliation in 2007 and forest tent caterpillar (Malacosoma disstria) in 2008 (table 4.2).

Hot spot analyses using both the 2007 and 2008 survey data detected several hot spots of insect and disease mortality associated with mountain pine beetle in the Interior West Region (fig. 4.2) [this is the region defined by the Forest Health Monitoring (FHM) Program of the Forest Service]. In both years, a large and highly clustered hot spot was located in the Northern Parks and Ranges of northern Colorado and southern Wyoming (M331I). In 2008, another large and highly clustered hot spot occurred in three ecoregion sections of western Montana, the Northern Rockies and Bitterroot Valley (M332B), the Belt Mountains (M332D), and the Beaverhead Mountains (M332E). A third, but smaller, hot spot in the Uinta Mountains (M331E) was also associated with mountain pine beetle in 2007 and 2008. A separate hot spot in the Wind River Mountains (M331J), the Overthrust Mountains (M331D), and the Yellowstone Highlands (M331A) was associated with several mortality agents in addition to mountain pine beetle, including five-needle pine decline, spruce beetle (Dendroctonus rufipennis), Douglas-fir beetle, and subalpine fir mortality.

The most highly clustered hot spot in the Pacific Coast region occurred both years in the Northern Cascades (M242D), associated most strongly with mortality caused by mountain pine beetle, along with mortality from fir engraver, spruce beetle, Douglas-fir beetle and western
Table 4.2-Defoliation agents and complexes affecting more than 5000 ha of forested area in the conterminous 48 States during 2007 and 2008

\begin{tabular}{|c|c|c|c|}
\hline 2007 Defoliation agents & Area & 2008 Defoliation agents & Area \\
\hline & ha & & ha \\
\hline Western spruce budworm & 879469 & Western spruce budworm & 784329 \\
\hline Gypsy moth & 569831 & Gypsy moth & 619002 \\
\hline Aspen defoliation & 220658 & Forest tent caterpillar & 152971 \\
\hline Forest tent caterpillar & 214927 & Defoliators & 92078 \\
\hline Defoliators & 148462 & Aspen defoliation & 59781 \\
\hline Jack pine budworm & 90807 & Larch casebearer & 37953 \\
\hline Needlecast & 85370 & Decline & 36328 \\
\hline Decline & 58905 & Jack pine budworm & 29915 \\
\hline Spruce budworm & 53356 & Spruce budworm & 19129 \\
\hline Fall hardwood defoliator complex & 39302 & Needlecast & 14457 \\
\hline Larch casebearer & 35071 & Cherry scallop shell moth & 10091 \\
\hline Winter moth & 15302 & Leaf spots & 6242 \\
\hline Pinyon needle scale & 13341 & Pinyon needle scale & 5495 \\
\hline Fall cankerworm & 12752 & & \\
\hline Septoria leaf spot & 10228 & & \\
\hline Orange-striped oakworm & 8919 & & \\
\hline Tent caterpillar & 8285 & & \\
\hline Eastern tent caterpillar & 7537 & & \\
\hline Douglas-fir tussock moth & 6353 & & \\
\hline Lodgepole needleminer & 6223 & & \\
\hline Maple trumpet skeletonizer & 5309 & & \\
\hline
\end{tabular}


(A)

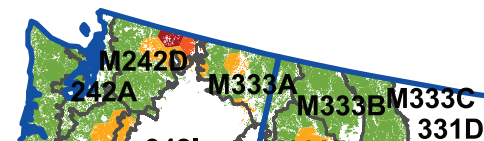
13336 $3331 \mathrm{C}$

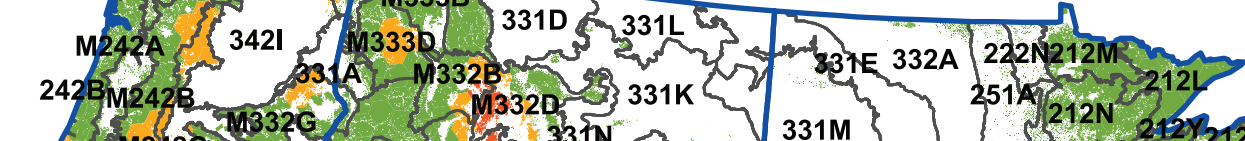

3 MI332G

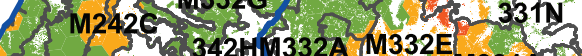

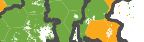

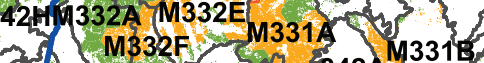

$331 \mathrm{M}$ $251 \times 12 \mathrm{~N}^{2}$

$212 \mathrm{~N} 212 \mathrm{~V} / 2 \mathrm{~N} 212 \mathrm{~S} 212 \mathrm{kR}$.

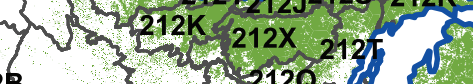

342C E

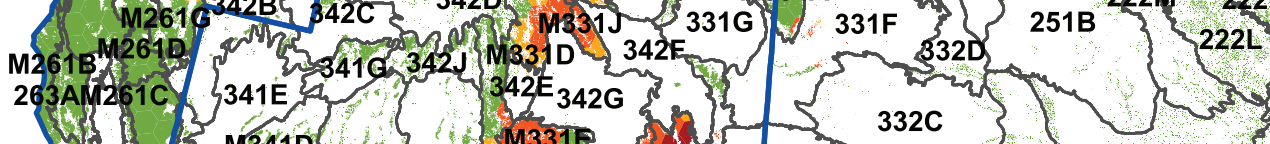

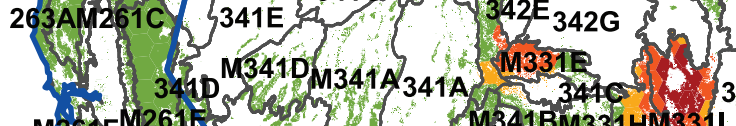

261262 341F 14 M34TC $341 \mathrm{~F}^{2}$

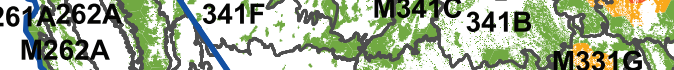

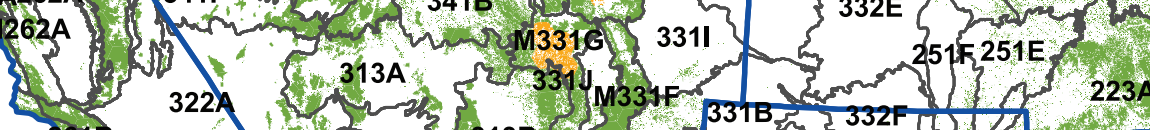

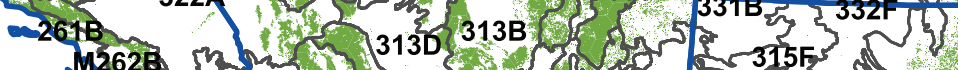

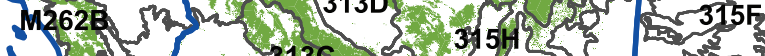

$1322 \mathrm{O} 322 \mathrm{~B}$

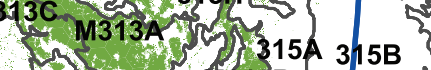

IIL

$321 \mathrm{~A}$

Degree of exposure clustering

68

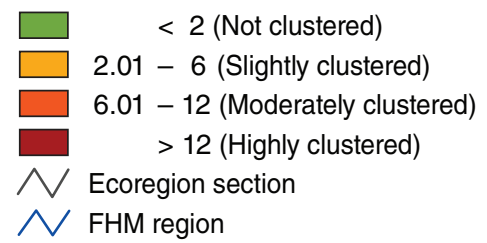

( M231A $234=231 \mathrm{~A}$, $231 \mathrm{C}$. $231 \mathrm{~A}$

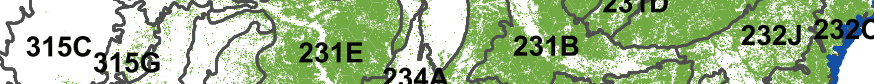

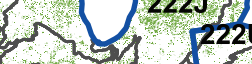

$211 F$

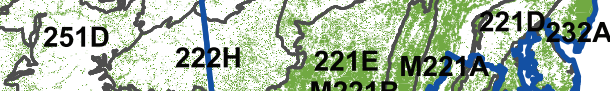

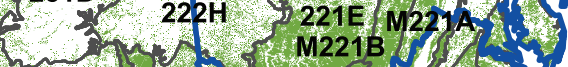

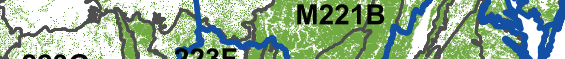

1. $223 \mathrm{D}^{223 \mathrm{~B}} \mathrm{M} 221 \mathrm{C}$

$2311^{2324}$ t.

$223 \mathrm{E} 221 \mathrm{~J} 1 \mathrm{1} 2210$

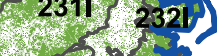

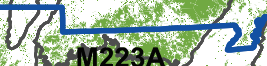

$255255 B=2315$

$232 \mathrm{~B}$

321B 315D
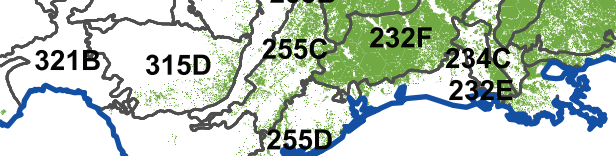

23
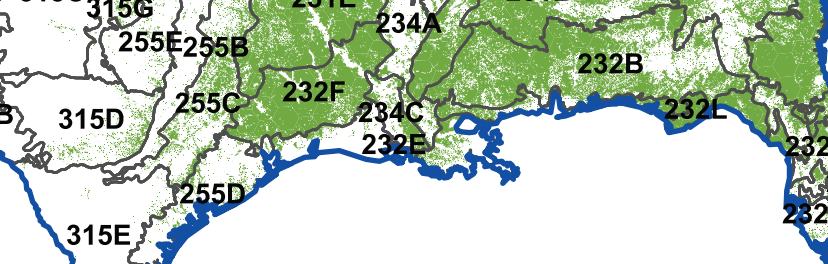

Eहै।

3

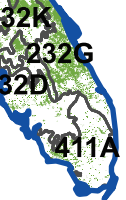

Figure 4.2-Hot spots of exposure to mortality-causing insects and diseases in (A) 2007 and (B) 2008. Values are Getis-Ord $\mathrm{G}_{\mathrm{i}}{ }^{*}$ scores, with values greater than 2 representing strong and significant clustering of high percentages of forest area exposed to mortality agents. (No areas of significant clustering of low percentages of exposure, less than -2, were detected). The gray lines delineate ecoregion sections (Cleland and others 2007), and blue lines delineate Forest Health Monitoring regions. Background forest cover is derived from MODIS imagery by the U.S. Forest Service Remote Sensing Applications Center. (Data source: U.S. Department of Agriculture Forest Service, Forest Health Protection.) (continued on next page) 


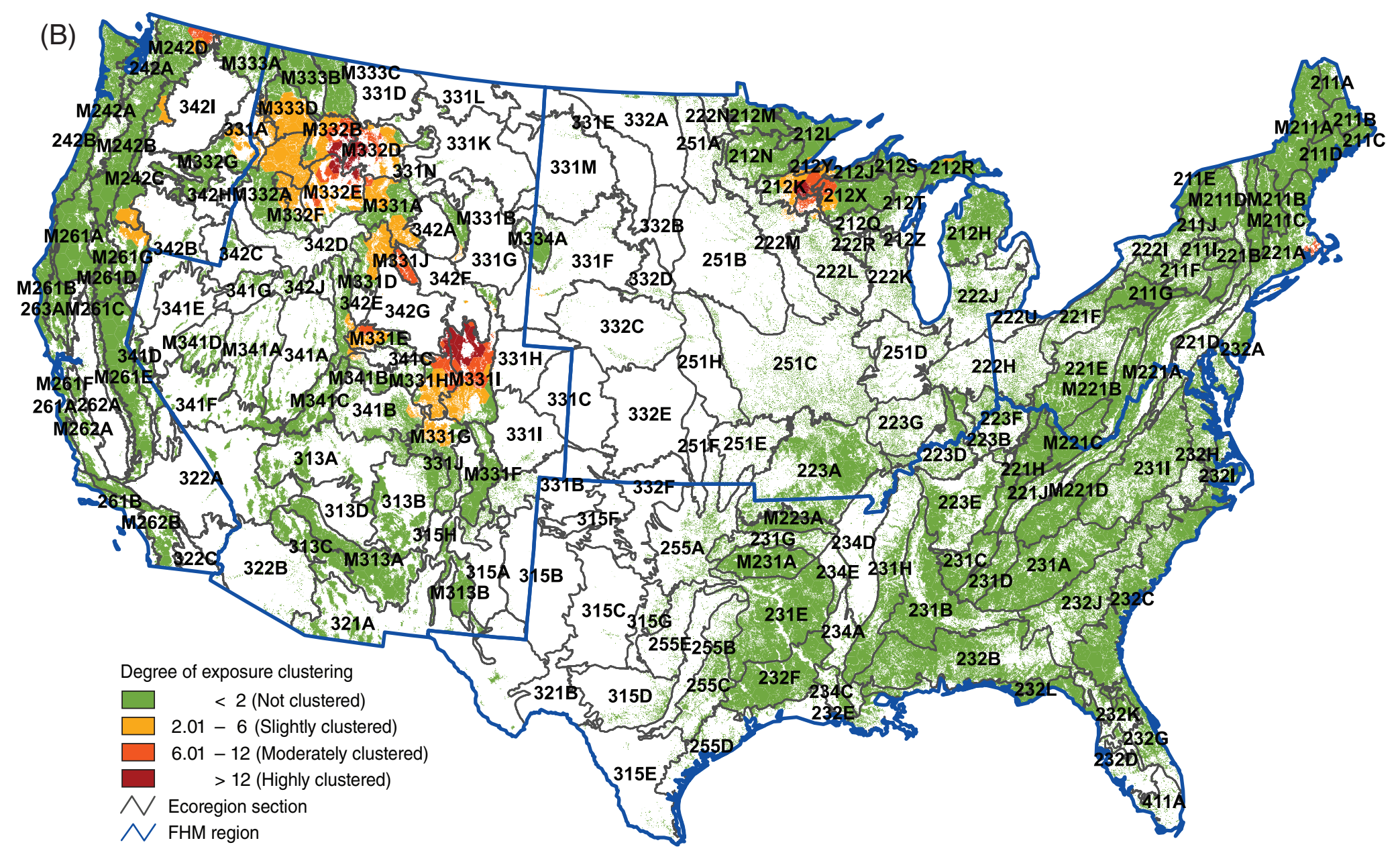

Figure 4.2 (continued) - Hot spots of exposure to mortality-causing insects and diseases in (B) 2008. Values are Getis-Ord $\mathrm{G}_{\mathrm{i}}{ }^{*}$ scores, with values greater than 2 representing strong and significant clustering of high percentages of forest area exposed to mortality agents. (No areas of significant clustering of low percentages of exposure, less than -2, were detected). The gray lines delineate ecoregion sections (Cleland and others 2007), and blue lines delineate Forest Health Monitoring regions. Background forest cover is derived from MODIS imagery by the U.S. Forest Service Remote Sensing Applications Center. (Data source: U.S. Department of Agriculture Forest Service, Forest Health Protection.) 
balsam bark beetle (Dryocoetes confusus). In 2007, a set of hot spots along the Eastern Cascades (M242C) and the surrounding ecoregions were caused by mortality associated with a suite of insects that included mountain pine beetle, western pine beetle (Dendroctonus brevicomis), fir engraver, western balsam bark beetle, Douglas-fir beetle, and the silver fir beetle (Pseudohylesinus sericeus) (fig. 4.2A). Directly to the east, a hot spot of mortality developed in the Blue Mountains (M332G), caused by Douglasfir beetle, fir engraver, mountain pine beetle, western pine beetle, and balsam woolly adelgid (Adelges piceae). Some of the same hot spots remained the following year, although they were generally smaller (fig. 4.2B).

The North Central region experienced a single mortality hot spot in 2007 (fig. 4.2A), associated with mountain pine beetle, in the Black Hills (M334A). In 2008, this region contained a highly clustered hot spot in the Western Superior Uplands (212K), the location of an extensive bronze birch borer outbreak (fig. 4.2B).

In each year, a single hot spot occurred in the North East region, in the Lower New England ecoregion section (221A), where mortality was associated primarily with winter moth (Operophtera brumata), gypsy moth (Lymantria dispar), and Diplodia canker (Sphaeropsis sapinea) both years, in addition to fall cankerworm (Alsophila pometaria) and red pine scale (Matsucoccus resinosae) in 2007 (fig. 4.2A). No hot spots of mortality exposure developed in the South FHM region either year.
The most extensive hot spot of defoliation activity in both 2007 and 2008 occurred in the North East region (fig. 4.3). In the first year, this was centered in the Northern Glaciated Allegheny Plateau (211F) and the Catskill Mountains (211I) and was caused by forest tent caterpillar and gypsy moth (fig. 4.3A). In the second year, it was centered in the Northern Ridge and Valley (M221A) and was primarily associated with gypsy moth, with a smaller component of forest tent caterpillar (fig. 4.3B). Also in 2008, a smaller defoliation hot spot caused by gypsy moth occurred on the boundary between the North East and South FHM regions, in the Northern Ridge and Valley (M221A), Allegheny Mountains (M221B), and Blue Ridge Mountains (M221D) ecoregion sections.

In 2007, the North Central region experienced a single hot spot in the Black Hills (M334A) and the Western Great Plains (331F) resulting from general defoliators (fig. 4.3A).

A year later, a fairly significantly clustered hot spot occurred in the Southern Superior Uplands (212J) and the Southwest Lake Superior Clay Plain (212Y) as a result of defoliation caused by gypsy moth and spruce budworm.

The Interior West contained several hot spots of defoliation exposure in both years (fig. 4.3). Most were caused by western spruce budworm, including the three hot spots centered in the Bitterroot Mountains (M333D), the Belt Mountains (M332D)/Beaverhead Mountains (M332E), and the South-Central Highlands (M331G)/Southern Parks and Rocky Mountain Range (M331F). Additionally, the Grand Canyon 
ecoregion section (313A) was the location of a hot spot caused by aspen defoliation in both 2007 and 2008, and the North-Central Highlands and Rocky Mountains (M331H)/ Northern Parks and Ranges (M331I) were the location of an aspen defoliation hot spot in 2007.

Finally, two defoliation hot spots in the Pacific Coast region were associated with western spruce budworm. One, centered in the Northern Cascades (M242D) occurred both years, while the other, centered in the Blue Mountains (M332G), was caused by both western spruce budworm and larch casebearer (Coleophora laricella) in 2007.

The low density of survey data from Alaska in 2007 and 2008 precluded the use of hot spot analyses for that State. Instead, mortality and defoliation data were summarized by ecoregion section, calculated as the percent of the forest within the surveyed areas affected by agents of mortality or defoliation. In 2007, six mortalitycausing agents and complexes were reported for Alaska, affecting 82428 ha. In 2008, five mortality-causing agents and complexes were reported across 56007 ha.

In both years, spruce beetle was the most widespread mortality agent, affecting 61128 ha across many of the forested areas of Alaska in 2007 and 28126 in 2008. Northern spruce engraver beetle (Ips perturbatus) was the second leading mortality agent both years, detected on 13273 ha in 2007 and 24130 ha in 2008 mostly in east-central Alaska. Yellow-cedar (Chamaecyparis nootkatensis) decline was also a major mortality agent in 2007 (10 605 ha), in the panhandle of the State, but less so in 2008 (3685 ha). The Northern Chugach Range (M135A) had the highest percent of exposure to mortality-causing agents in 2007 in surveyed forest areas (3.49 percent), followed by the nearby Wrangell Mountains (M135B) with 3.24 percent (fig. 4.4A). The Cook Inlet Lowlands (213B) and the Yukon Flats (139A) had slightly more than 1 percent of their surveyed forested area exposed to agents of mortality in 2007. The following year, the Bristol Bay Lowlands (M213A) and the Cook Inlet Lowlands had the greatest exposure to agents of mortality (2.32 percent and 2.21 percent, respectively) (fig. $4.4 \mathrm{~B}$ )

Alaska forests, meanwhile, were exposed to 10 defoliation agents recorded on 385369 ha in 2007. In 2008, they were exposed to 12 defoliation agents and complexes on 129458 ha.

Aspen leafminer had by far the largest extent in both years, observed on 305698 ha across central Alaska in 2007 and 85078 ha in 2008. As a result of aspen leafminer (Phyllocnistis populiella), four ecoregion sections had relatively high percentages of defoliation exposure in 2007 (fig. 4.5A): the Dawson Range (M139C), with 9.84 percent surveyed forest exposed; the Yukon Bottomlands (131A), with 9.19 percent; the Copper River Basin (135A), with 6.63 percent; and the Kuskokwim Colluvial Plain (131B), with 6.09 percent. The degree of defoliation was much reduced in 2008, with many of the same sections experiencing $<5$ percent defoliation within the surveyed areas (fig. 4.5B). 


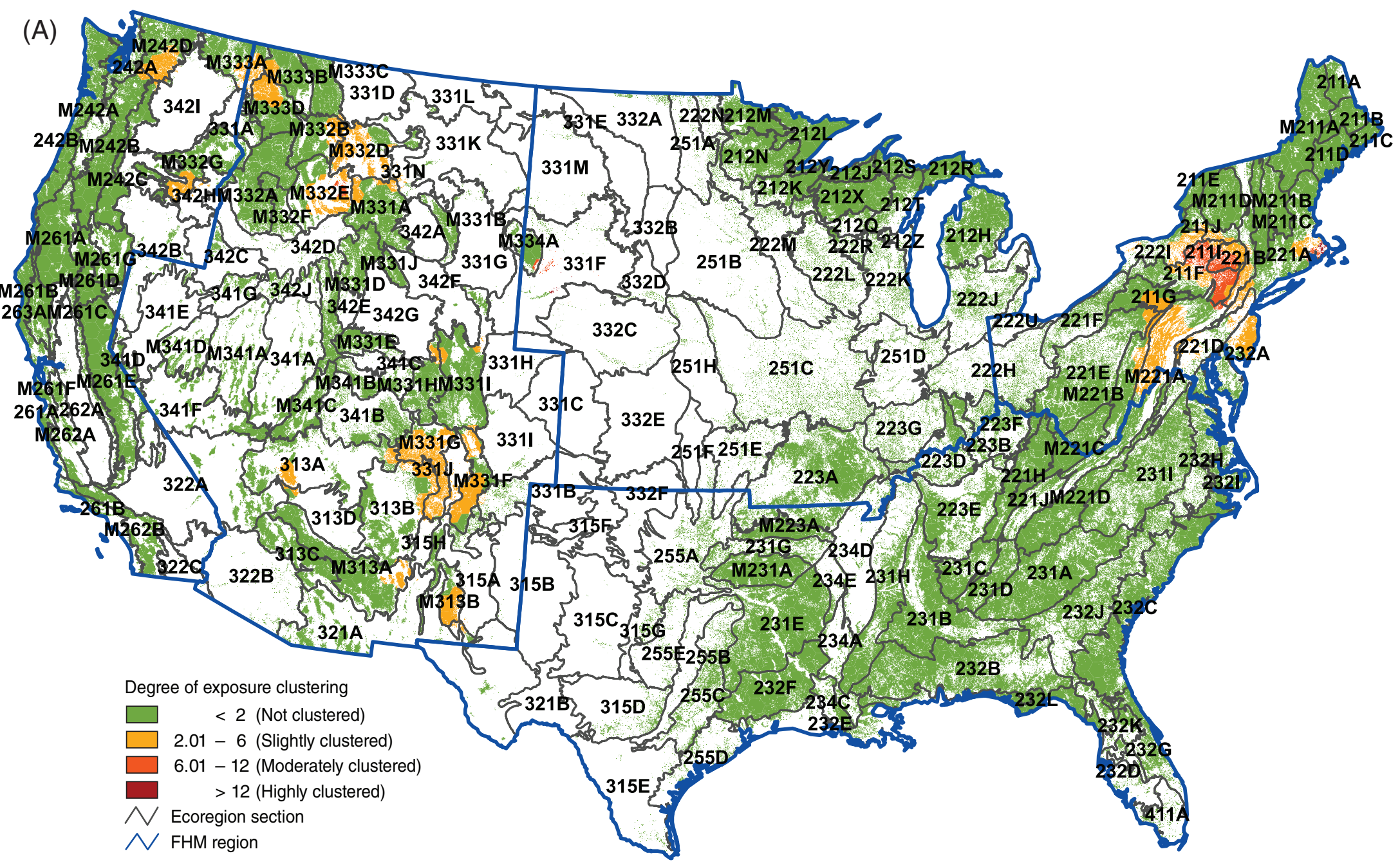

Figure 4.3-Hot spots of exposure to defoliation-causing insects and diseases in (A) 2007 and (B) 2008. Values are Getis-Ord $\mathrm{G}_{\mathrm{i}}$ * scores, with values greater than 2 representing strong and significant clustering of high percentages of forest area exposed to defoliation agents. (No areas of significant clustering of low percentages of exposure, less than -2, were detected). The gray lines delineate ecoregion sections (Cleland and others 2007), and blue lines delineate Forest Health Monitoring regions. Background forest cover is derived from MODIS imagery by the U.S. Forest Service Remote Sensing Applications Center. (Data source: U.S. Department of Agriculture Forest Service, Forest Health Protection.) (continued on next page) 


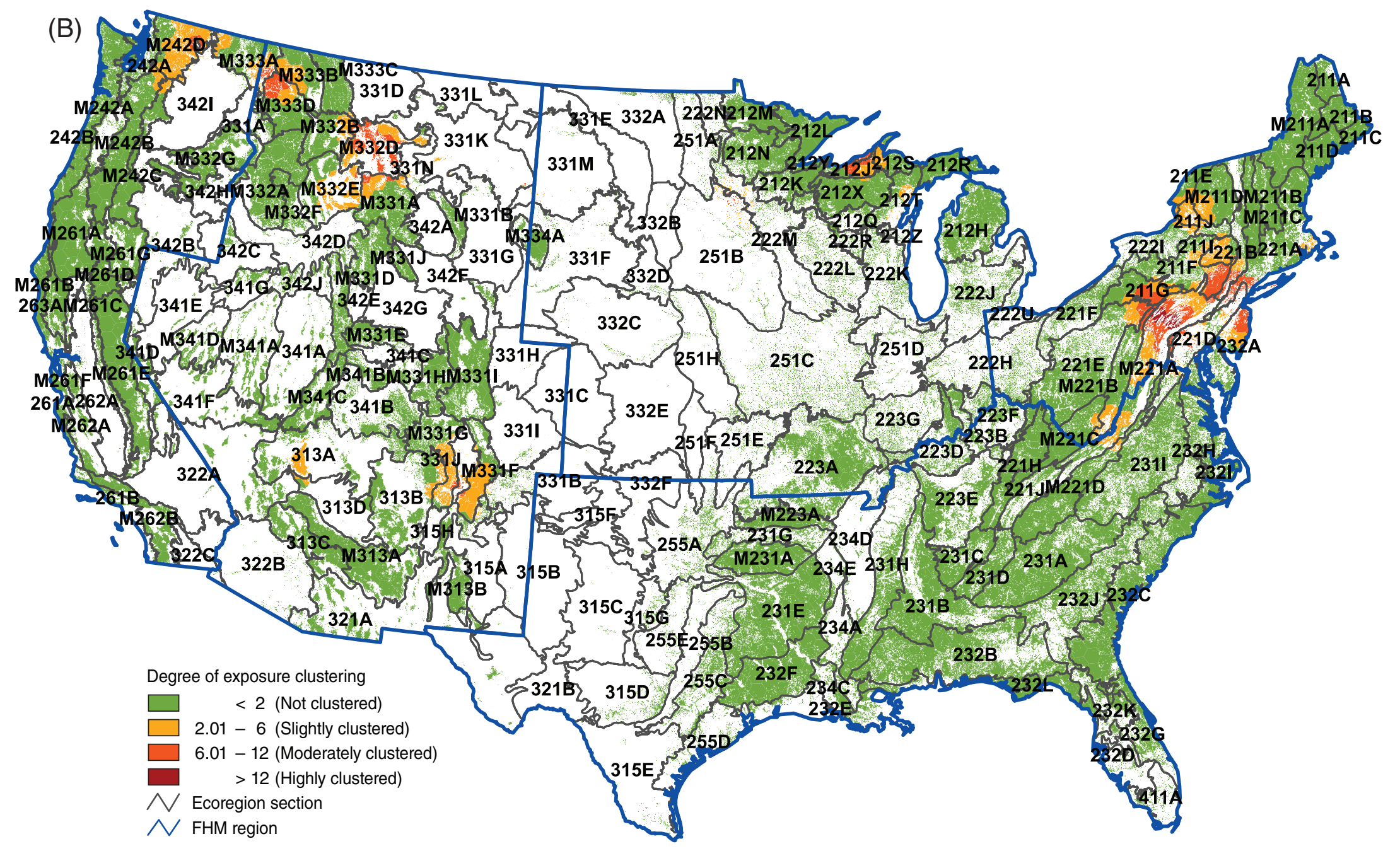

Figure 4.3 (continued) - Hot spots of exposure to defoliation-causing insects and diseases in (B) 2008. Values are Getis-Ord $\mathrm{G}_{\mathrm{i}}^{*}$ scores, with values greater than 2 representing strong and significant clustering of high percentages of forest area exposed to defoliation agents. (No areas of significant clustering of low percentages of exposure, less than -2, were detected). The gray lines delineate ecoregion sections (Cleland and others 2007), and blue lines delineate Forest Health Monitoring regions. Background forest cover is derived from MODIS imagery by the U.S. Forest Service Remote Sensing Applications Center. (Data source: U.S. Department of Agriculture Forest Service, Forest Health Protection.) 
(A)

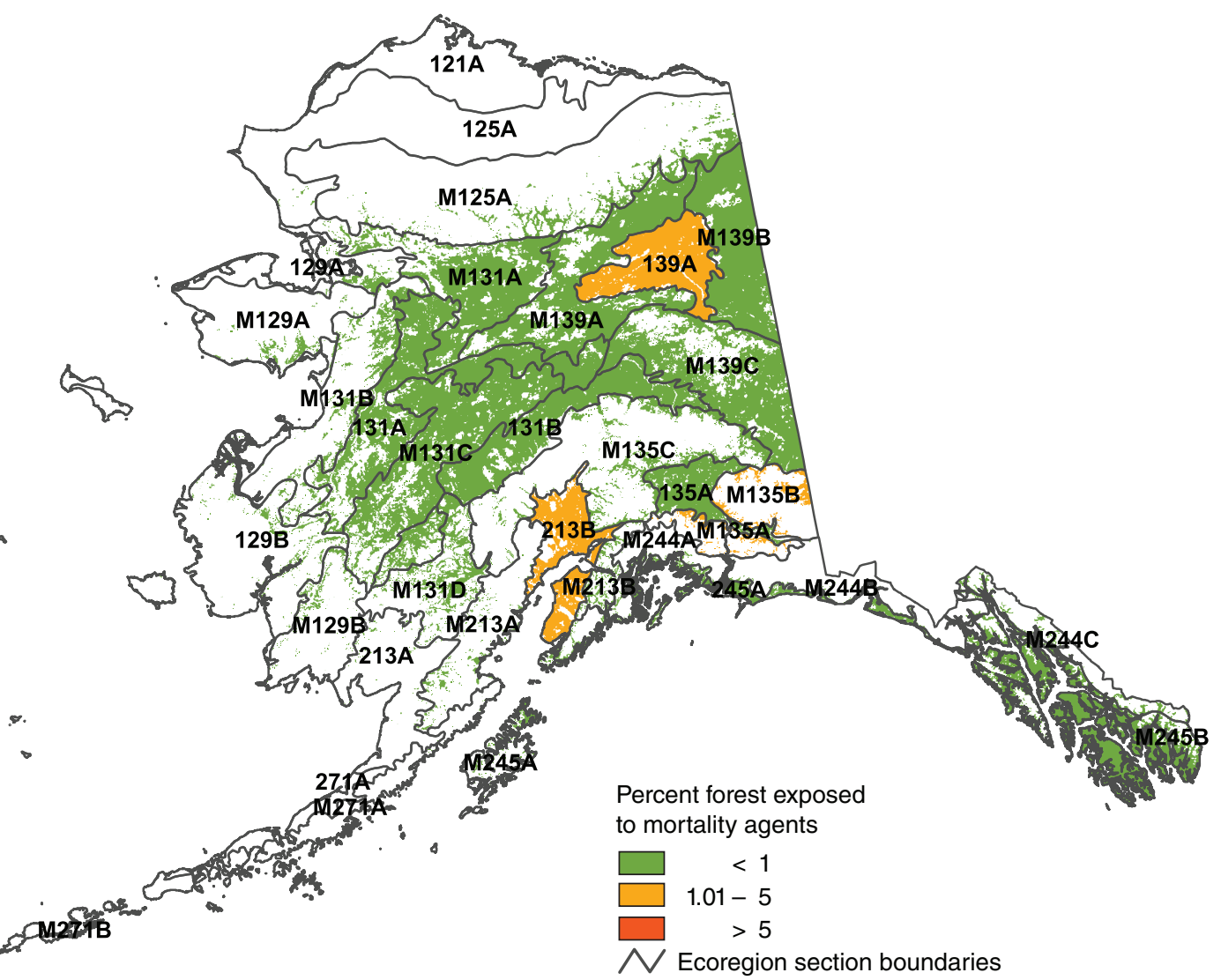

Figure 4.4-Percent of surveyed forest in Alaska ecoregion sections exposed to mortality-causing insects and diseases in (A) 2007 and (B) 2008. The gray lines delineate ecoregion sections (Nowacki and Brock 1995). Background forest cover is derived from MODIS imagery by the U.S. Forest Service Remote Sensing Applications Center. (Data source: U.S. Department of Agriculture Forest Service, Forest Health Protection.) (continued on next page) 
(B)

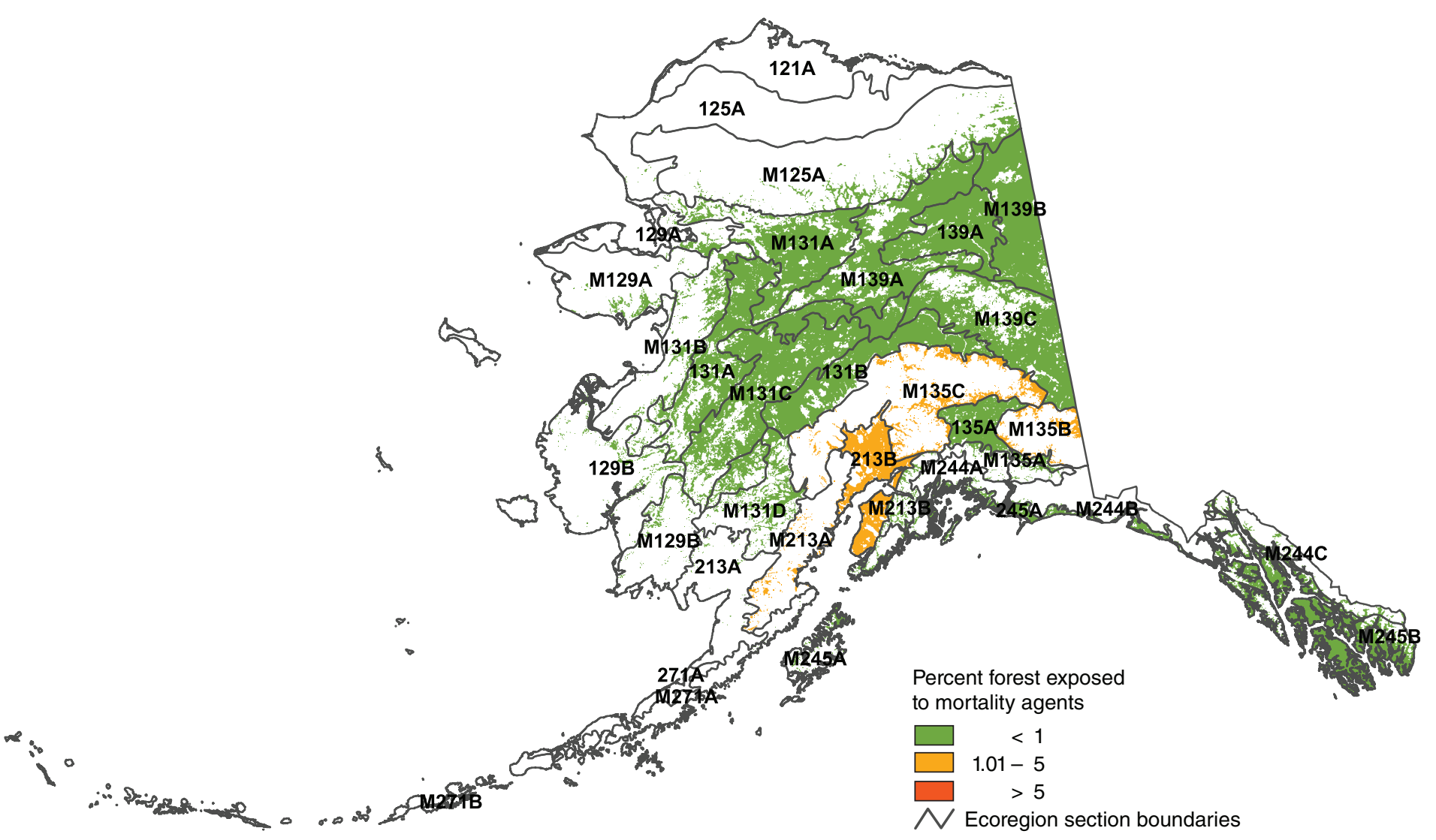

Figure 4.4 (continued)—Percent of surveyed forest in Alaska ecoregion sections exposed to mortality-causing insects and diseases in (B) 2008. The gray lines delineate ecoregion sections (Nowacki and Brock 1995). Background forest cover is derived from MODIS imagery by the U.S. Forest Service Remote Sensing Applications Center. (Data source: U.S. Department of Agriculture Forest Service, Forest Health Protection.) 
(A)

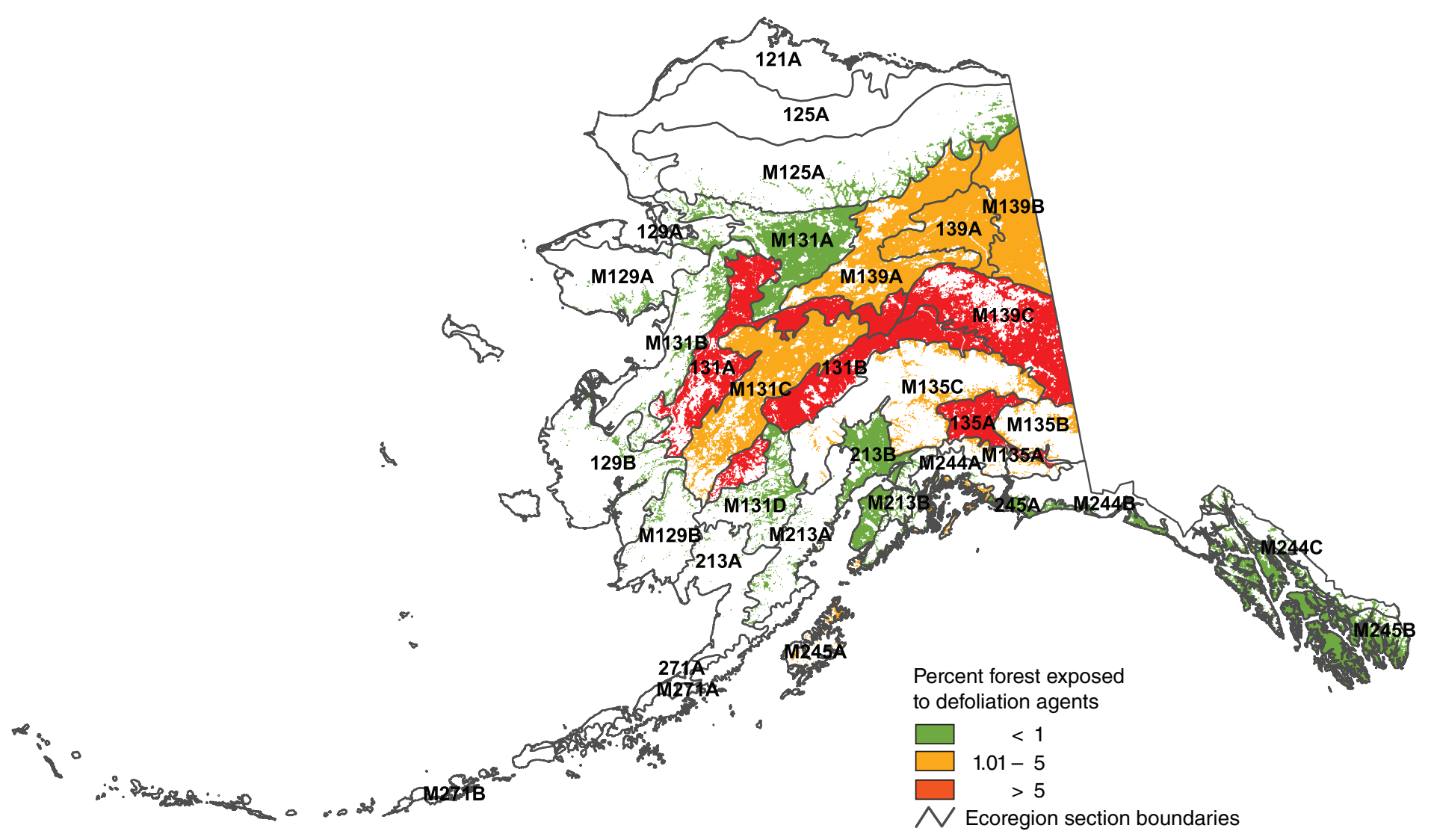

Figure 4.5-Percent of surveyed forest in Alaska ecoregion sections exposed to defoliation-causing insects and diseases in (A) 2007 and (B) 2008. The gray lines delineate ecoregion sections (Nowacki and Brock 1995). Background forest cover is derived from MODIS imagery by the U.S. Forest Service Remote Sensing Applications Center. (Data source: U.S. Department of Agriculture Forest Service, Forest Health Protection.) (continued on next page) 
(B)

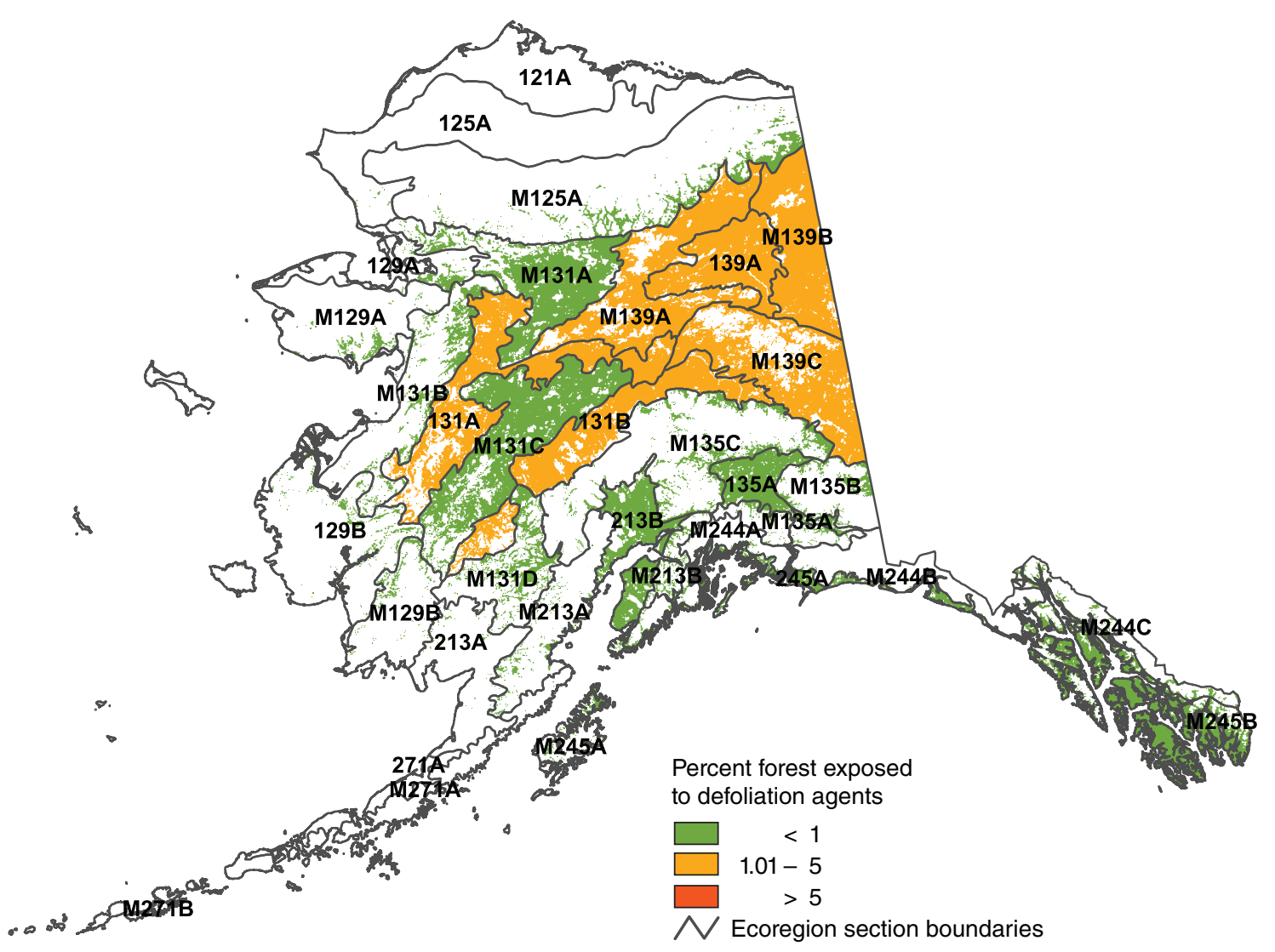

Figure 4.5 (continued)—Percent of surveyed forest in Alaska ecoregion sections exposed to defoliation-causing insects and diseases in (B) 2008. The gray lines delineate ecoregion sections (Nowacki and Brock 1995). Background forest cover is derived from MODIS imagery by the U.S. Forest Service Remote Sensing Applications Center. (Data source: U.S. Department of Agriculture Forest Service, Forest Health Protection.) 
Other important defoliators in 2007 were willow leaf blotchminer (Micrurapteryx salicifoliella) (37 $501 \mathrm{ha}$ ), large aspen tortrix (Choristoneura conflictana) (16 347 ha), and spruce budworm (15 151 ha). Other than aspen leafminer, the only important defoliator in 2008 was willow leaf blotchminer (31 086 ha).

Continued monitoring of insect and disease outbreaks across the United States will be necessary for determining appropriate followup investigation and management activities. As these analyses demonstrate, large-scale assessments of mortality and defoliation exposure, including geographical hot spot detection, offer a potentially useful approach for prioritizing geographic areas where the concentration of monitoring and management activities might be most effective.

\section{Literature Cited}

Anselin, L. 1992. Spatial data analysis with GIS: an introduction to application in the social sciences. Tech. Rep. 92-10. Santa Barbara, CA: National Center for Geographic Information and Analysis. 53 p.

Brockerhoff, E.G.; Liebhold, A.M.; Jactel, H. 2006. The ecology of forest insect invasions and advances in their management. Canadian Journal of Forest Research. 36(2): 263-268.

Castello, J.D.; Leopold, D.J.; Smallidge, P.J. 1995. Pathogens, patterns, and processes in forest ecosystems. Bioscience. 45(1): 16-24.
Cleland, D.T.; Freeouf, J.A.; Keys, J.E. [and others]. 2007. Ecological subregions: sections and subsections for the conterminous United States. Sloan, A.M., tech. ed. Gen. Tech. Report WO-76. Washington, DC: U.S. Department of Agriculture Forest Service. Map, presentation scale 1:3,500,000; Albers equal area projection; colored. Also as a GIS coverage in ArcINFO format on CD-ROM or at http://fsgeodata.fs.fed.us/other_resources/ecosubregions. html. [Date accessed: March 18, 2011].

ESRI. 2006. ArcMap 9.2. Redlands, CA: Environmental Systems Research Institute Inc.

Getis, A.; Ord, J.K. 1992. The analysis of spatial association by use of distance statistics. Geographical Analysis. 24(3): 189-206

Holdenrieder, O.; Pautasso, M.; Weisberg, P.J.; Lonsdale, D. 2004. Tree diseases and landscape processes: the challenge of landscape pathology. Trends in Ecology \& Evolution. 19(8): 446-452.

Laffan, S.W. 2006. Assessing regional scale weed distributions, with an Australian example using Nassella trichotoma. Weed Research. 46(3): 194-206.

Mack, R.N.; Simberloff, D.; Lonsdale, W.M. [and others] 2000. Biotic invasions: Causes, epidemiology, global consequences, and control. Ecological Applications. 10(3): 689-710

Nowacki, G.; Brock, T. 1995. Ecoregions and subregions of Alaska, EcoMap version 2.0. Juneau, AK: U.S. Department of Agriculture Forest Service, Alaska Region. Map, presentation scale 1:5,000,000; colored.

U.S. Department of Agriculture (USDA) Forest Service. 2008 National forest type data development. http://fsgeodata. fs.fed.us/rastergateway/forest_type/. [Date accessed: March 22, 2011]

White, D.; Kimerling, A.J.; Overton, W.S. 1992. Cartographic and geometric components of a global sampling design for environmental monitoring. Cartography and Geographic Information Systems. 19(1): 5-22. 


\section{Introduction}

iological invasions represent one of the most significant environmental threats to the maintenance of natural forest ecosystems in North America and elsewhere (Liebhold and others 1995), and have been estimated to cause more than $\$ 100$ billion annually in damage and control costs (Pimentel and others 2000). However, these costs do not take into account the economic value of nonmarket ecosystem services such as landscape aesthetics, outdoor recreation, and the knowledge that healthy forest ecosystems exist (Holmes and others 2009). Failure to address biotic invasions could result in severe consequences, including wholesale loss of natural resources in some regions, disruption of the natural processes that supply ecological services important to humans, and the impoverishment of ecosystems with the spread of cosmopolitan species (Mack and others 2000).

Plant invaders are a particular environmental concern because they can alter fire regime, nutrient cycling, hydrology, and energy budgets in native ecosystems, and can greatly diminish the abundance or survival of native species (Mack and others 2000). At least 138 nonindigenous tree and shrub species in the United States have invaded native forest and shrubland ecosystems (Pimentel and others 2000), with several of these species displacing native plant species and, in turn, reducing populations of some associated native animal species (Office of Technology Assessment 1993).
Because nonnative species continue to be introduced to the United States from other countries via trade and transportation, it is increasingly important to synthesize existing data on nonnative species abundance and distributions (Crall and others 2006). The Forest Inventory and Analysis (FIA) Program of the Forest Service, U.S. Department of Agriculture, offers a potentially important source of information about nonnative tree abundance and distributions because the data are collected from a large network of standardized forest plots across the conterminous United States, selected using a standardized sampling intensity (Reams and others 2005).

Analyses using these FIA data may help quantify the invasiveness of nonnative species, while also identifying locations in which nonnative tree species are concentrated and where they may have the most significant ecological impacts. Such information may aid in management decisions regarding the detection and control of nonnative tree species.

\section{Methods}

The primary objective of this work was to generate two sets of metrics, one quantifying the invasiveness of individual nonnative forest tree species, and the other measuring the prevalence of nonnative tree species, or "invadedness," of each ecoregion section in the conterminous United States.
CRITERION 3Chapter 5. Large-Scale Assessment of Invasiveness and Potential for Ecological Impact by Nonnative Tree
Kevin M. Potter

William D. Smith 
To do this, we analyzed forest inventory data from 112,439 one-sixth-acre FIA plots. These plots represented the latest available FIA phase 2 tree [ $\geq 5$ inch diameter at breast height (d.b.h)] and sapling ( $\geq 1$ inch d.b.h and $<5$ inches d.b.h.) inventory data as of February 2009 (FIA 2009). They encompassed the latest annualized data available or periodic data when a full cycle of annualized data was unavailable; most States in the last 10 years have moved to an annual inventory, in which each plot is re-measured on a regular basis (5-7 years in the East, 10 years in the West). The number of years required to complete earlier periodic surveys varied based on the availability of resources and the number of plots and field crews (McRoberts 2005). The FIA program inventories only forested land, which is defined as being at least 1 acre in extent and at least 10 percent stocked by forest trees of any size, or as formerly having such tree cover and not currently developed for a nonforest use (Reams and others 2005). As a result, nonnative forest trees invading grasslands are not recorded, until and unless the invasion results in the area qualifying as forest. Not all exotic tree species found on FIA plots have species codes in the FIA system, particularly those that are not commonly found and/or have recently been introduced to forests in the United States; the presence of these uncommon and recently introduced species was recorded instead using a generic hardwood or conifer species code. This may result in a slight underestimate of the overall presence of exotic species existing on FIA plots, so our measures of ecoregion "invadedness" by exotic species may in turn be slightly underestimated.
Two types of nonnative tree species were included in the study: (1) those with origins outside North America, referred to here as "exotic" species, and (2) those native to North America but occurring outside their historical distributions, referred to here as "nonindigenous native" species. Potentially nonindigenous native tree species included in the FIA database were identified within the Biota of North America county-level plant species distribution data (Kartesz 2009) as those with different portions of their ranges classified as "native" and "adventive or introduced/native." Non-indigenous occurrences of these species were included in the study if at least 10 trees occurred on two or more FIA plots outside a $100-\mathrm{km}$ buffer drawn around the historic range map of the species (U.S. Geological Survey 1999). Trees within these buffers, created using ArcGIS 9.2 (ESRI 2006), were excluded to ensure that our analyses did not include natural populations missed by the historic range maps as well as newer natural populations established since the creation of the maps in the mid- $20^{\text {th }}$ century. This buffer corresponds with the greatest distance trees are expected to be able to migrate without assistance over a 100-year timeframe, given that trees migrated a maximum of $100 \mathrm{~km}$ per year following the most recent glaciation (McLachlan and others 2005).

We report four metrics of "invasiveness" for each tree species included in the study: (1) overall abundance in the FIA data; (2) overall abundance of saplings $[\geq 1$ inch and $<5$ inch diameter at breast height (d.b.h.)], as 
a proxy for reproductive success; (3) number of ecoregion sections in which the species occurs, as a measure of geographic spread; and (4) mean percent of trees per acre represented by the species on the plots on which it occurs, as a measure of local ecological impact.

Additionally, we report four metrics of "invadedness" at the ecoregion section scale. Each of these metrics was reported separately for exotic nonnative species, for non-indigenous native species, and for all nonnative species, a category which encompasses all the species included in the other two classifications. The four metrics of "invadedness" are (1) number of nonnative tree species at the ecoregion scale, as a measure of nonnative species richness; (2) percent of plots within each ecoregion section containing at least one nonnative tree or sapling, as a measure of nonnative distribution across the ecoregion; (3) the mean percent of nonnative species basal area, across plots within each ecoregion, as a measure of local ecological impact; and (4) the mean percent of nonnative saplings per acre, across plots within each ecoregion, as an indicator of nonnative species reproductive success.

\section{Results and Discussion}

Of the nearly 3.1 million individual trees recorded in the FIA data and used in our analyses, 21,338 , or 0.69 percent, were classified as nonnative. Of the 21,338 nonnative trees, 12,944 were exotic nonnatives (60.66 percent) and 8,394 were non-indigenous natives (39.34 percent)
In our results, the most abundant tree, a non-indigenous native, was Osage-orange (Maclura pomifera) (table 5.1), which was widely prevalent in the FIA data throughout the Midwestern States, outside of its native range of eastern Texas, southeastern Oklahoma, and southwestern Arkansas. Before barbed wire had become available, Osage-orange had been planted across large areas of the United States and southeastern Canada as a living fence, because the species reproduces well in full sun from the large seed crops it produces in most years (Preston and Braham 2002).

In our results, Scots pine (Pinus sylvestris) was the most abundant exotic nonnative species, relatively common throughout the Great Lakes States and the Northeast. With a large distribution across the northern reaches of Eurasia, this species has been widely used in reforestation for pulpwood, erosion control, and Christmas tree plantations in the parts of the Northern United States where it has become locally naturalized (Hardin and others 2001).

The third most abundant tree in our results also had the most saplings, suggesting recent introduction and/or reproduction. Despite its abundance, Chinese tallow-tree (Triadica sebifera) thus far exists in only 15 ecoregion sections in the Southeast, many fewer than other abundant nonnatives (table 5.1). Exhibiting very rapid growth, this species is a major pest of coastal tallgrass prairies and a persistent invader of abandoned agricultural lands and bottomland hardwoods of the Southeast (Hardin and others 
2001). It invades stream banks, riverbanks, and wet areas like ditches as well as upland sites, and it is spread by bird- and water-dispersed seeds in addition to colonizing by prolific surface root sprouts (Miller 2003).

Among species with relatively high abundance, the Australian exotic Melaleuca quinquinervia appears to have the most significant ecological impact, encompassing an average of 54.88 percent of the trees per acre on the plots where it occurs (table 5.1). This prolific and rapidly growing species is of considerable environmental concern in southern Florida, where it was planted to lower water tables, to stabilize shore lines, and to create windbreaks (Liebhold and others 1995). Other abundant exotic species with apparently high local ecological impacts (i.e., occurring on more than 25 FIA plots) are Chinese tallow-tree, Russianolive (Elaeagnus angustifolia), tungoil tree (Vernicia fordii), and Siberian elm (Ulmus pumila).

The species richness of nonnative tree species is much higher in the Eastern half of the country than in the West, where they are largely absent (fig. 5.1). Of the 106 ecoregions containing at least one nonnative species, all but three are in the East, and only a handful of ecoregions in the East lack nonnatives. The sections containing the most nonnative species are generally in the interior portions of the East, with the South Central Great Lakes region (222J) having the most (19), followed by the Southern Unglaciated
Table 5.1-Four metrics of "invasiveness" for nonnative tree species: overall abundance in the Forest Inventory and Analysis data, overall abundance of saplings, number of ecoregion sections in which each species occurs, and the mean percent of trees per acre represented by each species on the plots on which it occurs

\begin{tabular}{|c|c|c|c|c|}
\hline Species & Trees & Saplings & Sections & Mean relative tpa \\
\hline Maclura pomifera ${ }^{a}$ & 3,558 & 463 & 37 & 23.61 \\
\hline Pinus sylvestris & 3,243 & 267 & 41 & 26.80 \\
\hline Triadica sebifera & 3,156 & 1,364 & 15 & 31.23 \\
\hline Robinia pseudoacacia ${ }^{a}$ & 2,095 & 306 & 55 & 23.39 \\
\hline Picea abies & 1,891 & 90 & 33 & 23.53 \\
\hline Ailanthus altissima & 1,822 & 592 & 34 & 18.64 \\
\hline Pinus taeda ${ }^{\mathrm{a}}$ & 779 & 52 & 14 & 26.97 \\
\hline Melia azedarach & 640 & 198 & 24 & 18.06 \\
\hline Picea glauca ${ }^{\mathrm{a}}$ & 442 & 33 & 16 & 24.32 \\
\hline Ulmus pumila & 412 & 61 & 33 & 27.13 \\
\hline Melaleuca quinquenervia & 325 & 158 & 6 & 54.88 \\
\hline Morus alba & 325 & 90 & 35 & 13.43 \\
\hline Pinus strobus ${ }^{\mathrm{a}}$ & 260 & 21 & 13 & 22.30 \\
\hline Carya illinoinensis ${ }^{\mathrm{a}}$ & 240 & 49 & 14 & 15.23 \\
\hline Picea pungens ${ }^{\mathrm{a}}$ & 237 & 47 & 12 & 27.14 \\
\hline Paulownia tomentosa & 220 & 46 & 20 & 8.63 \\
\hline Pinus nigra & 213 & 3 & 14 & 21.58 \\
\hline Albizia julibrissin & 188 & 85 & 28 & 15.89 \\
\hline Pinus virginiana $^{\mathrm{a}}$ & 185 & 36 & 17 & 6.72 \\
\hline Prunus avium & 142 & 13 & 15 & 7.44 \\
\hline Pseudotsuga menziesii ${ }^{\mathrm{a}}$ & 138 & 9 & 9 & 29.50 \\
\hline Catalpa speciosa ${ }^{a}$ & 118 & 13 & 17 & 15.77 \\
\hline Elaeagnus angustifolia & 107 & 86 & 10 & 37.92 \\
\hline Gleditsia triacanthos $^{\mathrm{a}}$ & 81 & 17 & 18 & 13.18 \\
\hline Acer platanoides & 77 & 24 & 14 & 22.55 \\
\hline Quercus palustris ${ }^{\mathrm{a}}$ & 52 & 7 & 13 & 8.30 \\
\hline Catalpa bignoniodes ${ }^{\mathrm{a}}$ & 42 & 9 & 11 & 10.63 \\
\hline
\end{tabular}


Table 5.1-Four metrics of "invasiveness" for nonnative tree species: overall abundance in the Forest Inventory and Analysis data, overall abundance of saplings, number of ecoregion sections in which each species occurs, and the mean percent of trees per acre represented by each species on the plots on which it occurs (continued)

\begin{tabular}{|c|c|c|c|c|}
\hline Species & Trees & Saplings & Sections & Mean relative tpa \\
\hline Alnus glutinosa & 36 & 3 & 9 & 14.64 \\
\hline Vernicia fordii & 32 & 21 & 3 & 28.02 \\
\hline Catalpa spp. ${ }^{a}$ & 31 & 1 & 8 & 13.46 \\
\hline Quercus michauxii ${ }^{a}$ & 31 & 4 & 8 & 7.13 \\
\hline Carya laciniosa $a^{a}$ & 29 & 10 & 10 & 9.60 \\
\hline Cinnamomum camphora & 20 & 9 & 4 & 23.61 \\
\hline Salix alba & 20 & 3 & 10 & 10.59 \\
\hline Magnolia grandiflora ${ }^{a}$ & 19 & 9 & 4 & 11.80 \\
\hline Pinus banksiana ${ }^{a}$ & 18 & 3 & 4 & 36.55 \\
\hline Eucalyptus grandis & 17 & 6 & 1 & 100.00 \\
\hline Magnolia acuminata ${ }^{a}$ & 15 & 8 & 4 & 11.96 \\
\hline Castanea dentata $^{a}$ & 14 & 8 & 2 & 55.14 \\
\hline Eucalyptus spp. & 11 & 0 & 1 & 46.89 \\
\hline Pinus ponderosa ${ }^{a}$ & 10 & 0 & 3 & 5.81 \\
\hline Populus nigra & 7 & 3 & 2 & 77.21 \\
\hline Citrus spp. & 7 & 7 & 2 & 41.26 \\
\hline Salix sepulcralis & 7 & 0 & 4 & 16.22 \\
\hline Castanea mollissima & 6 & 0 & 4 & 12.15 \\
\hline Populus alba & 5 & 2 & 1 & 47.82 \\
\hline Casuarina lepidophloia & 4 & 0 & 1 & 63.64 \\
\hline Eucalyptus globulus & 3 & 1 & 3 & 18.34 \\
\hline Sorbus aucuparia & 3 & 3 & 2 & 11.16 \\
\hline Tamarix spp. & 2 & 2 & 1 & 100.00 \\
\hline Syzygium cumini & 2 & 0 & 1 & 10.00 \\
\hline Prunus persica & 1 & 0 & 1 & 0.70 \\
\hline
\end{tabular}

a Species are "non-indigenous native" tree species that are native to North America, but occurring outside their historic ranges.
Allegheny Plateau (221E) with 18, and by the Coastal Plains-Middle (231B) and the Northern Ridge and Valley (M221A), each having 16 (fig. 5.1A). Patterns of abundance of exotic nonnatives (fig. 5.1B) and non-indigenous natives (fig. 5.1C) were generally similar.

Ecoregion sections with the greatest distribution of nonnative species (having the highest percentage of FIA plots containing a nonnative species) tended to encompass a relatively small amount of forest cover and to be located in the central part of the country (fig. 5.2A). In the sparsely forested South Central and Red Bed Plains (332F), for example, 61.9 percent of forest plots included a nonnative species. More than 40 percent of plots in three other sections also included at least one nonnative tree: the Western Glaciated Plains (332B), the Louisiana Coastal Prairie and Marshes (232E), and the Osage Plains (251E). Exotic nonnatives tended to be more common in ecoregion sections along the Gulf Coast, in the Mid-Atlantic States, and in the eastern portions of the Midwest (fig. 5.2B), while non-indigenous native trees were more prevalent in the central Midwest and in the Southern Plains States (fig. 5.2C).

Nonnative trees had the greatest apparent ecological impact along the Gulf Coast and on the Great Plains, where these species constituted the highest mean percentage of basal area at the plot level (fig. 5.3A). The ecoregions with 


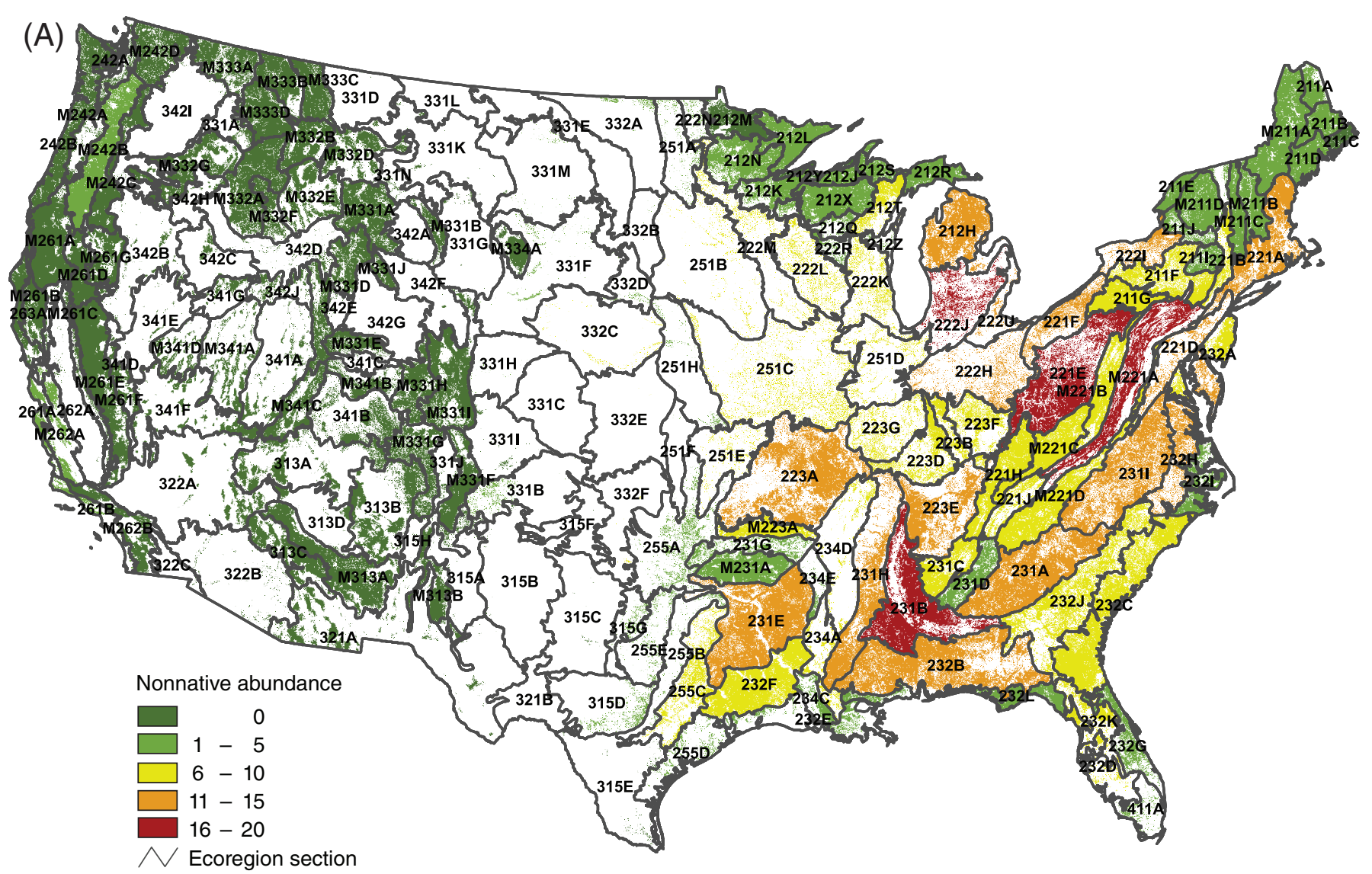

Figure 5.1-Species richness of (A) all nonnative forest tree species, (B) exotic nonnative forest tree species, and (C) non-indigenous native forest tree species at the ecoregion section scale (Cleland and others 2007). Forest cover is derived from MODIS imagery by the U.S. Forest Service Remote Sensing Applications Center. (Data source: U.S. Department of Agriculture Forest Service, Forest Inventory and Analysis Program.) (continued on next page) 


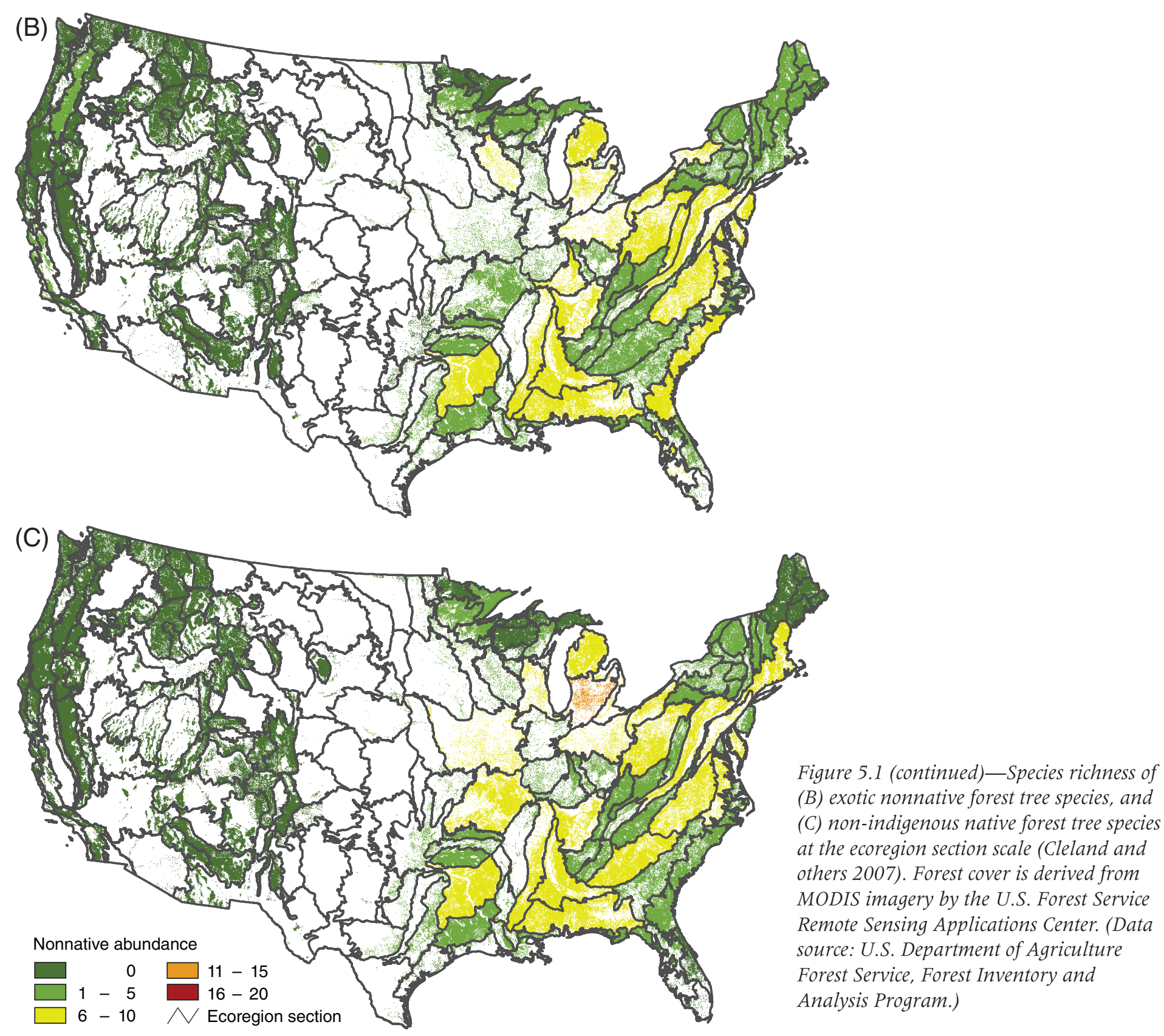




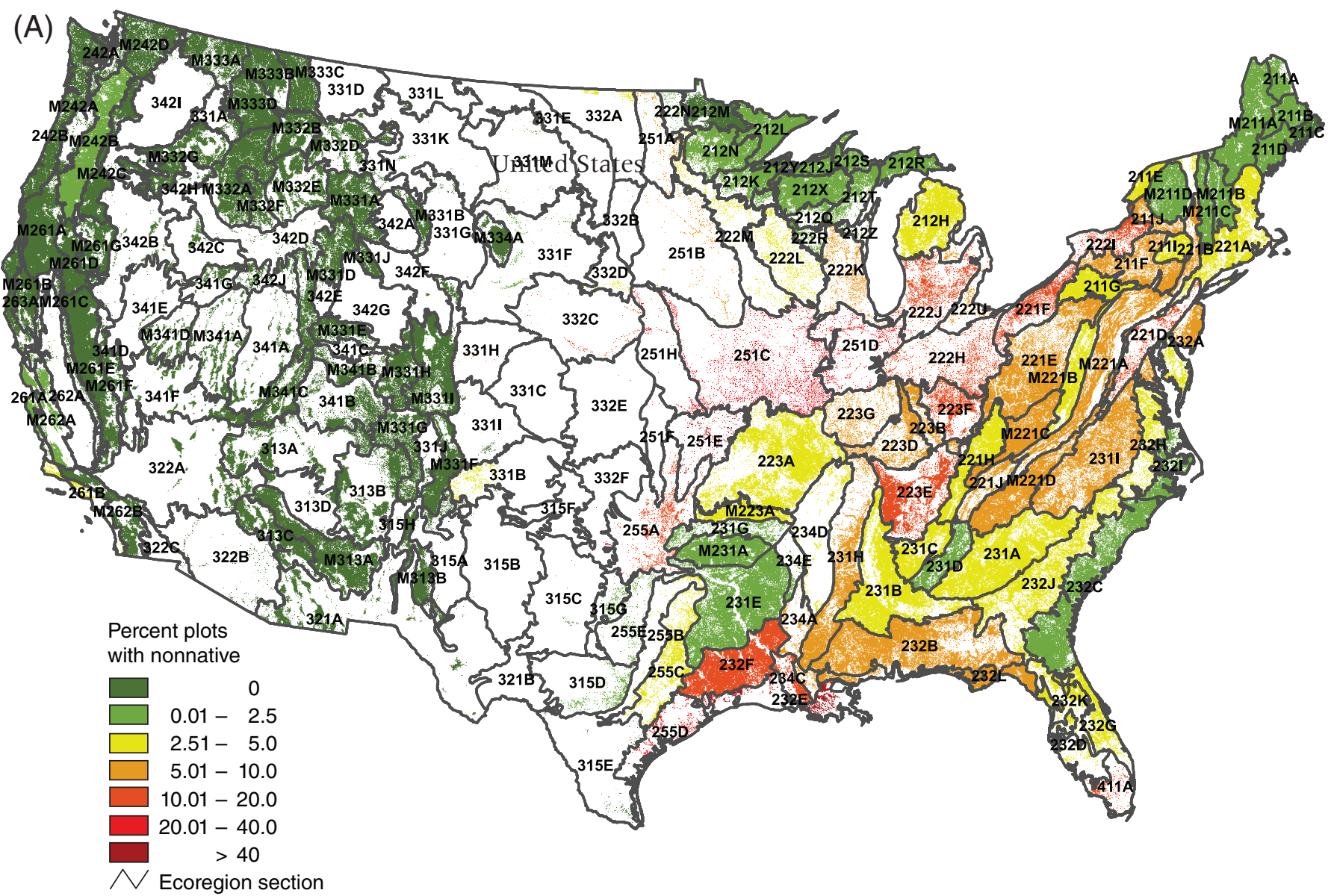

Figure 5.2-Percent of Forest Inventory and Analysis plots at the ecoregion section scale (Cleland and others 2007) containing at least one (A) nonnative tree, $(B)$ exotic nonnative tree, and (C) non-indigenous native tree. Forest cover is derived from MODIS imagery by the U.S. Forest Service Remote Sensing Applications Center. (Data source: U.S. Department of Agriculture Forest Service, Forest Inventory and Analysis Program.) (continued on next page) 


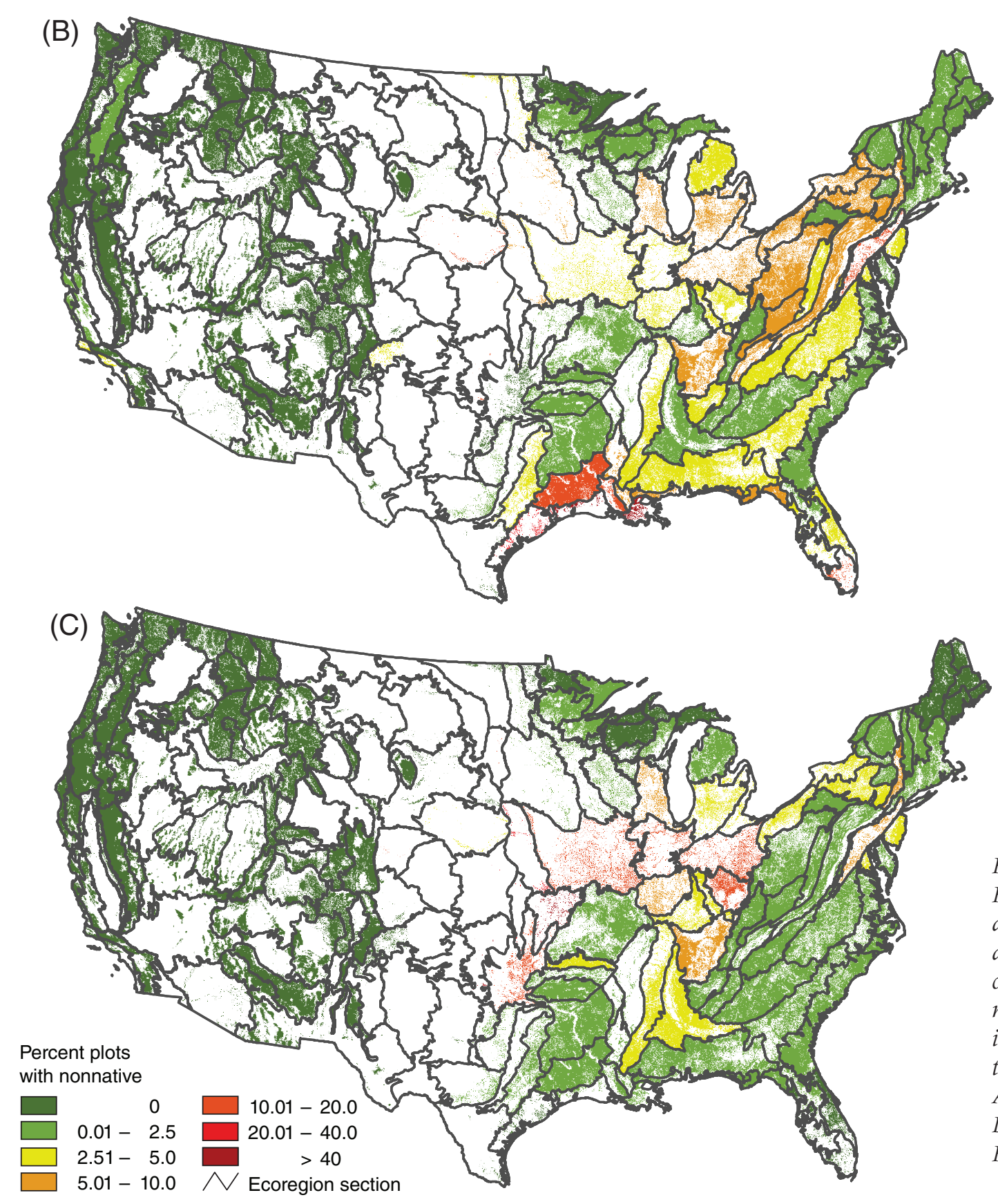

Figure 5.2 (continued)—Percent of Forest Inventory and Analysis plots at the ecoregion section scale (Cleland and others 2007) containing at least one $(B)$ exotic nonnative tree, and $(C)$ non-indigenous native tree. Forest cover is derived from MODIS imagery by the U.S. Forest Service Remote Sensing Applications Center. (Data source: U.S. Department of Agriculture Forest Service, Forest Inventory and Analysis Program.) 


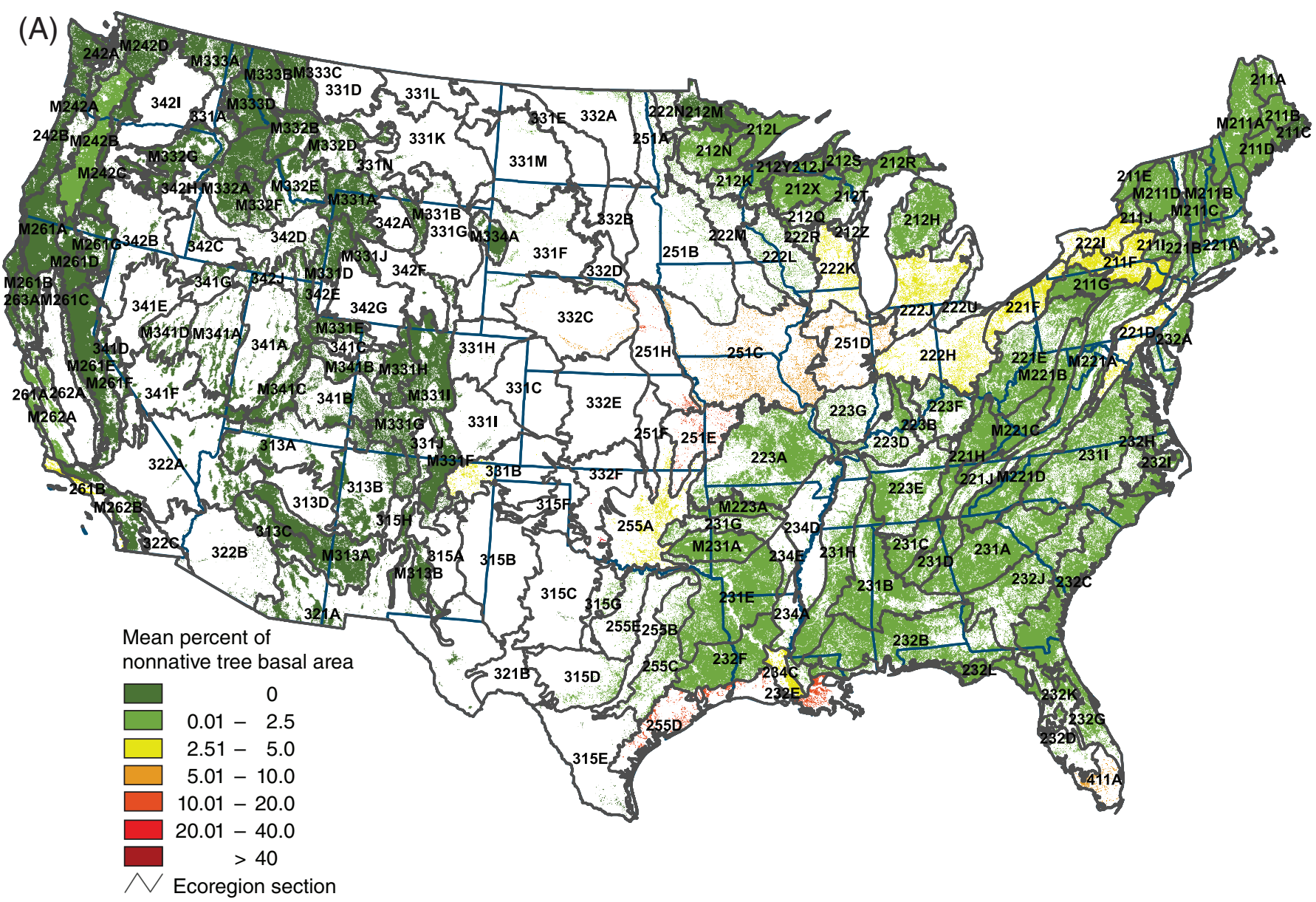

Figure 5.3-Mean percent of plot-level basal area that is $(A)$ nonnative, $(B)$ exotic nonnative, and $(C)$ non-indigenous native, across Forest Inventory and Analysis plots at the ecoregion section scale (Cleland and others 2007). Forest cover is derived from MODIS imagery by the U.S. Forest Service Remote Sensing Applications Center. (Data source: U.S. Department of Agriculture Forest Service, Forest Inventory and Analysis Program.) (continued on next page) 


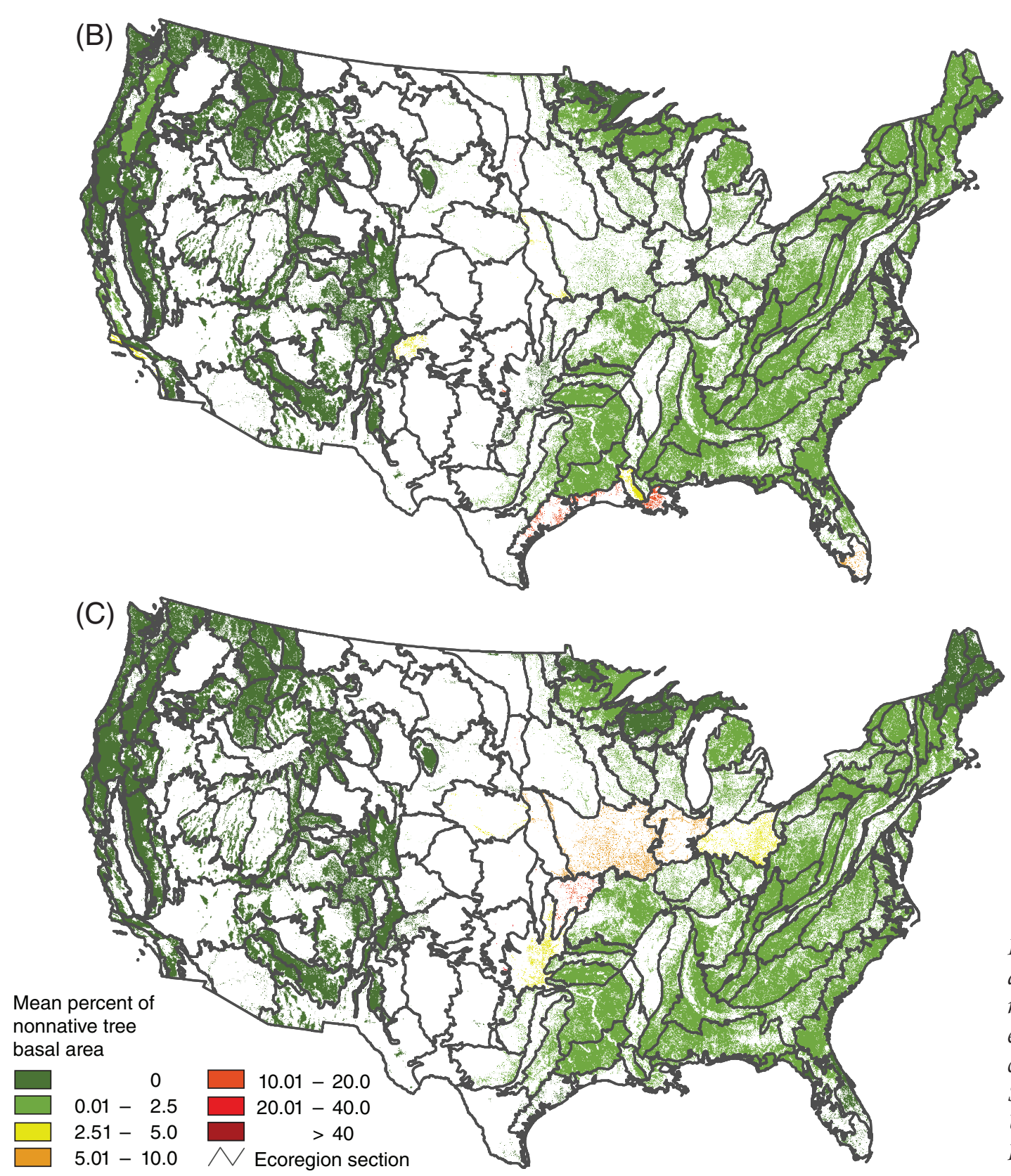

the highest percent of nonnative basal area contain very little forest cover: just under half of the basal area in the Western Glaciated Plains (332B), for example, was not native (47.9 percent), compared to 34.7 percent in the South Central and Red Bed Plains (332F), and 15.1 percent in the Flint Hills (251F). Among more heavily forested areas, meanwhile, the Louisiana Coastal Prairie and Marshes (232E) and the Central Gulf Prairie and Marshes (225D) had the highest percentage of nonnative basal area, with 15.0 percent and 10.9 percent, respectively. Exotic trees appear to have had a greater potential impact along the Gulf Coast and in southern Florida (fig. 5.3B) while nonindigenous native trees may have had a greater potential impact in the Midwest (fig. 5.3C).

Patterns of nonnative sapling occurrence at the plot level (fig. 5.4) appear to differ in some significant ways from the analysis of nonnative basal area across all tree sizes. Sections with large percentages of plots containing a nonnative sapling are concentrated along the Gulf Coast, on the Great Plains, and in southern California

Figure 5.3 (continued) - Mean percent of plot-level basal area that is (B) exotic nonnative, and $(C)$ non-indigenous native, across Forest Inventory and Analysis plots at the ecoregion section scale (Cleland and others 2007). Forest cover is derived from MODIS imagery by the U.S. Forest Service Remote Sensing Applications Center. (Data source: U.S. Department of Agriculture Forest Service, Forest Inventory and Analysis Program.) 


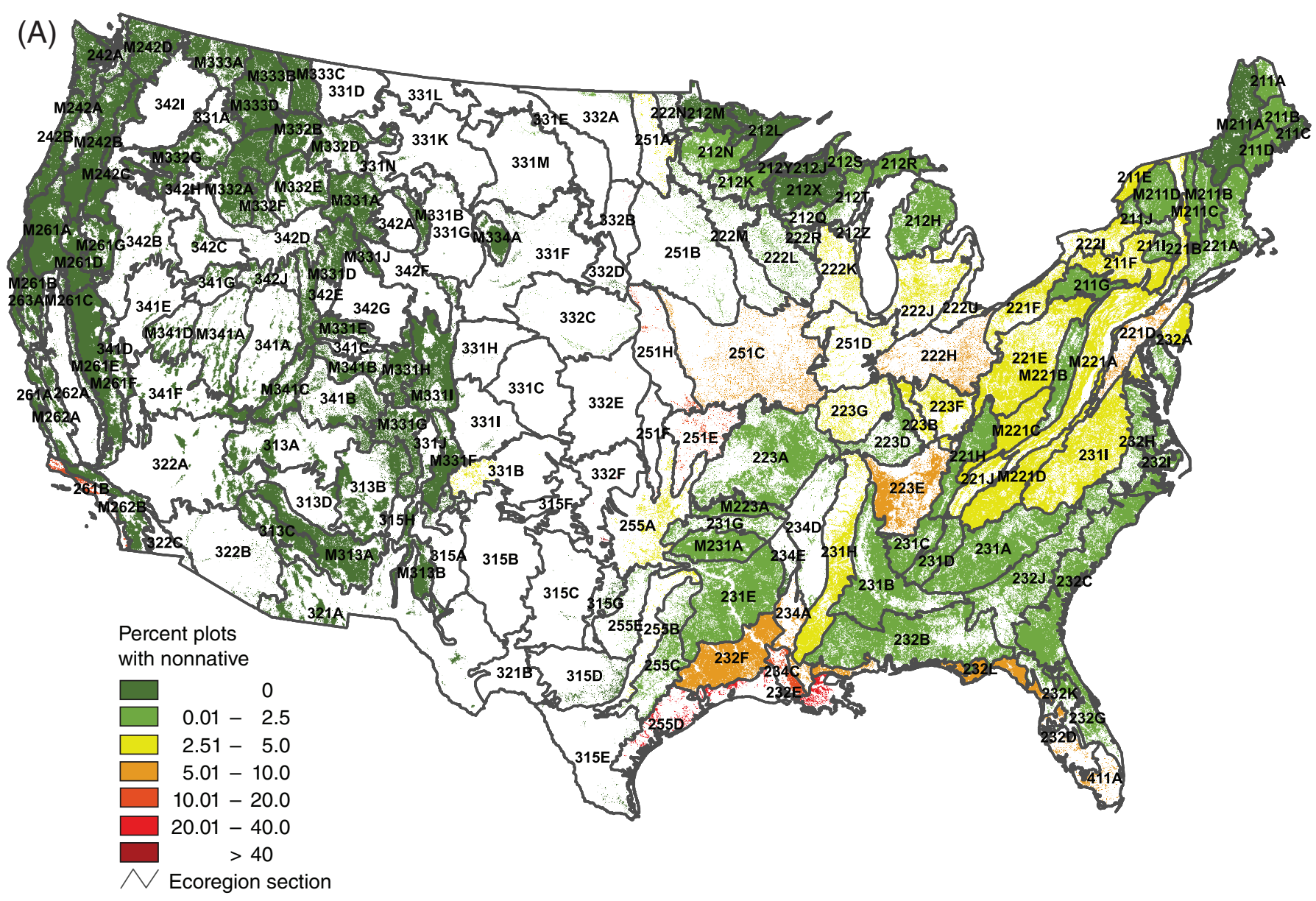

Figure 5.4-Percent of Forest Inventory and Analysis plots at the ecoregion section scale (Cleland and others 2007) containing at least one $(A)$ nonnative sapling, $(B)$ exotic nonnative sapling, and $(C)$ non-indigenous native sapling. Forest cover is derived from MODIS imagery by the U.S. Forest Service Remote Sensing Applications Center. (Data source: U.S. Department of Agriculture Forest Service, Forest Inventory and Analysis Program.) (continued on next page) 


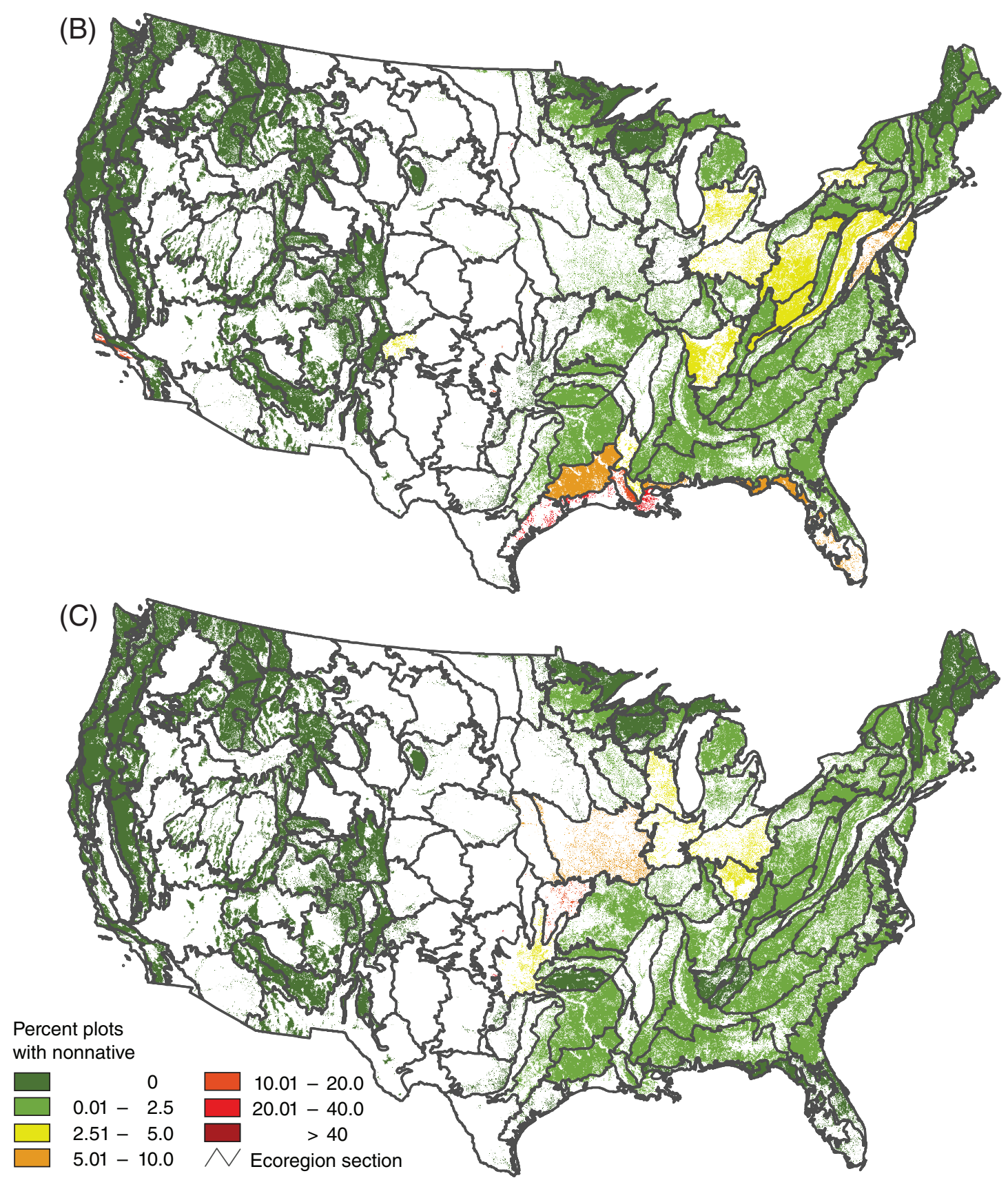

(fig. 5.4A). The widespread distribution of exotic saplings is limited almost entirely to the Gulf Coast, southern Florida, and southern California (fig. 5.4B), while the widespread distribution of non-indigenous native saplings is confined to the Midwest (fig. 5.4C). These findings are largely consistent with the analysis of the ecological impact of nonnative saplings, as measured by the mean percentage of trees per acre at the plot level that are not native. It appears that the relative importance of all nonnative saplings is highest along the western Gulf Coast, southern California, and in southern Florida (fig. 5.5A), places where exotic nonnative saplings seem most important (fig. 5.5B). Nonindigenous native saplings are most important in a handful of sections in the southern Great Plains region (fig. 5.5C).

This work was designed to offer insights into the invasiveness of specific forest tree species and into the extent to which those species may impact ecological processes across large ecological regions. Such information may be useful to assist in the targeting of activities to

Figure 5.4 (continued)-Percent of Forest Inventory and Analysis plots at the ecoregion section scale (Cleland and others 2007) containing at least one (B) exotic nonnative sapling, and (C) non-indigenous native sapling. Forest cover is derived from MODIS imagery by the U.S. Forest Service Remote Sensing Applications Center. (Data source: U.S. Department of Agriculture Forest Service, Forest Inventory and Analysis Program.) 


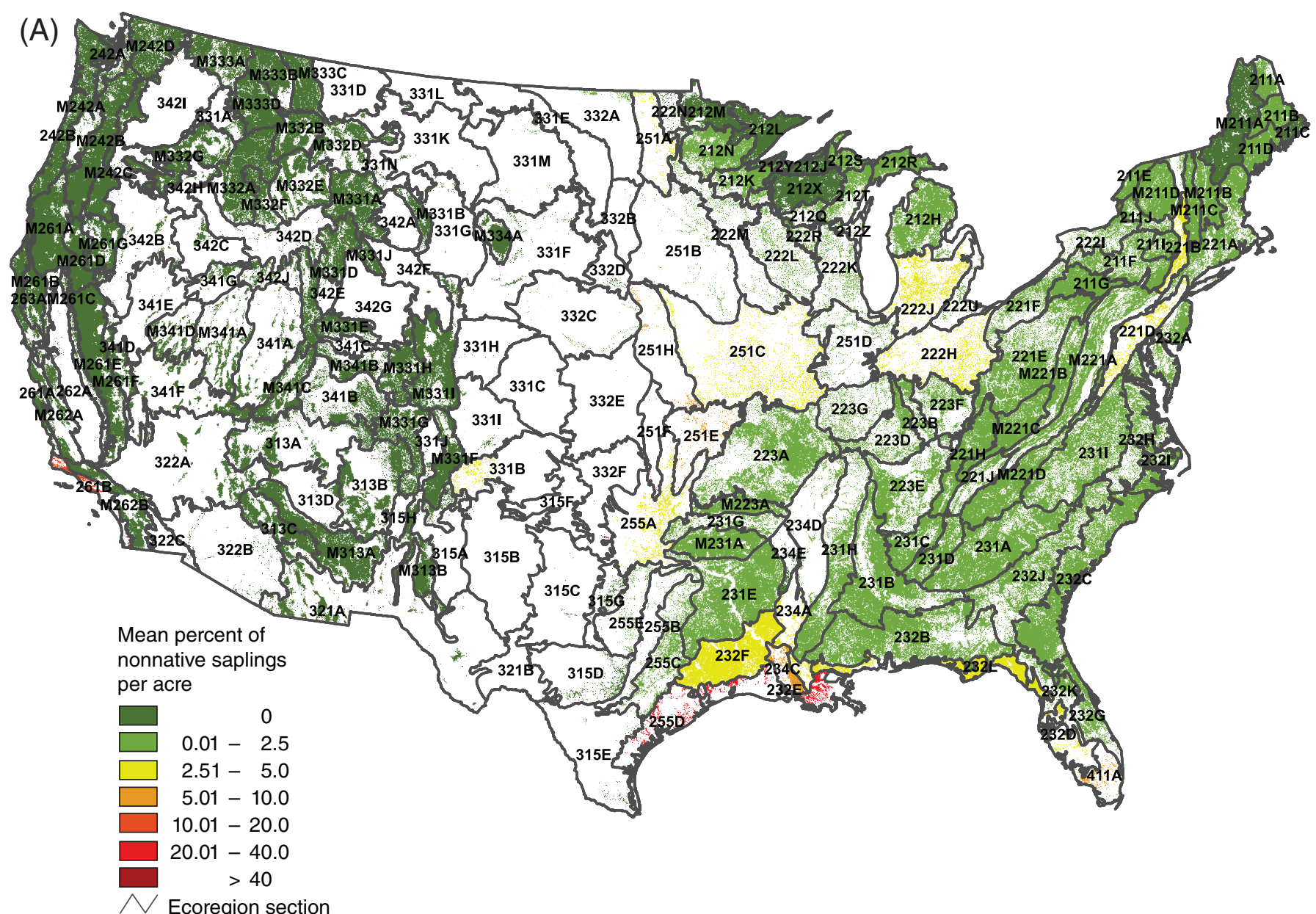

Figure 5.5-Mean percent of total saplings per acre that are (A) nonnative, (B) exotic nonnative, and (C) non-indigenous native, across Forest Inventory and Analysis plots at the ecoregion section scale (Cleland and others 2007). Forest cover is derived from MODIS imagery by the U.S. Forest Service Remote Sensing Applications Center. (Data source: U.S. Department of Agriculture Forest Service, Forest Inventory and Analysis Program.) (continued on next page) 


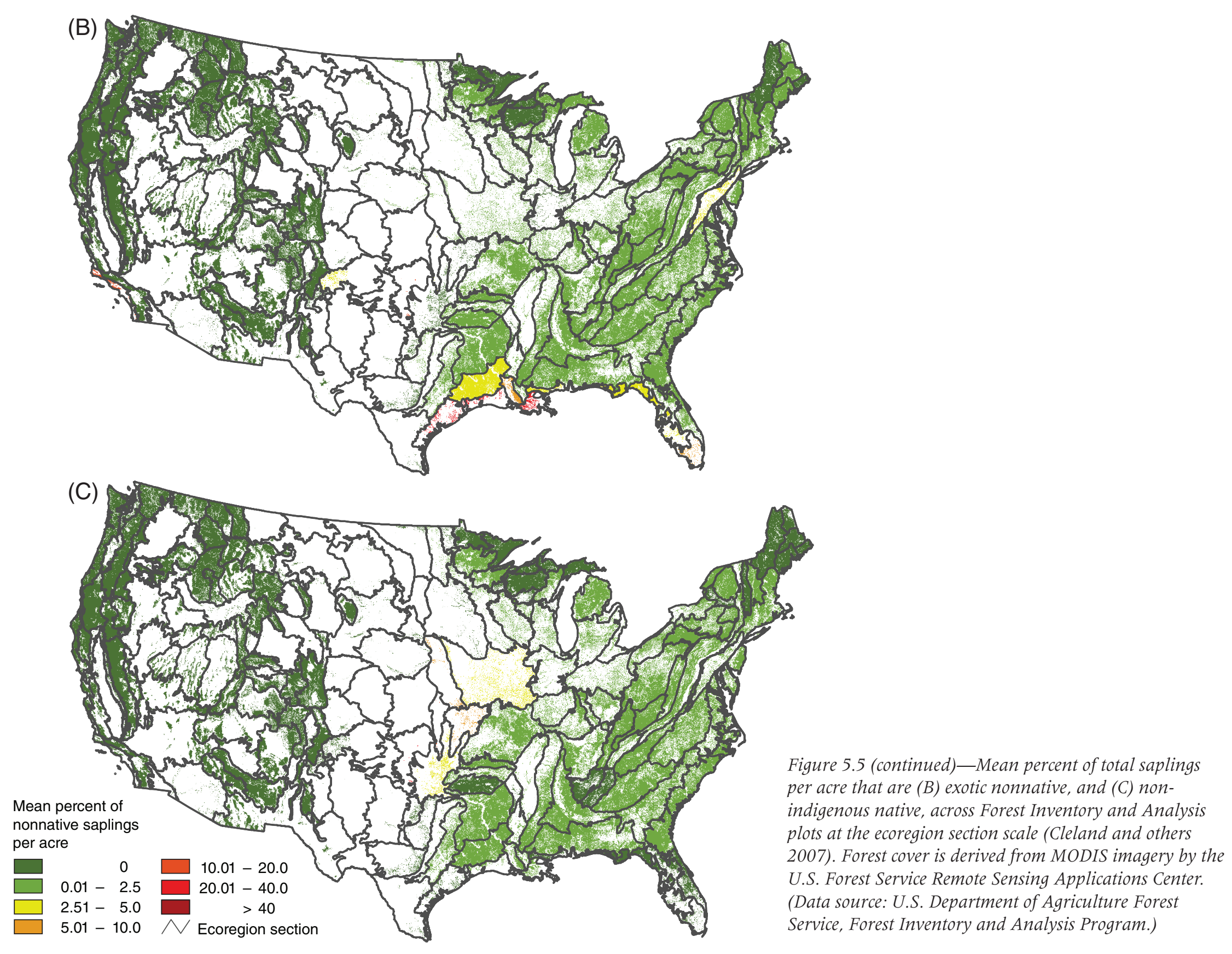


detect and suppress nonnative tree species. As data become available, we recommend repeating these analyses for other plant habits, such as herbaceous plants and shrubs, which often tend toward greater invasiveness than forest tree species.

\section{Literature Cited}

Cleland, D.T.; Freeouf, J.A.; Keys, J.E. [and others]. 2007. Ecological subregions: sections and subsections for the conterminous United States. Sloan, A.M., tech. ed. Gen. Tech. Report WO-76. Washington, DC: U.S. Department of Agriculture Forest Service. Map, presentation scale 1:3,500,000; Albers equal area projection; colored. Also as a GIS coverage in ArcINFO format on CD-ROM or at http://fsgeodata.fs.fed.us/other_resources/ecosubregions. html. [Date accessed: March 18, 2011].

Crall, A.W.; Meyerson, L.A.; Stohlgren, T.J. [and others]. 2006. Show me the numbers: what data currently exist for nonnative species in the USA? Frontiers in Ecology and the Environment. 4(8): 414-418.

ESRI. 2006. ArcMap 9.2. Redlands, CA: Environmental Systems Research Institute Inc.

Forest Inventory and Analysis (FIA). 2009. The forest inventory and analysis database: database description and users manual version 3.0 for phase 2. Arlington, VA: United States Department of Agriculture Forest Service. $243 \mathrm{p}$.

Hardin, J.W.; Leopold, D.J.; White, F.M. 2001. Harlow and Harrar's textbook of dendrology, ninth edition. Boston: McGraw Hill. 543 p.

Holmes, T.P.; Aukema, J.E.; Von Holle, B. [and others]. 2009. Economic impacts of invasive species in forest past, present, and future. In: Ostfeld, R.S.; Schlesinger, W.H., ed. Year in ecology and conservation biology 2009 Oxford: Blackwell Publishing: 18-38.

Kartesz, J.T. 2009. A synonymized checklist and atlas with biological attributes for the vascular flora of the United States, Canada, and Greenland. version 2.0 [CD-ROM] Chapel Hill, NC: Biota of North America Program, North Carolina Botanical Garden, University of North Carolina.
Liebhold, A.M.; MacDonald, W.L.; Bergdahl, D.; Mastro, V.C. 1995. Invasion by exotic forest pests: a threat to forest ecosystems. Forest Science Monographs. 41 (2): 1-49.

Mack, R.N.; Simberloff, D.; Lonsdale, W.M. [and others]. 2000. Biotic invasions: Causes, epidemiology, global consequences, and control. Ecological Applications. 10(3) 689-710.

McLachlan, J.S.; Clark, J.S.; Manos, P.S. 2005. Molecular indicators of tree migration capacity under rapid climate change. Ecology. 86(8): 2088-2098.

McRoberts, R.E. 2005. The enhanced Forest Inventory and Analysis program. In: Bechtold, W.A.; Patterson, P. L., ed. The enhanced Forest Inventory and Analysis programnational sampling design and estimation procedures. Asheville, NC: United States Department of Agriculture Forest Service, Southern Research Station: 1-10.

Miller, J.H. 2003. Nonnative invasive plants of southern forests: a field guide for identification and control. Revised. Gen. Tech. Rep. SRS-62. Asheville, NC: U.S. Department of Agriculture Forest Service, Southern Research Station. $93 \mathrm{p}$.

Office of Technology Assessment. 1993. Harmful nonindigenous species in the United States. Washington, DC: United States Congress, Office of Technology and Assessment. 391 p.

Pimentel, D.; Lach, L.; Zuniga, R.; Morrison, D. 2000. Environmental and economic costs of non-indigenous species in the United States. Bioscience. 50(1): 53-65.

Preston, R.J.; Braham, R.R. 2002. North American Trees, Fifth Edition. Ames, IA: Iowa State University Press. $514 \mathrm{p}$

Reams, G.A.; Smith, W.D.; Hansen, M.H. [and others]. 2005. The Forest Inventory and Analysis sampling frame. In: Bechtold, W.A.; Patterson, P.L., ed. The enhanced Forest Inventory and Analysis program-national sampling design and estimation procedures. Asheville, NC: United States Department of Agriculture Forest Service, Southern Research Station: 11-26.

U.S. Geological Survey. 1999. Digital representation of "Atlas of United States Trees" by Elbert L. Little, Jr. http://esp. cr.usgs.gov/data/atlas/little/. [Date accessed: March 13, 2009] 


\section{Introduction}

1 ree mortality is a natural process in all forest ecosystems. However, extremely high mortality also can be an indicator of forest health issues. On a regional scale, high mortality levels may indicate widespread insect or disease problems. High mortality may also occur if a large proportion of the forest in a particular region is made up of older, senescent stands.

In early (i.e., 2001-04) national reports by the Forest Health Monitoring (FHM) Program of the Forest Service, U.S. Department of Agriculture, mortality was analyzed using FHM data and phase 3 data from the Forest Inventory and Analysis (FIA) Program of the Forest Service. Those data spanned a relatively long period (for some States, up to 12 years), but the sample was not spatially intense (approximately 1 plot per 96,000 acres). In the 2008 FHM national report (Ambrose 2011), the same method was applied to FIA phase 2 data. That phase 2 dataset was more spatially intense (approximately 1 plot per 6,000 acres) but came from the relatively small number of States in the Eastern United States where repeated plot measurements had been taken. In this report, the method is applied to a larger area of the Central and Eastern United States, using data from repeated phase 2 measurements from a larger number of States.

The mission of FHM is to monitor, assess, and report on the status, changes, and longterm trends in forest ecosystem health in the United States (FHM 1994). Thus, the aim of this mortality analysis contrasts with how mortality might be approached in other reports, such as FIA State reports or State Forest Health Highlights. The approach to mortality presented here seeks to detect mortality patterns that might reflect subtle changes to fundamental ecosystem processes (due to such large-scale factors as air pollution, global climate change, or fireregime change) that transcend individual tree species-pest/pathogen interactions. However, sometimes the proximate cause of mortality may be discernible. In such cases, the cause of mortality is reported, both because it is of interest in and of itself to many readers and because understanding such proximate causes of mortality might provide insight into whether the mortality is within the range of natural variation or reflects more fundamental changes to ecological processes.

At this point a mortality baseline is still being established for most of the United States. To discern trends in mortality rates, at least three cycles of FIA data are required. With the up to two cycles of data currently available, it is only possible to do a spatial comparison of ecoregions and identify regions of higher than average mortality (relative to growth) for further study.

\section{Data}

FIA phase 2 inventory data are collected using a rotating panel sample design (Bechtold and Patterson 2005). Field plots are divided into spatially balanced panels, with one panel being measured each year. A single cycle of measurements consists of measuring all panels. This "annualized" method of inventory was
CRITERION 3Chapter 6 . Tree Wortality

Mark J. Ambrose 
adopted, State by State, beginning in 1999. Any analysis of mortality requires data collected from at least two points in time from any given plot. Therefore, mortality analysis was possible for areas where data from repeated plot measurements using consistent sampling protocols were available (i.e., where one cycle of measurements had been completed and at least one panel of the next cycle had been measured, and where there had been no changes to the protocols affecting measurement of trees or saplings).

Because the data used here are collected using a rotating panel design and all available annualized data are used, most of the data used in this mortality analysis were also used in the analysis presented in the previous FHM national report. Using the data in this way, it would be very unusual to see any great changes in mortality patterns from one annual report to the next. Nevertheless, it is important to look at mortality patterns every year so as not to miss detecting changes in mortality patterns as soon as they may become discernible.

Table 6.1 shows the 21 States from which consistent, repeated phase 2 measurements were available, the time period spanned by the data, and the number of panels of data available. The States included in this analysis, as well as the forest cover within those States, are shown in figure 6.1.
Table 6.1 - States from which repeated Forest Inventory and Analysis phase 2 measurements were available, the time period spanned by the data, and the number of panels of data available. Each panel represents approximately one-fifth of the plots in a State

\begin{tabular}{llc}
\hline Time period & States $^{a}$ & Number of Phase 2 panels \\
\hline $1999-2006$ & ME & 3 \\
$1999-2007$ & MN, MO, WI & $3^{b c d}$ \\
$2000-2007$ & IA, IN, MI, PA & 3 \\
$2000-2008$ & VA & $3^{e}$ \\
$2001-2007$ & GA, IL, KS, NE, ND, SD & 2 \\
$2001-2008$ & AL, TN, TX & 3 \\
$2002-2007$ & AR, KY, SC & 1 \\
\hline
\end{tabular}

${ }^{a}$ States are listed by their standard abbreviations.

${ }^{b}$ In Minnesota and Wisconsin the phase 2 inventory was done at twice the standard FIA sample intensity, approximately 1 plot per 3,000 acres when the full 5 panels are measured.

${ }^{c}$ In Missouri the phase 2 inventory was done at twice the standard FIA sample

intensity, approximately 1 plot per 3,000 acres when the full 5 panels are measured, on National Forest lands and at the standard intensity on all other lands.

${ }^{d}$ In Minnesota, Missouri, and Wisconsin, the field season often begins late in the calendar year, so while the earliest data are from 1999, they do not represent a separate panel but are part of the panel mostly measured in 2000.

${ }^{e}$ Only a small proportion of the plots measured in Virginia in 2000 used the current national standard plot design, so just slightly more than 3 full panels of remeasurement data were available for this analysis.

${ }^{f}$ Annualized growth and mortality data were only available for eastern Texas. 


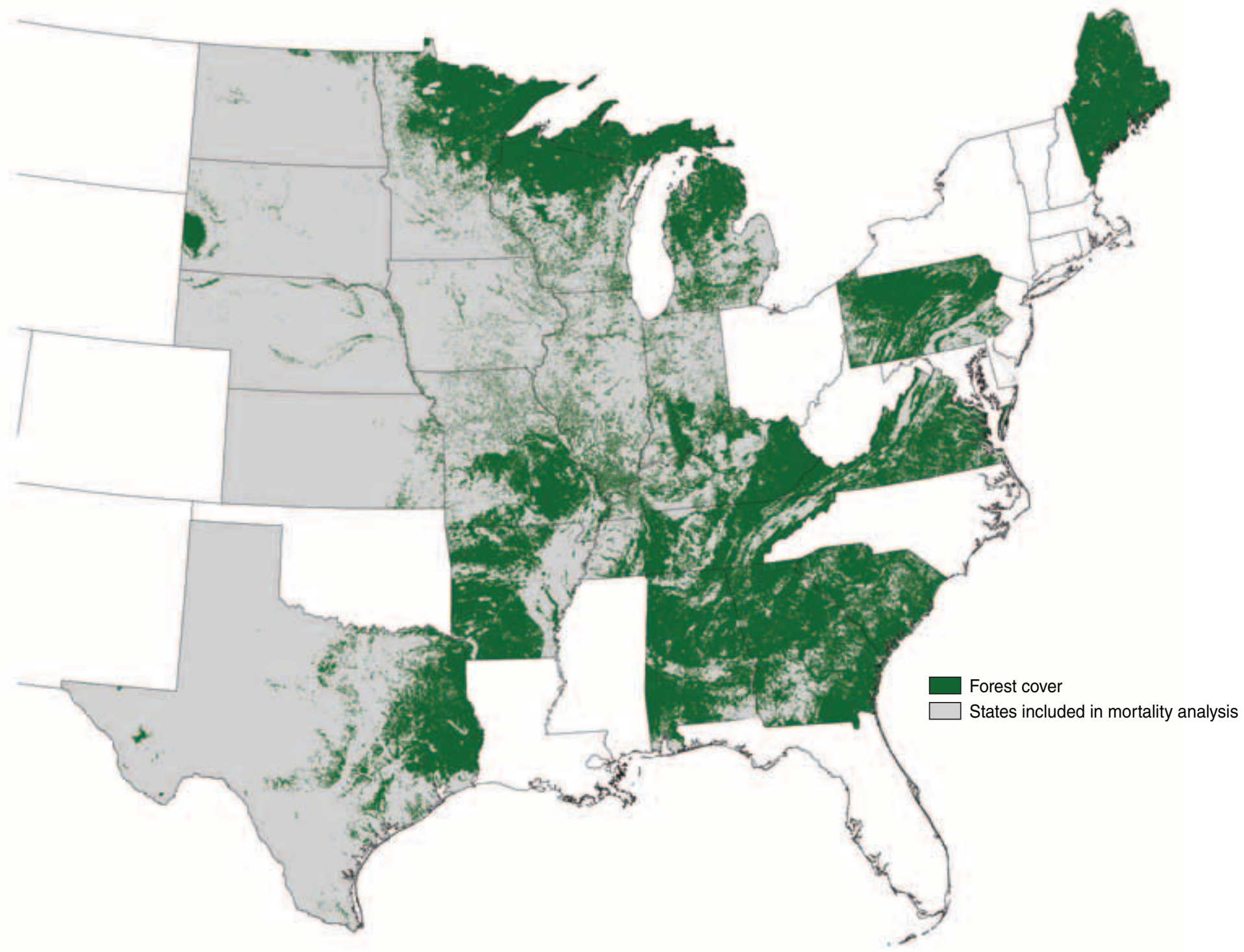

Figure 6.1-Forest cover in the States where mortality was analyzed. Forest cover was derived from Advanced Very High Resolution Radiometer satellite imagery (Zhu and Evans 1994). 


\section{Methods}

FIA phase 2 tree and sapling data were used to estimate average annual tree mortality in terms of tons of biomass per acre. The biomass represented by each tree in tons was calculated by FIA and provided in the FIA Databaseversion 3.0 (FIA 2008). To compare mortality rates across forest types and climate zones, the ratio of annual mortality to gross growth (MRATIO) is used as a standardized mortality indicator (Coulston and others 2005a). Gross growth rate and mortality rate, in terms of tons of biomass per acre, were independently calculated for each ecoregion section (Cleland and others 2007) using a mixed modeling procedure. The mixed model is efficient for estimation using data where not all plots have been measured over identical time intervals (Gregoire and others 1995). MRATIOs were then calculated from the growth and mortality rates. For details on the method, see "Appendix A: Supplemental Methods" in the 2001 and 2003 FHM national technical reports (Coulston and others 2005b, 2005c, respectively) as well as Smith and Conkling (2004).

The MRATIO can be large if an over-mature forest is senescing and losing a cohort of older trees. If forests are not naturally senescing, a high MRATIO (>0.6) may indicate high mortality due to some acute cause (insects or pathogens) or due to generally deteriorating forest health conditions. An MRATIO value greater than 1 indicates that mortality exceeds growth and live standing biomass is actually decreasing.
In addition, the ratio of average dead tree diameter to average surviving live tree diameter (DDLD ratio) was calculated for each plot where mortality occurred. Low DDLD ratios (much less than 1) usually indicate competitioninduced mortality typical of young, vigorous stands, while high ratios (much greater than 1) indicate mortality associated with senescence or some external factors such as insects or disease (Smith and Conkling 2004). (Intermediate DDLD ratios can be hard to interpret because a variety of stand conditions can produce such DDLD values.) The DDLD ratio is most useful for analyzing mortality in regions that also have high MRATIOs. High DDLD values in regions with very low MRATIOs may indicate small areas experiencing high mortality of large trees or locations where the death of a single large tree (such as a remnant pine in a young hardwood stand) has produced a deceptively high DDLD.

To further analyze tree mortality, the number of stems and the total biomass of trees that died also were calculated by species within each ecoregion. Identifying the tree species experiencing high mortality in an ecoregion is a first step in identifying what forest health issue may be affecting the forests. Although determining particular causal agents associated with all the observed mortality is beyond the scope of this report, often there are well-known insects and pathogens that are "likely suspects" once the affected tree species are identified. 
Also, a biomass weighted mean mortality age was calculated by ecoregion and species. For each species experiencing mortality in an ecoregion the mean stand age was calculated, weighted by the dead biomass on the plot. This value gives a rough indicator of the average age of trees that died. However, the age of individual trees may differ significantly from the age assigned to a stand by FIA field crews, especially in mixed species stands. When the age of trees that die is relatively low compared with the age at which trees of a particular species usually become senescent, it suggests that some pest, pathogen, or other forest health problem may be affecting the forest.

\section{Results and Discussion}

The MRATIO values are shown in figure 6.2. Table 6.2 shows the tree species experiencing the greatest mortality in ecoregions having MRATIOs of 0.6 or greater.

The highest MRATIOs occurred in ecoregion sections 332C-Nebraska Sand Hills (MRATIO $=1.21), 332 \mathrm{~A}-$ Northeastern Glaciated Plains $($ MRATIO $=1.18)$, and 332E-South Central Great Plains $($ MRATIO $=1.11)$. Another area of extremely high mortality relative to growth occurred in section 251C-Central Dissected Till Plains (MRATIO $=0.91$ ). Other areas having relatively high MRATIOS were sections 255A-Cross Timbers and Prairies (MRATIO = 0.79 ), M334A-Black Hills (MRATIO $=0.66$ ), and 251H-Nebraska Rolling Hills (MRATIO =0.60).
The results of the analysis of the relative sizes of trees that died to those that lived, the DDLD ratio, are shown in figure 6.3 . The DDLD ratio is a plot-level indicator and is so represented in the figure. However, given the density of FIA phase 2 plots, overlap of markers representing plot values on a national scale map sometimes can give a misleading impression, so close-up views of the Lake States, the Northeast, and the Southeast are also provided.

In the three ecoregion sections exhibiting highest mortality relative to growth (332A-Northeastern Glaciated Plains, 332C-Nebraska Sand Hills, and 332E-South Central Great Plains), the predominant vegetation is grassland, and there were very few forested plots measured. Most of the forest in these sections is riparian forest, and, indeed, the species experiencing greatest mortality (table 6.2 ) are commonly found in riparian areas. DDLD values vary widely within each of these sections. There are a small number of plots with high DDLDs, and these plots represent most of the biomass that died in these sections. However, on many of these plots the overall level of mortality is fairly low, as would be the case when remnant larger trees die, leaving young, vigorous stands behind. Tree growth is generally slow in these ecoregion sections because of naturally dry conditions. Where the number of sample plots is small and tree growth is slow, care must be taken in interpreting mortality relative to growth over short time intervals. 


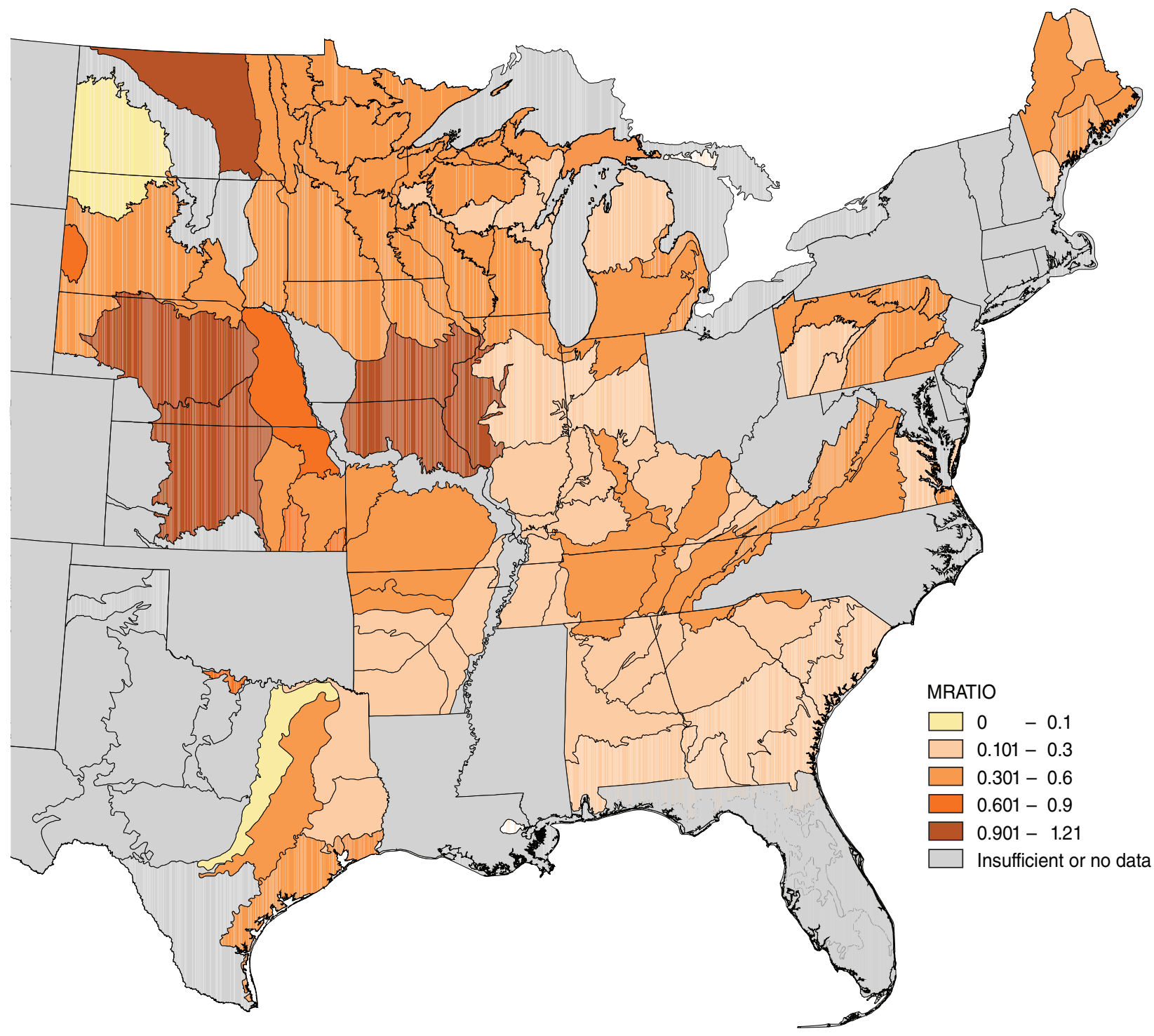

Figure 6.2-Tree mortality expressed as the ratio of annual mortality of woody biomass to gross annual growth in woody biomass (MRATIO) by ecoregion section (Cleland and others 2007). (Data source: U.S. Department of Agriculture Forest Service, Forest Inventory and Analysis Program) 
Table 6.2-Tree species responsible for at least 10 percent of the mortality (in terms of biomass) for ecoregions where the MRATIO was 0.60 or greater, including the mean age of the dead trees of these species and the species-level percent mortality within the ecoregion

\begin{tabular}{|c|c|c|c|c|c|c|}
\hline \multirow[t]{2}{*}{ Ecoregion section } & \multirow[t]{2}{*}{ MRATIO } & \multirow[t]{2}{*}{ Tree species } & \multirow[t]{2}{*}{$\begin{array}{l}\text { Percent of total } \\
\text { mortality biomass }\end{array}$} & \multirow[t]{2}{*}{$\begin{array}{l}\text { Mean age of } \\
\text { dead trees }^{a}\end{array}$} & \multicolumn{2}{|c|}{$\begin{array}{l}\text { Percent mortality } \\
\text { of each species }\end{array}$} \\
\hline & & & & & (biomass) & (stems) \\
\hline \multirow{3}{*}{ 332C-Nebraska Sand Hills } & \multirow{3}{*}{1.21} & Eastern cottonwood (Populus deltoides) & 67.09 & 54 & 55.45 & 35.46 \\
\hline & & Green ash (Fraxinus pennsylvanica) & 10.46 & 62 & 19.67 & 17.06 \\
\hline & & Eastern redcedar (Juniperus virginiana) & 10.14 & 64 & 8.17 & 25.00 \\
\hline \multirow{4}{*}{$\begin{array}{l}\text { 332A-Northeastern Glaciated } \\
\text { Plains }\end{array}$} & \multirow{4}{*}{1.18} & Quaking aspen (Populus tremuloides) & 33.82 & 53 & 16.44 & 13.05 \\
\hline & & Bur oak (Quercus macrocarpa) & 26.29 & 101 & 10.01 & 4.13 \\
\hline & & Green ash (F. pennsylvanica) & 20.59 & 95 & 14.30 & 16.76 \\
\hline & & Balsam poplar (Populus balsamifera) & 14.44 & 45 & 52.73 & 67.47 \\
\hline \multirow{3}{*}{ 332E-South Central Great Plains } & \multirow{3}{*}{1.11} & Hackberry (Celtis occidentalis) & 34.72 & 60 & 29.33 & 1.91 \\
\hline & & Box elder (Acer negundo) & 16.94 & 30 & 41.73 & 16.33 \\
\hline & & Eastern cottonwood (P. deltoides) & 10.68 & 62 & 7.37 & 17.65 \\
\hline \multirow{2}{*}{ 251C-Central Dissected Till Plains } & \multirow{2}{*}{0.91} & American elm (UImus americana) & 14.52 & 51 & 19.46 & 21.67 \\
\hline & & Black oak (Quercus velutina) & 12.09 & 66 & 20.70 & 25.47 \\
\hline \multirow{3}{*}{ 255A-Cross Timbers and Prairies } & \multirow{3}{*}{0.79} & Blackjack oak (Quercus marilandica) & 29.34 & 75 & 24.41 & 4.90 \\
\hline & & Hackberry (C. occidentalis) & 18.11 & 49 & 10.66 & 10.08 \\
\hline & & Black oak (Q. velutina) & 11.89 & 7 & 73.76 & 40.00 \\
\hline \multirow{2}{*}{ M334A-Black Hills } & \multirow{2}{*}{0.66} & Ponderosa pine (Pinus ponderosa) & 80.65 & 95 & 4.39 & 10.08 \\
\hline & & Quaking aspen (P. tremuloides) & 11.45 & 64 & 37.76 & 32.35 \\
\hline \multirow{4}{*}{ 251H-Nebraska Rolling Hills } & \multirow{4}{*}{0.60} & Slippery elm (UImus rubra) & 23.35 & 48 & 46.34 & 45.60 \\
\hline & & American elm ( $U$. americana) & 14.78 & 43 & 10.66 & 16.71 \\
\hline & & Eastern cottonwood (P. deltoides) & 13.61 & 45 & 3.53 & 7.23 \\
\hline & & Box elder (A. negundo) & 10.11 & 54 & 22.94 & 33.39 \\
\hline
\end{tabular}

${ }^{a}$ Ages are estimated from the stand age as determined by the Forest Inventory and Analysis field crew. It is possible, especially in mixed-species stands, that the age of individual trees that died differed significantly from the stand age. 
(A)

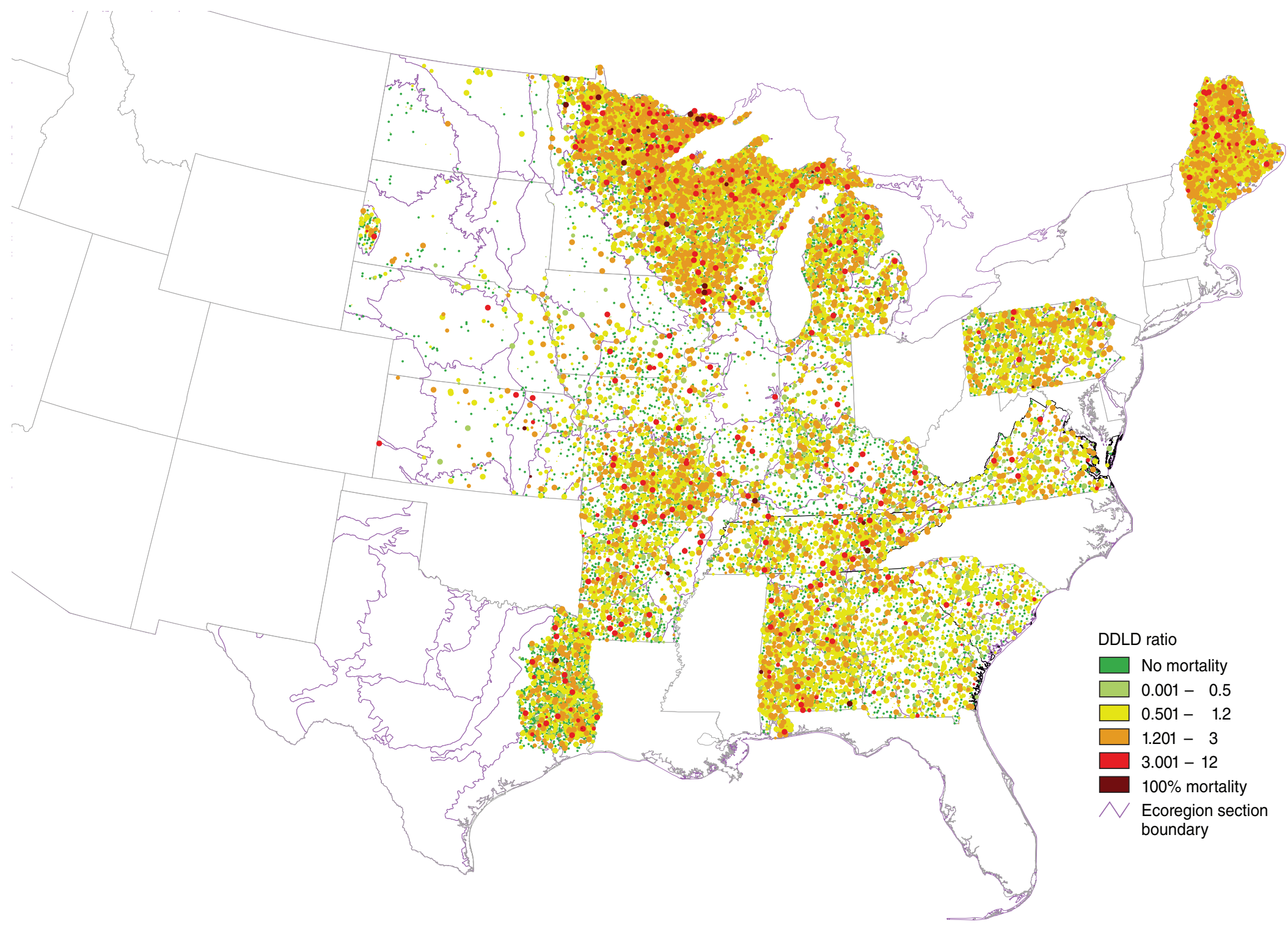

Figure 6.3-The ratio of average dead tree diameter to average surviving tree diameter (DDLD) on each plot at the time of its last measurement: (A) Eastern United States, (B) Upper Midwest, (C) Northeast, (D)Southeast. DDLD is indicated by dot color; dot sizes are scaled relative to the biomass that died on each plot. Plot locations are approximate. (Data source: U.S. Department of Agriculture Forest Service, Forest Inventory and Analysis Program) (continued on next page) 
(B)

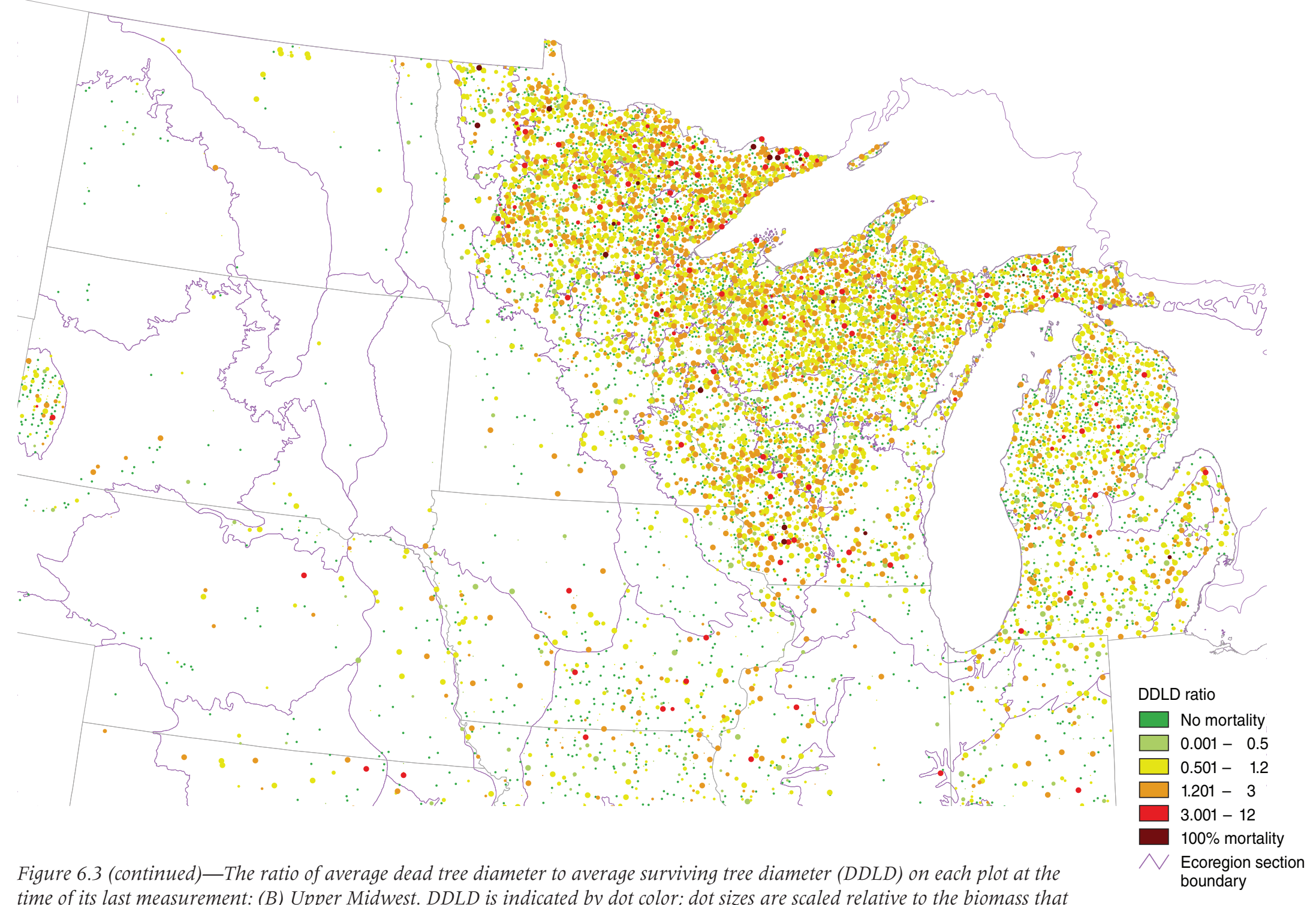
and Analysis Program) (continued on next page) 
(C)

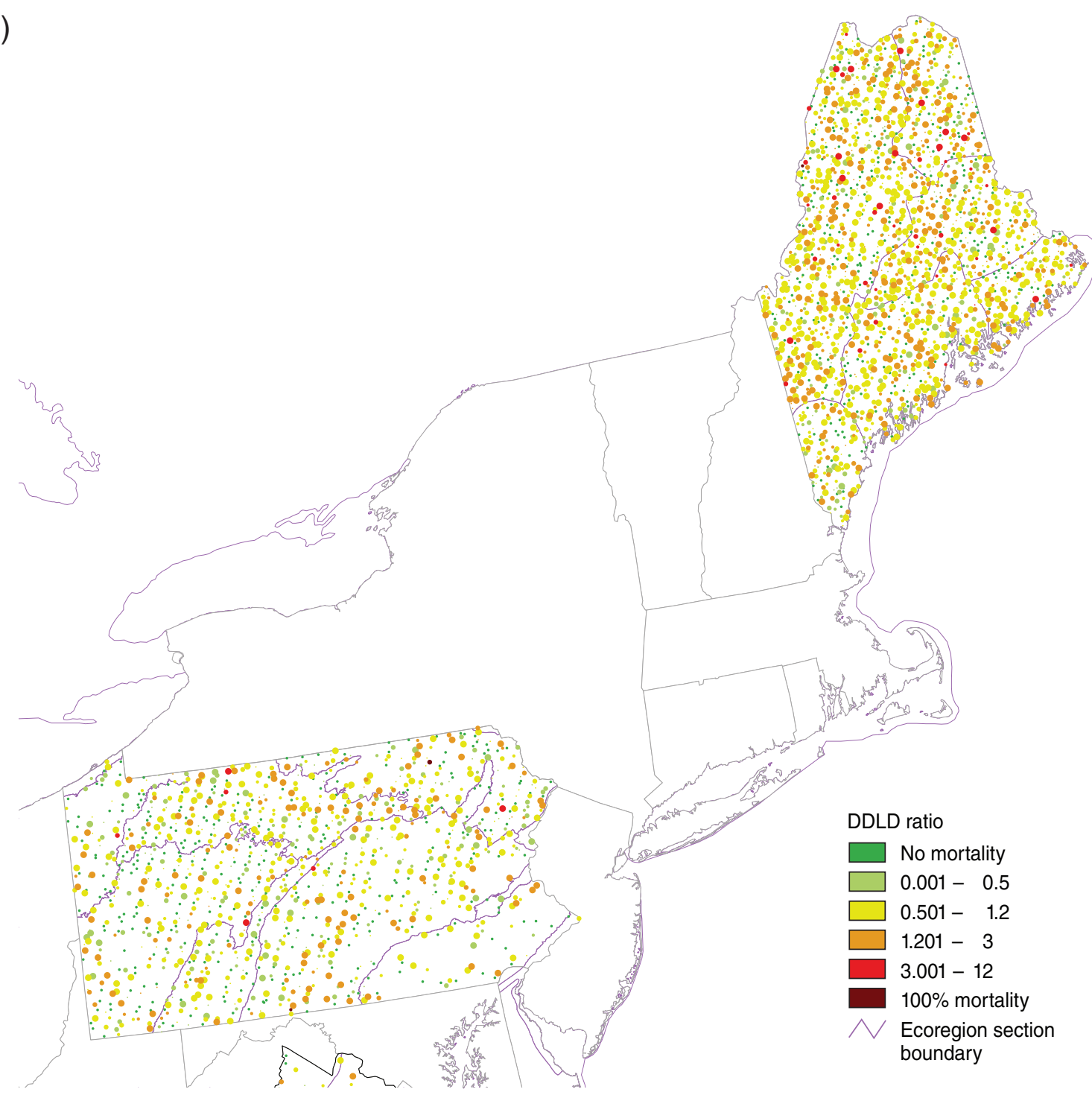

Figure 6.3 (continued) - The ratio of average dead tree diameter to average surviving tree diameter (DDLD) on each plot at the time of its last measurement: (C) Northeast. DDLD is indicated by dot color; dot sizes are scaled relative to the biomass that died on each plot. Plot locations are approximate. (Data source: U.S. Department of Agriculture Forest Service, Forest Inventory and Analysis Program) (continued on next page) 
(D)

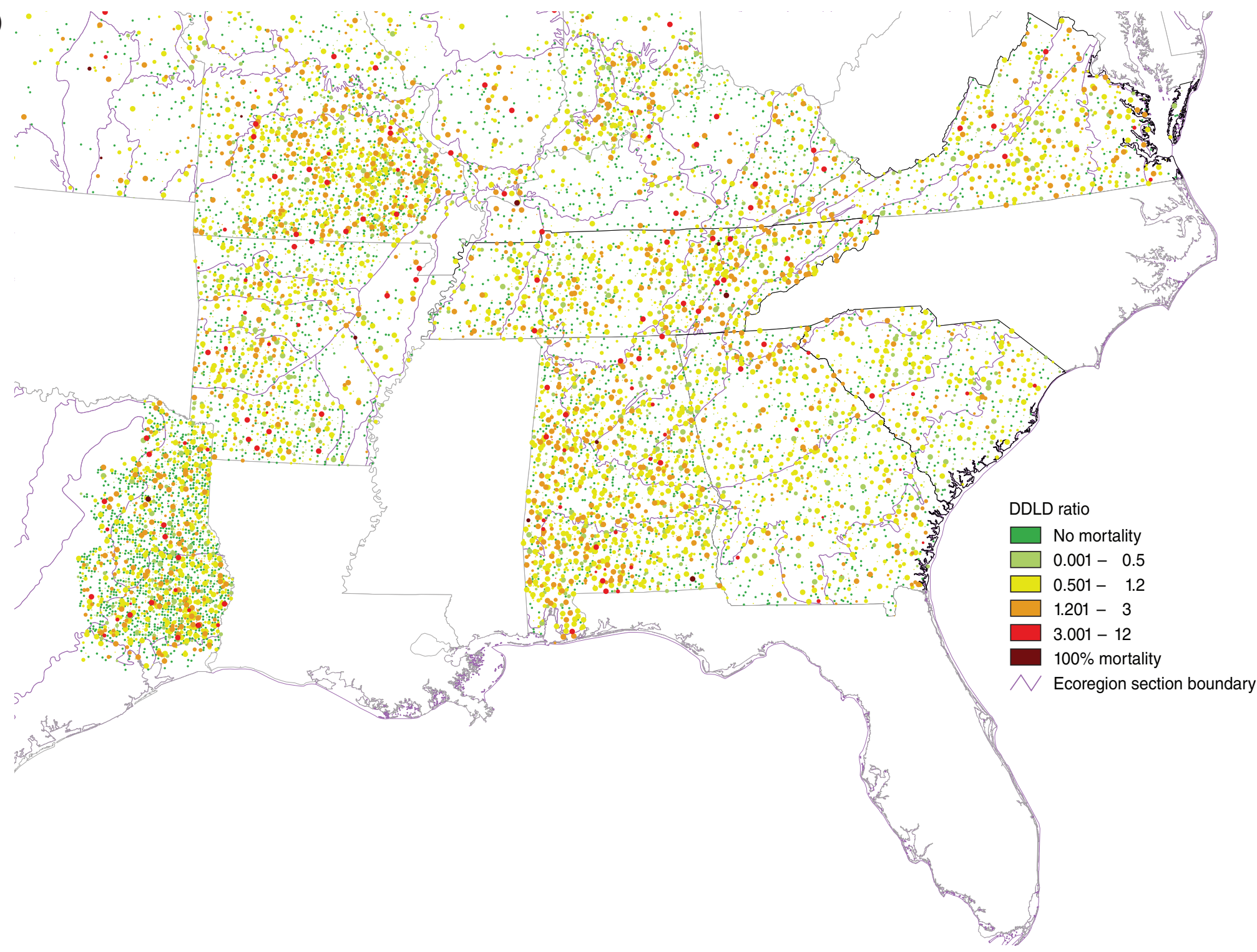

Figure 6.3 (continued) - The ratio of average dead tree diameter to average surviving tree diameter (DDLD) on each plot at the time of its last measurement: (D) Southeast. DDLD is indicated by dot color; dot sizes are scaled relative to the biomass that died on each plot. Plot locations are approximate. (Data source: U.S. Department of Agriculture Forest Service, Forest Inventory and Analysis Program) 
In ecoregion section 332C-Nebraska Sand Hills, where the MRATIO was highest, by far the largest amount of biomass that died was eastern cottonwood (table 6.2); more cottonwood biomass died than had survived at the end of the analysis period. In contrast, the largest number of trees that died in the section was eastern redcedar, but the biomass associated with the dead redcedars was less than one-sixth of the biomass of the cottonwood that died. Thus, much larger (and probably older) cottonwoods were dying than redcedar.

In ecoregion section 332A-Northeastern Glaciated Plains, three species experienced the highest total mortality in terms of biomass and together represent over 80 percent of the mortality in the ecoregion: bur oak, green ash, and quaking aspen. About 13 percent of the trees of these species, representing about 13 percent of their biomass, died over the analysis period. A fourth species, balsam poplar, represented only 14.4 percent of the mortality in the ecoregion, but that mortality was more than half of the balsam poplar growing in the ecoregion, both in terms of biomass and number of trees. In ecoregion section 332E-South Central Great Plains, the three species experiencing the greatest mortality were hackberry, boxelder, and eastern cottonwood.
In ecoregion section 251C-Central Dissected Till Plains, the largest amount of biomass that died was American elm. About 20 percent of the elms (in terms of both number of stems and biomass) died over the measurement cycle. Black oak made up a slightly smaller proportion of the mortality in the ecoregion, but had a slightly higher mortality rate (about 21 percent of biomass and 25 percent of stems).

The mortality patterns shown in these analyses do not immediately suggest largescale forest health issues. Mortality is rather low in most of the areas for which data are available. The areas of highest mortality occur in the mostly riparian forests of several plains ecoregions. Further study of the health of these forests may be warranted.

\section{Literature Cited}

Ambrose, M.J. 2011. Chapter 5-Mortality. In: Conkling, B.L, ed. Forest health monitoring: 2007 national technical report. Gen. Tech. Rep. SRS-147. Asheville, NC: U.S. Department of Agriculture Forest Service, Southern Research Station: 97-159.

Bechtold, W.A.; Patterson, P.L., eds. 2005. The enhanced Forest Inventory and Analysis program-national sampling design and estimation procedures. Gen. Tech. Rep. SRS-80. Asheville, NC: U.S. Department of Agriculture Forest Service, Southern Research Station. $85 \mathrm{p}$. 
Cleland, D.T.; Freeouf, J.A.; Keys, J.E. [and others]. 2007. Ecological subregions: sections and subsections for the conterminous United States. Sloan, A.M., tech. ed. Gen. Tech. Report WO-76. Washington, DC: U.S. Department of Agriculture Forest Service. Map, presentation scale 1:3,500,000; Albers equal area projection; colored. Also as a GIS coverage in ArcINFO format on CD-ROM or a http://fsgeodata.fs.fed.us/other_resources/ecosubregions. html. [Date accessed: March 18, 2011].

Coulston, J.W.; Ambrose, M.J.; Stolte. K.S. [and others]. 2005a. Criterion 3-health and vitality. In: Conkling, B.L.; Coulston, J.W.; Ambrose, M.J., eds. Forest Health Monitoring 2001 national technical report. Gen.

Tech. Rep. SRS-81. Asheville, NC: U.S. Department of Agriculture Forest Service, Southern Research Station. $203 \mathrm{p}$.

Coulston, J.W.; Smith, W.D.; Ambrose, M.J. [ and others] 2005b. Appendix A: supplemental methods. In: Conkling B.L.; Coulston, J.W.; Ambrose, M.J., eds. Forest Health Monitoring 2001 national technical report. Gen.

Tech. Rep. SRS-81. Asheville, NC: U.S. Department of Agriculture Forest Service, Southern Research Station. $203 \mathrm{p}$.

Coulston, J.W. ; Ambrose, M.J.; Riitters, K. H. [and others] 2005c. Appendix A - supplemental methods. In: Forest Health Monitoring 2003 national technical report. Gen. Tech. Rep. SRS-85. Asheville, NC: U.S. Department of Agriculture, Forest Service, Southern Research Station. $97 \mathrm{p}$
Forest Health Monitoring (FHM). 1994. Forest Health Monitoring: a national strategic plan. Research Triangle Park, NC: U.S. Department of Agriculture Forest Service, Forest Health Monitoring Program. $13 \mathrm{p}$

Forest Inventory and Analysis (FIA). 2008. The Forest Inventory and Analysis database: database description and users manual version 3.0 for phase 2, revision 1 . Washington, DC: U.S. Department of Agriculture Forest Service. http://www.fia.fs.fed.us/library/databasedocumentation/. [Date accessed: October 20, 2008].

Gregoire, T.G.; Schabenberger, O.; Barret, J.P. 1995. Linear modeling of irregularly spaced, unbalanced, longitudinal data from permanent-plot measurements. Canadian Journal of Forest Research. 25: 137-156.

Smith, W.D.; Conkling, B.L. 2004. Analyzing forest health data. Gen. Tech. Rep. SRS-77. Asheville, NC: U.S

Department of Agriculture Forest Service, Southern Research Station. 35 p.

Zhu, Z.; Evans, D.L. 1994. U.S. forest types and predicted percent forest cover from AVHRR data. Photogrammetric Engineering and Remote Sensing. 60: 525-531. 



\section{Introduction}

/ he impact of sudden oak death on Pacific Coast wildlands has received much attention from scientists, popular media, and the public. Disease symptoms were first observed in Marin County, in California, in 1994 on tanoak (Lithocarpus densiflorus) and, in 1995, on coast live oak (Quercus agrifolia) and California black oak (Q. kelloggii) (McPherson and others 2003). The crown foliage of affected trees appeared to die over several weeks, while bleeding cankers appeared on the lower trunks of larger trees (Rizzo and others 2002). During the next several years, sudden oak death reached epidemic levels in central and northern California (Frankel 2008, Garbelotto and others 2003, Rizzo and others 2005), with tree mortality estimated in one study to be three to four times the historic rate for tanoak and two times the historic rate for susceptible oak species (Swiecki and Bernhardt 2002). In 2001, the disease was discovered in Curry County, OR, likely having arrived there 3 or 4 years earlier (Frankel 2008, Goheen and others 2002, Hansen and others 2005). In addition to a now-quarantined portion of Curry County, sudden oak death outbreaks have so far been recorded in fourteen counties in California, extending from Monterey County northward to Humboldt County (Frankel 2008).

In 2000, sudden oak death was positively linked to the pathogen Phytophthora ramorum, which had been isolated from the leaves of ornamental Viburnum and Rhododendron plants in Germany and the Netherlands (Garbelotto and others 2003, Rizzo and others 2002, Werres and others 2001). This linkage highlights that there are actually two distinct diseases caused by P. ramorum: (1) lethal cankers on the trunks and/or branches of host trees such as coast live oak and tanoak, and (2) nonlethal foliage and twig infections on a wide variety of host species, especially ericaceous trees and shrubs such as California bay laurel (Umbellularia californica) (Rizzo and Garbelotto 2003, Tooley and others 2004). In natural stands, these "foliar" hosts are key to the persistence and spread of the pathogen because they serve as a source of inoculum and yield large numbers of aerially dispersed $P$. ramorum spores following rainfall (Rizzo and others 2005). In contrast, susceptible oak species represent an epidemiological endpoint, although tanoak also behaves as a foliar host (Rizzo and Garbelotto 2003, Rizzo and others 2005). Spores of P. ramorum may be dispersed from foliar hosts by rain splash or wind-driven rain, and have been found in watercourses downstream from infected areas as well as in soil on the shoes of hikers traveling through these areas (Davidson and others 2005, Webber and Rose 2008). Moreover, the discontinuous distribution of the pathogen across a large geographic area of California and Oregon suggests the presence of additional longdistance dispersal mechanisms that likely involve humans, who historically have been responsible for the global-scale spread of numerous Phytophthora species (Davidson and Shaw 2003, Ristaino and Gumpertz 2000).

Indeed, the potential and, in some cases, actual movement of infected plants via the commercial nursery trade has raised $P$. ramorum
CRITERION 3Chapter'? A Revised Sudden Oak Death Risk Map to Facilitate National Surverss

\section{Frank H. KOCH}

William D. Smith 
from a regional forest health issue to one of global concern. A number of confirmed host species, particularly in genera from the family Ericaceae (e.g., Rhododendron), are grown in nurseries and sold in large quantities for planting as ornamentals. In 2001, the pathogen was detected on containerized Rhododendron plants in a nursery in Santa Cruz County, CA, as well as in waterways surrounding the nursery (Frankel 2008). Although this discovery was followed by the issuance of an interim regulation by the Animal and Plant Health Inspection Service (APHIS) (of the U.S. Department of Agriculture) and related quarantine efforts, the ramifications of $P$. ramorum having been detected in the commercial nursery network in the United States were not fully realized until 2004, when two large wholesale nurseries in California were found to be infected. Prior to detection of the pathogen, these nurseries had shipped millions of potentially infected ornamental plants to outlets in 39 States (Frankel 2008, Stokstad 2004). Trace-forward inspections of the receiving nurseries revealed 110 infected locations across 20 States (Suslow 2008). An APHIS 2005 emergency order broadened the quarantine on nursery stock shipments and stepped up inspection and eradication efforts, and although a small number of nurseries nationwide have been found positive for $P$. ramorum in the years since, the pathogen is not believed to be established in any wildlands or semi-natural environments outside of California and Oregon. However, the pathogen was detected in southern England in 2002, and subsequently at least 160 outbreaks have been confirmed in woodlands or semi-natural environments of the United Kingdom, along with several hundred nurseries (Webber and Rose 2008). Evidence also suggests that $P$. ramorum was introduced to several other European countries via nursery stock (Brasier and others 2004a). There is general consensus that the pathogen is native to neither North America nor Europe, and the presence of three distinct clades in some nurseries in the United States further underlines the contribution of the commercial nursery plant trade to the pathogen's introduction and dispersal (Brasier and others 2004a, Ivors and others 2006).

In 2002, motivated in part by the discoveries of $P$. ramorum in California and European nurseries as well as the economic threat posed to oak forests in the United States, the Forest Service, U.S. Department of Agriculture, initiated a national survey to detect $P$. ramorum in wildland environments. The survey was intended as a companion to the APHIS nursery inspection program (USDA Forest Service 2004). To aid the detection effort, a team of Forest Service scientists created a risk map to serve as a national sampling frame. Their approach involved spatial overlay of data sets representing three factors: (1) distributions of host species; (2) suitable climatic conditions for the pathogen's persistence and spread; and (3) probable pathways of introduction into previously uninfected areas (Smith and others 2002). The resulting map of the conterminous United States (fig. 7.1) consisted of hexagons for three ordinal levels of risk (high/moderate/ low), with the high-risk hexagons falling in areas where all three factors coincided. Although 


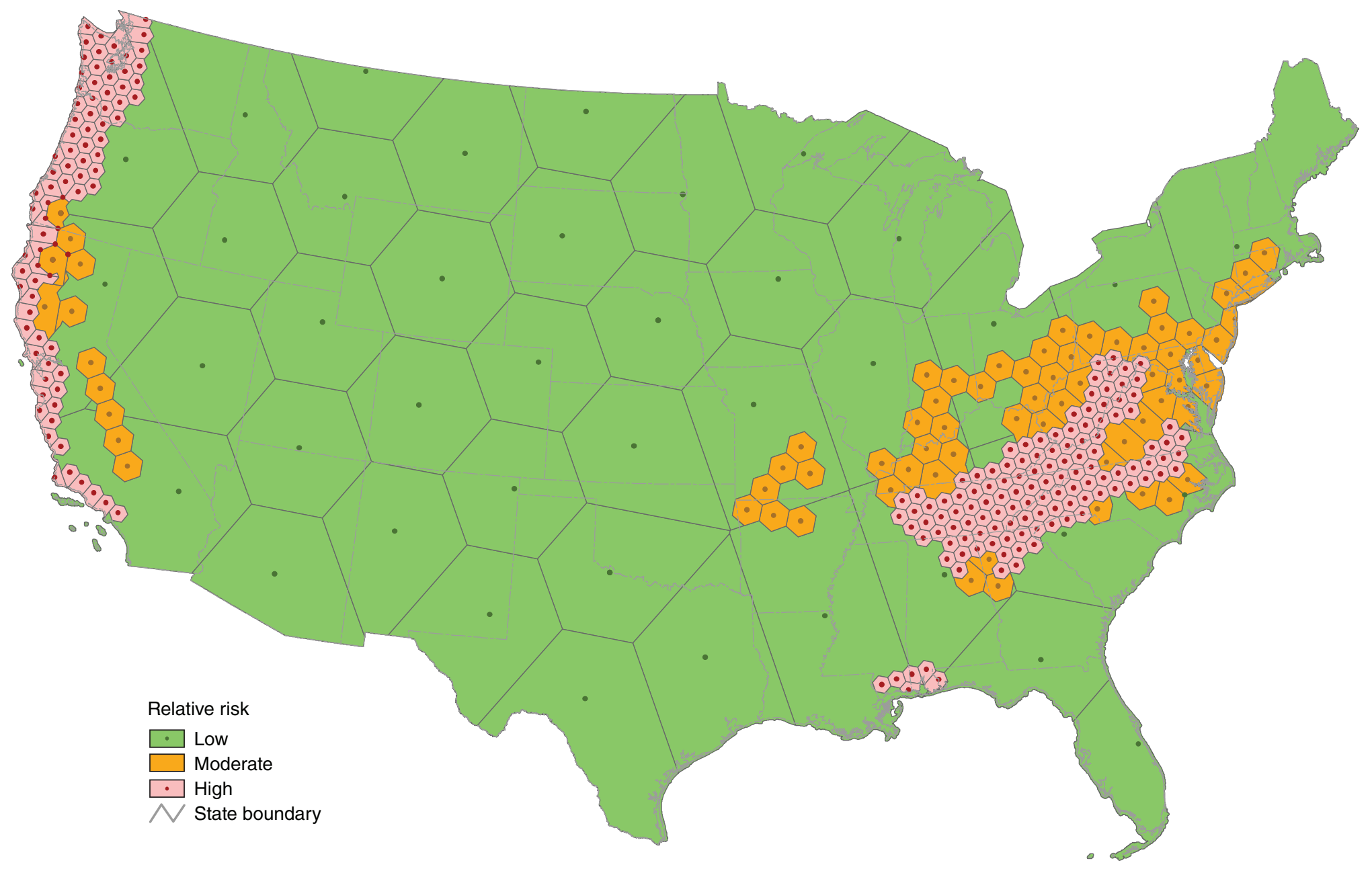

Figure 7.1-2002 national sudden oak death (Phytophthora ramorum) risk map, designed to facilitate surveys of forested environments. State boundaries are included for reference. 
the methodology of the P. ramorum national detection survey has changed over the past several years-now emphasizing stream baiting techniques rather than vegetation surveys-the 2002 risk map has continued to serve as a guide in prioritizing sample placement (Oak and others 2008a, Oak and others 2008b). Nevertheless, in subsequent years the list of susceptible hosts has expanded, the climatic factors favoring the pathogen are better understood, and much more is known about basic epidemiology of P. ramorum. Therefore, the objective of this analysis was to create a new national risk map utilizing the most current information and also incorporating data sources and analytical techniques not employed for the 2002 map.

\section{Methods}

We adopted a decision rule-based approach for assembling the host, climate, and pathways datasets used in our map. To construct our final map of ordinal risk hexagons, we first combined the host and climate layers into a single hazard map and then analyzed its spatial intersection with the corresponding pathways map. The hazard map may be basically interpreted as a representation of the risk of $P$. ramorum establishment, while the pathways map may be seen as a representation of the risk of introduction. These two gridded maps $\left(1-\mathrm{km}^{2}\right.$ spatial resolution) are also intended to serve as stand-alone reference products that may be suited to a given user's specific objectives (e.g., a State forest health specialist who is attempting to survey residential landscapes for infected ornamental plants).
Host sub-layers-Our host layer was designed to reflect the particular epidemiology (i.e., the two distinct diseases and diverse suite of hosts) of $P$. ramorum. It is a combination of five sub-layers, each corresponding to a particular category of hosts for the pathogen:

\section{(1) Overstory hosts with high predicted mortality}

levels (fig. 7.2A)-Tanoak (L. densiflorus) exhibits the highest mortality rates in the infected areas

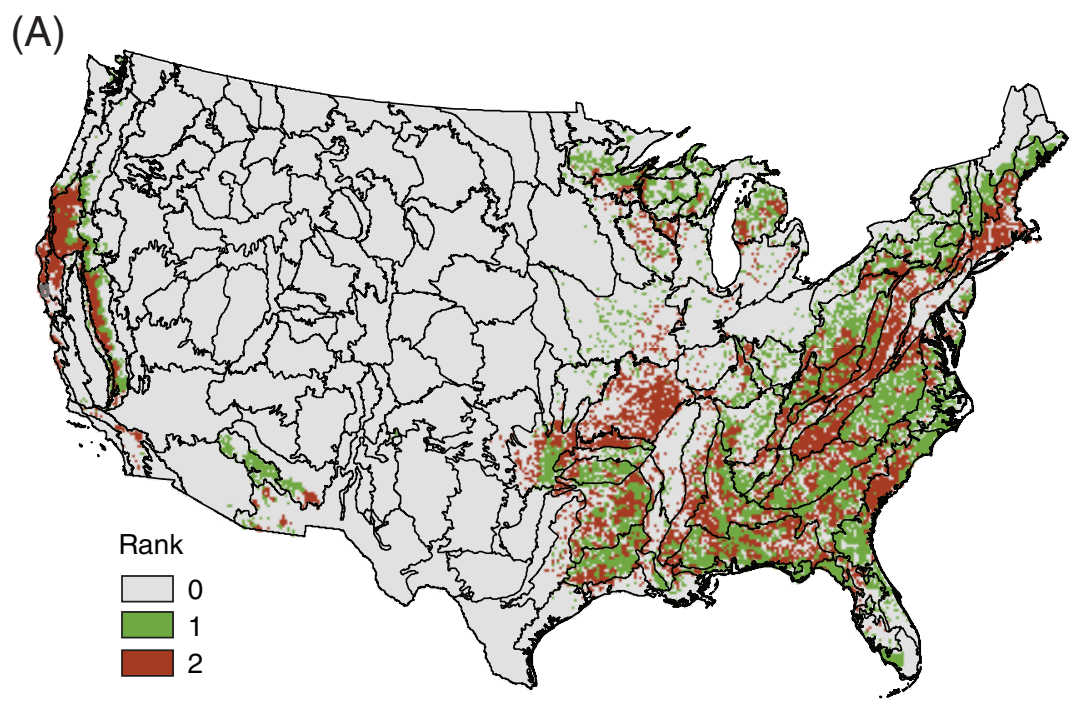

Figure 7.2-Host sub-layers used in the construction of the combined host layer: (A) overstory hosts with high predicted mortality levels; (B) evergreen midstory foliar hosts; $(C)$ deciduous midstory foliar hosts; $(D)$ evergreen background hosts; and (E) deciduous background hosts. The rank scoring criteria for $(A),(B)$, and $(C)$ are described in tables $7.2,7.3$, and 7.4, respectively. For $(D)$ and $(E)$, a rank of 1 indicates the presence of at least one species listed in table 7.5 or table 7.6, respectively, while a rank of 0 indicates absence of listed species. See text regarding data sources for each sub-layer. Ecoregion section boundaries (Cleland and others 2007) are included for reference. (continued on next page) 
(B)

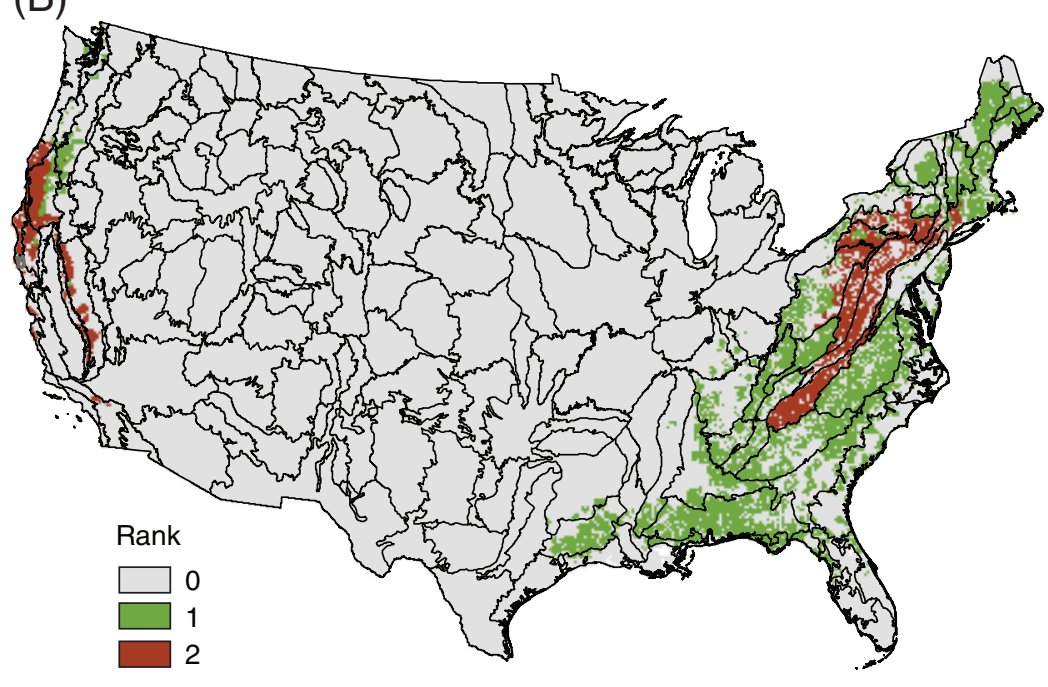

(C)

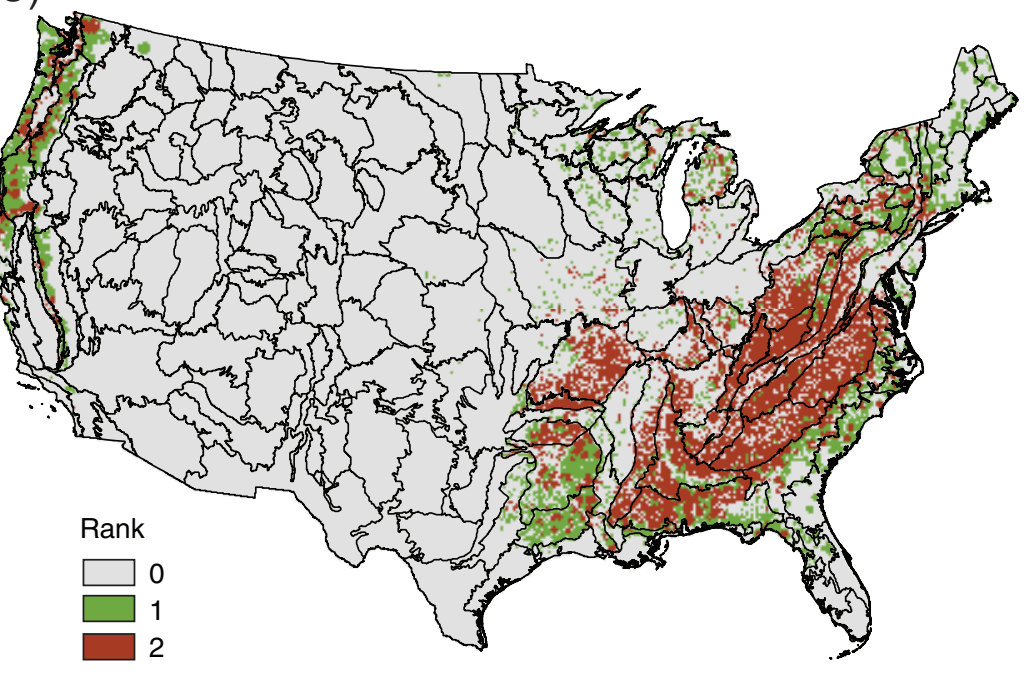

(D)

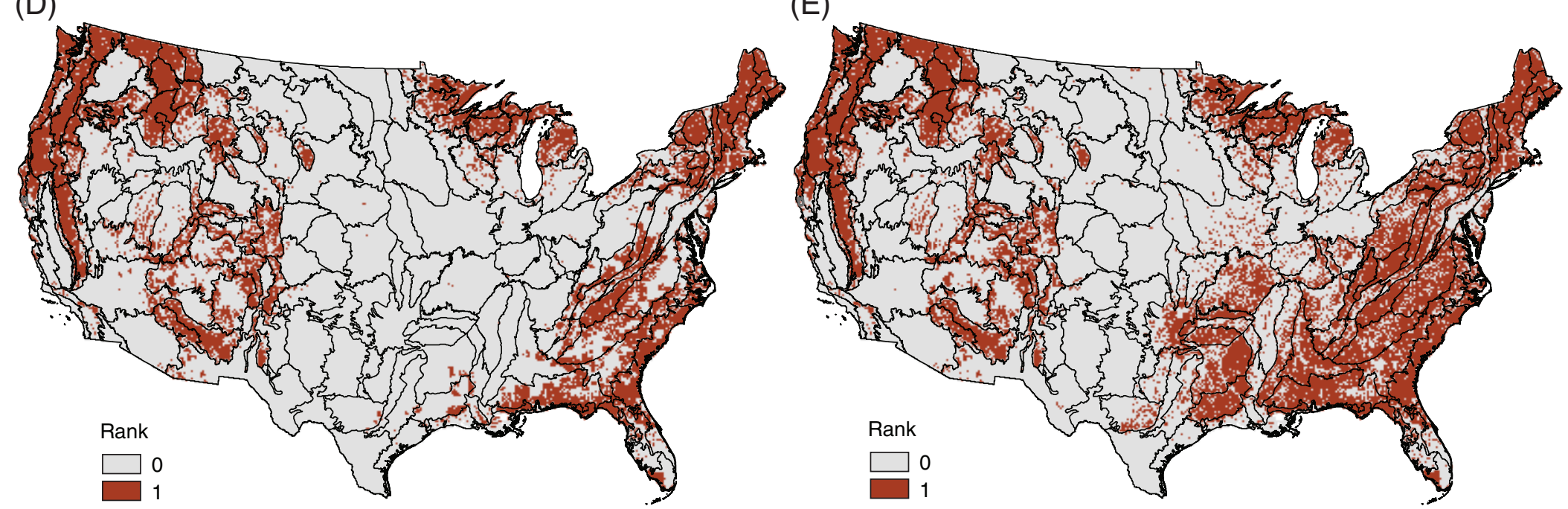

$(\mathrm{E})$

Figure 7.2 (continued) - Host sub-layers used in the construction of the combined host layer: (B) evergreen midstory foliar hosts; (C) deciduous midstory foliar hosts; (D) evergreen background hosts; and (E) deciduous background hosts. The rank scoring criteria for $(A),(B)$, and $(C)$ are described in tables 7.2, 7.3, and 7.4, respectively. For (D) and (E), a rank of 1 indicates the presence of at least one species listed in table 7.5 or table 7.6, respectively, while a rank of 0 indicates absence of listed species. See text regarding data sources for each sub-layer. Ecoregion section boundaries (Cleland and others 2007) are included for reference. 
of California and Oregon (Rizzo and others 2005). Four oak species have also displayed high mortality due to the pathogen (Murphy and Rizzo 2003, Rizzo and Garbelotto 2003, Rizzo and others 2002): coast live oak (Q. agrifolia), California black oak (Q. kelloggii), canyon live oak (Q. chrysolepis), and Shreve's oak (Q. shrevei), although the latter has a limited geographic distribution and is not recorded in the database of the Forest Inventory and Analysis (FIA) Program of the Forest Service. The affected species are from the red/black oak (Quercus section Lobatae) and intermediate oak (Quercus section Protobalanus) groups; notably, white oaks do not appear to be affected by P. ramorum in natural stands (Rizzo and Garbelotto 2003). Although relatively few North American oak species have been tested for susceptibility to the pathogen, southern red oak ( $Q$. falcata) was the first tree discovered to have $P$. ramorum cankers in the United Kingdom, while northern red oak (Q. rubra) trees were found naturally infected in the Netherlands (Brasier and others 2004a, Brasier and others 2004b). Based on these observations as well as the general taxonomy of North American oaks (Dodd and others 2005, Jensen 1997, Nixon 1993, 2002), we included a group of oak species from the Eastern and Southwestern United States for which we predict high mortality in our overstory host layer for P. ramorum (table 7.1 ). In addition, research has demonstrated fairly high mortality rates in
Pacific madrone (Arbutus menziesii) due to the pathogen (Maloney and others 2004), so we also included that species in the overstory layer.

We constructed the layer via ordinary kriging of FIA phase 2 plot data. We first identified all ecoregion sections (Cleland and others 2007) containing FIA plots where the species of interest were present, and then assembled all plots that fell within these sections into geographically referenced samples of basal area values. We fit spherical semivariogram models to each section-level sample using weighted least squares (Cressie 1993). To predict basal area values for unknown locations, we used the 30 nearest neighboring FIA plots or, if fewer plots were available within a $60-\mathrm{km}$ radius of the unknown location, we included all plots within this distance threshold. We performed separate interpolations for each ecoregion section containing the species of interest and then mosaiced the kriged sections into $1-\mathrm{km}^{2}$ resolution grids for the conterminous United States, masking the results using a forest cover map developed from Moderate Resolution Imaging Spectroradiometer (MODIS) satellite imagery by the USDA Forest Service Remote Sensing Applications Center.

We added together the grids for all overstory species using map algebra, and then re-classed the total overstory basal area grid according to a three-level ordinal risk ranking (table 7.2). The 
Table 7.1-0ak species included in the overstory host layer for $\boldsymbol{P}$. ramorum. All species listed are classified as red or black oaks (Quercus sect. Lobatae) except for canyon live oak (Quercus chrysolepis), which is an intermediate oak (Quercus sect. Protobalanus)

\begin{tabular}{lll}
\hline Species & Common name & Regional distribution \\
\hline Q. agrifolia & Coast live oak & California \\
Q. buckleyi & Nuttall oak & Oklahoma and Texas \\
Q. chrysolepis & Canyon live oak & West Coast and Southwestern United States \\
Q. coccinea & Scarlet oak & Eastern United States \\
Q. ellipsoidalis & Northern pin oak & Great Lakes \\
Q. emoryi & Emory oak & Southwestern United States \\
Q. falcata & Southern red oak & Southeastern United States \\
Q. hypoleucoides & Silverleaf oak & Southwestern United States \\
Q. ilicifolia & Bear oak, scrub oak & Northeastern United States \\
Q. imbricaria & Shingle oak & Eastern United States \\
Q. incana & Bluejack oak & Southeastern United States \\
Q. kelloggii & California black oak & West Coast United States \\
Q. laevis & Turkey oak & Southeastern United States \\
Q. laurifolia & Laurel oak & Southeastern United States \\
Q. marilandica & Blackjack oak & Eastern United States (esp. SE) \\
Q. nigra & Water oak & Southeastern United States \\
Q. pagoda & Cherrybark oak & Southeastern United States \\
Q. palustris & Pin oak & Eastern United States (esp. NE) \\
Q. phellos & Willow oak & Eastern United States (esp. SE) \\
Q. rubra & Northern red oak & Eastern United States \\
Q. shumardii & Shumard oak & Eastern United States \\
Q. velutina & Black oak & Eastern United States \\
Q. wizlenii & Interior live oak & California \\
\hline
\end{tabular}

Note: Data for all species were compiled from the Forest Inventory and Analysis FIADB 3.0 database. Species distributions are based on Kartesz (2008) and Stein and others (2003).

${ }^{a}$ Species re-named 0 . texana.
Table 7.2-Decision rules used to reclassify overstory host basal area (BA) values into an ordinal ranking

\begin{tabular}{lc}
\hline Decision rule & Overstory host rank \\
\hline $\mathrm{BA} \geq 10.43 \mathrm{ft}^{2} / \mathrm{ac}$ & 2 \\
$0.7 \mathrm{ft}^{2} / \mathrm{ac} \geq \mathrm{BA}<10.43 \mathrm{ft}^{2} / \mathrm{ac}$ & 1 \\
$\mathrm{BA}<0.7 \mathrm{ft}^{2} / \mathrm{ac}$ & 0 \\
\hline
\end{tabular}

ranking is built upon an estimate of the basal area (per acre) necessary to achieve average spacing of 60 feet or less between overstory host trees. Davidson and others (2005) suggested that rain splash, the most likely mode by which P. ramorum spores are dispersed locally, may commonly disperse spores up to distances of 32.8 feet $(10 \mathrm{~m})$ from infected foliar hosts, and more rarely distances of 49.2 feet ( $15 \mathrm{~m}$ ) or more. At an average overstory spacing of 60 feet or less, it is likely that one or more overstory host trees in an area of interest falls within the potential rain splash dispersal range of relevant foliar hosts. The average diameter at breast height (d.b.h.) of a host tree from the FIA data is 11.3 inches, with a corresponding basal area of 0.7 square feet. If we assume, for simplicity, that host trees are all of average size and are uniformly distributed over a hexagonal lattice, then a basal area of 10.43 square feet per acre will yield an approximate overstory host tree spacing of 60 feet. 
(2) Evergreen midstory foliar hosts (fig. 7.2B)-

Foliar hosts that grow into the midstory of forest stands have the potential to support $P$. ramorum sporulation and, hence, spore dispersal over relatively large areas. Furthermore, species that are evergreen may serve as year-round sources of inoculum. In the currently infected zone, the evergreen California bay laurel $(U$. californica) is probably the single most important host because it supports high levels of spore production; quite simply, infection levels tend to be high in areas wherever the species is dominant (Condeso and Meentemeyer 2007, Maloney and others 2005, Rizzo and others 2005). Midstory tanoaks-also an evergreen species-are similarly important, especially on sites where California bay laurel is less common (Maloney and others 2005). Furthermore, based on their known level of susceptibility, potential for supporting sporulation, growth habit, and wide distributions, two evergreen species seem likely to serve similar epidemiological roles in the Eastern United States (Rizzo and others 2005, Tooley and Browning 2009, Tooley and others 2004): mountain laurel (Kalmia latifolia) and great rhododendron (R. maximum). These species grow densely in many Eastern United States forests and can reach heights of 20-35 feet (Preston and Braham 2002).

We developed a ranking for evergreen midstory hosts (table 7.3) that highlights the presence of these species in their respective
Table 7.3-Decision rules used to develop ordinal rankings for important evergreen midstory hosts found in the Eastern and Western United States

\begin{tabular}{|c|c|}
\hline Decision rule & $\begin{array}{l}\text { Evergreen midstory host } \\
\text { rank }\end{array}$ \\
\hline \multicolumn{2}{|l|}{ Eastern United States } \\
\hline Rhododendron maximum and/or Kalmia latifolia present & 2 \\
\hline Magnolia grandiflora present but neither $R$. maximum nor $K$. latifolia present & 1 \\
\hline None of these three species present & 0 \\
\hline \multicolumn{2}{|l|}{ Western United States } \\
\hline Umbellularia californica and/or Lithocarpus densiflorus present & 2 \\
\hline Arbutus menziesii present, but neither U. californica nor L. densiflorus present & 1 \\
\hline None of these three species present & 0 \\
\hline
\end{tabular}

regions. In addition, for the Western United States, the ranking assigns a moderate level of risk to Pacific madrone, which exhibits both stem and foliar symptoms (Hansen and others 2005, Maloney and others 2004) but is believed to support only low levels of sporulation. For the Eastern United States, the ranking assigns a moderate risk level to southern magnolia (Magnolia grandiflora), a foliar host that can grow to heights of 100 feet or more, but which is sparsely distributed relative to mountain laurel or great rhododendron.

We derived distribution maps for these species in two different ways. First, to supplement the existing basal area maps for tanoak and 
Pacific madrone, we created basal area maps for California bay laurel and southern magnolia through spatial interpolation of FIA phase 2 plot data (see overstory host layer description). For each species, we then created a presenceabsence map by labeling any grid cell with a basal area $>0$ as having the species present. Second, because neither mountain laurel nor great rhododendron is recorded in the FIA database, we created presence-absence maps based on county-level distribution data (Kartesz 2008), masking the results using the previously described forest cover map.

(3) Deciduous midstory foliar hosts (fig. 7.2C)Although not year-round sources of inoculum, deciduous hosts growing in the midstory may still support sporulation and spore dispersal over relatively large areas. On the West Coast, three proven or associated host species of $P$. ramorum grow to moderate heights in forests (Preston and Braham 2002, USDA Animal and Plant Health Inspection Service 2008): bigleaf maple (Acer macrophyllum), California buckeye (Aesculus californica), and Oregon ash (Fraxinus latifolia). Furthermore, recent research (Tooley and Browning 2009) suggests that a number of deciduous species from the Eastern United States also exhibit high susceptibility and potential to support sporulation, perhaps most notably serviceberry (Amelanchier species), dogwood (Cornus florida), and black locust (Robinia pseudoacacia).
We created a deciduous midstory layer in a similar fashion to our overstory host layer. For each of the species named above, we interpolated density maps, in trees per acre, from FIA phase 2 plot data for all relevant ecoregion sections, which were then mosaiced and masked using the previously described forest cover map. We next added the individual species layers together using map algebra, resulting in one combined grid of midstory deciduous host density in trees per acre, which we reclassified according to a three-level ordinal ranking (table 7.4). The ranking is based on the density necessary to provide complete coverage of a forest area in terms of potential rain splash dispersal of spores (Davidson and others 2005) from deciduous midstory foliar hosts. A density of 12.1 trees per acre translates to a mean spacing of 30 feet between host trees in this category (Pielou 1977), a distance that would potentially facilitate transmission of $P$. ramorum from one deciduous midstory foliar host tree to another as well as to overstory hosts.

(4) Evergreen and (5) Deciduous background host layers (figs. 7.2D and 7.2E)-We created two additional map layers depicting the distributions of hosts not included in the overstory or midstory layers. Because these "background" hosts are low in stature and/ or sparsely distributed, they are not especially important in an epidemiological sense, yet 
Table 7.4-Decision rules used to reclassify deciduous midstory host trees per acre (TPA) values into an ordinal ranking

\begin{tabular}{lc}
\hline Decision rule & $\begin{array}{c}\text { Deciduous midstory } \\
\text { host rank }\end{array}$ \\
\hline TPA $\geq 12.1$ trees/acre & 2 \\
0 trees/acre $>$ TPA $<12.1$ trees/acre & 1 \\
TPA $=0$ trees/acre & 0
\end{tabular}

they may allow $P$. ramorum to persist in a site where no overstory or midstory hosts occur. Using county-level plant distribution data for the conterminous United States (Kartesz 2008), we mapped counties containing at least one evergreen (table 7.5) and/or deciduous (table 7.6) host species on the APHIS list of proven and associated hosts for P. ramorum (USDA Animal and Plant Health Inspection Service 2008). We omitted species already included in the overstory and midstory layers from these lists. As with all other host layers, we masked the results using the forest cover map developed by the Remote Sensing Applications Center.

Combined host layer-To create a single host layer for P. ramorum (fig. 7.3), we first combined the midstory and background host layers into a single layer according to a simple set of decision rules (table 7.7). These rules emphasize the important midstory foliar hosts over background hosts, as well as evergreen over deciduous host species. We then combined this midstory/background host layer with our overstory, high-mortality host layer using a
Table 7.5- List of species used in constructing the evergreen background host layer

Species or genus name

Abies species (A. concolor, A. grandis, A. magnifica)

Arbutus unedo ${ }^{a}$

Arctostaphylos species (A. columbiana, A. manzanita, A. uva-ursi)

Calluna vulgaris ${ }^{a}$

Ceanothus thyrsiflorus

Cinnamomum camphora ${ }^{a}$

Dryopteris arguta

Euonymus kiautschovicus ${ }^{a}$

Frangula californica

Garrya elliptica

Gaultheria shallon

Heteromeles arbutifolia

Kalmia species (all species in U.S.)

Laurus nobilis $^{a}$

Leucothoe species (L. axillaris, L. fontanesiana)

Mahonia aquifolium

Nerium oleander ${ }^{2}$

Pieris species

Pittosporum undulatum

Prunus species (P. laurocerasus ${ }^{a}$, P. lusitanica $\left.{ }^{a}\right)$

Quercus ilex ${ }^{a}$

Quercus parvula var. shrevei

Pseudotsuga menziesii var. menziesii

Pyracantha koidzumii ${ }^{a}$

Rhododendron species (evergreen)

Rosa rugosa ${ }^{a}$

Sequoia sempervirens

Taxus species (T. baccata ${ }^{a}$, T. brevifolia)

Torreya californica

Vaccinium species (evergreen)

${ }^{a}$ Nonnative species confirmed as host, but with very limited distribution in the United States. 


\section{Table 7.6- List of species used in constructing the deciduous background host layer}

Species or genus name

Acer species (A. pseudoplatanus ${ }^{a}, A$. circinatum)

Adiantum species ( $A$. aleuticum, $A$. jordanii)

Aesculus hippocastanum ${ }^{a}$

Calycanthus occidentalis

Castanea sativa ${ }^{a}$

Corylus cornuta (var. californica, var. cornuta)

Fagus sylvatica $^{a}$

Frangula purshiana

Fraxinus excelsior ${ }^{a}$

Hamamelis virginiana

Lonicera hispidula

Maianthemum racemosum

Magnolia species (M. kobus ${ }^{a}$, M. stellata ${ }^{a}$, M. $\times$ soulangiana $\left.{ }^{a}\right)$

Osmorhiza berteroi

Physocarpus opulifolius

Quercus cerris ${ }^{a}$

Rhododendron species (deciduous)

Rosa gymnocarpa

Rubus spectabilis

Salix caprea ${ }^{a}$

Syringa vulgaris ${ }^{a}$

Toxicodendron diversilobum

Trientalis borealis ssp. latifolia

Vaccinium species (deciduous)

Vancouveria planipetala

Viburnum species (all species in U.S.)

${ }^{a}$ Nonnative species confirmed as host, but with very limited distribution in the United States. second set of rules (table 7.8) that assigned ranks on a six-point scale. The rules emphasize the midstory/background host rank, under the assumption that the occurrence of any midstory or background foliar hosts translates to some degree of $P$. ramorum establishment risk, whether overstory hosts are present or not. In the latter case, however, the rules assign a very low combined host rank (rank = 1) except when the midstory/background host rank is relatively high $($ rank $\geq 4)$.

\section{Climatic suitability layer-Laboratory}

evidence indicates that $P$. ramorum has high infection potential during periods of persistent precipitation and relatively mild temperatures (DEFRA-UK 2004, Moralejo and others 2006, Rizzo and Garbelotto 2003, Werres and others 2001). Based on this evidence, we used daily weather station data from the National Climatic Data Center (NCDC) to create annual grid maps (4- $\mathrm{km}^{2}$ spatial resolution) of the longest string of consecutive days where two conditions occurred simultaneously: (1) a temperature between 15.56 and $26.67{ }^{\circ} \mathrm{C}\left(60\right.$ and $\left.80^{\circ} \mathrm{F}\right)$ during the day and (2) some precipitation, fog, or mist during the day, or alternatively, mean relative humidity during the day of $>90$ percent. We created the maps for each year in the 10year period 1997-2006; typically for any given year, between 4,000 and 5,000 NCDC station points were available nationwide after initial filtering (i.e., after removing any stations with lengthy data gaps). While all of the stations record precipitation amount and temperature, only a small percentage (typically $<10$ percent) 


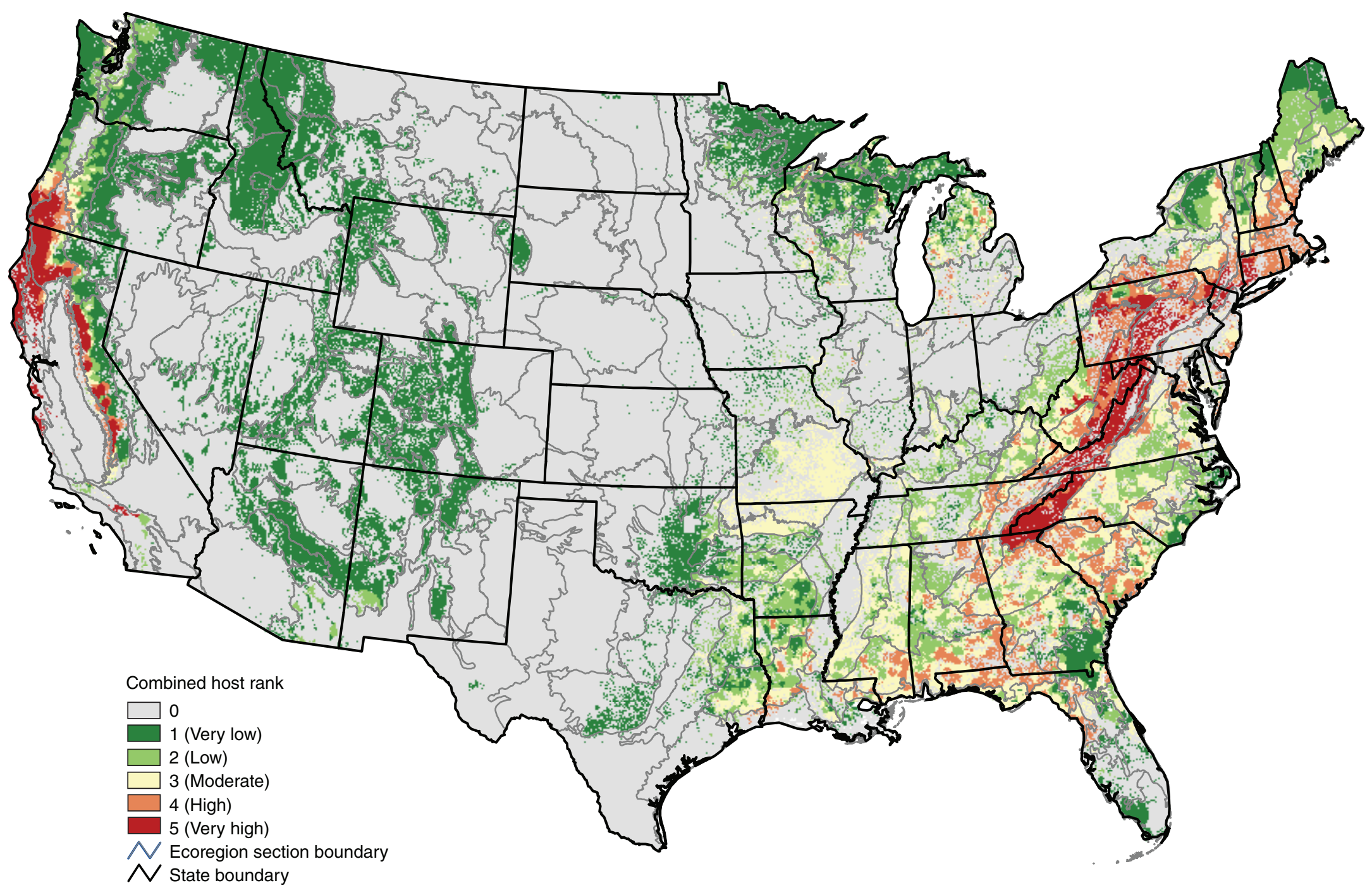

Figure 7.3-Host layer created by combining the host sub-layers. Please see text regarding the determination of rank scores. Ecoregion section (Cleland and others 2007) and State boundaries are included for reference. 
Table 7.7-Decision rules for combining the midstory and background host layers into a single ordinal ranking. See tables 7.3 and 7.4 , respectively, regarding the evergreen and deciduous midstory host ranks

\begin{tabular}{|c|c|}
\hline Decision rule & $\begin{array}{l}\text { Midstory/background } \\
\text { host rank }\end{array}$ \\
\hline Evergreen midstory host rank $=2$ & 5 \\
\hline Evergreen midstory host rank = 1 and evergreen background host rank = 1 & 4 \\
\hline $\begin{array}{l}\text { Deciduous midstory host rank }=2 \text { and evergreen background host rank = } 1 \\
\text { (evergreen midstory host rank }=0 \text { ) }\end{array}$ & 4 \\
\hline Evergreen midstory host rank $=1$ and evergreen background host rank $=0$ & 3 \\
\hline $\begin{array}{l}\text { Deciduous midstory host rank }=2 \text { and evergreen background host rank }=0 \\
\text { (evergreen midstory host rank }=0 \text { ) }\end{array}$ & 3 \\
\hline $\begin{array}{l}\text { Deciduous midstory host rank }=1 \text { and evergreen background host rank = } 1 \\
\text { (evergreen midstory host rank }=0 \text { ) }\end{array}$ & 3 \\
\hline $\begin{array}{l}\text { Deciduous midstory host rank }=1 \text { and evergreen background host rank }=0 \\
\text { (evergreen midstory host rank }=0 \text { ) }\end{array}$ & 2 \\
\hline Evergreen background host rank = 1 and deciduous background host rank $=0$ or 1 & 2 \\
\hline Deciduous background host rank $=1$ and no other component ranked $>0$ & 1 \\
\hline No component ranked $>0$ & 0 \\
\hline
\end{tabular}

record observations of foggy or misty conditions. Because this latter group of stations tends to exhibit longer strings of consecutive days with suitable conditions, we used co-kriging (Cressie 1993) to interpolate our grids, treating the stations that record fog and mist as our primary dataset and the remaining stations as our covariate or supporting dataset. We then averaged the ten annual co-kriged grids into a single consecutive-day grid using map algebra.

According to laboratory and field evidence, P. ramorum spores do not survive well at low relative humidity levels (Davidson and others
2002, Venette and Cohen 2006). Therefore, we masked out areas on our consecutive-day map where mean annual relative humidity fell below 60 percent; this excluded much of the Interior West and northern Great Plains. In addition, based on laboratory observation of high spore mortality at a temperature of $-25{ }^{\circ} \mathrm{C}$ (DEFRA-UK 2004), we applied a mask that excluded areas where the annual extreme minimum temperature fell below this threshold. We did not use a high-temperature mask because evidence suggests that $P$. ramorum is relatively heat-tolerant (Tooley and others 
2008) and, furthermore, because forest canopy structure may have a significant cooling effect that mitigates the deleterious impact of heat on pathogen survival (Potter and others 2001). We used Parameter-elevation Regression on Independent Slopes (PRISM) climate data (Daly and others 2002) to generate both the relative humidity and cold-temperature masks; cell values in the PRISM data sets $\left(4-\mathrm{km}^{2}\right.$ spatial resolution) were calculated for the 30-year period 1971-2000.

We modified our consecutive-day map in order to account for the seasonal (i.e., monthto-month) distribution of precipitation across the conterminous United States. Using 30-year PRISM climate data, we created two national grids, the first depicting, for each cell, the number of wet days per month averaged across the 12 months of the year, and the second depicting the number of wet days in the wettest month of the year. We subsequently created a ratio map by dividing the wettest-month grid by the 12-month mean grid using map algebra, then divided the result by the maximum value (3.07692) to scale it between 0 and 1 . This ratio map represents an approximation of the precipitation distribution throughout the year using a method of moments approach. To create our final climatic suitability layer (fig. 7.4), we multiplied our consecutive-day and precipitation ratio maps using map algebra, then reclassified the resulting map of adjusted climate scores into five ordinal levels of climatic suitability (table 7.9).

\section{Table 7.8—Decision rules for the final combined host layer ranking}

\begin{tabular}{|c|c|c|}
\hline $\begin{array}{l}\text { Overstory host rank } \\
\text { (see table 7.2) }\end{array}$ & $\begin{array}{c}\text { Midstory/background } \\
\text { host rank (see table 7.7) }\end{array}$ & $\begin{array}{l}\text { Combined host } \\
\text { layer rank }\end{array}$ \\
\hline \multirow{6}{*}{2} & 5 & 5 (very high) \\
\hline & 4 & 4 (high) \\
\hline & 3 & 3 (moderate) \\
\hline & 2 & 2 (low) \\
\hline & 1 & 1 (very low) \\
\hline & 0 & 0 \\
\hline \multirow{6}{*}{1} & 5 & 4 \\
\hline & 4 & 3 \\
\hline & 3 & 2 \\
\hline & 2 & 1 \\
\hline & 1 & 1 \\
\hline & 0 & 0 \\
\hline \multirow{6}{*}{0} & 5 & 3 \\
\hline & 4 & 2 \\
\hline & 3 & 1 \\
\hline & 2 & 1 \\
\hline & 1 & 1 \\
\hline & 0 & 0 \\
\hline
\end{tabular}

Hazard layer-We created a national hazard layer (fig. 7.5) by combining our host and climate layers according to a set of decision rules (table 7.10). The hazard layer is intended to portray the risk of $P$. ramorum establishment were the pathogen to be introduced to an area of interest. The assigned hazard rank (from 0 to 5) depends on both the optimality of climatic conditions for the pathogen's persistence and the presence of sufficient host to facilitate sporulation and dispersal (i.e., to provide 


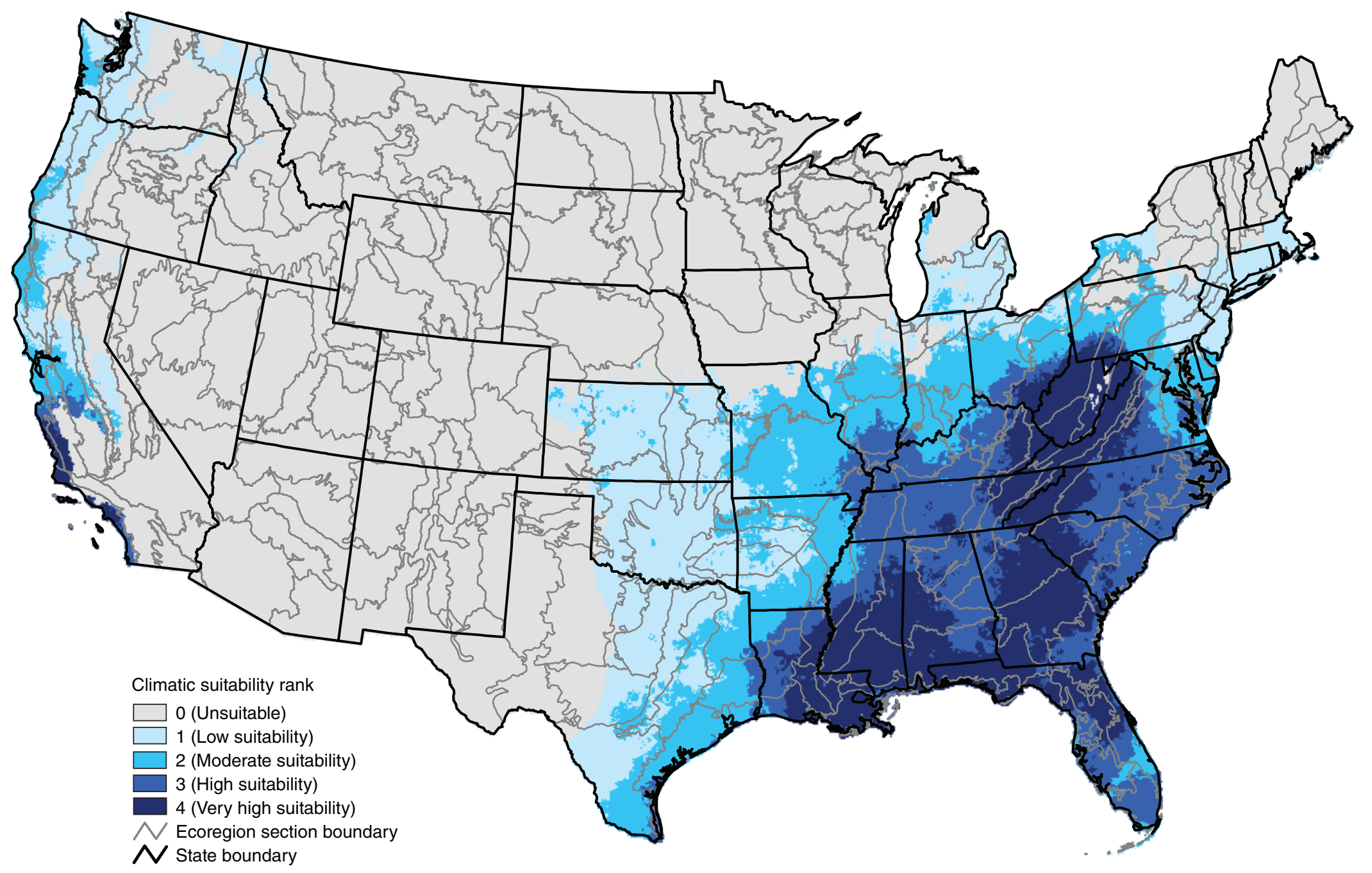

Figure 7.4-Climatic suitability layer. Please see text regarding the determination of rank scores. Ecoregion section (Cleland and others 2007) and State boundaries are included for reference. 
Table 7.9-Ordinal ranking of climatic suitability derived by reclassifying adjusted climate scores

\begin{tabular}{ll}
\hline Adjusted climate score & Climatic suitability rank \\
\hline$\geq 10$ & 4 (very high suitability) \\
$7.5-9.99$ & 3 (high suitability) \\
$5-7.49$ & 2 (moderate suitability) \\
$2.5-4.99$ & 1 (low suitability) \\
$<2.5$ & 0 (unsuitable) \\
\hline
\end{tabular}

functional connectivity for further spread). In practice, the decision rules place greater emphasis on the combined host rank than on the climatic suitability rank; basically, the hazard rank is equivalent to the host rank unless the suitability rank is simultaneously very high (which typically increases the hazard rank) or very low (which typically decreases the hazard rank). This reflects our view that host presence is more critical to the long-term establishment of $P$. ramorum than climate, given that the pathogen can persist in far less than optimal climatic conditions (Browning and others 2008, Tooley and others 2008) if appropriate hosts are available.

Pathways layer-We developed a pathways map layer by re-categorizing wildlandurban interface (WUI) spatial datasets for the conterminous United States. Since 2004, P. ramorum has been periodically detected at nurseries in various parts of the country (Frankel 2008, Suslow 2008). Notably, plants brought in from wholesalers or other sources typically remain in nurseries only briefly before they are sold to homeowners or other customers. We believe that the epidemiological risk of $P$. ramorum moving unbeknownst from an infected ornamental plant in a developed (e.g., residential) landscape to host plants in a nearby, naturally vegetated landscape can be reasonably represented through re-categorization of data primarily intended to characterize interface areas according to their degree of fire risk. Once re-categorized, these data, developed by the University of Wisconsin-Madison and the Northern Research Station of the Forest Service, allowed us to highlight geographic areas where $P$. ramorum seems most likely to be introduced and subsequently spread into naturally vegetated environments (Radeloff and others 2005).

We started with polygon WUI coverages for each State and the District of Columbia. The coverages are composed of U.S. Census blocks, each of which has been assigned a housing density value according to data from the 2000 Census. In addition, 1992 National Land Cover Data (NLCD) were used to determine percentages of various land cover classes in each block (Radeloff and others 2005). Based on the calculated housing density and landcover percentage values, each census block polygon was assigned to one of 14 wildland-urban interface categories (table 7.11).

We reclassified the original WUI categories to emphasize those we believe present the greatest risk in terms of facilitating the spread of $P$. ramorum (table 7.11). We assigned our highest risk ranking of 3 to the Low and Medium Density Intermix categories, because 


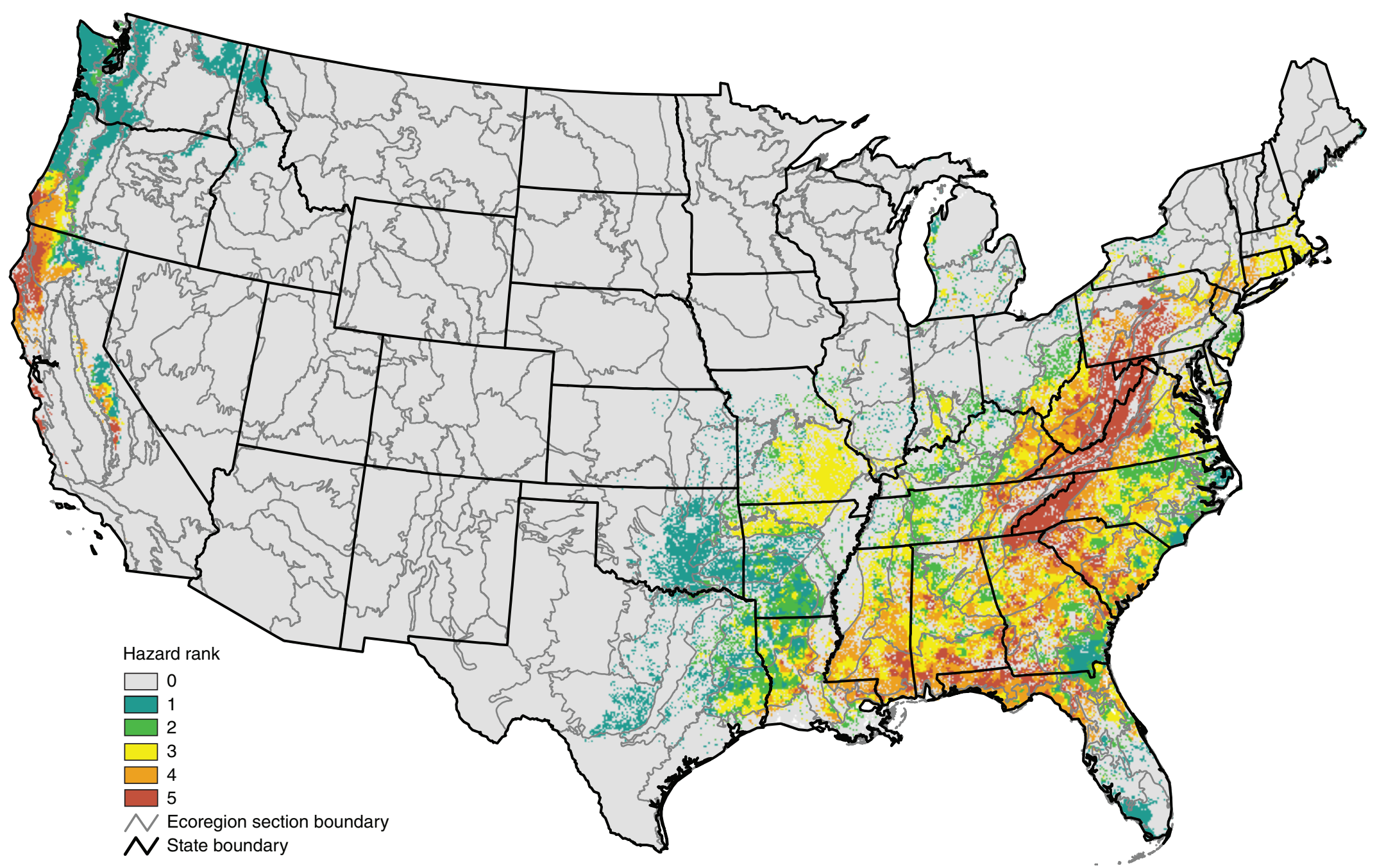

Figure 7.5-Hazard layer generated by combining the host and climatic suitability layers. Please see text regarding the determination of rank scores. Ecoregion section (Cleland and others 2007) and State boundaries are included for reference. 


\section{Table 7.10 —Decision rules for the final hazard layer ranking}

\begin{tabular}{|c|c|c|}
\hline $\begin{array}{l}\text { Combined host layer rank } \\
\text { (see table 7.8) }\end{array}$ & $\begin{array}{l}\text { Climatic suitability rank } \\
\text { (see table 7.9) }\end{array}$ & Hazard rank \\
\hline \multirow{5}{*}{5 (very high) } & 4 (very high suitability) & 5 (very high) \\
\hline & 3 (high suitability) & 5 \\
\hline & 2 (moderate suitability) & 5 \\
\hline & 1 (low suitability) & 4 (high) \\
\hline & 0 (unsuitable) & 0 \\
\hline \multirow{5}{*}{4 (high) } & 4 & 5 \\
\hline & 3 & 4 \\
\hline & 2 & 4 \\
\hline & 1 & 3 (moderate) \\
\hline & 0 & 0 \\
\hline \multirow{5}{*}{3 (moderate) } & 4 & 4 \\
\hline & 3 & 3 \\
\hline & 2 & 3 \\
\hline & 1 & 2 (low) \\
\hline & 0 & 0 \\
\hline \multirow{5}{*}{2 (low) } & 4 & 3 \\
\hline & 3 & 2 \\
\hline & 2 & 2 \\
\hline & 1 & 1 (very low) \\
\hline & 0 & 0 \\
\hline \multirow{5}{*}{1 (very low) } & 4 & 2 \\
\hline & 3 & 1 \\
\hline & 2 & 1 \\
\hline & 1 & 1 \\
\hline & 0 & 0 \\
\hline \multirow{5}{*}{0} & 4 & 0 \\
\hline & 3 & 0 \\
\hline & 2 & 0 \\
\hline & 1 & 0 \\
\hline & 0 & 0 \\
\hline
\end{tabular}


Table 7.11-Original wildland-urban interface categories, with brief descriptions, and their new ranking values for the introduction pathways layer

\begin{tabular}{|c|c|c|}
\hline Category & Description & Pathways rank \\
\hline Low Density Interface & $\begin{array}{l}\text { Housing density } \geq 6.177635 \text { and }<49.42108 \text { units } / \mathrm{km}^{2} \text {, Vegetation } \\
\leq 50 \% \text {, within } 2.414 \mathrm{~km} \text { of area with } \geq 75 \% \text { Vegetation }\end{array}$ & 2 (moderate) \\
\hline Medium Density Interface & $\begin{array}{l}\text { Housing density } \geq 49.42108 \text { and }<741.3162 \text { units } / \mathrm{km}^{2} \text {, Vegetation } \\
\leq 50 \% \text {, within } 2.414 \mathrm{~km} \text { of area with } \geq 75 \% \text { Vegetation }\end{array}$ & 2 \\
\hline High Density Interface & $\begin{array}{l}\text { Housing density } \geq 741.3162 \text { units } / \mathrm{km}^{2} \text {, Vegetation } \leq 50 \% \text {, within } \\
2.414 \mathrm{~km} \text { of area with } \geq 75 \% \text { Vegetation }\end{array}$ & 1 (low) \\
\hline Low Density Intermix & $\begin{array}{l}\text { Housing density } \geq 6.177635 \text { and }<49.42108 \text { units } / \mathrm{km}^{2} \text {, Vegetation } \\
>50 \%\end{array}$ & 3 (high) \\
\hline Medium Density Intermix & $\begin{array}{l}\text { Housing density } \geq 49.42108 \text { and }<741.3162 \text { units } / \mathrm{km}^{2} \text {, Vegetation } \\
>50 \%\end{array}$ & 3 \\
\hline High Density Intermix & Housing density $\geq 741.3162$ units $/ \mathrm{km}^{2}$, Vegetation $>50 \%$ & 1 \\
\hline Uninhabited, Low Vegetation & Housing density $=0$, Vegetation $\leq 50 \%$ & $-1^{b}$ \\
\hline Very Low Density, Low Vegetation & Housing density $>0$ and $<6.177635$ units $/ \mathrm{km}^{2}$, Vegetation $\leq 50 \%$ & $-1^{b}$ \\
\hline Low Density, Low Vegetation & $\begin{array}{l}\text { Housing density } \geq 6.177635 \text { and }<49.42108 \text { units } / \mathrm{km}^{2} \text {, Vegetation } \\
\leq 50 \%\end{array}$ & $-1^{b}$ \\
\hline Medium Density, Low Vegetation & $\begin{array}{l}\text { Housing density } \geq 49.42108 \text { and }<741.3162 \text { units } / \mathrm{km}^{2} \text {, Vegetation } \\
\leq 50 \%\end{array}$ & $-1^{b}$ \\
\hline High Density, Low Vegetation & Housing density $\geq 741.3162$ units $/ \mathrm{km}^{2}$, Vegetation $\leq 50 \%$ & $-1^{b}$ \\
\hline Uninhabited, High Vegetation & Housing density $=0$, Vegetation $>50 \%$ & 0 \\
\hline Very Low Density, High Vegetation & Housing density $>0$ and $<6.177635$ units $/ \mathrm{km}^{2}$, Vegetation $>50 \%$ & 0 \\
\hline Water & Water & $-2^{b}$ \\
\hline
\end{tabular}

a "Vegetation" is the percentage of an area of interest that falls within one or more of the following landcover types: deciduous, evergreen, or mixed forest; shrubland; grassland/herbaceous; woody or emergent wetlands; or transitional land.

${ }^{b}$ Negative ranking values for sparsely vegetated categories and water served as temporary placeholders during the edge zone analysis (see text), after which all negative values were set to zero. 
census blocks in these categories typically contain large inclusions of natural vegetation. We assigned our next highest ranking of 2 to the Low and Medium Density Interface categories because, while census blocks in these categories usually have fewer inclusions, areas dominated by natural vegetation can be found in close proximity (within less than $2.5 \mathrm{~km}$ ). We assigned a risk ranking of 1 to census blocks in the High Density Intermix and High Density Interface categories because they contain numerous residential parcels distributed throughout, likely resulting in smaller (although not necessarily fewer) inclusions of natural vegetation. Negative values for sparsely vegetated areas and water served as placeholders that were set to zero after we performed an additional "edge zone" analysis, which is described below.

We joined the reclassified State WUI coverages into a single national coverage, converted it to grid format at a $0.625-\mathrm{km}^{2}$ spatial resolution, and then resampled to a $1-\mathrm{km}^{2}$ grid using block majority filtering. As a last step, we defined an edge zone composed of grid cells that were classified as either "high" natural vegetation (risk ranking $=0$ ) or highrisk intermix (risk ranking $=3$ ) and were also adjacent to at least one grid cell in the other category based on an eight-neighbor rule. We assigned grid cells in this zone a ranking of 4 , thus expanding our risk scale (fig. 7.5).

Final risk map-For the 2002 P. ramorum map, three hexagonal tessellations covering the conterminous United States, with hexagon sizes increasing from low to high relative risk, were generated through intensification of the North American hexagon of the global Environmental Monitoring and Assessment (EMAP) sampling grid (White and others 1992). We used these same tessellations in constructing our new map; hence, our final risk map is composed of high-, moderate-, and low-risk polygons with typical areas of $\sim 2600 \mathrm{~km}^{2}, \sim 7900 \mathrm{~km}^{2}$, and $\sim 166,000 \mathrm{~km}^{2}$, respectively. Because each tessellation was wall-to-wall (i.e., covered the entire conterminous United States), we developed a set of rules for selecting which individual hexes would be retained for each risk category. These rules (table 7.12) dictate

Table 7.12-Rules for selecting the high-, moderate-, and low-risk hexagons that were retained in the final composite risk map

\begin{tabular}{|c|c|}
\hline Risk rating & Rule \\
\hline High & $\begin{array}{l}\text { \{IF } \geq 5 \% \text { of the hex is forested } \\
\text { AND } \geq 10 \% \text { of the hex's forested area is "in hazard" (hazard score }>0 \text { ) } \\
\text { AND } \geq 10 \% \text { of the forest area in hazard has a score }=5 \\
\text { AND } \geq 40 \% \text { of the forest area in hazard has a score } \geq 4 \\
\text { AND } \geq 10 \% \text { of the hex's area is "in pathways" (pathways score }>0 \text { ) } \\
\text { AND } \geq 60 \% \text { of the hex area in pathways has a score }=4\} \\
\text { OR } \\
\{\text { IF } \geq 5 \% \text { of the hex is forested } \\
\text { AND } \geq 10 \% \text { of the hex's forested area is "in hazard" (hazard score }>0 \text { ) } \\
\text { AND any portion of the forest area in hazard has a score =5 } \\
\text { AND } \geq 60 \% \text { of the forest area in hazard has a score } \geq 4 \\
\text { AND any portion of the hex has a pathways score }>0\} \\
\text { OR } \\
\{\text { IF } \geq 10 \% \text { of the hex's forested area is "in hazard" (hazard score }>0 \text { ) } \\
\text { AND } \geq 99 \% \text { of the forest area in hazard has a score } \geq 4\}\end{array}$ \\
\hline Moderate & $\begin{array}{l}\{\mathrm{IF} \geq 5 \% \text { of the hex is forested } \\
\quad \text { AND } \geq 10 \% \text { of the forested area is "in hazard" (hazard score }>0 \text { ) } \\
\text { AND } \geq 50 \% \text { of the forest area in hazard has a score } \geq 3\}\end{array}$ \\
\hline Low & All remaining areas \\
\hline
\end{tabular}


requirements for the high- and moderate-risk categories with respect to the percentage of a hex that is forested, the percentage of a hex's forested area that is at-risk (i.e., "in hazard" according to our combined hazard map; see fig. 7.5), and/or the percentage of forested area that falls in one of the higher hazard classes. In addition, the three rules defining the highrisk category include tiered requirements for the presence of pathway areas (see fig. 7.6); briefly, as the percentage of a hex's forested area falling within a higher hazard class increases, then the importance of pathways within the hex decreases (to zero in the case of the third high-risk rule). In our view, if virtually all of a hex's forested area falls in a higher hazard class, then the hex should be considered high-risk, regardless of its pathways status.

We removed a small number $(<15)$ of hexes from our chosen high-risk set that either did not share an edge with any other hex in the set or were in an isolated cluster of two (i.e., they only shared a single edge with each other and no other hex in the set). The areas associated with these hexes were subsequently assigned to the moderate-risk category (i.e., were assigned to moderate-risk hexes). Finally, any areas that did not meet the requirements for either the high- or moderate-risk categories were assigned to low-risk hexes.

\section{Results and Discussion}

A number of recent studies (Fowler and others 2006, Kelly and others 2007, Kluza and others 2007, Magarey and others 2008, Venette and Cohen 2006) have presented national- or global-scale map products related to $P$. ramorum risk. These studies typically focused on identifying environments where P. ramorum would be likely to persist and subsequently become established were it to be introduced, although most also included a limited representation of the pathogen's host species (e.g., the spatial distributions of overstory hosts but not those of foliar hosts that support sporulation). The aforementioned studies suggest broadly similar areas of suitability for $P$. ramorum in the conterminous United States, as does the climatic suitability layer we generated for our analysis (fig. 7.4). Indeed, some of these studies (Kluza and others 2007, Venette and Cohen 2006) indicated, as did our analysis, that large areas of the Eastern United States are highly suitable for the pathogen, while areas in California and Oregon where the pathogen is currently established exhibit only moderate suitability. These findings may seem counterintuitive, until one considers that many parts of the East experience long periods of persistent moisture and moderate temperatures; regardless, the findings emphasize the importance of adopting a suitably broadscale perspective with respect to P. ramorum risk. Towards this end, another goal for our analysis was the creation of a comprehensive, nationwide representation of host spatial distribution that reflected key aspects of $P$. ramorum epidemiology, such as the co-occurrence of critical host species at the landscape level (Holdenrieder and others 2004). We were additionally interested in depicting the pathways by which introductions are likely to occur. Including this 


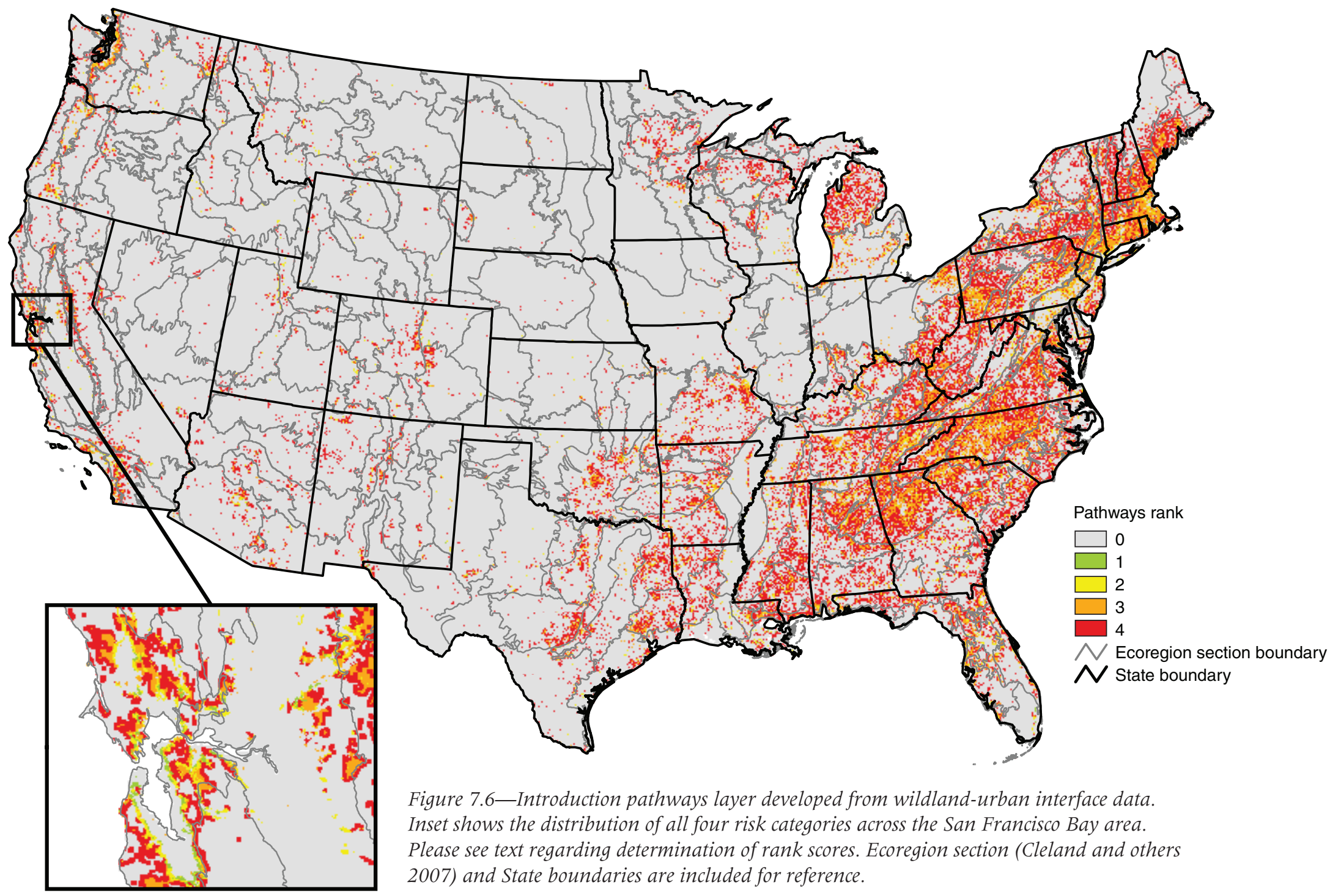


pathways component was intended to yield a more integrated picture of $P$. ramorum risk, thus making the map more useful for optimizing the national detection survey.

Our new risk map is shown in figure 7.7. The map includes 241 high-risk hexes, 177 moderate-risk hexes, and 70 low-risk hexes. (In the current version, sliver polygons-portions of some hexes that remain after eliminating any overlap between different risk categories-have not been reassigned to a neighboring hex.) The new map departs from the 2002 version (fig. 7.1) in a couple of key ways. Foremost, instead of labeling nearly all of the Pacific Coast from Los Angeles to Seattle as uniformly high risk, the new map highlights a more limited coastal region extending from central California (near the city of San Luis Obispo) to southern Oregon. We believe this smaller region represents a more optimal target area for the implementation of surveys focused on forest (or more broadly, wildland) environments. Although much of the Pacific Coast appears to be climatically suitable for P. ramorum (fig. 7.4), the most epidemiologically important host species (tanoak and California bay laurel) reach their greatest densities in our smaller highlighted region, as do the known susceptible oak species (see figs. 7.2 and 7.3). Areas to the south of this region are only sparsely forested, and thus have limited, and disconnected, host presence. Furthermore, areas to the north of this region feature only one notable host, Pacific madrone, but this species is considered a relatively minor foliar host (i.e., it supports only limited sporulation by P. ramorum).
With respect to the Eastern portion of the country, our new risk map emphasizes the Southeastern United States to a greater degree (i.e., has more high- and moderate-risk hexes in this region) than the 2002 map. This difference is due to a combination of factors operating at a regional scale. For instance, our analysis indicates a generally higher level of climatic suitability for this region than estimated in the previous map, which instead emphasized an area encompassing the Central and Southern Appalachian Mountains. The discrepancy can be attributed in part to the data used to portray suitability in each map. In particular, the 2002 map defined climatic limits for $P$. ramorum using maps from the Climate Atlas of the United States. Because Climate Atlas maps are monthly or annual summaries, they cannot capture the fine-temporal-scale, simultaneous occurrence of temperature and moisture conditions that appear to promote the pathogen's persistence (Garbelotto and others 2003, Rizzo and Garbelotto 2003); for this reason, we believe our new map is more realistic in portraying suitability in the Eastern United States (Venette and Cohen 2006). Furthermore, because of evidence that the pathogen is able to tolerate fairly high temperatures (Tooley and others 2008), we did not mask out some areas of the East that were deemed unsuitable in the 2002 map. Another major factor in the difference between the two maps relates to the representation of host species. Our new map depicts, in some detail, the epidemiological status of the several dozen species that have been linked to $P$. ramorum in some fashion; only 14 


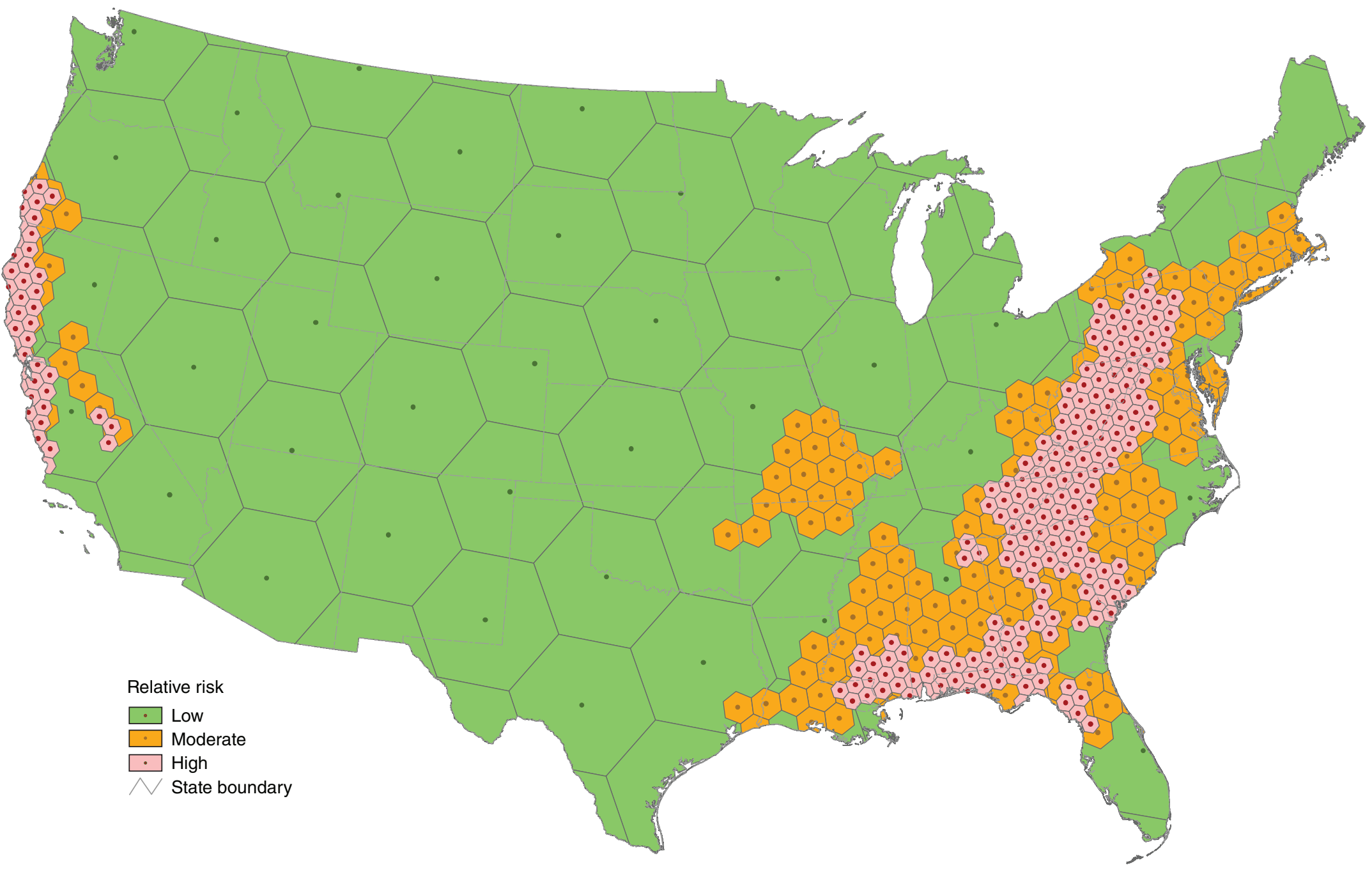

Figure 7.7-New national risk map for sudden oak death (Phytophthora ramorum). State boundaries are included for reference. 
forest species were even known to be affected by the pathogen in 2002, and virtually nothing was known about the susceptibility of Eastern United States species.

Another distinction between the 2002 map and the new map is our inclusion of a pathways layer adapted from wildland-urban interface data. However, as previously noted, the pathways layer played only a relatively minor role in our selection of high-risk hexes. Furthermore, we did not consider the pathways layer during our selection of moderate- or low-risk hexes. Given the absence of good information regarding the likelihood that P. ramorum could move from developed to natural environments, we did not feel justified in choosing especially restrictive pathway thresholds for our current analysis. Nevertheless, we believe that the pathways layer could serve a greater role as a discriminatory factor in future risk mapping efforts, either for $P$. ramorum or other invasive organisms of interest.

We recognize that numerous unknowns remain regarding the behavior and potential impact of $P$. ramorum in the conterminous United States. Perhaps most significantly, because the pathogen has not been detected in natural environments outside of Oregon and California, the roles of many potential host species in enabling the persistence and spread of $P$. ramorum remain uncertain, particularly for the Eastern United States. This forced us to make a number of simplifying assumptions regarding hosts in our current analysis. Indeed, it is possible that we omitted some potentially significant host species. For example, Tooley and Kyde (2007) found that chestnut oak (Q. prinus), a white oak (Quercus section Quercus) species that is widely distributed in parts of the East, was highly susceptible to foliar inoculations of $P$. ramorum during laboratory trials; however, those authors also acknowledged that they do not know how foliar infection of oaks fits into the overall epidemiology of the pathogen. There is also uncertainty regarding the amount of inoculum that may be necessary for $P$. ramorum to become established upon arriving in a new location. Thus, while our pathways layer may highlight where spread of inoculum from anthropogenic to natural landscapes is most likely, the absolute likelihood that such spread will result in long-term establishment of the pathogen is still unknown.

In short, our new risk map should only be interpreted as a representation of a set of current hypotheses regarding P. ramorum. It is possible that additional information will necessitate changes to these hypotheses or, alternatively, will identify new factors that must be considered when characterizing introduction and/or establishment risk. An advantageous feature of our approach is that, as new information about the pathogen comes to light, it is relatively straightforward to alter the decision rules or replace an individual input layer with a revised version. In any case, we believe that our map, in its current form, can serve as a useful guide for national surveys. We hope that this strategy will continue to prevent $P$. ramorum from becoming a forest health issue in parts of the United States where the pathogen is not currently established. 


\section{Literature Cited}

Brasier, C.: Denman, S.; Brown, A.; Webber, J. 2004a. Sudden oak death (Phytophthora ramorum) discovered on trees in Europe. Mycological Research. 108(10): 1108-1110

Brasier, C.M.; Denman, S.; Rose, J. [and others]. 2004b. First report of ramorum bleeding canker on Quercus falcata, caused by Phytophthora ramorum. Plant Pathology.

53(6): 804-804.

Browning, M.; Englander, L.; Tooley, P.W.; Berner, D. 2008. Survival of Phytophthora ramorum hyphae after exposure to temperature extremes and various humidities. Mycologia. 100(2): 236-245.

Cleland, D.T.; Freeouf, J.A., Keys, J.E. [and others]. 2007. Ecological subregions: sections and subsections for the conterminous United States. Sloan, A.M., tech. ed. Gen. Tech. Report WO-76. Washington, DC: U.S. Department of Agriculture Forest Service. Map, presentation scale 1:3,500,000; Albers equal area projection; colored. Also as a GIS coverage in ArcINFO format on CD-ROM or at http://fsgeodata.fs.fed.us/other_resources/ecosubregions. html. [Date accessed: March 18, 2011].

Condeso, T.E.; Meentemeyer, R.K. 2007. Effects of landscape heterogeneity on the emerging forest disease sudden oak death. Journal of Ecology. 95(2): 364-375.

Cressie, N.A.C. 1993. Statistics for spatial data. New York: John Wiley. $900 \mathrm{p}$

Daly, C.; Gibson, W.P.; Taylor, G.H. [and others]. 2002. A knowledge-based approach to the statistical mapping of climate. Climate Research. 22: 99-113.

Davidson, J.M.; Rizzo, D.M.; Garbelotto, M.; Tjosvold, S. 2002. Phytophthora ramorum and sudden oak death in California: II. Transmission and survival. Gen. Tech. Rep. PSW-GTR-184. In: Standiford, R.B.; McCreary, D.; Purcell, K.L., eds. Fifth Symposium on Oak Woodlands: Oaks in California's Changing Landscape. U.S. Department of Agriculture Forest Service, Pacific Southwest Research Station: 741-749.

Davidson, J.M.; Shaw, C.G. 2003. Pathways of movement for Phytophthora ramorum, the causal agent of sudden oak death. In: Sudden Oak Death Online Symposium St. Paul, MN: American Phytopathological Society. http://www. scientificsocieties.org/aps/proceedings/sod/Papers/Shaw Davidson/default.htm. [Date accessed: March 22, 2011].
Davidson, J.M.; Wickland, A.C.; Patterson, H.A. [and others] 2005. Transmission of Phytophthora ramorum in mixed-

evergreen forest in California. Phytopathology. 95(5): 587-596.

DEFRA-UK. 2004. Phytophthora ramorum epidemiology: sporulation potential, dispersal, infection, latency and survival. Research project PH0194 final report. United Kingdom: Department for Food, Environment, and Rural Affairs, Plant Health Division. 22 p.

Dodd, R.S.; Huberli, D.; Douhovnikoff, V. [and others]. 2005. Is variation in susceptibility to Phytophthora ramorum correlated with population genetic structure in coast live oak (Quercus agrifolia)? New Phytologist. 165(1): 203-214.

Fowler, G.; Magarey, R.; Colunga, M. 2006. Climate-host mapping of Phytophthora ramorum, causal agent of sudden oak death. Gen. Tech. Rep. PSW-GTR-196. In: Frankel, S.J.; Shea, P.J.; Haverty, M.I., eds. Proceedings of the Sudden Oak Death Second Science Symposium. Albany, CA: U.S. Department of Agriculture Forest Service, Pacific Southwest Research Station: 329-331.

Frankel, S.J. 2008. Sudden oak death and Phytophthora ramorum in the USA: a management challenge. Australasian Plant Pathology. 37(1): 19-25.

Garbelotto, M.; Davidson, J.M.; Ivors, K. [and others]. 2003. Non-oak native plants are main hosts for sudden oak death pathogen in California. California Agriculture. 57(1): 18-23.

Goheen, E.M.; Hansen, E.M.; Kanaskie, A. [and others] 2002. Sudden oak death caused by Phytophthora ramorum in Oregon. Plant Disease. 86: 441

Hansen, E.M.; Parke, J.L.; Sutton, W. 2005. Susceptibility of Oregon forest trees and shrubs to Phytophthora ramorum: a comparison of artificial inoculation and natural infection. Plant Disease. 89(1): 63-70.

Holdenrieder, O.; Pautasso, M.; Weisberg, P.J.; Lonsdale, D. 2004. Tree diseases and landscape processes: the challenge of landscape pathology. Trends in Ecology \& Evolution. $19(8): 446-452$

Ivors, K.; Garbelotto, M.; Vries, I.D.E. [and others]. 2006. Microsatellite markers identify three lineages of Phytophthora ramorum in U.S. nurseries, yet single lineages in U.S. forest and European nursery populations. Molecular Ecology. 15(6): 1493-1505. 
Jensen, R.N. 1997. Quercus sect. Lobatae G. Don. In: Flora of North America Editorial Committee, ed. Flora of North America North of Mexico, Vol. 3. http://www.efloras. org/florataxon.aspx?flora_id=1\&taxon_id=302020. [Date accessed: August 5, 2008]

Kartesz, J.T. 2008. A synonymized checklist and atlas with biological attributes for the vascular flora of the United States, Canada, and Greenland. In: Kartesz, J.T., ed. Synthesis of the North American flora, version 2.0 [CDROM]. Chapel Hill, NC: Biota of North America Program North Carolina Botanical Garden, University of North Carolina.

Kelly, M.; Guo, Q.; Liu, D.; Shaari, D. 2007. Modeling the risk for a new invasive forest disease in the United States: an evaluation of five environmental niche models. Computers Environment and Urban Systems. 31(6): 689-710

Kluza, D.A.; Vieglais, D.A.; Andreasen, J.K.; Peterson, A.T. 2007. Sudden oak death: geographic risk estimates and predictions of origins. Plant Pathology. 56(4): 580-587.

Magarey, R.; Fowler, G.; Colunga, M. [and others]. 2008. Climate-host mapping of Phytophthora ramorum, causal agent of sudden oak death. In: Frankel, S.J.; Kliejunas, J.T.; Palmieri, K.M., eds. Proceedings of the Sudden Oak Death Third Science Symposium. Gen. Tech. Rep. PSWGTR-2 14. Albany, CA: U.S. Department of Agriculture Forest Service, Pacific Southwest Research Station: 269-275.

Maloney, P.E.; Lynch, S.C.; Kane, S.F. [and others]. 2005. Establishment of an emerging generalist pathogen in redwood forest communities. Journal of Ecology. 93(5): 899-905.

Maloney, P.E.; Lynch, S.C.; Kane, S.R.; Rizzo, D.M. 2004 Disease progression of Phytophthora ramorum and Botryosphaeria dothidea on Pacific madrone. Plant Disease. 88(8): 852-857

McPherson, B.A.; Wood, D.L.; Storer, A.J. [and others] 2003. Sudden oak death, a new forest disease in California. Integrated Pest Management Reviews. 6: 243-246.

Moralejo, E.; Munoz, J.A.G.; Descals, E. 2006. Insights into Phytophthora ramorum sporulation: epidemiological and evolutionary implications. EPPO Bulletin. 36(2): 383-388.
Murphy, K.; Rizzo, D.M. 2003. First report of Phytophthora ramorum on canyon live oak in California. Plant Disease. 87: 315-321.

Nixon, K.C. 1993. Infrageneric classification of Quercus (Fagaceae) and typification of sectional names. Annals of Forest Science. 50(Suppl 1): 25s-34s.

Nixon, K.C. 2002. The oak (Quercus) biodiversity of California and adjacent regions. Gen. Tech. Rep. PSW-GTR-184. In Standiford, R.B.; McCreary, D.; Purcell, K.L., eds. Fifth Symposium on Oak Woodlands: Oaks in California's Changing Landscape. Albany, CA: U.S. Department of Agriculture Forest Service, Pacific Southwest Research Station: 3-20.

Oak, S.W.; Elledge, A.H.; Yockey, E.K. [and others]. 2008a. Phytophthora ramorum early detection surveys for forests in the United States, 2003-2006. Gen. Tech. Rep. PSWGTR-214. In: Frankel, S.J.; Kliejunas, J.T.; Palmieri, K.M., eds. Proceedings of the Sudden Oak Death Third Science Symposium. Albany, CA: U.S. Department of Agriculture Forest Service, Pacific Southwest Research Station: 413-416.

Oak, S.W.; Hwang, J.; Jeffers, S.N.; Tkacz, B.M. 2008b. 2006 pilot survey for Phytophthora ramorum in forest streams in the USA. Gen. Tech. Rep. PSW-GTR-214. In: Frankel, S.J.; Kliejunas, J.T.; Palmieri, K.M., eds. Proceedings of the Sudden Oak Death Third Science Symposium. Albany, CA: U.S. Department of Agriculture Forest Service, Pacific Southwest Research Station: 59-64.

Pielou, E.C. 1977. Mathematical Ecology. New York: Wiley. $385 \mathrm{p}$.

Potter, B.E.; Teclaw, R.M.; Zasada, J.C. 2001. The impact of forest structure on near-ground temperatures during two years of contrasting temperature extremes. Agricultural and Forest Meteorology. 106: 331-336.

Preston, R.J.; Braham, R.R. 2002. North American Trees. Ames, IA: Iowa State Press. 520 p.

Radeloff, V.C.; Hammer, R.B.; Stewart, S.I. [and others]. 2005. The wildland-urban interface in the United States. Ecological Applications. 15(3): 799-805.

Ristaino, J.B.; Gumpertz, M.L. 2000. New frontiers in the study of dispersal and spatial analysis of epidemics caused by species in the genus Phytophthora. Annual Review of Phytopathology. 38: 541-576. 
Rizzo, D.M.; Garbelotto, M. 2003. Sudden oak death: endangering California and Oregon forest ecosystems. Frontiers in Ecology and the Environment. 1(4): 197-204.

Rizzo, D.M.: Garbelotto, M.: Davidson, J.M. [and others] 2002. Phytophthora ramorum as the cause of extensive mortality of Quercus spp. and Lithocarpus densiflorus in California. Plant Disease. 86(3): 205-214

Rizzo, D.M.; Garbelotto, M.; Hansen, E.A. 2005. Phytophthora ramorum: integrative research and management of an emerging pathogen in California and Oregon forests. Annual Review of Phytopathology. 43: 309-335.

Smith, W.D.; Coulston, J.W.; Goheen, E.M. [and others]. 2002. Development of a national survey protocol for detection of Phytophthora ramorum. In: Proceedings of the Sudden Oak Death Science Symposium. Albany, CA: U.S. Department of Agriculture Forest Service, Pacific Southwest Research Station. 24 p.

Stein, J.; Binion, D.; Acciavatti, R. 2003. Field guide to native oak species of eastern North America. Morgantown, WV: U.S. Department of Agriculture Forest Service, Forest Health Technology Enterprise Team, FHTET-2003-01. $161 \mathrm{p}$.

Stokstad, E. 2004. Plant pathology - Nurseries may have shipped sudden oak death pathogen nationwide. Science. 303(5666): 1959.

Suslow, K. 2008. Determining the effectiveness of the Federal order/interim rule on Phytophthora ramorum dissemination in nurseries. Gen. Tech. Rep. PSW-GTR-214. In: Frankel, S.J.; Kliejunas, J.T.; Palmieri, K.M., eds. Proceedings of the Sudden Oak Death Third Science Symposium. Albany, CA: U.S. Department of Agriculture Forest Service, Pacific Southwest Research Station: 27-30.

Swiecki, T.J.; Bernhardt, E. 2002. Evaluation of stem water potential and other tree and stand variables as risk factors for Phytophthora ramorum canker development in coast live oak. Gen. Tech. Rep. PSW-GTR-184. In: Standiford, R.B.; McCreary, D.; Purcell, K.L., eds. Proceedings of the Fifth Symposium on Oak Woodlands: Oaks in California's Changing Landscape. Albany, CA: U.S. Department of Agriculture Forest Service, Pacific Southwest Research Station: 787-798.

Tooley, P.W.; Browning, M. 2009. Susceptibility to Phytophthora ramorum and inoculum production potential of some common eastern forest understory plant species. Plant Disease. 93: 249-256.
Tooley, P.W.; Browning, M.; Berner, D. 2008. Recovery of Phytophthora ramorum following exposure to temperature extremes. Plant Disease. 92: 431-437.

Tooley, P.W.; Kyde, K.L. 2007. Susceptibility of some Eastern forest species to Phytophthora ramorum. Plant Disease. $91(4)$ : 435-438.

Tooley, P.W.; Kyde, K.L.; Englander, L. 2004. Susceptibility of selected ericaceous ornamental host species to Phytophthora ramorum. Plant Disease. 88(9): 993-999.

U.S. Department of Agriculture, Animal and Plant Health Inspection Service. 2008. APHIS list of regulated hosts and plants associated with Phytophthora ramorum. http:// www.aphis.usda.gov/plant_health/plant_pest_info/ pram/downloads/pdf_files/usdaprlist.pdf. [Date accessed February 11, 2009].

U.S. Department of Agriculture Forest Service. 2004 Sudden oak death: protecting America's woodlands from Phytophthora ramorum. FS-794. Arlington, VA: U.S. Department of Agriculture Forest Service, State and Private Forestry, Forest Health Protection.12 p. http:// www.fs.fed.us/foresthealth/publications/SOD_Report.pdf. [Date accessed: March 18, 2011].

Venette, R.C.; Cohen, S.D. 2006. Potential climatic suitability for establishment of Phytophthora ramorum within the contiguous United States. Forest Ecology and Management. 231(1-3): 18-26.

Webber, J.F. Rose, J. 2008. Dissemination of aerial and root infecting Phytophthoras by human vectors. Gen. Tech. Rep. PSW-GTR-214. In: Frankel, S.J.; Kliejunas, J.T.; Palmieri, K.M., eds. Proceedings of the Sudden Oak Death Third Science Symposium. Albany, CA: U.S. Department of Agriculture Forest Service, Pacific Southwest Research Station: 195-198.

Werres, S.; Marwitz, R.; Veld, W. [and others]. 2001. Phytophthora ramorum sp. nov., a new pathogen on Rhododendron and Viburnum. Mycological Research. 105: 1155-1165.

White, D.; Kimerling, J.A.; Overton, W.S. 1992. Cartographic and geometric components of a global sampling design for environmental monitoring. Cartography and Geographic Information Systems. 19(1): 5-22. 


\section{Introduction}

đriterion 3, Indicator 16, of the Montréal Process Criteria and Indicators for the

$\checkmark$ Conservation and Sustainable Management of Temperate and Boreal Forests was designed to assess the impact of abiotic agents upon forests (Montréal Process Working Group 2007). Various abiotic agents, both natural and humaninduced, can change forest structure and species composition. Where such change goes beyond a critical threshold, forest ecosystem health may be significantly altered and its ability to recover from disturbance reduced or lost, often meaning a reduction or loss of benefits associated with that forest ecosystem. Monitoring the area and percent of forests affected by abiotic agents beyond reference conditions may provide information needed in the formulation of management strategies to mitigate risk. The summary of this analysis is reported in the National Report on Sustainable Forests 2010 Report (USDA Forest Service 2011) while the purpose of this document is to provide the detailed evidence to support the reported data.

\section{Objectives and Methods}

The original National Report on Sustainable Forests 2003 (USDA Forest Service 2004) and the Montréal Process Working Group (2007) identified several abiotic agents: fire, storm, land clearance, permanent flooding, salinization, specific air pollutants (e.g., sulfates, nitrate, ozone), ultraviolet $\mathrm{B}$, and soil nutrient cycling. These were addressed in three separate indicators. In the National Report on Sustainable
Forests 2010, these were reorganized and addressed as one indicator (Criterion 3, Indicator 16) and were grouped into five sub-indicators that have the greatest impact on forest health. These abiotic sub-indicators are fire, weatherrelated damage, pollution, land use, and climate.

Quantitative temporal analyses of these abiotic sub-indicators were completed based on spatial and tabular data between the most recent 5-year analysis period (2003-07) and the previous 5-year time period (1998-2002). To summarize specific impact on forests, all sub-indicator assessments were limited to forested areas by using a forest/nonforest mask generated by the Remote Sensing Applications Center of the Forest Service, U.S. Department of Agriculture (Blackard and others 2008).

Fire-Data for acreage burned (1960-2007) were acquired from the National Interagency Fire Center-Wildland Fire Statistics, and the data include all wildland cover types burned. Additional data for 1916 to 1959 were acquired from the Heinz Center Report (2008). These data give a reasonably accurate national acreage estimate, but the data are nonspatial and do not specifically report forested acreage. Burn severity data from the Monitoring Trends in Burn Severity (MTBS) program come from a multi-year project designed to consistently map the burn severity and perimeters of fires across all lands of the United States starting from 1984 using the remotely sensed Landsat archive (Eidenshink and others 2007). For this report, nationwide data were available from 2004 to
CRITERION 3Chapter 8. Area and Percent of Forest Affected by Abiotic Agents Beyond Reference
Conditions

JiM ELLENWOOD 
2007, with older historical data available from 1984 for the western region and from 1997 for the southern region. The data show the proportion of burn severity classes within each landcover type. For this report, data were limited to the forested landcover type.

Weather-related damage-Weather-related damage is tracked through the Aerial Detection Survey (ADS) Program of the Forest Service (USDA Forest Service 2008a). Weather-related damage caused by drought, flood, ice, hail, lightning, wind (hurricane/tornado), and avalanche agents is represented only in areas that have been tasked for survey and may not represent all of the area impacted by the agent. Areas surveyed are often preselected due to known active agents, and the total area that may be damaged cannot be estimated based upon a statistically valid sample due to the preselection bias. Data were either sketched directly on maps using standard coding and reporting criteria or captured using Digital Aerial Sketch Mapping (DASM) as an aide in the airplane or on the ground. The collected data are stored in a national ADS database (USDA Forest Service 2008a). Other sources of storm damage data, such as the National Climate Data Center storm event database, do not specifically track forest damage. It may be possible to build a geospatial dataset to produce relative damage severity; however, this effort was not pursued for this report.

Pollution-The ozone $\left(\mathrm{O}_{3}\right)$ biomonitoring program of the Forest Health Monitoring (FHM) Program of the Forest Service uses ozone- sensitive plants to monitor air quality and the potential impacts of tropospheric $\mathrm{O}_{3}(\mathrm{smog})$ on forest lands. These data include both tabular regional synopses and a raster surface model using the biomonitoring site point data. The surface ozone-injured indicator plants regional summary and graph were obtained from Smith and others (2008). A Critical Acid Loading (CAL) surface raster model obtained from McNulty and others (2007), and the forest mask were applied to create a CAL grid layer for forested areas. The data were summarized and graphed.

Land use-Assessments about urban sprawl have focused on quantifying land use changes in urban and metropolitan areas. It is critical for ecologists to examine and improve understanding of land use changes beyond the urban fringe, also called exurban sprawl, because of the extensive and widespread changes that are occurring. Human development and its impacts are continually expanding into forest land. Housing density is used as a sub-indicator of that human development. Housing density raster surfaces were obtained from the Forest Service's Forest on the Edge Program (Stein and others 2005), which analyzed housing density data for 1970-2000 and projected the data for 2000-2020 (Theobald 2005). The 2000 and 2010 housing density raster surfaces were reassigned to four classes. The four housing density classes are: (1) rural and undeveloped ( $>40$ acres per unit), (2) exurban (1.7-40 acres per unit), (3) suburban (0.6-1.7 acres per unit), and (4) urban $(<0.6$ acres per unit). All data were limited to forested areas using the forest mask. 
Climate-The moisture index difference (MID) raster model (Koch and others 2012) is classified according to distinct value ranges for drought and wetness categories based on the 100-year average standard deviation of MID. An averaged MID grid surface for each analysis period (19982002 and 2003-07) was created by averaging the annual grid surfaces. The average MID grid surfaces were limited to only forested areas by applying a forest mask.

\section{Results and Products}

Results are presented assessing recent trends in the five abiotic sub-indicators listed above, discussing changes in these sub-indicators since the most recent 5-year reference period (19982002), and describing regional variation in the results.

Reference periods are generally arbitrary, but selecting a reference period for which data can be comparably measured offers a fixed point from which to analyze. Techniques and standards for historical data may have changed over time and would confound analysis. Recent developments in mapping technologies and available base data have allowed for a higher degree of accuracy and precision in mapping the extent of many of the sub-indicators. Improvements to mapping technologies will only improve subsequent data analysis.

Fire-As the most extensive among the subindicators in terms of area impacted, fire is an integral part of forested ecosystems. Since the early half of the $20^{\text {th }}$ century, extensive livestock grazing followed by increasingly effective fire suppression substantially reduced the annual acreage burned until the mid-1980s, when the trend reversed (Westerling and others 2006). The area burned in 2006 was the highest recorded since 1954 (fig. 8.1), but mapping standards and technologies have changed substantially and data compilations may not be comparable. Data compiled prior to 1983 were not spatially explicit in that the data had been collated from tabular reports received from the various fire agencies and summarized by the National Interagency Coordination Center. Many of the individual fire agencies are reconstructing spatially explicit historical data and future tallies of historical data may vary.

Wildland fire summaries for the entire time period are for all landcover types, and, due to the nonspatially explicit data, forested acreage burned cannot be determined. Many nonforested ecosystems have not experienced reduced fire frequencies in the $20^{\text {th }}$ century (Omi and others 2004). For this reason, the overall trends witnessed in the recorded historical fire data may not be reflective of the trends for forested areas. The compilation of spatially explicit historical data would be necessary to precisely evaluate the long-term trends for fire in forested ecosystems. In addition to being inclusive of nonforested area, the acreage reported also summarizes area over an entire fire perimeter which includes areas nonburned or minimally burned. 


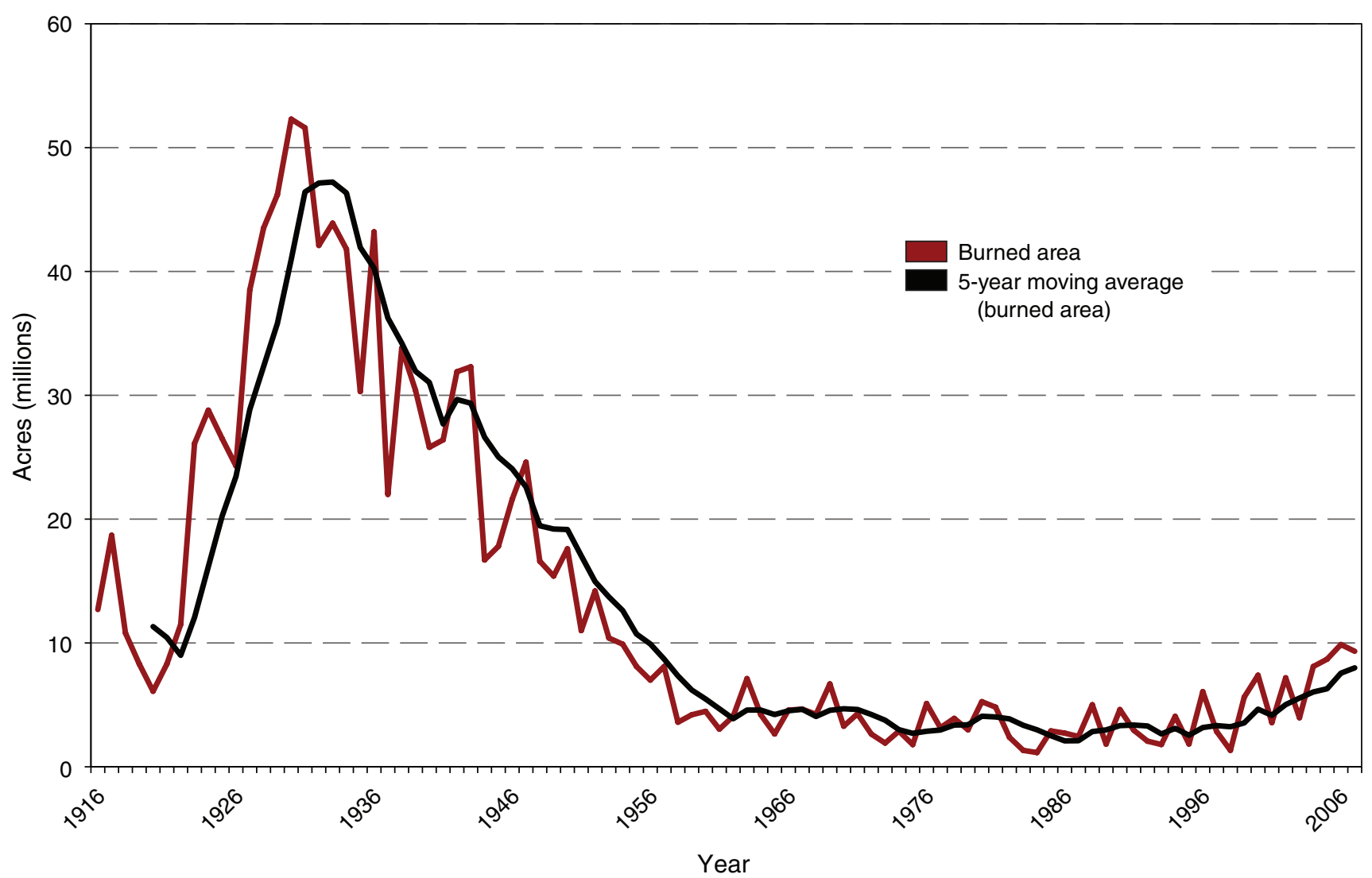

Figure 8.1-Historical acreage burned (Data source: National Interagency Fire Center, Heinz Center 2008).

Wildland fire data for the most recent period (2003-07) show the extent of wildland fires has increased. Forty million acres burned in the 5 -year period, as compared to 25 million acres in the preceding 5-year period (table 8.1). Both of these periods are substantially less than the historic 5-year period maximum that occurred in the late 1920s, prior to the advent of effective fire suppression (fig. 8.1).
While a significant increase in the extent of wildland fires has occurred recently, concern over burn severity has prompted efforts to map the severity of large fires. The spatially explicit Monitoring Trends in Burn Severity (MTBS) data show for the most recent period (2003-07) that forested lands account for 13.1 million acres of the burned area or approximately 1.7 percent of all forested land, inclusive of Alaska and 
Hawaii. Burn severity data for the Pacific and Rocky Mountain regions show the proportion of high and moderate burn severity in the forested areas has increased from 45 to 50 percent of the forested area burned for the most recent period versus the previous period (table 8.1). The increasing trend has been relatively consistent over the past 24 years, with the proportion of high and moderate burn severity on forested lands increasing from a proportion of 30 percent for the 1984-87 period to 50 percent of the burned forested area for the most recent period, with the 1993-97 period being anomalous (table 8.1). The subsequent effect of the reduced fire frequency observed in the mid-20 $0^{\text {th }}$ century manifested itself in increased fuel loadings and created recent burns of higher severity.

Data for the reference period in the southern region are incomplete, but the burn severity data indicate a different trend from the western regions between the reference period and the most recent period, with the proportion of high and moderate severity declining from 22 percent to 15 percent between the reference period and the recent period (table 8.2).

Weather-related damage-The ADS data on damage from weather-related events show that 1.761 million acres were impacted by drought, flood, hail, lightning, wind (hurricanes and tornados), and avalanches from 2003 to 2007 (table 8.3, fig. 8.2). These 1.761 million acres represent approximately 0.3 percent of the total forested area. Damage from Hurricanes Katrina and Rita is underrepresented in this data due to limited survey. Even with this damage unaccounted for in the summary, weatherrelated damage has increased substantially over the previous 5-year period. This is largely the result of a greater than tenfold increase in acres affected by drought-induced mortality, the

\section{Table 8.1—Severity of forested area burned for the Pacific and Rocky Mountain regions}

\begin{tabular}{|c|c|c|c|c|c|}
\hline Fire & $1983-87^{a}$ & 1988-1992 & 1993-97 & 1998-2002 & 2003-07 \\
\hline & \multicolumn{5}{|c|}{ thousand acres } \\
\hline Burned area-U.S. all lands & 10,535 & 16,482 & 16,635 & 25,105 & 39,950 \\
\hline \multicolumn{6}{|l|}{ Burn severity on forested lands-Western States } \\
\hline High severity & 135 & 322 & 187 & 946 & 1,717 \\
\hline Moderate severity & 204 & 243 & 247 & 966 & 1,521 \\
\hline Other severity (includes unburned) & 779 & 1,038 & 103 & 2,351 & 3,220 \\
\hline Percent of burned area in high and moderate severity & 30 & 35 & 30 & 45 & 50 \\
\hline
\end{tabular}

1983 data not included.

Data source: U.S. Department of Agriculture Forest Service, Monitoring Trends in Burn Severity. http://www.mtbs.gov/. [Date accessed: December 4, 
Table 8.2-Grand summary of fire abiotic sub-indicators

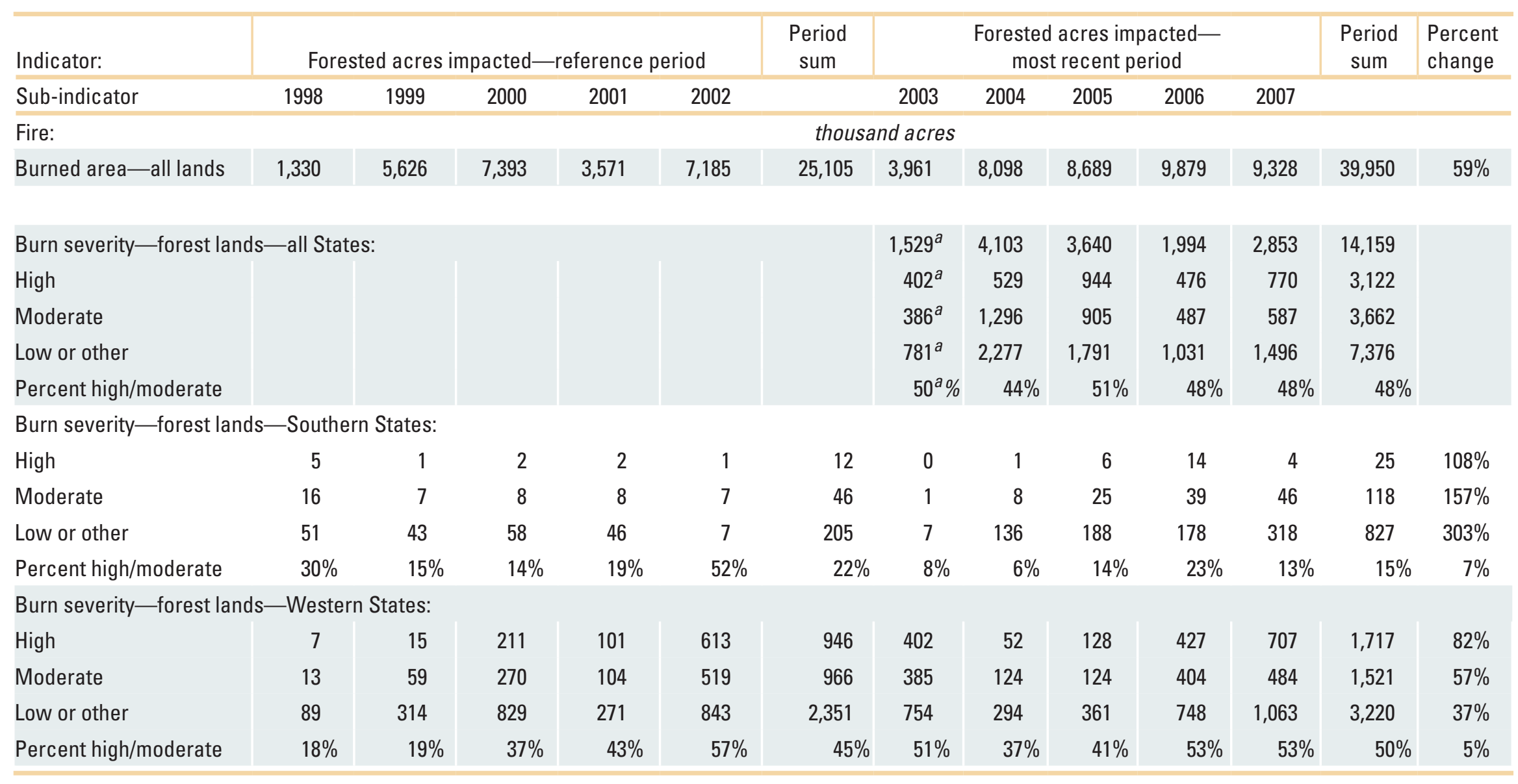

${ }^{a}$ Summarized for Western and Southern States only.

Data sources: http://www.nifc.gov/firelnfo/firelnfo_statistics.html and http://www.mtbs.gov/. [Date accessed: December 4, 2009]. 
Table 8.3-Grand summary of nonfire abiotic subindicators

\begin{tabular}{|c|c|c|c|c|c|c|c|c|c|c|c|c|c|}
\hline \multirow{2}{*}{$\begin{array}{l}\text { Indicator: } \\
\text { Sub-indicator }\end{array}$} & \multicolumn{5}{|c|}{$\begin{array}{l}\text { Forested acres impacted- } \\
\text { reference period }\end{array}$} & \multirow[t]{2}{*}{$\begin{array}{l}\text { Period } \\
\text { sum }\end{array}$} & \multicolumn{5}{|c|}{$\begin{array}{l}\text { Forested acres impacted- } \\
\text { most recent period }\end{array}$} & \multirow[t]{2}{*}{$\begin{array}{l}\text { Period } \\
\text { sum }\end{array}$} & \multirow[t]{2}{*}{$\begin{array}{l}\text { Percent } \\
\text { change }\end{array}$} \\
\hline & 1998 & 1999 & 2000 & 2001 & 2002 & & 2003 & 2004 & 2005 & 2006 & 2007 & & \\
\hline & \multicolumn{12}{|c|}{ thousand acres } & \\
\hline Weather: & 449 & 89 & 60 & 21 & 170 & 788 & 1,370 & 124 & 224 & 10 & 33 & 1,761 & $123 \%$ \\
\hline Drought & 41 & 2 & 37 & 19 & 59 & 158 & 1,126 & 114 & 12 & 0 & 10 & 1,263 & $699 \%$ \\
\hline Flood & 81 & 26 & 24 & 1 & 11 & 142 & 16 & 8 & 23 & 5 & 12 & 66 & $-54 \%$ \\
\hline Hail & $0.024^{a}$ & 61 & 0 & $0.016^{a}$ & 67 & 128 & 43 & 0 & 1 & 0 & 1 & 45 & $-65 \%$ \\
\hline Lightning & 0 & 0 & 0 & 0 & 0 & 0 & $0.102^{a}$ & $0.232^{a}$ & $0.114^{a}$ & 0 & 0 & $0.448^{a}$ & NA \\
\hline Wind & 326 & 1 & 0 & $0.259^{a}$ & 32 & 360 & 184 & 1 & 188 & 5 & 9 & 387 & $8 \%$ \\
\hline Avalanche & 0 & 0 & 0 & $0.142^{a}$ & 0 & $0.142^{a}$ & 0 & 0 & 0 & $0.197^{a}$ & $0.024^{a}$ & $0.221^{a}$ & $55 \%$ \\
\hline \multicolumn{14}{|l|}{ Pollution: } \\
\hline Percent plant injury & $41 \%$ & $17 \%$ & $21 \%$ & $13 \%$ & $10 \%$ & & $8 \%$ & $7 \%$ & $7 \%$ & $7 \%$ & NA & & \\
\hline Southern ${ }^{b}$ & & & & & & 10.2 & & & & & & 1.6 & \\
\hline Northeast $^{b}$ & & & & & & 7.0 & & & & & & 3.4 & \\
\hline Central $^{b}$ & & & & & & 5.0 & & & & & & 1.0 & \\
\hline Rocky $^{b}$ & & & & & & 0.0 & & & & & & 0.0 & \\
\hline Pacific $^{b}$ & & & & & & 1.5 & & & & & & 1.8 & \\
\hline \multicolumn{14}{|l|}{ Land use $\mathrm{e}^{c}$ : } \\
\hline Urban/Sub & & & 764 & & & & & & 821 & & & & \\
\hline Exurban & & & 16,635 & & & & & & 17,660 & & & & \\
\hline \multicolumn{14}{|l|}{ Moisture deficit: } \\
\hline Extreme & & & & & & 400 & & & & & & 138 & \\
\hline Severe & & & & & & 2,098 & & & & & & 1,809 & \\
\hline
\end{tabular}

$\mathrm{NA}=$ not available.

Data sources: Aerial Detection Survey Program; Ozone Biomonitoring Program; Stein and others 2005; Koch and others 2012.

${ }^{a}$ Acreage $<500$ acres are in decimal.

${ }^{b}$ Summarized for 1997-2001 and 2002-2006 period.

${ }^{c} 2000$ actual data, data projected to 2010 and pro-rated to 2005 


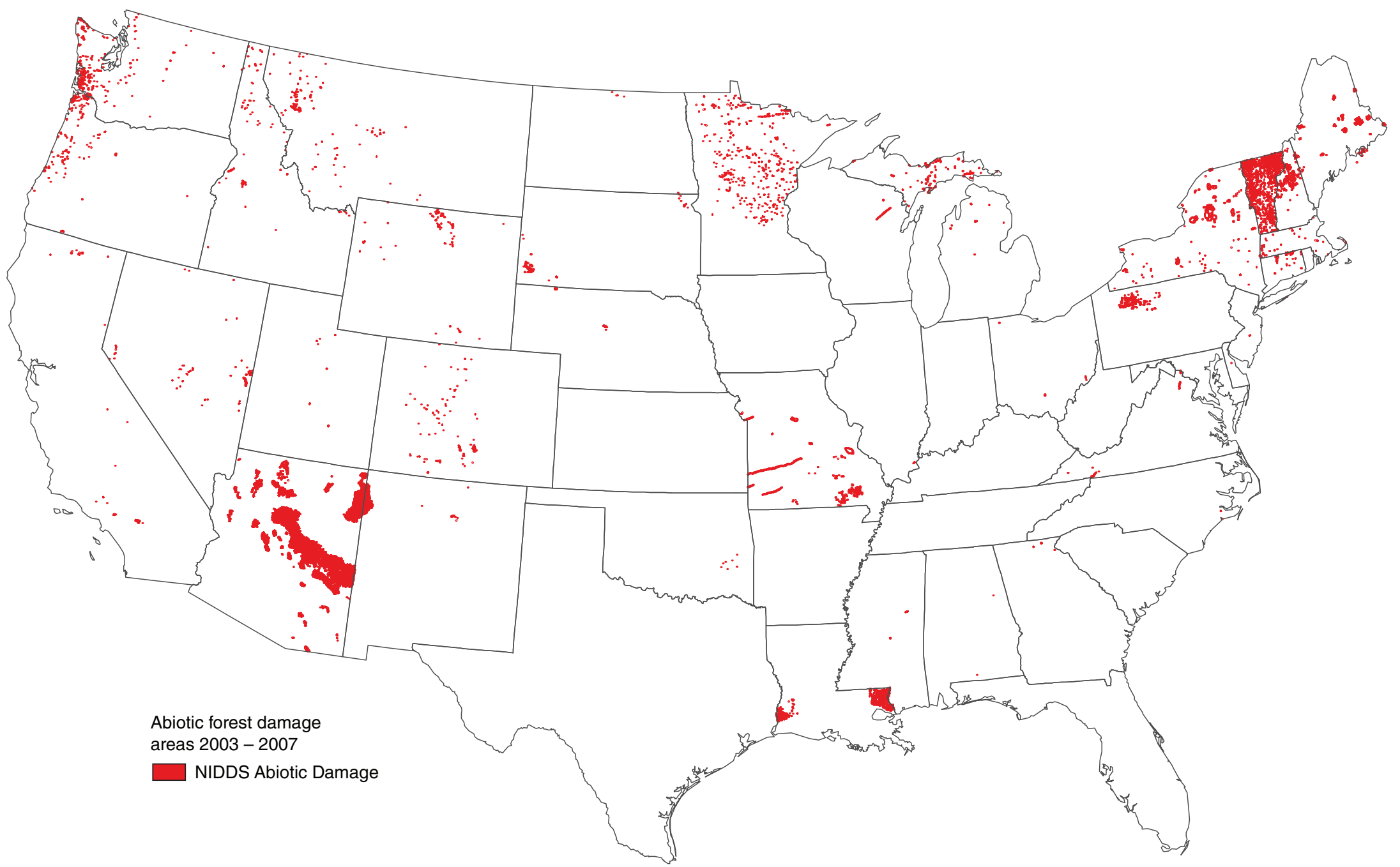

Figure 8.2-Weather-related forest damage areas, 2003-07 (Data source: U.S. Department of Agriculture Forest Service 2008a). 
largest increase in acreage impacted by weather (fig. 8.3). Though the observed differences are compelling, conclusive evidence for a trend cannot be made, due to the selection bias in the sampling. A better monitoring of weatherrelated damage impacts may be achieved by developing a program modeled after the MTBS program, which can utilize the vast archive of Landsat imagery.

Pollution-Surface ozone $\left(\mathrm{O}_{3}\right)$ is an important air pollutant that affects vegetation (U.S. Environmental Protection Agency 1996). Ozone is routinely monitored throughout the world, and data were mostly recorded as hourly or half-hourly averages. Over the last 30 years, hourly averaged data have been summarized in different ways for the purpose of assessing vegetation effects. The development of exposure indices to characterize plant exposure and to quantify the relationship between $\mathrm{O}_{3}$ exposure and ensuing plant response has been, and remains, a challenge (Musselman and others 2006). The FHM program utilizes ozone-sensitive plants (bio-indicators) to assess $\mathrm{O}_{3}$ impact upon forest ecosystems (Smith and others 2008). There is not yet any evidence linking FHM ozone bio-indicator response data to specific tree health problems or regional declines. Nevertheless, the mapped data demonstrate that plant damaging concentrations of ozone air pollution are widespread in parts of the Nation. Continued monitoring and analysis will be important when determining probable or significant ozone damage (Smith and others 2008). Ozone damage is far greater in the northeastern States; however the 5-year trend indicates a decline in damage, while the west coast States have experienced an increase in ozone damage (fig. 8.4).

Concern regarding the impacts of continued nitrogen and sulfur deposition on ecosystem health has prompted the development of critical acid load (CAL) assessments for forest soils. A CAL is a quantitative estimate of exposure to one or more pollutants at or above which harmful acidification-related effects on sensitive elements of the environment occur. A pollutant load in excess of a CAL is termed exceedance. Simple mass balance equations were used to estimate forest soil critical acid loads for the conterminous United States (McNulty and others 2007). These spatial data were acquired and masked by the forest mask and summarized. From 1994 to 2000, 74.2 million acres or 17 percent of the soils on forest land exceeded their CAL threshold by more than 101 equivalents per acre per year. These areas include much of New England and West Virginia with very few areas of exceedance predicted in the Western United States.

Land use-In 2000, there were 28.4 million forested acres in urban and suburban $(<1.67$ acres per unit) residential housing density in the conterminous United States, but there were slightly more than seven times that (205.6 million acres) in exurban housing density (1.67-40 acres per unit). According to Theobald (2005), the development footprint had grown from 10.1 percent in 1980 to 13.3 percent in 2000 of total national land area, roughly at a rate of 1.6 percent per year. This rate outpaced the population growth rate (1.18 percent per 


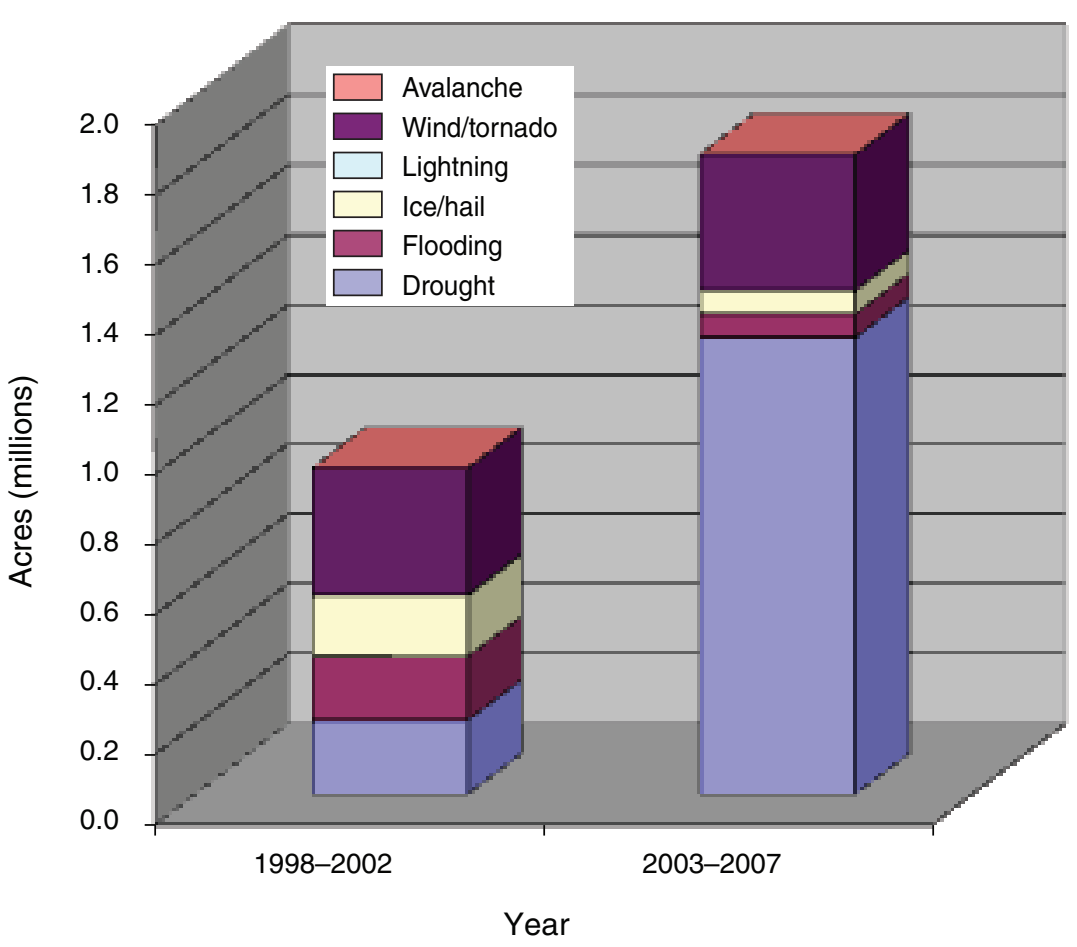

Figure 8.3-Weather-related damage-reference period comparison to current period (Data source: U.S. Department of Agriculture Forest Service 2008a).

year) by 25 percent. Based on model forecasts (fig. 8.5), urban and suburban housing densities will expand to 1.3 percent by 2020 , whereas exurban development will expand to 28.7 percent of the forested area.

Climate change-The effects of climate change confound the impacts of other indicators such as fire, insect mortality, and storm damage. Most biotic disturbance factors have been impacted in complex ways by potential climate change. Tree growth and productivity will also change with increasing temperatures and increased atmospheric carbon concentrations. Lower snowpacks and longer growing seasons may result in increasing growth and productivity in subalpine forests. However, forest productivity may decrease in lower elevation forests owing to water limitations. The highest and coldest alpine (tundra) zones will likely contract significantly with increased temperatures in the Western United States. The boreal and temperate forest zones (primarily conifer dominated) will likely shift up in elevation helping to squeeze the high-elevation zones into smaller domains. The frost-sensitive vegetation of the subtropical zone, including oaks and other woody and ephemeral species, will also likely expand northward and to higher elevations. The expansion of southern species could result in a contraction of the Great Basin shrublands (USDA Forest Service 2008b).

Significant inferences can be made based upon climate data projections, but the direct impacts may not be fully understood. Warming contributes to increasing mortality rates by increasing water deficits and thus drought stress on trees, with possible direct and indirect contributions to tree mortality (van Mantgem and others 2009). Drought-caused tree mortality is immediately noticeable; however changes in productivity and regeneration success of species within their historic range would not be discernable at the 5-year reference period. While drought-induced mortality is monitored and reported under the weather sub-indicator, the drought condition is reported here to account for these additional impacts on productivity and regeneration success. 
Moisture index difference (MID) data (Koch and others 2012) were analyzed as a way to quantify drought conditions for the reference and most recent periods (1998-2002 and 2003-07, respectively) using averages of the annual MID surfaces. For the reference period, a total of $2,497,881$ acres of forest land was in extreme and severe moisture deficit (fig. 8.6). For the most recent period, 1,947,604 acres of forest land were in extreme and severe moisture deficit (fig. 8.7). The area summarized does not appear to match the area reported under the weather sub-indicator for drought-induced mortality. The monitoring of drought conditions does not always relate to the degree of forest health impact.

\section{Summary}

The Montréal Process defines a set of conditions or processes for which forest management may be assessed. A criterion is characterized by a set of related indicators which are monitored to periodically assess change (Montréal Process, 2007). Criterion 3 is the maintenance of forest ecosystem health and vitality of which indicator $3 b(16)$ is the area and percent of forest affected by abiotic agents (e.g., fire, storm, land clearance) beyond reference conditions. Many of these agents have been monitored anecdotally and projections of climate change indicate that if warming continues as anticipated over the next 30 years: the number and severity of large wildfires are likely to increase, the range and frequency of large insect outbreaks are likely to increase, and hurricanes and ice storms are likely to increase. Storm damage can reduce forest productivity

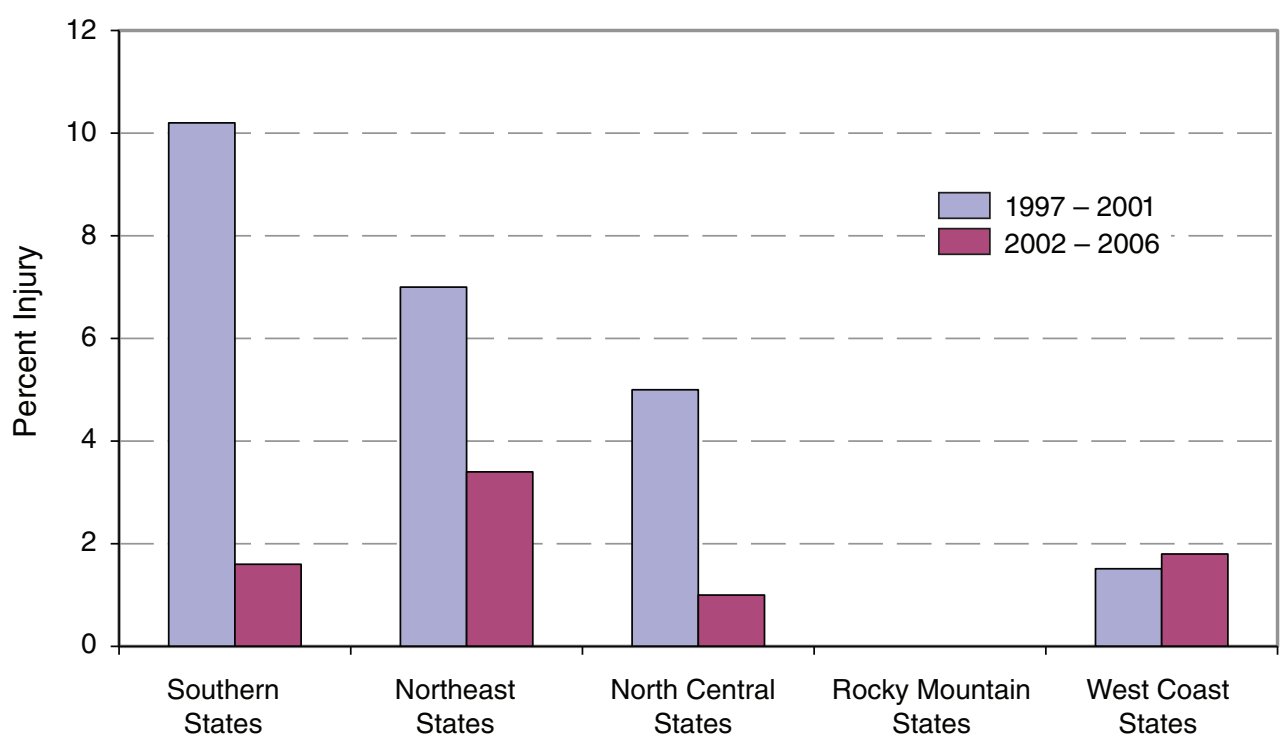

Figure 8.4-Regional comparison of 5-year reference period for ozone plant injury by region (Data source: Smith and others 2008).

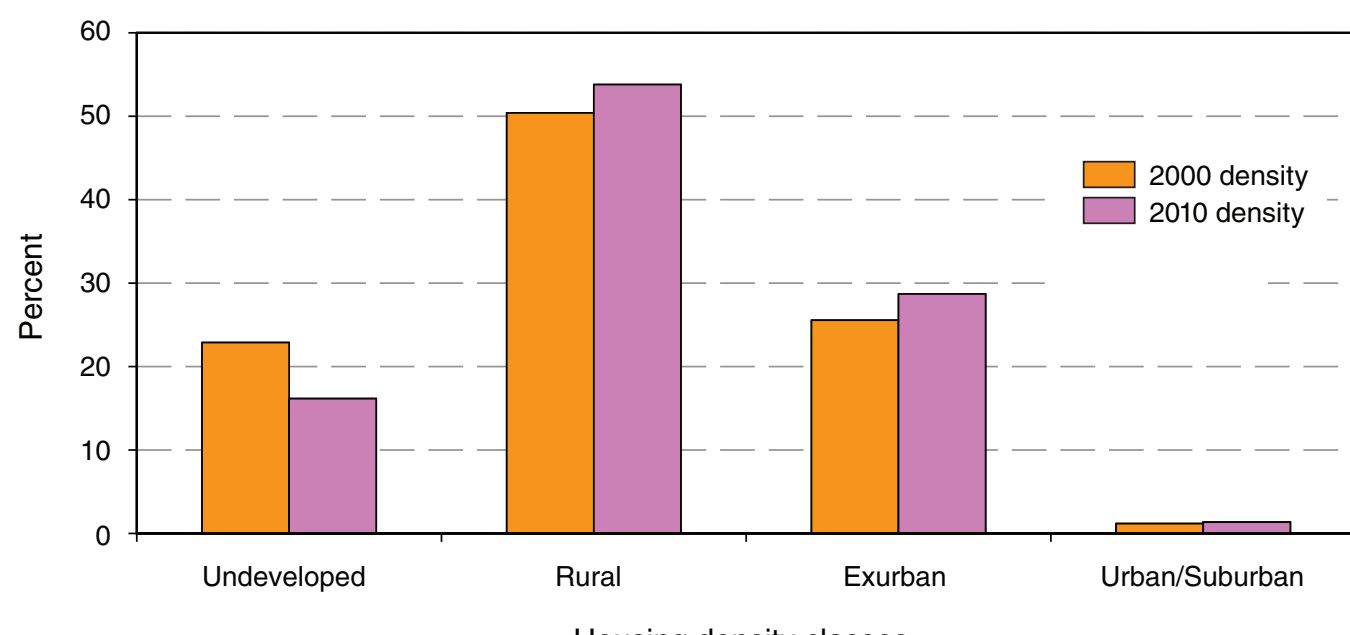

Housing density classes

Figure 8.5-Comparison of projected housing density (Data source: Theobald 2005). 


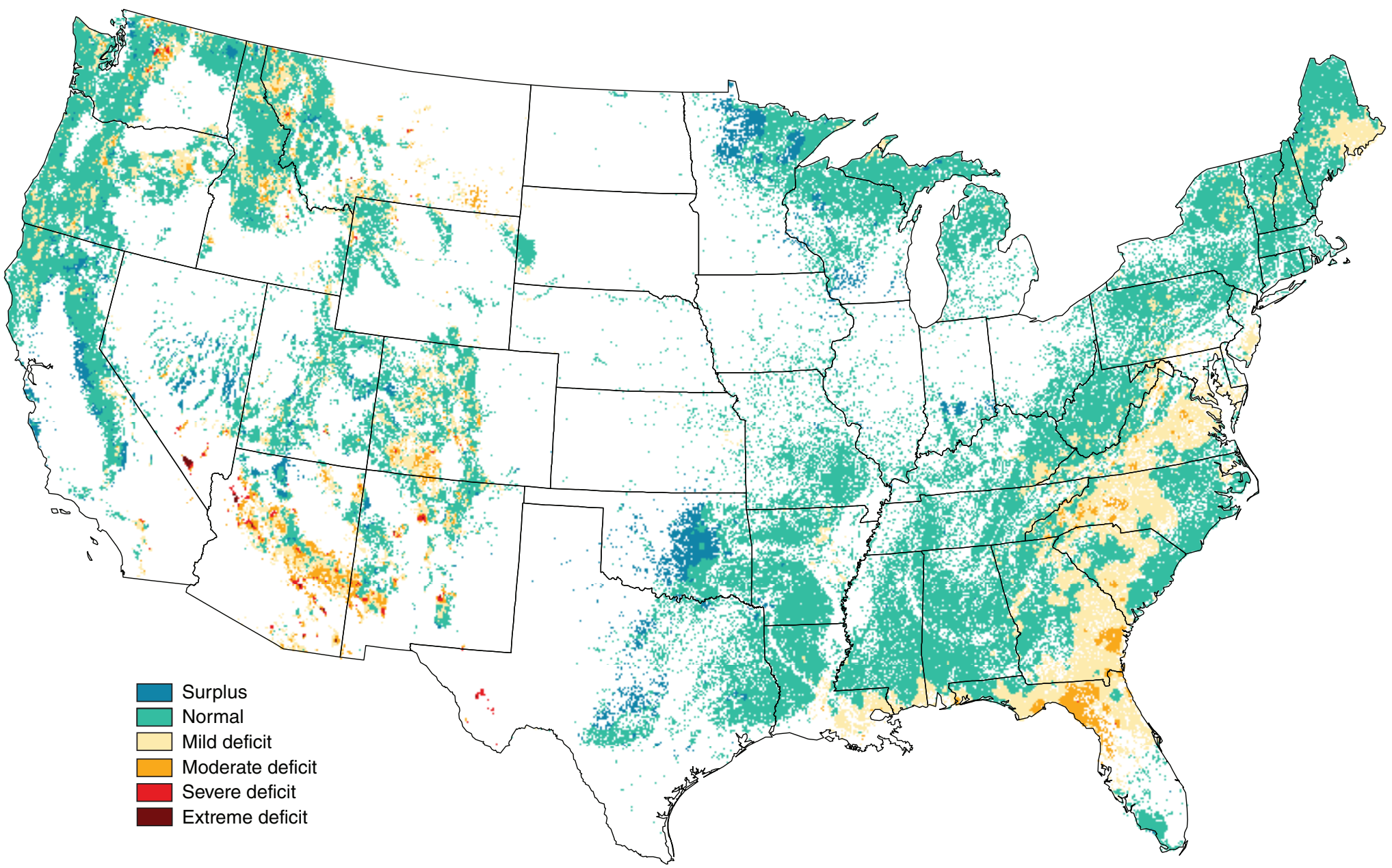

Figure 8.6-Mean moisture index deficit for the reference period, 1998-2002 (Data source: derived from Koch and others 2012). 


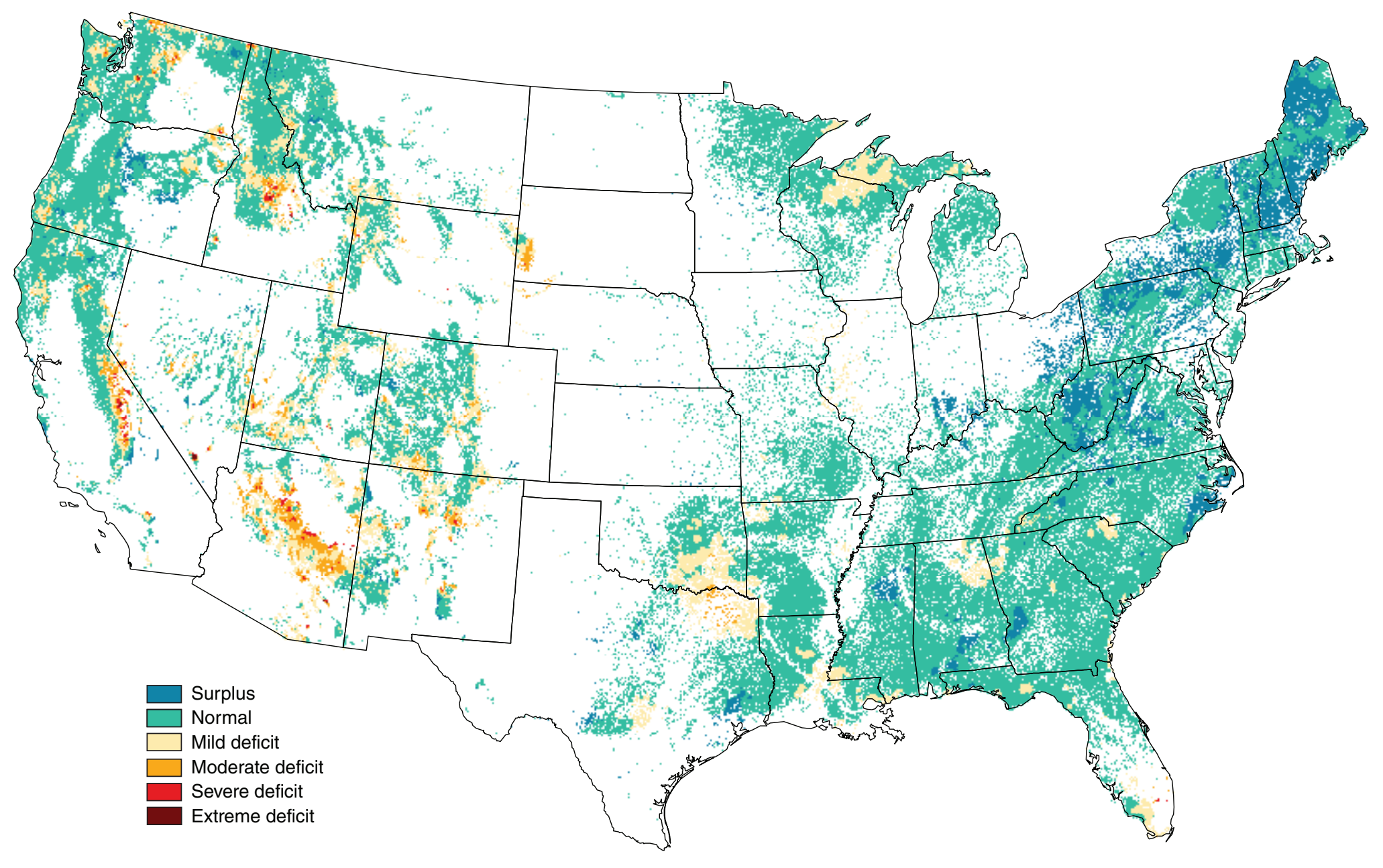

Figure 8.7-Mean moisture index deficit for the most recent period, 2003-07 (Data source: derived from Koch and others 2012). 
and carbon storage (USDA Forest Service 2008b). The intent of this paper was to establish a baseline reference condition from which to monitor these changing conditions, to evaluate the trend, and determine a course for action.

\section{Literature Cited}

Blackard, J.A.; Finco, M.V· Helmer, E.H. [and others]. 2008. Mapping U.S. forest biomass using nationwide forest inventory data and moderate resolution information. Remote Sensing of Environment. 112: 1658-1677.

Eidenshink, J.; Schwind, B.; Brewer, K. [and others]. 2007. A project for monitoring trends in burn severity. Fire Ecology. 3(1): 3-21.

Heinz Center, The. 2008. The state of the Nation's Ecosystems 2008: measuring the lands, waters, and living resources of the United States. Washington, DC: Island Press. 352 p.

Koch, F.H.; Coulston, J.W.; Smith, W.D. 2012. Chapter 4: high-resolution mapping of drought conditions. In: Potter, K.M.; Conkling, B.L., eds. Forest health monitoring: 2008 national technical report. Gen. Tech. Rep. SRS-158. Asheville, NC: U.S. Department of Agriculture Forest Service, Southern Research Station: 45-62.

McNulty, S.G.; Cohen, E.C.; Moore Mayers, J.A. [and others]. 2007. Estimates of critical acid loads and exceedances for forest soils across the conterminous United States. Environmental Pollution. 149: 281-292.

Montréal Process Working Group. 2007. The Montréal Process, third edition. 12 p. http://www.rinya.maff.go.jp/ mpci/rep-pub/1995/santiago_e.html. [Date accessed: May 22, 2008].

Musselman, R.C.; Lefohn, A.S.; Massman, W.J.; Heath, R.L. 2006. A critical review and analysis of the use of exposureand flux-based ozone indices for predicting vegetation effects. Atmospheric Environment. 40(10): 1869-1888.

Omi, P.N.; Martinson, E.J. 2004. Fuel treatments and fire regimes: final report submitted to the Joint Fire Science Program Governing Board. Fort Collins, CO: Western Forest Fire Research Center. Colorado State University. $44 \mathrm{p}$.
Smith, G.C.; Coulston, J.W.; O'Connell, B.M. 2008. Ozone bioindicators and forest health: a guide to the evaluation, analysis, and interpretation of the ozone injury data in the Forest Inventory and Analysis Program. Gen. Tech. Rep. NRS-34. Newtown Square, PA: U.S. Department of Agricluture Forest Service, Northern Research Station. $100 \mathrm{p}$.

Stein, S.M.; McRoberts, R.E.; Alig, R.J. [and others]. 2005 Forests on the edge: housing development on America's private forests. Gen. Tech. Rep. PNW-GTR-636. Portland, OR: U.S. Department of Agriculture Forest Service, Pacific Northwest Research Station. 16 p.

Theobald, D.M. 2005. Landscape patterns of exurban growth in the USA from 1980 to 2020. Ecology and Society. $10(1): 32$.

U.S. Environmental Protection Agency. 1996. Air quality criteria for ozone and related photochemical oxidants. Report Nos. EPA/600/P-93/004aF. National Center for Environmental Assessment-RTP Office. Research Triangle Park, NC: Environmental Protection Agency. 426 p.

U.S. Department of Agriculture (USDA) Forest Service. 2004. National report on sustainable forests-2003. Report FS-766, Washington, DC: U.S. Department of Agriculture Forest Service. 139 p.

U.S. Department of Agriculture (USDA) Forest Service. 2008a. Forest insect and disease conditions in the United States 2007. Washington, DC: U.S. Department of Agriculture Forest Service, Forest Health Protection. 176 p. http://www.fs.fed.us/foresthealth/technology/gis shtml\#ADS. [Date accessed: June 26, 2009].

U.S. Department of Agriculture (USDA) Forest Service. 2008b. Climate change. http://www.fs.fed.us/ climatechange. [Date accessed: June 26, 2009].

U.S. Department of Agriculture (USDA) Forest Service. 2011. National report on sustainable forests-2010. Report FS-979, U.S. Department of Agriculture Forest Service, Washington, DC. $182 \mathrm{p}$.

van Mantgem, P.J.; Stephenson, N.L.; Byrne, J.C. [and others]. 2009. Widespread increase of tree mortality rates in the Western United States. Science. 323: 521-524.

Westerling, A.L.; Hidalgo, H.G.; Cayan, D.R.; Swetnam, T.W. 2006. Warming and earlier spring increase Western U.S. forest wildfire activity. Science. 313: 940-943. 


\section{Introduction}

TTildland fire represents an important ecological mechanism in many forest ecosystems. It shapes the distributions of species, maintains the structure and function of fire-prone communities, and is a significant evolutionary force (Bond and Keeley 2005). At the same time, fire outside the historic range of frequency and intensity can have extensive economic and ecological impacts. More than half the forested area in the conterminous United States is either moderately or significantly altered from historical fire regimes, potentially altering key ecosystem components such as species composition, structural stage, stand age, canopy closure, and fuel loadings (Schmidt and others 2002). Fire suppression and the introduction of nonnative plants, in particular, have dramatically altered natural fire regimes (Barbour and others 1999), while fire regimes altered by global climate change could cause large-scale shifts in vegetation spatial patterns (McKenzie and others 1996).

\section{Methods}

The Moderate Resolution Imaging Spectroradiometer (MODIS) Active Fire Detections for the United States database (USDA Forest Service 2009) allows analysts to spatially display and summarize fire occurrence on a yearly basis (Coulston and others 2005, Potter 2012). Fire occurrences are defined as the satellite detection of wildland fire in a $1-\mathrm{km}^{2}$ pixel for one day, in a given year across the United States. The data are derived using the
MODL and Rapid Response algorithm from the thermal infrared bands of imagery collected daily by two satellites at a resolution of $1 \mathrm{~km}^{2}$, with the center of a pixel recorded as a fire occurrence when the satellites' MODIS sensors identify the presence of a fire at the time of image collection (USDA Forest Service 2009). The data represent only whether a fire was active, because the MODIS sensors do not differentiate between a hot fire in a relatively small area $\left(0.01 \mathrm{~km}^{2}\right.$, for example) and a cooler fire over a larger area $\left(1 \mathrm{~km}^{2}\right.$, for example). The MODIS Active Fire database does well at capturing large fires, but may underrepresent rapidly burning, small and low-intensity fires, as well as fires in areas with frequent cloud cover (Hawbaker and others 2008).

The mean number of fire occurrences per $100 \mathrm{~km}^{2}$ (10 $\left.000 \mathrm{ha}\right)$ of forested area was determined for each ecoregion section in the conterminous United States (Cleland and others 2007) and Alaska (Nowacki and Brock 1995) for each year between 2001 (the first full year of MODIS data) and 2008 (the most recent full year of available data at the time of analysis). This forest fire occurrence density measure was calculated after screening out wildland fires on nonforested pixels using a forest cover layer derived by the Remote Sensing Applications Center of the Forest Service, U.S. Department of Agriculture, from MODIS imagery (USDA Forest Service 2008). The total number of fire occurrences in each year across the conterminous States and Alaska was also calculated.
CRITERION 3-
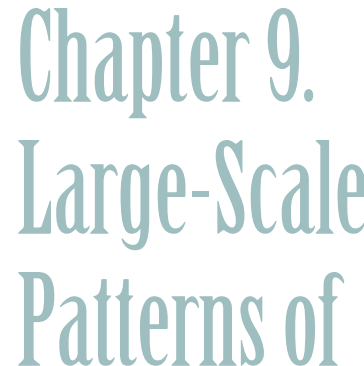

Forest Fire

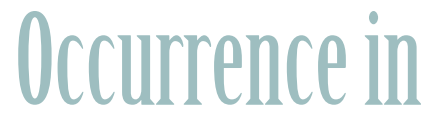
the Conterminous United States and Alaska,

Kevin M. Potter 
Additionally, a Getis-Ord hot spot analysis (Getis and Ord 1992) in ArcMap 9.2 (ESRI 2006) was employed to identify forested areas in the conterminous United States with greater-thanexpected fire occurrence density. A hot spot analysis was conducted for the total number of fire occurrences from 2001 to 2008 , all of the years for which a full 12 months of data were available. Separate hot spot analyses were then conducted for each of the last 4 years of available data, to depict recent annual trends in fire occurrences.

The spatial units of analysis were cells of approximately $2500 \mathrm{~km}^{2}$ from a hexagonal lattice of the conterminous United States, intensified from Environmental Monitoring and Assessment Program (EMAP) North America hexagon coordinates (White and others 1992). This cell size allows for analysis at a mediumscale resolution of approximately the same area as a typical county. Fire occurrence density values for each hexagon were quantified as the number of forest fire occurrences per $100 \mathrm{~km}^{2}$ (10 000 ha) of forested area within the hexagon. For each of the temporal units of analysis, the Getis-Ord $G_{i}{ }^{*}$ statistic was used to identify clusters of hexagonal cells with fire occurrence density values higher than expected by chance.

Briefly, $G_{i}{ }^{*}$ sums the differences between the mean values in a local sample, determined in this case by a moving window of each hexagon and the six neighboring hexagons, and the global mean of all the forested hexagonal cells in the conterminous United States. $G_{i}{ }^{*}$ is standardized as a $z$ score with a mean of 0 and a standard deviation of 1 , with values greater than 1.96 representing significant local clustering of higher fire occurrence densities $(p<0.025)$ and values less than -1.96 representing significant clustering of lower fire occurrence densities $(p<0.025)$, since 95 percent of the observations under a normal distribution should be within approximately 2 standard deviations of the mean (Laffan 2006). Increasingly large values indicated greater spatial clustering of fire occurrence densities. Values between -1.96 and 1.96 have no statistically significant concentration of high or low values; a hexagon and its six neighbors, in other words, have a range of both high and low numbers of fire occurrences per $100 \mathrm{~km}^{2}$ of forested area. The threshold values are not exact because the correlation of spatial data violates the assumption of independence required for statistical significance (Laffan 2006). The GetisOrd approach does not require that the input data be normally distributed because the local $G_{i}{ }^{*}$ values are computed under a randomization assumption, with $G_{i}{ }^{*}$ equating to a standardized $z$ score that asymptotically tends to a normal distribution (Anselin 1992). The $z$ scores are reliable, even with skewed data, as long as the distance band is large enough to include several neighbors for each feature (ESRI 2006). 


\section{Results and Discussion}

The MODIS Active Fire database captured 94,825 wildland forest fire occurrences across the conterminous United States in 2008, the most since the initial collection of MODIS data in 2000, and more than double the 8-year mean of 44,837 forest fire occurrences (fig. 9.1). Meanwhile, the database captured only 1,220 fire occurrences in Alaska, much lower than the peak fire year of 2004, when MODIS recorded 51,871 fire occurrences in Alaska. The patterns of fire occurrences in the conterminous United States and Alaska are considerably different, with the most fires occurring in the conterminous United States in 2006, 2007, and 2008, while the peak fire years in Alaska were 2004 and 2005 (fig. 9.1). This peak in Alaska fire occurrences coincides with two relatively lowfire years in the conterminous United States, where fewer fire occurrences were recorded than in Alaska.

Over the 8-year period during which MODIS fire occurrence data have been recorded, ecoregion section 261 A-Central California Coast has experienced the most fires per year, 12.78 fires per $100 \mathrm{~km}^{2}$ of forested area (fig.9.2A). Other ecoregion sections with high mean fire occurrence densities are M332F-Challis Volcanics

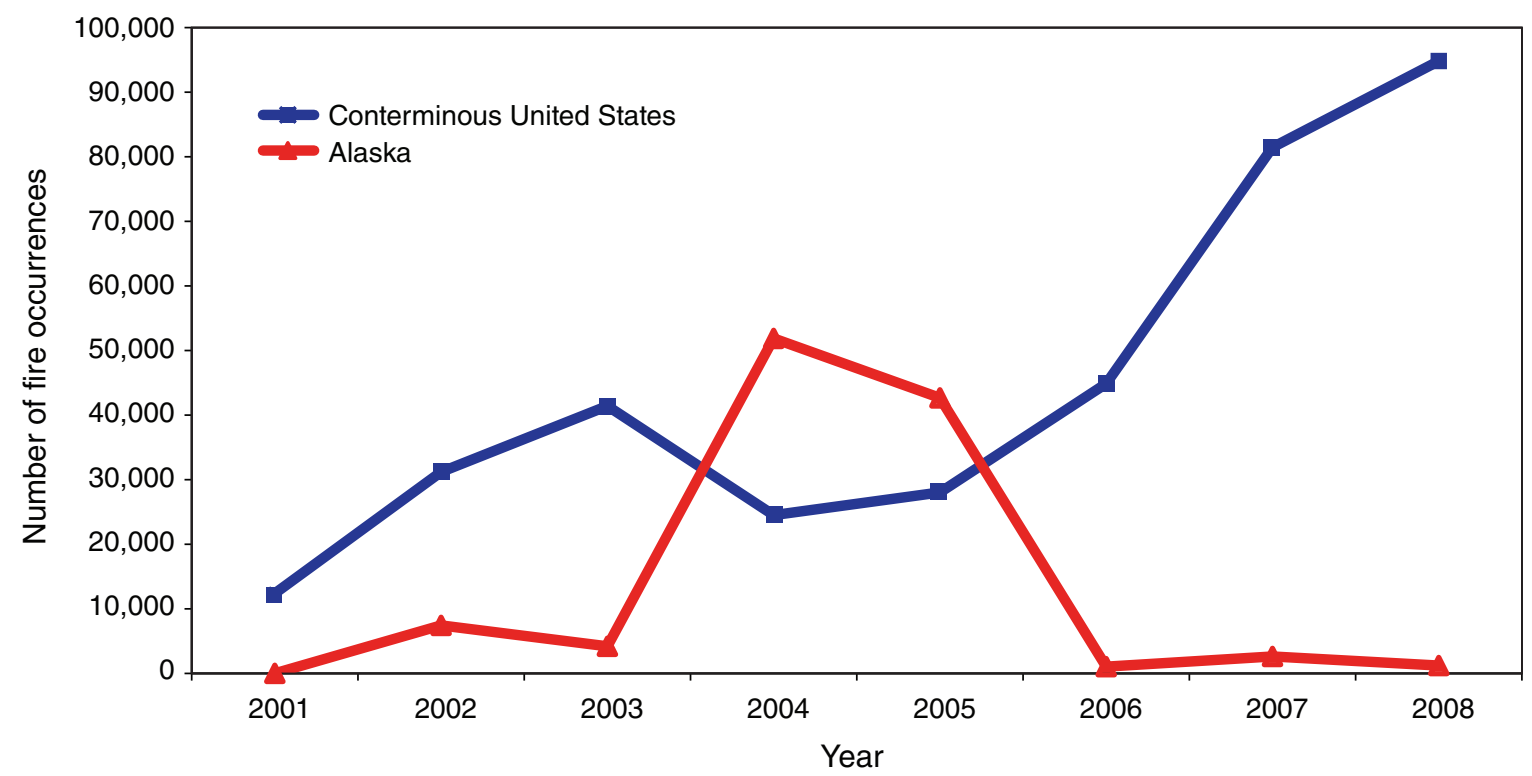

Figure 9.1-Forest fire occurrences detected by MODIS from 2001 to 2008, for the conterminous United States and Alaska (Data source: U.S. Department of Agriculture Forest Service, Remote Sensing Applications Center.) 


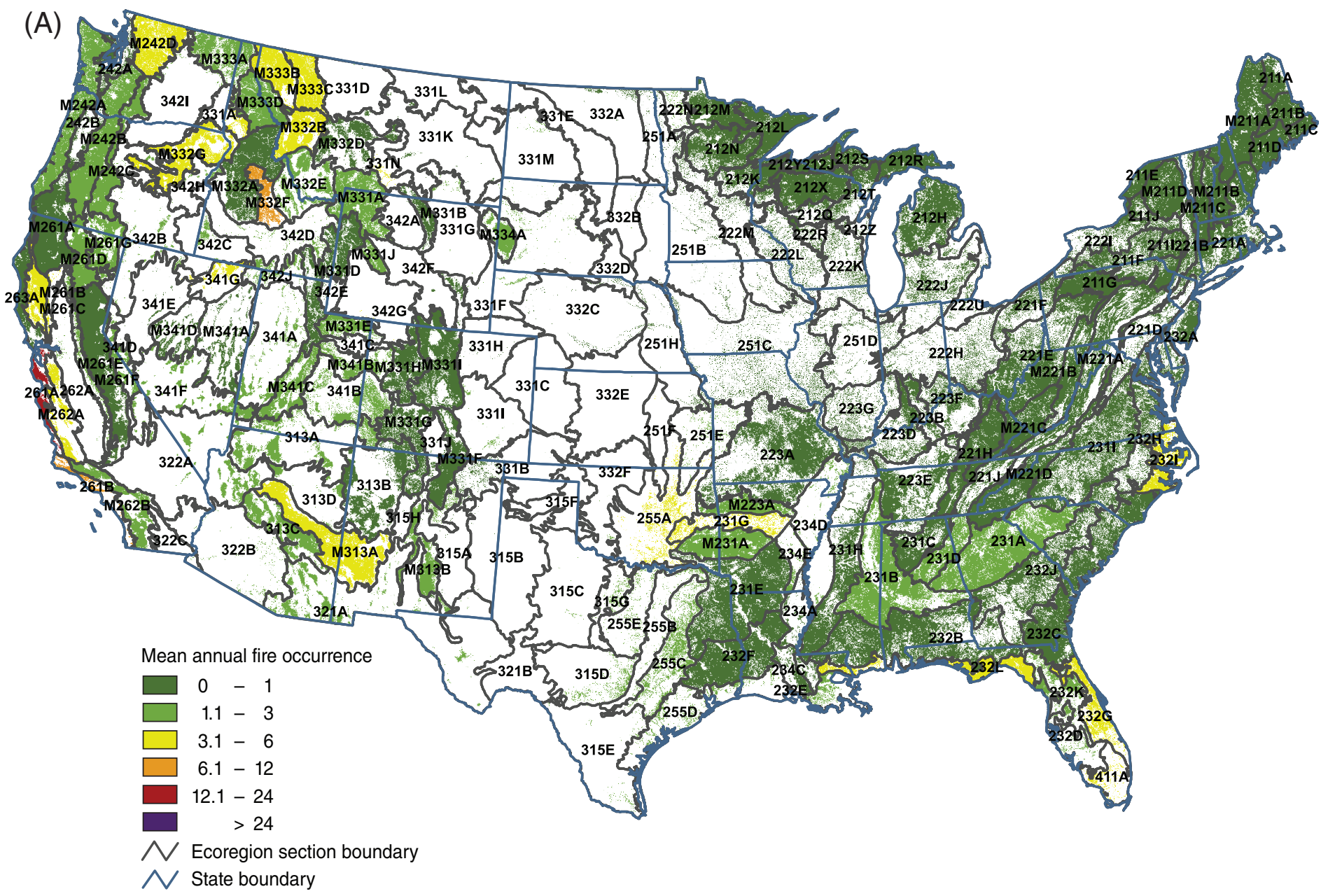

Figure 9.2-The mean annual number of forest fire occurrences, per $100 \mathrm{~km}^{2}(10000 \mathrm{ha})$ of forested area, by ecoregion section (Cleland and others 2007) within the conterminous United States, for (A) 2001-08, (B) 2003-05 and (C) 2006-08. The gray lines delineate ecoregion sections (Cleland and others 2007). Forest cover is derived from MODIS imagery by the U.S. Forest Service Remote Sensing Applications Center. (Source of fire data: U.S. Department of Agriculture Forest Service, Remote Sensing Applications Center.) (continued on next page) 


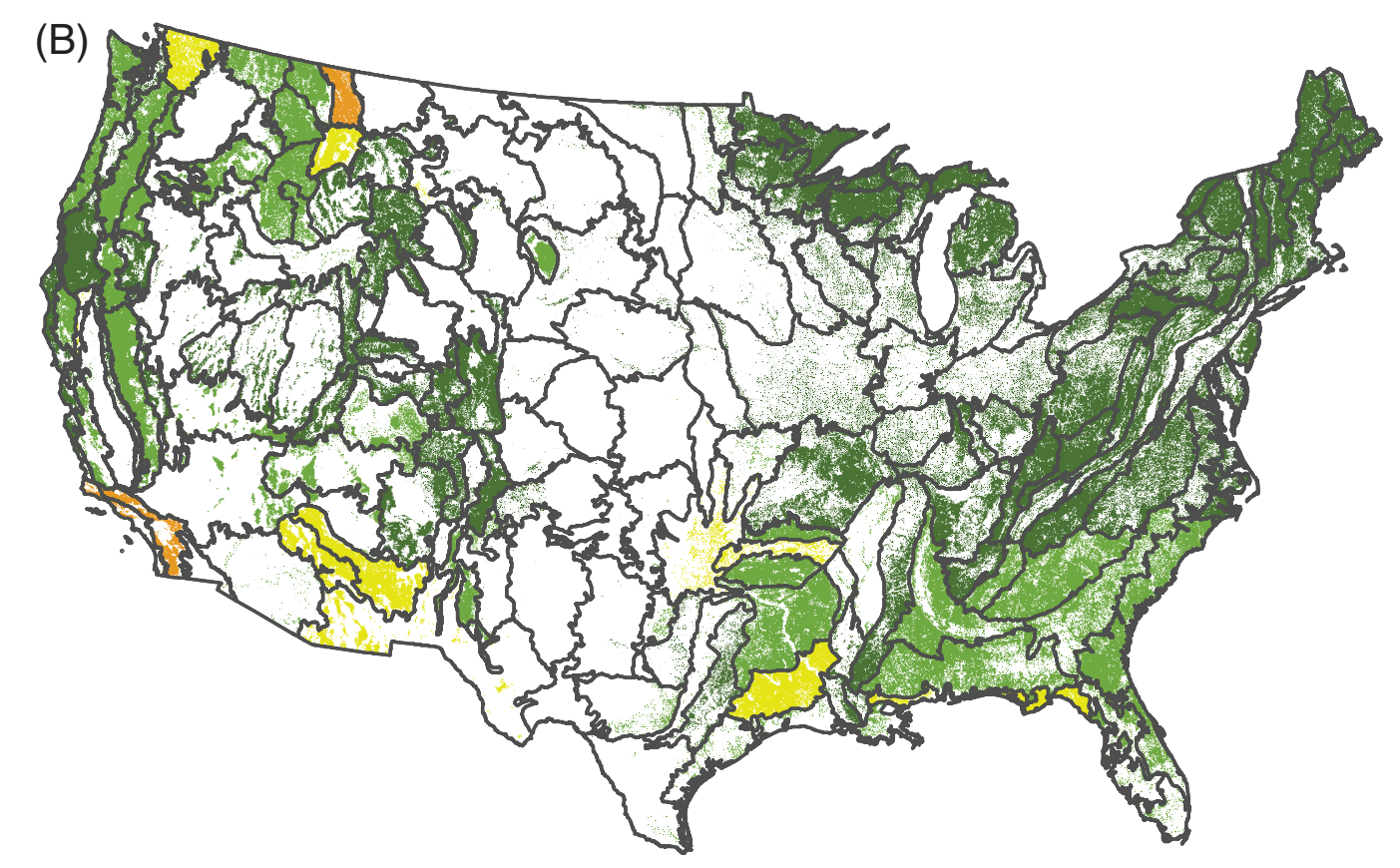

in central Idaho, with 6.14 fires per year per 100 $\mathrm{km}^{2}$ of forest; 261B-Southern California Coast, with 6.02; and M261B-Northern California Coast Ranges with 5.98 fires. Ecoregion sections with moderate fire occurrence densities are generally located in the northern Rocky Mountains, the Southeast, and the Southwest.

An ecoregion-level comparison of fire occurrence densities during 2003-05 and 2006-08 reveals a large increase in the number of fires in several ecoregion sections (fig. 9.2B and fig. 9.2C). From 2003 to 2005, 16 sections had more than three fire occurrences per year per $100 \mathrm{~km}^{2}$ of forest, while 3 sections had more than six fires per year for that amount of forest, compared to 52 and 20 sections, respectively, for 2006-08. The Central California Coast averaged a remarkable 33.18 fire occurrences each year per $100 \mathrm{~km}^{2}$ of forest from 2006 to 2008 .

In Alaska, the highest fire occurrence densities over the 8 years of MODIS data collection were recorded in the four ecoregion sections of the 139-Upper Yukon Taiga Province, particularly 139A-Yukon Flats and M139A-Ray Mountains (fig. 9.3A). In contrast to the pattern in the

Figure 9.2 (continued)-The mean annual number of forest fire occurrences, per $100 \mathrm{~km}^{2}$ (10 $000 \mathrm{ha}$ ) of forested area, by ecoregion section (Cleland and others 2007) within the conterminous United States, for (B) 2003-05 and (C) 2006-08. The gray lines delineate ecoregion sections (Cleland and others 2007). Forest cover is derived from MODIS imagery by the U.S. Forest Service Remote Sensing Applications Center. (Source of fire data: U.S. Department of Agriculture Forest Service, Remote Sensing Applications Center.) 


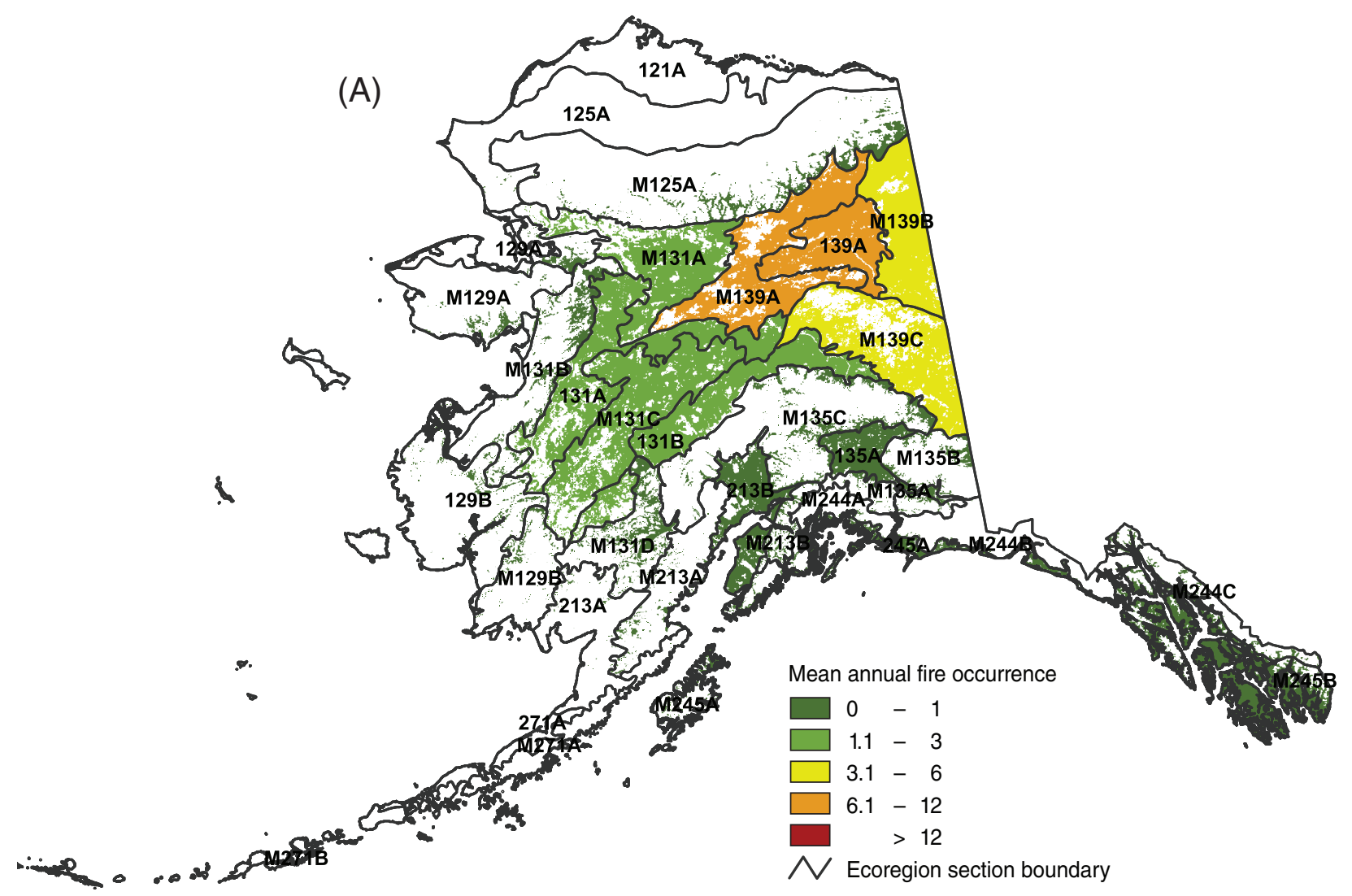

Figure 9.3-The mean annual number of forest fire occurrences, per $100 \mathrm{~km}^{2}(10000 \mathrm{ha})$ of forested area, by ecoregion section (Nowacki and Brock 1995) within Alaska, for (A) 2001-08, (B) 2003-05, and (C) 2006-08. The gray lines delineate ecoregion sections. Forest cover is derived from MODIS imagery by the U.S. Forest Service Remote Sensing Applications Center. (Source of fire data: U.S. Department of Agriculture Forest Service, Remote Sensing Applications Center.) (continued on next page) 

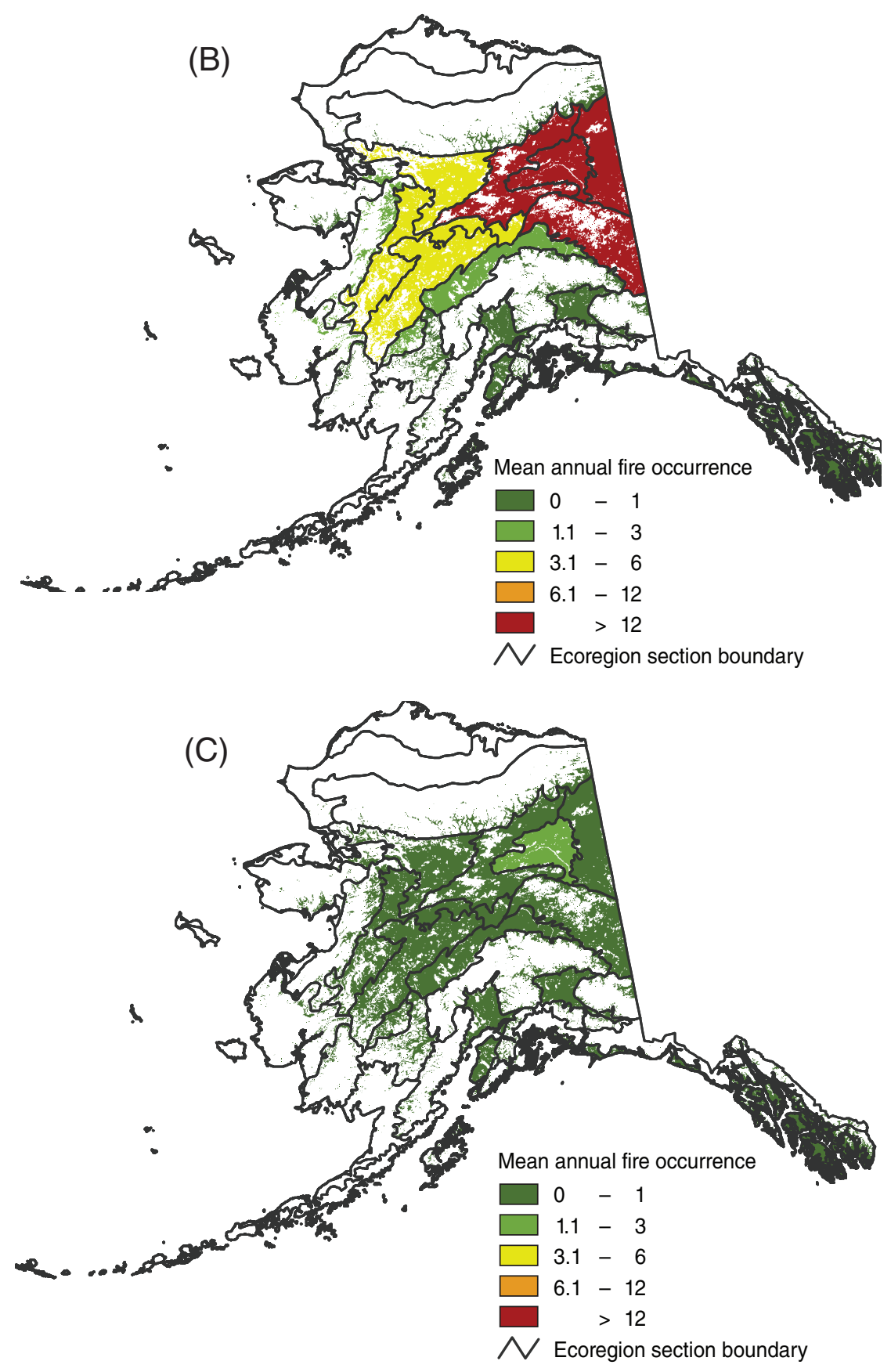

Figure 9.3 (continued)-The mean annual number of forest fire occurrences, per $100 \mathrm{~km}^{2}$ (10 $000 \mathrm{ha}$ ) of forested area, by ecoregion section (Nowacki and Brock 1995) within Alaska, for (B) 2003-05, and (C) 200608. The gray lines delineate ecoregion sections. Forest cover is derived from MODIS imagery by the U.S. Forest Service Remote Sensing Applications Center. (Source of fire data: U.S. Department of Agriculture Forest Service, Remote Sensing Applications Center.) 
conterminous United States, the fire occurrence densities were much greater in the period of 2003-05 (fig. 9.3B) than in 2006-08 (fig. 9.3C). During the earlier period, seven ecoregions averaged more than six fire occurrences per year per $100 \mathrm{~km}^{2}$ of forest, with four ecoregions averaging more than 12 fires. During the later period, only one ecoregion (139A-Yukon Flats) averaged more than one fire occurrence per $100 \mathrm{~km}^{2}$ of forest.

While summarizing fire occurrence data at the ecoregion scale allows for the summary of fire density over time in a relatively large geographic area, a geographical hot spot analysis can offer insights into where fire occurrences are concentrated at a finer scale during a given length of time.

Across the 8-year period during which MODIS fire detection data were collected, geographical hot spots of fire occurrence density were limited almost entirely to the Pacific Coast, the Rocky Mountains, and the Southeastern Coastal

Plain (fig. 9.4). Four of the highest-density hot spots were located in California, while another three were spread across the northern Rocky Mountains, in M333A-Okanogan Highlands in
Washington, M332A-Idaho Batholith, and M332F-Challis Volcanics in Idaho, and M331I-Northern Parks and Ranges in Wyoming. New high-density hot spots were detected in 2008 on the central coast of California, in coastal North Carolina, and in west Texas (fig. 9.5D), compared to hot spots from the 3 previous years (fig. 9.5A-C). Lower-density hot spots during that year were located in the central and southern Sierra Nevada of California; in south Florida; and in the Gulf Coastal Plains of northwest Florida, southwestern Georgia, and southeastern Alabama.

The results of these hot spot analyses are intended to offer insights into where fire occurrences have been concentrated both over time and during specific years. They are not intended to quantify the severity of a given fire season. When considered across multiple years, information about the concentration of fire occurrences may be useful for the identification of areas for management activities and for follow-up investigations related to the ecological, economic, and sociological impact of fires that may be outside the range of historic frequency. 


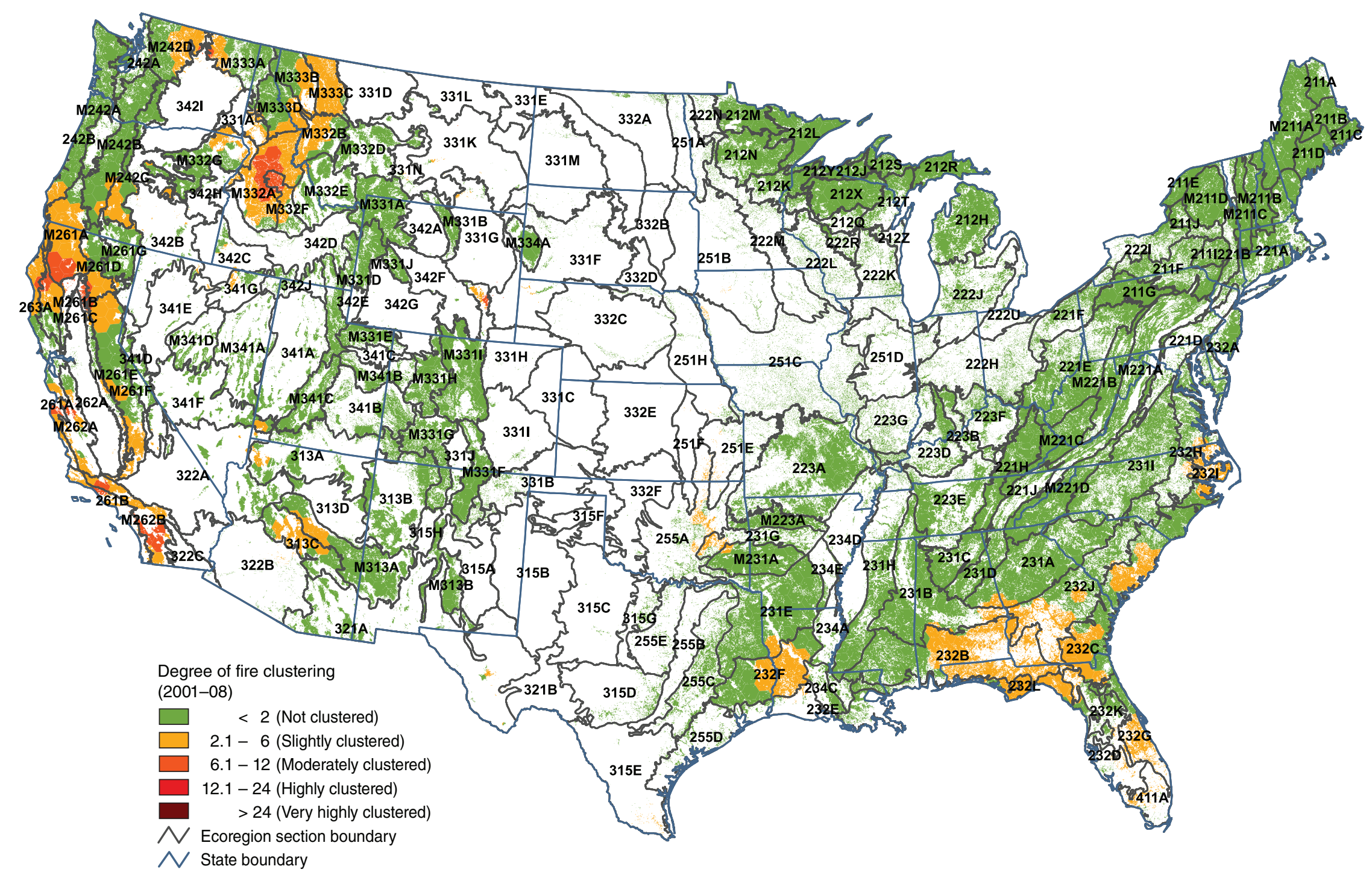

Figure 9.4-Hot spots of high fire occurrence density across the conterminous United States for the years 2001-08. Values are Getis-Ord $\mathrm{G}_{\mathrm{i}}{ }^{*}$ scores, with values greater than 2 representing strong and significant clustering of high fire occurrence densities. (No areas of significant clustering of low fire occurrence densities, less than -2, were detected.) The gray lines delineate ecoregion sections (Cleland and others 2007). Background forest cover is derived from MODIS imagery by the U.S. Forest Service Remote Sensing Applications Center. (Source of fire data: U.S. Department of Agriculture Forest Service, Remote Sensing Applications Center.) 
Figure 9.5-Hot spots of high fire occurrence across the conterminous United States for (A) 2005, (B) 2006, (C) 2007, and (D) 2008. Values are Getis-Ord $\mathrm{G}_{\mathrm{i}}{ }^{*}$ scores, with values greater than 2 representing strong and significant clustering of high fire occurrence densities. (No areas of significant clustering of low fire occurrence densities, less than -2 , were detected.) The gray lines delineate ecoregion sections (Cleland and others 2007). Background forest cover is derived from MODIS imagery by the U.S. Forest Service Remote Sensing Applications Center. (Source of fire data: U.S. Department of Agriculture Forest Service, Remote Sensing Applications Center.) (continued on next page)

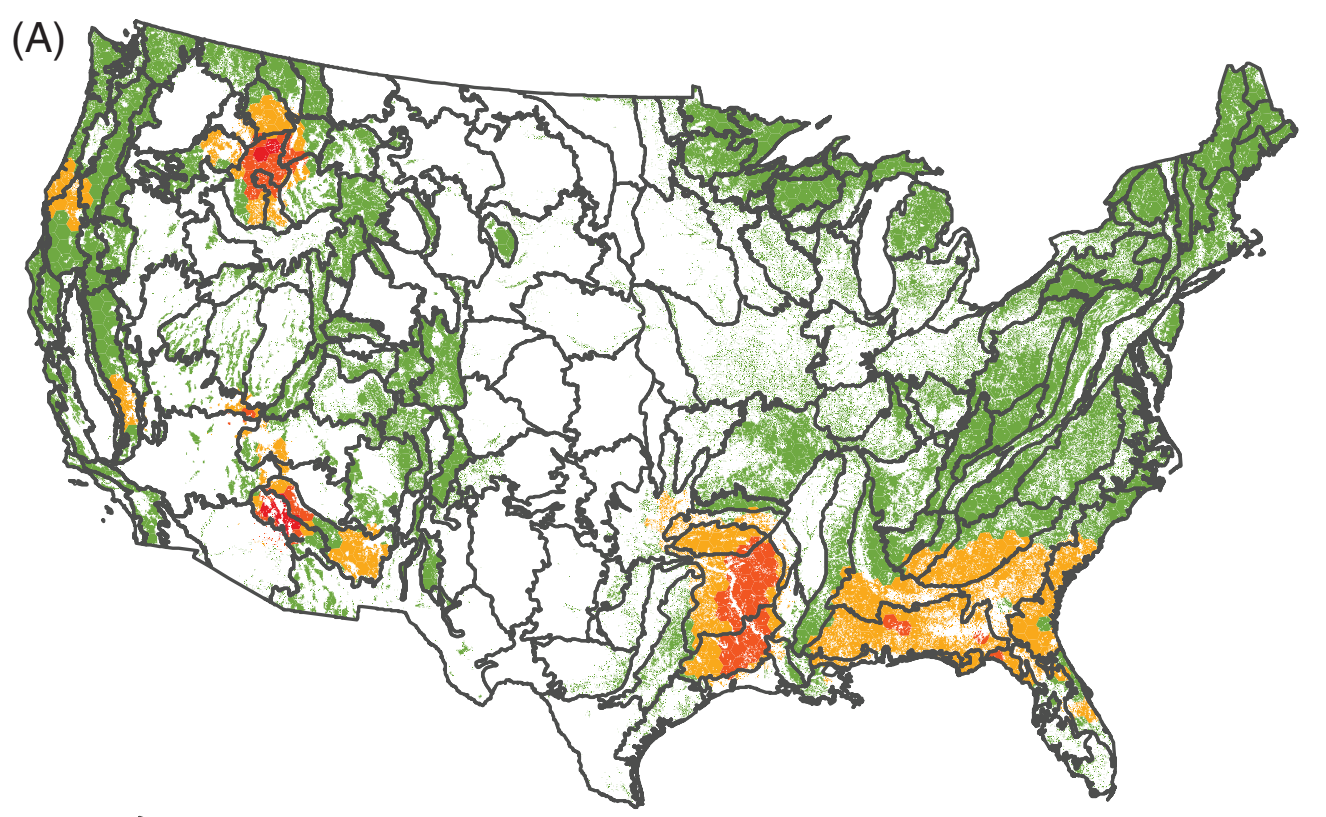

(B)

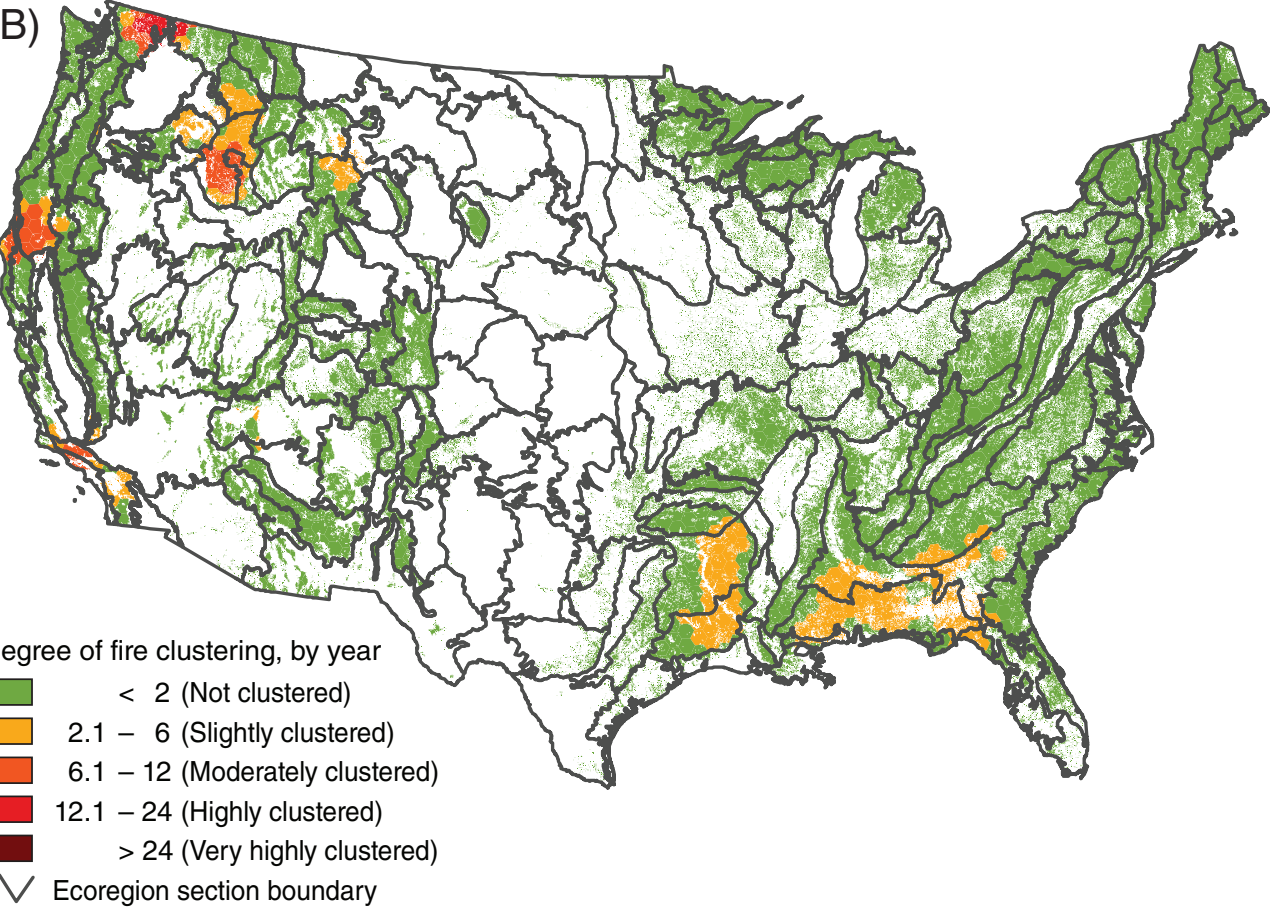



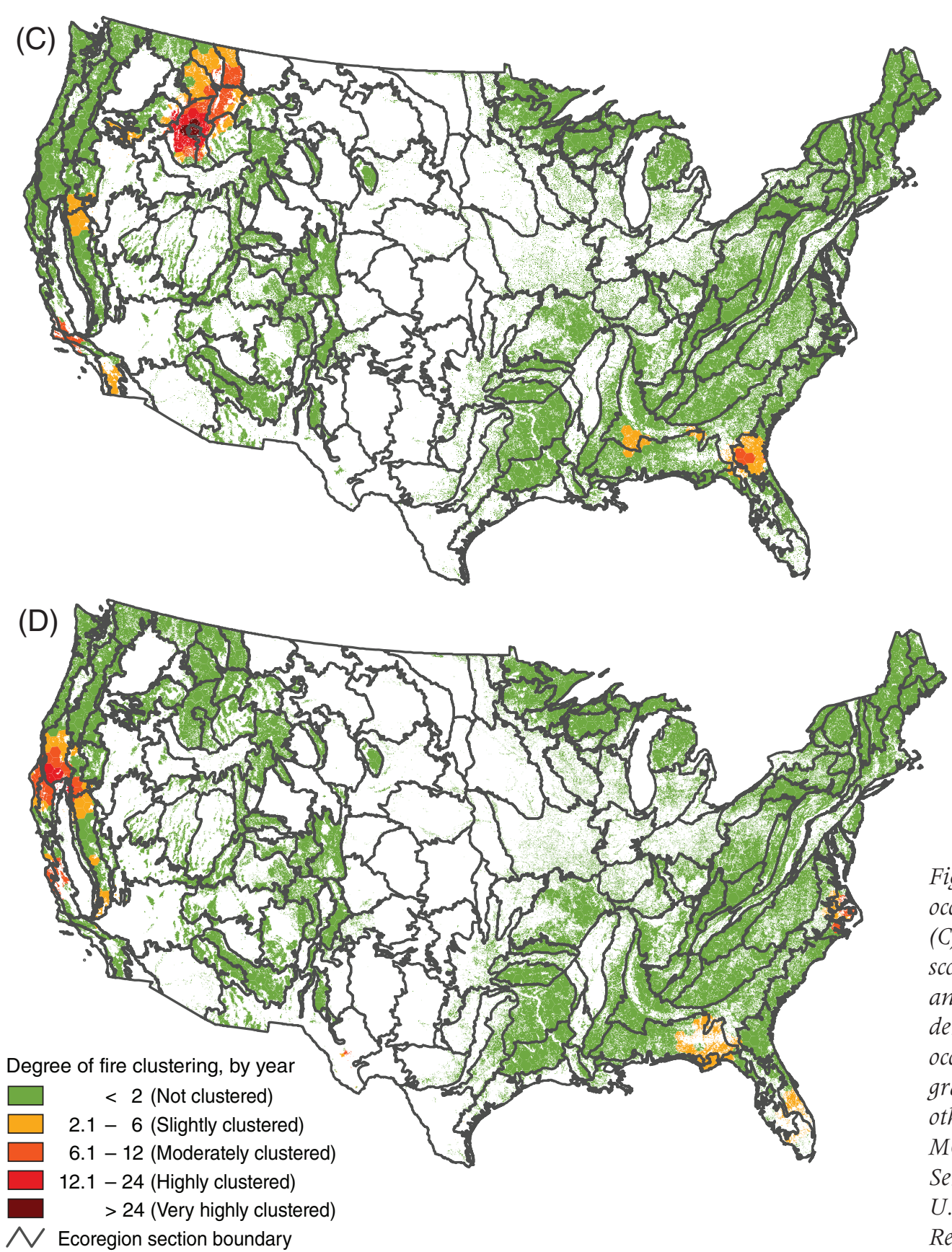

Figure 9.5 (continued) - Hot spots of high fire occurrence across the conterminous United States for (C) 2007, and (D) 2008. Values are Getis-Ord $\mathrm{G}_{\mathrm{i}}{ }^{*}$ scores, with values greater than 2 representing strong and significant clustering of high fire occurrence densities. (No areas of significant clustering of low fire occurrence densities, less than -2, were detected.). The gray lines delineate ecoregion sections (Cleland and others 2007). Background forest cover is derived from MODIS imagery by the U.S. Forest Service Remote Sensing Applications Center. (Source of fire data: U.S. Department of Agriculture Forest Service, Remote Sensing Applications Center.) 


\section{Literature Cited}

Anselin, L. 1992. Spatial data analysis with GIS: An introduction to application in the social sciences. Technical Report 92-10. Santa Barbara, CA: National Center for Geographic Information and Analysis. 53 p.

Barbour, M.G.; Burk, J.H.; Pitts, W.D. [and others]. 1999. Terrestrial plant ecology. Menlo Park, CA: Addison Wesley Longman, Inc. 649 p.

Bond, W.J.; Keeley, J.E. 2005. Fire as a global 'herbivore': the ecology and evolution of flammable ecosystems. Trends in Ecology \& Evolution. 20(7): 387-394.

Cleland, D.T.; Freeouf, J.A.; Keys, J.E. [and others]. 2007. Ecological subregions: sections and subsections for the conterminous United States. Gen. Tech. Report WO-76. Sloan, A.M., tech. ed. Washington, DC: U.S. Department of Agriculture Forest Service. Map, presentation scale

1:3,500,000; Albers equal area projection; colored. Also as a GIS coverage in ArcINFO format on CD-ROM or at http://fsgeodata.fs.fed.us/other_resources/ecosubregions. html. [Date accessed: March 18, 2011]

Coulston, J.W.; Ambrose, M.J.; Riitters, K.H.; Conkling, B.L. 2005. Forest health monitoring 2004 national technical report. Gen. Tech. Rep. SRS-90. Asheville, NC: United States Department of Agriculture Forest Service, Southern Research Station. $81 \mathrm{p}$

ESRI. 2006. ArcMap 9.2. Redlands, CA: Environmental Systems Research Institute Inc.

Getis, A.; Ord, J.K. 1992. The analysis of spatial association by use of distance statistics. Geographical Analysis. 24(3): 189-206.

Hawbaker, T.J.; Radeloff, V.C.; Syphard, A.D. [and others]. 2008. Detection rates of the MODIS active fire product. Remote Sensing of Environment. 112: 2656-2664.
Laffan, S.W. 2006. Assessing regional scale weed distributions, with an Australian example using Nassella trichotoma. Weed Research. 46(3): 194-206.

McKenzie, D.; Peterson, D.L.; Alvarado, E. 1996. Predicting the effect of fire on large-scale vegetation patterns in North America. Res. Pap. PNW-RP-489. United States Department of Agriculture Forest Service, Pacific Northwest Research Station. 38 p.

Nowacki, G.; Brock, T. 1995. Ecoregions and subregions of Alaska, EcoMap Version 2.0. Juneau, AK: U.S. Department of Agriculture Forest Service, Alaska Region. Map, presentation scale 1:5,000,000; colored.

Potter, K.M. 2012. Chapter 6: large-scale patterns of forest fire occurrence in the conterminous United States and Alaska, 2005-2007. In: Potter, K.M.; Conkling, B.L., eds. Forest health monitoring: 2008 national technical report. Gen. Tech. Rep. SRS-158. Asheville, NC: U.S. Department of Agriculture Forest Service, Southern Research Station. $179 \mathrm{p}$.

Schmidt, K.M.; Menakis, J.P.; Hardy, C.C. [and others]. 2002 Development of coarse-scale spatial data for wildland fire and fuel management. Gen. Tech. Rep. RMRS-GTR-87. Fort Collins, CO: United States Department of Agriculture Forest Service, Rocky Mountain Research Station. 41 p.

U.S. Department of Agriculture (USDA) Forest Service. 2008 National forest type data development. http://svinetfc4.

fs.fed.us/rastergateway/forest type/. [Date accessed: May 13, 2008].

U.S. Department of Agriculture (USDA) Forest Service. 2009. MODIS Active Fire Mapping Program: continental United States fire detection GIS data. http://activefiremaps.fs.fed. us/gisdata.php. [Date accessed: February 2, 2009].

White, D.; Kimerling, A.J.; Overton, W.S. 1992. Cartographic and geometric components of a global sampling design for environmental monitoring. Cartography and Geographic Information Systems. 19(1): 5-22. 


\section{Introduction}

rought, especially persistent drought, may impact forests in direct and indirect ways. Low to moderate drought stress directly reduces plant growth processes at the cellular level, while more severe stress also substantially diminishes photosynthesis (Kareiva and others 1993, Mattson and Haack 1987). Indirectly, forest communities subjected to drought stress may be more susceptible to infestations, and in some cases major outbreaks, of tree-damaging insects (Mattson and Haack 1987). Furthermore, drought impedes decomposition of organic matter and reduces moisture content in woody debris and other potential fire fuels, substantially heightening wildland fire risk (Clark 1989 , Keetch and Byram 1968, Schoennagel and others 2004).

During the past several decades, a number of indices have been created to monitor drought conditions in the United States. The Palmer Drought Severity Index (PDSI) (Palmer 1965) is the most prominent, but others such as the Palmer Hydrologic Drought Severity Index or the Crop Moisture Index have been developed to highlight particular aspects or impacts of drought stress (Keyantash and Dracup 2002). Several spatially referenced data products are available that employ one or more of these indices. For instance, the National Climatic Data Center (NCDC) releases monthly PDSI data for each climate division in the conterminous United States (National Climatic Data Center 2007), while the U.S. Drought Monitor project releases weekly contour maps that blend the PDSI and other drought indices with daily streamflow percentiles and a remote sensing-derived vegetation health index (Svoboda and others 2002).

Such products are useful for coarse-scale reporting, but are typically inadequate for finer-scale analyses. For this reason, in the 2008 national technical report by the Forest Health Monitoring (FHM) Program of the Forest Service, U.S. Department of Agriculture, we outlined a methodology for mapping drought stress using historical, high-resolution climate data (Koch and others 2012). Briefly, we developed annual moisture index maps for the conterminous United States using gridded climate data (approximately $4-\mathrm{km}^{2}$ spatial resolution) created with the Parameter-elevation Regression on Independent Slopes (PRISM) climate mapping system (Daly and others 2002). In contrast to maps of annual precipitation amount, these moisture index maps documented the relationship between precipitation and potential evapotranspiration (i.e., the water balance) for each year. Then, for 1908-2007, we calculated per-map-cell differences between each year's moisture index map and a corresponding long-term normal (i.e., 100-year mean) moisture index map. Based on these difference values as well as characteristics of their statistical distribution through time, we assigned each map cell to one of nine categories ranging from extreme wetness to extreme drought, thus allowing us to create national maps of drought conditions for each year in the study period.
CRITERION 3Chapter 10 . Mapping Drought Conditions Using Multi-Year Windows

\section{Frank H. Koch}

John W. Coulston

William D. Smith 
Recent evidence suggests that multiple consecutive years of drought (2-5 years) are more likely to result in high tree mortality than a single dry year (Guarín and Taylor 2005, Millar and others 2007). Therefore, to provide a more realistic characterization of drought impact in forested areas, we expanded our methodology to examine moisture conditions over longer (i.e., multi-year) time windows. As in our previous analysis, we have assembled historical and recent examples that illustrate the new methodology and its interpretability.

\section{Methods}

When we performed these analyses, monthly PRISM grids for total precipitation, mean daily minimum temperature, and mean daily maximum temperature were available from the PRISM group Web site (PRISM Group 2009) for all years from 1895 to 2007 . We did not include 2008 in our analyses because monthly grids for most of the year were not yet available at the time of analysis.

\section{Calculating a Moisture Index-In our} previous work (Koch and others 2012), we employed a modified moisture index $\left(M I^{\prime}\right)$ described by Willmott and Feddema (1992):

$$
M I^{\prime}=\left\{\begin{array}{cc}
P / P E T-1 & , \quad P<P E T \\
1-P E T / P, & P \geq P E T \\
0, & P=P E T=0
\end{array}\right.
$$

where

$$
P=\text { precipitation }
$$

$P E T=$ potential evapotranspiration, in equivalent units

$M I^{\prime}=$ is a dimensionless index scaled between -1 and 1 .

( $P$ and $P E T$ must be in equivalent measurement units, e.g., $\mathrm{mm}$ )

Potential evapotranspiration measures soil moisture loss due to plant uptake and transpiration (Akin 1991). Rather than actual moisture loss, it estimates the loss that would occur given ideal conditions (i.e., if there was unlimited moisture for plants to transpire) (Akin 1991, Thornthwaite 1948). By considering both precipitation and potential evapotranspiration, the $M I^{\prime}$ is designed to provide a reasonable representation of the water balance for locations of interest.

To create $M I^{\prime}$ maps for all months in our study time period (1904-2007), we first had to generate monthly potential evapotranspiration grids to complement the PRISM monthly precipitation grids for the conterminous United States. We calculated potential evapotranspiration for each month using the Thornthwaite formula (Akin 1991,

Thornthwaite 1948): 


$$
P E T_{m}=1.6 L\left(10 \frac{T_{m}}{I}\right)^{a}
$$

where

$P E T_{m}=$ the potential evapotranspiration for a given month $m$ in $\mathrm{cm}$

$L=$ a correction factor for the hours of daylight and number of days in a month for all locations at a particular latitude

$T_{m}=$ the mean temperature for month $m$ in ${ }^{\circ} \mathrm{C}$

$I=$ an annual heat index, calculated as $I=\sum_{i=1}^{12}\left(\frac{T_{i}}{5}\right)^{1.514}$, where $T_{i}$ is the mean temperature in ${ }^{\circ} \mathrm{C}$ for each month $i$ of the year

$a=$ an arbitrary exponent calculated by $a=$ $6.75 \times 10^{-7} I^{3}-7.71 \times 10^{-5} I^{2}+1.792 \times 10^{-2} I+$ 0.49239

To implement equation 2 spatially, we created a grid of latitude values for determining the $L$ adjustment for any given $4-\mathrm{km}^{2}$ grid cell in the conterminous United States [see Thornthwaite (1948) for a table of $L$ correction factors]. For $T_{m^{\prime}}$ we calculated mean monthly temperature grids as the mean of the corresponding PRISM daily minimum and maximum monthly temperature grids.
Moisture Index Maps for Multi-year Time Windows-We applied equation 1 to calculate $M I^{\prime}$ from the precipitation and potential evapotranspiration grids for each month in the study time period. However, unlike in our prior effort (Koch and others 2012), where we afterward calculated an annual $M I^{\prime}$ as the mean of the 12 monthly $M I^{\prime}$ values in a given year, we instead calculated a 5-year moisture index $\left(\mathrm{MI}_{5}{ }^{\prime}\right.$ hereafter) as the mean of 60 consecutive monthly $M I^{\prime}$ values (i.e., the mean over a time window extending from January of the first year in the window to December in the fifth year). In addition, we constructed a "normal" 5-year $\mathrm{MI}_{5}{ }^{\prime}$ grid as the mean of the 100 individual $M I_{5}{ }^{\prime}$ grids for all 5-year time windows between 1904-08 and 2003-07.

\section{Drought Category Thresholds and Probabilities Based on Moisture Index \\ Difference-We created moisture index} difference $\left(M D_{5}\right)$ grids by subtracting the long-term normal $M I_{5}{ }^{\prime}$ grid from the $M I_{5}{ }^{\prime}$ grid for each 5-year time window in the study period. Drought occurrence may be regarded as a stochastic phenomenon (Weber and Nkemdirim 1998). Hence, we assumed $M I D_{5}$ to be a temporally random variable with an approximately normal distribution; across all time windows from 1904-08 to 2003-07 
inclusive, $M I D_{5}$ had a mean of approximately zero and a standard deviation of approximately 0.045 . As we did with the annual MID grids in our previous work (Koch and others 2012), we classified each $M I D_{5}$ grid into drought or wetness categories based on the standard deviation: values between 0.5 and 1 standard deviation below the mean indicate a mild drought; between 1 and 1.5 standard deviations, a moderate drought; between 1.5 and 2 standard deviations, a severe drought; and values 2 or more standard deviations below the mean indicate extreme drought conditions. Mild, moderate, severe, and extreme wetness were defined similarly by corresponding standard deviations above the mean, with values between 0.5 and -0.5 standard deviations indicating near normal conditions. [These deviation-based categories are similar to the categories in the Standardized Precipitation Index; see McKee and others (1993) and Steinemann (2003).] Table 10.1 summarizes the $M I D_{5}$ value ranges for each drought or wetness category based on the calculated standard deviations.

In our previous work, we created a series of four empirical drought probability grids by overlaying the annual MID grids and subsequently determining, for each grid cell, the proportion of years out of 100 that the cell exhibited (1) at least a mild drought, (2) at least a moderate drought, (3) at least a severe drought, and (4) an extreme drought. We adopted a similar approach for our multi-year window analyses. In this case, we overlaid the set of $M I D_{5}$ grids and counted the number of times (out of 100) in which grid cell values indicated at least mild, at least moderate, at least severe, or extreme drought conditions. We then divided these counts by 100 to estimate 5 -year drought probabilities in each of the outlined drought categories.

Table 10.1-Moisture index difference $\left(M I D_{5}\right)$ value ranges for nine wetness and drought categories, along with the equivalent ranges in standard deviation from the mean value (i.e., zero)

\begin{tabular}{lcc}
\hline Category & $M I D_{5}$ values & Standard deviations \\
\hline Extreme wetness & $\geq 0.09$ & $\geq 2$ \\
Severe wetness & $0.0675-0.09$ & $1.5-2$ \\
Moderate wetness & $0.045-0.0675$ & $1-1.5$ \\
Mild wetness & $0.0225-0.045$ & $0.5-1$ \\
Near normal & $0.0225--0.0225$ & $0.5--0.5$ \\
Mild drought & $-0.0225--0.045$ & $-0.5--1$ \\
Moderate drought & $-0.045--0.0675$ & $-1--1.5$ \\
Severe drought & $-0.0675--0.09$ & $-1.5--2$ \\
Extreme drought & $\leq-0.09$ & $\leq-2$
\end{tabular}




\section{Current and Historical Examples-In}

addition to the $M I D_{5}$ map for the conterminous United States from the most recently available 5-year analysis window (2003-07), we also compiled two time series of $M I D_{5}$ maps that depict major regional droughts that occurred during the last few decades. These historical time series demonstrate the utility of our methodology for depicting the inception and development of multi-year drought events. The first series portrays conditions in California, which experienced a significant drought, with accompanying widespread forest mortality, beginning in the late 1980s and lasting into the early 1990s (Benson and others 2002, Ferrell and others 1994, Millar and others 2007). We compiled a series of five temporally overlapping $M I D_{5}$ maps for the State, representing the following time windows: 1983-87, 1985-89, 1987-1991, 1989-1993, and 1991-95.

The second historical time series portrays the Southwestern United States, which has experienced more than a decade of ongoing drought starting in the mid-1990s, resulting in significant tree mortality in pinyon-juniper woodlands (McDowell and others 2008, Mueller and others 2005). Drought severity has fluctuated during this time period, with 1996 and 2002 reported as particularly dry years (Mueller and others 2005). We compiled a series of seven temporally overlapping $M I D_{5}$ maps for the Southwestern United States region, representing the following time windows: 199195, 1993-97, 1995-99, 1997-2001, 1999-2003, 2001-05, and 2003-07.

\section{Results and Discussion}

Drought Probability Maps-Figure 10.1 shows the four probability maps developed through overlay of the $M I D_{5}$ maps. These maps can be compared to the 1-year drought probability maps in our previous work (Koch and others 2012); for simplicity, new versions of the 1-year probability maps, classified in the same manner as the 5-year maps, have been included here (fig. 10.2). Overall geographic patterns are generally consistent between the two analyses, in that the highest probabilities for all drought categories are generally found across the Southern United States, particularly the Southwest, and in the Great Plains. Nearly the entire conterminous United States exhibits a moderate probability $(P \geq 0.20)$ of at least mild drought persisting over a 5 -year time window (fig. 10.1 A), as is also the case with the 1-year probability of at least mild drought (fig. 10.2A). Furthermore, the probabilities of at least severe and extreme 5-year drought occurrence (figs. 10.1C and 10.1D) in the southern Great Plains are quite similar to the 1-year severe 
and extreme drought probabilities for this region (figs. 10.2C and 10.2D). This suggests not only that the region is prone to significant droughts but also that the droughts that occur tend to endure for several years. The most drought-prone ecoregion sections (e.g., sections 315A-Pecos Valley, 315B-Texas High Plains, and 331B-Southern High Plains) are largely unforested.

There are a few noteworthy differences between the probability maps from the 5 -year and 1-year methodologies. For instance, drought probabilities across much of Florida, particularly in the central portion of the State (sections 232G-Florida Coastal Lowlands-Atlantic and 232K-Florida Coastal Plains Central Highlands),

Figure 10.1-Maps for 5-year drought probability in the conterminous United States: probability (A) of at least mild drought; (B) at least moderate drought; (C) at least severe drought; (D) extreme drought. Probabilities were calculated as the number of 5-year windows out of 100 possible overlapping windows (from 1904-08 to 2003-07) in which the 5-year moisture index difference $\left(M I D_{5}\right)$ was less than or equal to corresponding drought category threshold values (see table 10.1). Ecoregion section (Cleland and others 2007) boundaries are included for reference. Forest cover data (overlaid green hatching) derived from MODIS imagery by the U.S. Department of Agriculture Forest Service, Remote Sensing Applications Center. (Data source: PRISM Group, Oregon State University) (continued on next page)
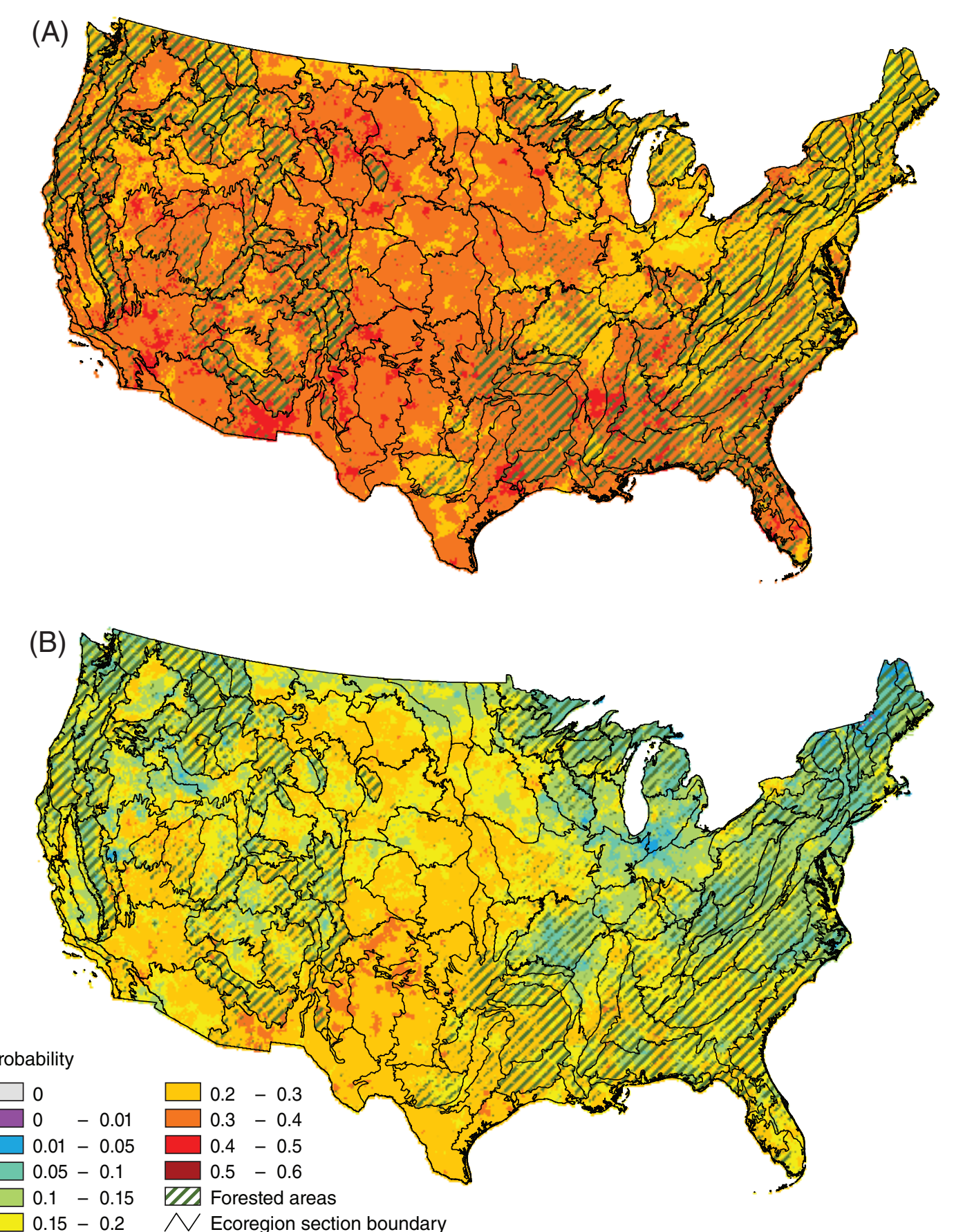
are commonly lower under the $M I D_{5}$ approach (fig. 10.1) than under the annual MID approach (fig. 10.2), regardless of drought category. This suggests that while moisture deficits may be relatively common in Florida, drought conditions tend to be relatively short-lived rather than persisting for several years. At a broader geographic scale, northern portions of the Interior West, the Pacific Coast, and much of the Great Lakes region exhibit lower probabilities of extreme drought (fig. 10.1D) under the $M I D_{5}$ approach than in the annual MID approach (fig. 10.2D). Indeed, many of these areas appear to exhibit zero or close to zero probability of extreme drought conditions persisting for 5 years. Of course, the 1-year extreme drought probabilities in these areas also tend to be fairly low in absolute terms.

Figure 10.1 (continued)-Maps for 5-year drought probability in the conterminous United States: $(C)$ at least severe drought; $(D)$ extreme drought. Probabilities were calculated as the number of 5-year windows out of 100 possible overlapping windows (from 1904-08 to 2003-07) in which the 5-year moisture index difference $\left(\mathrm{MID}_{5}\right)$ was less than or equal to corresponding drought category threshold values (see table 10.1). Ecoregion section (Cleland and others 2007) boundaries are included for reference. Forest cover data (overlaid green hatching) derived from MODIS imagery by the U.S. Department of Agriculture Forest Service, Remote Sensing Applications Center. (Data source: PRISM Group, Oregon State University)

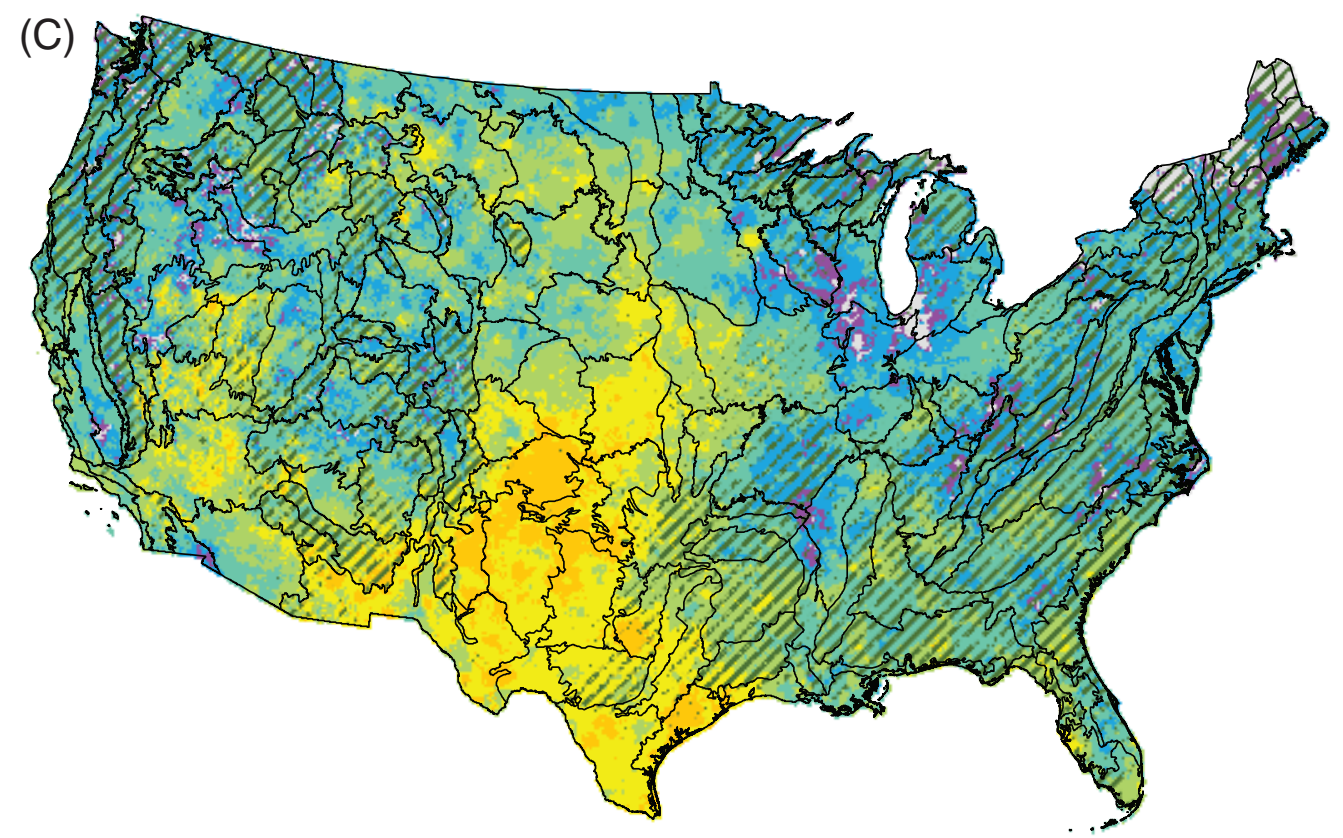

(D)

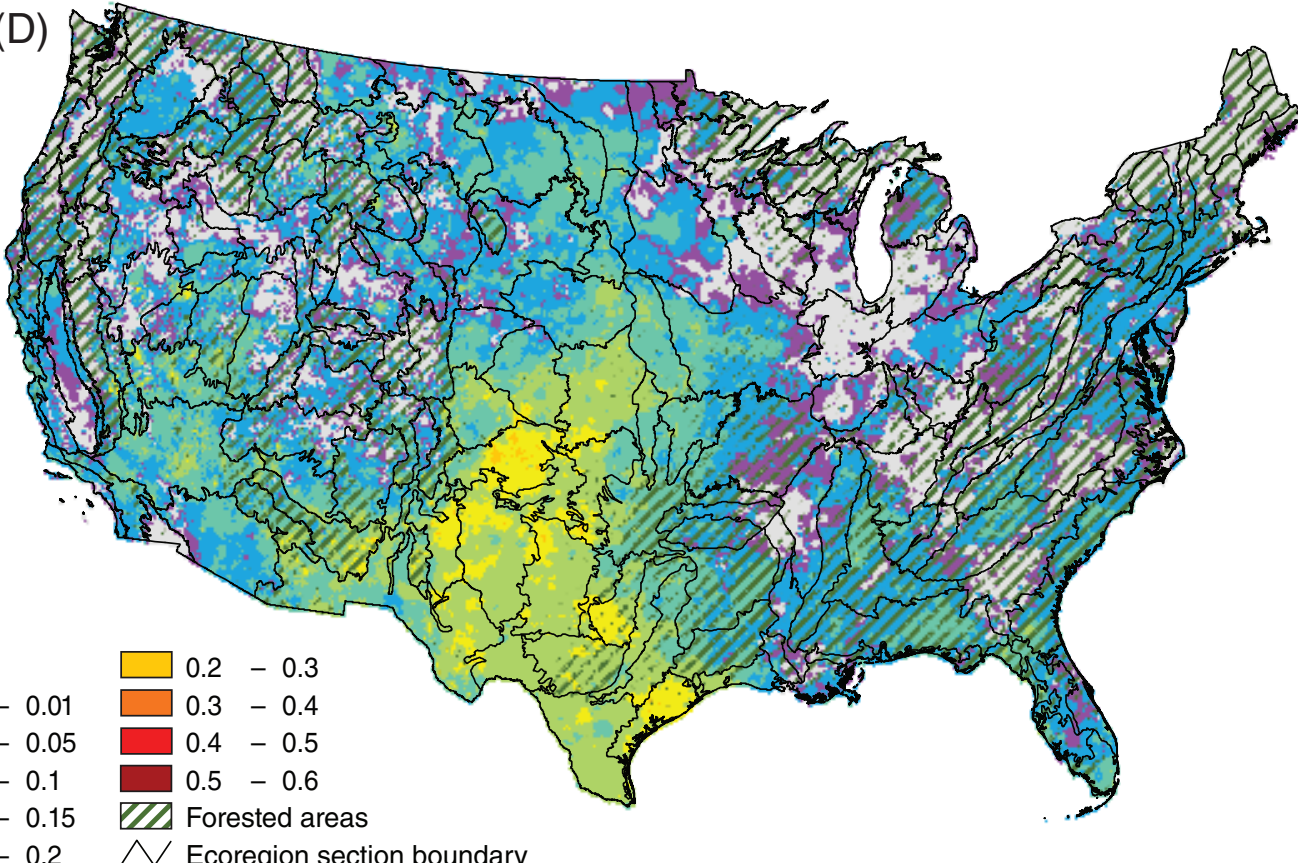

Probability

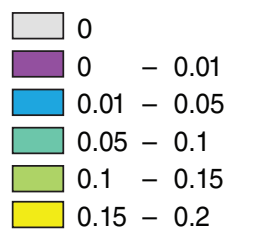

$\checkmark$ Ecoregion section boundary 
Figure 10.2-Maps for 1-year drought probability in the conterminous United States: probability $(A)$ of at least mild drought; $(B)$ at least moderate drought; (C) at least severe drought; (D) extreme drought. Maps adapted from figure 4.2 in Koch and others (2012). Ecoregion section (Cleland and others 2007) boundaries are included for reference. Forest cover data (overlaid green hatching) derived from MODIS imagery by the U.S. Department of Agriculture Forest Service, Remote Sensing Applications Center. (Data source: PRISM Group, Oregon State University) (continued on next page)
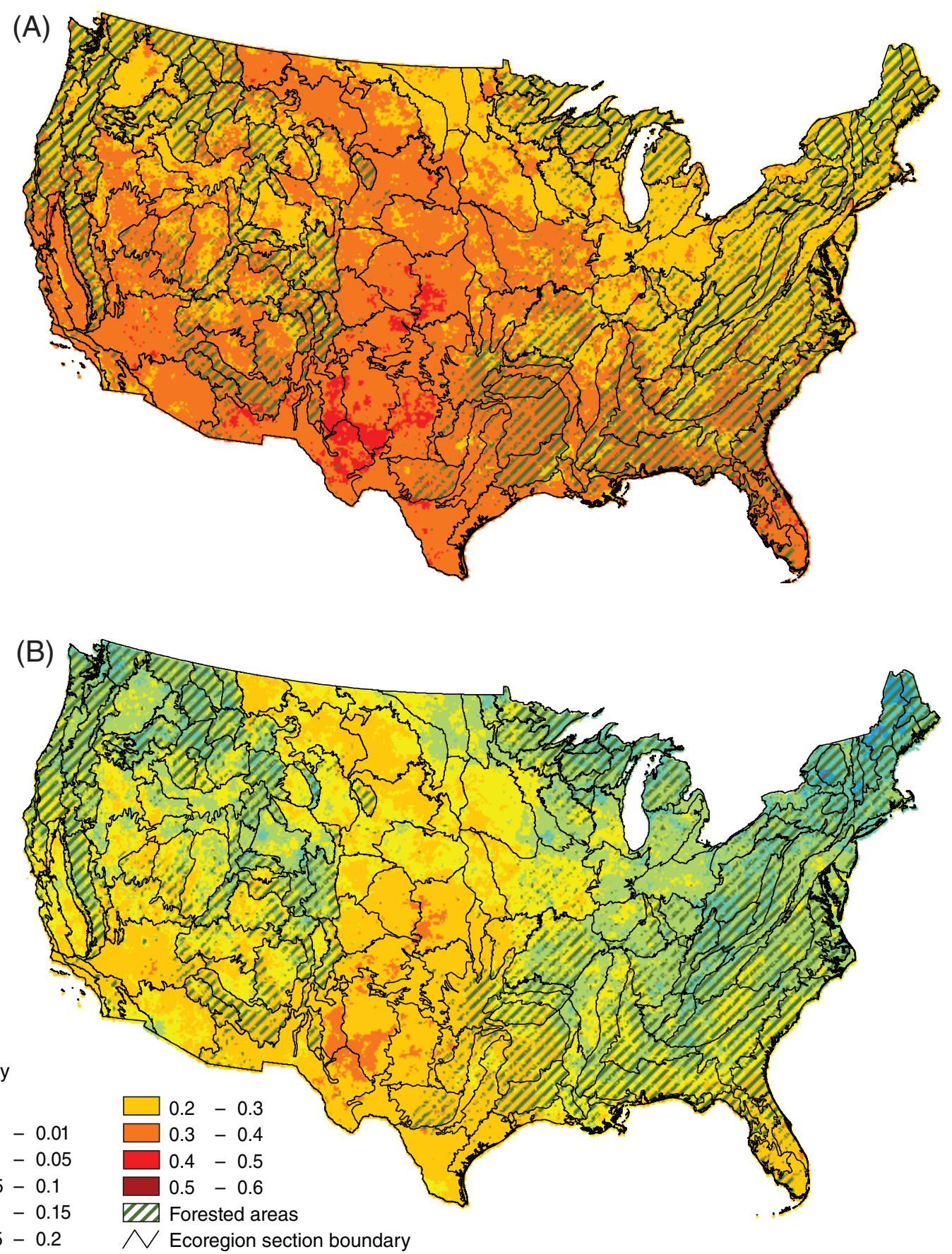
Figure 10.2 (continued)—Maps for 1-year drought probability in the conterminous United States: (C) at least severe drought; (D) extreme drought. Maps adapted from figure 4.2 in Koch and others (2012). Ecoregion section (Cleland and others 2007) boundaries are included for reference. Forest cover data (overlaid green hatching) derived from MODIS imagery by the U.S. Department of Agriculture Forest Service, Remote Sensing Applications Center. (Data source: PRISM Group, Oregon State University)

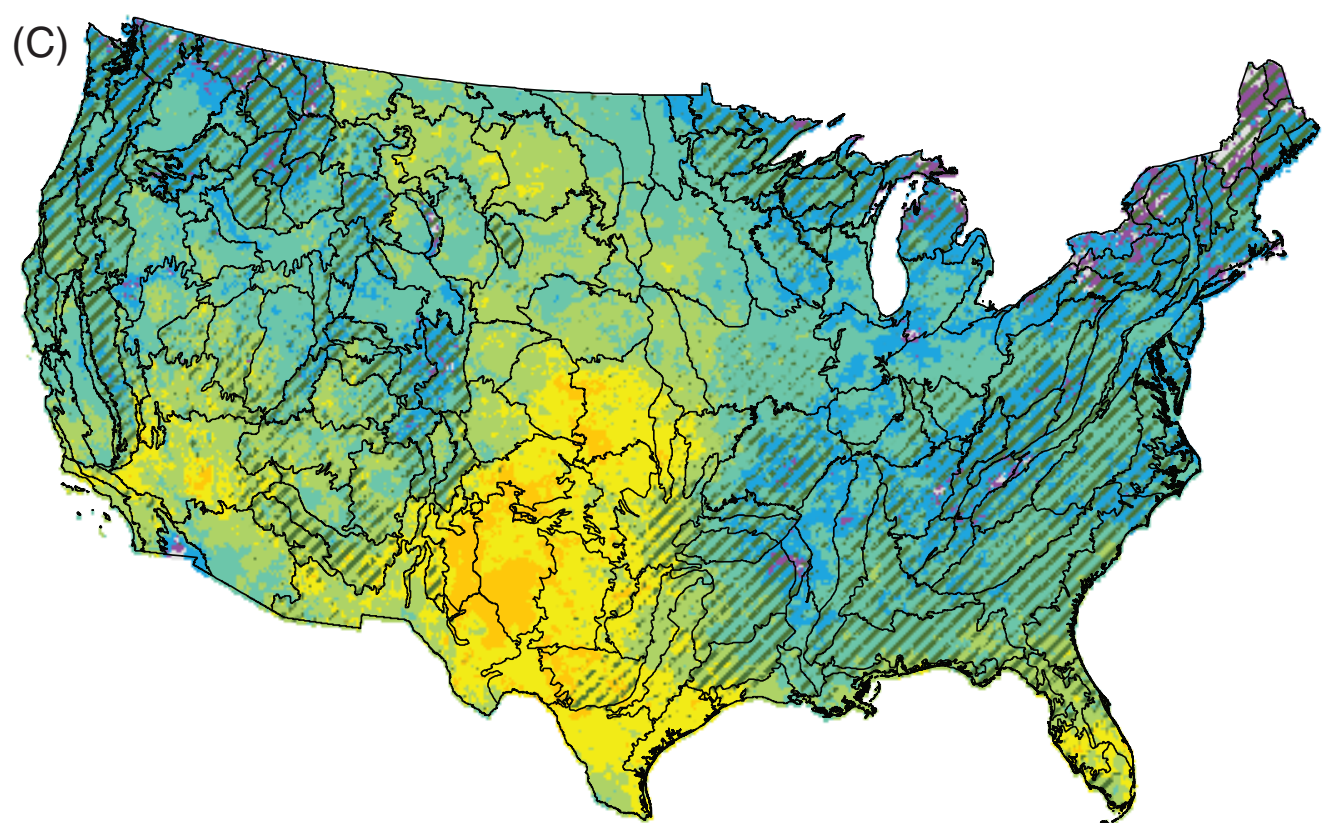
Probability
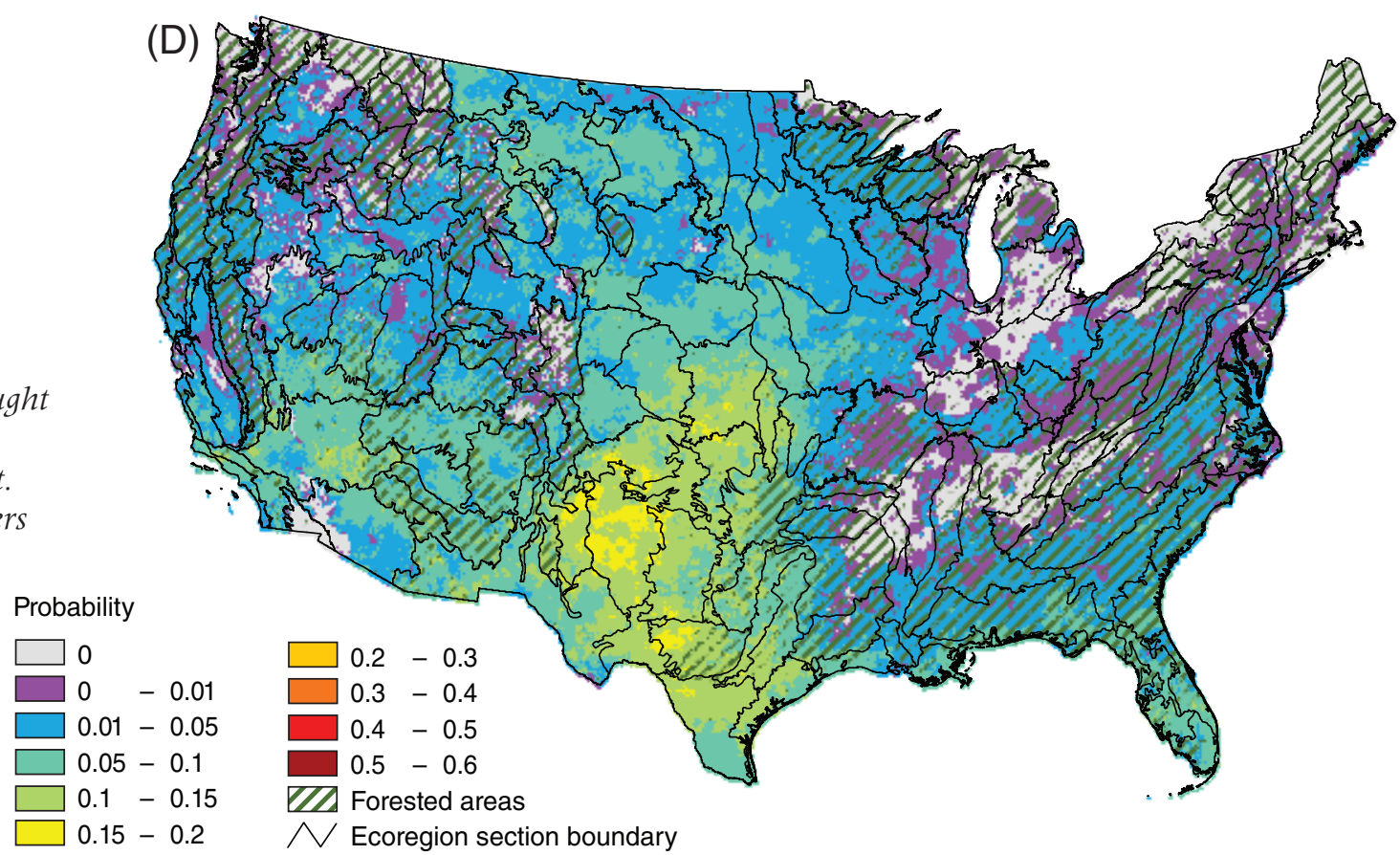
Historical Examples-Figure 10.3 displays the time series of $M I D_{5}$ maps for California. The map for 1983-87 (fig. 10.3A), representing the time window prior to the major drought that started in the late 1980s, shows normal to wetter-than-normal conditions across most of the State. In turn, the map for 1985-89 (fig. 10.3B) depicts worsening moisture conditions throughout much of California. Peak drought extent and severity occurred during 1987-91 (fig. 10.3C), a time window including the core years of the drought. Coastal areas were particularly affected during this window. The $M I D_{5}$ map for 1989-93 (fig. 10.3D) appears to show the State, especially its northern portion, moving gradually out of drought status,

although southern portions of ecoregion sections M261E-Sierra Nevada Mountains and M261FSierra Nevada Foothills and a number of coastal sections (e.g., 261A-Central California Coast and M262A-Central California Coast Ranges) still exhibited areas of extreme moisture deficit. Most of California returned to normal or surplus moisture conditions during the 1991-95 time window (fig. 10.3E).

Figure 10.4 shows the time series of $M I D_{5}$ maps for the Southwestern United States.

The map for 1991-95 (fig. 10.4A) indicates that normal to wetter-than-normal conditions occurred across most of the region during this time period, just prior to the inception of the region's ongoing drought. A number of areas exhibited localized but extreme moisture deficits during the 1993-97 time window (fig. 10.4B), with the largest drought "hot spot" falling in the
(A)

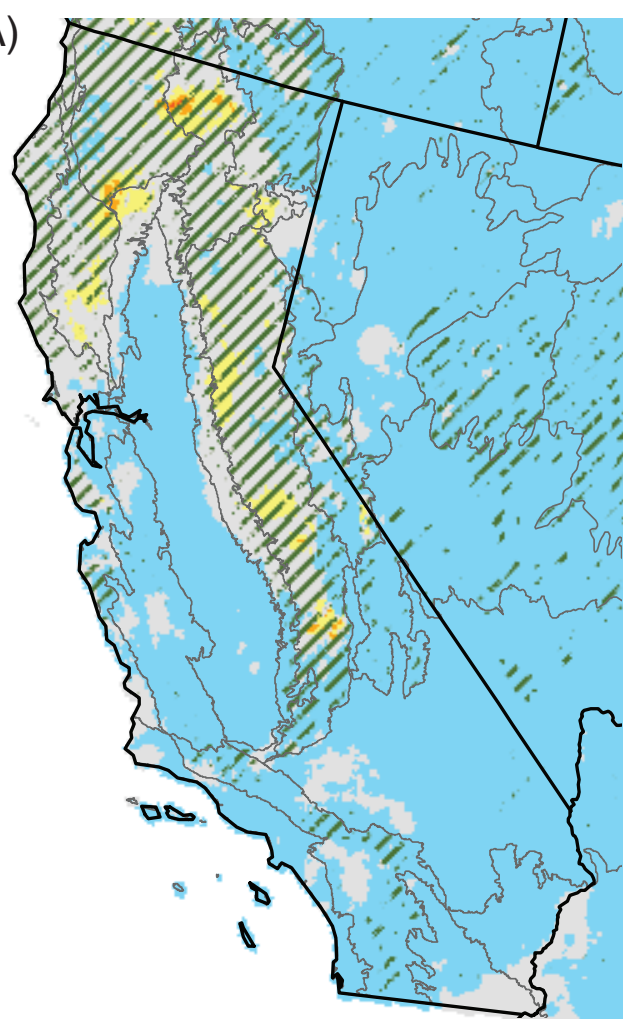

Moisture index difference (5-year window)

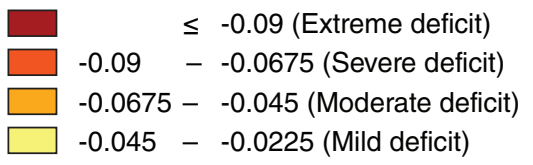

(B)

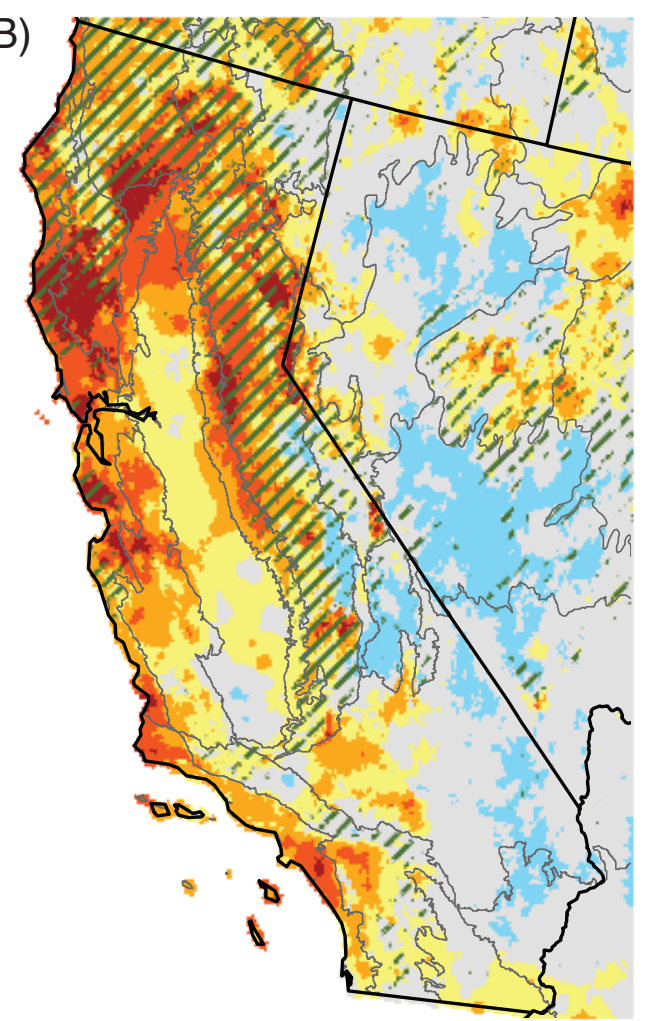

\footnotetext{
$-0.0225-0.0225$ (Near normal)

VIA Forested areas

$\checkmark$ Ecoregion section boundary

$\sim$ State boundary
}

Figure 10.3-Moisture index difference $\left(M_{1} D_{5}\right)$ maps for California for overlapping 5-year time windows: (A) 1983-87; (B) 1985-89; (C) 1987-91; (D) 1989-93; (E) 1991-95. Ecoregion section (Cleland and others 2007) and State boundaries are included for reference. Forest cover data (overlaid green hatching) derived from MODIS imagery by the U.S. Department of Agriculture Forest Service, Remote Sensing Applications Center. (Data source: PRISM Group, Oregon State University) (continued on next page) 

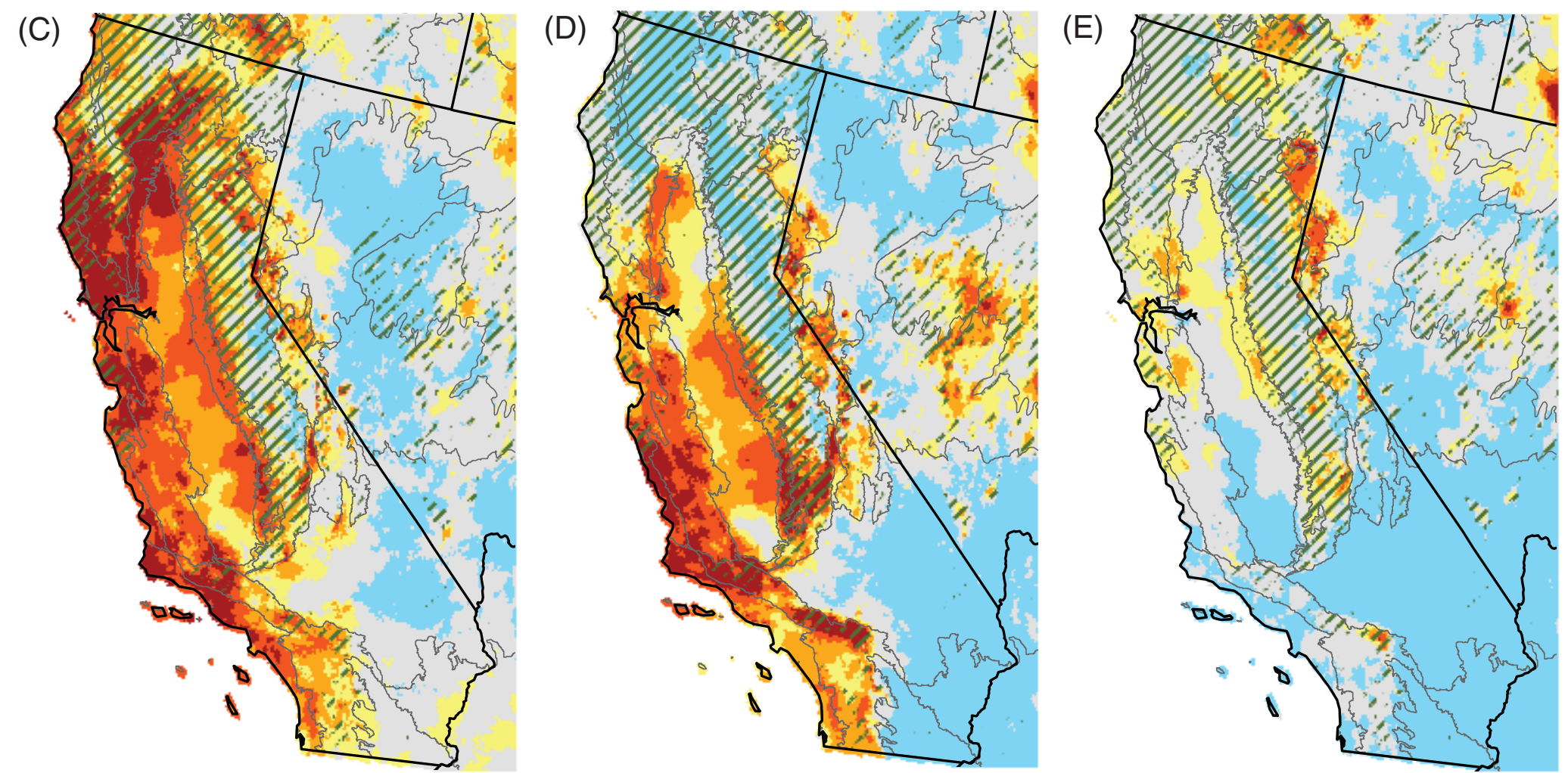

Moisture index difference

(5-year window)

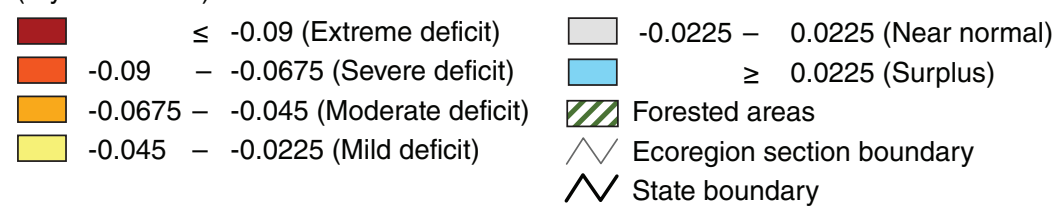

Figure 10.3 (continued)-Moisture index difference $\left(M^{2} D_{5}\right)$ maps for California for overlapping 5-year time windows: (C) 1987-91; (D) 1989-93; (E) 1991-95. Ecoregion section (Cleland and others 2007) and State boundaries are included for reference. Forest cover data (overlaid green hatching) derived from MODIS imagery by the U.S. Department of Agriculture Forest Service, Remote Sensing Applications Center. (Data source: PRISM Group, Oregon State University) mostly unforested sections 315A-Pecos Valley and 315B-Texas High Plains (among the most drought-prone sections in the conterminous United States-see fig. 10.1). The $M I D_{5}$ map for 1995-99 (fig. 10.4C) depicts severe drought across most of the Southwest, but these conditions diminish in the grid for 1997-2001 (fig. 10.4D); notably, this latter time window falls between the reportedly driest years of 1996 and 2002 (Mueller and others 2005). The grid for 1999-2003 (fig. 10.4E) indicates extreme drought not just in the Southwest, but also 
extending northward into the Rocky Mountain region. The geographic extent of moderate to extreme drought conditions in the Southwestern United States decreases substantially in the $M I D_{5}$ maps for 2001-05 (fig. 10.4F) and 2003-2007 (fig. 10.4G), yet extreme drought conditions persist in many areas, most notably sections 313C-Tonto Transition and M313A-White Mountains-San Francisco Peaks-Mongollon Rim, both of which contain a mix of ponderosa pine forest, pinyon-juniper woodland, and other vegetation types.

(A)

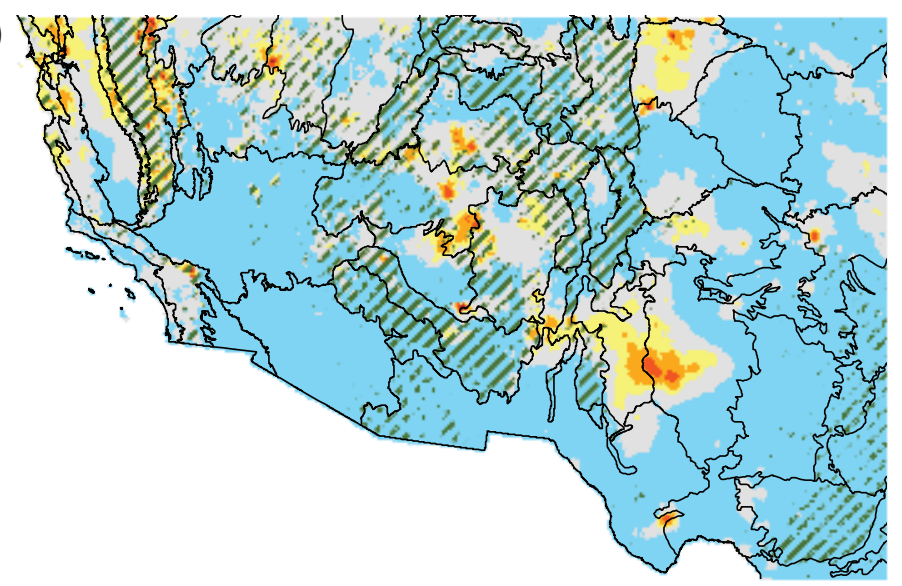

Figure 10.4-Moisture index difference $\left(M_{1} D_{5}\right)$ maps for the Southwestern United States for overlapping 5-year time windows: (A) 1991-95; (B) 1993-97; (C) 1995-99; (D) 19972001; (E) 1999-2003; (F) 2001-05; (G) 2003-07. Ecoregion section (Cleland and others 2007) and State boundaries are included for reference. Forest cover data (overlaid green hatching) derived from MODIS imagery by the U.S. Department of Agriculture Forest Service, Remote Sensing Applications Center. (Data source: PRISM Group, Oregon State University) (continued on next page)
(B)

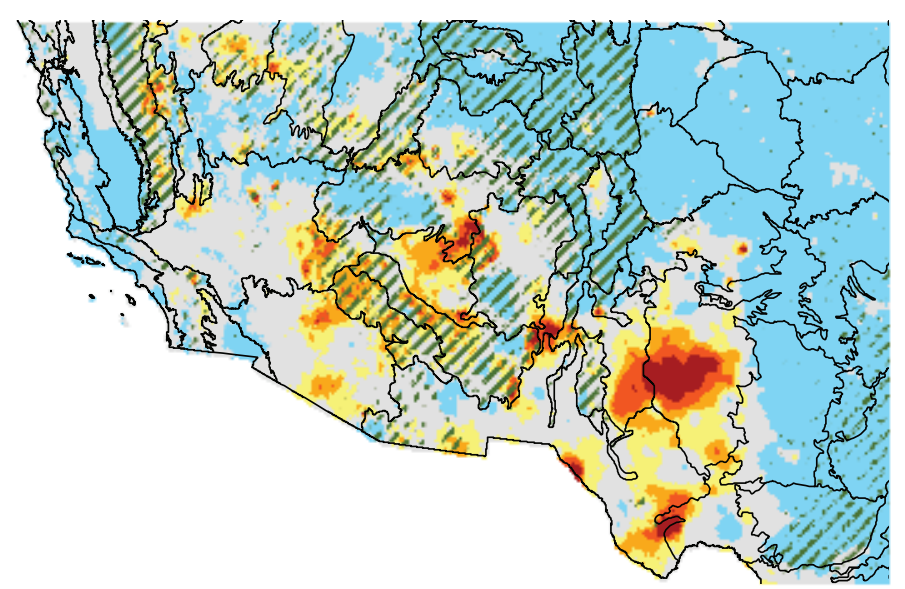

(C)

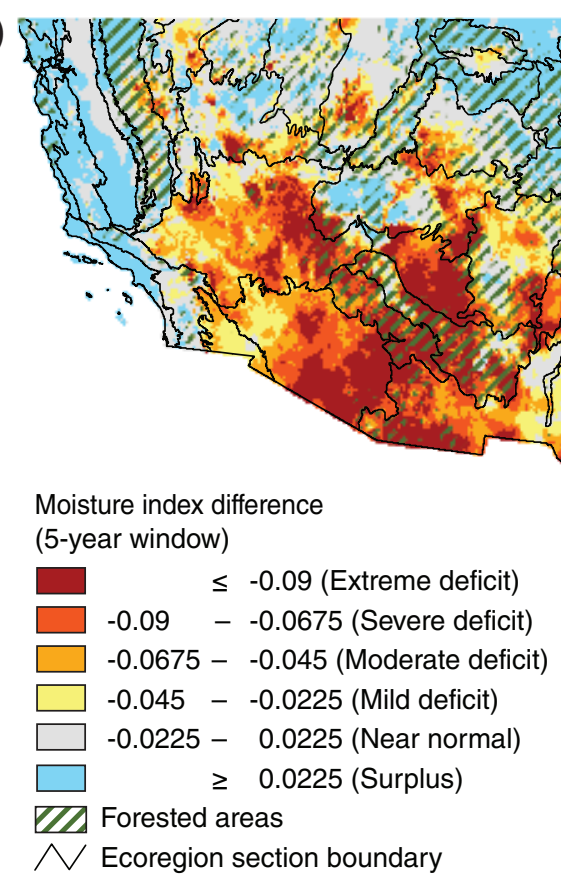


(D)

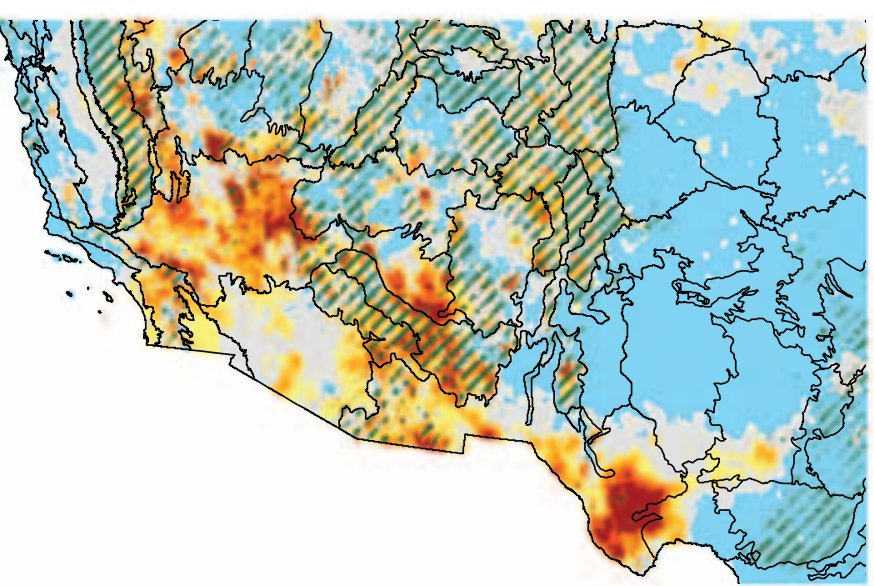

(E)

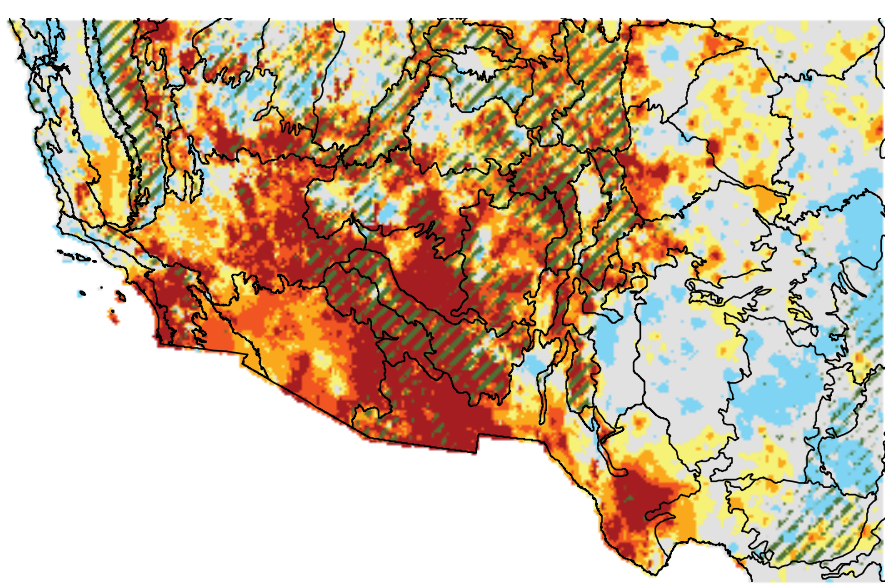

Figure 10.4 (continued)—Moisture index difference $\left(M I D_{5}\right)$ maps for the Southwestern United States for overlapping 5-year time windows: (D) 1997-2001; (E) 1999-2003; (F) 2001-05;

(G) 2003-07. Ecoregion section (Cleland and others 2007) and State boundaries are included for reference. Forest cover data (overlaid green hatching) derived from MODIS imagery by the U.S. Department of Agriculture Forest Service, Remote Sensing Applications Center. (Data source: PRISM Group, Oregon State University)
(F)

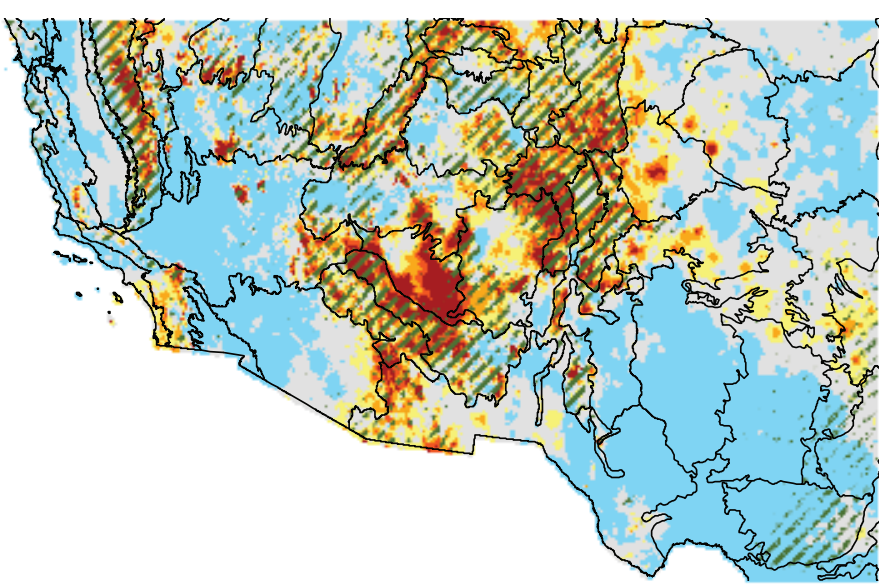

(G)

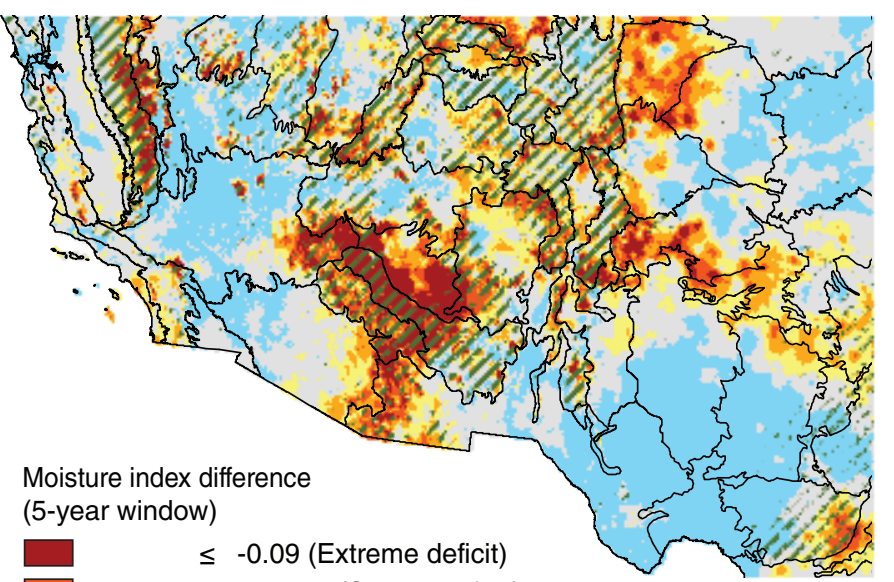

$\leq-0$

$-0.09--0.0675$ (Severe deficit)

$-0.0675--0.045$ (Moderate deficit)

$-0.045--0.0225$ (Mild deficit)

$-0.0225-0.0225$ (Near normal)

$$
\geq 0.0225 \text { (Surplus) }
$$

VIA Forested areas

$\checkmark$ Ecoregion section boundary 
Drought Map for 2003-07-Figure 10.5 shows the $M I D_{5}$ map for 2003-07, the most recent 5 -year window that could be analyzed given the available data. The map indicates that much of the Western United States experienced significant and prolonged drought conditions during this time period. The largest contiguous area of extreme drought was in the Southwestern United States, covering most of the two forested ecoregion sections $(313 \mathrm{C}$ and M313A) highlighted in the historical sample as well as portions of adjacent, sparsely forested sections (i.e., 313D-Painted Desert, 321A-Basin and Range, and 322A-Mojave Desert). There were numerous smaller pockets of severe to extreme drought throughout the Rocky Mountains and the Pacific Northwest, as well as a sizeable area of extreme drought in California located primarily in sections 341D-Mono and M261E-Sierra Nevada.

Virtually the entire northeastern portion of the conterminous United States experienced near normal or surplus moisture conditions during the 2003-07 time window. However there were two large areas of moderate to extreme drought near the Great Lakes: one found largely within sections 212J-Southern Superior Uplands, 212S-Northern Upper Peninsula, and 212X-Northern Highlands, and the other covering parts of sections 222K-Southwestern Great Lakes Morainal and 251C-Central Dissected Till Plains. There were several pockets of drought throughout the Southeastern United States, with one large contiguous area of extreme drought falling primarily in sections 231E-Mid Coastal PlainsWestern, 255A-Cross Timbers and Prairie, 255B-Blackland Prairie, and 255C-Oak Woods and Prairie. A second large contiguous drought area occurred in southern Florida, particularly section $411 \mathrm{~A}$-Everglades.

\section{Issues and Implications}

Whether executed using a single- or multiyear window, the moisture index differencing method is a straightforward and repeatable way to map drought conditions. Input data requirements are relatively modest; while we used PRISM data for our work, other spatially referenced climatic datasets may also be applicable, assuming adequate historical data are available to determine long-term normal conditions. The method does not account for all aspects of the environmental moisture balance, and so is probably best viewed as a complement to, rather than replacement for, other indices and tools available for broad-scale drought monitoring.

A legitimate criticism of our previous analysis was that a 1-year window was basically arbitrary; this was our chief motivation for moving to what we believe is a more ecologically relevant multiyear window. Although we utilized a 5-year window in this case, a 2- or 3-year window may also be appropriate. Indeed, Guarín and Taylor (2005) showed high tree mortality to be strongly correlated with 3 consecutive years of drought.

However, a drought index calculated for a 5-year time window is less sensitive to short-term, intense moisture deficits than an index for a 


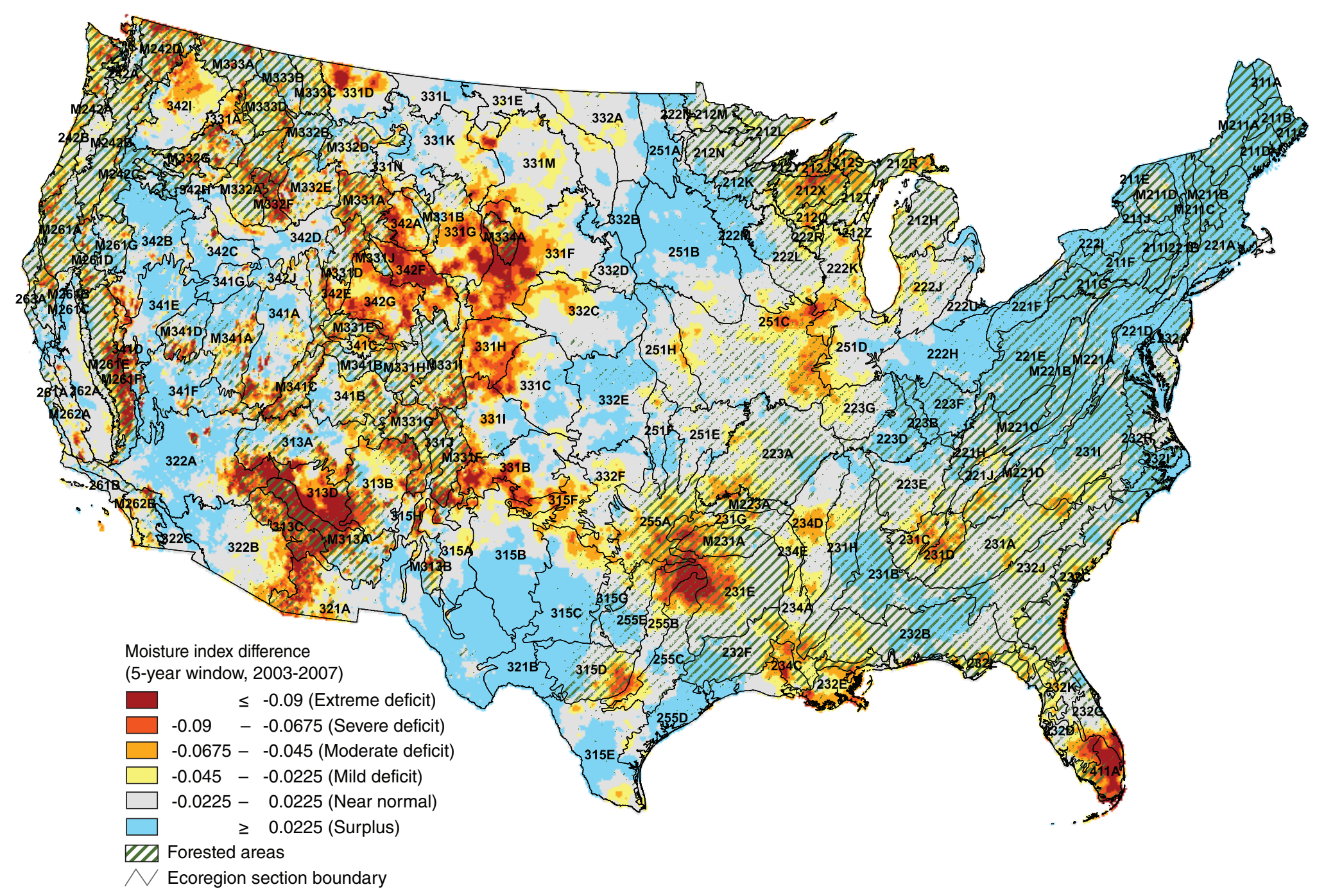

Figure 10.5-Map of the 2003-07 moisture index difference (MID $)$ for the conterminous United States. Ecoregion section (Cleland and others 2007) boundaries and labels are included for reference. Forest cover data (overlaid green hatching) derived from MODIS imagery by the U.S. Department of Agriculture Forest Service, Remote Sensing Applications Center. (Data source: PRISM Group, Oregon State University) 
3-year window. In short, users should carefully consider the goal of their analyses when selecting the most appropriate window.

We believe that data generated using our outlined methodology could be easily applied to a variety of forest health research topics. For instance, as already noted, outbreak populations of many insect pest species are commonly associated with prolonged drought conditions (Mattson and Haack 1987). High-resolution, multi-year drought maps may significantly enhance the capabilities of spatial models to predict where outbreaks of such pests will occur. Another potential application may be to examine associations between multi-year drought data and data describing the geographic patterns of wildfires through time. Significantly, a number of climate models predict that droughts will be more frequent in coming decades, accompanied by increasing tree mortality and regional-scale loss of forest cover (McDowell and others 2008). The historical drought map series and probability maps described here may serve as a baseline for geographically analyzing changes in drought frequency patterns, or alternatively, predicting which ecosystems may be most vulnerable to such changes.

\section{Literature Cited}

Akin, W.E. 1991. Global patterns: climate, vegetation, and soils. Norman, OK: University of Oklahoma Press. 370 p.

Benson, L.; Kashgarian, M.; Rye, R. [and others]. 2002. Holocene multidecadal and multicentennial droughts affecting Northern California and Nevada. Quaternary Science Reviews. 21: 659-682.

Clark, J.S. 1989. Effects of long-term water balances on fire regime, north-western Minnesota. Journal of Ecology. 77: 989-1004.

Cleland, D.T.; Freeouf, J.A.; Keys, J.E. [and others]. 2007. Ecological subregions: sections and subsections for the conterminous United States. Sloan, A.M., tech. ed. Gen. Tech. Report WO-76. Washington, DC: U.S. Department of Agriculture Forest Service. Map, presentation scale 1:3,500,000; Albers equal area projection; colored. Also as a GIS coverage in ArcINFO format on CD-ROM or at http://fsgeodata.fs.fed.us/other_resources/ecosubregions. html. [Date accessed: March 18, 2011].

Daly, C.; Gibson, W.P.; Taylor, G.H. [and others]. 2002. A knowledge-based approach to the statistical mapping of climate. Climate Research. 22: 99-113.

Ferrell, G.T.; Otrosina, W.J.; Demars, C.J. 1994. Predicting susceptibility of white fir during a drought-associated outbreak of the fir engraver, Scolytus ventralis, in California. Canadian Journal of Forest Research. 24: 302-305.

Guarín, A.; Taylor, A.H. 2005. Drought triggered tree mortality in mixed conifer forests in Yosemite National Park, California, USA. Forest Ecology and Management. 218: 229-244.

Kareiva, P.M.; Kingsolver, J.G.; Huey, B.B., eds. 1993. Biotic interactions and global change. Sunderland, MA: Sinauer Associates, Inc. 559 p. 
Keetch, J.J.; Byram, G.M. 1968. A drought index for forest fire control. Res. Pap. SE-38, Asheville, NC: U.S. Department of Agriculture Forest Service, Southeastern Forest Experiment Station. $33 \mathrm{p}$.

Keyantash, J.; Dracup, J.A. 2002. The quantification of drought: an evaluation of drought indices. Bulletin of the American Meteorological Society. 83(8): 1167-1180.

Koch, F.H.; Coulston, J.W.; Smith, W.D. 2012. Chapter 4. High-resolution mapping of drought conditions. In: Potter, K.M.; Conkling, B.L., eds. Forest health monitoring 2008: national technical report. Gen. Tech. Rep. SRS-158. Asheville, NC: U.S. Department of Agriculture Forest Service, Southern Research Station. 179 p.

Mattson, W.J.; Haack, R.A. 1987. The role of drough in outbreaks of plant-eating insects. BioScience. 37(2): 110-118.

McDowell, N.; Pockman, W.T.; Allen, C.D. [and others] 2008. Mechanisms of plant survival and mortality during drought: why do some plants survive while others succumb to drought? New Phytologist. 178: 719-739.

McKee, T.B.; Doesken, N.J.; Kleist, J. 1993. The relationship of drought frequency and duration to time scales. In: Eighth Conference on Applied Climatology. Boston, MA American Meteorological Society: 179-184.

Millar, C.I.; Westfall, R D.; Delany, D.L. 2007. Response of high-elevation limber pine (Pinus flexilis) to multiyear droughts and 20th-century warming, Sierra Nevada, California, USA. Canadian Journal of Forest Research. 37: $2508-2520$.

Mueller, R.C.; Scudder, C.M.; Porter, M.E. [and others]. 2005. Differential tree mortality in response to severe drought: evidence for long-term vegetation shifts. Journal of Ecology. 93: 1085-1093.
National Climatic Data Center. 2007. Time bias corrected divisional temperature-precipitation-drought index. Documentation for dataset TD-9640. http://wwwl.ncdc. noaa.gov/pub/data/cirs/drought.README. [Date accessed: April 7, 2009].

Palmer, W.C. 1965. Meteorological drought. Res. Pap. No. 45 Washington, DC: U.S. Department of Commerce, Weather Bureau. 58 p.

PRISM Group. 2009. 2.5-arcmin (4 km) gridded monthly climate data. ftp://prism.oregonstate.edu//pub/prism/us/ grids. [Date accessed: April 6, 2009].

Schoennagel, T.: Veblen, T.T.; Romme, W.H. 2004. The interaction of fire, fuels, and climate across Rocky Mountain forests. BioScience. 54(7): 661-676.

Steinemann, A. 2003. Drought indicators and triggers: a stochastic approach to evaluation. Journal of the American Water Resources Association. 39(5): 1217-1233.

Svoboda, M.; LeComte, D.; Hayes, M. [and others]. 2002. The drought monitor. Bulletin of the American Meteorological Society. 83(8): 1181-1190.

Thornthwaite, C.W. 1948. An approach towards a rational classification of climate. Geographical Review. 38(1): 55-94.

Weber, L. Nkemdirim, L. 1998. Palmer's drought indices revisited. Geografiska Annaler. Series A, Physical Geography. 80(2): 153-172.

Willmott, C.J.; Feddema, J.J. 1992. A more rational climatic moisture index. Professional Geographer. 44(1): 84-87. 

ach year the Forest Health Monitoring

Program of the Forest Service, U.S.

Department of Agriculture, funds Evaluation Monitoring projects, which are "designed to determine the extent, severity, and causes of undesirable changes in forest health identified through Detection Monitoring and other means" (FHM 2003). In addition, Evaluation Monitoring projects can produce information about forest health improvements. More detailed information about how Evaluation Monitoring projects are selected, the most recent call letter, lists of Evaluation Monitoring projects awarded by year, and Evaluation Monitoring project poster presentations can all be found on the Forest Health Monitoring Web site: http://www.fhm. fs.fed.us.
Beginning in 2008, each Forest Health Monitoring national technical report contains summaries of recently completed Evaluation Monitoring projects. Each summary provides an overview of the project and results, and provides a contact for more information. Nine project summaries, from projects completed in 2006, 2007, and 2008 are included in this report.

\section{Literature Cited}

Forest Health Monitoring (FHM). 2003. Evaluation monitoring. Forest Health Monitoring Fact Sheet Series. http://www.fhm.fs.fed.us/. [Date accessed: July 31, 2009].
SECTION2. Pvaluation Monitoring Ind Summaries 



\section{Introduction}

An increase in dieback and mortality of thinleaf alder (Alnus incana ssp. tenuifolia) raised concern in southern Wyoming and Colorado two decades ago. In 1990, there was concern over extensive mortality of thinleaf alder along Big Laramie River near Jelm, WY, as well as in multiple locations in Colorado. ${ }^{2}$ Trees of all ages were affected and Cytospora canker was associated with the mortality. In 1996, records of the Sulphur Ranger District, Arapaho National Forest indicated that a grazing allotment had severe dieback and mortality of alder (fig. 11.1) In 2005, damage was continuing, consistently associated with Cytospora canker. In other areas, property owners and biologists have noted the damage, some indicating that it began before 1995 .

By 2000 , land managers and others increasingly noted the problem and inquired as to the cause. The goals of the work reported here were to quantify the extent and severity of dieback and mortality from southern Wyoming to northern New Mexico, and to assess a variety of potential direct and indirect causal factors. A portion of this work has been published (Worrall 2009, Worrall and others 2010).

2 Johnson, D.W. 1991. Letter to State Forester of Wyoming. On file with: U.S. Department of Agriculture Forest Service, Rocky Mountain Region, Forest Pest Management,

LSC-91-4, 240 West Prospect Road, Fort Collins, CO 80526.

\section{Methods}

Two surveys were conducted. The first was an extensive survey of randomly selected, 4th-level watersheds likely to have alder in southern Wyoming, Colorado, and northern New Mexico in 2004. Transects were placed in accessible areas on public land that had alder according to the following hierarchical criteria: (1) accurately represent the proportion of dieback and mortality of alder in the area (2) include as much alder as possible, and (3) otherwise represent the vegetation and site conditions in the area (fig. 11.2). Along 30-m transects, canopy intercept was measured, separated by live versus dead. For each genet of alder whose canopy intersected the transect, the following data were recorded: distance to edge of stream; distance to road; number of standing stems in the categories healthy, alive with dieback, and dead; and within each of those categories, the number with Cytospora canker or fruiting and the number with evidence of wood borers. Number of live sprouts of the genet was scored none, low ( $1-5$ sprouts), medium (6-15 sprouts), and high (>15 sprouts). Evidence of browsing and notes on solar exposure were recorded.

A similar but more intensive survey was conducted within the upper Gunnison River basin, in Colorado, in 2005. The transect

\section{Chapter 11.} Climate, Canker, and Alder Mortality in the Southern Rockies

(Project INT-EM-04-01)

JAMES J. WORRALL ${ }^{1}$

${ }^{1}$ Plant Pathologist, U.S. Department of Agriculture, Forest Service, Forest Health Management, Gunnison, CO 81230. 


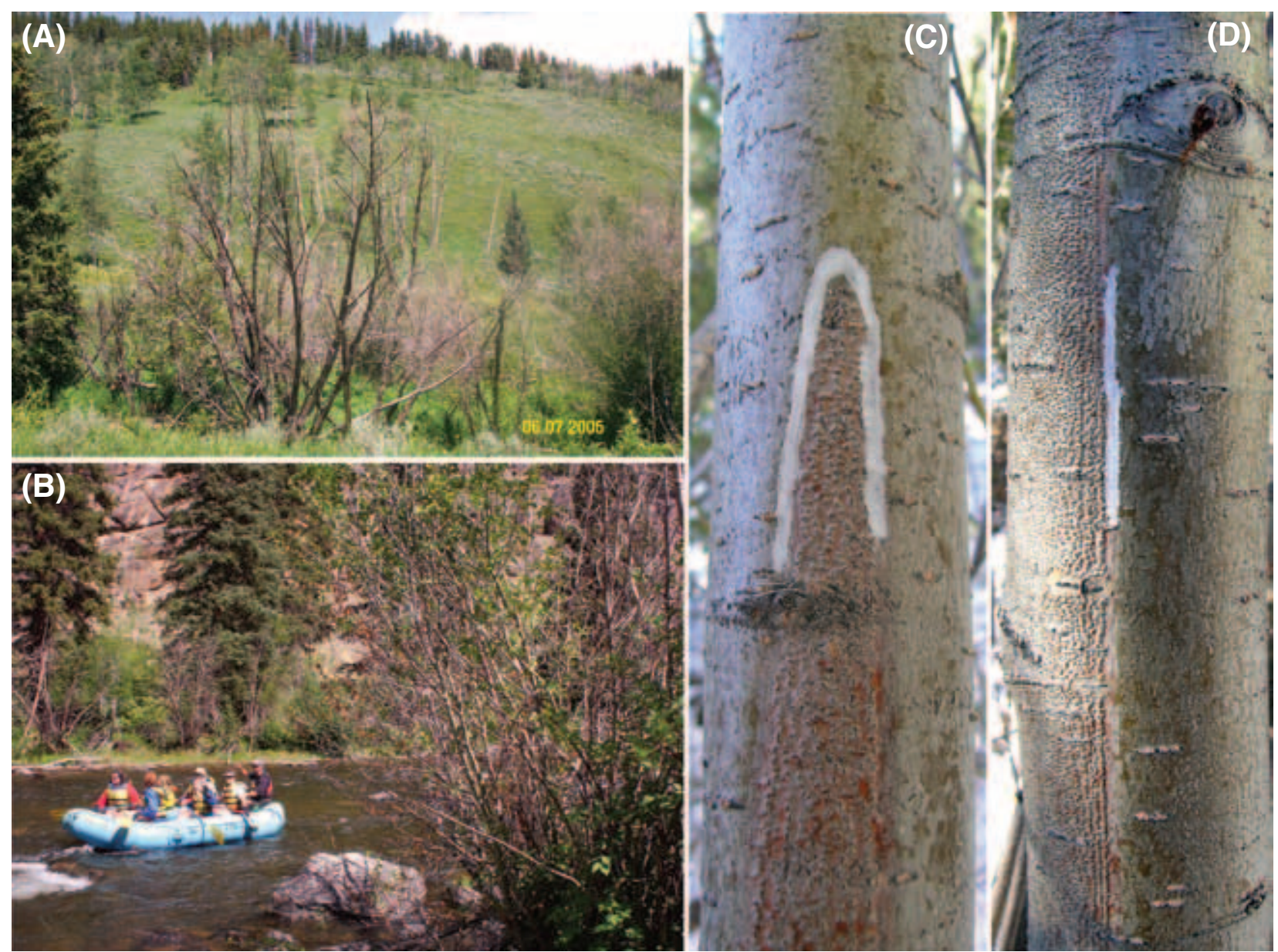

Figure 11.1-Dieback and mortality of thinleaf alder in Colorado and associated Cytospora canker. (A) Mortality in 2005 on a tributary of Eight Mile Creek in the Cottonwood grazing allotment near Granby, CO. The larger stems shown here were already dead in a 1996 photo (not shown). (B) Dead and dying alder in 2005 on both sides of Taylor River near Gunnison, CO, heavily used for recreation. (C) and (D) Cytospora canker associated with dieback and mortality. Note the dense fruiting completely filling the canker surface. The top $(C)$ and side $(D)$ of a canker are marked with white paint. [Photos by Doreen Sumerlin, U.S. Department of Agriculture Forest Service (A) and James Worrall. U.S. Department of Agriculture Forest Service (B), (C), and (D) (from Worrall 2009)] 


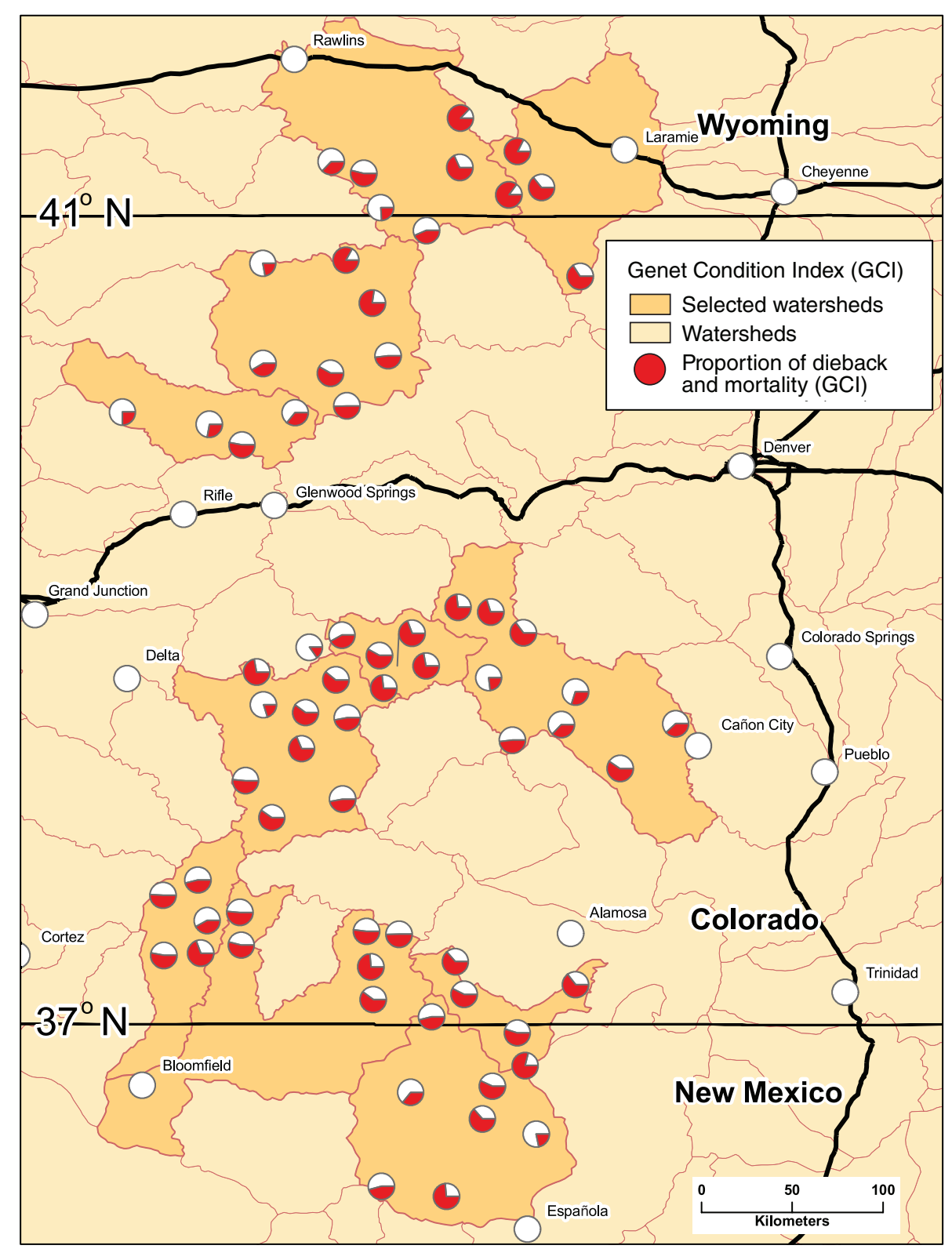

Figure 11.2-Transect and watershed locations in the extensive survey, 2004. The proportion of the circle that is filled indicates the severity of dieback and mortality as calculated by the Genet Condition Index (from Worrall 2009). intercept of alder was recorded, and stems in each alder genet were classed as healthy, dieback, and dead. In 2006, a subsample of the 2004 transects in or near the upper Gunnison River basin was relocated and remeasured. In addition to the alder intercept, d.b.h. of each stem was recorded, and live and dead sprouts were counted on each genet.

Alder condition was expressed as Genet Condition Index (GCI). GCI was based on number of stems of intercepted genets classified as healthy $(\mathrm{H})$, dieback $(\mathrm{B})$ or dead $(\mathrm{D})$ : GCI $=$ $(0.5 \bullet \mathrm{B}+\mathrm{D}) \bullet 100 /(\mathrm{H}+\mathrm{B}+\mathrm{D})$. As a measure of damage, this index weights stems with dieback at one-half the value of dead stems. Growth of 50 cankers was measured monthly from March through October 2006 in locations throughout the upper Gunnison River basin, in Colorado.

Long-term climate data were subjected to spectral analysis to detect oscillations in summer temperatures. A summer heat index was calculated using the methodology of and the same reference period as Hansen and others (1998) and further described at http://data.giss. nasa.gov/csci. The three variables used were extreme maximum monthly temperature, the monthly mean maximum temperature, and the monthly mean temperature. For each year, each variable was averaged over the months of June, July, and August. The mean of the reference period (1951-80) was subtracted from the value 
for each year and the result divided by the standard deviation of the mean for the reference period. The resulting values for the three variables were averaged to obtain the annual index value. Various periodograms and evolutive spectra were used to assess the periodicity of the data using the SSA-MTM Toolkit for Spectral Analysis (Ghil and others 2002).

\section{Results and Discussion}

In the extensive survey, 68 transects from southern Wyoming to northern New Mexico were measured (fig. 11.2). Of 6,503 standing stems, 37 percent were dead, 29 percent had dieback, and 34 percent were healthy. Transects intercepted 1,479 $\mathrm{m}$ of live and 1,177 $\mathrm{m}$ of dead alder canopy. The second, more localized survey had 32 transects and yielded very similar results. Abundance of live sprouts decreased as dieback and mortality increased. Genets with no live sprouts had significantly poorer stem condition $(\mathrm{GCI}=77)$ than those with live sprouts, and genets in the highest sprout class had significantly better stem condition $(\mathrm{GCI}=45)$ than those with fewer sprouts (Fishers protected least significant difference, $\mathrm{P}<0.05)$. Canopy dieback and mortality (GCI) were strongly correlated with percentage of sprouts that were dead at both the transect level (Pearson product moment correlation; $r=0.72, P=0.002$ ) and the genet level $(\mathrm{r}=0.40, \mathrm{P}<0.001, \mathrm{n}=157$ genets $)$. These findings suggest that affected genets are dying and are not replacing themselves successfully through vegetative reproduction.

Damage did not vary substantially by geographic area (fig. 11.2) and was not related to elevation, animal browsing, or distance to nearest road. Symptoms were not consistent with disease of alder caused by Phytophthora alni in Europe, and isolations for Phytophthora species were negative.

Cytospora canker was consistently associated with dieback and mortality when stems and branches were examined closely. Gerard Adams, Michigan State University, identified the pathogen as Valsa melanodiscus (anamorph Cytospora umbrina), and subsequent isolations and microscopic examination of fruiting bodies indicated that it was the proximate cause of the dieback and mortality.

Canker expansion and killing of branches and stems occurred primarily in the warmest part of summer (fig. 11.3; temperature data should be regarded as relative, as most alder sites probably have somewhat cooler weather than the station in Gunnison). Most cankers grew little or not at all up to late June, except those on trees whose tops had already been largely killed by the 


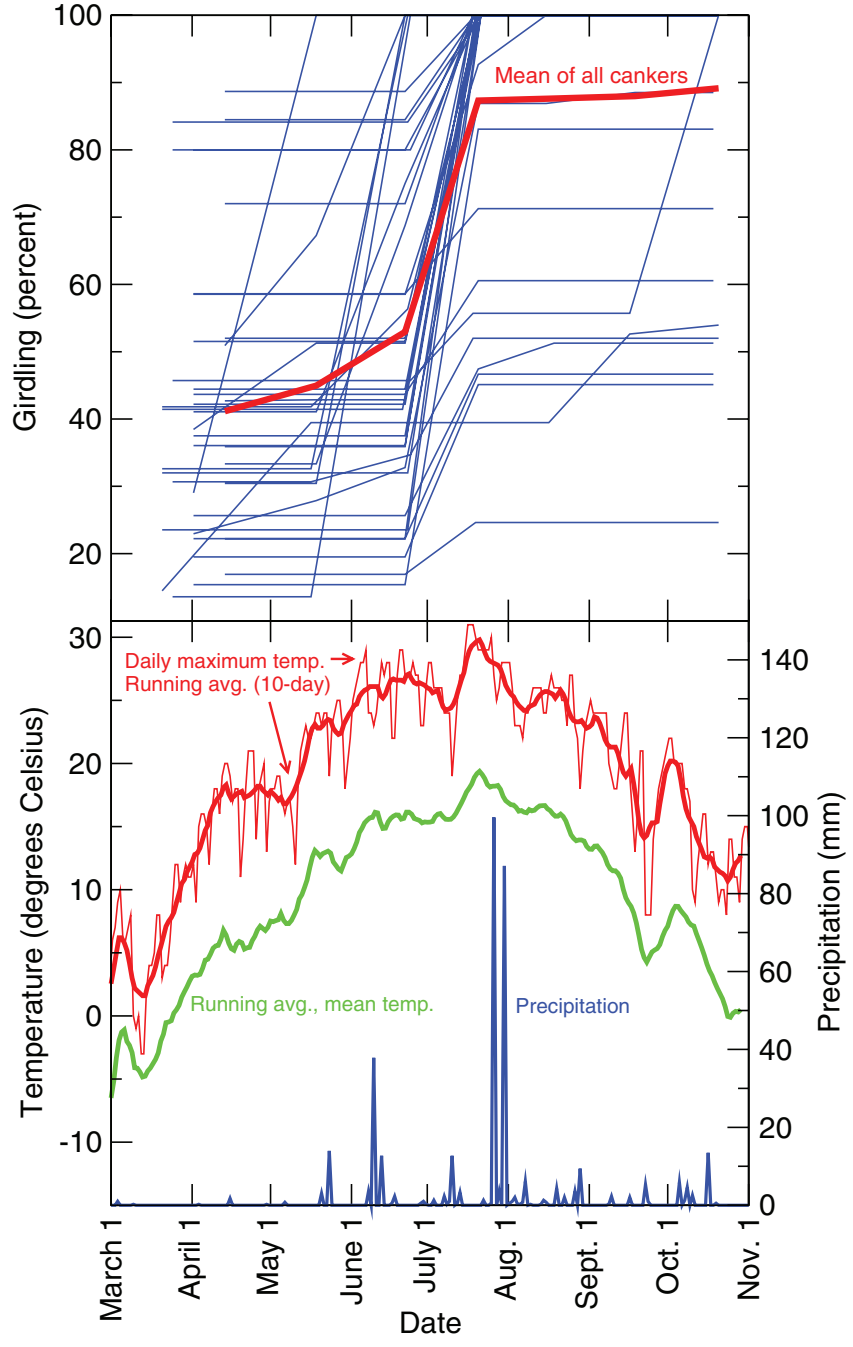

Figure 11.3-Development of 39 marked cankers (thin blue lines) that grew significantly during March-October 2006, expressed as percent girdling (growth of canker around the circumference). The bold red line is the average of all cankers. The graph below shows weather at Gunnison (weather station number 724677) for the corresponding period. Bold red and green lines are moving averages of the 10-day period centered at each point. pathogen the previous year. However, from late June to late July almost all cankers grew rapidly and most girdled their stems. Most did not grow at all after late July. The period of rapid canker growth was the hottest part of summer (fig. 11.3). Between June 20 and July 20, maximum temperature was $\geq 25^{\circ} \mathrm{C}$ on 24 days and peaked at $30^{\circ} \mathrm{C}$ or above on four consecutive days. The warm period was then broken by 2 days with the highest precipitation of the summer. This marked the arrival of the summer monsoon climate pattern. Precipitation occurred on 21 days of the first 4 weeks of the monsoon, while temperature dropped to daily means generally below $15{ }^{\circ} \mathrm{C}$ and daily maxima mostly below $25{ }^{\circ} \mathrm{C}$.

Although drought is often suspected in this damage, several facts argue against it: (a) alder condition improved slightly with distance from stream (significant but weak correlation); (b) alder damage began well before the drought of 2000-2005; (c) active dieback was common in many alders rooted immediately on the banks of streams that remained flowing, with their roots bathed in flowing water continuously through this and other droughts. 
Long-term climate data were analyzed to determine if climate patterns could account for the long-term epidemic of Cytospora canker in alder. Positive values of a summer heat index indicate temperatures warmer than the mean of the reference period (1951-80) and vice versa (fig. 11.4). Spectral analysis (Blackman-Tukey and Maximum Entropy Method) indicated that the time series contained a dominant signal with a frequency of 0.047 cycles per year, or a period of 21.3 years. Multi-taper analysis led to rejection of the white-noise null hypothesis for the peak $(\mathrm{P}<0.01)$. Singular spectrum analysis showed two empirical orthogonal functions (EOFs) forming an oscillating pair with frequencies of 0.048 and 0.049 above the 95 percent confidence interval. Reconstruction of that oscillation showed a good correspondence with variation in the summer heat index. The oscillation was particularly regular with high amplitude in the middle of the 20th century, with alternating cold and warm phases lasting about a decade each. However, the oscillation gradually became slower and dampened after the late 1970s, and a subsequent phase shift cannot be reliably identified. This coincided with the beginning of significantly increasing trend of temperatures in most regions of Colorado (Ray and others 2008).
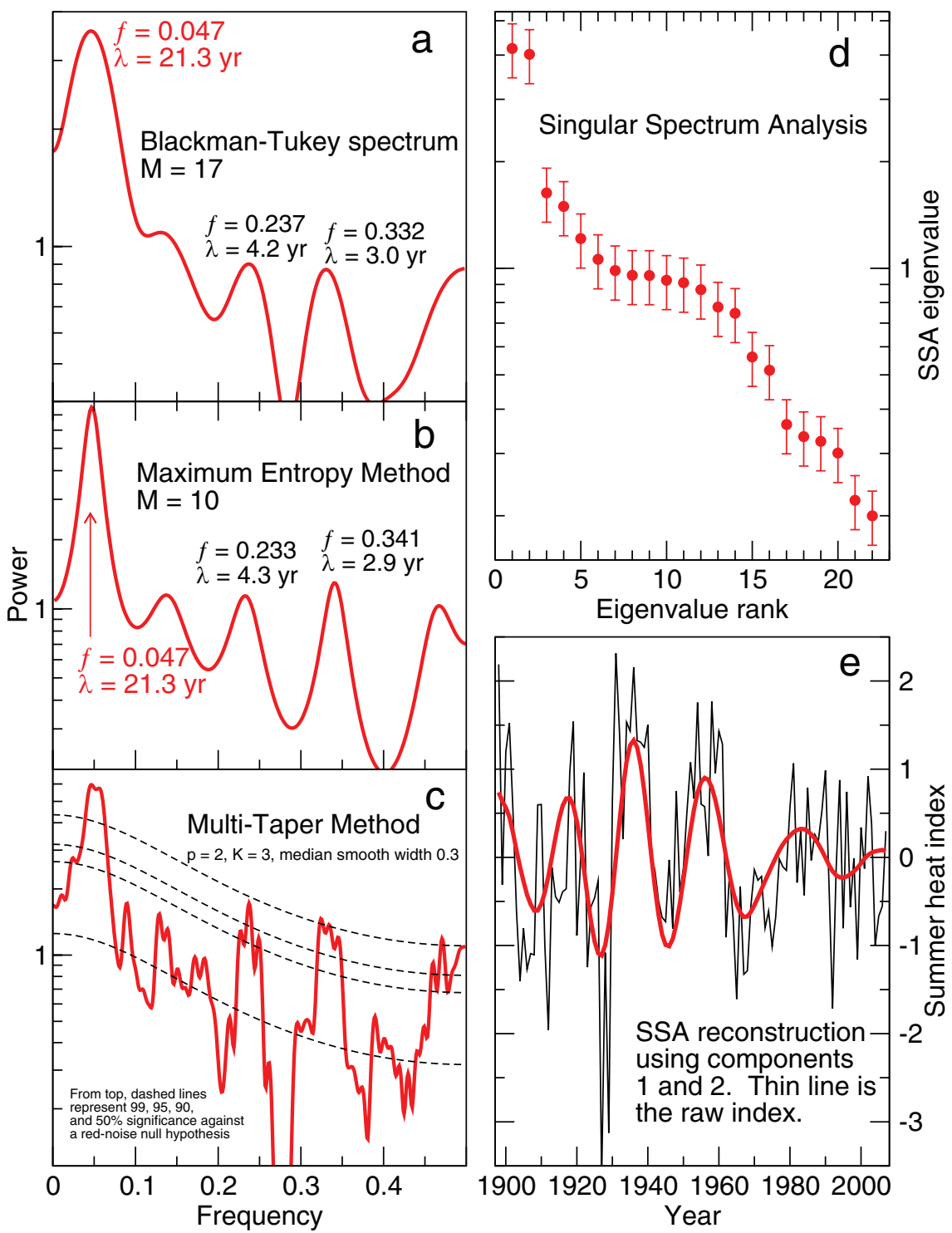

Figure 11.4-Spectral analysis of Gunnison summer heat index using Blackman-Tukey, Maximum Entropy Method, Multi-Taper Method, and Singular Spectrum Analysis. The first pair of components in the eigenvalue plot (upper right) represent a significant oscillation $(f=0.047)$, which is reconstructed at lower right against the raw index. 


\section{Conclusions}

1. Observers noted increased dieback and mortality of thinleaf alder in the southern Rocky Mountains beginning on or before 1990.

2. As of 2004, about one-third of standing alder stems were dead, and one-third had dieback in the southern Rocky Mountains.

3. Genets with dying and dead stems have fewer live sprouts and higher sprout mortality than healthy genets. Genets appear to be dying rather than replacing themselves vegetatively.

4. Cytospora canker, caused by Valsa melanodiscus, is the proximate cause of the dieback and mortality.

5. Except on stems near death, cankers grow only during the hottest part of summer.

6. A spectral analysis of long-term climate data revealed a 21-year cycle of summer heat, but the frequency has slowed and amplitude has weakened since the late 1970s.

7. During periods with high summer temperatures, alder is apparently stressed and becomes susceptible to Cytospora canker. The canker grows and kills very quickly during warm periods. During cool phases, cankers may not develop, giving alder an opportunity to recover and regenerate. With the dampened cycle in recent decades, periods of consecutive cool summers may not be long enough to permit recovery.

8. With recent and projected increases in summer temperatures in the southern Rocky Mountains, more severe epidemics of Cytospora canker may be expected.

\section{Literature Cited}

Ghil, M.; Allen, R.M.; Dettinger, M.D. [and others]. 2002 Advanced spectral methods for climate time series. Review of Geophysics. 40(1): 1.1-1.41.

Hansen, J.; Sato, M.; Glascoe, J.; Ruedy, R. 1998. A commonsense climate index: is climate changing noticeably? Proceedings National Acadamy of Sciences. U.S.A Geophysics. 95: 4113-4120.

Ray, A.J.; Barsugli, J.J.; Averyt, K.B. [and others]. 2008. Climate change in Colorado: a synthesis to support water resources management and adaptation: a report by the Western Water Assessment for the Colorado Water Conservation Board. Boulder, CO: University of Colorado at Boulder, Cooperative Institute for Research in Environmental Sciences, Western Water Assessment. $52 \mathrm{p}$ http://wwa.colorado.edu/CO_Climate_Report/index.html. [Date accessed: March 22, 2011 ].

Worrall, J.J. 2009. Dieback and mortality of Alnus in the Southern Rocky Mountains, USA. Plant Disease. 93(3): 293-298.

Worrall, J.J.; Adams, G.C.; Tharp, S.C. 2010. Summer heat and an epidemic of cytospora canker of Alnus. Canadian Journal of Plant Pathology. 32(3): 376-386. 



\section{Introduction}

/ he purpose of this evaluation monitoring project was to document the losses of

flowering dogwood, Cornus florida (L.), an important ornamental and wildlife tree that grows across much of Eastern North America. The project was prompted in 2001 by the apparent abundance of flowering dogwoods along roadsides in the Morgantown, WV, area, despite a history of severe impacts ascribed mainly to dogwood anthracnose. The native range of dogwood extends from southeastern Canada and Maine south to Florida and as far west as Kansas and Texas (McLemore 1990). However, during the past 20 to 30 years, dogwood has been suffering from the impacts of Discula destructiva (Redlin 1991), causal agent of dogwood anthracnose. This project was based on more than 20 years of cooperative work between employees and their contractors from five States-Maryland, Tennessee, Virginia, West Virginia, and North Carolina-and forest health specialists from three Federal programs-the Forest Health Protection Program of the Forest Service, U.S. Department of Agriculture; the Southern Research Station of the Forest Service; and the National Park Service, U.S. Department of the Interior.

The main objective of this project was to determine the potential impacts to dogwood following the introduction of dogwood anthracnose. Analyses were based on the spatial patterns of reductions in dogwood occurrence and the relationships to various ecological and environmental factors thought to be important in disease development, in particular aspect, elevation, and distance to streams. The purpose of this study was to use data from the Forest Inventory and Analysis (FIA) Program of the Forest Service (Miles 2005) to document the population structure of Cornus florida and how that has changed, if at all, after discovery of $D$. destructiva in the 1970s. After initial results from the first portion of this study were gathered, a series of transect plots were established to enhance population estimates with an estimate of tree health. The final step was to attempt to determine if there was a pattern to where dogwood still occurs and if there were differences in tree health between ecoregions.

This study comprised three separate components: (1) the estimation of regional change in dogwood population using a mixed model approach to analyze FIA data, (2) the examination of current health conditions of dogwoods on 102 transect plots, and (3) collection of data from permanent monitoring plots in North Carolina (1988-2008) to determine the role of anthracnose in dogwood mortality. Although observed mortality cannot simply be linked to dogwood anthracnose even within the permanent plots, any analyses investigating a decline for this species need to consider anthracnose as a critical factor. Other significant factors affecting dogwood health may include anthropogenic factors (e.g., pollution), other diseases, insects, but assigning cause to mortality even where positive infections for $D$. destructiva were found was outside the scope of this study.

\section{Chapter 12.} Tracking Population Loss in Cornus florida Since Discovery of Discula destructiva. Causal Agent of Dogwood Anthracnose, in Eastern North America

(Project SO-EM-05-01)

William E. Jones 1

William D. SMith ${ }^{2}$

Daniel B. Twardus ${ }^{3}$

\footnotetext{
${ }^{1}$ Plant Pathologist, U.S. Department of Agriculture, Forest Service, Forest Health Protection, Asheville, NC 28802.

${ }^{2}$ Research Scientist, U.S. Department of Agriculture, Forest Service, Southern Research Station, Research Triangle Park, NC 27709

${ }^{3}$ Forest Health Group Leader, U.S. Department of Agriculture, Forest Service, Forest Health Protection, Morgantown,
} WV 26505. 
Methods and Results of

the Three Project Components

Component 1: A Mixed Model Approach for Examining Forest Inventory and

Analysis Data to Document the Decline in Cornus florida since Dogwood

Anthracnose Appeared (1984 to 2004)

Methods and materials-For this project, FIA data for Maryland, North Carolina, Tennessee, Virginia, and West Virginia were analyzed to determine what, if any, changes have occurred with the population structure of dogwoods since the discovery of $D$. destructiva. The three most recent measurement cycles of FIA data were analyzed. Only remeasured fixed-area plots were analyzed. If the FIA plots contained no living or dead dogwood at the initial measurement, the plots were dropped from the analysis. Plots were also dropped if there were irreconcilable errors in the data, making the analysis of that plot invalid for this study (e.g., incorrect year of measurement, aspect, or elevation).

The structure of the FIA plots by ecoregion and dogwood anthracnose hazard class is listed in table 12.1. For analyses, measurement years were grouped into Cycle 1, Cycle 2, and Cycle 3. Table 12.2 lists year of inventory and whether FIA data were derived via periodic $(\mathrm{P})$ or annualized (A) surveys. However, since in

Table 12.1-Data structure of the number of Forest Inventory and Analysis plots per ecoregion and the number of plots in each of the six disease hazard classes

\begin{tabular}{|c|c|c|c|c|c|c|c|}
\hline \multirow[b]{2}{*}{ Ecoregion $^{a}$} & \multirow[b]{2}{*}{$\mathrm{n}$} & \multicolumn{6}{|c|}{ Disease hazard class } \\
\hline & & None & Very Low & Low & Moderate & High & Severe \\
\hline Allegheny Mountains & 673 & 0 & 179 & 240 & 226 & 15 & 13 \\
\hline Coastal Plain & 1228 & 0 & 1057 & 7 & 164 & 0 & 0 \\
\hline Cumberland Mountains & 2479 & 0 & 962 & 662 & 700 & 150 & 5 \\
\hline Northern Blue Ridge & 1615 & 0 & 100 & 337 & 796 & 199 & 183 \\
\hline Piedmont & 3200 & 0 & 2046 & 435 & 688 & 25 & 6 \\
\hline Southern Blue Ridge & 1168 & 4 & 51 & 117 & 582 & 125 & 289 \\
\hline Upper Gulf Coastal Plain & 518 & 0 & 482 & 25 & 11 & 0 & 0 \\
\hline Total & 10,881 & 4 & 4,877 & 1,823 & 3,167 & 514 & 496 \\
\hline
\end{tabular}

${ }^{a}$ Ecoregion $=$ Subsections

Coastal Plain = 232Aa, 232Ab, 232Ac, 232Ad, 232Ca, 232Cb, 232Ce, 232Cg, 232Ha, 232Hb, 232Hc, 232Hd, 232la, 232lb, 232Jb

Piedmont = 221Da, 221Db, 221Dd, 221De, 231Af, 231la, 231 lb, 231lc, 231ld, 231le, 231lf, 231l g

Mountains = M221Aa, M221Ab, M221Ac, M221Ba, M221Bc, M221Bd,M221Be, M221Bf, M221Ca, M221Cb, M221Cc, M221Cd, M221Ce, 221Ea,

$221 \mathrm{~Eb}, 221 \mathrm{Ec}, 221 \mathrm{Eg}, 221 \mathrm{Ei}, 221 \mathrm{En}, 221 \mathrm{Ha}, 221 \mathrm{Hb}, 221 \mathrm{Hc}, 221 \mathrm{Hd}, 221 \mathrm{He}, 221 \mathrm{Ja}, 221 \mathrm{Jb}, 221 \mathrm{Jc}, 222 \mathrm{Hc}, 223 \mathrm{Fa}, 223 \mathrm{Fb}, 223 \mathrm{Fd}, 231 \mathrm{Cd}, 231 \mathrm{Cg}, 231 \mathrm{Ba}$ 
all cases the cycle covered multiple years, the number of live dogwood trees per acre was included for all years within the study period to determine the annual rate of change. Data were analyzed using a mixed model procedure [PROC MIXED SAS] (SAS Institute 1996) using the REPEATED statement. This creates a temporal covariance matrix within each ecoregion to ensure valid estimates and tests. Since the measurement years differ between States, the values for the years 1984, 1994, and 2004 are empirical Best Linear Unbiased Predictions (BLUPs) for each major ecoregion using the ESTIMATE statement as presented in figure 12.1. For establishment of 1984 as the baseline population, State forest health specialists were contacted for each of the five States to confirm or reject the assumption that data for Cycle 1 were not significantly contaminated (i.e., mortality was considered to be at the expected baseline). They concluded that dogwood anthracnose was not a significant cause of mortality affecting data from the 1980s for the five States, so the baseline was set to 1984 .

Results-The number of live dogwood is decreasing in all ecoregions. A test of equal slope was made using the CONTRAST statement in PROC MIXED. The trend for mortality in the Northern Blue Ridge is significantly greater $(p<0.01)$ than the Piedmont and Coastal Plain (fig. 12.1). There were no significant differences in sub-regions within the three coastal plains, piedmont, and mountains ecoregions (fig. 12.2).
Table 12.2-Definition table for Forest Inventory and Analysis measurement Cycle 1, Cycle 2, and Cycle 3 of year of inventory and type ( $\mathrm{P}=$ Periodic survey and $A=$ annualized survey)

\begin{tabular}{llll}
\hline State & Cycle 1 & Cycle 2 & Cycle 3 \\
\hline MD & $1983(\mathrm{P})$ & $1999(\mathrm{P})$ & $2004(\mathrm{~A})$ \\
NC & $1984(\mathrm{P})$ & $1990(\mathrm{P})$ & $2000(\mathrm{~A})$ \\
TN & $1989(\mathrm{P})$ & $1999(\mathrm{P})$ & $2003(\mathrm{~A})$ \\
VA & $1984(\mathrm{P})$ & $1992(\mathrm{P})$ & $2004(\mathrm{~A})$ \\
WV & $1989(\mathrm{P})$ & $2000(\mathrm{P})$ & $2004(\mathrm{~A})$
\end{tabular}

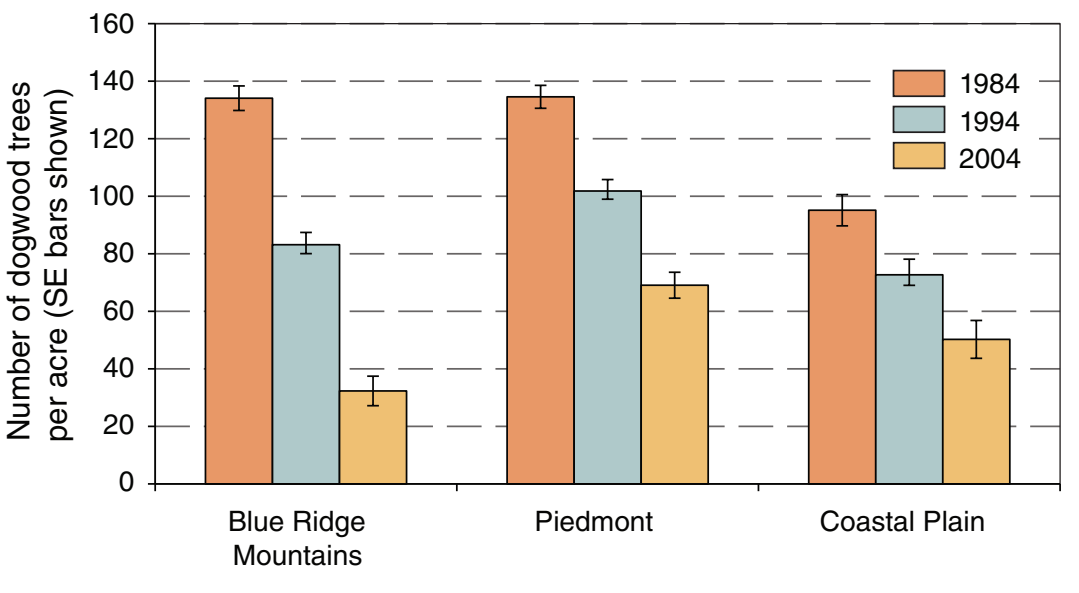

Major Ecoregion Type

Figure 12.1-Change in the unweighted mean number of dogwoods trees per acre from Cycle 1 (1980s), Cycle 2 (1990s), and Cycle 3 (2000s) in the Coastal Plain, Piedmont, and

Northern Blue Ridge Mountain ecoregions. (Data source: U.S Department of Agriculture Forest Service, Forest Inventory and Analysis Program) 


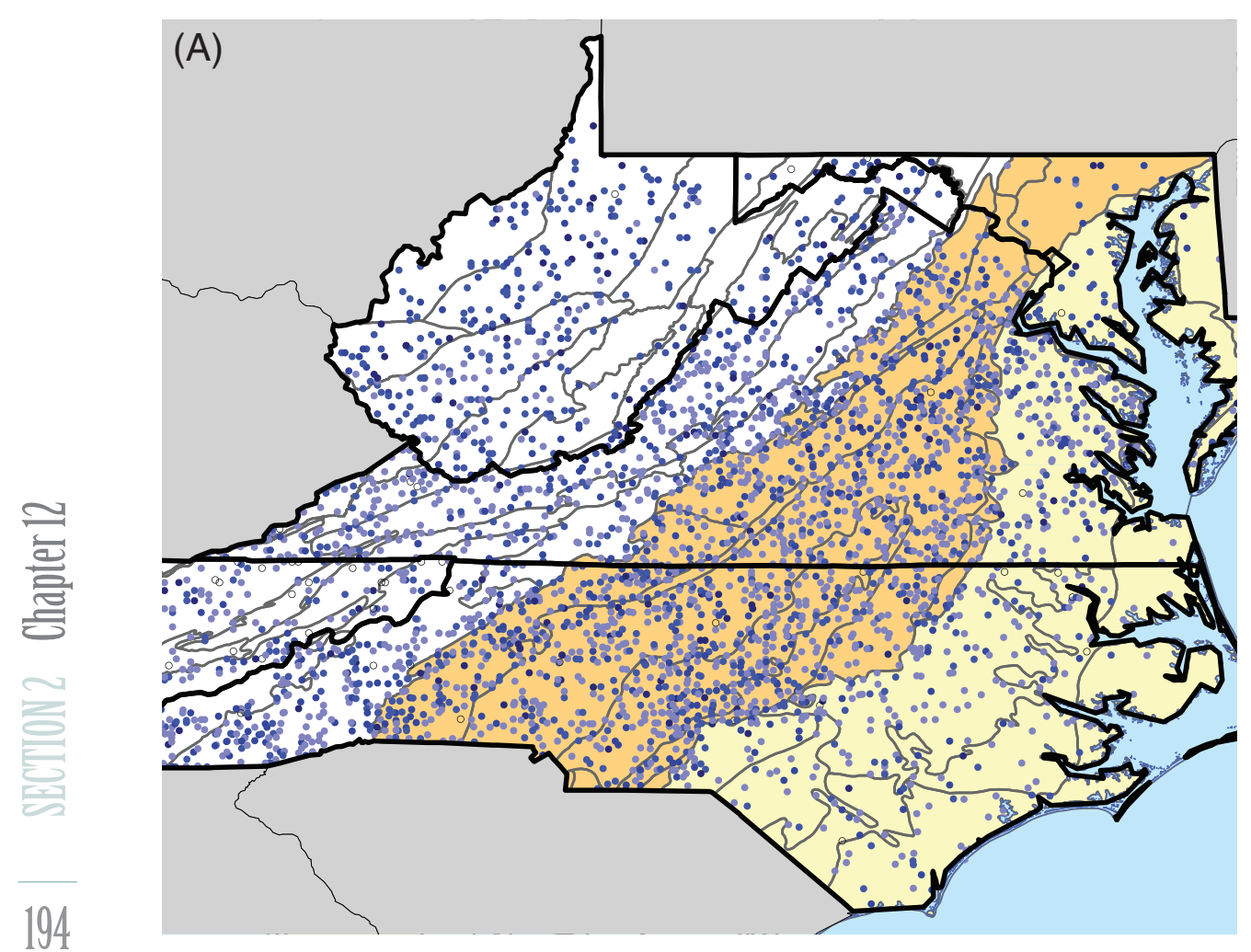

Figure 12.2-Change in the number of dogwood trees per acre from the past

three Forest Inventory and Analysis (FIA) measurements, Cycle I (A), and Cycle 2 (B). The regions are identifed as: mountains — white background; piedmont — tan background; coastal-yellow background. Plot locations are approximate. (continued on next page)

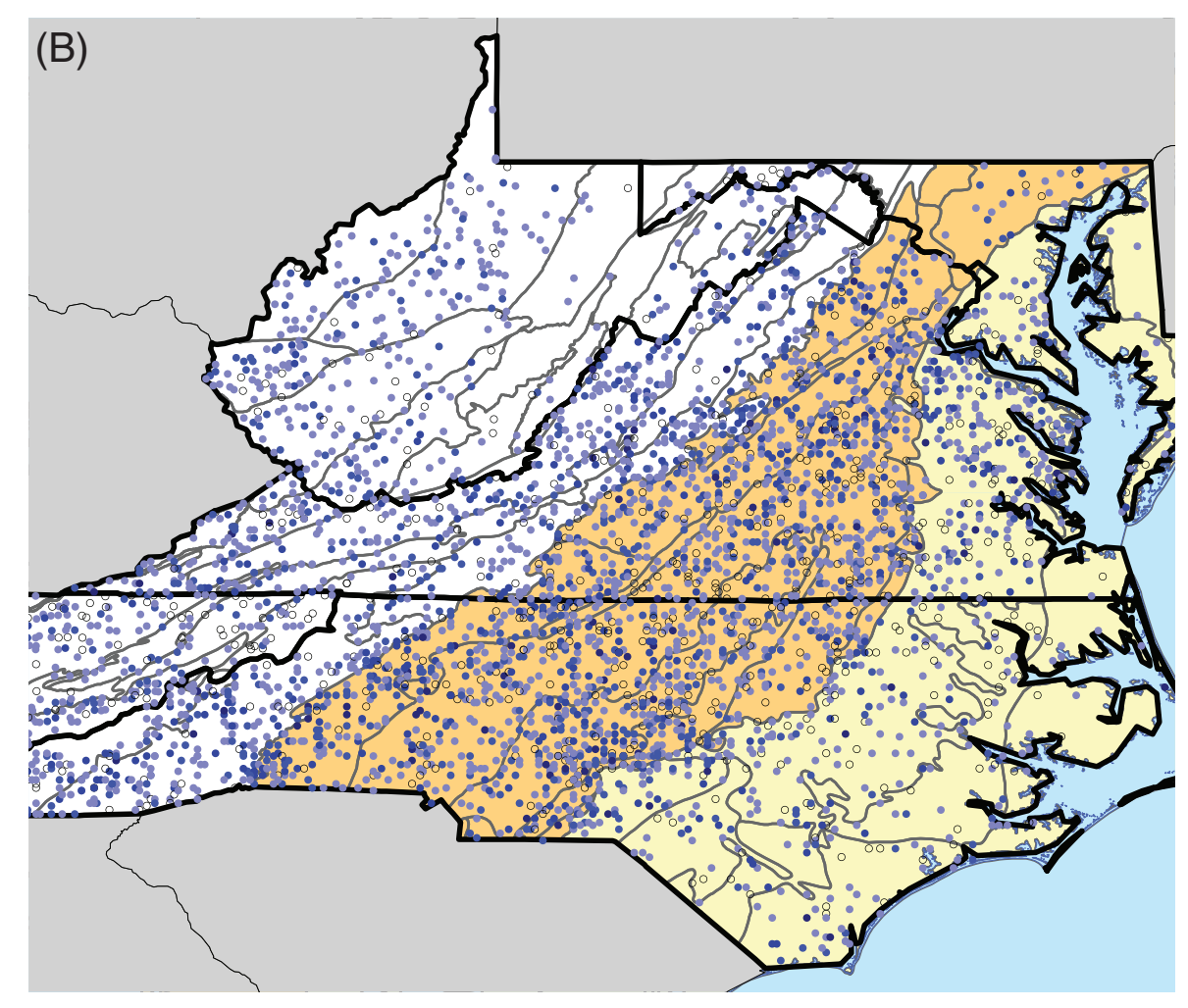

Live dogwoods per acre

$\square \quad 0$
$\square \quad-\quad 142$
$\square 143-289$
$290-531$
$532-2525$ 


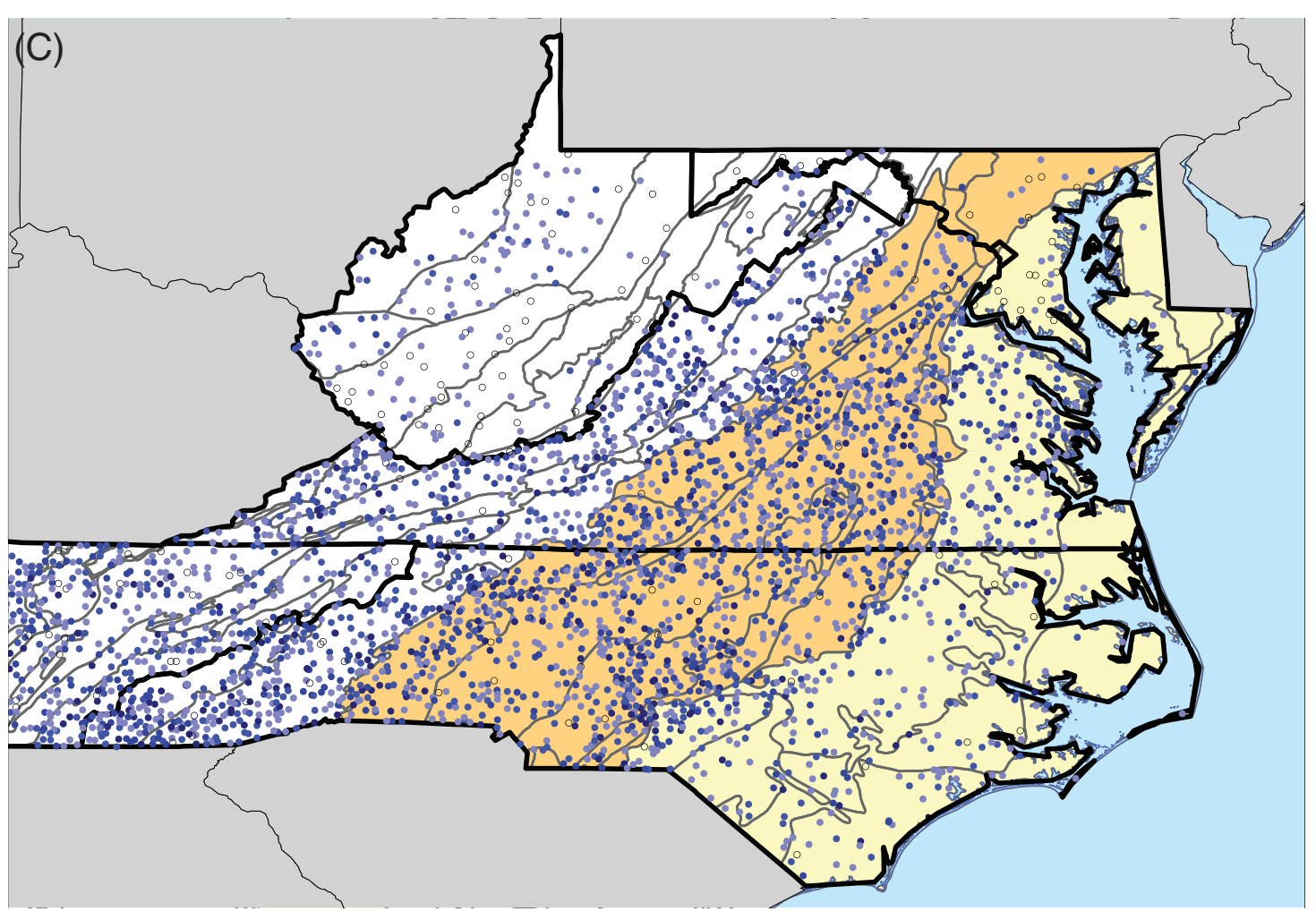

Figure 12.2 (continued)-Change in the number of dogwood trees per acre from the past three Forest Inventory and Analysis (FIA) measurements, (C) Cycle 3. The regions are identifed as: mountains - white background; piedmont - tan background; coastal-yellow background. Plot locations are approximate.
Live dogwoods per acre

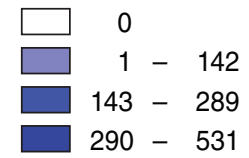

\section{Component 2: Transect Data}

Methods and materials - During the spring and summer of 2006, 102 transect plots were established in North Carolina and Tennessee to evaluate dogwood condition, crown position, and tree health. Plots consisted of four transects in the cardinal directions (north, south, east, and west) that were 5 feet wide and 330 feet long. All dogwoods with tree center falling on or within transects were tallied. The distance from transect origin, diameter at breast height (d.b.h.), (inches) and the tree's status as live or dead was recorded. For live trees additional information was collected including: presence of stem cankers, percent of anthracnose-diseased foliage (including attached and dead foliage), percent of fine-twig dieback, percent crown transparency, percent crown density, crown position in canopy, crown light exposure (CLE), and the distance and direction from base of tree to a large canopy opening (feet).

Results - A total of 453 live and 300 dead dogwood (39.8 percent) were intercepted on the 102 transect plots. Using an area expansion for each plot, the mean number of live dogwood trees per acre was 27.7 (SE 4.3) trees per acre. The mean number of dead dogwood trees per acre intersected was 16.4 (SE 3.2) dead trees per acre. Live dogwood were small understory trees with a mean diameter of 2.3 inches (SE 0.1). 
On average, the coarse tree health measurements were: 70.1 percent of live trees possessing stem cankers, 20.1 percent (SE 0.1 percent) of crowns impacted by foliar infections, and crowns possessing 20.2 percent (SE 0.7 percent) mean crown dieback. In terms of crown health ratings, approximately 50 percent of the dogwood was classified as "unhealthy" (> 25 percent foliar crown infections). On only two occasions was dogwood regeneration (trees too small to have a d.b.h. but fell on transect) intercepted by transects, a rate of only one dogwood per 15.1 miles of transect.

\section{Component 3: Permanent Dogwood Monitoring Plots Maintained in North Carolina (1988-2006)}

Methods and materials-From 1988 to 2006, the North Carolina Division of Forest Resources maintained permanent monitoring plots to track the condition of flowering dogwood, particularly in the mountainous western parts of the State. The methods and data forms used to collect data were previously published (Knighten and Anderson 1993) but the results from 1993 through 2006 have not been previously reported. ${ }^{4}$ Plots consisted of the closest 10 flowering dogwood trees to a plot center located on a random stratified 15-minute grid system. Locations were determined with the aid of topographic maps. If fewer than 10 trees could be located near plot centers the locations were retained, but if no dogwood were present in a 1-mile radius of the plots, they were abandoned. If all 10 trees died, plots were also abandoned and not revisited. The total number of trees tracked in North Carolina was 293 trees on 31 plots. These 31 plots were part of a larger regional project involving 210 plots across seven States in the Southeastern United States, but only North Carolina has visited plots continuously since 1993 on a yearly basis.

The basic tree health information collected between 1993 and 2005 was dieback class, diameter (d.b.h.), height, infection presence, and whether a leaf sample was obtained to culture Discula. Once a tree was laboratory-confirmed as being Discula-positive, that tree was maintained as "positively infected" in the database but no longer resampled to culture the fungus. Crown ratings were based on a six-point scale from 0 to - 5 based on the Mielke-Langdon dieback classes (Mielke and Langdon 1984):

$0=$ tree dead

$1=$ greater than 75 percent of foliage affected

$2=51-75$ percent of foliage affected

$3=26-50$ percent of foliage affected

$4=$ less than 25 percent of foliage affected

$5=$ healthy

Results-Approximately 80 percent of dead trees had confirmed $D$. destructiva infections. As of 2006, 245 of the 294 (85 percent) flowering

${ }^{4}$ NCDFR. Unpublished data. 1993-2006. On file: NCDFR 1616 Mail Service Center, Raleigh, NC 27699-1616. 
dogwoods in the permanent plots had died. Of the dead trees, 67 percent (196 trees) died after being confirmed as positive for infection. However, of the 43 trees still alive as of 2006, 79 percent had also been confirmed as positively infected by anthracnose. Since 2000, mean crown rating for living trees has remained relatively constant. Prior to 2000 , mean crown rating had declined steadily from a high of 5.0 in 1989 to a low of 2.3 in 2002. As of 2000, no trees were rated "healthy," or a crown rating equal to five. Of surviving trees, those infected during the secondary peak infection year of 1999 were in the poorest health.

\section{Conclusions}

A breakdown of mortality by ecoregion showed there were some significant differences, but there were reductions in all ecoregions examined ranging from -2.3 percent to -6.3 percent of the trees per year. Rather than an indication that disease pressure has been reduced via significant host plant reductions, the rate of mortality has increased in the past 10 years compared to the previous decade (fig. 12.1). With nearly 2 billion trees dying per decade, the rate and scale of mortality from dogwood anthracnose is akin to other North American forest pandemics including chestnut blight (causal agent: Cryphonectria parastitica) and Dutch elm disease (causal agent: Ophiostoma novo ulmi).
Although this project was prompted by the observation of abundant dogwoods flowering along roadsides in areas of Maryland and West Virginia, an analysis of population trends show that dogwoods have been significantly impacted and further decreases can be expected. This project has demonstrated the utility of FIA data to document wide-scale population declines and the need for more site-specific studies. Although dogwood does not appear to have been eliminated from any portion of its range, there is currently little understanding of the role dogwood trees play as an associate forest species. We conclude that dogwood has been significantly impacted throughout the study area.

\section{Literature Cited}

Knighten, J.; Anderson, R.L., eds. 1993. Results of the 1992 dogwood anthracnose impact assessment and pilot test in the Southeastern United States. Protection Report R8-PR 24. U.S. Department of Agriculture, Forest Service Region 8.

McLemore, B.F. 1990. Cornus florida L. flowering dogwood In: Burns, R.M.; Honkala, B.H., tech. coord. Silvics of North America: vol 2. Hardwoods. Agric. Handb. Washington, DC: U.S. Department of Agriculture Forest Service: $278-283 \mathrm{p}$

Mielke, M.; Langdon, K. 1984. Dogwood anthracnose fungus threatens Catoctin Mountain Park. Park Science. 6: 6-8.

Miles, P.D. 2005. FIADB version 2.1 database. St. Paul, MN U.S. Department of Agriculture Forest Service, North Central Research Station.

Redlin, S.C. 1991. Discula destructiva sp. nov., cause of dogwood anthracnose. Mycologia. 83(5): 633-642.

SAS Institute. 1996. SAS system for mixed models. Cary, NC: SAS Institute. $633 \mathrm{p}$ 



\section{Introduction}

Oince the late 1970s, oak decline and mortality have plagued Midwestern-upland oakhickory forests, particularly species in the red oak group (Quercus Section Lobatae) across the Ozark Highlands of Missouri, Arkansas, and Oklahoma (Dwyer and others 1995). Drought is a common inciting factor in oak decline, while advanced tree age is considered a predisposing factor, and opportunistic organisms such as armillaria root fungi and red oak borers are believed to contribute to oak decline and mortality. Declining trees first show foliage wilt and browning followed by progressive branch dieback in the middle and/or upper crown. Trees eventually die if crown dieback continues. Our objective was to analyze oak mortality by species group and inventory year to illustrate the general spatial and temporal trends of oak decline and mortality by using data from the Forest Inventory and Analysis (FIA) Program of the Forest Service, U.S. Department of Agriculture; specifically, we used the 1999-2006 annualized data from FIA plots in the Ozark Highlands of Arkansas and Missouri.

\section{Methods and Data}

The data for this study included 3,945 oakpresent FIA plots measured from 1999 through 2006 in the Ozark Highlands of Arkansas and Missouri. The percentage of dead trees was calculated in terms of basal area (ba) for white oak group, red oak group, and non-oak species on each plot. Gaussian kernel density (smoothing) (Wand and Jones 1995) was used to evaluate the spatial trend of average oak mortality in terms of proportion of dead basal area for the decline-prone red oak group over the Ozark Highlands by using FIA plots measured from 2002 to 2006. To evaluate the impact of droughts on regional red oak mortality, the Palmer Drought Severity Index (PDSI) data from 1990 to 2006 for four climate divisions [Arkansas divisions 1 and 2, Missouri divisions 4 and 5 (http://www.esrl.noaa.gov/psd//data/ usclimdivs/data/map.html)] were downloaded from the National Center for Atmospheric Research (NCAR) Web site and correlated with the transformed (taking arc sine square root of) average red oak mortality for each division with the lag time equal to $0,1,2, \ldots, 17$ years (Gottman and Roy 1990). Classification and regression tree (CART) (Breiman and others 1984) analysis was applied to Missouri Ozark Forest Ecosystem Project (MOFEP) 16-year data to identify site/stand and tree level risk factors contributing to oak decline and mortality.

${ }^{1}$ Research Forest Ecologist, U.S. Department of Agriculture, Forest Service, Southern Research Station, Hot Springs, AR 71902

${ }^{2}$ Assistant Professor, Mississippi State University, Department of Forestry, Starkville, MS 39762.

${ }^{3}$ Research Technician, Department of Forestry, University of Missouri, Columbia, MO 65211.

${ }^{4}$ Associate Professor, University of Missouri, Department of Forestry, Columbia, MO 65211

${ }^{5}$ Research Forester (Biometrics), U.S. Department of Agriculture, Forest Service, Northern Research Station, Columbia, MO 65211.

${ }^{6}$ Research Forester, U.S. Department of Agriculture, Forest Service Northern Research Station, St. Paul, MN 55108.

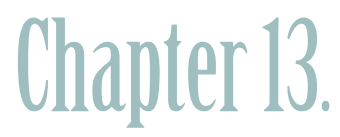

Risk Factors for Oak Decline and Regional Mortality Patterns in the Ozark Highlands of Arkansas and Missouri

(Project SO-EM-06-04)

Martin A. Spetich ${ }^{1}$

ZHAOFEI FAN ${ }^{2}$

Xivli FAn ${ }^{3}$

Hong HE ${ }^{4}$

StePHEN R. SHIFLEY ${ }^{5}$

W. KeIth Moser ${ }^{6}$ 


\section{Results and Discussion}

The proportion of dead basal area of red oak group species showed escalating relative mortality compared with non-oak and white oak group species. Red oak group species decline was the major determinant of this trend, while the white oak group and non-oak species maintained a relatively stable mortality rate (fig. 13.1).

Dead basal area for the non-oak and white oak groups fluctuated around 4 to 5 percent of total basal area during the sequence, while for the red oak group as a whole it increased from around 8 percent in 1999 to 16 to 18 percent by 2006. Fan and others (2008) found that red oak group trees had higher mortality (three or four times higher) than white oaks in this geographic region, which agrees well with the trends found in this study. Note that the mortality trends shown in fig. 13.1 are based on annualized data from the 3,945 FIA oak-present plots. Therefore, each year represents mortality on a subset (between 445 and 960) of those plots.

Two mortality peaks at 2001 and 2004 in the sequence corresponded to the dry cycles in the Ozark Highlands. Cross-correlation analyses

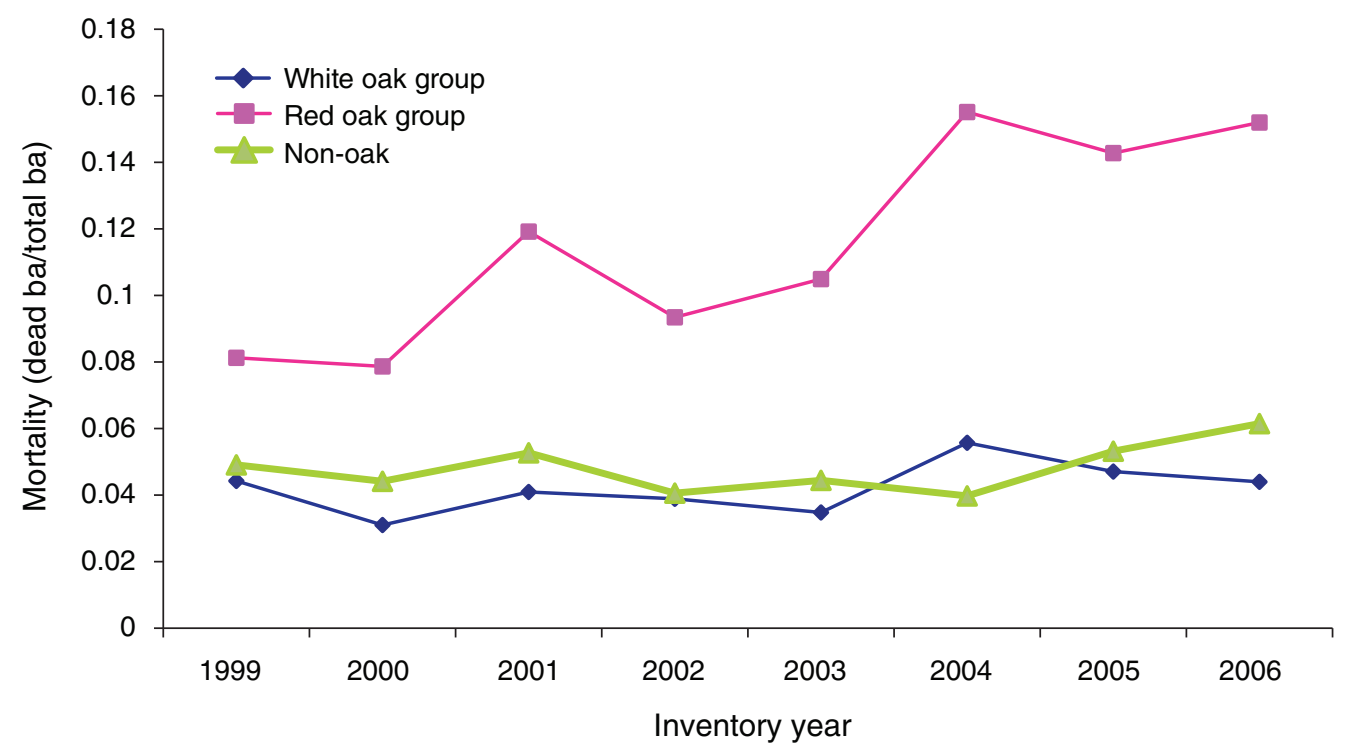

Figure 13.1-Temporal mortality trends for the white oak group, red oak group, and the non-oak group. (Data source: U.S. Department of Agriculture Forest Service, Forest Inventory and Analysis Program) 
indicated that mortality was significantly correlated with the growing season PDSI and usually lagged 2 to 3 years behind single drought events. Moreover, the cumulative impact of droughts on red oak decline and mortality might last up to 10 years based on the past 17 years of PDSI data. The Ozarks experienced a severe drought period from 1998 to 2000 and a mild drought period in 2005 and 2006. These likely triggered the escalation of mortality starting from 2000 (fig. 13.1).

Spatially, high red oak mortality areas (hot spots with a cumulative proportion of dead basal area $>0.15$ ) mainly occurred in the central area of the Ozarks (fig. 13.2). Moderate mortality (with the proportion of dead basal area of $0.10 \sim 0.15$ ) was widespread over most areas of the Ozarks and low mortality was distributed around the outer area of the region (fig. 13.2).

Cross-correlation analysis between PDSI and red oak mortality in FIA plots indicated that drought pattern appears to be the major driver of large-scale (e.g., region) oak decline and mortality patterns compared to temperature regimes. In addition, at small scales like a stand or management unit, tree characteristics (crown class and d.b.h.) and competition condition (e.g., basal area in larger trees) were most important to oak decline and mortality based on 16-year monitoring data from the MOFEP (Fan and others 2006, Shifley and others 2006). On the MOFEP study sites, seven risk groups of declining red oak group species (black oak and scarlet oak) were identified by CART based on tree crown class, d.b.h., and basal area in larger trees (bal), with annual mortality ranging from 0.9 to 7.3 percent (fig. 13.3). Resource managers and foresters could use the identified risk groups to treat declining stands to mitigate oak decline and mortality. We will use a hierarchical approach to explore how regional climatic conditions like drought interact with local factors to affect oak decline and mortality in our followup study.

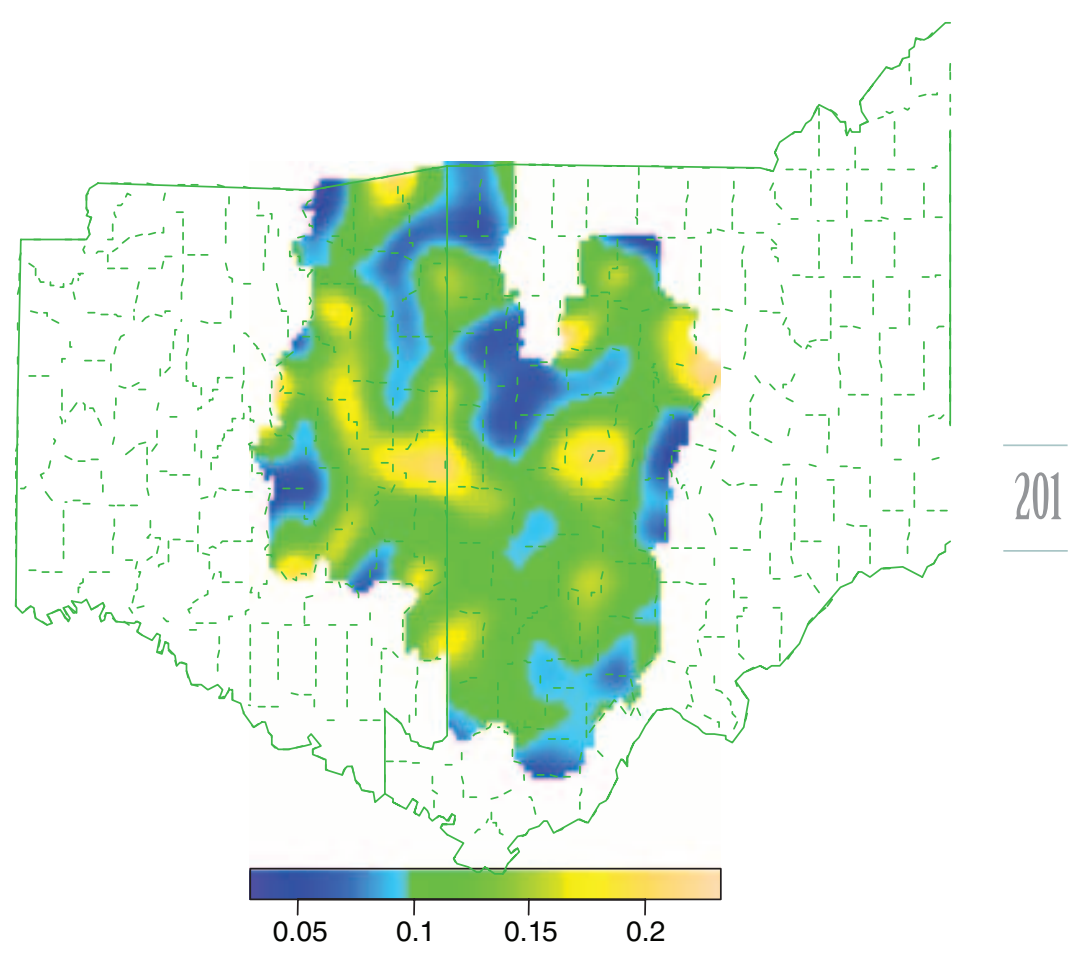

Figure 13.2-Spatial mortality (dead basal area/total basal area) trends of red oak group in the Ozark Highlands. (Data source: U.S. Department of Agriculture Forest Service, Forest Inventory and Analysis Program) 


\section{Conclusions}

Oaks are a major component of the upland oak-hickory forests of Arkansas and Missouri. Episodes of drought and subsequent decline have been a persistent problem in these forests. Of the groups examined in this study, the red oak group consistently dominated dead basal area as a proportion of the total basal area. Regionally, this mortality was significantly correlated with growing season PDSI with 2- to 3-year lag behind single drought events, but at stand level, tree mortality was mainly correlated with tree crown class, d.b.h., and competition. Spatially, hot spots of mortality mainly occurred toward the central part of the Ozarks.

\section{Literature Cited}

Breiman, L.; Friedman, J.H.; Olshen, R.A.; Stone, C.J. 1984. Classification and regression trees. Monterey, CA: Wadsworth and Brooks. 358 p.

Dwyer, J.P.; Cutter, B.E.; Wetteroff, J.J. 1995. A dendrochronological study of black and scarlet oak decline in the Missouri Ozarks. Forest Ecology and Management. 75: 69-75.

Fan, Z.; Kabrick, J.M.; Shifley, S.R. 2006. Classification and regression tree based survival analysis in oak-dominated forests of Missouri's Ozark highlands. Canadian Journal of Forest Research 36: 1740-1748.

Fan, Z.; Kabrick, J.M.; Spetich, M.A. [and others]. 2008. Oak mortality associated with crown dieback and oak borer attack in the Ozark Highlands. Forest Ecology and Management. 255: 2297-2305.

Gottman, J.M.; Roy, A.K. 1990. Sequential analysis: a guide for behavioral researchers. Cambridge, UK: Cambridge University Press. 288 p.

Shifley, S.R.; Fan, Z.; Kabrick, J.M.; Jensen, R.G. 2006 Oak mortality risk factors and mortality estimation. Forest Ecology and Management. 229: 16-26.

Wand, M.P.; Jones, M.C. 1995. Kernel smoothing. Boca Raton, FL: Chapman and Hall/CRC Press. 224 p.

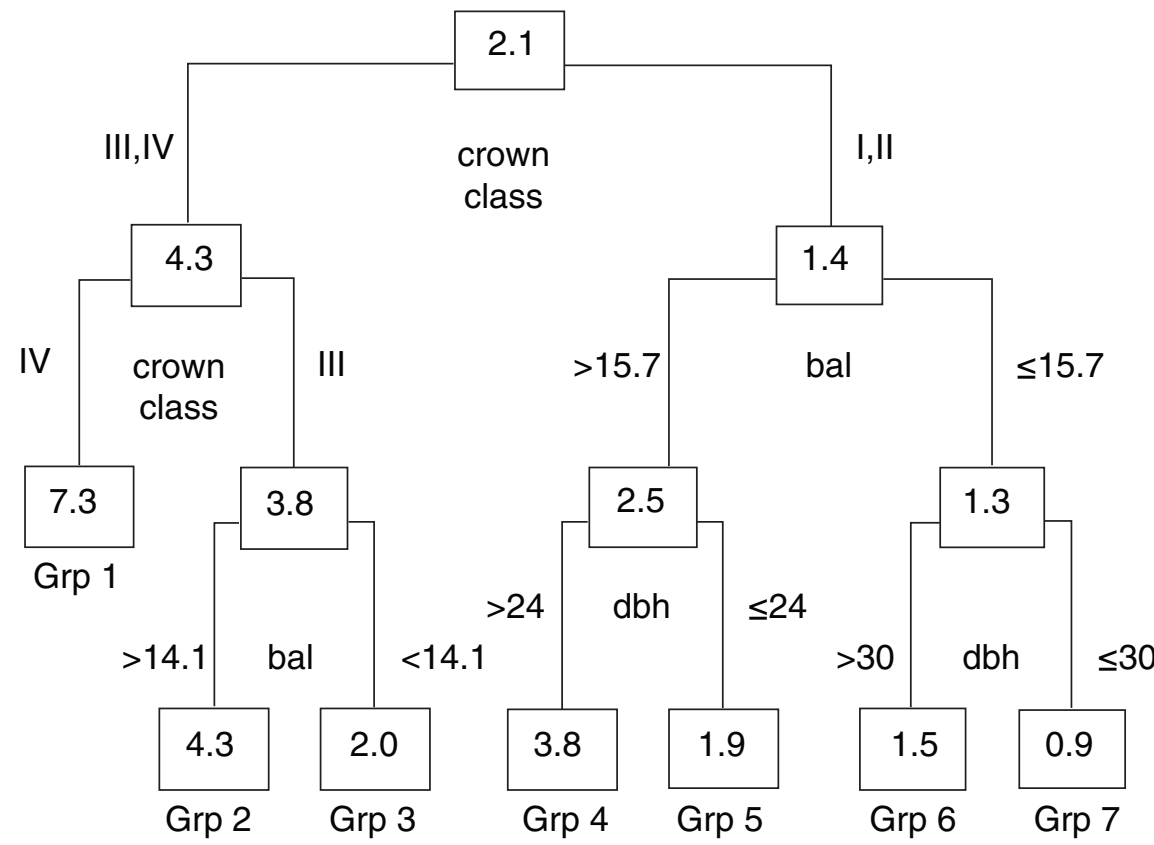

Figure 13.3-Annual mortality (percent) of red oak group species by risk factors for the Missouri Ozark Forest Ecosystem Project (MOFEP) sites. Crown classes are: (I) dominant, (II) codominant, (III) intermediate, and (IV) suppressed. Basal area in larger trees (bal) is computed uniquely for each tree on an inventory plot as the total basal area $\left(\mathrm{m}^{2} / \mathrm{ha}\right)$ of the trees on that plot that are as large or larger in diameter at breast height (d.b.h.). Tree d.b.h. classes are in $\mathrm{cm}$ (from Shifley and others 2006). Note: the numbers in the boxes are the mortality percent at each node. 


\section{Introduction}

حurrent fire policy to restore ecosystem function and resiliency and reduce buildup of hazardous fuels implies a larger future role for fire (both natural and human ignitions) (USDA Forest Service and U.S. Department of the Interior 2000). Yet some fire management (such as building fire line, spike camps, or helispots) potentially causes both short- and longterm impacts to forest health. In the short run, these practices may increase soil disturbance, thereby promoting post-fire weed establishment (Keeley 2005, Merriam and others 2006). Fire management practices also may initiate longterm changes to aspects of landscape structure (such as patch connectivity, size, and shape) that may exacerbate future fire, insect, or disease risk, or jeopardize wildlife habitat (Backer and others 2004). Quantification of these effects can provide important information to guide fire strategy, tactics, and restoration decisionmaking (Sugihara and others 2006).

We sought to determine whether fire management tactics undertaken across a strategic continuum from aggressive suppression to minimum impact create substantially different post-fire conditions as measured by nonnative weeds and landscape patch structure. To do so, we investigated the potential to associate current fire incident data, along with grid locations from the Forest Inventory and Analysis (FIA) of the Forest Service, U.S. Department of Agriculture, to extend the ability of the network to monitor ecological conditions and assess trends.

\section{Objectives}

Specifically, we considered the following questions for weeds:

1. Do fire management tactics increase short-term post-fire weed establishment?

2. Do FIA data assist in monitoring shortand long-term weed establishment?

For landscape structure:

3. Do fire records capture and report management tactics in sufficient detail and consistency to answer extensive research questions?

4. Are digital images of fires (fire line, perimeters, and burn severity) collected in a consistent manner and archived in a central location, thus allowing for programmatic assessment of fire management?

5. Does satellite imagery such as Landsat Thematic Mapper (TM) imagery capture sufficient edge detail to allow identification of ecologically significant edge characteristics and comparison of sharp vs. diffuse burned area edges?

If sufficient landscape data exist, then:

6. Do suppressed fires have a simpler shape than natural fires?

7. Is there less internal heterogeneity in suppressed fires than natural fires?

8. Are the data in such a format (spatial, digital) that they can be associated and stored with FIA data?
Chapter 14.

Understanding the Eiffects of Fire Management Practices on Forest Health: Implications for Weeds and Vegetation Structure

(Project INT-F-04-01)

Anne E. Black ${ }^{1}$

Peter Landres ${ }^{2}$

${ }^{1}$ Interdisciplinary Social Scientist/ Ecologist, U.S. Department of Agriculture Forest Service, Rocky Mountain Research Station, Aldo Leopold Wilderness Research Institute, Missoula, MT 59801.

${ }^{2}$ Peter B. Landres, Ecologist and Research Application Program Leader, U.S.

Department of Agriculture, Forest Service, Rocky Mountain Research Station, Aldo Leopold Wilderness Research Institute, Missoula, MT 59801. 


\section{Methods}

The active fire seasons of 2000, 2003, and 2005 within and surrounding the SelwayBitterroot Wilderness (northern Rocky Mountains of Idaho and Montana) offer an intriguing natural experiment with potential for statistically comparing the effects of fire management strategies and tactics on resulting forest health, here defined as impact on nonnative plant species at a fine scale and landscape patch structure at the broad scale.

FIA data captures common species well, yet weed infestations begin as small, rare, often low density occurrences. Theoretically, a more extensive sampling methodology would be more likely to detect infestations early, as compared to the relatively fine-scale standard FIA Phase 2 sampling design. To test this (Objective 2), in 2004 and 2005 we draped an extensive sampling design over nine approximate FIA plots in areas burned in 2000 or 2003 in the AnacondaPintlar and Selway-Bitterroot Wilderness areas. At each FIA plot location, we sampled a total area of $40 \mathrm{~m}^{2}$ randomly within a $500-\mathrm{m}^{2}$ area centered on the approximate location of an FIA plot. We established four 250-m long randomly oriented transects originating at the approximate center of an FIA plot, one in each quadrant, with quadrants delineated by the main cardinal directions. One $1-\mathrm{m}^{2}$ sample was located at random along each $25-\mathrm{m}$ interval of each transect for a total of $401-\mathrm{m}^{2}$ samples. This design ensures extensive sampling with plots randomly spread throughout the entire sampling area. We then set up a standard FIA phase 2 sampling plot design following the Forest Inventory and Analysis National Core Field Guide (Volume 1: Field Data Collection Procedures for Phase 2 Plots, Version 2.0, January 2004) using the same center point as was used for the extensive sampling. We then recorded all herbaceous weeds within the four sampling subplots of this phase 2 design.

To test whether constructed fire-lines (including dozer, $\mathrm{n}=8$ and hand-line, $\mathrm{n}=11$ ) increase the likelihood of weed species becoming established in wilderness (Objective 1), we randomly sampled for weeds at prescribed distances from a 150-m transect laid down the center of the fire-line. We divided each 150-m transect into 3-m segments and at a random point in each segment, a 20-m transect was established perpendicular to and centered on the main transect ( $10 \mathrm{~m}$ on each side). Along each of these 50 perpendicular transects, all plant species were recorded within a $0.5-\mathrm{m}^{2}$ sampling frame at $0.5-\mathrm{m}, 3-\mathrm{m}$, and $10-\mathrm{m}$ distances from each side of the center. Thus, a total of $150 \mathrm{~m}^{2}$ (300 $0.5-\mathrm{m}^{2}$ samples) were sampled along the fire-line. The sampling frame $10 \mathrm{~m}$ from the fire-line was considered as the control because in all cases these sample points were within forest undisturbed by the fire-line by a distance of at least $3 \mathrm{~m}$.

To test whether areas of high impact, such as back-country camps (spike camps, $\mathrm{n}=2$ ) and helicopter pads (heli-spots) have a greater presence of weeds than surrounding areas (Objective 1), $50 \mathrm{~m}^{2}$ was sampled at various distances from a randomly orientated, 50-m 
transect placed in the approximate center of the disturbed area. This transect was divided into 10-m segments, a random point chosen within each segment, and at this point a 100$\mathrm{m}$ perpendicular transect bisected the main transect. A $0.5-\mathrm{m}^{2}$ sampling frame was placed at 5-m intervals along the $100-\mathrm{m}$ transect. This led to 5 segments each with 20 sampling frames for a total of $100 * 0.5 \mathrm{~m}^{2}=50 \mathrm{~m}^{2}$. The area surrounding the spike camp or heli-spot and in the same vegetation type and physiographic conditions was thoroughly searched for the occurrence of weed species to serve as a control.

To address our landscape structure questions (Objectives 3-8) we collected and analyzed archived incident records (daily incident activity forms and GIS files) and digital imagery $(30 \mathrm{~m}$ Landsat) for 96 fires (ranging in size from 3 ha to 8079 ha) that burned in 2003 and 2005 . For fires occurring within similar biophysical conditions $(\mathrm{n}=49$ in subalpine Potential Vegetation Types), we calculated area and cover-type specific (landscape and class) metrics using FRAGSTATS (McGarigal and Marks 1995) and assessed patterns in burn severity and edge characteristics across the spectrum of fire management strategies reflecting management goals: aggressive suppression (suppress), minimal suppression (contain), and for resource benefits (at the time, called Wildland Fire Use [WFU], fire use). Data were analyzed using a variety of methods due to the messiness of the data-no containment fires in 2005, relatively small sample sizes, very different climatic years in 2003 from 2005. We report results from univariate analysis of variance and GLIMMIX because our dataset, though the largest known, is still somewhat limited and unbalanced.

\section{Results}

Objective 1-Do fire management tactics increase short-term post-fire weed establishment? Yes, our data showed a marked increase of nonnative invasive plant species on the 11 hand-lines measured (73 percent of occurrences) compared to control plots (27 percent of occurrences). This increase was most notable near the "anchorpoint" (where the hand-line is anchored to another feature that prevents fire movement) most likely because of the proximity of this location to previously disturbed areas. Over time, the hand-line may serve as a corridor for the dispersal and establishment of nonnative invasive plants as they move along the length of the hand-line.

Objective 2-Do FIA data assist in monitoring short- and long-term weed establishment? Yes, FIA data did detect several nonnative invasive plant species following fire. However, FIA methods appeared useful only in terrain that is not very complex. In contrast, a less intensive sampling procedure that covers a greater area appeared to be more useful in complex terrain, likely because this method sampled a greater variety of habitats that occur in complex terrain. However, neither method detected all the nonnative invasive plant species that were seen in the area surrounding the sampling plots. 
Objective 3-Do fire incident records capture and report management tactics in sufficient detail and consistency to answer landscape-level research questions? No. Fire records collected for incident management purposes in and around the Selway-Bitterroot Wilderness in western Montana and northern Idaho in 2000, 2003, and 2005 inconsistently captured planned and implemented tactics and were inconsistently archived, resulting in limited utility for post-fire analyses. To conduct such assessments, records would need to note whether and where planned tactics were implemented.

Objective 4-Are digital images of fires (fire line, perimeters, and burn severity) collected in a consistent manner and archived in a central location to allow for programmatic assessment of fire management? High potential. To date, as noted above, there is no central location where fire information (hard copy or electronic) generated on an incident is consistently archived. Fire perimeters were mapped using a variety of techniques; fire-line tactics were not consistently digitized. Moreover, archived data rarely include actual GIS data. This situation inhibits all but local efforts to assess potential ecological impacts of various fire tactics. However, the Forest Service's Remote Sensing Applications Center (RSAC) produces initial burn severity data for all suppression (suppression and containment) fires over 100 acres [Burned Area Reflectance Classification (BARC); Key and Benson 2002, 2006] and was willing to generate similar information for WFU events. These satellite-derived data are sufficient to address landscape ecological questions at a minimum spatial resolution above several ha (O'Neill and others 1999).

Objective 5-Does Landsat TM imagery capture sufficient edge detail to allow for identification of ecologically significant edge characteristics and comparison of sharp vs. diffuse edges? No. TM data were not sufficient for a number of reasons: (1) temporal differences between date of imagery and final fire perimeter (up to 16 days between over-flights plus additional time if smoke obscures the scene); (2) variations in methods used to generate final fire perimeters across and within incidents (varying from handheld ground-based GPS units, to hand-held air-based GPS units, to digitizing from 30-m resolution satellite imagery); and (3) a mismatch in scale between TM data and that at which edge effects occur (30 m for satellite imagery and sub-units of meters for ecological effects) result in an inability to use TM data for considerations of edge characteristics such as sharpness of edge and sinuosity. Changes in how perimeters are derived for purposes of BARC calculation, and storage of these perimeters confounded year effects for patches and area of unburned vegetation within the final fire perimeter. If this could be standardized, the data would be even more useful.

Objective 6-Do suppressed fires have a simpler shape than natural fires? No. We analyzed the BARC data for our 49 sub-alpine fires at two scales: by entire fire and by severity class. 
Looking at the final fire perimeter, we find larger fires are significantly more complex (as measured by Area Weighted Mean Patch Fractal Dimension) even after controlling for total fire size $\left(F_{1,39}=29.93, P \leq 0.000\right)$. Using a randomized complete block design with year as a random effect, a GLIMMIX model indicates there is no significant difference in perimeter shape by strategy or by year once size and year are controlled. However, there appear to be differences between suppression fires in warm, dry years (2003) and wildfire use fires (2003, 2005) as indicated by significant p-values in least squares means tests for year*firetype after adjusting for multiple comparisons (Tukey-Kramer).
In the absence of year and size considerations, high severity patches are less complex than other severities (fig. 14.1). Univariate analysis of variance shows patches of all severities within a suppression fire are significantly more complex than either WFU or containment fires $\left(F_{2,36}=4.113, P \leq 0.025\right.$ high severity; $F_{2,46}=14.352, P \leq 0.000$ moderate; $F_{2,46}=5.26, P \leq 0.009$ low severity; $F_{2,45}=5.838, P \leq 0.006$ unburned). These statistical differences disappear when controlling for year and size effects, although the resulting models have low power. Patches do become somewhat more complex with increasing size, and 2005 was a less severe season than 2003, as measured by number of days above $80^{\text {th }}$ percent

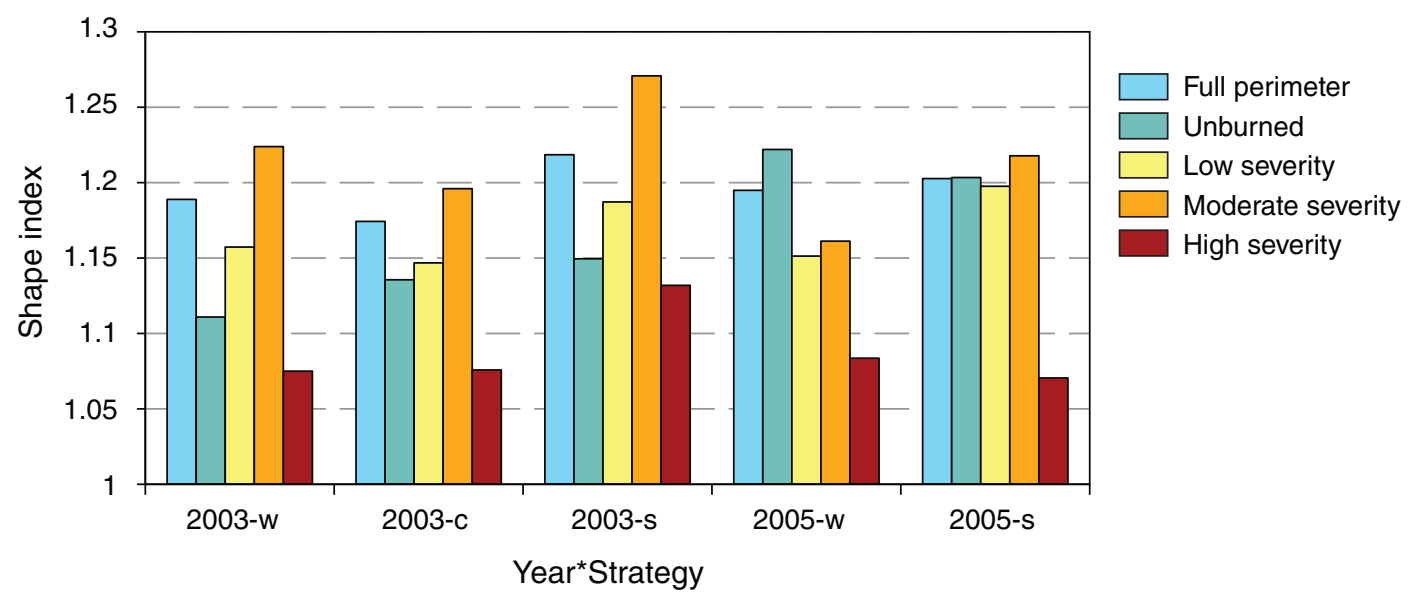

Figure 14.1-Comparison of fire and internal patch shape (defined by severity class and measured by Area Weighted Mean Shape Index) for wildland fire use (w), confinement (c), and suppression (s) fires in 2003 and 2005. Note: there were no confinement fires in 2005. 
Energy Release Component. Overall, the trend appears to be that complexity increases with size and decreases with increasing fire severity and fire weather conditions.

Objective 7-Is internal heterogeneity lower in suppressed fires than natural fires? In some respects, yes. We measured heterogeneity several wayspatch density, mean patch size, interspersion, aggregation, contagion, and percent area-at both scales: entire fire and by severity class. Comparison among strategies indicates that patch density in fire use events is higher than in suppression events for unburned, low, and moderate severity classes and the entire fire (fig. 14.2A). Overall, density was higher in cooler 2005 and decreased for larger fires. We used several FRAGSTATS metrics to assess interspersion, aggregation, and contagion. As with other metrics, when considered irrespective of year and size, fire use events were more disaggregated (lower contagion, aggregation) and heterogeneous (variability in patch size, higher interspersion) than suppression events at both the fire scale and by fire severity class (fig. 14.2B through 14.2E). Once again, these differences were over-shadowed by year and size effects. Degree of aggregation differs with size of fire regardless of year, but was significantly lower in the cooler 2005.

Objective 8-Are the data in such a format (spatial and digital) that they can be associated and stored with FIA data? Possible, not currently. As noted earlier, data are not currently consistently or accessibly archived. If tactical-level GIS data, and associated BARC imagery, were to be consistently generated and centrally stored, it would be quite possible to tag with FIA plot numbers to create a national network for monitoring trends in ecological effects of fire management.

\section{Discussion}

Landscape results are consistent across a variety of different models based on oneway and multi-way analyses of variance. The emerging picture is a trend toward greater heterogeneity in internal post-fire patch structure during cooler years, and a pattern of smaller, more dispersed patches on WFU and containment as opposed to suppression events, particularly when considering patches of high severity burns. Warmer years appear to result in more homogeneous patches of high severity burn. If this trend plays out statistically, the implication for future forest health has more to do with timing of choice of fire management strategy and overall climate than with the strategy per se. This assumes that heterogeneity post-fire translates into more diverse future vegetative succession, and patchier fuels (more heterogeneity in cover type and structure), which is likely to influence future fire behavior through patchier fuel moisture. The robustness of significant differences in this study, and the low power of non-significant results, combined with policy and demographic changes that will undoubtedly affect strategic decisions for fire management, suggest that it would be useful to pay closer attention to this issue. Consistently associating and storing BARC data with FIA plots could be one way to build a sufficient database for more robust analyses. 


\section{(A) Patch density}

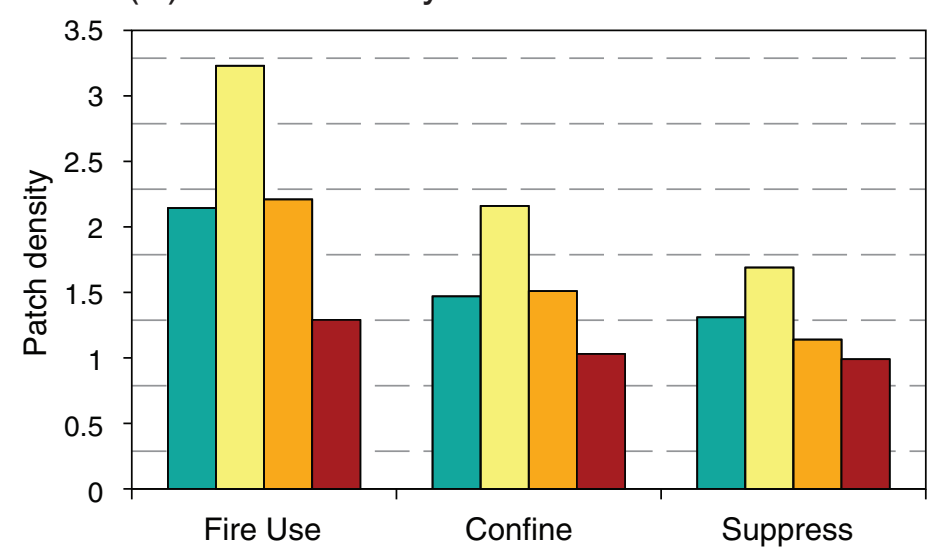

(B) Mean patch size

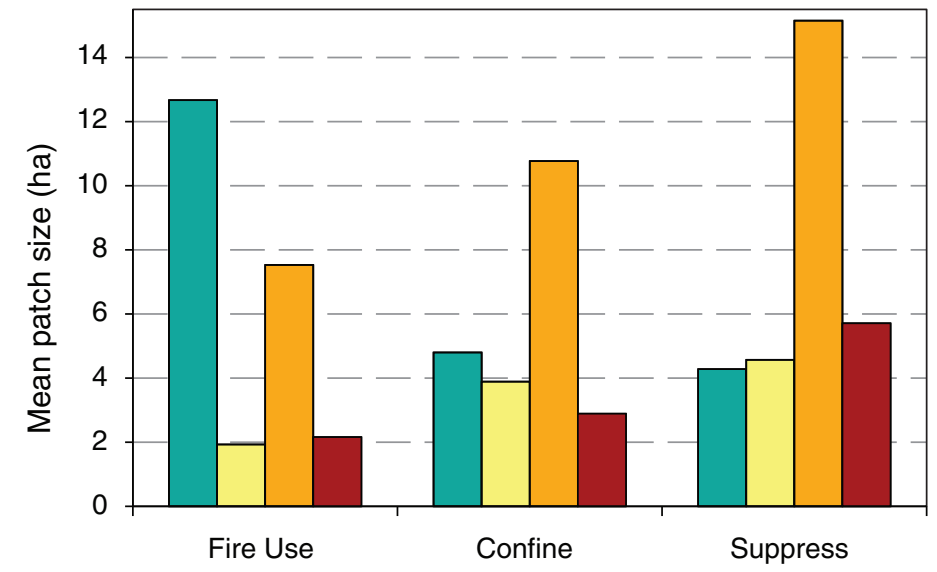

(C) Clumpiness

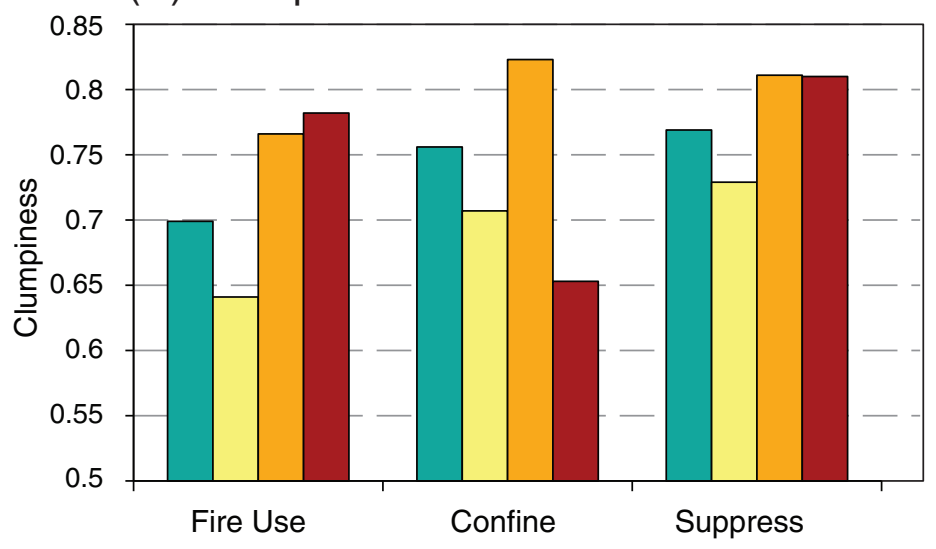

(D) Percent like adjacencies

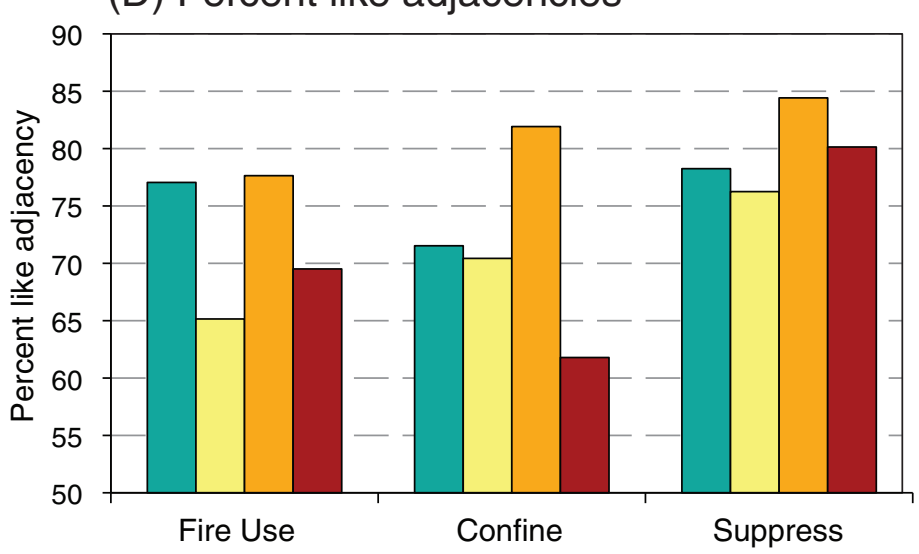

(E) Interspersion and juxtaposition

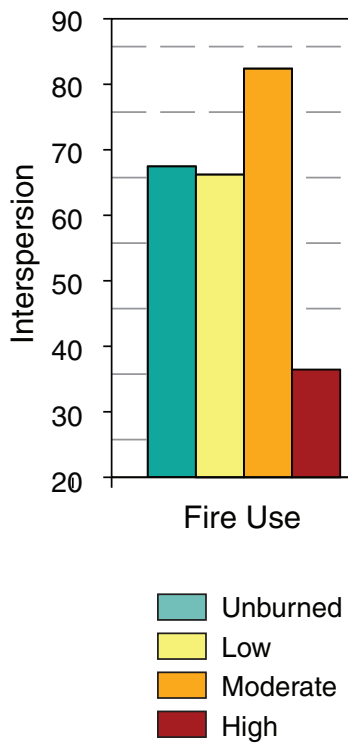

Figure 14.2-Class metrics, defined by severity class, for wildland fire use, confinement, and suppression strategies for subalpine fires $>3$ ha in and around the SelwayBitterroot Wilderness in 2003 and 2005. 


\section{Literature Cited}

Backer, D.M.; Jensen, S.E.; McPherson, G.R. 2004. Impacts of fire-suppression activities on natural communities. Conservation Biology. 18(4): 937-946

Keeley, J.E. 2005. Fire management impacts on invasive plants in the western United States. Conservation Biology. 20: 375-384.

Key, C.H.; Benson, N.C. 2002. Post-fire burn assessment by remote sensing on National Park Service lands, and measuring and remote sensing of burn severity. Open-File Report 02-11. Albuquerque, NM: U.S. Geological Survey: $55-56$.

Key, C.H.; Benson, N.C. 2006. Landscape assessment: ground measure of severity, the Composite Burn Index; and remote sensing of severity, the Normalized Burn Ratio. 1 CD. In: Lutes, D.C.; Keane, R.E.; Caratti, J.F. [and others]. 2005. FIREMON: Fire Effects Monitoring and Inventory System. Gen. Tech. Rep. RMRS-GTR-164-CD. Ogden, UT: U.S. Department of Agriculture Forest Service, Rocky Mountain Research Station: LAl-51.
McGarigal, K.; Marks, B.J. 1995. FRAGSTATS: spatial analysis program for quantifying landscape structure. Gen. Tech. Rep. PNW-GTR-351. Portland, OR: U.S. Department of Agriculture Forest Service. $122 \mathrm{p}$.

Merriam, K.E.; Keeley, J.E.; Beyers, J.L. 2006. Fuel breaks affect nonnative species abundance in California plant communities. Ecological Applications. 16: 515-527.

O’Neill, R.V.; Riitters, K.H.; Wickham, J.D.; Jones, K.B. 1999. Landscape pattern metrics and regional assessment. Ecosystem Health. 5: 225-233.

Sugihara, N.G.; van Wagtendonk, J.W.; Fites-Kaufman J. 2006. Fire as an ecological process. In: Sugihara, N.J. van Wagtendonk, J.W.; Fites-Kaufman, J. [and others], eds. Fire in California's ecosystems. Berkeley, CA University of California Press: 58-74.

U.S. Department of Agriculture (USDA) Forest Service and U.S. Department of the Interior. 2000. A report to the President in response to the wildfires of 2000. Www. fireplan.gov/president.cfm. [Date accessed: April 7, 2009]. 


\section{Introduction}

Te of environmental variables as predictors of vegetation distribution patterns has long

been a focus of ecology. However, the effect of edaphic factors on vegetation pattern is often measured using surrogates such as topography, because accurate measures of soil fertility and nutrients are unavailable or rare (Marage and Gégout 2009). Kalmia latifolia and Rosa multiflora exhibit contrasting regional vegetation patterns in which $K$. latifolia is more abundant in north central Pennsylvania and eastern West Virginia than in western West Virginia and eastern Ohio. In contrast, $R$. multiflora is more abundant in eastern Ohio and eastern West Virginia than it is in western West Virginia and north central Pennsylvania (FIA 2007). The distribution of these two species could be explained by changes in elevation over this region, and increasing elevations have been correlated with decreasing temperatures, decreasing soil moisture,

decreasing soil $\mathrm{pH}$, increasing organic matter, and increasing soil C (Niklinska and Klimek 2007). Studying the two species at the regional scale as well as local scale (under which the topographic conditions are more similar) will enable us to evaluate the relative importance of non-topographic variables, such as soil fertility (soil pH and nutrients).
Kalmia latifolia is a native shrub species of eastern forests that is typically associated with more xeric site conditions, and is considered invasive by some land managers (Chastain and Townsend 2008, Monk and Day 1985). The ability of $K$. latifolia to inhabit such xeric sites is potentially linked to a tight mineral cycle due to its ability to slowly return nutrients from very slowly decaying litter (Chastain and others 2006). Rosa multiflora is a nonnative invasive shrub that was intentionally introduced as a hedgerow species for pastures in the 1930s and has been spreading throughout the Eastern, Midwestern, and Western United States, including into closed canopy forests. There is evidence that $R$. multiflora has a preference for more fertile and mesic habitats (Huebner and Tobin 2006), which suggests that $K$. latifolia and $R$. multiflora should rarely coexist.

The purpose of this research is to determine if a soil fertility gradient exists across both regional and local scales and if this fertility gradient helps

\footnotetext{
${ }^{1}$ Research Botanist/Ecologist, U.S. Department of Agriculture, Forest Service, Northern Research Station, Morgantown, WV 26505.

${ }^{2}$ Research Ecologist, U.S. Department of Agriculture, Forest Service, Northern Research Station, Delaware, OH 43015.

${ }^{3}$ Research Ecologist, U.S. Department of Agriculture, Forest Service, Northern Research Station, Irvine, PA 16329.

${ }^{4}$ Research Ecologist, U.S. Department of Agriculture, Forest Service, Northern Research Station, Irvine, PA 16329.

${ }^{5}$ Northeast Regional Program Manager, U.S. Department of Agriculture, Forest Service, Forest Health Monitoring, Newtown Square, PA 19073.
}

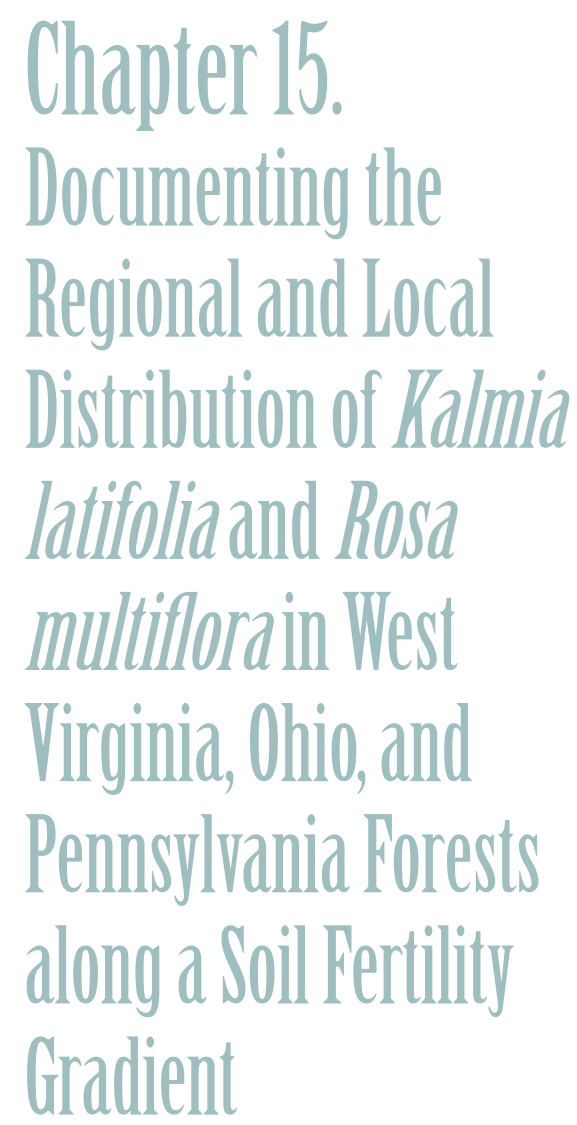

Cynthia D. Huebner ${ }^{1}$

Todd Hutchinson ${ }^{2}$

Todd RIstau ${ }^{3}$

Alejandro Royo ${ }^{4}$

James Steinman $^{5}$ 
explain the regional vegetation pattern or local presence of $K$. latifolia or $R$. multiflora.

\section{Methods}

We conducted this study from June to August in 2007 and 2008. In 2007, we randomly located (starting point) four $1-\mathrm{km}$ transects within forests 70 years or older in each State's national forest (i.e., Monongahela, Allegheny, and Wayne National Forests, in West Virginia, Pennsylvania, and Ohio, respectively), resulting in a total of 12 transects. Along each transect, a $100-\mathrm{m}^{2}$ plot was located every $100 \mathrm{~m}$, with each transect therefore having ten $100-\mathrm{m}^{2}$ plots. Four $10-\mathrm{m}^{2}$ plots were nested within each of the $100-\mathrm{m}^{2}$ plots and percent cover of all shrub species was estimated in each. We sampled canopy and subcanopy trees using a 10-factor wedge prism at each $100-\mathrm{m}^{2}$ plot center. Four B horizon soil cores were taken outside each $10-\mathrm{m}^{2}$ plot, totaling 16 subsamples for each $100-\mathrm{m}^{2}$ plot; subsamples were mixed for each $100-\mathrm{m}^{2}$ plot. We collected elevation, slope, aspect, light, and canopy opening data at the center of each $100-\mathrm{m}^{2}$ plot.

In 2008, we randomly established 10 plots per State and species from known locations of either K. latifolia or R. multiflora. Each individual shrub was at least $2 \mathrm{~m}$ in diameter and served as the center of each plot. These plots were located within forests at least 70 years old. Openings and other disturbances were avoided. Eight B-horizon soil samples were collected and mixed from each of the 30 shrub plots (four from under the shrub canopy and four $2 \mathrm{~m}$ away from the canopy edge). We also sampled eight $1-\mathrm{m}^{2}$ subplots (four under the shrub canopy and four $2 \mathrm{~m}$ outside the canopy) of each shrub for herb/shrub/vine and tree seedling cover and calculated richness and diversity for each $1-\mathrm{m}^{2}$ subplot. Topographic and canopy/subcanopy tree data were collected using the 2007 methods. We collected 10 leaves from each shrub for nutrient analysis. Nutrients measured in plant tissue included total nitrogen $(\mathrm{N})$, carbon $(\mathrm{C})$, calcium $(\mathrm{Ca})$, potassium $(\mathrm{K})$, magnesium $(\mathrm{Mg})$, phosphorus $(\mathrm{P})$, iron $(\mathrm{Fe})$, manganese $(\mathrm{Mn})$, and zinc (Zn); analyses conducted on the soil samples included $\mathrm{pH}$, total $\mathrm{N}, \mathrm{Ca}, \mathrm{K}, \mathrm{Mg}, \mathrm{P}, \mathrm{Fe}, \mathrm{Mn}, \mathrm{Na}$, and $\mathrm{Zn}$. Tissue analyses data were collected in order to relate measured soil nutrient availability with plant nutrient uptake and storage.

The soil and plant nutrient data and topographic data were analyzed by State and species using a generalized linear model (Proc GenMod, SAS v. 9.01) with a gamma distribution and log link function for all the variables except herb/shrub/vine diversity, which was normally distributed. No significant differences were noted for soil samples directly under the shrubs and those taken $2 \mathrm{~m}$ outside the shrub canopies.

\section{Results}

There were a total of 12,8 , and 20 shrub species in West Virginia, Pennsylvania, and Ohio, respectively, along the random transects. Based on relative importance values, Smilax rotundifolia was the most important shrub in both Ohio 
and West Virginia and Rubus sp. was the most important shrub in Pennsylvania. Kalmia latifolia was the fifth most important shrub in both West Virginia and Pennsylvania but did not occur on the Ohio transects. Berberis thunbergii only occurred in the West Virginia and Pennsylvania transects, Lonicera x bella, both of which are nonnative invasive species, only on the Pennsylvania transects, and $R$. multiflora only on the Ohio transects. Ohio was the only State that had an exotic shrub ( $R$. multiflora) that ranked in the top 10 most important species. Ohio tree diversity (calculated with the ShannonWeaver index) along the transects was greater than that of Pennsylvania. Ohio shrub diversity was greater than that of both West Virginia and Pennsylvania, and West Virginia shrub diversity was greater than that of Pennsylvania. The State transects did not differ significantly in terms of canopy cover, but Ohio transects were located on steeper slopes, while Pennsylvania transects were located on slopes that were more northeast-facing than those of Ohio and West Virginia. Ohio transects were located at lower elevations than both Pennsylvania and West Virginia transects. Results confirmed a significant regional soil $\mathrm{pH}$ and fertility gradient, revealing higher soil pH and $\mathrm{Ca}$ (with $\mathrm{K}$ and Mg showing similar results) in Ohio followed by Pennsylvania and West Virginia (figs. 15.1A, 15.1B). An inverse relationship was found for $\mathrm{N}$ as well as Mn (except West Virginia) and Zn (fig. 15.1C,
15.1D; Zn is not shown). These differences in soil $\mathrm{pH}$ and nutrients are likely correlated with the topographic differences found among the States.

At the local scale, R. multiflora plots were located on more shallow slopes, at lower elevations, and under more open canopies than K. latifolia, but only in West Virginia. Rosa multiflora plots were associated with higher levels of plant species diversity (but not significantly so in Pennsylvania). Kalmia latifolia plots were found on more acidic soils than $R$. multiflora, but only in Ohio (fig. 15.2A). In fact, the soil pH for the $K$. latifolia plots in Ohio was significantly lower than the $K$. latifolia plots in Pennsylvania and West Virginia. Rosa multiflora plots were generally located on soils with higher levels of soil Ca, K, Mg, and Mn than K. latifolia, with Ohio having the highest values of soil $\mathrm{Ca}, \mathrm{K}$, and $\mathrm{Mg}$ (not shown) and West Virginia having the highest values of Mn (figs. 15.2B, 15.2C, 15.2D). The amount of soil $\mathrm{N}$ occurring within $R$. multiflora and $K$. latifolia plots did not differ between species, though West Virginia plots were higher in soil $\mathrm{N}$ than Pennsylvania and Ohio plots. In contrast, $R$. multiflora's tissue was higher in $\mathrm{N}$ and $\mathrm{K}$ (with West Virginia having the highest values), as well as Ca (with Ohio having the highest values) (figs. 15.3A, 15.3B, 15.3C). Kalmia latifolia tissue had higher levels of Mn (as well as $\mathrm{Zn}$ ) than R. multiflora in all three States (fig. 15.3D). 
(A)

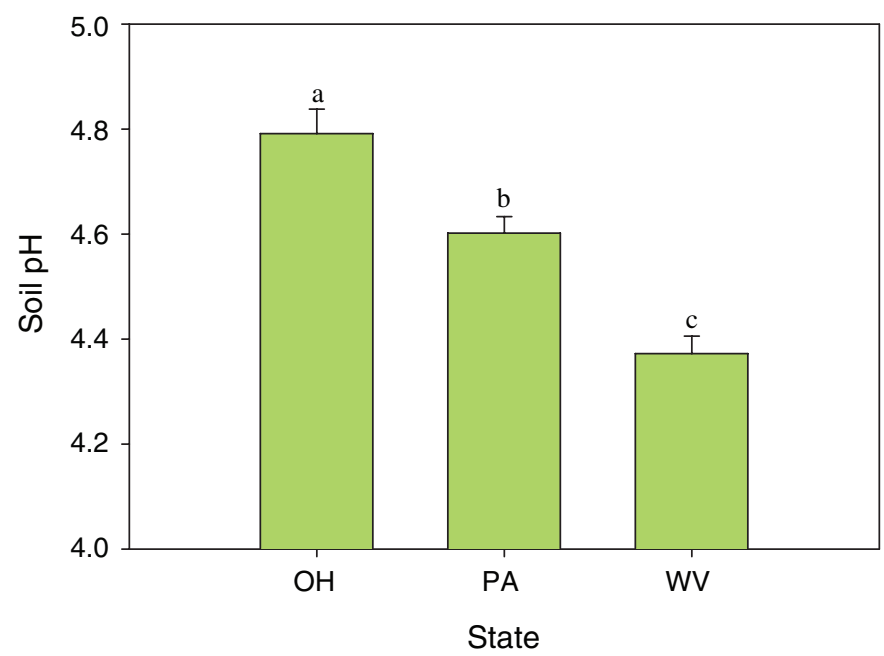

(B)

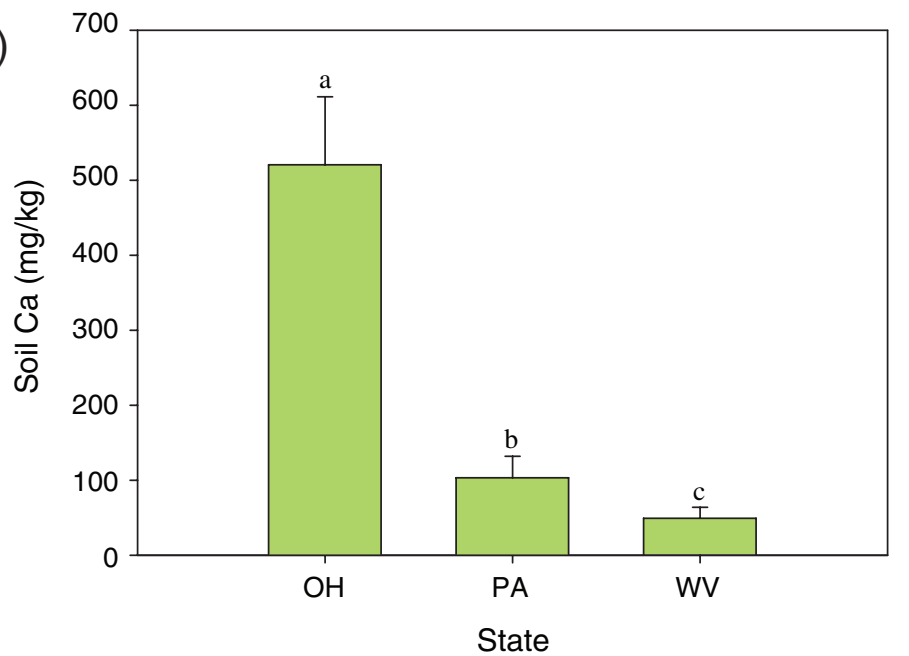

(C)

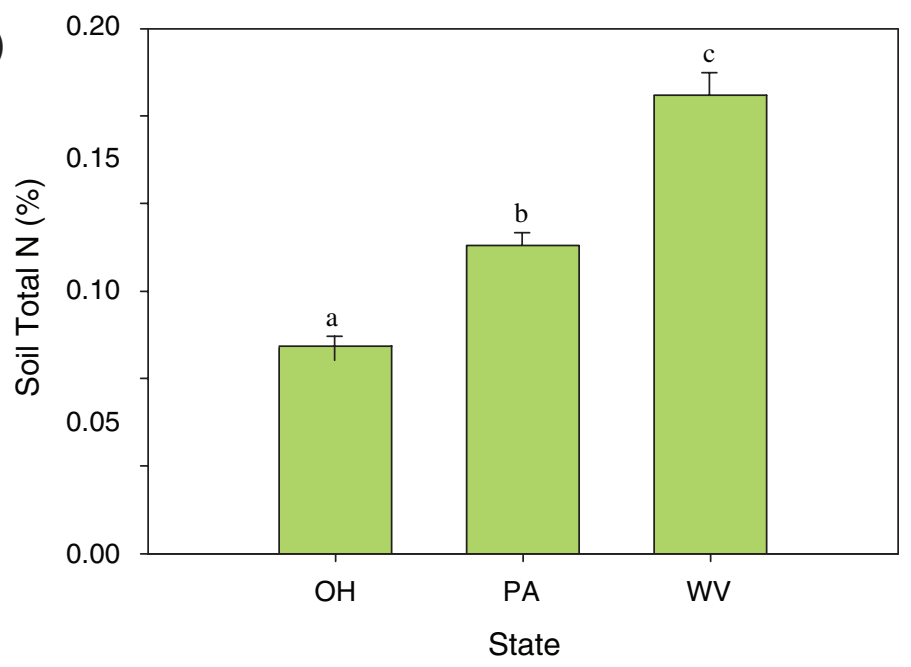

(D)

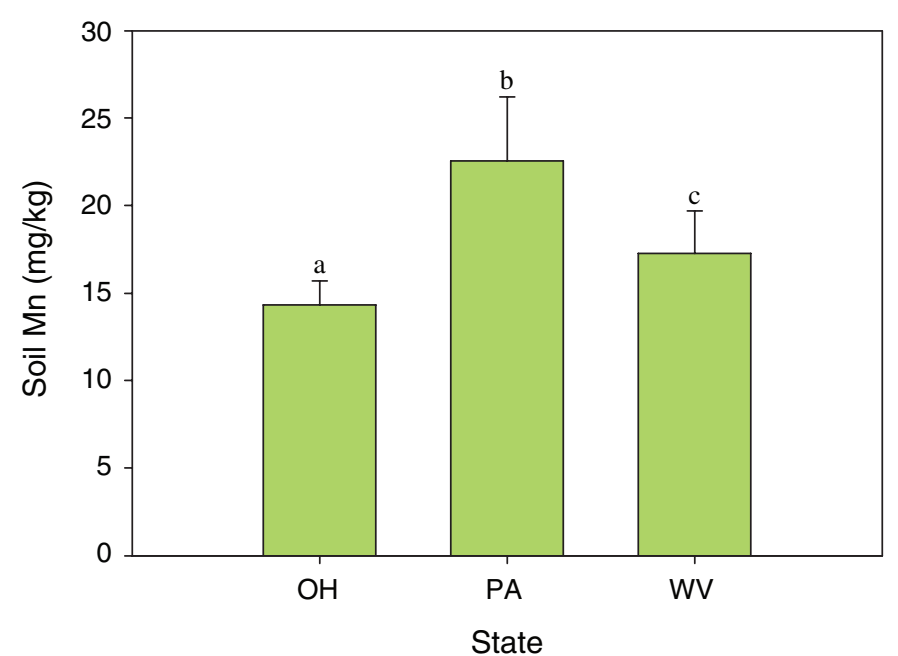

Figure 15.1-Soil pH (A), soil calcium (mg/kg) (B), soil total N (percent) (C), and soil manganese (mg/kg) (D) in Ohio, Pennsylvania, and West Virginia. Lowercase letters indicate statistical differences among groups. 
(A)

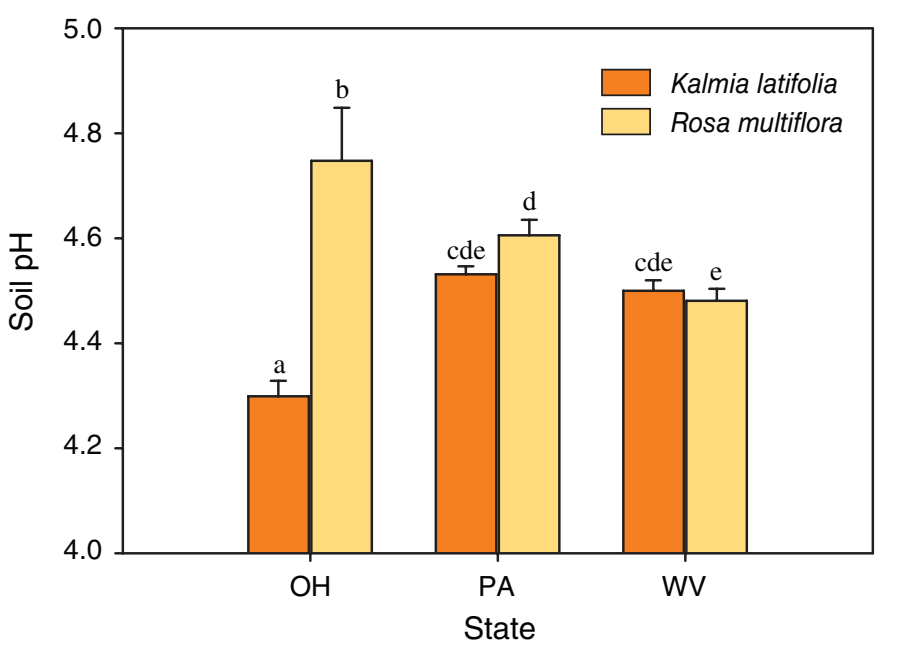

(B)

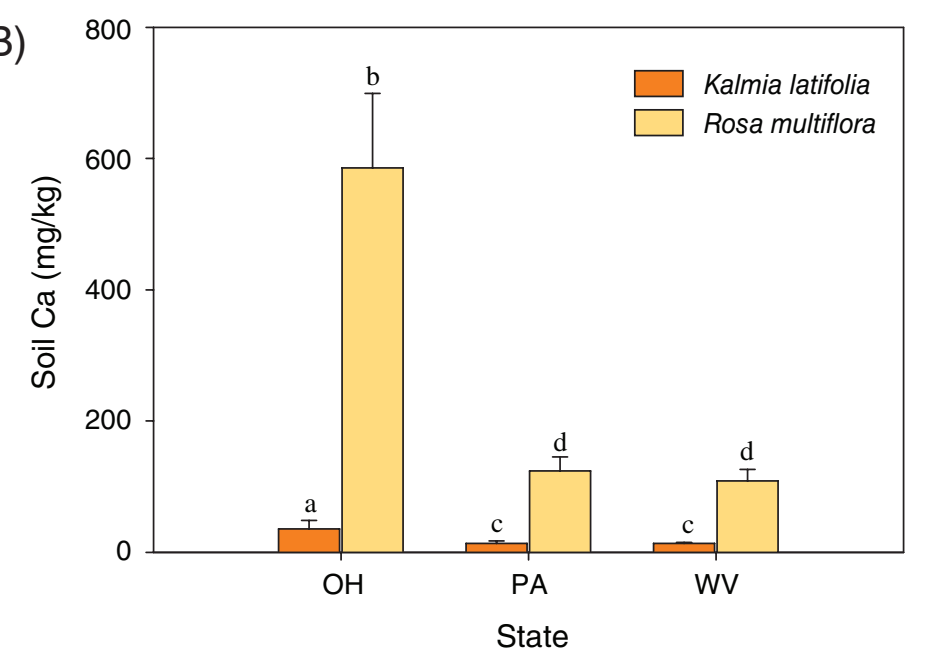

(C)

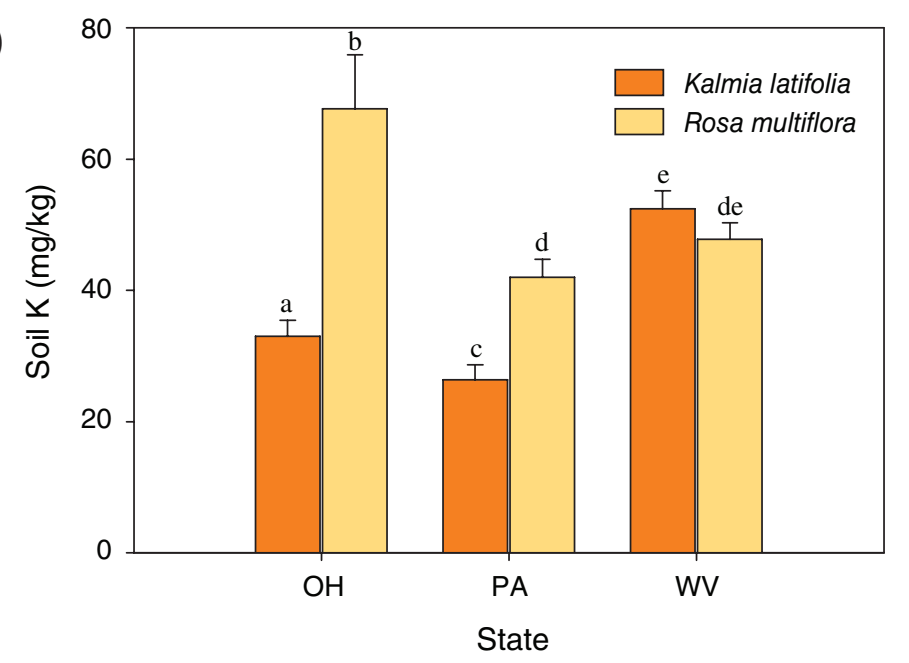

(D)

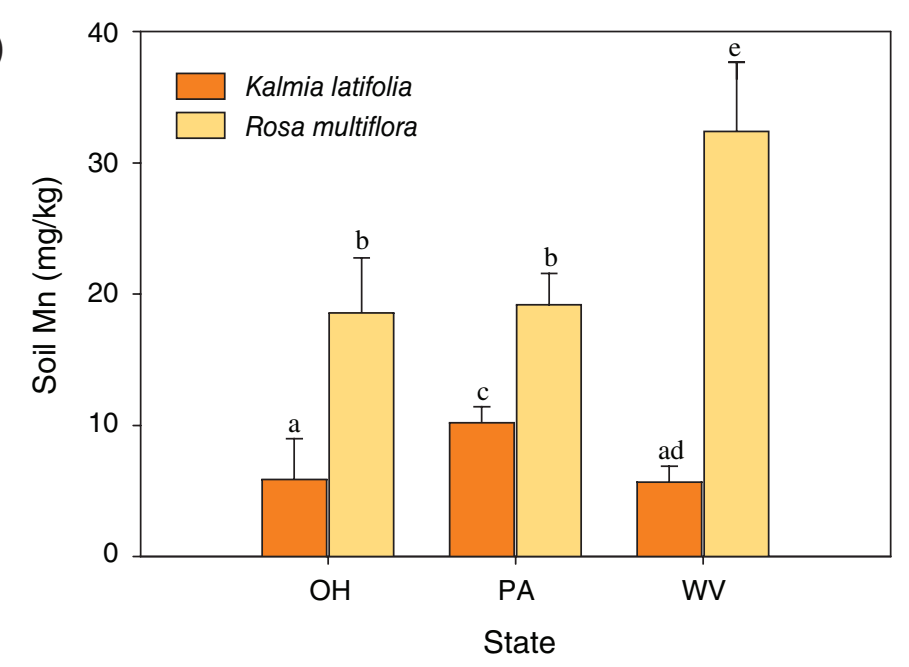

Figure 15.2-Soil pH (A), soil calcium (mg/kg) (B), soil potassium (mg/kg) (C), and soil manganese $(\mathrm{mg} / \mathrm{kg})(D)$ on Kalmia latifolia and Rosa multiflora plots in Ohio, Pennsylvania, and West Virginia. Lowercase letters indicate statistical differences, or lack of statistical differences, among groups. 
(A)

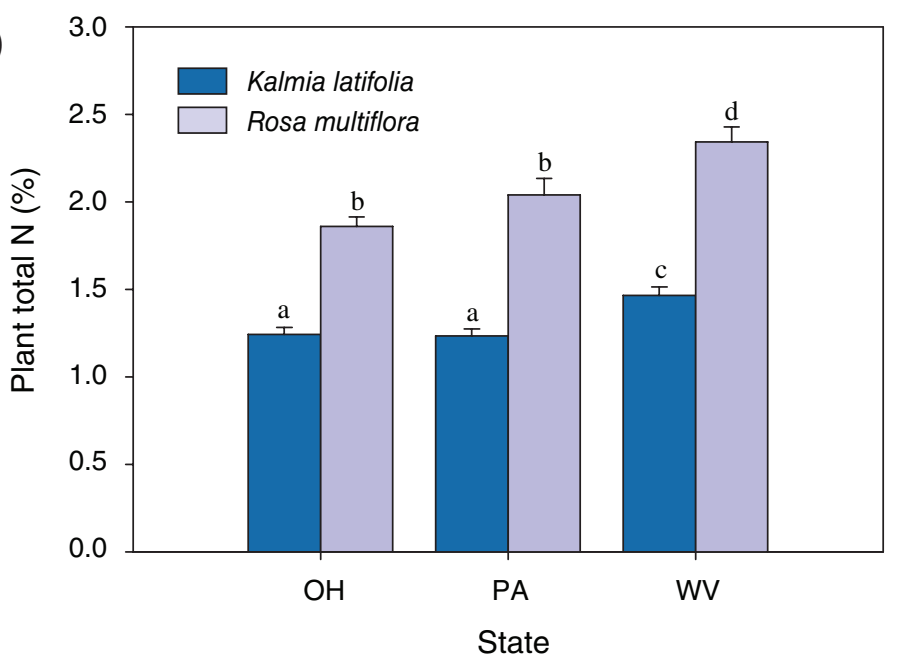

(B)

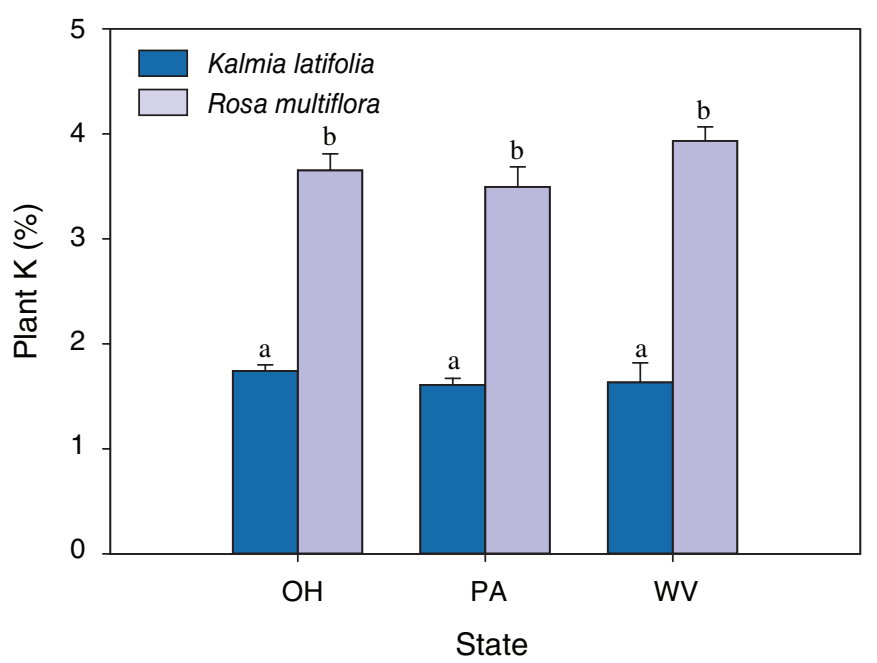

(C)

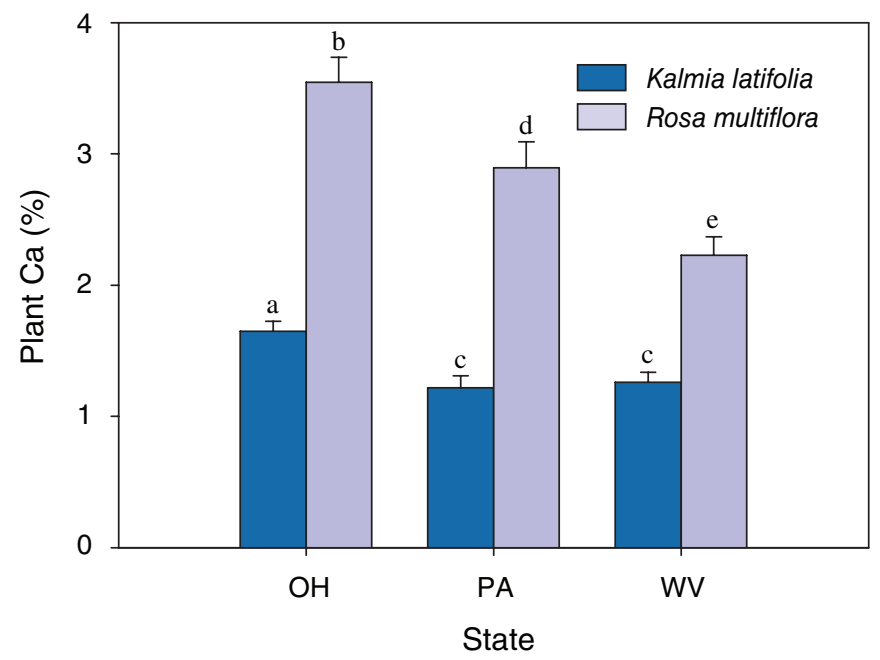

(D)

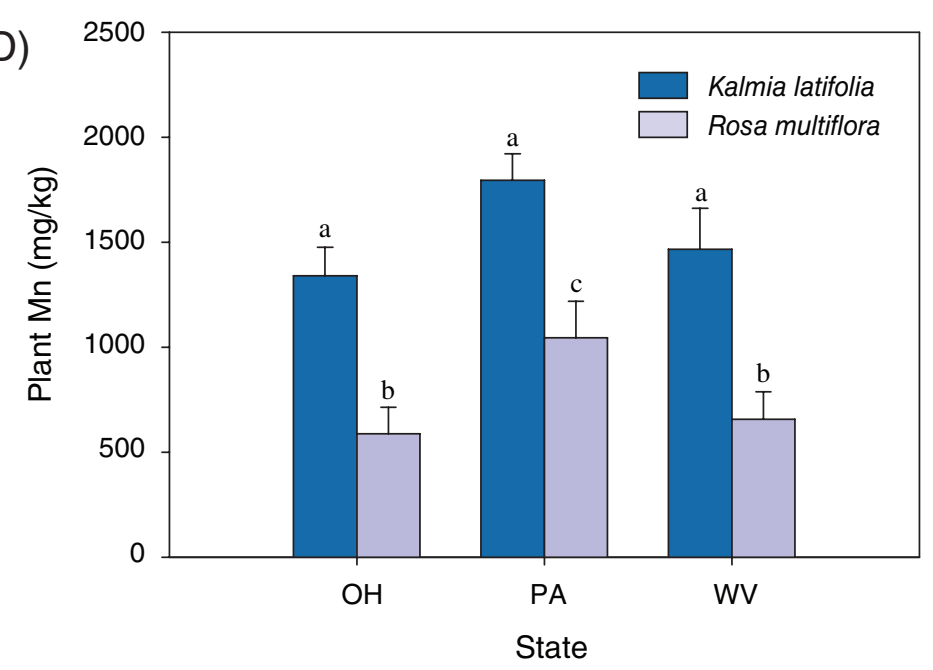

Figure 15.3-Plant total nitrogen (percent) (A), plant potassium (percent) (B), plant calcium (percent) (C), and plant manganese (percent) (D) of Kalmia latifolia and Rosa multiflora plots in Ohio, Pennsylvania, and West Virginia. Lowercase letters indicate statistical differences, or lack of statistical differences, among groups. 


\section{Discussion and Conclusions}

$K$. latifolia is regionally more abundant than $R$. multiflora (and other exotic invasive species) but less likely to be present in areas of high soil fertility or low acidity. Nonetheless, topographic differences, including elevation, remain important. At the local scale, soil $\mathrm{pH}$ and nutrients appear to play a more important role in determining the distribution of these two species in Ohio and Pennsylvania than topography, while topography is still a key factor at the local scale in West Virginia. While these results enable us to predict that invasion of $R$. multiflora is more likely in areas of high soil fertility, we can only separate out the importance of these soil variables from topographic factors at the local scale in Ohio and Pennsylvania. The strongest pattern was for R. multiflora to be associated with soils high in $\mathrm{Ca}, \mathrm{K}, \mathrm{Mg}$, and $\mathrm{Mn}$. The higher soil values of $\mathrm{Ca}, \mathrm{K}$, and $\mathrm{Mg}$ associated with R. multiflora were also evident in its tissue, but this was not true for $\mathrm{Mn}$. In contrast, K. latifolia apparently stores larger amounts of Mn than $R$. multiflora, despite being located in soils lower in Mn than soils near R. multiflora. Kalmia latifolia may be limited by Mn (and Zn). However, the extreme acidity on which $K$. latifolia was found in Ohio may also result in absorption of $\mathrm{Mn}$ to toxic levels. The poor condition of $K$. latifolia shrubs in Ohio may provide support for possible Mn toxicity. While elevation, moisture gradients, and historic disturbances likely play an important role in the current distribution of both species regionally and locally in West Virginia, our data show that soil $\mathrm{pH}$ and nutrients are also significant factors that may explain local distribution patterns that cannot be explained by topography.

\section{Literature Cited}

Chastain, R.A.; Currie, W.S.; Townsend, P.A. 2006. Carbon sequestration and nutrient cycling implications of the evergreen understory layer in Appalachian forests. Forest Ecology and Management. 231: 63-77.

Chastain, R.A.; Townsend, P.A. 2008. Role of evergreen understory shrub layer in the forests of the central Appalachian Highlands. The Journal of the Torrey Botanical Society. 135: 208-223.

Forest Inventory and Analysis Program. 2007. The Forest Inventory and Analysis database: database description and users guide version 3.0. Arlington, VA: U.S. Department of Agriculture, Forest Service. $230 \mathrm{p}$

Huebner, C.D.; Tobin, P.C. 2006. Invasibility of mature and 15-year old deciduous forests by exotic plants. Plant Ecology. 186: 57-68.

Marage, D.; Gégout, J-C. 2009. Importance of soil nutrients in the distribution of forest communities on a large geographical scale. Global Ecology and Biogeography. 18: 88-97.

Monk, C.D.; Day, F.P., Jr. 1985. Vegetation analysis, primary production and selected nutrient budgets for a southern Appalachian oak forest: a synthesis of IBP studies at Coweeta. Forest Ecology and Management. 10: 87-1 13.

Niklinska, M.; Klimek, B. 2007. Effect of temperature on the respiration rate of forest soil organic layer along an elevation gradient in Polish Carpathians. Biology and Fertility of Soils. 43: 511-518. 



\section{Introduction}

nalysis of crown condition data for the 2006 national technical report of the Forest 1 Health Monitoring (FHM) Program of the Forest Service, U.S. Department of Agriculture, exposed clusters of phase 3 plots (by the Forest Inventory and Analysis [FIA] Program of the Forest Service) with northern white-cedar (Thuja occidentalis L.) crown dieback averages of 10 percent or more in Maine and northern Michigan (Randolph 2009). Such elevated levels of dieback were of concern because unlike hardwood trees, conifers often do not exhibit crown dieback unless the tree, and in particular its root system, is under serious stress (Millers and others 1992). An examination of the plots with elevated dieback showed that the high dieback averages for northern whitecedar (NWC) were not necessarily accompanied by elevated average dieback levels among the other tree species on the same plots. Plot-level condition and disturbance information, the NWC literature, and local experts were consulted to ascertain potential causes of the elevated levels of crown dieback. When no specific causes were evident, we initiated an Evaluation Monitoring (EM) project in order to verify the apparently elevated levels of crown dieback (Randolph 2008). Through additional ground work and more in-depth data analyses, we proposed to answer three primary questions:

(1) Was the crown dieback level of NWC significantly higher than that of other species?
(2) Was there a change in the average level of NWC crown dieback over an approximately 10-year period?

(3) What, if any, stand conditions were associated with elevated plot-level NWC crown dieback averages?

\section{Methods}

The EM project was completed in two phases. The first phase entailed field work to verify the original FIA field crew assessments and search for evidence of disturbances not recorded by the field crews. For this, 13 plots with average NWC crown dieback of at least 10 percent ("poor" plots) and 5 comparison plots with an average NWC crown dieback of $<10$ percent (based on the 2000-2004 FIA surveys) were visited. Plot visits were made in the summer of 2007 and occurred 4 to 7 years after the FIA assessments

\section{${ }^{1}$ Mathematical Statistician, U.S. Department of Agriculture Forest Service, Southern Research Station, Forest Inventory and Analysis Program, 4700 Old Kingston Pike, Knoxville, TN 37919. krandolph@fs.fed.us.}

${ }^{2}$ Mathematical Statistician (retired), U.S. Department of Agriculture, Forest Service, Southern Research Station, 200 Weaver Blvd., Asheville, NC 28804. wabechtold@fs.fed.us.

${ }^{3}$ Research Forester, U.S. Department of Agriculture, Forest Service, Northern Research Station, Forest Inventory and Analysis Program, 11 Campus Dr., Suite 200, Newtown Square, PA 19073.rsmorin@fs.fed.us.

${ }^{4}$ Research Scientist and Mathematical Statistician, U.S Department of Agriculture, Forest Service, Southern Research Station, 200 Weaver Blvd., Asheville, NC 28804 szarnoch@fs.fed.us.

\section{Chapter 16.} Evaluating Elevated Levels of Crown Dieback amono Northern White-cedar (Thuja occidentalis L.) Trees in Maine and Michigan:

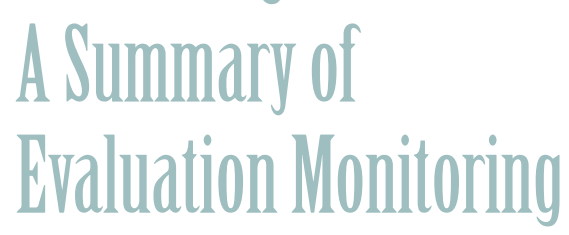

KaDonna RANDOLPH ${ }^{1}$

William A. Bechtold ${ }^{2}$

RANDALl S. MORIN ${ }^{3}$

STANLEY J. ZARNOCH ${ }^{4}$ 
on which the study was based. Tree status (live or dead), crown conditions, and diameter at breast height (d.b.h.) were recorded for NWC trees with d.b.h. at least 5.0 inches $(12.7 \mathrm{~cm})$ on each plot. Observations about individualtree damages, e.g. broken tops, and standlevel growing conditions, e.g., soil drainage and disturbances, were made as well. Plant pathologists and forest health specialists from the Forest Service, the Maine Forest Service, and the Michigan Department of Natural Resources provided assistance in looking for insect and disease problems during the plot visits.

In the second phase of the project, we analyzed the forest health monitoring data collected by FHM during the 1990s and by the FIA program between 2000 and 2005. During both time periods, crown dieback, defined as recent mortality of branches with fine twigs that begins at the terminal portion of a branch and proceeds toward the trunk, was recorded in 5 percent classes (Schomaker and others 2007). Randolph and others (2009) describe the analytical procedures for questions (1) and (2). Briefly, an analysis of variance model, with plot-level average crown dieback as the response variable and taxa (hardwoods, NWC, and other softwoods), measurement year, and the taxa * measurement year interaction as the explanatory factors, was applied to answer question (1). This was done separately by State for the time periods 1990-1999 and 2000-2005 in Maine and 1994-99 and 2000-2005 in Michigan. For question (2), individual tree crown dieback for a subset of NWC survivor trees with observations spanning the 1990-2005 time period was modeled as a linear function of measurement year, by State. For question (3), data from all FIA Phase 3 plots measured in Maine and Michigan between 2000 and 2005 were used to relate plot-level average crown dieback for NWC to the following seven plot-level stand condition variables:

1. plot-level quadratic mean diameter of all live trees at least 5 inches $(12.7 \mathrm{~cm})$ d.b.h.

2. plot-level quadratic mean diameter of all live NWC trees at least 5 inches $(12.7 \mathrm{~cm})$ d.b.h.

3. latitude

4. longitude

5. total precipitation $(\mathrm{cm})$ accumulated December-February prior to the FIA assessment

6. average minimum temperature $\left({ }^{\circ} \mathrm{C}\right)$ December-February prior to the FIA assessment

7. soil drainage index, an index of the relative amount of water that a soil contains on a long-term basis that is available to plants under normal climatic conditions (Schaetzl 1986). 
An analysis of variance model with an autoregressive order 1 covariance structure was used to test for significant relationships between plot-level average NWC crown dieback and the seven stand condition variables all together. To accommodate the repeated measures, the SAS software procedure MIXED (Littell and others 1996) with a REPEATED statement was used to analyze the data for all three questions.

\section{Results}

Through the observations made during the field visits we were able to verify the elevated levels of NWC crown dieback (fig. 16.1) and identify the likely causes of the high crown dieback averages for some of the poor plots. Of the five poor plots visited in Michigan, three were impacted by high water levels and one by wind damage. Detrimental stand conditions on the remaining plot were not clearly identifiable, though water stress seemed to be a possibility. Of the eight poor plots visited in Maine, one was visibly impacted by high water and two were damaged by wind. Besides the plot-level disturbances, poor tree conditions consistent with those noted in the NWC literature (Hofmeyer and others 2007) were observed during the plot visits (Randolph and others 2008). Pistol-butted trees, particularly in northern Maine, and leaning or fallen
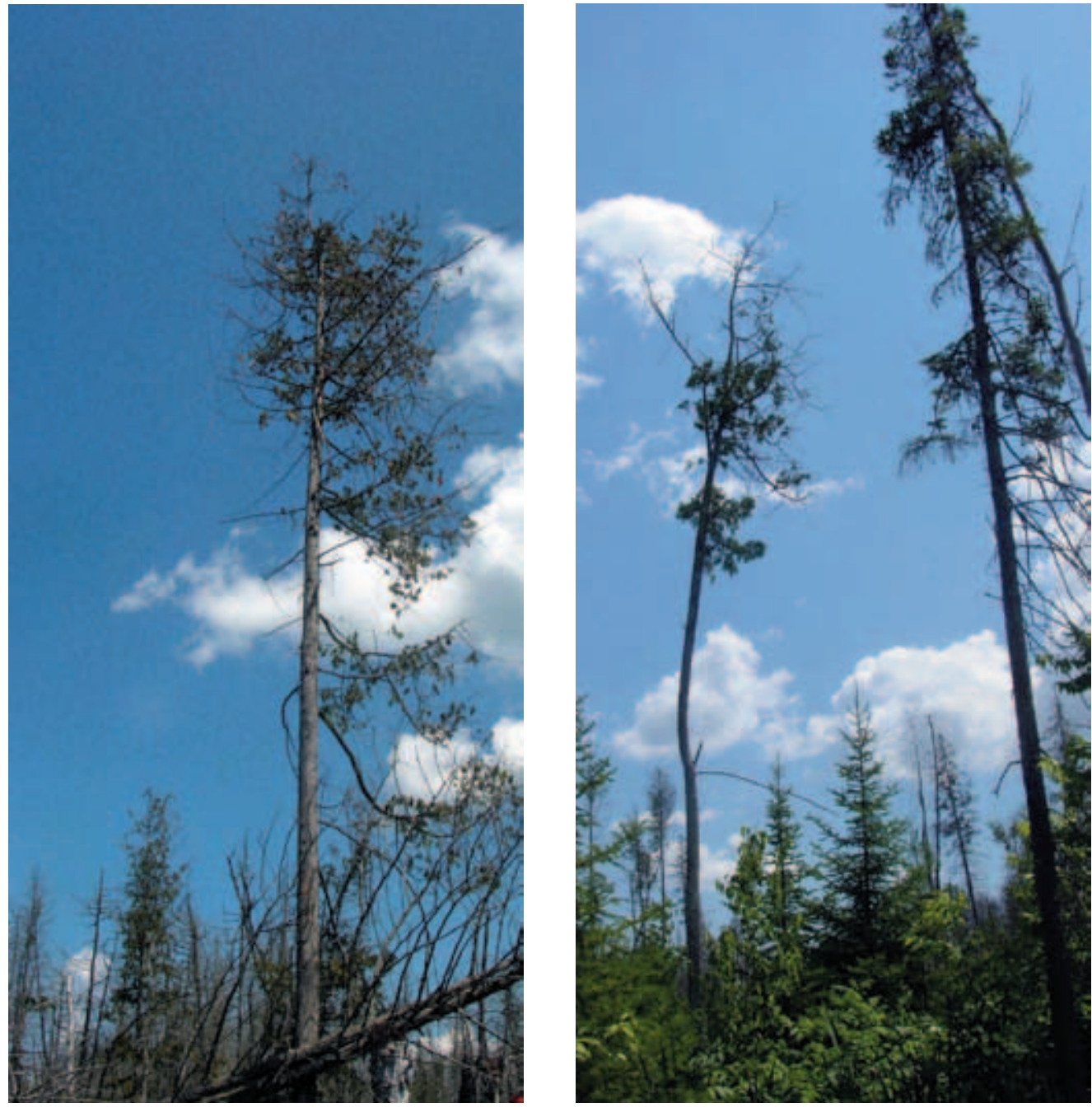

Figure 16.1-Northern white-cedar trees with poor crown conditions observed during the 2001 summer assessment. (Photos by KaDonna Randolph) 
boles were prominent. Wind events were the apparent cause of many of the leaning and fallen trees; however, leaners were common even in areas not obviously disturbed by wind. Such conditions may be attributed to shallow root systems (Johnston and Hyvarinen 1979) and perhaps heavy snow loads (Curtis $1941^{5}$ ). Many trees also had exposed roots, either due to windthrow or microsite growing conditions such as hummocks.

Results of the data analysis showed that between 1990 and 2005, there was not a significant increase in average NWC crown dieback in either State ( $\mathrm{p}$-values greater than 0.1900 ) (question 2), but there were significant differences among the average crown dieback levels of the NWC, hardwoods, and other softwoods (question 1) (Randolph and others 2009). When significant differences among the taxa means existed, NWC crown dieback levels were higher than the dieback levels of other softwoods and lower than the dieback levels of hardwoods, though these differences were sometimes dependent upon measurement year. None of the seven plot-level stand condition variables were significantly related $(\alpha=0.05)$ to average NWC plot-level dieback between 2000 and 2005 (question 3).

\section{Conclusions}

Through the follow-up EM project, the causes of the relatively high NWC crown dieback plot averages observed in Maine and Michigan were determined to be associated with local factors such as disturbances and water levels rather than broader climatic variables such as temperature and precipitation. Though some causes were indeterminable, there did not appear to be an insect or disease problem. Overall, this project demonstrated the effectiveness of the tiered forest health monitoring strategy implemented by the Forest Service to identify, investigate, and in this particular case, nullify a suspected forest health problem.

\section{Literature Cited}

Hofmeyer, P.V.; Kenefic, L.S.; Seymour, R.S. 2007.

Northern white-cedar (Thuja occidentalis L.) an annotated bibliography. CFRU RR 07-01. Orono, ME: University of Maine Cooperative Forestry Research Unit. 30 p. http:// www.treesearch.fs.fed.us/pubs/14234. [Date accessed: April 15, 2009].

Johnston, W.F.; Hyvarinen, M.J. 1979. Northern white-cedar an American wood. Misc. Res. Rep. FS-227. Washington, DC: United States Department of Agriculture Forest Service. $4 \mathrm{p}$.

Littell, R.C.; Milliken, G.A.; Stroup, W.W.; Wolfinger, R.D. 1996. SAS ${ }^{\circledR}$ system for mixed models. Cary, NC: SAS Institute, Inc. 633 p.

${ }^{5}$ Curtis, J.D. 1941. Report of northern white cedar research in Maine. 23 p. Unpublished manuscript. On file with: K. Randoph, 4700 Old Kingston Pike, Knoxville, TN 37919. 
Millers, I.; Anderson, R.; Burkman, W.; Hoffard, W. 1992. Crown condition rating guide. Newtown Square, PA: U.S Department of Agriculture Forest Service. Northeastern Area State and Private Forestry. 26 p

Randolph, K. 2008. Evaluating elevated levels of crown dieback among northern white-cedar (Thuja occidentalis) trees in Maine and Michigan. U.S. Department of Agriculture Forest Service. Forest Health Monitoring

Program evaluation monitoring project NE-EM-07-01. 4 p. http://fhm.fs.fed.us/em/funded/08/ne_em_07_01.pdf. [Date accessed: January 27, 2009].

Randolph, K.C. 2009. Crown condition. In: Ambrose, M.J.; Conkling, B.L., eds. 2009. Forest health monitoring: 2006 national technical report. Gen. Tech. Rep. SRS- 117 Asheville, NC: U.S. Department of Agriculture Forest Service, Southern Research Station: 65-110.

Randolph, K.; Bechtold, W.A.; Morin, R. S.; Zarnoch, S.J. 2009. From detection monitoring to evaluation monitoring-a case study involving crown dieback in northern white-cedar. [l CD]. In: Proceedings, 2008 Forest Inventory and Analysis (FIA) Symposium: climate change, fire, and other hot topics. McWilliams, W.; Moisen, G.; Czaplewski, R., comps. RMRS-P-56CD. Fort Collins, CO: U.S. Department of Agriculture Forest Service, Rocky Mountain Research Station.
Randolph, K.; Ostrofsky, B.; Steinman, J. [and others]. 2008. Field observations of northern white-cedar (Thuja occidentalis) crown dieback in Maine and Michigan (NE-EM-07-01). http://fhm.fs.fed.us/posters/posters08/ northern_white_cedar.pdf. [Date Accessed: August 22, 2008]

Schaetzl, R.J. 1986. A soilscape analysis of contrasting glacial terrains in Wisconsin. Annals of the Association of American Geographers. 76(3): 414-425.

Schomaker, M.E.; Zarnoch, S.J.; Bechtold, W.A. [and others]. 2007. Crown-condition classification: a guide to data collection and analysis. Gen. Tech. Rep. SRS-102. Asheville, NC: U.S. Department of Agriculture Forest Service, Southern Research Station. 78 p. 



\section{Introduction}

his project summary describes a probabilistic model developed with funding support from

the Forest Health Monitoring Program of the Forest Service, U.S. Department of Agriculture (BaseEM Project SO-R-08-01). The model has been implemented in SODBuster, a standalone software package developed using the Java software development kit from Sun Microsystems.

The goal of the probabilistic model and implementing software is to give the Forest Service an analytical tool to help focus scarce inspection resources on the early detection of Phytophthora ramorum outbreaks in those parts of North America where P. ramorum, the organism that causes Sudden Oak Death (SOD), is not yet endemic. Through the use of trace-forward information regarding the shipment of $P$. ramorum infected nursery stock provided by the Animal and Plant Health Inspection Service (APHIS), U.S. Department of Agriculture, supplemented by commodity flow data from the U.S. Departments of Commerce and Transportation, the analytical techniques and software identify areas with the greatest likelihood of new P. ramorum infestation, thus increasing the likelihood of successful intervention before the pathogen crosses the urban-forest interface. Briefly, this is accomplished by using partial survey results and commodity flow information to create an ordered list of those sites presently not known to be infected. The list is ordered by likelihood of each site having recently become infected through the importation of infectious nursery stock.

\section{Methods}

The process of creating this ordered list consists of several stages. In the first stage a subset of sites vulnerable to infection by $P$. ramorum is surveyed. These sites will typically be areas east of the Rocky Mountains. As detailed below, the physical boundaries of these sites are defined by the U.S. Department of Transportation and can range in size from dozens of square miles to entire States. The surveyed sites are categorized as being recently infected, very likely to be uninfected (clean), or as sites for which current infection status is uncertain. Sites with an uncertain infection status are subsequently treated as though they were not surveyed. The combination of newly infected sites and recently certified clean sites is called an infection pattern.

${ }^{1}$ Associate Professor of Mathematics and Computer
Science, Saint Olaf College, Northfield, MN 55057. mckelvey@stolaf.edu.

${ }^{2}$ Research Scientist, U.S. Department of Agriculture, Fores Service, Southern Research Station, 3041 Cornwallis Rd., Research Triangle Park, NC 27709. bdsmith@fs.fed.us.

${ }^{3}$ Research Ecologist, U.S. Department of Agriculture, Fores Service, Southern Research Station, Research Triangle Park NC 27709. fhkoch@fs.fed.us. (Formerly Research Assistant Professor, North Carolina State University, Department of Forestry and Environmental Resources).

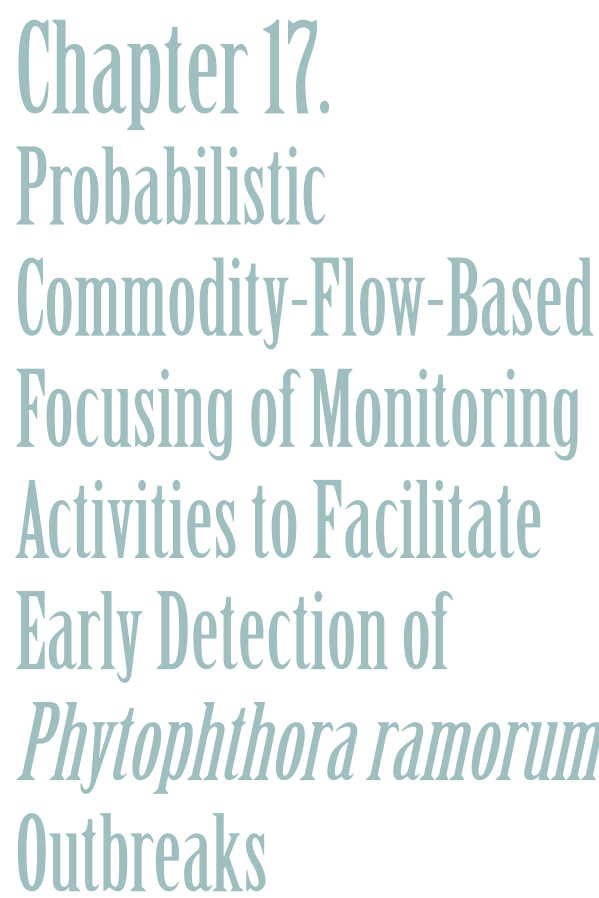

(Project SO-R-08-01)

Steven C. McKelvey ${ }^{1}$

WILLIAM D. SMith ${ }^{2}$

FranK KOCH ${ }^{3}$ 
Once newly infected and known clean sites are identified, potential sources of infectious nursery stock are assigned probabilities of being active sources of infectious nursery stock. In the terminology of probability theory this is a Bayesian process in which the a priori probability of infectious exports assigned to each potential source is updated from some previous value based on the infection pattern observed. For example, those sources which happen to send a large amount of nursery stock to newly infected destinations will be assigned a high probability of exporting infectious materials because the new infections must have originated somewhere and the sources sending the most materials to these destinations are obvious suspects. Similarly, sources that send large amounts of nursery stock to sites known to be clean will be given a low probability of sending infectious exports because receiving these exports has not resulted in infection.

After the probabilities of exporting infectious materials have been updated, attention moves to the unsurveyed recipients of nursery stock. For each unsurveyed recipient of nursery stock (hereafter called destinations), a probability is computed that this site has become recently infected. This probability is based on two characteristics of the destination: the sources from which the destination's nursery stock was sent and how much nursery stock comes from each source. If a given destination receives a significant amount of its stock from a highrisk source, that destination will be assigned a relatively high probability of infection.
Conversely, if a destination receives very little stock from high-risk sources, it will be assigned a relatively low risk of infection.

Once risks have been assigned to the unsurveyed destinations, inspection resources can be mobilized to high-risk destinations with the aim of identifying any sites that are, in fact, infected and taking action to eliminate the threat of introducing P. ramorum into forests currently free of Sudden Oak Death.

The data representing nursery stock flows between source and destination sites are adapted from the Freight Analysis Framework (FAF) Commodity Origin-Destination database (version 2.2). This relational database was created by the U.S. Federal Highway Administration to quantify the movement of commercial freight between major geographic regions in the United States. It is built upon publicly available data, most prominently the 2002 Commodity Flow Survey issued by the U.S. Bureau of Transportation Statistics, but it also incorporates specific data from other sources related to the movement of freight by water, air, and rail. More than 100 geographic regions across the United States (i.e., metropolitan areas or, in some cases, partial or entire States) serve as the source or destination sites for the nursery stock flow data.

The SODBuster software package and underlying analytical methodology are best highlighted with a hypothetical example. Consider a fictitious network with three sources (S1, S2, and S3) and five destinations (D1, D2, D3, D4, D5). Suppose the three sources have 
been assigned a priori probabilities of exporting infectious nursery stock of 0.30 (S1), 0.40 (S2) and 0.25 (S3). These a priori probabilities might be based on a simple criterion such as the sites' relative numbers of APHIS-regulated wholesale nurseries (i.e., nurseries that ship plant stock associated with $P$. ramorum). Nonzero annual flows, by weight, of nursery stock are given by $\mathrm{S} 1 \rightarrow \mathrm{D} 1=60, \mathrm{~S} 1 \rightarrow \mathrm{D} 2=100, \mathrm{~S} 1 \rightarrow \mathrm{D} 3=10, \mathrm{~S} 2 \rightarrow$ $\mathrm{D} 2=70, \mathrm{~S} 2 \rightarrow \mathrm{D} 3=90, \mathrm{~S} 2 \rightarrow \mathrm{D} 4=50, \mathrm{~S} 3 \rightarrow \mathrm{D} 3=60$, $\mathrm{S} 3 \rightarrow \mathrm{D} 4=40, \mathrm{~S} 3 \rightarrow \mathrm{D} 5=90$. Furthermore, it is assumed that one unit of infectious nursery stock has a probability of 0.01 of causing an infection at the receiving site.

In this scenario, suppose officials conduct a survey of three of the five destinations. The survey shows that destinations D 1 and D5 are shown to be clear of $P$. ramorum infection while destination D3 is infected.

The hypothetical data laid out so far are inputs to the SODBuster model. The next step is to run the model and examine the results. The model creates, for each of the three sources, a new (a posteriori) likelihood that the source is exporting material capable of infecting receiving sites. These updated likelihoods are $0.226,0.854$, and 0.240 for sources S1, S2 and $\mathrm{S} 3$, respectively. These updated values are mathematically rigorous and intuitively pleasing. D1, known to be uninfected, receives all its nursery stock from S1, suggesting the material being sent from $\mathrm{S} 1$ is not infectious. The cleanliness of D5 suggests that S3 is not a source of infectious material. D3, the sole known infected site, receives a lot of material from S2 and S3. We have already argued that the survey results suggest $\mathrm{S} 3$ is not a source of infectious materials, but the results offer no analogous shelter for S2. It is not surprising that S2 earns the highest likelihood of being a source of infectious material.

Armed with the updated source likelihoods, we move back to the unsurveyed destinations and see that destination D2 has a 0.521 likelihood of being infected, while destination D4 has a 0.400 likelihood of being infected. These values reflect the fact that $\mathrm{D} 2$ receives more material from a likely source of infection (S2) than does D4 (fig. 17.1).

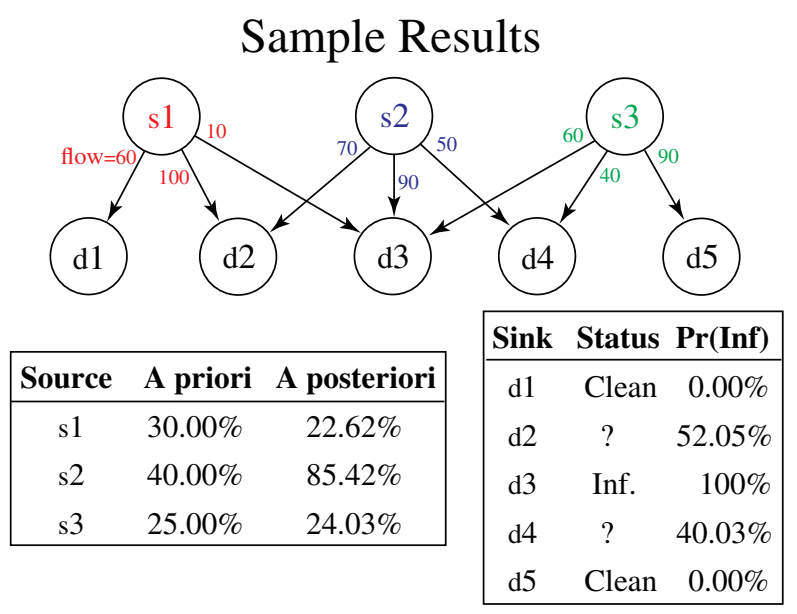

Figure 17.1-Sample results for the SODBuster example described in the Methods section. 


\section{Results}

This model has not yet been applied to genuine $P$. ramorum survey information, so we are not able to provide the results of a true application of the model. The software produces results that fall into two broad categories.

The first, textual results, are displayed within a graphical window. Values for all input parameters are presented so the user can easily determine which output goes with each collection of parameter values. The output also presents the a posteriori likelihoods of each source being, in fact, a source of infectious materials. Lastly, the output presents the risk of each destination site being infected and sorts this list in various ways (fig. 17.2). The listings can be saved for subsequent printing to a hard copy by any text editor. If the program's user so chooses, these data can be organized into a commadelimited text file designed to be easily imported into a standard spreadsheet program for further processing and analysis.

The non-textual output consists of a series of maps of the continental United States. The first of these maps show the underlying commodity transportation network superimposed upon the various FAF regions (fig. 17.3). The second (fig. 17.4) uses solid red discs of various sizes to indicate the relative risks of destinations. Both of these maps can be saved as PNG images for further processing, subsequent inclusion in documents, etc.
Parameter File Name:

C: \Documents and Settings\SampleFiles\sample2.sdp Node Information File Name: C: Documents and Settings SampleFiles\sample2.sniLink Information File Name: C:\Documents and Settings\SampleFiles\sample2.sfl

Source Infection Probabilities

$\begin{array}{llll}\text { Node ID } & \text { Node Name } & \text { A priori } & \text { Posterior } \\ 1 & \text { CA Los A } & 0.3000 & 0.2262 \\ 2 & \text { CA San D } & 0.4000 & 0.8542 \\ 3 & \text { CA Sacra } & 0.2500 & 0.2403\end{array}$

--Destination Nodes Sorted by probability of infection--

(* indicates known infected or known clean node.)

$\begin{array}{llr}\text { ID } & \text { Node Name } & \text { P(Infected) } \\ 6^{*} & \text { CT rem } & 1.0000 \\ 5 & \text { CO rem } & 0.5205 \\ 7 & \text { DE } & 0.4003 \\ 8^{*} & \text { DC Washi } & 0.0000 \\ 4^{*} & \text { CO Denve } & 0.0000\end{array}$

Figure 17.2-Sample output information from the SODBuster computer program. Note values of input parameters (a priori) are presented as well as the likelihoods of each source being a source of infection as determined by the model (a posteriori). 


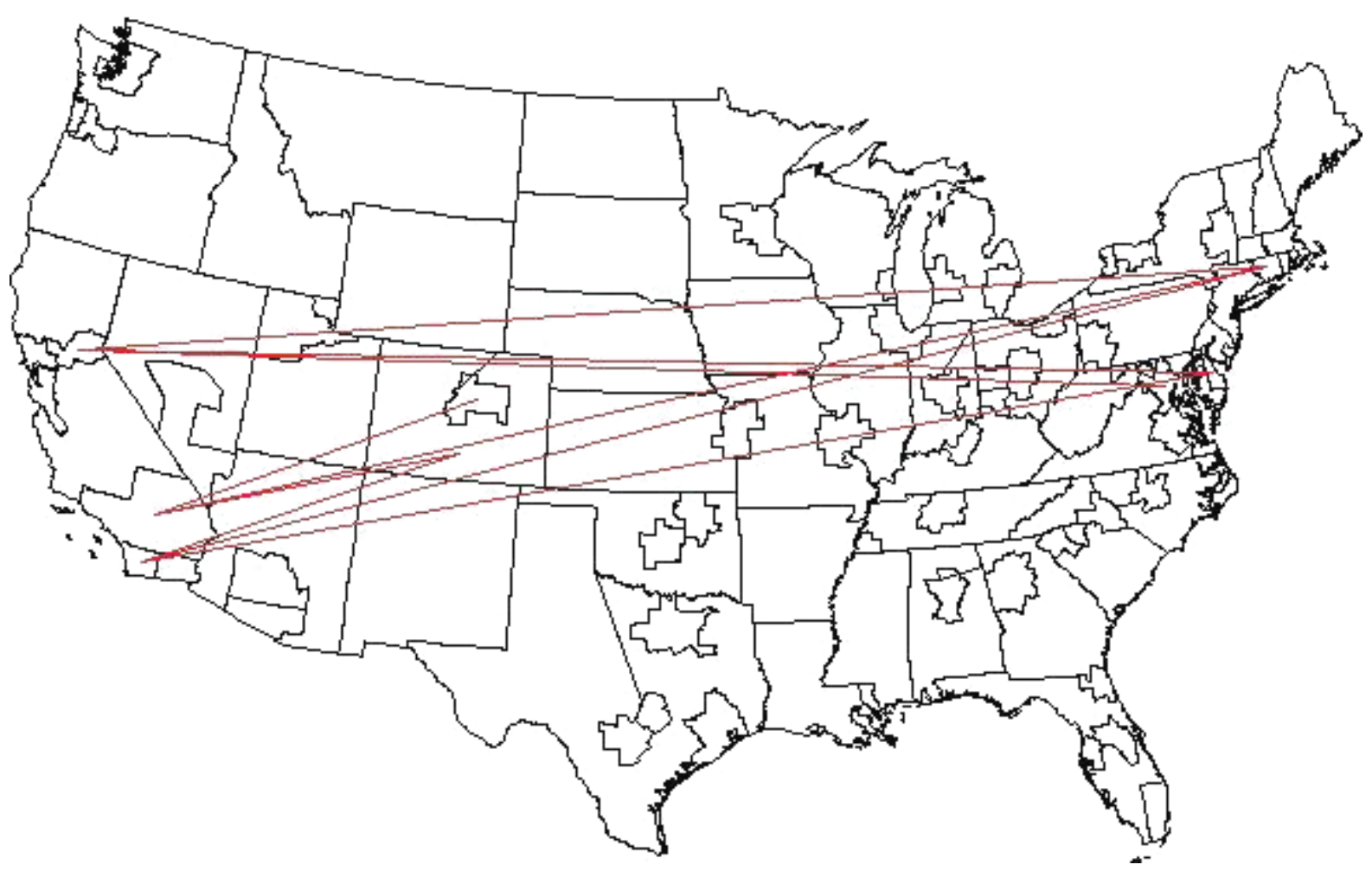

Figure 17.3-Example map output from the SODBuster computer program showing the underlying commodity transportation network (red lines) superimposed upon the various Freight Analysis Framework (FAF) regions. (Data source: U.S. Federal Highway Administration)

\section{Discussion}

There are a number of important assumptions and caveats with respect to the probabilistic model underlying the SODBuster software. Bayesian models update probabilities as more data become available. In our case, the probabilities updated by the model are the probabilities of a given source being one that is exporting infectious nursery stock. The very nature of updating something requires a starting point. In our case one model input is an initial probability, also called an a priori probability, of each source being one that exports infectious material.

Typically, there is very little information upon which to base these a priori probabilities. One might choose to give all sources the same a priori probability of being a source of infectious material. However, if there is reason to believe a particular group of sources is more likely to 


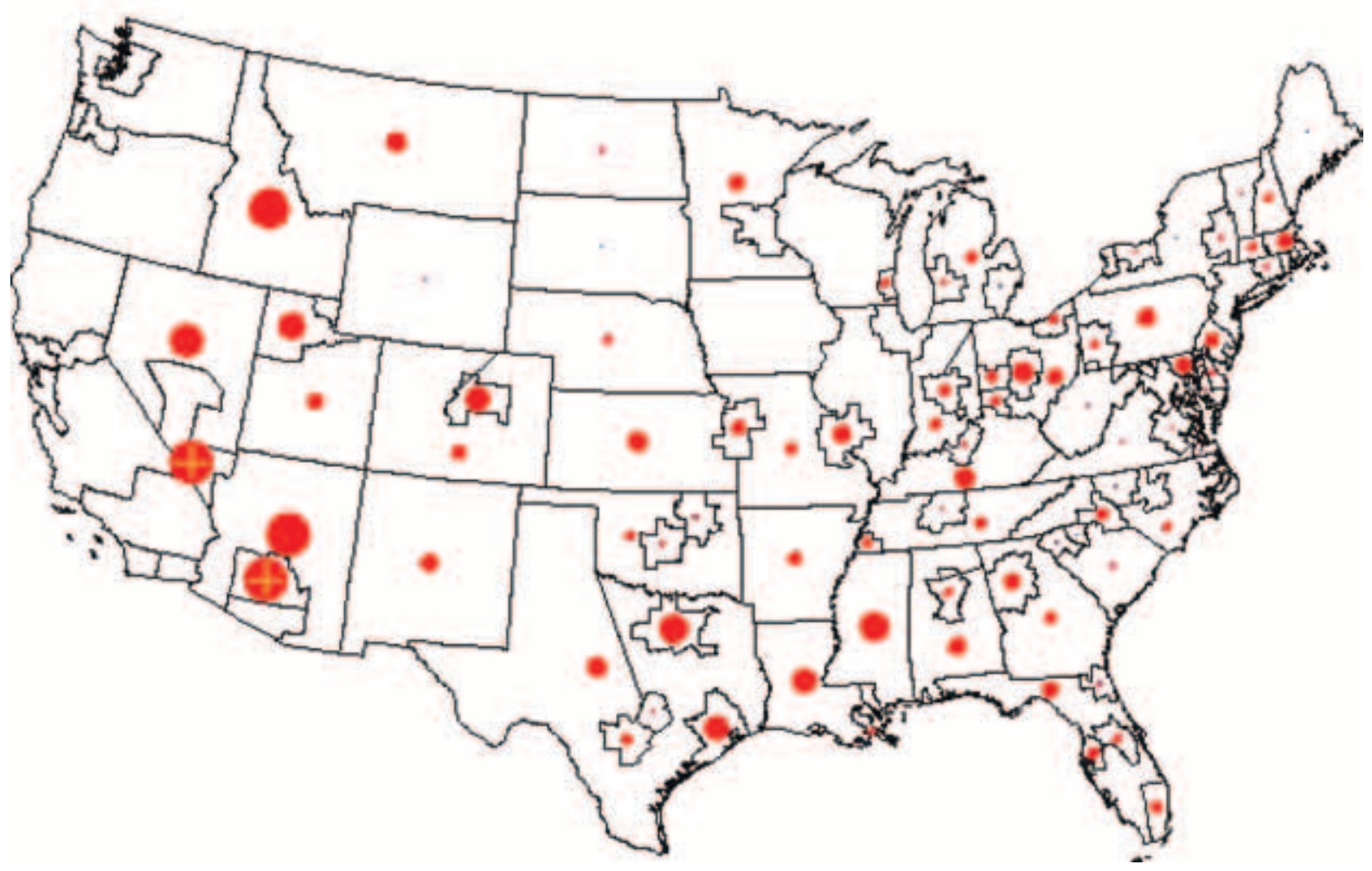

Figure 17.4-Example map output from the SODBuster computer program showing solid red discs to indicate the relative risks of destinations, superimposed upon the various Freight Analysis Framework (FAF) regions. (Data source: U.S. Federal Highway Administration)

be exporting infectious nursery stock than some other group, a model user could consider giving members of the riskier group higher a priori probabilities of sending infectious material. Generally, a priori probabilities should reflect known information regarding the relative risks of various sources.

Another probability that must be provided as an input to this model is a parameter that quantifies how the amount of material flowing from an exporter of infectious material to a destination affects the probability that the recipient will become infected as a result of receiving that material. The Unit Flow Probability of Infection is the probability that a destination will become infected upon receiving a single unit of infectious nursery stock.

Precise values for the a priori probabilities of exporting infectious materials and the unit flow probability of infection parameter are difficult to 
obtain. Fortunately, precision is not necessary. Keeping in mind that the goal of this model is to rank not yet infected destinations according to risk, what is important are the relative risks, which sites have greater risks than others, rather than the precise value of the risks. We expect that this ranking is not particularly sensitive to the exact choices of a priori probabilities.

Choosing reasonable values is all that is required for this model to correctly perform its task.

The worst-case running time and memory requirements of this model are related exponentially to the number of included source sites. This arises from the model's dependence on quantities associated with every subset of the sources. If a set contains $n$ items, the set has $2^{n}$ subsets. For example, the set $\{1,2,3\}$ has $2^{3}$ subsets, specifically \{\} (the empty set), $\{1\},\{2\},\{3\},\{1,2\},\{1,3\},\{2,3\}$, and $\{1,2,3\}$. The model performs summations over all of these subsets. Users can expect the running time and memory requirements of the model to approximately double for each additional source. The nationwide test data included with the SODBuster software uses nine sources and results in a model that requires just a few seconds to run. Careful consideration must be given before increasing the resolution of the model by reducing the size of source regions. Such a change would increase the number of sources, drastically increasing the running time and memory requirements of the model.

A more detailed description of the probability model and a users' guide for the SODBuster software can be found on the following Web sites:

- Detailed Model Description: http://www. stolaf.edu/people/mckelvey/SOD.dir/ BaseEMTech.pdf.

- Software Users' Guide: http://www.stolaf.edu/ people/mckelvey/SOD.dir/UserGuide.pdf. 



\section{Introduction}

imber pine (Pinus flexilis James) is an ecologically and culturally important, yet

little studied, tree species within the Western United States. Its distribution extends from Alberta and southeastern British Colombia to New Mexico, Arizona, and southeastern California with isolated populations in North Dakota, South Dakota, Nebraska, eastern Oregon, and southwestern California (Burns and Honkala 1990). Limber pine has a very wide elevational distribution as well, ranging from 2,850 feet in North Dakota to 12,500 feet in Colorado (Burns and Honkala 1990). Limber pines serve many important ecological functions such as providing food for wildlife, stabilizing slopes, regulating snow retention and runoff, and maintaining cover on harsh, rugged sites where little else can grow (Schoettle 2004). They are some of the oldest and largest pines in the Rocky Mountains and are especially valued because of their unique cultural and ecological characteristics. However, recent reports suggest that they are experiencing significant ecological impacts as the result of the exotic invasive disease white pine blister rust (Cronartium ribicola J. C. Fisch. ex Rabenh.) and other damaging agents (Blodgett and others 2005, Kearns and Jacobi 2007). Information on the status of limber pines and the long-term ecological impacts of this disease is needed to facilitate management and restoration efforts. The objectives of this study were to (1) assess the current ecological impacts of white pine blister rust on limber pine within white pine blister rust-infested and threatened areas of the Rocky
Mountains and a small outlying population in North Dakota, (2) establish plots for future re-measurement to assess long-term and cumulative ecological impacts, and (3) gather baseline information needed to sustain, protect, and restore impacted stands.

\section{Methods}

Long-term monitoring plots were established in 2006 and 2007 in four study areas: (1) northern Colorado and southern Wyoming (2006), (2) northern Wyoming (2007), (3) central Montana (2007), and (4) southwestern North Dakota (2007) (fig. 18.1). Plots were located by systematically selecting stands with a high limber pine component (20 percent or greater) based on vegetation layers, previous surveys, and suggestions from local land managers. Plot locations were stratified by elevation and white pine blister rust intensity (if information was present) and were widely distributed to cover a range of stand and site conditions.

\footnotetext{
${ }^{1}$ Forest Pathologist, U.S. Department of Agriculture, Forest Service, Forest Health Management, Golden, CO 80401.

2 Plant Pathologist, U.S. Department of Agriculture, Forest Service, Forest Health Management, Rapid City, SD 57702.

${ }^{3}$ Plant Pathologist, U.S. Department of Agriculture, Forest Service, Forest Health Protection, Missoula, MT 59807.

${ }^{4}$ Aerial Survey Program Manager, U.S. Department of Agriculture, Forest Service, Forest Health Management Golden, CO 80401.

${ }^{5}$ Professor of Forest and Shade Tree Pathology, Colorado State University, Department of Bioagricultural Sciences and Pest Management, Fort Collins, CO 80523.
}

\section{Chapter 18.} Monitoring Limber Pine Health in the Rocky Mountains and North Dakota

\section{(Project INT-EM-06-03)}

Kelly Burns, ${ }^{1}$ Jim Blodgett, ${ }^{2}$

Marcus Jackson, ${ }^{3}$ Brian Howell, ${ }^{4}$

William Jacobi, ${ }^{5}$ Anna Schoettle, ${ }^{6}$

Anne Marie Casper, ${ }^{7}$ And

JENNIFER KLUTSCH ${ }^{8}$

${ }^{6}$ Research Plant Ecophysiologist, U.S Department of Agriculture, Forest Service, Rocky Mountain Research Station, Fort Collins, CO 80526 .

${ }^{7}$ Graduate Student, Colorado State University, Department of Bioagricultural Sciences and

${ }^{8}$ Data Analyst, U.S. Department of Agriculture, Forest Service, Rocky Mountain Research Station, Fort Collins, CO 80526. 


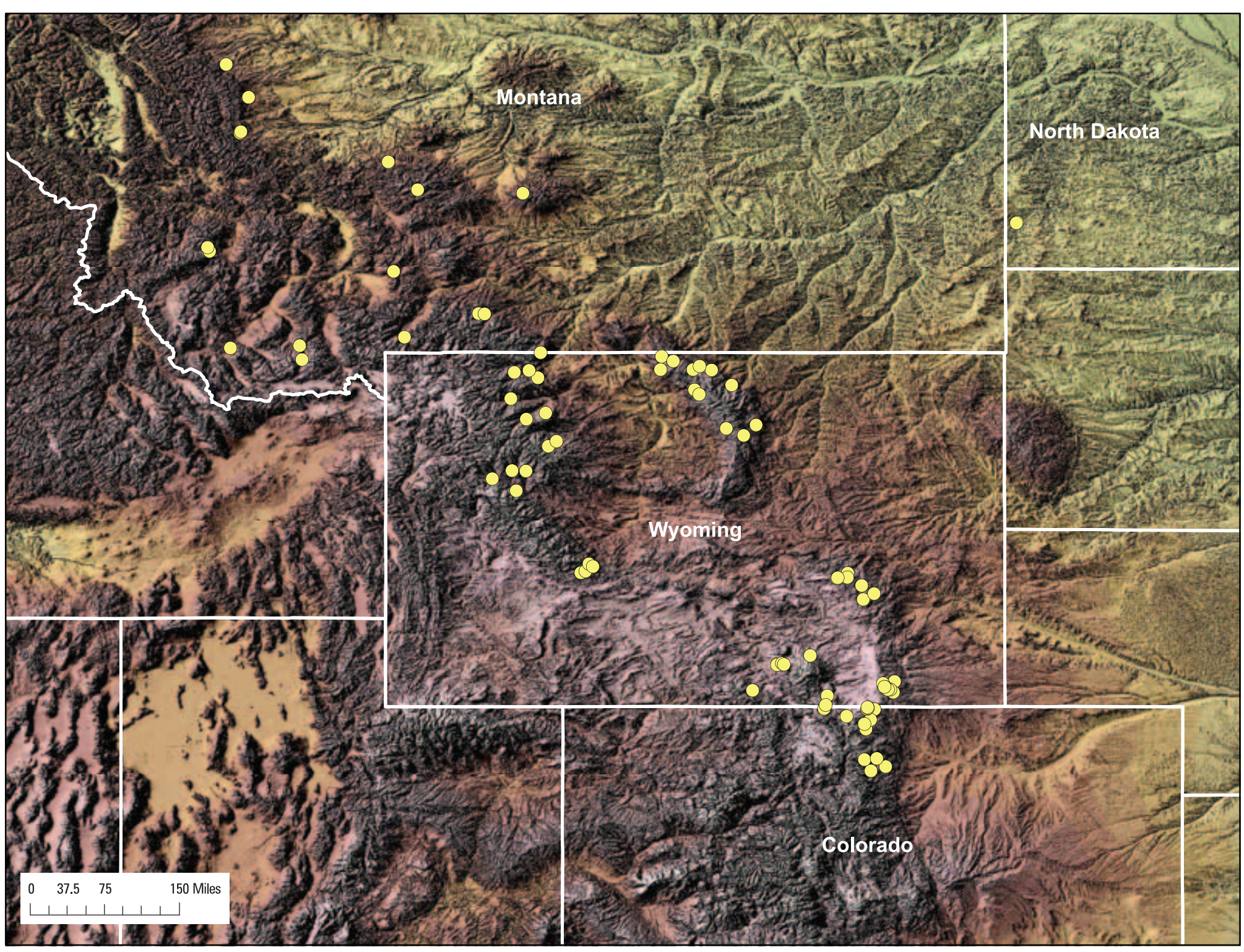

Figure 18.1-Limber pine monitoring plots (yellow dots) in Colorado, Wyoming, Montana, and North Dakota. 
Plots in northern Colorado and southern Wyoming (COWY) are located within the Roosevelt and Medicine Bow National Forests and Rocky Mountain National Park. Plots in northern Wyoming (NWY) are on the Bighorn and Shoshone National Forests. Montana (MT) plots are located on lands administered by national forests (Custer, Lewis and Clark, Deer Lodge), the Blackfeet Indian Reservation, The Nature Conservancy, and Montana Department of Natural Resources and Conservation. North Dakota (ND) plots are on the Little Missouri National Grassland.

Monitoring plots were established as belt transect plots using methods adapted from the Whitebark Pine Ecosystem Foundation (Tomback and others 2004) and Six and Newcomb (2005). Plots (200 feet by 50 feet) were divided into three sections (fig. 18.2) with a fixed area circular regeneration and understory vegetation subplot (1/100 acre, 11.8 -foot radius) at the center point of each section. The three sections provided stand density and species composition information associated with each regeneration plot. Plots were monumented with a labeled rebar stake at the center point of the beginning and end; GPS coordinates were collected at these points as well.

Transect-level data collected included transect bearing, elevation, slope, aspect, slope position,

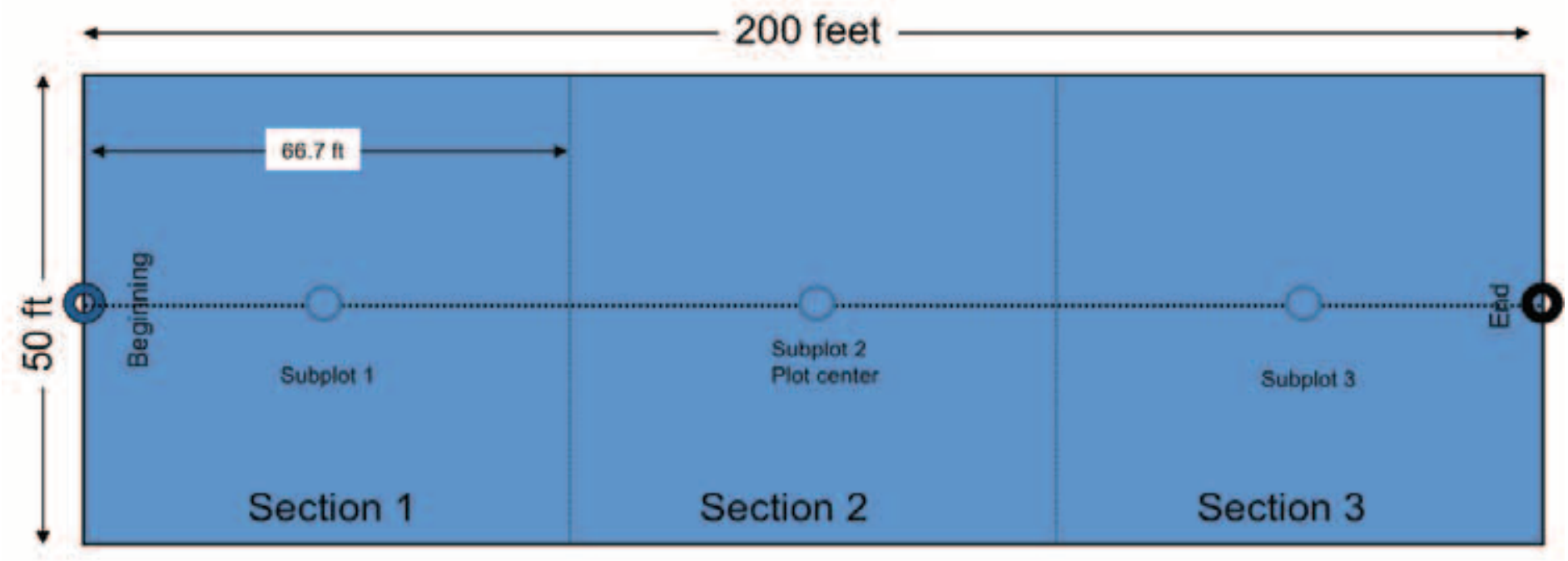

Figure 18.2-Diagram of plot layout. 
stand structure, and disturbance history. The three most common shrub species within each section were listed by genus and species.

Data recorded for all trees greater than 4.5 feet $\operatorname{tall}^{9}(1.4 \mathrm{~m})$ included tree tag number*, stem clump number, section number*, species*, health status*, d.b.h.*, height*, size class* (small: $>0-2$ inches d.b.h.; medium $>2-8$ inches d.b.h.; large: $>8$ inches d.b.h.), height to lowest live branch with needles within 1 foot of stem, crown class, crown ratio, percent canopy kill (topkill), and all damages and their severities impacting more than 5 percent of the tree. Needle retention was recorded for three limber pine trees per section (nine per plot) that were average tree height and (ideally) single stemmed. Whorls were counted back from branch tip and average foliated length was recorded for each branch.

For white pines, stem damage associated with blister rust was quantified by dividing the stem into thirds and recording stem condition (no blister rust stem infections, 1 to 25 percent infected, 25 to 50 percent infected, and $>50$ percent infected) and the number of stem cankers (cankers on the main stem or within 6 inches of the main stem) for each third. Similarly, crown damage was quantified by dividing the crown into thirds horizontally and recording crown condition (no visible blister

${ }^{9}$ Variables with an asterisk were collected for all species. All variables were recorded for white pine species. rust branch infections, $<25$ percent branches infected, 25 to 50 percent branches infected, $>50$ percent branches infected), number of branch cankers, canker lengths (only on live branches), and percent of outer branch tips with fresh green cones for each third. White pine blister rust disease severity was calculated for each tree based on cumulative crown and stem damage (Six and Newcomb 2005).

In subplots, all regeneration (trees $<4.5$ feet tall), regardless of species, were tallied by species and height class (0-10 inches or 10-54 inches) and blister rust infection was recorded for white pine species. Percent ground cover of litter, rock, bare soil, tree stems, shrubs, and forbs was estimated within each subplot, as was percent cover of Ribes species.

\section{Results and Discussion}

A total of 83 long-term monitoring plots were established including 36 in COWY, 29 in NWY, 16 in MT, and 2 in ND (fig. 18.1). The limber pine population in North Dakota is very small and isolated (Potter and Green 1964) and so was fairly adequately surveyed with a small sample size. Monitoring plots ranged in elevation from 2,900 to 10,243 feet and were located on a variety of aspects, slopes, and slope positions. On average, 40 limber pines were sampled per plot (range 9-180). A variety of stand compositions and structures were represented, ranging from open savannahs to mixed conifer forests. On 13 percent of plots, limber pine was the only species present. Across all plots, limber pine density ranged from 39 to 783 trees per acre. 
Other species that were frequently associated with limber pine included juniper (NWY, MT, and ND), Douglas-fir (COWY, NWY, MT), lodgepole pine (COWY), aspen (COWY), and ponderosa pine (COWY). The only other white pine species encountered was whitebark pine, which was present in 2 plots within the MT study area.

A total of 6,533 trees were sampled in all of the study areas combined. This included 3,293 limber pines and 22 whitebark pines. Arithmetic mean diameter of surveyed limber pines was 5.0 inches (range $=0.1$ to 46.5 inches d.b.h.) and average height was 16.3 feet (range $=4.5$ to 55.0 feet). Most of the limber pines surveyed were classified as healthy (74 percent) while 19 percent were classified as declining or dying, and 7 percent were dead (table 18.1). White pine blister rust and twig beetles were the most common damages observed, although twig beetle damage severity was generally classified as low. Fifty-three percent of declining and dying trees were infected with white pine blister rust and 51 percent had twig beetle damage. Evidence of bark beetles including mountain pine beetle, Ips engravers, and others was identified on 40 percent of all recently killed trees. Other less common damages included limber pine dwarf mistletoe, other canker diseases, and porcupine damage.

The average incidence of white pine blister rust over all plots was 36 percent ( 30 percent in COWY, 38 percent in NWY, 50 percent in MT, and 0 percent in ND plots). Based on Six and Newcomb (2005), disease severity is currently low in all areas (table 18.2). The total score for

Table 18.1 - Limber pine by health status and percent impacted by white pine blister rust (WPBR), twig beetles, and bark beetles in northern Colorado and southern Wyoming (COWY), northern Wyoming (NWY), Montana (MT), and North Dakota (ND) study areas

\begin{tabular}{|c|c|c|c|c|c|c|c|c|c|c|}
\hline \multirow[b]{2}{*}{ Study area } & \multirow[b]{2}{*}{$\mathrm{N}$} & \multicolumn{3}{|c|}{ Healthy } & \multicolumn{3}{|c|}{ Declining/dying } & \multicolumn{3}{|c|}{ Recent dead } \\
\hline & & Count & WPBR & $\begin{array}{c}\text { Twig } \\
\text { beetle }\end{array}$ & Count & WPBR & $\begin{array}{c}\text { Twig } \\
\text { beetle }\end{array}$ & Count & WPBR & $\begin{array}{c}\text { Bark } \\
\text { beetles }\end{array}$ \\
\hline & & & percent & percent & & percent & percent & & percent & percent \\
\hline COWY & 1,401 & 1,216 & 23 & 12 & 153 & 55 & 21 & 32 & 3 & 16 \\
\hline NWY & 985 & 884 & 33 & 61 & 84 & 39 & 76 & 17 & 0 & 71 \\
\hline MT & 638 & 303 & 36 & 49 & 312 & 69 & 63 & 23 & 57 & 57 \\
\hline ND & 94 & 17 & 0 & 6 & 77 & 0 & 38 & 0 & 0 & 0 \\
\hline Total & 3,293 & 2,420 & 28 & 34 & 626 & 53 & 51 & 72 & 19 & 40 \\
\hline
\end{tabular}

$\mathrm{N}=$ number of limber pine trees sampled.

${ }^{a}$ The proportion of limber pines showing evidence of damage caused by mountain pine beetles, Ips engraver beetles, or other bark beetles. 
Table 18.2 - Mean incidence and severity of white pine blister rust (WPBR) in northern Colorado and southern Wyoming (COWY), northern Wyoming (NWY), Montana (MT), and North Dakota (ND) study areas

\begin{tabular}{lccc|ccccc}
\hline & \multicolumn{4}{c}{ All plots } & \multicolumn{5}{c}{ Plots with WPBR } \\
\cline { 2 - 9 } Study area & N & Incidence & \\
\hline COWY & 36 & 30 & 28 & 29 & 37 & 27 & 1.1 & 1.1 \\
NWY & 29 & 38 & 30 & 25 & 44 & 28 & 1.1 & 1.1 \\
MT & 16 & 50 & 36 & 13 & 62 & 29 & 2.3 & 1.2 \\
ND & 2 & 0 & 0 & 0 & NA & NA & NA & NA \\
\hline Total & 83 & 29 & 21 & 67 & 48 & 13 & 1.3 & 1.2 \\
\hline
\end{tabular}

$\mathrm{N}=$ number of limber pine trees sampled.

NA = not applicable.

S.D. = Standard deviation

${ }^{a}$ Incidence is the number of infected limber pines / the number of evaluated limber pines.

${ }^{b}$ White pine blister rust (WPBR) disease severity was calculated for all white pines based on cumulative crown and stem damage (Six and Newcomb 2005). The total score for a tree can range from 0 (no infection) to 18 (tota infection), with scores from 1 to 4 associated with low severity, 5 to 8 with moderate severity, and over 8 with

severe damage.

a tree can range from 0 (no infection) to 18 (all branches and stem infected), with scores from 1 to 4 associated with low severity, 5 to 8 with moderate severity, and over 8 with severe damage. Average disease severity for all plots with infected trees was 1.3 and ranged from 0.1 to 3.9 (SD: 1.2 ; 95 percent CL: 1.0-1.6).

Most infected limber pines (80 percent) had 10 or fewer branch cankers, but 45 percent of all infected trees had stem cankers (table 18.3). White pine blister rust occurred more frequently on medium (> 2-8 inches d.b.h.) and large ( $>8$ inches d.b.h.) trees than on small (>0-2 inches d.b.h.) trees (table 18.3). Large trees had a greater number of total infections but the incidence of stem cankers was highest (65 percent) in small trees and lowest (25 percent) in large trees. Fourteen percent of all infected trees had stem cankers in the bottom third of the crown, 22 percent had stem cankers in the middle third of the crown, and 26 percent had stem cankers in the top third of the crown. The incidence of basal stem cankers was greatest ( 24 percent) in small trees and least ( 2 percent) in large trees. Branch cankers occurred throughout the crown in all size classes in all areas.

Limber pine regeneration (trees $<4.5$ feet tall) was present in 60 percent of all plots with an average density of 95 trees per acre (range $0-1,000$ trees per acre). White pine blister rust was detected on regeneration in 7 percent of all 
Table 18.3-Proportion of living limber pine trees infected with white pine blister rust (WPBR) by size class, mean number of WPBR cankers per infected limber pine, and proportion of infected trees with stem cankers by size class

\begin{tabular}{lccccccc}
\hline & & \multicolumn{2}{c}{ WPBR } & \multicolumn{3}{c}{ Total cankers } & Proportion of infected trees \\
\cline { 3 - 6 } Size class & $N$ & Count & $\%$ & Mean & Range & S.D. & with stem cankers \\
\hline Small & 830 & 201 & 24 & 2.6 & $0-13$ & 2.2 & $65 \%$ \\
Medium & 1,630 & 617 & 38 & 3.9 & $0-43$ & 4.4 & $46 \%$ \\
Large & 589 & 211 & 36 & 7.0 & $0-48$ & 8.6 & $25 \%$ \\
\hline \multicolumn{1}{c}{ Total } & 3,049 & 1,029 & 34 & 4.3 & $0-48$ & 5.5 & $45 \%$ \\
\hline
\end{tabular}

$\mathrm{N}=$ number of limber pine trees sampled.

S.D. = Standard deviation

plots. The average incidence of white pine blister rust in regeneration plots where limber pine occurred was 3 percent (range $0-75$ percent). Limber pine was the most commonly regenerating species followed by aspen, Douglasfir, and Engelmann spruce. Other less commonly regenerating species included juniper, lodgepole pine, subalpine fir, and whitebark pine.

On average, the percent of limber pine branches with cones was 6.4 percent (range $=0-43$ percent). The percent of branches with cones was higher at the top of the tree (12.5 percent) as compared to mid-crown (4.3 percent) and low crown ( 1.5 percent). Limber pine infected with blister rust had similar amounts of cones as uninfected trees. On plots with a high incidence of rust (> 50 percent of trees infected with white pine blister rust), infected and uninfected trees had on average 6.8 percent and 5.4 percent branches with cones, respectively.

\section{Conclusions}

White pine blister rust is well established in all of the study areas except North Dakota, and results from this survey suggest that the disease is a major damaging agent in limber pine in the Rocky Mountains. This study provides baseline information on limber pine health in four study areas within the Rocky Mountains. Long-term monitoring of limber pine at these sites will provide critical information to guide future management and restoration.

Although blister rust severity is currently low in all study areas based on the Six and Newcomb (2005) rating system, results suggest that ecological impacts of white pine blister rust are occurring. Blister rust damage was observed on most declining and dying trees, and small (>0-2 inches d.b.h.) trees had a higher frequency of severe infections, suggesting that mortality of small trees is occurring and can be 
expected to continue. Small trees are particularly susceptible to the disease because the distance the fungus needs to travel from foliage, the point where infection occurs, to the main stem is small compared to larger trees, and because small branches and stems are quickly girdled. Impacts to medium (>2-8 inches d.b.h.) and large (> 8 inches d.b.h.) trees are evident as well. Unlike western white pine and sugar pine, which are infected near the ground where the microclimate is more favorable for infection, infections in limber pine occur throughout the crown (Kearns 2005). Although medium and large trees have fewer severe infections, they have more total infections; this may eventually impact cone production and regeneration potential.

The incidence of blister rust on regeneration (trees $<4.5$ feet tall) currently appears to be low, but it is possible that trees this small are quickly killed and therefore not adequately represented in surveys of this kind. A more thorough examination of limber pine regeneration and the implications of blister rust is warranted.

Mountain pine beetle and other bark beetles are contributing to mortality in all study areas but at the time of the survey impacts were minimal. Mountain pine beetle activity has since increased substantially and it is predicted that most mature limber pines are threatened. The combined impacts of mountain pine beetle and white pine blister rust could be devastating in some areas since mountain pine beetles kill mature trees and since young trees are especially susceptible to rust. Continued monitoring of limber pine health in the Rocky Mountain region will be critical for assessing impacts of these two threats.

\section{Literature Cited}

Blodgett, J.T.; Schaupp, W.C.; Long, D.F.; Cross, F. 2005 Evaluation of white pine blister rust and mountain pine beetle on limber pine in the Bighorn National Forest. Biological Evaluation. R2-05-08. Golden, CO: U.S. Department of Agriculture Forest Service, Rocky Mountain Region, Renewable Resources. 19 p.

Burns, R.M.; Honkala, B.H., tech. coords. 1990. Silvics of North America: 1. Conifers; 2. Hardwoods. Agric. Handb. 654. Washington, DC: U.S. Department of Agriculture Forest Service. $877 \mathrm{p}$

Kearns, H.S.J. 2005. White pine blister rust in the central Rocky Mountains: modeling current status and potential impacts. Fort Collins, CO: Colorado State University. 243 p. Ph.D. dissertation.

Kearns, H.S.J.; Jacobi, W.R. 2007. The distribution and incidence of white pine blister rust in central and southeastern Wyoming and northern Colorado. Canadian Journal of Forest Research. 37: 462-472.

Potter, L.D.; Green, D.L. 1964. Ecology of a northeastern outlying stand of Pinus flexilis. Ecology. (45) 4: 866-868.

Schoettle A.W. 2004. Ecological roles of five-needle pine in Colorado: potential consequences of their loss. In: Sniezko, R.; Samman, S.; Schlarbaum S.; Kriebel, H., eds. Breeding and genetic resources of five-needle pines: growth adaptability and pest resistance. Proceedings RMRS-P-32. Ogden, UT: U.S. Department of Agriculture Forest Service, Rocky Mountain Research Station: 124-135.

Six, D.L.; Newcomb, M. 2005. A rapid system for rating white pine blister rust incidence, severity, and within-tree distribution in whitebark pine. Northwest Science: 189-193. (79) 2, 3.

Tomback, D.F.; Keane, R.E.; McCaughey, W.W.; Smith, C. 2004. Methods for surveying and monitoring whitebark pine for blister rust infection and damage. Missoula, MT: Whitebark Pine Ecosystem Foundation. 28 p. 
ark beetles (Coleoptera: Scolytinae) are important biotic agents of conifer mortality forests of western North America (Furnis and Carolin 1977) and play an important role in the disturbance ecology of these ecosystems (Fettig and others 2007). Bark beetle outbreaks affect subsequent fire behavior in part by influencing the spatial distribution and state of fuels [see review by Jenkins and others (2008)]. Crown fire hazard following a bark beetle outbreak likely varies as a function of time (Romme and others 2006) with increased risk of crown fire initiation immediately following outbreak, reduced crown fire spread and initiation after needle drop, and increased crown fire initiation and spread after snags fall. There is a paucity of "scientifically and statistically sound studies" on this topic; therefore, a better understanding of the fate of fuels after bark beetle outbreaks is needed to develop management options related to treating fuels (Negrón and others 2008). Furthermore, because rates of needle drop, tree fall, and surface fuel decomposition vary across elevation gradients and forest types (Cahill 1977, Jenkins and others 2008), it is important to quantify relationships between bark beetle outbreaks and potential fire behavior across this variability. In contrast to higher-elevation forest types, relationships between bark beetle outbreaks, fuel loading, and fire behavior have not been reported for ponderosa pine forests (Jenkins and others 2008).

A drought-induced bark beetle outbreak resulted in high levels of ponderosa pine mortality throughout much of Arizona between
2001 and 2003 (Negrón and others 2009, Williams and others 2008). Although ponderosa pine mortality approached 100 percent in some stands, reductions in tree density (stems $\cdot \mathrm{ha}^{-1}$ ) averaged $<25$ percent across five national forests monitored between 2001 and 2004 (Negrón and others 2009). The goal of our study was to quantify how canopy and surface fuels changed through time following this outbreak and to better understand the implications of these changes in terms of predicted fire behavior. The objectives were to (1) quantify effects of bark beetle outbreaks on canopy and surface fuels in ponderosa pine forests of the Southwest, (2) model potential fire behavior in stands with tree mortality caused by bark beetles, and (3) examine relationships between amount of bark beetle-caused tree mortality and both fuel loadings and fire hazard.

\section{Methods}

We utilized a network of plots established in 2003-04 across five national forests (ApacheSitgreaves, Coconino, Kaibab, Prescott, and Tonto) in Arizona to quantify overstory impacts

\footnotetext{
${ }^{1}$ Instructor, University of Idaho, Wildland Fire Program, College of Natural Resources, Moscow, ID 83844.

${ }^{2}$ Entomologist, U.S. Department of Agriculture, Forest Service, Region 3 Forest Health Protection, 2500 Pine Knoll Drive, Flagstaff, AZ 86001

${ }^{3}$ Research Plant Ecologist, U.S. Department of Agriculture, Forest Service, Rocky Mountain Research Station, Flagstaff AZ 86001.

${ }^{4}$ Professor, Northern Arizona University, School of Forestry and Ecological Restoration Institute, Flagstaff, AZ 86011.
}

\section{Chapter 19.} Influence of Bark Beetle-Caused Mortality on Fuel Loadings and Crown Fire Hazard in Southwestern Ponderosa Pine

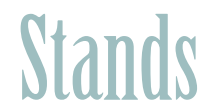

(Project INT-F-07-01)

Chad M. Hoffman $^{1}$

JoEl D. McMillin $^{2}$

Carolyn Hull Sieg ${ }^{3}$

Peter Z. Fulé ${ }^{4}$ 
of bark beetle outbreaks in ponderosa pine stands (Negrón and others 2009). We selected 37 plots with at least 10 percent ponderosa pine mortality (basal area killed) and paired them with plots without mortality. Pairing was based on proximity, elevation, and percent ponderosa pine. We quantified tree stand attributes and canopy and surface fuels $4-5$ years post-outbreak during June-August 2007. We modeled crown fire hazard using NEXUS (Scott and Reinhardt 1999), plus torching index, which is the wind speed at which a surface fire is expected to transition into the canopy, and crowning index, which is the wind speed at which active crowning is possible (Scott and Reinhardt 2001).

We ran three separate sets of fire behavior simulations for each plot. In the first simulation, fire behavior fuel model was held constant for all plots (model 9, see Anderson 1982 for description of standardized fuel models) to quantify the influence of bark beetle-caused tree mortality on the canopy stand structure and potential fire behavior while ignoring the effects of tree mortality on surface fire properties and windflow within a stand. In the second simulation we used fire behavior fuel model 10 for all plots that had surface fuel loadings $>22.4 \mathrm{Mg} / \mathrm{ha}$ to account for changes in quantity and position of canopy fuel and quantity of surface fuels. The third simulation adjusted the wind reduction factor for stands with basal areas of $<11.5 \mathrm{~m}^{2} / \mathrm{ha}$, to account for differences caused by tree mortality. Fuel moisture and slope were held constant in all simulations. Crown fire hazard was predicted for upper $97.5^{\text {th }}$ percentile weather conditions to represent severe fire weather conditions during the fire season. We analyzed the effects of bark beetle-caused tree mortality on fuel loadings and crown fire hazard by comparing means for mortality and no-mortality plots using an unequal variance Student's two-tailed t-test $(\alpha=0.05)$.

\section{Results}

Bark beetle-caused tree mortality resulted in significant changes in several stand variables which affect the vertical and horizontal

distribution of canopy fuels (table 19.1). Stands

Table 19.1-Comparison of stand structural characteristics in mortality and no-mortality plots in ponderosa pine stands of north-central Arizona

\begin{tabular}{lcc}
\hline Stand variables & No mortality & Mortality \\
\hline Total stems $\cdot \mathrm{ha}^{-1}$ & $378(35.7)$ & $314(32.7)$ \\
Stems $\cdot \mathrm{ha}^{-1}$ ponderosa pine & $282(28.7)$ & $123(24.4)^{a}$ \\
Stems $\cdot \mathrm{ha}^{-1}$ other species & $96(20.2)$ & $191(26.9)^{a}$ \\
Total basal area $\left(\mathrm{m}^{2} \cdot \mathrm{ha}^{-1}\right)$ & $26.5(2.5)$ & $16.4(2.2)^{a}$ \\
Basal area ponderosa pine $\left(\mathrm{m}^{2} \cdot \mathrm{ha}^{-1}\right)$ & $18.0(2.5)$ & $11.0(2.2)^{a}$ \\
Basal area other species $\left(\mathrm{m}^{2} \cdot \mathrm{ha}^{-1}\right)$ & $8.5(1.9)$ & $5.4(1.2)$ \\
Stand density index & $181.2(15.4)$ & $117.5(13.9)^{a}$ \\
Tree height (m) & $10.5(0.6)$ & $10.8(1.0)$ \\
Quadratic mean diameter $(\mathrm{cm})$ & $29.5(1.6)$ & $30.2(0.9)$ \\
Crown base height minimum $(\mathrm{m})$ & $1.3(0.3)$ & $2.7(0.003)^{a}$ \\
Crown base height 20 percent $(\mathrm{m})$ & $2.0(0.3)$ & $3.3(0.002)^{a}$ \\
Crown base height average $(\mathrm{m})$ & $3.2(0.3)$ & $4.2(0.03)^{a}$ \\
Crown base height calculated $(\mathrm{m})$ & $1.2(1.8)$ & $2.0(0.02)^{a}$ \\
\hline
\end{tabular}

Values in parentheses are standard errors.

${ }^{a}$ Means within a row are significantly different $(\alpha=0.05)$. 
with mortality had lower ponderosa pine density (stems $\cdot \mathrm{ha}^{-1}$ ) and higher density of other species than stands with no mortality. However, these differences did not equate to a significant difference in total tree density. Stands with mortality also had significantly lower stand density index, total basal area, and basal area of ponderosa pine, but basal area of other species did not differ from stands without mortality. All measures of canopy base height were significantly higher in mortality plots compared to the no-mortality plots.

Bark beetle-caused tree mortality resulted in significant increases for all surface fuels except total 1,000-hour rotten fuels, and increases in litter depth (table 19.2). Total surface fuel loading was, on average, two times greater in mortality plots compared with no-mortality

Table 19.2 - Surface fuel loadings by fuel classes and duff and fuel bed depth in mortality and no-mortality plots in ponderosa pine stands of north-central Arizona

\begin{tabular}{|c|c|c|}
\hline Surface fuel measurements & No mortality & Mortality \\
\hline 1-hr $\left(M g \cdot h a^{-1}\right)$ & $0.4(0.1)$ & $1.1(0.2)^{a}$ \\
\hline 10-hr $\left(\mathrm{Mg} \cdot \mathrm{ha}^{-1}\right)$ & $1.9(0.2)$ & $3.2(0.4)^{a}$ \\
\hline $100-\mathrm{hr}\left(\mathrm{Mg} \cdot \mathrm{ha}^{-1}\right)$ & $1.4(0.3)$ & $3.9(0.6)^{a}$ \\
\hline $1000-\mathrm{hr}$ sound $\left(\mathrm{Mg} \cdot \mathrm{ha}^{-1}\right)$ & $0.0(0.0)$ & $10.7(3.7)^{a}$ \\
\hline 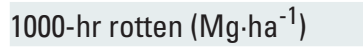 & $6.9(3.2)$ & $6.1(1.5)$ \\
\hline Total fuel loading (Mg $\left.\cdot \mathrm{ha}^{-1}\right)$ & $10.6(3.3)$ & $25.2(4.1)^{a}$ \\
\hline Litter depth (cm) & $5.8(.2)$ & $13.6(0.2)^{a}$ \\
\hline Duff depth (cm) & $1.6(1.0)$ & $1.7(1.1)$ \\
\hline
\end{tabular}

Values in parentheses are standard errors.

${ }^{a}$ Means within a row are significantly different $(\alpha=0.05)$. plots. Surface fuel loadings in 1-, 10- and 100hour fuels averaged more than two times higher those of no-mortality plots.

Mortality plots had lower canopy foliage biomass, canopy 10- and 100-hour fuel load, and total canopy fuel loading with and without foliage compared with no-mortality plots (table 19.3). The total available canopy fuel loading was also significantly lower in the mortality stands. Canopy bulk density estimates did not differ significantly between no-mortality and mortality plots despite significant differences in the amount of available canopy fuel loadings.

In our first simulation with weather, topographic and surface fuel conditions held constant, torching index (fig. 19.1) and

Table 19.3-Canopy fuel loadings by size class, total and available canopy fuel, and canopy bulk density of mortality and no-mortality plots in ponderosa pine stands of north-central Arizona

\begin{tabular}{|c|c|c|}
\hline Canopy measurements & No mortality & Mortality \\
\hline Foliage $\left(\mathrm{Mg} \cdot h \mathrm{a}^{-1}\right)$ & $8.7(0.8)$ & $5.8(0.7)^{a}$ \\
\hline $1-\mathrm{hr}\left(\mathrm{Mg} \cdot \mathrm{ha}^{-1}\right)$ & $1.6(0.2)$ & $1.2(0.2)$ \\
\hline 10-hr (Mg.ha $\left.{ }^{-1}\right)$ & $9.8(0.8)$ & $6.5(0.9)^{a}$ \\
\hline $100-\mathrm{hr}\left(\mathrm{Mg} \cdot \mathrm{ha}^{-1}\right)$ & $10.3(1.4)$ & $6.5(1.1)^{a}$ \\
\hline Total canopy fuel $\left(\mathrm{Mg} \cdot \mathrm{ha}^{-1}\right)$ & $33.4(3.3)$ & $21.5(2.9)^{a}$ \\
\hline Available canopy fuel $\left(\mathrm{Mg} \cdot \mathrm{ha}^{-1}\right)$ & $9.4(0.8)$ & $6.4(0.7)^{a}$ \\
\hline Canopy bulk density $\left(\mathrm{kg} \cdot \mathrm{m}^{-3}\right)$ & $0.127(0.003)$ & $0.092(0.002)$ \\
\hline
\end{tabular}

Values in parentheses are standard errors.

${ }^{a}$ Means within a row are significantly different $(\alpha=0.05)$ 


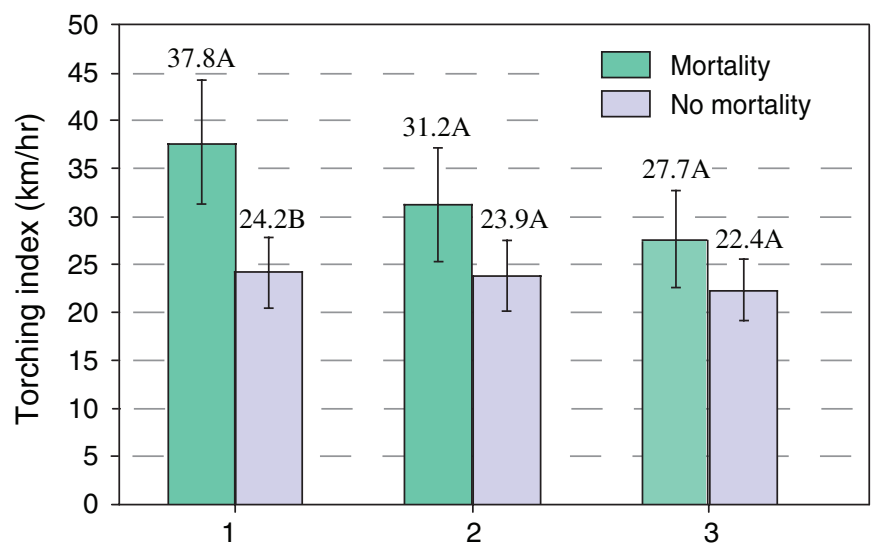

Simulation number

Figure 19.1-Simulated torching index (mean with standard error) for plots with tree mortality and with no mortality for three sets of assumptions in ponderosa pine stands of north-central Arizona. Simulation 1 shows changes in torching index based only on changes in the canopy fuels complex; simulation 2 shows changes in torching index based on combined effects of changes in canopy and surface fuels complex; and simulation 3 shows changes in torching index based on a combination of changes in canopy and surface fuels complex as well as a reduction in wind adjustment factor. Means within a group followed by a different letter are significantly different $(\alpha=0.05)$. crowning index (mortality: $39.7 \mathrm{~km} \cdot \mathrm{h}^{-1} \pm 6.4$ SE, no mortality: $27.8 \pm 2.8 ; p=0.02$ ) were significantly higher in mortality plots compared to no-mortality plots. These results reflect the increased canopy base height estimates and decreased tree densities and canopy fuels in the mortality plots. In the second simulation, the torching index was not significantly different between the no-mortality and mortality plots. Three out of 37 (8 percent) no-mortality plots had surface fuel levels high enough to be classified as fuel model 10 , while 15 out of 37 (40 percent) mortality plots were classified as fuel model 10. In the third simulation, torching index did not differ significantly between mortality and no-mortality plots given that seven no-mortality plots and 16 mortality plots had their wind reduction factor increased to represent less vegetative drag in the canopy fuel stratum due to lower basal areas.

\section{Discussion}

Our preliminary results suggest that crown fire hazard was not higher in mortality stands despite 2.5 times higher surface fuel loadings $4-5$ years after mortality occurred. This finding is based on crown fire hazard being comprised of two components: first, the ability of a surface fire to transition into the canopy of a stand, and second, the ability of a crown fire to spread through a stand. In stands with mortality, a surface fire was predicted to need about three times as much energy release per unit area per minute to promote the surface fire into the 
canopy compared to stands without mortality. If fuel loadings and moisture were held constant, this increase in energy would require an increase in wind speed of about $13 \mathrm{~km} \cdot \mathrm{h}^{-1}$ (fig. 19.1simulation 1). However, the effect of epidemic insect outbreaks is not limited just to changes in vertical fuel distributions. As the canopy fuels from the dead trees fall, an increase in the surface fuel loading and composition along with corresponding changes in fire behavior can be expected. In our simulations, this increase counteracted the effect of bark beetlecaused mortality on the vertical distribution of fuels (fig. 19.1-simulation 2). Accounting for the decrease in drag caused by a reduction in canopy biomass further reduced any effect the changes in the vertical distribution of fuels had on the ability of surface fire to transition in mortality stands (fig. 19.1-simulation 3). These preliminary modeling results suggest a tradeoff between increased canopy base heights and increased surface fuel loadings. The end result of this tradeoff was that a surface fire can transition into the canopy, but physical properties driving this mechanism have switched from low surface fuels and low crown base heights to higher surface fuels and higher crown base heights.

Although this work provides insights into the effect of bark beetle-caused mortality on fuels and potential fire behavior in ponderosa pine, it is limited to $4-5$ years post-mortality. Questions remain about effects of bark beetle- caused mortality at other points in time, such as immediately following mortality or many years after mortality, to fully assess the model proposed by Romme and others (2006).

\section{For more information contact:}

Joel D. McMillin, jmcmillin@fs.fed.us, 928.556.2074.

\section{Acknowledgments}

Melissa Joy Fischer and Grace Hancock collected and entered field data. Jesse Anderson and Kelly Williams created GIS maps. The Apache-Sitgreaves, Coconino, Kaibab, Prescott, and Tonto National Forests permitted this work on public lands. Funding was provided by U.S.

Department of Agriculture, Forest Service, Forest Health Monitoring, Evaluation Monitoring grant INT-F-07-01 (fiscal years 2007 and 2008); U.S. Department of Agriculture, Forest Service Southwestern Region, Forest Health; and U.S. Department of Agriculture, Forest Service, Rocky Mountain Research Station.

\section{Literature Cited}

Anderson, H.E. 1982. Aids to determining fuel models for estimating fire behavior. Gen. Tech. Rep. INT-122. Ogden, UT: U.S. Department of Agriculture Forest Service, Intermountain Forest Range Experiment Station. $22 \mathrm{p}$.

Cahill, D.B. 1977. Net impacts of spruce beetle outbreaks on White River National Forest, 1939-1951. Reg Rep. Ogden, UT: U.S. Department of Agriculture Forest Service, Rocky Mountain Research Station. 46 p. 
Fettig, C.J.; Klepzig, K.D.; Billings, R.F. [and others]. 2007. The effectiveness of vegetation management practices for prevention and control of bark beetle infestations in coniferous forests of the Western and Southern United States. Forest Ecology and Management. 238: 24-53.

Furniss, R.L.; Carolin, V.M. 1977. Western forest insects. Misc. Pub. 1339. Washington, DC: U.S. Department of Agriculture Forest Service. 654 p.

Jenkins, M.J.; Hebertson, E.; Page, W.; Jorgensen, C.A. 2008. Bark beetles, fuels, fires and implications for forest management in the Intermountain West. Forest Ecology and Management. 254: 16-34.

Negrón, J.F.; Bentz, B.J.; Fettig, C.J. [and others]. 2008. U.S. Forest Service bark beetle research in the Western United States: looking toward the future. Journal of Forestry. 106 325-331.
Negrón, J.F.; McMillin, J.D.; Anhold, J.A.; Coulson, D. 2009. Bark beetle-caused mortality in a drought-affected ponderosa pine landscape in Arizona, USA. Forest Ecology and Management. 257: 1353-1362.

Romme, W.H.; Clement, J.; Hicke, J. [and others] 2006. Recent forest insect outbreaks and fire risk in Colorado forests: a brief synthesis of relevant research. Fort Collins, CO: Colorado State University. $24 \mathrm{p}$

Scott, J.H.; Reinhardt, E.D. 1999. NEXUS fire behavior and hazard assessment system. Software program. Missoula, MT: Systems for Environmental Management.

Scott. J.H.; Reinhardt, E.D. 2001. Assessing crown fire potential by linking models of surface and crown behavior. Res. Pap. 29. Washington, DC: U.S. Department of Agriculture Forest Service. 59 p.

Williams, K.; McMillin, J.D.; DeGomez, T.E. [and others] 2008. Influence of elevation on bark beetle community structure in ponderosa pine stands of north-central Arizona. Environmental Entomology. 37: 94-109. 
he research described in this report was supported in part through the project "Forest Health Monitoring and Assessment" of Research Joint Venture Agreement 07-JV11330146-134 (August 13, 2007, through October 31, 2009), the project "Forest Health Monitoring, Analysis and Assessment" of Research Joint Venture Agreement 08-JV11330146-078 (July 31, 2008, through May 31, 2010), the project "Forest Health Monitoring, Assessment and Analysis" of Research Joint Venture Agreement 09-JV-11330146-087 (July 22, 2009, through March 21, 2011), the project "Forest Health Monitoring, Analysis and Assessment" of Research Joint Venture Agreement 10-JV-11330146-064 (June 10, 2010, through February 28, 2012), and the project “Forest Health Monitoring, Assessment, and Analysis" of Research Joint Venture Agreement 11-JV-11330146-090 (July 12, 2011, through October 31, 2012), between North Carolina State University (this institution is an equal opportunity provider) and the U.S. Department of Agriculture, Forest Service,

Southern Research Station, Asheville, NC. This research was supported by funds provided by the U.S. Department of Agriculture, Forest Service, Southern Research Station, Asheville, NC.

The editors and authors of this report thank the following for their reviews and constructive comments: Mark Ambrose, Frank Koch,

KaDonna Randolph, Kurt Riitters, Dale Starkey, Borys Tkacz, James Worrall, Stanley Zarnoch, and an additional anonymous reviewer. 


\section{Authors for Section 1, Forest Health Monitoring Research}

Mark J. Ambrose, Research Assistant, North Carolina State University, Department of Forestry and Environmental Resources, Raleigh, NC 27695.

John W. Coulston, Research Scientist, U.S. Department of Agriculture, Forest Service, Southern Research Station, Knoxville, TN 37919.

Jim ElLenwood, Remote Sensing and Image Analysis Program Manager, U.S. Department of Agriculture, Forest Service, Forest Health Technology Enterprise Team, Fort Collins, CO 80526.

Frank H. Koch, Research Ecologist, U.S. Department of Agriculture, Forest Service, Southern Research Station, Research Triangle Park, NC 27709 (formerly Research Assistant Professor, North Carolina State University, Department of Forestry and Environmental Resources, Raleigh, NC 27695).

Jefrerey A. MaI, Aerial Survey and Aviation Safety Manager, U.S. Department of Agriculture, Forest Service, Forest Health Protection, Fort Collins, CO 80526.

Kevin M. Potter, Research Assistant Professor, North Carolina State University, Department of Forestry and Environmental Resources, Raleigh, NC 27695.

KunT H. RiITTERS, Research Scientist, U.S. Department of Agriculture, Forest Service, Southern Research Station, Research Triangle Park, NC 27709.

WiLliam D. Smith, Research Scientist, U.S. Department of Agriculture, Forest Service, Southern Research Station, Research Triangle Park, NC 27709. 
William A. Bechtold, Mathematical Statistician (retired), U.S. Department of Agriculture, Forest Service, Southern Research Station, Asheville, NC 28804.

Anne E. Black, Interdisciplinary Social Scientist/Ecologist, U.S. Department of Agriculture, Forest Service, Rocky Mountain Research Station, Aldo Leopold Wilderness Research Institute, Missoula, MT 59801.

James T. Blodgett, Plant Pathologist, U.S. Department of Agriculture, Forest Service, Forest Health Management, Rapid City, SD 57702.

Kelly S. Burns, Forest Pathologist, U.S. Department of Agriculture, Forest Service, Forest Health Management, Golden, CO 80401.

Anne Marie Casper, Graduate Student, Colorado State University, Department of Bioagricultural Sciences and Pest Management, Fort Collins, CO 80523.

Xiuli Fan, Research Technician, University of Missouri, Department of Forestry, Columbia, MO 65211.

Zhaofer Fan, Assistant Professor, Mississippi State University, Department of Forestry, Starkville, MS 39762.

Peter Z. Fulé, Professor, Northern Arizona University, School of Forestry and Ecological Restoration Institute, Flagstaff, AZ 86011.

Hong S. He, Associate Professor, University of Missouri, Department of Forestry, Columbia, MO 65211. 
Chad M. Hoffman, Instructor, University of Idaho, Wildland Fire Program, College of Natural Resources, Moscow, ID 83844.

Brian E. Howell, Aerial Survey Program Manager, U.S. Department of Agriculture, Forest Service, Forest Health Management, Golden, CO 80401.

Cynthia D. Huebner, Research Botanist/Ecologist, U.S. Department of Agriculture, Forest Service, Northern Research Station, Morgantown, WV 26505.

Todd F. Hutchinson, Research Ecologist, U.S. Department of Agriculture, Forest Service, Northern Research Station, Delaware, OH 43015.

Marcus B. Jackson, Plant Pathologist, U.S. Department of Agriculture, Forest Service, Forest Health Protection, Missoula, MT 59807.

William Jacobi, Professor of Forest and Shade Tree Pathology, Colorado State University, Department of Bioagricultural Sciences and Pest Management, Fort Collins, CO 80523.

William E. Jones, Plant Pathologist, U.S. Department of Agriculture, Forest Service, Forest Health Protection, Asheville, NC 28802.

Jennifer Klutsch, Data Analyst, U.S. Department of Agriculture, Forest Service, Rocky Mountain Research Station, Fort Collins, CO 80526.

Frank H. Koch, Research Ecologist, U.S. Department of Agriculture, Forest Service, Southern Research Station, Research Triangle Park, NC 27709 (formerly Research Assistant Professor, North Carolina State University, Department of Forestry and Environmental Resources, Raleigh, NC 27695). 
Peter B. Landres, Ecologist and Research Application Program Leader, U.S. Department of

Agriculture, Forest Service, Rocky Mountain Research Station, Aldo Leopold Wilderness Research Institute, Missoula, MT 59801.

Steven C. McKelvey, Associate Professor of Mathematics and Computer Science, Saint Olaf College, Northfield, MN 55057.

Joel McMiluin, Entomologist, U.S. Department of Agriculture, Forest Service, Forest Health Protection, Flagstaff, AZ 86001.

Randall S. Morin, Research Forester, U.S. Department of Agriculture, Forest Service, Northern Research Station, Newtown Square, PA 19073.

W. Keith Moser, Research Forester, U.S. Department of Agriculture, Forest Service, Northern Research Station, St. Paul, MN 55108.

KaDonna C. Randolph, Mathematical Statistician, U.S. Department of Agriculture, Forest Service, Southern Research Station, Knoxville, TN 37919.

Todd E. Ristau, Research Ecologist, U.S. Department of Agriculture, Forest Service, Northern Research Station, Irvine, PA 16329.

Alejandro A. Rojo, Research Ecologist, U.S. Department of Agriculture, Forest Service, Northern Research Station, Irvine, PA 16329.

Anna W. Schoettle, Research Plant Ecophysiologist, U.S. Department of Agriculture, Forest Service, Rocky Mountain Research Station, Fort Collins, CO 80526. 
STEPHEN R. ShIFLEY, Research Forester (Biometrics), U.S. Department of Agriculture, Forest Service, Northern Research Station, Columbia, MO 65211.

Carolyn Hull Sieg, Research Plant Ecologist, U.S. Department of Agriculture, Forest Service, Rocky Mountain Research Station, Flagstaff, AZ 86001.

William D. Sмith, Research Scientist, U.S. Department of Agriculture, Forest Service, Southern Research Station, Research Triangle Park, NC 27709.

Martin A. Spetich, Research Forest Ecologist, U.S. Department of Agriculture, Forest Service, Southern Research Station, Hot Springs, AR 71902.

James Steinman, Northeast Regional Program Manager, U.S. Department of Agriculture, Forest Service, Forest Health Monitoring, Newtown Square, PA 19073.

Daniel B. Twardus, Forest Health Group Leader, U.S. Department of Agriculture, Forest Service, Forest Health Protection, Morgantown, WV 26505.

James J. Worrall, Plant Pathologist, U.S. Department of Agriculture, Forest Service, Forest Health Management, Gunnison, CO 81230.

Stanley J. Zarnoch, Research Scientist and Mathematical Statistician, U.S. Department of Agriculture, Forest Service, Southern Research Station, Moore, SC 29369. 


Potter, Kevin M.; Conkling, Barbara L., eds. 2012. Forest health monitoring: 2009 national technical report. Gen. Tech. Rep. SRS-167. Asheville, NC: U.S. Department of Agriculture Forest Service, Southern Research Station. 252 p.

The annual national technical report of the Forest Health Monitoring Program of the Forest Service, U.S. Department of Agriculture, presents forest health status and trends from a national or multi-State regional perspective using a variety of sources, introduces new techniques for analyzing forest health data, and summarizes results of recently completed Evaluation Monitoring projects funded through the national Forest Health Monitoring program. Landscape pattern assessments are presented for Alaska, Hawaii, and Puerto Rico. Data from detection and monitoring surveys are used to identify trends relating to biotic agents posing forest sustainability concerns. Aerial survey data are used to identify geographic patterns of insect and disease activity. Data from the Forest Inventory and Analysis Program of the Forest Service are used to identify geographic patterns of nonnative tree species occurrence. Forest Inventory and Analysis data from 20 States also are employed to detect regional differences in tree mortality. A new risk map for Phytophthora ramorum is presented to assist in detection surveys. Quantitative temporal analyses are conducted for five categories of abiotic agents impacting forest health. Satellite data are employed to detect geographic clusters of forest fire occurrence. A new methodology for the comparison of moisture conditions among different geographical areas and time periods is described using multi-year windows. Nine recently completed evaluation monitoring projects are summarized, addressing forest health concerns at smaller scales.

Keywords: Drought, fire, forest health, forest insects and disease, fragmentation, nonnative species, tree mortality.

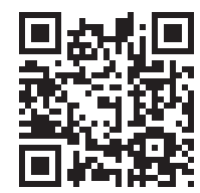




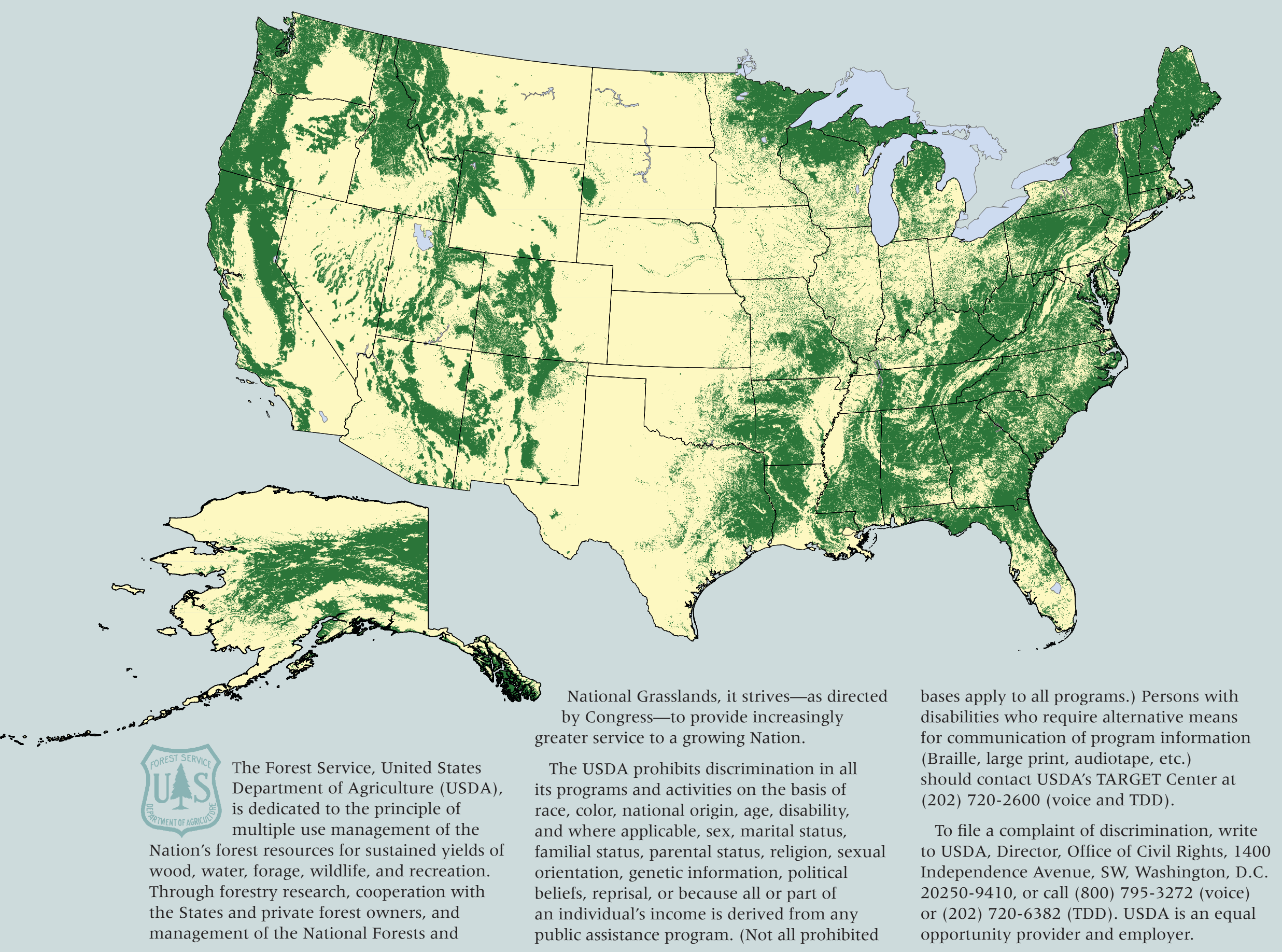




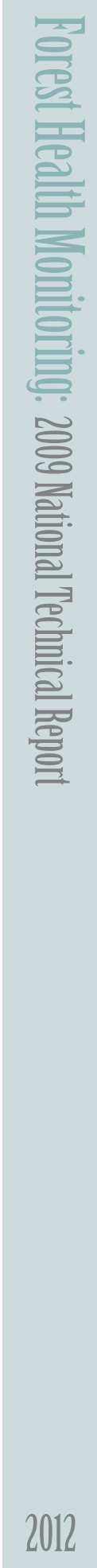

